\title{
DA LEI 8.078/90 NA FORMATAÇÃO DO DIREITO MATERIAL POSITIVO DAS RELAÇÕES DE CONSUMO
}

\author{
Tese de doutorado
}

Orientador: Professor Titular Doutor Fernando Campos Scaff

\author{
UNIVERSIDADE DE SÃO PAULO - FACULDADE DE DIREITO DO \\ LARGO SÃO FRANCISCO \\ SÃO PAULO


Examinadores 
Aos meus amados pais, Iray e Diniz Ferreira da Cruz, exemplos vivos de dedicação e ternura.

Aos meus caríssimos irmãos, Diniz Fernando e Gilberto, lídimos magistrados que honram a toga paulista.

À doce e sensivel Fernanda, companheira de todas as horas. 
Ao professor Fernando Campos Scaff, jurista devoto à academia, louvo a divina providência pelo dia em que nos conhecemos. De mim o senhor terá sempre a mais profunda admiração, como a de um irmão mais novo. 
AGRADECIMENTOS

Ao professor Rui Geraldo Camargo Viana, de talento ímpar para a judicatura e o magistério, a quem tanto devo desde antes do ingresso no curso de doutorado.

Aos professores Teresa Ancona Lopez e Carlos Alberto Dabus Maluf, cujos ensinamentos me fizeram refletir deveras sobre novos e antigos conceitos, agradeço a dileta atenção que sempre me dispensaram.

Aos professores Patrícia Faga Iglecias Lemos, José Fernando Simão, José Luiz Gavião de Almeida e Wanderlei de Paula Barreto, do fundo da alma, jamais esquecerei do nosso convívio, sempre marcado por palavras de apoio e de incentivo.

Ao professor e amigo Luiz Antonio Rizzatto Nunes, grande responsável pelo início dessa longa caminhada. 
RESUMO

A investigação dos reflexos condicionantes da Parte Geral da Lei 8.078/90 na formatação do direito material positivo das relações de consumo se vincula diretamente à sistemática legislativa empregada na confecção do CDC, notadamente quanto aos seus dez primeiros artigos e à opção de neles se inscreverem as vigas mestras estruturantes de todo o seu sistema protetivo.

É dizer: o direito material positivo das relações de consumo não pode ser visto de forma dissociada da Parte Geral da Lei 8.078/90, lídima regra de interpretação dirigida a fixar o alcance e a profundidade desse arcabouço jurídico instituído, por determinação constitucional, para amparar esse específico sujeito que é o consumidor; mais que isso, inclinado a buscar a materialização do equilíbrio nas relações obrigacionais que gravitam em torno do mercado.

A ideia é visusalizar a Parte Geral do Código como um fator condicionante das regras de direito material privado criadas no intuito de concretizar a vontade do Poder Constituinte originário de defender o consumidor, operando uma espécie de justiça distributiva em uma relação jurídica historicamente desequilibrada, relegando-se às demais regras da parte especial função meramente explicativa.

Nessa linha de raciocínio, foram examinados a dogmática positiva, as balizas de incidência do Código, a política nacional das relações de consumo, a boa-fé objetiva como mínimo ético exigível, os direitos básicos do consumidor e o risco como elemento de responsabilidade civil. Arremata-se com um resumo analítico da proposta, a identificar conclusões diretas sobre os problemas teóricos e práticos examinados.

Torna-se imprescindível, assim, compreender a real amplitude dos direitos materiais outorgados aos consumidores e, para tanto, só há um caminho: investigar profundamente os reflexos condicionantes da Parte Geral da Lei 8.078/90 na formatação daquilo que de melhor se pensou, em termos legislativos, para promover a defesa do consumidor.

Palavras-chave: Consumidor - Código - Parte geral - Reflexos condicionantes - Relação de consumo - Elementos formadores - Direito material - Interpretação Boa-fé objetiva - Direitos básicos - Risco - Responsabilidade civil. 


\begin{abstract}
The investigation of constraining reflexes of the General Part of Act 8.078/90 in formatting the positive substantive law of consumption relationship is directly related to the legal systematic employed in the CDC confection, especially regarding the first ten articles and the option to enroll in them the main structuring foundations of the whole protective system.

Indeed, the positive substantive law of consumption relationship cannot be dissociated of the General Part of Act 8.078/90, true interpretation rule aimed at setting the range and depth of this legal framework, established by constitutional determination to support this specific subject, the consumer, beyond that, inclined to search the real balance in the obligational relations focused on the consumption market.

The main purpose is to visualize the Code's General Part as a constraining factor of substantive private law rules created in order to materialize the Congress originary will to protect the consumer, working as a distributive justice in a historically unbalanced legal relation, demoting the remaining special part rules to a purely explanatory function.

Moreover, the positive dogmatic, the Code applicability limits, the Consumption Relationships National Policy, the objective good-faith as a minimum ethical demandable, the consumer's basic rights and the risk as an element of civil liability were examined. At the end, a purpose analytical summary is presented, identifying direct conclusions concerning the theoretical and practical problems examined.

It becomes imperative to comprehend the real dimension of the substantive rights granted to consumers and therefore, the only path is to deeply investigate the constraining reflexes of the General Part of Act 8.078/90 in structuring the best consideration in legal terms to promote consumer protection.
\end{abstract}

Key-words: Consumer - Code - General part - Constraining reflexes - Consumption relationship - Formatting elements - Substantive rights - Interpretation Objective good-faith - Basic rights - Risk - Civil liability. 


\section{RÉSUMÉ}

L'étude des effets contraignants de la «Partie générale» de la Loi 8.078/90, dans le façonnement du droit du consommateur, est directement reliée à l'approche législative utilisée lors de la rédaction du «Code de protection du consommateur » (CDC), notamment dans ses dix premiers articles, et à l'option d'y faire inscrire les assises de tout le système de protection.

Autrement dit: l'étude du droit du consommateur ne peut être dissocié de la «Partie générale » de la loi 8.078/90, compte tenu du fait que celle-ci constitue une véritable règle d'interprétation, dont le but est d'établir la portée et l'amplitude de ce cadre juridique, fruit d'une détermination constitutionnelle, adressé à la protection de ce sujet qu'est le consommateur, mais également de trouver un équilibre entre les obligations des parties au sein du marché.

L'objectif est de considérer la « Partie générale » de cette loi comme étant un élément déterminant des règles de droit privé, créées dans le but de mettre en œuvre la volonté constitutionnelle de protéger le consommateur et de rééquilibrer une relation juridique historiquement inégale, en reléguant les articles de la «Partie spéciale» à une fonction essentiellement explicative.

Dans ce sens, nous avons étudié la dogmatique, le cadre applicatif du CDC, la politique nationale de protection du consommateur, la bonne foi objective en tant que minimum étique requis, les droits de base du consommateur et le risque en tant qu'élément de la responsabilité civile. Nous concluons avec un résumé analytique de notre proposition afin d'identifier les impacts directs sur les questions théoriques et pratiques examinées.

Nous démontrons donc que pour comprendre l'ampleur réelle des droits octroyés aux consommateurs, il n'y a qu'une seule voie : étudier de manière approfondie les effets contraignants de la «Partie générale » de la loi 8.078/90 dans le façonnement de l'instrument qui a été conçu par le législateur, afin de promouvoir la protection du consommateur.

Mots-clés : Consommateur - Code - Partie générale - Effets contraignants - Éléments formateurs - Droit matériel - Interprétation - Bonne foi objective - Droits de base - Responsabilité civile. 


\section{ABREVIATURAS}

AC - Apelação cível

ADCT - Ato das disposições constitucionais transitórias

ADI - ação direta de inconstitucionalidade

Ag. - agravo de instrumento

AGA - agravo

AgRg. - agravo regimental

AI - agravo de instrumento

AP - Ação Penal

Art. - artigo

Atual. - atualização

CADE - Conselho Administrativo de Defesa Econômica

Cap. - capítulo

CBARP - Código Brasileiro de Autorregulamentação Publicitária

CC - Código Civil de 2002

CC/1916 - Código Civil de 1916 (revogado pela Lei 10.406/2002)

CCom - Código Comercial

CDC - Código de Proteção e Defesa do Consumidor

CE - Constituição do Estado de São Paulo

CEE - Comunidade Econômica Européia

CF - Constituição Federal

Cf. - confira-se

CONAR - Conselho Nacional de Autorregulamentação Publicitária

CPC - Código de Processo Civil

CNDC - Conselho Nacional de Defesa do Consumidor

CP - Código Penal

Dec. - decreto

Des. - Desembargador

DJ - Diário Oficial da Justiça

E. - Egrégio

EC - Emenda constitucional

ed. - edição 
EREsp. - Embargos de divergência em recurso especial

exe. - exemplar

fig. - figura

g.n. - grifo nosso

g.o. - grifado no original

HC - habeas corpus

i. - item, itens

IDEC - Instituto de Defesa do Consumidor

inc. - inciso

incs. - incisos

j. - julgado em

JTJ - Jurisprudência do Tribunal de Justiça

LICC - Lei de introdução ao Código Civil

LGT - Lei Geral de Telecomunicações

Min. - Ministro, Ministros

m.v. - maioria de votos

n. - nota

$\mathrm{n}^{\mathrm{o}} \quad-$ número

ONU - Organização das Nações Unidas

p. - página, páginas

p. ex. - por exemplo

par. ún. - parágrafo único

p/Ac. - para o Acórdão

RE - Recurso extraordinário

rel. - Relator

Res. - resolução

REsp. - Recurso especial

REsps.- Recursos especiais

Rev. - Revista

RHC - Recurso ordinário em habeas corpus

RJTJRS - Revista de Jurisprudência do Tribunal de Justiça do Rio Grande do Sul

RT - Revista dos Tribunais 


$$
\begin{aligned}
& \text { RTJ - Revista Trimestral de Jurisprudência } \\
& \text { ss } \quad-\text { seguintes } \\
& \text { SNDE - Secretaria Nacional de Direito Econômico } \\
& \text { STF - Supremo Tribunal Federal } \\
& \text { STJ - Superior Tribunal de Justiça } \\
& \text { Súm. - Súmula } \\
& \text { t. }- \text { tomo } \\
& \text { te. - tema } \\
& \text { TJBA - Tribunal de Justiça da Bahia } \\
& \text { TJDFT - Tribunal de Justiça do Distrito Federal e Territórios } \\
& \text { TJGO - Tribunal de Justiça de Goiás } \\
& \text { TJMG - Tribunal de Justiça de Minas Gerais } \\
& \text { TJPR - Tribunal de Justiça do Paraná } \\
& \text { TJRJ - Tribunal de Justiça do Rio de Janeiro } \\
& \text { TJRN - Tribunal de Justiça do Rio Grande do Norte } \\
& \text { TJRS - Tribunal de Justiça do Rio Grande do Sul } \\
& \text { TJSC - Tribunal de Justiça de Santa Catarina } \\
& \text { TJSE - Tribunal de Justiça de Sergipe } \\
& \text { TJSP - Tribunal de Justiça de São Paulo } \\
& \text { Trad. - Tradução } \\
& \text { TacCiv - Tribunal de Alçada Civil } \\
& \text { UFRGS - Universidade Federal do Rio Grande do Sul } \\
& \text { v.g. - verbi gratia } \\
& \text { v.u. - votação unânime } \\
& \text { v. - volume } \\
& \text { V. - Venerando }
\end{aligned}
$$


SUMÁRIO

INTRODUÇÃO

CAPÍTULO I - O CÓDIGO DAS RELAÇÕES DE CONSUMO E SUA DOGMÁTICA

1. INDERROGABILIDADE 23

2. ORDEM PÚBLICA E RETROATIVIDADE 26

2.1 A teoria objetiva de Roubier 28

2.2 Graus de retroatividade $\quad 29$

2.3 Paradigma do STF (leading case) 30

2.4 A defesa do consumidor como garantia fundamental 32

2.5 Solução correta 35

2.6 Código Civil x CDC (o diálogo das fontes) 36

2.7 A multa de 2\% (Lei 9.298/96) 38

2.7.1 Contrato anterior ao CDC 39

2.7.2 Contrato posterior ao CDC 39

3. INTERESSE SOCIAL 41

3.1 Difusos 42

3.2 Coletivos 43

3.3 Individuais homogêneos $\quad 43$

3.4 A legitimidade do MP para as ações coletivas $\quad 44$

3.5 Obrigatoriedade de intervenção ministerial 46

CAPÍTULO II - BALIZAS DE INCIDÊNCIA

1. RELAÇÃO DE CONSUMO: ELEMENTOS FORMADORES 48

2. OS CONSUMIDORES 50

2.1 Consumidor próprio $\quad 50$

2.1.1 Critérios identificadores 51

2.1.2 Núcleos de conduta $\quad 53$ 
2.1.2.1 Adquirir

2.1.2.2 Utilizar

2.1.3 Elemento finalista e teorias $\quad 54$

2.2 Consumidor equiparado $\quad 57$

2.2.1 Coletividade de pessoas $\quad 59$

$\begin{array}{ll}2.2 .2 \text { Vítimas do evento } & 60\end{array}$

2.2.2.1 Vítima e vício do produto e do serviço 62

2.2.2.2 Vício e defeito: distinção $\quad 62$

2.2.3 Pessoas expostas às práticas comerciais $\quad 65$

$\begin{array}{ll}\text { 2.2.3.1 A norma de extensão e os bancos } & 67\end{array}$

2.3 Consumidor estrangeiro não residente (turista) 68

3. O FORNECEDOR 70

$\begin{array}{ll}3.1 \text { Pessoa jurídica } & 72\end{array}$

$\begin{array}{ll}3.1 .1 \text { Associações civis e cooperativas } & 72\end{array}$

3.1.2 Instituições financeiras (ADI 2591) 75

$\begin{array}{ll}3.2 \text { Ente despersonalizado } & 79\end{array}$

$\begin{array}{lr}3.3 \text { Pessoa física } & 80\end{array}$

4. PRODUTOS E SERVIÇOS

4.1 Produto $\quad 82$

4.1.1 Crédito 83

4.1.2 Durável 83

4.1.2.1 Produto descartável 84

4.1.3 Não durável 84

4.1.4 Produto gratuito (amostra grátis) 85

4.2 Serviço $\quad 86$

$\begin{array}{ll}\text { 4.2.1 Durável } & 87\end{array}$

$\begin{array}{ll}\text { 4.2.2 Não durável } & 88\end{array}$

CAPÍTULO III - POLÍTICA NACIONAL DAS RELAÇÕES DE CONSUMO

1. CONSIDERAÇÕES GERAIS $\quad 89$

2. VULNERABILIDADE 93 
2.1 Vulnerabilidade como conceito de ordem material 94

2.2 Vulnerabilidade x hipossuficiência 95

2.3 Espécies de vulnerabilidade 96

3. AÇÃO GOVERNAMENTAL 98

3.1 Fornecedor e autocontrole (CONAR e recall) 99

$\begin{array}{ll}3.2 \text { Inviabilidade de abuso no mercado } & 101\end{array}$

$\begin{array}{ll}3.2 .1 \text { Práticas abusivas } & 102\end{array}$

$\begin{array}{ll}\text { 3.2.2 Cláusulas abusivas } & 105\end{array}$

$\begin{array}{ll}\text { 3.2.2.1 A expressão cláusula abusiva } & 107\end{array}$

$\begin{array}{ll}\text { 3.2.2.2 Rol exemplificativo } & 108\end{array}$

$\begin{array}{ll}\text { 3.2.2.3 Oportunidade de reconhecimento e prazo } & 109\end{array}$

3.2.3 Cobrança de dívidas x repetição do indébito 110

$\begin{array}{ll}\text { 3.2.3.1 Cobrança de dívida de consumo } & 111\end{array}$

$\begin{array}{ll}\text { 3.2.3.2 Efetivo pagamento pelo consumidor } & 112\end{array}$

$\begin{array}{ll}\text { 3.2.3.3 Engano injustificável do fornecedor } & 113\end{array}$

$\begin{array}{ll}3.2 .4 \text { Os bancos de dados e seus prazos } & 115\end{array}$

$\begin{array}{ll}3.2 .4 .1 \text { Irregularidade no registro } \mathrm{x} \text { dano moral } & 118\end{array}$

$\begin{array}{ll}3.2 .4 .2 \text { Vida útil da restritiva } & 122\end{array}$

4. HARMONIA E EQUILÍBRIO 127

$\begin{array}{ll}4.1 \text { Transparência } & 128\end{array}$

4.2 Confiança 132

$\begin{array}{ll}\text { 4.2.1 Cheque pré-datado (pós-datado) } & 134\end{array}$

$\begin{array}{ll}\text { 4.2.2 Troca imotivada de mercadorias } & 136\end{array}$

$\begin{array}{ll}4.3 \text { Prescrição e decadência } & 137\end{array}$

$\begin{array}{ll}\text { 4.3.1 Garantia } & 138\end{array}$

$\begin{array}{ll}\text { 4.3.2 Prazos de decadência } & 139\end{array}$

$\begin{array}{ll}\text { 4.3.3 Vício: fácil constatação e oculto } & 140\end{array}$

$\begin{array}{ll}\text { 4.3.4 Garantias: legal x contratual } & 141\end{array}$

$\begin{array}{ll}\text { 4.3.4.1 Contagem dos prazos } & 142\end{array}$

$\begin{array}{ll}\text { 4.3.4.2 Garantia estendida } & 147\end{array}$

$\begin{array}{ll}\text { 4.3.5 O sentido de obstar } & 148\end{array}$

$\begin{array}{ll}\text { 4.3.6 Prescrição } & 151\end{array}$ 
$\begin{array}{ll}\text { 4.3.7 Direito comum como norma supletiva } & 153\end{array}$

5. SERVIÇOS PÚBLICOS 157

5.1 Serviço essencial 157

5.2 Continuidade x inadimplemento 159

5.3 Consumidor x contribuinte 162

5.4 Responsabilidade do agente prestador 163

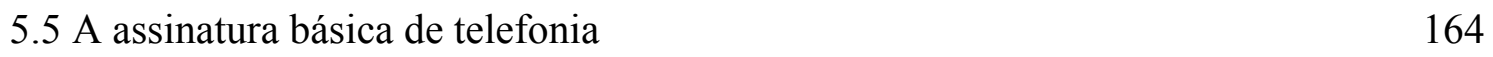

5.5.1 Dinâmica fático-jurídica proposta pelas operadoras 164

$\begin{array}{ll}\text { 5.5.2 Natureza jurídica da chamada tarifa de assinatura } & 165\end{array}$

$\begin{array}{ll}\text { 5.5.3 Impossibilidade de cobrança } & 167\end{array}$

$\begin{array}{ll}\text { 5.5.4 Repetição do indébito } & 170\end{array}$

CAPÍTULO IV - O MÍNIMO ÉTICO EXIGÍVEL

1. BOA-FÉ (noções gerais) 172

2. EVOLUÇÃO HISTÓRICA 174

3. OBJETIVAÇÃO DA BOA-FÉ NO DIREITO COMPARADO 177

$\begin{array}{ll}3.1 \text { França } & 177\end{array}$

$\begin{array}{ll}3.2 \text { Alemanha } & 177\end{array}$

$\begin{array}{ll}3.3 \text { Itália } & 178\end{array}$

$\begin{array}{ll}3.4 \text { Portugal } & 179\end{array}$

$\begin{array}{ll}3.5 \text { Espanha } & 180\end{array}$

3.6 Suíça $\quad 180$

3.7 Argentina 181

$\begin{array}{ll}3.8 \text { Outros ordenamentos } & 181\end{array}$

4. EXPERIÊNCIA BRASILEIRA 183

5. BOA-FÉ SUBJETIVA X OBJETIVA 185

6. A BOA-FÉ OBJETIVA E SUAS FUNÇÕES 187

$\begin{array}{ll}\text { 6.1 Fonte autônoma de deveres especiais de conduta } & 188\end{array}$

$\begin{array}{ll}\text { 6.1.1 Informar } & 189\end{array}$ 
6.1.1.1 O consentimento informado

$\begin{array}{ll}\text { 6.1.2 Colaboração (lealdade ou cooperação) } & 199\end{array}$

$\begin{array}{ll}6.1 .3 \text { Cuidado } & 199\end{array}$

$\begin{array}{ll}\text { 6.1.4 Sigilo } & 200\end{array}$

6.2 Limite ao exercício de direitos subjetivos 200

$\begin{array}{ll}\text { 6.2.1 Doutrina dos atos próprios } & 201\end{array}$

$\begin{array}{ll}\text { 6.2.2 Suppressio x surrectio } & 204\end{array}$

6.2.3 Teoria do adimplemento substancial 205

6.3 Critério de interpretação e concreção dos negócios jurídicos 207

7. O CDC E SUAS CLÁUSULAS ESPECÍFICAS 209

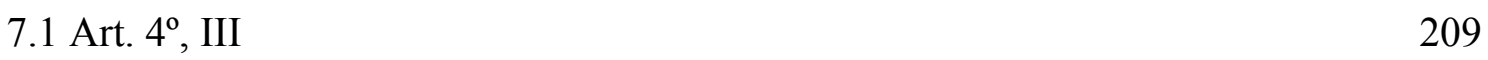

$\begin{array}{ll}7.2 \text { Art. 51, IV } & 210\end{array}$

8. INCIDÊNCIA AMPLA E IRRESTRITA 212

9. O SEGURO-SAÚDE E AS FALSAS DECLARAÇÕES 214

9.1 Distinção entre plano de saúde e seguro-saúde 215

9.2 Os reflexos jurídicos das falsas declarações 218

$\begin{array}{ll}9.3 \text { Doença preexistente } & 220\end{array}$

9.3.1 Consequências jurídicas $\quad 222$

$\begin{array}{ll}\text { 9.4 Dos contratos anteriores à Lei 9.656/98 } & 227\end{array}$

10. DIREITO DE ARREPENDIMENTO 231

10.1 Natureza jurídica 233

10.2 Elenco exemplificativo 235

10.3 Prazo (contagem e manifestação) 235

$\begin{array}{ll}10.4 \text { Vendas emocionais } & 238\end{array}$

CAPÍTULO V - DIREITOS BÁSICOS DO CONSUMIDOR

1. CONSIDERAÇÕES GERAIS 240

2. OFERTA (informação adequada) 241

2.1 Princípio da vinculação $\quad 242$

$\begin{array}{ll}2.2 \text { Exclusão ou limitação da obrigatoriedade } & 244\end{array}$ 
2.2.1 Interrupção do processo de formação

2.2.2 Reservas

2.2.3 Termo

2.2.4 Caso Fortuito e força maior

2.2.5 Falência do ofertante

2.2.6 Diversidade entre o anunciante e o fornecedor

2.3 Erro na oferta

2.4 Informação e seus caracteres

2.5 Descumprimento e opções

2.6 Contratos de adesão

\section{PUBLICIDADE}

3.1 Publicidade $\mathrm{x}$ propaganda

3.2 Publicidade $\mathrm{x}$ verdade

3.3 Os três vícios da publicidade

3.3.1 Publicidade clandestina

3.3.2 Publicidade enganosa

3.3.3 Publicidade abusiva

3.3.3.1 Publicidade comparativa

3.5 Responsabilidade civil 284

3.6 A questão do speedy 291

3.6.1 A dinâmica proposta pela fornecedora 292

3.6.2 Natureza do speedy 293

3.6.3 Análise do STJ (provedores de acesso x conteúdo) 294

3.6.4 Da prática abusiva e da publicidade enganosa 299

3.6.5 A obrigação de recompor o patrimônio do consumidor 304

4. REVISÃO CONTRATUAL 308

4.1 Modificação de cláusulas desproporcionais 309

4.2 Revisão superveniente x base do negócio 310

5. ACESSO À JUSTIÇA 314

5.1 Foro de eleição 314

5.1.1 Execução x local de pagamento do título 317 
5.2 Inversão do ônus da prova

5.2.1 Verossimilhança da alegação

5.2.2 Hipossuficiência

5.2.3 Momento da inversão 322

5.2.4 Ônus econômico x teoria da carga dinâmica 325

5.3 Desconsideração da personalidade jurídica 327

5.3.1 Desconsideração inversa x oportunidade de reconhecimento 330

5.4 A solidariedade ampla (a questão do comerciante) 331

CAPÍTULO VI - RISCO E RESPONSABILIDADE

1. PANORAMA CONSTITUCIONAL DA RESPONSABILIDADE CIVIL 336

2. OS RISCOS ENVOLVIDOS X A PERSPECTIVA CIVIL 343

2.1 Atividade 344

2.2 Normalmente desenvolvida $\quad 346$

2.2.1 Art. 931 do Código Civil: noção ampliada de fato do produto. 347

$2.3 \mathrm{O}$ risco e suas variações $\quad 348$

2.3.1 Risco integral x risco mitigado 349

2.3.2 Risco criado x risco proveito 349

2.4. Conteúdo normativo 351

3. A PRECAUÇÃO COMO FORMA DE CONTROLE DO RISCO 353

3.1. Delimitação da problemática 353

3.2 Natureza jurídica $\quad 354$

3.3 Noção e extensão

3.4 Precaução x prevenção 359

3.5 Precaução x responsabilidade civil 363

3.6 Risco residual x movimento pendular 365

$\begin{array}{ll}3.7 \text { Risco de desenvolvimento } & 369\end{array}$

4. A RESPONSABILIDADE DAS EMPRESAS FABRICANTES DE CIGARROS 374

4.1 Abuso do poder econômico x autonomia da vontade 376

4.2 Elementos inerentes à economia de massa 377

$\begin{array}{ll}4.3 \text { Atividade lícita } & 380\end{array}$ 
4.4 Conhecimento público dos riscos 382

4.5 A questão da publicidade e das advertências 389

4.6 Um histórico de respeito à lei 390

4.7 A questão do livre arbítrio 392

4.8 Inimputabilidade de danos x assunção de risco 394

4.9 Nexo causal como requisito da obrigação de indenizar 394

4.10 Possibilidade de consumo de diferentes marcas 397

4.11 Risco do produto segundo o CDC 398

CAPÍTULO VII - RESUMO ANALÍTICO DA PROPOSTA

1. PROPOSIÇÕES ANALÍTICAS 402

$\begin{array}{ll}\text { CONCLUSÃO } & 434\end{array}$

BIBLIOGRAFIA 436

$\begin{array}{ll}\text { ANEXOS } & 459\end{array}$

1. LEI 8.078/90 (texto compilado até 26.07.2011) 459

2. MENSAGEM DE VETO 


\section{INTRODUÇÃO}

Com efeito, a proposta para estudo e pesquisa durante o curso de doutorado da Universidade de São Paulo, Faculdade de Direito do Largo São Francisco, com área de concentração em Direito Civil, teve sua gênese a partir do título "os reflexos condicionantes da Parte Geral da Lei 8.078/90 na formatação do direito material positivo das relações de consumo".

Percebe-se, prima facie, que o tema se vincula diretamente à sistemática legislativa empregada na confecção do Código de Proteção e Defesa do Consumidor, notadamente quanto aos seus dez primeiros artigos e à opção de neles se inscreverem as vigas mestras estruturantes de todo o direito material positivo privado que a partir daí se formou.

É dizer: o direito material positivo das relações de consumo não pode ser visto e/ou interpretado de forma dissociada da Parte Geral da Lei 8.078/90, lídima regra de exegese dirigida a fixar o alcance e a profundidade desse arcabouço jurídico instituído, por determinação constitucional, para amparar esse especial sujeito que é o consumidor; mais que isso, inclinado a buscar a materialização do equilíbrio nas relações obrigacionais que gravitam em torno do mercado.

De fato, ao aglutinar normas com carga valorativa pinçada dos mais variados ramos do direito (v.g., processual, administrativo, penal, etc.), o Código de Defesa do Consumidor assume uma essência multidisciplinar, quase um microssistema hermenêutico auto-suficiente.

No entanto, a despeito da sua carga principiológica, o ponto medular desenvolvido na tese, que ora se apresenta, limita-se à análise da sua Parte Geral como fator condicionante das regras de direito material privado criadas no intuito de concretizar a vontade do Poder Constituinte originário de defender o consumidor, operando uma espécie de justiça distributiva em uma relação jurídica historicamente desequilibrada.

Essa linha de pensamento, pois, objetiva demonstrar a importância fundamental dos dez primeiros artigos da Lei 8.078/90, bastantes a sustentar toda a proteção material do consumidor, relegando-se às demais regras dessa natureza, constantes da parte especial, função meramente explicativa.

Problemas teóricos e práticos serão examinados e resolvidos sempre a partir do vetor interpretativo imposto pela Parte Geral do Código, v.g., como as 
questões relativas aos conflitos de direito intertemporal, à adequada inteligência do elemento finalista do conceito de consumidor, ao direito de o sujeito vulnerável receber mesmo sem pagamento algum - o que dele se cobrou indevidamente, à responsabilidade solidária entre o credor e o arquivista de dados e entre o fornecedor indireto e o comerciante também pelo fato do produto, à correta intelecção do sentido de obstar a decadência, ao termo inicial do praxo de reflexão, à possibilidade de imposição judicial da contrapropaganda, à responsabilidade civil de todos os envolvidos na cadeia da publicidade ilícita, à eventual divergência entre a oferta e o contrato, à inversão do ônus da prova a qualquer momento no processo, inclusive quanto ao seu encargo econômico, ao uso dos prazos extintivos mais elásticos previstos no sistema, e tantas outras.

A Constituição de 1988 contemplou toda a esfera de liberdades públicas, inclusive - num passo ambicioso - tratou dos direitos difusos e coletivos, o que determinou, em larga medida, ganhasse a Lex Fundamentalis força positiva própria ao definir ações estatais em benefício dos consumidores.

Por este prisma, o Código de Defesa do Consumidor representa uma preocupação do legislador moderno em garantir a eficácia desses novos direitos fundamentais, positivando-os em normas ordinárias; além disso, atua como instrumento de aplicação direta dos princípios constitucionais nas relações de direito privado, visando à preservação da dignidade da pessoa humana.

Força é concluir, assim, que se torna imprescindível compreender a real amplitude dos direitos materiais outorgados aos consumidores e, para tanto, só há um caminho: investigar profundamente os reflexos condicionantes da Parte Geral da Lei 8.078/90 na formatação daquilo que de melhor se pensou, em termos legislativos, para promover a defesa do consumidor. 


\section{CAPÍTULO I \\ O CÓDIGO DAS RELAÇÕES DE CONSUMO E SUA DOGMÁTICA}

SUMÁRIO: 1. INDERROGABILIDADE - 2. ORDEM PÚBLICA E RETROATIVIDADE 3. INTERESSE SOCIAL.

\section{INDERROGABILIDADE}

Prima facie, essa tentativa de construir uma teoria geral de proteção ao consumidor se desenvolverá a partir dos consistentes pilares estabelecidos pelos três primeiros Capítulos, do Título I, da Lei 8.078/90: Disposições Gerais (I), Da Política Nacional de Relações de Consumo (II) e Dos Direitos Básicos do Consumidor (III).

Indispensável, para tanto, manter-se sempre nítidos na memória certos elementos nucleares já verificados ${ }^{1}$ : as origens históricas, a mudança introduzida pela globalização e pela economia de massa, o declínio do voluntarismo, o abandono da falsa idéia da irrestrita autonomia da vontade, os conceitos, os fundamentos e os princípios constitucionais, a função principiológica da nova lei e as conclusões adotadas.

Pois bem. Concebeu-se a Lei 8.078/90 ex vi de comando transitório específico (ADCT, art. 48), em sintonia com a intenção marcante do Constituinte de proteger o consumidor (CF, arts. $5^{\circ}$, XXXII e 170, V), o que lhe confere status de garantia fundamental indisponível. Não bastasse isso, o legislador ordinário, para que nenhuma dúvida remanescesse, deixou clara como o sol que reluz a natureza jurídica das normas promulgadas: de ordem pública e de interesse social. ${ }^{2}$

Esses qualificativos significam que no microssistema protetivo instituído pela Lei 8.078/90 não se faculta às partes optar ou não pela aplicação dos seus dispositivos, que, portanto, não podem ser afastados pela simples convenção dos interessados, exceto havendo autorização legal expressa ${ }^{3}$, como nas hipóteses de

\footnotetext{
${ }^{1}$ Guilherme Ferreira da Cruz. Princípios constitucionais das relações de consumo e dano moral - outra concepção. São Paulo RT, 2008.

${ }^{2}$ CDC, art. $1^{\circ}$ : "o presente Código estabelece normas de proteção e defesa do consumidor, de ordem pública e interesse social, nos termos dos arts. $5^{\circ}$, XXXII, 170, V, da Constituição Federal e art. 48 de suas Disposições Transitórias".

${ }^{3}$ Arruda Alvim et alii. Código do Consumidor comentado. 2. ed. São Paulo: RT, 1995, p. 16.
} 
convenção coletiva (CDC, art. $107^{4}$ ), onde se admite a livre disposição de alguns interesses de caráter patrimonial. ${ }^{5}$

Objetiva-se, com esse cunho inderrogável, preservar a seguridade das relações jurídicas, proporcionando um equilíbrio para que possa o consumidor se equiparar ao fornecedor, inviabilizando a obtenção de indevidas vantagens contratuais. ${ }^{6}$

Elucida, com argúcia, Adalberto Pasqualotto: "a lei, assim, restringe a autonomia privada, retirando da esfera de disponibilidade dos indivíduos faculdades que tornavam mais desentravado o tráfego jurídico. Os interesses tutelados pelo Código tornaram-se indisponíveis, isto é, suscetíveis de tutela jurídica além da vontade individual do lesado. O Código procedeu assim tendo em vista o interesse social, posto que, na sociedade moderna, as relações de massa se sobrepuseram às individuais, de tal modo que estas se tornaram simples referências daquelas. A lesão de um pode ser a lesão de todos. Por conseguinte, os conflitos devem ser solucionados coletivamente, não se tolerando mais o individualismo cerceador da sua justicialidade". 7

Do ponto de vista prático, essa índole cogente permite ao magistrado, no exercício regular da jurisdição e presente uma relação de consumo, aplicar ex officio ${ }^{8}$ os comandos imperativos da Lei 8.078/90 para o fim de assegurar a observância dos direitos nela insculpidos. ${ }^{9}$

E mais, para Nelson Nery Júnior: "o tribunal pode, inclusive, decidir contra o único recorrente, reformando a decisão recorrida para pior, ocorrendo assim o que denominamos de reformatio in pejus permitida, já que se trata de matéria de

\footnotetext{
${ }^{4} \mathrm{CDC}$, art. 107: "as entidades civis de consumidores e as associações de fornecedores ou sindicatos de categoria econômica podem regular, por convenção escrita, relações de consumo que tenham por objeto estabelecer condições relativas ao preço, à qualidade, à quantidade, à garantia e características de produtos e serviços, bem como à reclamação e composição do conflito de consumo".

5 José Geraldo Brito Filomeno et alii. Código Brasileiro de Defesa do Consumidor, comentado pelos autores do anteprojeto. $4^{\mathrm{a}}$ ed. São Paulo: Forense Universitária, 1996, p. 23.

${ }^{6}$ Antônio Carlos Efing. Contratos e procedimentos bancários à luz do Código de Defesa do Consumidor. $1^{\mathrm{a}}$ ed. São Paulo: RT, 2000, p. 38.

${ }^{7}$ Conceitos fundamentais do Código de Defesa do Consumidor. RT, São Paulo: RT, v. 666, p. 49.

${ }^{8}$ Não se desconhece a Súm. 381 do STJ: "nos contratos bancários, é vedado ao julgador conhecer, de ofício, da abusividade das cláusulas". Aliás, seu enunciado, ao excluir apenas os contratos bancários da possibilidade de o Poder Judiciário conhecer abusos de ofício, na verdade, acaba confirmando para todas as outras situações o caráter inderrogável da Lei 8.078/90.

${ }^{9}$ Luiz Antonio Rizzatto Nunes. Comentários ao Código de Defesa do Consumidor. $4^{\mathrm{a}}$ ed. São Paulo: Saraiva, 2009, p. 94.
} 
ordem pública a cujo respeito a lei não exige a iniciativa da parte, mas, ao contrário, determina que o juiz a examine de ofício". ${ }^{10}$

Entretanto, em que pesem aos argumentos até aqui alinhados, essa incidência compulsória do CDC é limitada, pois não pode, de maneira alguma, prejudicar o consumidor, pena de inconstitucionalidade por afronta direta ao protecionismo determinado pela Lex Fundamentalis.

A matéria ganha relevo em sede de responsabilidade civil, verbi gratia, pelo fato do produto, ou seja, ultrapassado o prazo prescricional de cinco anos para exercício da pretensão à reparação de danos $\left(\mathrm{CDC}\right.$, art. $\left.27^{11}\right)$, poderá ainda o consumidor vítima invocar o direito comum para recompor seu prejuízo. ${ }^{12}$

Essa questão será renovada quando da análise da decadência e da prescrição (infra, Cap. III, 4.3.7).

\footnotetext{
${ }^{10}$ Os princípios gerais do Código Brasileiro de Defesa do Consumidor. Revista de Direito do Consumidor, São Paulo: RT, v. 3, set.-dez. 1992, p. 51/52.

${ }^{11}$ CDC, art. 27: "prescreve em 5 (cinco) anos a pretensão à reparação pelos danos causados por fato do produto ou do serviço prevista na Seção II deste Capítulo, iniciando-se a contagem do prazo a partir do conhecimento do dano e de sua autoria".

${ }^{12}$ Hoje o prazo prescricional para ações pessoais é de 10 anos (CC, art. 205).
} 


\section{ORDEM PÚBLICA E RETROATIVIDADE}

Com efeito, sendo de ordem pública e, por isso, dotado de incidência compulsória, o CDC acaba por provocar o ingresso do intérprete nas trilhas sinuosas do conflito de leis no tempo ${ }^{13}$, sem dúvida um dos temas mais tormentosos do direito.

Assinale-se, $a b$ initio, que o assunto guarda estreita afinidade com o princípio geral da segurança jurídica.

Mister se faz, neste passo, trazer à colação o magistério de J.

J. Gomes Canotilho:

"O homem necessita de segurança para conduzir, planificar e conformar autônoma e responsavelmente a sua vida. Por isso, desde cedo se consideravam os princípios da segurança jurídica e da protecção da confiança como elementos constitutivos do Estado de direito.

\section{$(\ldots)$}

Deduz-se já que os postulados da segurança jurídica e da proteção da confiança são exigíveis perante qualquer acto de qualquer poder legislativo, executivo e judicial.

\section{$(\ldots)$}

As refracções mais importantes do princípio da segurança jurídica são as seguintes: (1) relativamente a actos normativos - proibição de normas retroactivas restritivas de direitos ou de interesses juridicamente protegidos; (2) relativamente a actos jurisdicionais - inalterabilidade do caso julgado; (3) em relação a actos da administração - tendencial estabilidade dos casos decididos através de actos administrativos constitutivos de direitos."

Esse princípio da segurança jurídica, comentado pelo eminente jurista português, há muito conquistou status constitucional no direito pátrio ${ }^{15}$, e

\footnotetext{
${ }^{13}$ Francisco Amaral (Direito civil, introdução. $3^{\mathrm{a}}$ ed. Rio de Janeiro: Renovar, 2000, p. 101) entende que, "a vigência da norma jurídica manifesta-se no tempo (dimensão temporal) e no espaço (dimensão espacial). Quando surge a questão de saber qual a norma aplicável a determinado fato, a revogada ou a vigente, configura-se o conflito de normas no tempo".

${ }_{15}^{14}$ Direito constitucional e teoria da constituição. $4^{\mathrm{a}}$ ed. Coimbra: Almedina, p. 256.

${ }^{15}$ Segundo Celso Ribeiro Bastos (Curso de direito constitucional. 13 ${ }^{\mathrm{a}}$ ed. São Paulo: Saraiva, 1990, p. 199), "salvo a Constituição de 1937, todas as demais Constituições mantiveram-se fiéis à sacrossanta irretroatividade, respeitada, sempre, a formação técnica consistente no resguardo da já clássica trilogia (direito adquirido, ato jurídico perfeito e coisa julgada)".
} 
hoje se encontra insculpido, tal qual a defesa do consumidor (e isso é importante), como uma das garantias fundamentais da sociedade. ${ }^{16}$

Harmônica com o texto constitucional, intacta permanece a Lei de Introdução ao Código Civil, inclusive quanto às definições dos institutos do direito adquirido e do ato jurídico perfeito, núcleos de direito material. ${ }^{17}$

Salientam Luiz Alberto David Araujo e Vidal Serrano Nunes Júnior: "como se vê, em princípio, a lei tem eficácia imediata e ultra-ativa, passando a regular os atos e fatos jurídicos a partir de sua edição. Todavia, não existe uma proibição absoluta à retroeficácia. Respeitado o ato jurídico perfeito, a coisa julgada e o direito adquirido, a lei pode ter efeito retroativo, o qual, contudo, em face de seu caráter excepcional, deve vir textualmente declarado". ${ }^{18}$

É de pouca relevância para a temática proposta a investigação dos precisos significados desses institutos e, consequentemente, das suas semelhanças e das suas distinções ${ }^{19}$. Basta, in casu, assentar-se que, apesar da intrínseca diferença valorativa, as figuras do direito adquirido e do ato jurídico perfeito estão intimamente ligadas e exercem idêntica função: conferir força e legitimidade a direitos e a obrigações contrários ao disposto em leis posteriores. ${ }^{20}$

Aliás, nesse sentido já era a lição de Clóvis Beviláqua: “estas definições são sufficientemente claras e precisam o que se deve entender pela retroactividade das leis. Em rigor, tudo se reduz ao respeito assegurado aos direitos adquiridos; mas, como, no acto juridico e na coisa julgada, apresentam-se momentos

\footnotetext{
${ }^{16} \mathrm{CF}$, art. $5^{\circ}$, XXXVI: "a lei não prejudicará o direito adquirido, o ato jurídico perfeito e a coisa julgada".

${ }^{17}$ LICC, art. $6^{\circ}$ : "a Lei em vigor terá efeito imediato e geral, respeitados o ato jurídico perfeito, o direito adquirido e a coisa julgada". $\S 1^{\text {o: }}$ "reputa-se ato jurídico perfeito o já consumado segundo a lei vigente ao tempo em que efetuou". $\S 2^{\circ}$ : "consideram-se adquiridos assim os direitos que o seu titular, ou alguém por ele, possa exercer, como aqueles cujo começo do exercício tenha termo pré-fixo, ou condição preestabelecida inalterável, a arbítrio de outrem".

${ }^{18}$ Curso de direito constitucional. $4^{\text {a }}$ ed. São Paulo: Saraiva, 2001, p. 129.

${ }^{19}$ Para Celso Ribeiro Bastos (Curso..., cit., p. 203/204), “a rigor, o ato jurídico perfeito está compreendido no direito adquirido. Em outras palavras, não se pode conceber um direito adquirido que não advenha de um ato jurídico perfeito. (...) $\mathrm{O}$ ato jurídico perfeito é aquele que, se bem que acabado quanto aos elementos de sua formação, aguarda um instante ainda, ao menos virtual ou potencial, de vir a produzir efeitos no futuro. (...) Ato jurídico perfeito, pois, é aquele que se encontra apto a produzir os seus efeitos. (...). O direito adquirido, pelo contrário, implica fazer valer um direito, cujo conteúdo já se encontra revogado pela lei nova". Já para Francisco Amaral (Direito civil..., cit., p. 102), "direito adquirido é a conseqüência de uma lei, por via direta ou por intermédio de fato idôneo que, tendo passado a integrar o patrimônio do adquirente, não se fez valer antes da vigência da lei nova sobre o mesmo objetivo".

${ }^{20}$ Cláudia Lima Marques. Contratos no Código de Defesa do Consumidor. O novo regime das relações contratuais. $4^{\text {a }}$ ed. São Paulo: RT, 2002, p. 564/565.
} 
distinctos, aspectos particulares do direito adquirido, foi de vantagem, para esclarecimento da doutrina, que se destacassem esses casos particulares e delles se désse a justa noção". ${ }^{21}$

Quanto à lei nova e à possível influência da mudança legislativa na vida dos indivíduos, distinguem-se três realidades:

a) a influência nas relações futuras é certa e geralmente impossível de ser afastada, mesmo por disposição contratual;

b) a influência nas relações contratuais que já surtiram efeitos e consumaram-se é nenhuma, por motivos práticos e também em virtude da aplicação da garantia do ato jurídico perfeito; e

c) a influência, se possível, sobre os efeitos atuais de relações já existentes antes da entrada em vigor da nova lei. ${ }^{22}$

Eis a grande pergunta e o ponto medular da quaestio.

Não basta ao intérprete, pois, incidir naquilo que Pontes de Miranda chamou de vício das dicotomias simplistas, ou seja, “(...) a lei antiga rege os fatos realizados; as leis novas, os fatos que sob elas se deram. Esqueceu-lhe que há terceira espécie: os fatos ainda em curso de realização, os facta pendentia". ${ }^{23}$

Antes de se adentrar numa investigação mais profunda do tema, há de se registrar o magistério de Vicente Ráo: “a inviolabilidade do passado é princípio que encontra fundamento na própria natureza do ser humano, pois, segundo as sábias palavras de Portalis, o homem, que não ocupa senão um ponto no tempo e no espaço, seria o mais infeliz dos seres, se não se pudesse julgar seguro nem sequer quanto à sua vida passada. Por essa parte de sua existência, já não carregou todo o peso do seu destino? Na ordem do universo e da natureza, só o futuro é incerto e esta própria incerteza é suavizada pela esperança, a fiel companheira da nossa fraqueza. Seria agravar a triste condição da humanidade querer mudar, através do sistema da legislação, o sistema da natureza, procurando, para o tempo que já se foi, fazer reviver as nossas dores, sem nos restituir nossas esperanças". 24

\subsection{A teoria objetiva de Roubier}

\footnotetext{
${ }^{21}$ Theoria geral do direito civil. $6^{\mathrm{a}}$ ed. São Paulo: Editora Paulo de Azevedo, 1953, p. 22.

${ }^{22}$ Cláudia Lima Marques. Contratos..., cit., p. 559/562.

${ }^{23}$ Comentários à Constituição de 1967 com a emenda $n^{o} 1$ de 1969. $2^{\mathrm{a}}$ ed. São Paulo: RT, 1971, t. V, p. 60.

${ }^{24}$ O direito e a vida dos direitos. Quinto Milheiro - reedição, São Paulo: Max Limonad, 1960, v. I - t. II, p. 428.
} 
Paul Roubier ${ }^{25}$ partiu da distinção entre efeito retroativo e efeito imediato, procurando conceito mais precioso de retroatividade. Fez da incidencia imediata da lei a regra de direito comum, considerando que hoje e futuro são o mesmo. Daí ser indispensável separar o efeito imediato (permitido) e do efeito retroativo (proibido). ${ }^{26}$

Veja-se: "se a lei pretende aplicar-se aos fatos realizados (facta praeterita), é ela retroativa; se pretende aplicar-se a situações em curso (facta pendentia), convirá estabelecer uma separação entre as partes anteriores à data da modificação da legislação, que não poderão ser atingidas sem retroatividade, e as partes posteriores, para as quais a lei nova, se ela deve aplicar-se, não terá senão efeito imediato; enfim, diante dos fatos a ocorrer (facta futura), é claro que a lei não pode jamais ser retroativa". ${ }^{27}$

Igualmente se pronunciara Marcel Planiol: “(...) a lei é retroativa quando ela se volta para o passado, seja para apreciar as 'condições de legalidade de um ato', seja para modificar ou suprimir os 'efeitos de um direito já realizados'. Fora daí, não há retroatividade, e a lei pode modificar os 'efeitos futuros' de fatos ou atos anteriores, sem ser retroativa". 28

Porém, o próprio Roubier, depois de assentar que o efeito imediato é o direito comum, o normal - adotando, portanto, atitude estreme de reacionarismo - concedeu, contraditoriamente, que, em certas matérias, tanto se exclui o efeito imediato quanto o retroativo ${ }^{29}$. Ainda que os efeitos produzidos anteriormente à lei nova não fossem atingidos, a retroatividade seria temperada no seu efeito, não deixando, porém, de ser uma verdadeira retroatividade. ${ }^{30}$

\subsection{Graus de retroatividade}

\footnotetext{
${ }^{25}$ Le droit transitoire - conflits des lois dans le temps. $2^{\mathrm{a}}$ ed. Paris: Éditions Dalloz et Sirey, 1960.

${ }^{26}$ Pontes de Miranda. Comentários à Constituição de 1967..., cit., t. V, p. 63.

${ }^{27}$ Paul Roubier. Le droit transitoire..., cit., p. 177.

${ }^{28}$ Traité élémentaire de droit civil. 4a ed. Paris: Libraire Générale de Droit et de Jurisprudence, 1906 v. I, p. 95.

${ }^{29}$ Pontes de Miranda. Comentários à Constituição de 1967..., cit., t. V, p. 63.

${ }^{30} \mathrm{STF}$, ADI no 493-0, voto do rel. Min. Moreira Alves, j. 25.06.1992.
} 
Para que a matéria assuma um espectro mais claro no plano expositivo, vale lembrar a proposta de Matos Peixoto quanto à graduação da retroatividade pela sua intensidade:

"Dá-se a retroatividade máxima (também chamada restitutória, porque em geral restitui as partes ao 'statu quo ante'), quando a lei nova ataca a coisa julgada e os fatos consumados (transação, pagamento, prescrição). ${ }^{31}$

\section{$(\ldots)$}

A retroatividade é média quando a lei nova atinge os efeitos pendentes de ato jurídico verificados antes dela, exemplo: o decreto $\mathrm{n}^{\mathrm{o}} 22.626$, de 7 de Abril de 1933 (lei da usura), o qual limitou a taxa de juros e se aplicou aos contratos existentes, inclusive os ajuizados.

Enfim a retroatividade é mínima (também chamada temperada ou mitigada), quando a lei nova atinge apenas os efeitos dos atos anteriores produzidos após a data em que ela entrou em vigor.",32

Força é concluir, por conseguinte, que a incidência imediata da lei nova para afastar a antiga dos efeitos, agora proibidos mas ainda não produzidos, do ato jurídico perfeito corresponde à terceira espécie enumerada por Matos Peixoto: a retroatividade mínima.

\subsection{Paradigma do STF (leading case)}

E essa hipótese já foi objeto de apreciação pela plenária do STF, inclusive quanto à irrelevância da natureza jurídica da lei nova: se de ordem pública ou de ordem privada. Na oportunidade, por maioria, prevaleceu o voto primoroso do Min. Moreira Alves. ${ }^{33}$

\footnotetext{
${ }^{31}$ Tal é o decreto de Alexandre III que, em ódio à usura, mandou os credores restituírem os juros recebidos. À mesma categoria pertence a célebre lei francesa de 2 de novembro de 1973 (12 brumário do ano II), na parte em que anulou e mandou refazer as partilhas já julgadas, para os filhos naturais serem admitidos à herança dos pais, desde 14 de julho de 1789. A carta de 10 de novembro de 1937, artigo 95, parágrafo único, previa a aplicação da retroatividade máxima, porquanto dava ao Parlamento a atribuição de rever decisões judiciais, em excetuar as passadas em julgado, que declarassem inconstitucional uma lei.

${ }^{32}$ Limite temporal da lei. $R T$, ano 37, junho de 1948, v. 173, p. 468.

33 A ementa, no que interessa à temática sub examine, encontra-se assim redigida: "ação direta de inconstitucionalidade. - Se a lei alcançar os efeitos futuros de contratos celebrados anteriormente a ela, será essa lei retroativa (retroatividade mínima) porque vai interferir na causa, que é um ato ou fato ocorrido no
} 
Do V. Aresto extrai-se o seguinte excerto com referência às teorias de Roubier e de Planiol:

“Essas colocações são manifestamente equivocadas, pois dúvida não há de que, se a lei alcançar os efeitos futuros de contratos celebrados anteriormente a ela, será essa lei retroativa porque vai interferir na causa, que é um ato ocorrido no passado. Nesse caso, a aplicação imediata se faz, mas com efeito retroativo.

\section{$(\ldots)$}

Por outro lado, no direito brasileiro, a eficácia da lei no tempo é disciplinada por norma constitucional (...) que se aplica a toda e qualquer lei infraconstitucional, sem qualquer distinção entre a lei de direito público e lei de direito privado, ou entre lei de ordem pública e lei dispositiva."

No concernente às leis de ordem pública, citando o mesmo Roubier, prossegue o Min. Moreira Alves: “a idéia de ordem pública não pode ser posta em oposição ao princípio da não-retroatividade da lei, pelo motivo decisivo de que, numa ordem jurídica fundada na lei, a não-retroatividade das leis é ela mesma uma das colunas de ordem pública. (...) A lei retroativa é, em princípio, contrária à ordem pública; e, se excepcionalmente o legislador pode comunicar a uma lei a retroatividade, não conviria imaginar que, com isso, ele fortalece a ordem pública; ao contrário, é um fermento de anarquia que ele introduz na sociedade, razão por que não deve ser usada a retroatividade senão com a mais extrema reserva". 34

Irretorquível a lógica do voto condutor e, assim, em princípio, arreda-se a possibilidade de a lei nova, mesmo de ordem pública, alcançar os efeitos ainda não produzidos de ato jurídico perfeito (retroatividade mínima). Contudo, essa controvérsia está longe de ser resolvida ${ }^{35}$, mormente em sede de relações de consumo.

passado. - O disposto no artigo $5^{\circ}$, XXXVI, da Constituição Federal se aplica a toda e qualquer lei infraconstitucional, sem qualquer distinção entre lei de direito público e lei de direito privado, ou entre lei de ordem pública e lei dispositiva. Precedente do STF” (STF, ADI 493-0, rel. Min. Moreira Alves, j. 25.06.1992).

${ }^{34}$ Idem.

${ }^{35}$ Cf., em sentido contrário, Orlando Gomes (Direito Econômico. São Paulo: Saraiva, 1977, p. 59): “outro princípio que sofre alteração frente à ordem pública dirigista é o da intangibilidade dos contratos. Sempre que uma nova lei é editada nesse domínio, o conteúdo dos contratos que atinge tende se adaptar às suas inovações. Semelhante adaptação verifica-se por força de aplicação imediata das leis desse teor, sustentada como prática necessária à funcionalidade da legislação econômica dirigista. Derroga-se com o princípio da aplicação imediata a regra clássica do direito intertemporal que resguarda os contratos de qualquer intervenção legislativa decorrente de lei posterior à sua conclusão”. 
Por ora, cumpre lembrar, com Cláudia Lima Marques, que “(...) o Supremo Tribunal Federal solucionou o caso de forma extremamente positiva para os consumidores envolvidos, mas fixou uma interpretação pura de ato jurídico perfeito que está na prática determinando a não-aplicação do CDC a uma série de contratos hoje litigiosos". 36

2.4 A defesa do consumidor como garantia fundamental

Frise-se, desde já, que as generalizações (ou orientação de caráter agudo $^{37}$ ) nesta matéria são perigosas, pois nem todas as leis novas de ordem pública são benéficas aos consumidores e nem todas são prejudiciais. Basta anotar os diversos planos e mudanças econômicas implementados durante nossa recente história, quase sempre prejudiciais à coletividade. ${ }^{38}$

Infere-se do v. aresto analisado (supra, 2.3) que uma especial importância foi conferida à causa (expectativas legítimas) determinante do equilíbrio inicial do contrato, assim como a necessidade de resguardá-la quando da execução. ${ }^{39}$

Mas essa teoria colide, no mínimo, com três obstáculos intransponíveis. Guardando o direito adquirido fonte de legitimidade no sistema jurídico, impossível cogitar-se de direito adquirido ao abuso; da mesma forma, não se legitima o ato jurídico perfeito (assinado, porém ilícito ou inválido) tão-só pela introdução de lei nova no sistema; e, por fim, não há equilíbrio em contratos de massa.

Imperiosa, neste passo, é a precisa lição de Cláudia Lima Marques:

“Este argumento lógico da 'causa/efeito' falha ao extinguir a possibilidade de exame da 'causa', melhor dizendo da validade da 'causa', por exemplo, da cláusula contratual ilícita ou abusiva presente neste contrato que agora se examinam os 'efeitos'.

(...)

\footnotetext{
${ }^{36}$ Contratos..., cit., p. 568.

${ }^{37}$ Rubens Limongi França. A irretroatividade das leis e o direito adquirido. $4^{\mathrm{a}}$ ed. São Paulo: RT, 1994, p. 270.

${ }^{38}$ Idem, p. 255.

${ }^{39}$ STF, ADI 493-0, voto do Min. Nery da Silveira, j. 25.06.1992.
} 
Destaco o perigo desta argumentação e sua lógica, pois considero que o princípio da boa-fé nas relações contratuais e o ideal de combate ao abuso do direito e uso indevido das posições dominantes no mercado já existiam antes da entrada em vigor da Constituição Federal de 1988 (e sua garantia de proteção dos consumidores), assim como antes da entrada em vigor do Código de Defesa do Consumidor.

\section{(...)}

Face a nova lei, estaria o julgador impedido de examinar os 'atos jurídicos assinados' (causa) e teria que tolerar todos os efeitos, mesmo os antes não tolerados - abusivos - dos atos assinados (efeito)."40

Destaca Antonio Carlos Efing, com arrimo em precedente do extinto TAMG: "é importante observar, ainda nesse âmbito, que vários dos dispositivos do CDC coincidem com aquilo que a doutrina e a jurisprudência professavam há algum tempo, conferindo mesmo roupagem nova a antigas concepções. E muitas de suas modificações não importam novidade que despreza todas as construções anteriores: há, em verdade, rejuvenescimento, evolução; as limitações impingidas à liberdade contratual ocorrem não para exterminá-la, mas para preservar sua essência, atingida que estava pelas relações atuais, face ao desequilíbrio entre os contratantes. Surge uma nova concepção do contrato, em que o interesse social é a pedra angular". ${ }^{41}$

Lúcido como sempre o voto (apesar de vencido) do Min. Ruy Rosado de Aguiar: "diz-se que a sua aplicação a contrato assinado antes da sua vigência significaria violação ao princípio da irretroatividade da lei, assim como expresso na Constituição da República. Ocorre que, tanto agora como antes, não há como admitir um direito subjetivo fundado em cláusula iníqua, nem validade de ato negocial onde se manifesta o arbítrio de uma das partes, com exercício abusivo de direito". 42

De outra banda, em que pesem aos entendimentos contrários, é possível admitir a retroatividade mínima como exceção à regra da irretroatividade da lei nova vigente no direito brasileiro $^{43}$; porém, assim deve ser tratada, ou seja, sua interpretação e sua aplicação devem ser estritas.

\footnotetext{
${ }^{40}$ Contratos..., cit., p. 572/573.

${ }^{41}$ TAMG, AC 233177-1, Rel. Juiz Wander Marotta, DJ/MG de 12-08-1997.

${ }^{42}$ STJ, REsp. 45.666/SP, voto vencido do Min. Ruy Rosado de Aguiar, j. 17.05.1994.

${ }^{43} \mathrm{STF}, \mathrm{ADI} \mathrm{n}^{\circ}$ 493-0, voto do Min. Celso de Mello, j. 25.06.1992.
} 
Mas qual seria o critério para essa permitida retroatividade mínima?

Um norte objetivo para o intérprete é, sem dúvida, até pela sua posição hierárquica no sistema, a própria Constituição da República. Daí, mais uma vez, a importância de a preocupação com a defesa do consumidor estar incluída entre os direitos e as garantias fundamentais (CF, art. $\left.5^{\circ}, \mathrm{XXXII}\right)$.

Saliente-se que a incidência imediata das normas constitucionais, todas elas $^{44}$ revestidas de eficácia derrogatória das regras e dos atos dotados de positividade jurídica inferior, não permite que se invoque contra elas qualquer situação juridicamente consolidada. Assim, o ato jurídico perfeito, a coisa julgada e o direito adquirido, embora imunes à ação legislativa ordinária, que não poderá afetá-los, mostram-se irrelevantes em face da inquestionável supremacia formal e material das regras constitucionais. $^{45}$

Pois bem. Revela essa divergência, na verdade, uma antinomia entre duas regras de igual status jurídico: a preservação do ato jurídico supostamente perfeito (valor individual) x a defesa do consumidor como dever do Estado (valor social). Factível, assim, valer-se o operador do princípio da proporcionalidade a fim de buscar o equilíbrio dos interesses em jogo, relativizando-os se necessário para melhor concretizar a dignidade da pessoa humana.

E a professora Cláudia Lima Marques, invocando expressão utilizada pelo então Min. do STF Aliomar Baleeiro, ressalta que “(...) a defesa do consumidor é um 'quadrado' tão constitucional quanto o ato jurídico perfeito e que não deve ser ignorado pelo julgador". ${ }^{46}$

Segundo Gustavo Tepedino, “(...) é imperioso interpretar restritivamente a noção de direito adquirido, de molde a não abranger os efeitos futuros de negócios jurídicos que, posto praticados legalmente no passado, são hostilizados pela lei nova. Até a entrada em vigor desta, há de se proteger os efeitos produzidos pelo ato jurídico perfeito, sempre que definitivamente incorporados ao patrimônio de alguém. Cuidando-se, entretanto, de relações de trato sucessivo, pretender fazer prevalecer por anos a fio, projetada para o futuro, a produção de efeitos e a incorporação de novos efeitos no

\footnotetext{
${ }^{44}$ Com origem no Poder Constituinte originário, advirta-se.

${ }^{45}$ José Celso de Mello Filho. Constituição Federal anotada. $2^{a}$ ed. São Paulo: Saraiva, 1986, p. 431.

${ }^{46}$ Contratos..., cit., p. 575.
} 
patrimônio individual, por força de comportamento ou atividade que a sociedade considera nocivos ao convívio social, parece-nos excessivo. Mais que excessivo, parece-me deliberada subversão da vontade constitucional". ${ }^{47}$

\subsection{Solução correta}

Posturas radicais nessa esfera, como se verificou, podem gerar mais prejuízos do que benefícios à parte inferiorizada no vínculo contratual (supra, 2.4); logo, possível admitir-se nas relações de consumo a retroatividade mínima excepcional, porquanto há de se ponderar, sempre, a garantia constitucional da defesa do consumidor.

E por que só em benefício do consumidor?

A resposta está no próprio texto constitucional: “o Estado promoverá, na forma da lei, a defesa do consumidor" (CF, art. 5, XXXII); e não, ao contrário do que possa parecer, no caráter de ordem pública insculpido no art. $1^{\circ}$ da Lei $8.078 / 90$.

Com isso, a reconhecida vulnerabilidade do consumidor exige dos poderes estatais constituídos (Executivo, Legislativo e Judiciário) uma efetiva defesa, que só atingirá um sentido concreto se alcançar, na sua ótica protecionista subjetiva, uma retroatividade mínima.

Não é, pois, qualquer lei de ordem pública que pode incidir imediatamente sobre efeitos ainda não produzidos de atos jurídicos aperfeiçoados sob a égide de lei anterior, depende, para tanto, que haja expressa disposição constitucional autorizante, em plena sintonia com os fundamentos e com os objetivos da República.

Esta nova linha de interpretação relativa necessariamente a mencionada noção de ato jurídico perfeito, ou haverá violação de outro princípio constitucional, que é a defesa do consumidor, ao se negar o juiz a examinar a licitude da imposição contratual face ao novo mandamento de maior lealdade no mercado e relativização do dogma absoluto da autonomia da vontade. ${ }^{48}$

\footnotetext{
${ }^{47}$ As relações de consumo e a nova teoria contratual. Temas de Direito Civil. $2^{\mathrm{a}}$ ed. Rio de Janeiro: Renovar, 2001, p. 214.

${ }^{48}$ Cláudia Lima Marques. Contratos..., cit., p. 578.
} 
E conclui a brilhante professora gaúcha no sentido de que, “(...) a aceitação desta tese, quanto ao que se refere à aplicação do CDC como lei mais benéfica ao consumidor, mesmo aos contratos anteriores, significa a aceitação da mudança dos princípios orientadores do direito civil - talvez por influência mesmo constitucional e da possibilidade de intervenção e dirigismo estatal. Esta nova visão desloca a importância do corolário da autonomia da vontade e da obrigatoriedade do pactuado, para o problema da função social do direito privado, para considerar que a eficácia dos atos decorre da lei, a qual os sanciona porque são úteis, com a condição de serem justos tanto no momento de sua formação, quanto de sua execução". 49

\subsection{Código Civil x CDC (o diálogo das fontes)}

Partindo-se do inegável caráter especial do CDC, a lhe conferir preponderância de disciplina na esfera jurídica infraconstitucional naquilo que pertine às relações de consumo, a significativa contribuição da teoria do diálogo das fontes está justamente em harmonizar suas regras às de outros sistemas de direito privado, com destaque para o Código Civil, informado por idênticos princípios (v.g., função social, boafé objetiva, etc.), apesar de restrito a um campo de aplicação individual, sobretudo àquelas reguladoras de contratos e de obrigações, o que contribui para ampliar a proteção dos consumidores. ${ }^{50}$

Tal qual aborda, com precisão, Cláudia Lima Marques ${ }^{51}$, a antiga estrutura tripartite para solução dos conflitos de leis no tempo proposta por Norberto Bobbio $^{52}$ cede à necessidade de se coordenar/harmonizar as diversas fontes legislativas plúrimas de um único ordenamento sistêmico, cada vez mais fluído e complexo ${ }^{53}$, sem

\footnotetext{
${ }^{49}$ Cláudia Lima Marques. Contratos..., cit., p. 581.

${ }^{50}$ Adalberto Pasqualotto e Roberto Augusto Castellanos Pfeiffer (coord). Código de Defesa do Consumidor e $o$ Código Civil de 2002. Convergências e assimetrias. RT: São Paulo, 2005, p. 5.

${ }^{51}$ Três tipos de diálogos entre o Código de Defesa do Consumidor e o Código Civil de 2002: superação das antinomias pelo "diálogo das fontes". In: Pasqualotto, Adalberto e Pfeiffer, Roberto Augusto Castellanos (coord). Código de Defesa do Consumidor e o Código Civil de 2002..., cit, p. 11-82.

${ }_{52}$ Para ele (Teoria do ordenamento jurídico. São Paulo/Brasília: Pollis/Universidade de Brasília, 1990, p. 92), os critérios para resolver os conflitos de leis no tempo seriam três: anterioridade, especialidade e hierarquia, com primazia desta.

${ }_{53}$ Antonio Junqueira de Azevedo. O direito pós-moderno e a codificação. Revista de Direito do Consumidor, São Paulo: RT, v. 33, jan.-mar. 2000, p. 124 e ss.
} 
prévia exclusão de qualquer delas, num processo de coerência derivada ou restaurada ${ }^{54}$, naquilo que Erik Jayme sintetizou como diálogo das fontes. ${ }^{55}$

Diálogo porque há influências recíprocas, a ponto de se admitir a aplicação conjunta de diferentes normas, a um só tempo e ao mesmo caso, de modo tanto complementar quanto subsidiário; todavia, na tutela das relações obrigacionais estabelecidas entre não iguais, marcadas pelo desequilíbrio e pela preponderância de um sobre o outro, a ótica subjetiva protecionista do CDC permite apenas a intercomunicação de fontes para melhor concretizar a defesa do consumidor ${ }^{56}$, corolário do princípio do não retrocesso.

Por isso é que o art. $7^{\circ}$, caput, da Lei ${ }^{\circ}$ 8.078/90, lídima interface permeável, em nítido tônus de acréscimo, deixou claro que "os direitos previstos neste Código não excluem outros decorrentes de tratados ou convenções internacionais de que o Brasil seja signatário, da legislação interna ordinária, de regulamentos expedidos pelas autoridades administrativas competentes, bem como dos que derivem dos princípios geais do direito, analogia, costumes e equidades".

A equidade, percebe-se, entendida como a justiça do caso concreto, a cumprir a determinante constitucional positiva prevista no seu art. $3^{\mathrm{o}}, \mathrm{I}^{57}$, nas

\footnotetext{
${ }^{54}$ Nathalie Sauphanor. L'Influence du Droit de la Consommation sur le système juridique. Paris: LGDJ, 2000, p. 23-32 (cohérence dérivée ou restaurée).

55 Identité culturelle et intégration: Le droit internationale privé postmoderne. In: Recueil des Cours de l'Académie de Droit International de la Haye. 1995, II, p. 60 e ss. Para o autor, o fenômeno encerra uma coordenação flexível e útil (effet utile) das normas em conflito no sistema a fim de restabelecer a sua coerência, isto é, uma mudança de paradigma: da retirada simples (revogação) de uma das normas em conflito do sistema jurídico (ou do "monólogo" de uma só norma possível à "comunicar" a solução justa), à convivência destas normas, ao diálogo das normas para alcançar a sua ratio, a finalidade "narrada" ou "comunicada" em ambas.

${ }^{56}$ Em outra obra (et alii. Comentários ao Código de Defesa do Consumidor. $3^{\mathrm{a}}$ ed. São Paulo: RT, 2010, p. 312), assevera Cláudia Lima Marques: “diante da pluralidade atual de leis, há que se procurar o diálogo, utilizando a lei mais favorável ao consumidor. Assim, no caso do CC/2002, o ideal não é mais perguntar somente qual o campo de aplicação do novo Código Civil de 2002, quais seus limites, qual o campo de aplicação do CDC e quais seus limites, mas visualizar que a relação jurídica de consumo é civil e é especial, tem uma lei geral subsidiária por base e uma (ou mais) lei especial para proteger o sujeito de direito, sujeito de direitos fundamentais, o consumidor. Nesta ótica, ambas as leis se aplicam à mesma relação jurídica de consumo e colaboram com a mesma finalidade, concorrendo, dialogando, protegendo, com luzes e eficácias diferentes caso a caso, mas com uma mesma finalidade, a cumprir o mandamento constitucional. Nesse sentido, não é o CDC que limita o Código Civil, é o Código Civil que dá base e ajuda o CDC, e se o Código Civil for mais favorável ao consumidor do que o CDC, não será esta lei especial que limitará a aplicação da lei geral (art. $7^{\circ}$ do $\left.\mathrm{CDC}\right)$, mas sim dialogarão à procura da realização do mandamento constitucional de proteção especial do sujeito mais fraco. Assim, por exemplo, se o prazo prescricional ou decadencial do $\mathrm{CC} / 2002$ é mais favorável ao consumidor, deve ser este o usado, pois, ex vi art. $7^{\circ}$ do CDC, deve-se usar o prazo prescricional mais favorável ao consumidor".

${ }^{57} \mathrm{CF}$, art. $3^{\circ}$, I: "constituem-se objetivos fundamentais da República Federativa do Brasil: I - construir uma sociedade mais livre, justa e solidária".
} 
lacunas desse específico microssistema, sempre atua como fonte autônoma de direitos em prol da defesa do consumidor.

A opção legislativa brasileira, ao unificar - no Código Civil as obrigações civis e empresariais (assumidas entre iguais), mantendo uma regência autônoma, o CDC, com primazia hierárquica, aplicado em diálogo é certo, a extrair efeitos úteis, para os vínculos entre desiguais, difere dos paradigmas estrangeiros, a exemplo do que ocorre na França, na Itália e na Alemanha.

No direito francês permaneceram intactos os Códigos Civil e Comercial, enquanto o chamado Código do Consumo (Code de la Consommation) aglutinou as normas protetivas então dispersas no ordenamento. A Itália preferiu incorporar ao Código Civil algumas das suas leis especiais de direito privado, a unificar as obrigações civis e empresariais, mas também incluiu - na sua parte especial ${ }^{58}$ - a proteção do consumidor entre as normas contratuais (Dei contratti del consumatore), embora ainda subsistam esparsas outras regras protetivas; já a reforma alemã incorporou todas as leis especiais ao BGB, sua lei geral.

Conclui-se, nesta quadra, que o substrato desse diálogo de fontes é a busca da eficácia útil das normas existentes no sistema, complexo e plural, preferindo a aplicação conjunta - harmônica, coordenada e com coerência - à exclusão, total ou parcial, de uma delas com base em conflitos, reais ou aparentes, a impedir um monólogo legislativo desprovido de oxigenação.

2.7 A multa de 2\% (Lei 9.298/96)

Um dos possíveis reflexos concretos da questão até aqui tratada reside na incidência da multa moratória limite estabelecida pelo art. $52, \S 1^{\circ}$, da Lei $8.078 / 90$, cujo teto foi reduzido de $10 \%$ para $2 \%$ do valor da prestação pela Lei 9.298 , de $1^{\circ}$ de agosto de 1996.

Impende frisar que os contratos celebrados após a vigência da lei de redução não poderiam estipular multa de mora superior a $2 \%$ do valor da prestação, pena de ser reduzida ao patamar legal.

\footnotetext{
${ }^{58}$ Arts. 1.469 -bis a 1.469 -sexies.
} 
Surge o problema com a retroatividade, ou seja, para os ajustes aperfeiçoados antes da lei de redução.

Hão de se dividir dois grandes grupos, relegando-se ao primeiro aqueles onde o inadimplemento (causa da multa) já estava caracterizado quando da alteração legislativa e, assim, incorporado ao patrimônio do credor o direito de receber a multa tal qual pactuada (até $10 \%$ se de consumo a relação), sendo impossível a retroatividade (CF. art. $5^{\circ} \mathrm{XXXVI).}$

No outro grupo ficam os contratos onde, apesar da expressa menção de multa moratória superior ao novo limite $(2 \%)$, o inadimplemento só se materializou após a vigência da Lei 9.298/96. Aqui comporta uma subdivisão em face do momento do ajuste: se antes ou depois do CDC.

E isto é relevante.

\subsubsection{Contrato anterior ao CDC}

Nesta hipótese, a retroatividade mínima, excepcional (supra, 2.4 e 2.5), dependeria, para seu reconhecimento, da identificação do abuso, da injustiça, do enriquecimento ilícito, etc.

Por este prisma, a análise deve ser feita caso a caso, aferindose, em concreto, o dolo de aproveitamento e o desequilíbrio incomum do encargo entre as partes.

Em regra, essa multa ficava restrita a $10 \%$, o que não se mostra exagerado, aliás, a limitação da cláusula penal nesse patamar já era do nosso sistema (Dec. $\mathrm{n}^{\mathrm{o}} 22.626 / 33$, art. $9^{\circ}$ ), e tem sido usada pela jurisprudência quando da aplicação da regra do art. 924 do $\mathrm{CC}^{59}$, tanto que adotada pela redação original do art. $52, \S$ $1^{\circ}$, da Lei 8.078/90.

\subsubsection{Contrato posterior ao CDC}

Identifica-se diversa realidade jurídica, pois agora se tem a lei responsável pela defesa do consumidor, concretizando, em sua plenitude, direito e garantia

\footnotetext{
${ }^{59}$ STJ, REsp. 57.974-0/RS, rel Min. Ruy Rosado de Aguiar, j. 25.04.1995.
} 
fundamental da sociedade e princípio basilar da ordem econômica (CF, arts. $5^{\circ}$, XXXII, c.c. $170, \mathrm{~V})$; logo, os contratos de consumo celebrados a partir de 11 de março de 1991 estão impregnados desse animus protecionista do Estado.

E a Lei 9.298/96 veio justamente modificar um dispositivo do CDC para que este estatuto pudesse, mais adequadamente, cumprir sua função no sistema constitucional: a de melhor promover a defesa do consumidor.

Ressalte-se, por oportuno, que esses contratos já nasceram sob a força condicionante de um teto legal para as multas de mora; assim, não há surpresa na ação intervencionista do Estado em prol do consumidor, até porque fundada em diretriz positiva constitucional.

Ao rigor desse raciocínio, nos contratos celebrados entre as vigências das Leis $\mathrm{n}^{\circ} \mathrm{s}$ 8.078/90 e 9.298/96, despontando a mora após a segunda, a adequação dos $10 \%$ para os $2 \%$ nada mais faz do que assegurar o cumprimento imediato daquilo que a coletividade, por intermédio de seus representantes (Congresso Nacional), entendeu como razoável.

Distingue-se da primeira proposta (supra, 2.7.1) porque o julgador, aqui, não precisa se valer da teoria da retroatividade mínima, dependente do abuso no caso concreto, basta seja aclarado que sempre houve um limite máximo para a multa e a medida é de adequação e não de alteração. A substância do ato, pois, permanece inalterada. $^{60}$

\footnotetext{
${ }^{60}$ Não se desconhece a maciça inclinação jurisprudencial em sentido contrário: STJ, REsps. 323.807/RS, j. 21.06.2001; 314.517/RS, j. 17.05.2001; 230.672/SP, j. 03.04.2001; 258.160/RS, j. 16.11.2000; 283.095/MG, j. 28.11.2000; 177.637/RS, j. 05.10.1999; 257.001/SC, j. 17.08.2000; 192.181/MG, j. 29.06.2000; 250.971/SP, j. 06.06.2000; 247.504/RS, j. 01.06.2000; 232.266/SC, j. 04.05.2000; AGREsp. 317.816/DF, j. 07.08.2001 e AGA 262.595/SP, j. 15.03.2001.
} 


\section{INTERESSE SOCIAL}

Ao lado da ordem pública, o interesse social acentua a intenção protecionista do Estado, deixando evidente a função do CDC de ponto regulador da ordem econômica nacional, indispensável para que sejam efetivamente buscados e realizados os valores sociais da livre iniciativa.

Para Marcelo Gomes Sodré, "na verdade, esta é uma forma de dar, genericamente falando, um caráter de direito público às leis de defesa dos consumidores. Retirar as relações de consumo do mundo meramente privado importa em dar um caráter de relevância social a essa relação, na exata medida em que será essencial a toda a sociedade o respeito aos princípios básicos que a regulam". ${ }^{61}$

Com efeito, assume o interesse social papel de singular destaque no que tange à atuação do Ministério Público na defesa dos direitos dos consumidores, mormente quanto à legitimidade ativa ad causam para propor ações civis coletivas, remédios jurídicos de suma importância.

Elucida, com propriedade, Gabriel Stiglitz: "percebendo, então, que os interesses violados ou afetados dos consumidores habitualmente se revestem de natureza supra-individual (coletivos ou difusos), é lógico que as normas de defesa do consumidor devem apontar soluções coletivas". ${ }^{62}$

Diante disso, razoável se faça uma investigação, conquanto perfunctória, acerca das novas espécies de direitos introduzidos no sistema pátrio pela Constituição Federal e pelo CDC, ou seja, os de terceira geração ou metaindividuais: difusos, coletivos e individuais homogêneos.

Sublinhe-se, a propósito, que a adequada distinção entre eles depende da correta fixação do objeto litigioso do processo (pedido e causa de pedir) ${ }^{63}$ onde

\footnotetext{
${ }^{61}$ A construção do direito do consumidor. Um estudo sobre as origens das leis principiológicas de defesa do consumidor. São Paulo: Atlas, 2009, p. 199/200.

${ }^{62}$ Las acciones colectivas em proteccion del consumidor. Revista Direito do Consumidor, São Paulo: RT, v. 15, jul.-out. 1995, p. 20. No original: "atendiendo entonces, que los intereses amenazados o afectados de los consumidores, habitualmente revisten esa naturaleza supra-individual (colectivos o difusos), es lógico que las normas de defensa del consumidor han de apontar soluciones colectivas o grupales".

${ }^{63}$ Kazuo Watanabe et alii. Código Brasileiro de Defesa do Consumidor, comentado pelos autores do anteprojeto. $4^{\text {a }}$ ed. São Paulo: Forense Universitária, 1996, p. 507.
} 
se dará a defesa coletiva ${ }^{64}$. Ou, em outras palavras, a pedra de toque do método classificatório do direito ou do interesse posto em jogo é o tipo de tutela jurisdicional que se pretende quando se propõe a competente ação judicial. ${ }^{65}$

No mais, os termos interesses e direitos foram utilizados como sinônimos, certo é que, a partir do momento em que passam a ser amparados pelo direito, os interesses assumem o mesmo status de direitos, desaparecendo qualquer razão prática, e mesmo teórica, para a busca de uma diferenciação ontológica entre eles. ${ }^{66}$

\subsection{Difusos}

Entendem-se como interesses ou direitos difusos, para efeitos da lei consumerista, os transindividuais de natureza indivisível, de que sejam titulares pessoas indeterminadas e ligadas por circunstâncias de fato (CDC, art. 81, par. ún., I).

Neste conceito, optou-se pelo critério da indeterminação dos titulares e da inexistência entre eles de ralação jurídica-base, no aspecto subjetivo, e pela indivisibilidade do bem jurídico, no aspecto objetivo. ${ }^{67}$

São marcantes: a indivisibilidade do objeto e a indeterminação dos titulares.

Observe-se, os direitos e interesses estritamente individuais, esparsos mas conectados uns aos outros, pela similaridade de circunstâncias de fato enquanto aglutinados, configuram um outro bem jurídico, de interesse social, protegível pelo direito material e processual, através de regras cogentes e de ordem pública. ${ }^{68}$

Isto impede que uma ação meramente individual (partícula esparsa de direito) projete no mundo jurídico efeitos metaindividuais, como se fosse a própria representação de todos os sujeitos envolvidos. ${ }^{69}$

\footnotetext{
${ }^{64} \mathrm{CDC}$, art. 81: "a defesa dos interesses e direitos dos consumidores e das vítimas poderá ser exercida em juízo individualmente, ou a título coletivo". Par. ún.: "a defesa coletiva será exercida quando se tratar de:" voltar ao texto principal.

${ }^{65}$ Nelson Nery Júnior et alii. Código Brasileiro de Defesa do Consumidor, comentado pelos autores do anteprojeto. $4^{\mathrm{a}}$ ed. São Paulo: Forense Universitária, 1996, p. 630.

${ }^{66}$ Kazuo Watanabe et alii. Código Brasileiro de Defesa do Consumidor..., $4^{\text {a }}$ ed., cit., p. 500.

${ }^{67}$ Idem, p. 501/502.

${ }^{68}$ Arruda Alvim et alii. Código do Consumidor comentado, cit., p. 377.

${ }^{69}$ Luiz Antonio Rizzatto Nunes. As ações coletivas e a defesa do consumidor, da ordem econômica e da economia popular. Artigos de doutrina: Saraiva, disponível em www.saraivajur.com.br.
} 
Embora os direitos difusos já estivessem delineados, em seu conteúdo material, por leis ordinárias (v.g., Leis $\mathrm{n}^{\mathrm{o}} \mathrm{s}$ 6.938/81 e 7.347/85), havia necessidade de complementação. Daí a importância do CDC para esse aprimoramento e, consequentemente, suprir as lacunas legislativas até então existentes. ${ }^{70}$

\subsection{Coletivos}

Os interesses ou direitos coletivos, no que toca à Lei 8.078/90, são os transindividuais de natureza indivisível de que seja titular grupo, categoria ou classe de pessoas ligadas entre si ou com a parte contrária por relação jurídica base (CDC, art. 81, par. ún., II).

Destacam-se: a indivisibilidade e a relação jurídica base aglutinadora dos interesses de sujeitos determináveis.

A diferença está, em relação aos anteriores, na possível delimitação clara dos beneficiários do interesse ou direito, tendo em vista os pressupostos, em si mesmos definidos, para identificar a titularidade do grupo, classe ou categoria. ${ }^{71}$

Impende frisar que essa relação jurídica base é preexistente ao fato gerador, não é aquela originada da própria lesão ou da ameaça de lesão ao interesse ou direito do grupo, da categoria ou da classe de pessoas. Essas realidades não se confundem. $^{72}$

\subsection{Individuais homogêneos}

Aqueles que decorram de uma origem comum são os interesses ou direitos individuais homogêneos (CDC, art. 81, par. ún., III).

Justifica-se a defesa coletiva pela origem comum dos direitos ou interesses individuais, que na essência são puros. Tal origem comum não significa, necessariamente, uma unidade factual e temporal. ${ }^{73}$

\footnotetext{
${ }^{70}$ Celso Antonio Pacheco Fiorillo. Os sindicatos e a defesa dos interesses difusos no direito processual civil brasileiro. São Paulo: RT, 1995, p. 114/115.

${ }^{71}$ Arruda Alvim et alii. Código do Consumidor comentado, cit., p. 378/379.

${ }^{72}$ Kazuo Watanabe et alii. Código Brasileiro de Defesa do Consumidor..., 4 a ed., cit., p. 503.

${ }^{73}$ Idem, p. 506.
} 
São esses interesses ou direitos defensáveis a título coletivo, porque devem ser desprezadas e necessariamente desconsideradas as peculiaridades agregadas à situação pessoal e diferenciada de cada consumidor, exatamente porque refogem tais aspectos da homogeneidade. ${ }^{74}$

\subsection{A legitimidade do MP para as ações coletivas}

De fato, o CDC elenca o Ministério Público como um dos legitimados concorrentes a promover a defesa dos interesses e direitos dos consumidores $\left(\mathrm{CDC}, \operatorname{art} .82, \mathrm{I}^{75}\right)$.

No concernente aos difusos e aos coletivos, a própria Constituição Federal elencou sua proteção entre as funções institucionais do Ministério Público (CF, art. 129, III $^{76}$ ); porém, o problema surge ao se tratar da defesa de interesses ou direitos individuais homogêneos.

Há aqueles que simplesmente negam tal possibilidade ${ }^{77}$, outros exigem a indisponibilidade do interesse ou do direito tutelado ${ }^{78}$; a relevância e a repercussão sociais por vezes são fatores determinantes da aceitação, ou não, da legitimidade $^{79}$. De outra banda, também se admite irrestritamente o Ministério Público como autor nessas ações ${ }^{80}$, mesmo considerando o individual homogêneo subespécie do coletivo. $^{81}$

\footnotetext{
${ }^{74}$ Arruda Alvim et alii. Código do Consumidor comentado, cit., p. 380.

${ }^{75} \mathrm{CDC}$, art. 82: "para os fins do art. 81, parágrafo único, são legitimados concorrentemente: I - o Ministério Público".

${ }^{76} \mathrm{CF}$, art. 129: "são funções institucionais do Ministério Público: (...) III - promover o inquérito civil e a ação civil pública, para a proteção do patrimônio público e social, do meio ambiente e de outros interesses difusos e coletivos".

${ }^{77}$ STJ, REsp. 175.888/PR, j. 18.03.1999.

${ }^{78}$ STJ, REsp. 171.283/PR, j. 23.02.1999; TJSP, AC 354.514/3, j. 04.06.1998 (RT 756/213) e 20 TacCiv/SP, Apel. 408.869-00/8, j. 13.02.1996 (RT 731/321).

${ }^{79}$ STJ, REsps. 286.732/RJ, j. 09.10.2001; 242.643/SC, j. 19.10.2000; 211.019/SP, j. 11.04.2000; 168.859/RJ, j. 06.05.1999; 177.965/PR, j. 18.05.1999 e 95.347/SE, j. 24.22.1998; AGA 253.686/SP, j. 11.04.2000 e TJSP, AC 196.206-1, j. 11.11.1993 (JTJ-Lex 152/9); 264.428-2, j. 15.08.1995; 260.926-2, j. 19.10.1995; AI 261.450, j. 23.04.1996 e RJTJSP 187/9.

${ }^{80}$ STJ, REsps. 137.889/SP, j. 06.04.2000; 108.249/SP, j. 06.04.2000; 105.215/DF, 24.06.1997; 94.810/MG, j. 17.06.1997 e 89.646/PR, j. 10.12.1996 e EREsp. 141.491/SC, j. 17.11.1999; TJGO, Ap. $\mathrm{n}^{\mathrm{o}}$ 32.488-0/188, j. 26.05.1994 (RT 707/125); TRF/1ª Reg., Ap. 96.01.15603-8/RO, j. 22.10.1996 (RT 737/423); TJSC, AC 97004279-5, j. 26.08.1997 e TJSP, ACs 191.777-1, j. 12.08.1993; 263397-2, j. 26.10.1995 e 281.358-1, j. 03.06.1997.

${ }^{81}$ STF, RE 163.231/SP, rel. Min. Maurício Corrêa, j. 26.02.1997 e RE 185.360-3/SP, j. 11.07.1997 (RT 752/116).
} 
Pois bem. Note-se que a Constituição de 1988, anterior ao $\mathrm{CDC}$, evidentemente não poderia aludir, no seu art. 129, III, à categoria dos interesses individuais homogêneos, que só viria a ser criada pela Lei 8.078/90. Mas na dicção constitucional, a ser tomada em sentido amplo, segundo as regras de interpretação extensiva (quando o legislador diz menos de quanto quis), enquadra-se comodamente a categoria dos interesses individuais, quando coletivamente tratados. ${ }^{82}$

E adita, em outra oportunidade, Ada Pellegrini Grinover:

"Muito embora a Constituição atribua ao MP apenas a defesa de interesses individuais indisponíveis (art. 127), além dos difusos e coletivos (art. 129, III), a relevância social da tutela coletiva dos interesses ou direitos individuais homogêneos levou o legislador ordinário a conferir ao MP a legitimação para agir nessa modalidade de demanda, mesmo em se tratando de interesses ou direitos disponíveis. Em conformidade, aliás, com a própria Constituição, que permite a atribuição de outras funções ao MP, desde que compatíveis com sua finalidade (art. 129, IX).

\section{(...)}

Decorre daí que, pelo simples fato de serem tratados numa dimensão coletiva, os direitos individuais assumem relevância social, inserindo-se sua tutela, pela legitimação do MP, no art. 127 da CF, c/c o art. 129, IX. Não é por outra razão que o CDC determinou a atuação obrigatória do MP no processo, se não for ele o autor da ação em defesa dos interesses (ou direitos) individuais homogêneos (art. 92 do CDC)." ${ }^{83}$

No mesmo sentido se manifesta Antonio Gidi: “(...) os direitos individuais homogêneos globalmente considerados são indisponíveis pela comunidade de vítimas. Disponível é, apenas, cada um dos direitos isolada e individualmente considerados, por parte do seu titular individual, e não os direitos individuais homogêneos como um todo (coletivamente considerados)." ${ }^{84}$

\footnotetext{
${ }^{82}$ Ada Pellegrini Grinover et alii. Código Brasileiro de Defesa do Consumidor, comentado pelos autores do anteprojeto. $4^{\text {a }}$ ed. São Paulo: Forense Universitária, 1996, p. 545.

${ }^{83}$ A ação civil pública e a defesa de interesses individuais homogêneos. Revista de Direito do Consumidor, São Paulo: RT, v. 5, jan.-mar. 1993, p. 213/215.

${ }^{84}$ Legitimidade para agir em ações coletivas. Revista de Direito do Consumidor, São Paulo: RT, v. 14, abr.jun. 1995, p. 63.
} 
Faz sentido a visão coletiva dos interesses e dos direitos individuais homogêneos para o fim de se ver caracterizada a indisponibilidade e a relevância social exigidas no art. 127, caput, da Constituição da República.

Ocorre que, data venia, há caminho muito mais curto a ser percorrido pelo intérprete para outorgar, de uma vez por todas, legitimidade ativa ad causam ao Ministério Público na defesa dos interesses e dos direitos individuais homogêneos, ao menos nas relações de consumo.

É que o CDC - todo formado de normas de interesse social $\left(\operatorname{art.} 1^{\circ}\right)$ - o que atende, à saciedade, o requisito insculpido no comando do art. 127, caput, harmonizando-se ainda com o art. 129, IX, ambos da Constituição Federal.

Despiciendo, pois, cogitar-se de indisponibilidade do objeto ou de repercussão social.

\subsection{Obrigatoriedade de intervenção ministerial}

Percebe-se, agora, a importância do interesse social como atributo outorgado, ex vi legis, ao CDC. E, como já sustentou Nelson Nery Júnior ${ }^{85}$, esse interesse social é deveras que “(...) significa, em termos práticos, que o Ministério Público tem participação obrigatória em todas as ações sobre lides do consumidor (...)”86, sejam elas individuais, sejam elas coletivas. ${ }^{87}$

Como órgão de Estado, não pode o Ministério Público declinar da missão constitucional que lhe foi imposta, sendo inconcebível que - interna corporis $^{88}$ - reconheça serem leis inconstitucionais, praticamente escolhendo em que lides

\footnotetext{
${ }^{85}$ Referido autor, em outra obra (Leis civis comentadas. São Paulo: RT, 2006, p. 181, n. 2 ao art. $1^{\text {o }}$, e p. 255 , n. 1 ao art. 92), modificou sua convicção, passando a entender que: "ser de interesse social significa, em termos práticos, que o MP terá participação obrigatória (CDC, art. 92) em todas as ações coletivas sobre lides de consumo (...)", pois apenas "a defesa coletiva do consumidor é hipótese de interesse social (CDC, art. $1^{\mathrm{o}}$ )".

${ }^{86}$ Os princípios gerais..., cit., p. 52, i. 7.

${ }^{87}$ CDC, art. 92: “o Ministério Público, se não ajuizar a ação, atuará sempre como fiscal da lei”.

${ }^{88}$ Cf. ato administrativo editado, conjuntamente, pela Procuradoria Geral e pela Corregedoria Geral do Ministério Público de São Paulo tendente a regulamentar aquilo que se chamou de "racionalização da atuação do Ministério Público, como custos legis, no processo civil", especialmente quanto ao Mandado de Segurança (Ato n ${ }^{\circ}$ 313-PGJ/CGMP, de 24 de junho de 2003, art. 3º, VI). Aliás, o Conselho Nacional do Ministério Público já decidiu que "não há como prevalecer a norma que impõe responsabilidade disciplinar ao membro do Ministério Público que, com base em suas convicções, em obediência à Lei e à sua consciência, deixa de intervir em mandado de segurança" (Proc. $\mathrm{n}^{\circ}$ 0.00.000.000935/2007-41, apenso ao PCA n ${ }^{\circ}$ 0.00.000.000818/2009-79, rel. Cons. Cláudio Barros Silva, j. 27.04.2010). Igual paradoxo pode ser encontrado, também e v.g., em face das ações individuais de usucapião imóvel (Ato $\mathrm{n}^{\circ}$ 295-
} 
atuar, como se a ele tivesse a Carta Magna reservado, à exceção dos outros entes administrativos, parcela de exercício do controle difuso de constitucionalidade.

Observe-se, a propósito, que dentro da moldura do Estado Democrático de Direito traçado pela Constituição Federal, é da exclusiva competência do Poder Judiciário o exercício da jurisdição, inclusive para declarar e reconhecer as hipóteses em que devem atuar aqueles que exercem funções essenciais à justiça.

É dizer: não cabe ao Ministério Público - a seu talante avaliar a presença, ou não, de interesse público ou de lei incompatível com o seu panorama institucional pós 1988; ou seja, se discordar do pronunciamento jurisdicional da autoridade competente, resta-lhe manejar o recurso cabível previsto na legislação processual.

De qualquer forma, em última análise, é o Poder Judiciário e não o Ministério Público - que vai concretizar o direito previsto na norma abstrata. 


\title{
CAPÍTULO II \\ BALIZAS DE INCIDÊNCIA
}

\author{
SUMÁRIO: 1. RELAÇÃO DE CONSUMO: ELEMENTOS FORMADORES - 2. OS \\ CONSUMIDORES - 3. O FORNECEDOR - 4. PRODUTOS E SERVIÇOS.
}

\section{RELAÇÃO DE CONSUMO: ELEMENTOS FORMADORES}

Toda relação de consumo une em seus polos duas diferentes figuras (elemento subjetivo): o consumidor ${ }^{89}$ e o fornecedor ${ }^{90}$, que fazem movimentar no mercado o núcleo determinante da circulação de riqueza (elemento objetivo): $\operatorname{produtos}^{91} \mathrm{e}$ serviços ${ }^{92}$.

Irrelevante é a relação de direito material primária que envolva as partes, se evidenciados tais pressupostos, ela também será de consumo e, assim, preferencialmente regida pela Lei 8.078/90, à exceção daquelas de caráter trabalhista ${ }^{93}$, expressamente excluídas da sua esfera de abrangência (CDC, art. $3^{\circ}$, caput, in fine).

Ou seja: o CDC é uma lei principiológica que promove um corte horizontal no ordenamento jurídico pátrio, atingindo toda e qualquer relação inserida no seu âmbito, realidade que não implica inexoravelmente a revogação das outras tantas

\footnotetext{
${ }^{89} \mathrm{CDC}$, art. $2^{\mathrm{o}}$, caput: “consumidor é toda pessoa física ou jurídica que adquire ou utiliza produto ou serviço como destinatário final". Par. ún.: “equipara-se a consumidor a coletividade de pessoas, ainda que indetermináveis, que haja intervindo nas relações de consumo".

$90 \mathrm{CDC}$, art. $3^{\circ}$, caput: "fornecedor é toda pessoa física ou jurídica, pública ou privada, nacional ou estrangeira, bem como os entes despersonalizados, que desenvolvem atividades de produção, montagem, criação, construção, transformação, importação, exportação, distribuição ou comercialização de produtos ou prestação de serviços".

${ }^{91} \mathrm{CDC}$, art. $3^{\circ}, \S 1^{\mathrm{o}}$ : "produto é qualquer bem, móvel ou imóvel, material ou imaterial".

$92 \mathrm{CDC}$, art. $3^{\circ}, \S 2^{\circ}$ : "serviço é qualquer atividade fornecida no mercado de consumo, mediante remuneração, inclusive as de natureza bancária, financeira, de crédito e securitária, salvo as decorrentes das relações de caráter trabalhista".

${ }^{93}$ A exceção está em harmonia com a EC n 45 , de 08 de dezembro de 2004, que alterou o art. 114 da CF e atribuiu à Justiça do Trabalho a competência para processar e julgar as ações de indenização por dano moral ou patrimonial, decorrentes da relação de trabalho (VI). Muito embora se possa admitir uma diferença entre as relações de emprego e de trabalho, esta gênero e aquela espécie, a prestação de serviço desprovida de vínculo trabalhista típico continua submetida à cognição da Justiça Comum e ao império da Lei 8.078/90 (STJ, CC 67.330/MG, rel. Min. Nancy Andrighi, j. 13.12.2006).
} 
leis reguladoras (ainda válidas, mas tangenciadas por todos os princípios e regras da Lei $8.078 / 1990)^{94}$, agora aplicadas tão-só de modo subsidiário. ${ }^{95}$

${ }^{94}$ Luiz Antonio Rizzatto Nunes. É inconstitucional qualquer Medida Provisória que pretenda afastar o $\begin{array}{lllll}\text { Código de Defesa } & \text { do } & \text { Consumidor. } & \text { Disponível } & \mathrm{em}\end{array}$ http://www.saraivajur.com.br/index.cfm?link=bib_doutrina.cfm\&cod=15.

95 cf., v.g., Revista de Jurisprudência Escolhida - Primeiro Tribunal de Alçada Civil do Estado de São Paulo, São Paulo: Editora Jurídica Brasileira, v. 2, p. 525-528, apud, $1^{\text {o }}$ TacCiv/SP, AI 1.037.802-2, rel. Álvaro Torres Júnior, j. 26.09.2001: “deve-se observar que o Código Civil e o Código de Processo Civil são chamados supletivamente para as relações de consumo". 


\section{OS CONSUMIDORES}

Duas são as categorias de consumidor: o próprio (padrão ou standard) e o equiparado.

À semelhança de parte do direito comparado, preferiu a Lei 8.078/90 fixar conceitos de consumidor, aliás, lembra Artur Marques da Silva Filho alguns exemplos: “(...) o art. $3^{\circ}$ da 'Ley de Protección al Consumidor', do México; o art. $2^{\circ}$ da Lei 29/81, de Portugal; o art. $2^{\circ}, n^{\circ} 2$, da 'Ley de Consumo', da Espanha, e o art. $1^{\circ}$ da Lei sueca de 1973, sobre vendas ao consumidor". 96

Para Luiz Antonio Rizzatto Nunes, “(...) a opção do legislador por definir os conceitos em vez de deixar tal tarefa à doutrina e à jurisprudência pode gerar problemas na interpretação, especialmente porque corre o risco de delimitar o sentido do termo. No caso da Lei 8.078/90, as definições foram bem elaboradas". ${ }^{97}$

\subsection{Consumidor próprio}

É consumidor toda pessoa física ou jurídica que adquire ou utiliza produto ou serviço como destinatário final.

Nota-se, portanto, a presença de:

a) dois critérios identificadores: pessoa física ou jurídica;

b) dois núcleos de conduta: adquire ou utiliza;

c) um elemento finalista: destinatário final.

Observe-se que a capacidade civil não foi erigida em requisito essencial do conceito de consumidor, mas há motivo para tanto, pois o ato de consumo apresenta a vantagem da generalidade e da flexibilidade, ou seja, pode ser jurídico ou simplesmente material. ${ }^{98}$

Adalberto Pasqualotto, com perspicácia, elucida que, "a nota dominante nas relações de consumo não é a jurídica. Trata-se, basicamente, de uma relação de fato. A aquisição é tomada em sentido amplo, desimportando o pressuposto da

\footnotetext{
${ }^{96}$ Código do Consumidor, responsabilidade civil pelo fato de produto e do serviço. RT, São Paulo: RT, v. 666, p. 38.

97 Comentários..., cit., p. 95.

98 Thierry Bourgoignie. O conceito jurídico de consumidor. Revista de Direito do Consumidor, São Paulo: RT, v. 2, 1992, p. 24.
} 
capacidade jurídica. Naturalmente, estão sob o pálio legal as relações contratuais fáticas, como o uso de transporte coletivo, ainda que não se cogite de declaração de vontade. Assim também os atos existenciais, assim entendidas aquelas relações que decorrem do mero contato social e que explicam a validade, v.g., da aquisição de frutas feita por um menor na feira, embora não se possa cogitar de negócio jurídico, por ausência de capacidade, mas de simples ato-fato". 99

Ou, em outras palavras: os efeitos jurídicos fomentados pelo tráfico de massa acabam não sendo resultado da vontade negocial das partes, mas da valoração que o ordenamento jurídico atribui aos seus comportamentos. Assim, é suficiente uma atuação de vontade, definida como ato sem o significado de declaração, dirigido a produzir uma situação de fato correspondente ao efeito jurídico pretendido pelo sujeito, e que se expressa pela realização de um ato de cumprimento, de apropriação ou de utilização de uma prestação. Por isso, não há motivo para diferenciar as declarações de vontade das condutas socialmente típicas. ${ }^{100}$

Trata-se do reconhecimento social de que simples ações humanas, com ou sem capacidade, bastam a estabelecer vínculos obrigacionais; daí a moldura da contratação de fato e do comportamento concludente, afinal, numa economia de massa formatada por ajustes impessoais não há como se exigir capacidade. ${ }^{101}$

\subsubsection{Critérios identificadores}

Quanto à pessoa física (natural) não existe problema; todavia, sem embargo do texto expresso da lei, divergências há sobre a pessoa jurídica consumidora, mormente se considerada a restrição ao consumidor profissional defendida pelos adeptos da teoria finalista.

\footnotetext{
${ }^{99}$ Conceitos fundamentais do Código de Defesa do Consumidor..., cit, p. 50.

${ }^{100}$ Adalberto Pasqualloto. Oferta e publicidade no Código de Defesa do Consumidor. In: Lopez, Teresa Ancona e Aguiar Júnior, Ruy Rosado de (coord.). Contratos de consumo e atividade econômica. Série GVlaw. São Paulo: Saraiva, 2009, p. 45/47.

${ }^{101}$ E conclui Pasqualotto (idem, p. 73) que, “(...) as relações massificadas do mercado, especialmente as relações de consumo, são negócios jurídicos que devem ser interpretados de acordo com a boa-fé e os usos (art. 113 do CC), independentemente de forma (art. 107) e de acordo com a sua função social (art. 421), o que significa desconsiderar exigências desnecessárias como a capacidade em âmbitos do interesse humano em que prevalecem a objetividade e a praticidade. Sobre essas relações jurídicas paira o princípio constitucional da dignidade da pessoa humana".
} 
Aliás, nesse sentido é a intervenção de José Geraldo Brito Filomeno, para quem: “(...) o critério conceitual do Código brasileiro discrepa da própria filosofia consumerista ao colocar a pessoa jurídica como também consumidora de produtos e serviços". ${ }^{102}$

E note-se: como a norma não faz distinção, trata-se de toda e qualquer pessoa jurídica, quer seja uma microempresa, quer seja uma multinacional, civil ou comercial, associação, fundação, etc. ${ }^{103}$

Será efetivamente a análise do elemento teleológico que definirá, caso a caso, o regime jurídico adequado para a pessoa jurídica.

Tome-se emprestado ao professor Luiz Antonio Rizzatto Nunes um exemplo:

“(....) é evidente que não há relação protegida pelo Código quando a concessionária adquire o automóvel da montadora como intermediária para posterior venda ao consumidor.

\section{$(\ldots)$}

Mas o que acontece se a concessionária se utiliza do veículo como 'destinatária final', por exemplo, entregando-o para seu diretor usar?

A resposta a essa questão é fácil: para aquele veículo a concessionária não aparece como fornecedora, mas como consumidora, e a relação está tipicamente protegida pelo Código."104

Mister se faz, portanto, investigar se a pessoa jurídica atua na relação como um dos partícipes do ciclo de produção; logo, especial relevo ganha a identificação da atividade por ela explorada e dos insumos diretos utilizados no seu implemento. ${ }^{105}$

\footnotetext{
${ }^{102}$ Et alii. Código Brasileiro de Defesa do Consumidor..., $4^{\text {a }}$ ed., cit., p. 29/30.

${ }^{103}$ Luiz Antonio Rizzatto Nunes. Comentários..., cit., p. 96.

${ }^{104}$ Idem, p. 97.

${ }^{105}$ É preciso verificar se o fornecimento do produto e/ou do serviço se esgotou no âmbito da consumidora pessoa jurídica ou se atuou como insumo direto da atividade produtiva por ela explorada; contudo, para isso, há de se visualizar a matéria de um ponto de vista mais razoável, qual seja, o do objeto contratado. Avaliando as particularidades do contrato de transporte (paradigma exemplificativo), assim decidiu o STJ (REsp. 286.441/RS, rel. Min. Carlos Alberto Menezes Direito, j. 07.11.2002): “aplica-se a prescrição do Código de Defesa do Consumidor (art. 27), em caso de ação de indenização decorrente de dano causado em mercadoria durante o respectivo transporte marítimo, não importando para a definição do destinatário final do serviço de transporte o que é feito com o produto transportado. No caso, o serviço de transporte foi consumado com a chegada da mercadoria no seu destino, terminando aí a relação de consumo, estabelecida entre a transportadora e a empresa que a contratou". Na oportunidade, em Voto-Vista, o eminente Ministro Castro Filho consignou: "não se pode confundir o contrato de compra e venda da mercadoria, que não estaria
} 
Poder-se-ia afirmar, em princípio, que a pessoa jurídica será consumidora sempre que adquirir ou utilizar um produto ou um serviço não relacionado diretamente com o objeto da sua atividade, mas tal conclusão ainda não seria bastante (infra, 2.2).

\subsubsection{Núcleos de conduta}

Salienta Silvio Luís Ferreira da Rocha que "a primeira condição, isto é, a aquisição, posse ou utilização de um bem ou serviço, serve para ampliar o conceito, libertando-o da tradicional tendência de assimilar o consumidor tão-somente ao comprador de um bem ou serviço". ${ }^{106}$

\subsubsection{Adquirir}

De fato, adquirir tem um sentido muito mais extenso do que simplesmente comprar, visto que o consumidor pode estabelecer contato com o produto ou com o serviço por outras vias além de um contrato de venda e compra. ${ }^{107} \mathrm{~A}$ interpretação deve conduzir ao sentido de obter, seja a título oneroso ou gratuito ${ }^{108}$ (este só para o produto, pois o serviço depende de remuneração ${ }^{109}$ ).

protegido pelo Código de Defesa do Consumidor, por não ser a empresa alemã destinatária final do qualho importado, com o contrato de prestação de serviço de transporte, firmado entre a vendedora da mercadoria, ora recorrente, e a transportadora-ré, cujo objeto seria definitivamente cumprido com a entrega da carga nas condições avençadas. Entendo que a recorrente é consumidora enquanto destinatária final do serviço de transporte esgotado pela entrega, merecendo reparação pelos defeitos do serviço contratado. É de se ter presente, no que toca ao transporte aéreo nacional e internacional de cargas, a existência de jurisprudência pacífica de ambas as Turmas que compõem a Colenda Segunda Seção deste Tribunal no sentido de que a responsabilidade civil do transportador é regida pelo Código de Defesa do Consumidor. (...) Tranquila a incidência da lei sobre os contratos de transporte aéreo de mercadorias, não se justifica a distinção relativa ao transporte marítimo de cargas, razão pela qual afasto a prescrição do direito de ação, entendo aplicável ao caso o prazo quinquenal previsto no artigo 27 da Lei 8.078/90". É irrelevante se a empresa use o produto e/ou o serviço fornecido na sua atividade apenas de modo indireto. Ao interpretar o elemento finalista da definição legal de consumidor próprio (CDC, art. $2^{\circ}$, caput), outra vez, o STJ firmou a mesma diretriz (REsp. 488.274/MG, rel. Min. Nancy Andrighi, j. 22.05.2003): “insere-se no conceito de 'destinatário final' a empresa que se utiliza dos serviços prestados por outra, na hipótese em que se utilizou de tais serviços em benefício próprio, não os transformando para prosseguir na sua cadeia produtiva".

${ }^{106}$ Responsabilidade civil do fornecedor pelo fato do produto no direito brasileiro. $2^{\mathrm{a}}$ ed. São Paulo: RT, 2000 , p. 68 .

${ }^{107}$ Idem.

${ }^{108}$ Luiz Antonio Rizzatto Nunes. Comentários ..., cit., p. 96.

${ }^{109} \mathrm{CDC}$, art. $3^{\circ}, \S \S 1^{\circ}$ e $2^{\circ}$. 
Aqui existe um vínculo direto entre o consumidor e o fornecedor, ainda que fático (supra, 2.1).

\subsubsection{Utilizar}

Com efeito, a qualidade de consumidor não pode estar reservada apenas à pessoa que aceita contratar. Alguém pode entrar na posse de certos bens ou se beneficiar de certas prestações fora de toda relação contratual, ou seja, o ato de consumo pode se manifestar pelo simples ato material de utilização do bem ou do serviço. ${ }^{110}$

Isto é, a norma define como consumidor tanto quem efetivamente adquire (obtém) o produto ou o serviço, como aquele que, não o tendo adquirido, utiliza-o ou o consome. ${ }^{111}$

Esse núcleo protege aquelas pessoas que, apesar de não adquiri-los, têm contato com bens e com serviços, utilizando-os. Dispensa-se o vínculo formal (aquisição), bastando o que se denomina comportamento concludente (supra, 2.1).

\subsubsection{Elemento finalista e teorias}

Trata o presente tópico da análise da expressão destinatário final, elemento teleológico do conceito de consumidor. Esse processo conduz, inexoravelmente, à passagem por duas teorias que divergem quanto ao âmbito de abrangência das relações de consumo: a finalista e a maximalista.

Segundo Cláudia Lima Marques:

"Para os finalistas, pioneiros do consumerismo, a definição de consumidor é o pilar que sustenta a tutela especial, agora concedida aos consumidores. Esta tutela só existe porque o consumidor é a parte vulnerável nas relações contratuais no mercado, como afirma o próprio $\mathrm{CDC}$ no art. $4^{\circ}$, inciso I. Logo, convém delimitar claramente quem merece esta tutela e quem não a necessita, quem é o consumidor e quem não é. Propõem, então, que se interprete a

\footnotetext{
${ }^{110}$ Thierry Bourgoignie. O conceito jurídico de consumidor..., cit., p. 27.

${ }^{111}$ Luiz Antonio Rizzatto Nunes, Comentários ..., cit., p. 96.
} 
expressão 'destinatário final' do artigo $2^{\circ}$ de maneira restrita, como requerem os princípios básicos do CDC, expostos no art. $4^{\circ}$ e $6^{\circ}$.

Destinatário final é aquele destinatário fático e econômico do bem ou serviço (...) consumidor seria o não profissional, pois o fim do CDC é tutelar de maneira especial um grupo da sociedade que é mais vulnerável. Consideram que restringindo o campo de aplicação do $\mathrm{CDC}$ àqueles que necessitam da proteção, ficará assegurado um nível mais alto de proteção (...)."

Tal vertente (finalista) interpreta restritivamente o elemento teleológico (destinatário final), leva em conta o ato objetivo de retirar o bem de circulação e o critério econômico: não utilização do bem ou do serviço para produção, ainda que indiretamente.

E prossegue a renomada jurista da UFRGS: “já os maximalistas vêem nas normas do CDC o novo regulamento do mercado de consumo brasileiro, e não normas orientadas para proteger somente o consumidor não-profissional. (...) A definição do art. $2^{\circ}$ deve ser interpretada o mais extensivamente possível (...) para que as normas do CDC possam ser aplicadas a um número cada vez maior de relações no mercado. Consideram que a definição do art. $2^{\circ}$ é puramente objetiva, não importando se a pessoa física ou jurídica tem ou não fim de lucro quando adquire um produto ou utiliza um serviço. Destinatário final seria o destinatário fático do produto, aquele que o retira do mercado e o utiliza, o consome (...)".113

Relembre-se, antes de mais nada, que este trabalho firmou posição no sentido de ser a Lei 8.078/90 - sem embargo da sua essência específica (relações entre consumidores e fornecedores) - um estatuto geral, capaz de iluminar todo o sistema jurídico, aclarando situações fáticas das mais variadas esferas de direito material. $^{114}$

Como verdadeiro instrumento de aplicação direta dos princípios constitucionais nas relações de direito privado, visando à preservação da dignidade da pessoa humana, o CDC indiscutivelmente é uma lei principiológica e, assim, promove corte horizontal no ordenamento, atingindo toda e qualquer relação jurídica inserida no seu âmbito (supra, Cap. II, 1).

\footnotetext{
${ }^{112}$ Contratos..., cit., p. 253/254.

${ }^{113}$ Claudia Lima Marques. Contratos..., cit., p. 254/255. A adotar, expressamente, a teoria maximalista cf. TJSP, AC 992.08.055617-4, rel. Antonio Benedito Ribeiro Pinto, j. 10.06.2010.
} 
Falhas, pois, as duas teorias propostas.

A finalista peca ao sugerir uma interpretação tão restrita do conceito de consumidor que chega a ser contra legem, porquanto, ao excluir o consumidor profissional da proteção do Código, arranha sem dúvida alguma a pessoa jurídica. Mas não é só: a vingar esse raciocínio, o professor que compra, em uma banca de jornal, uma simples caneta, porém viciada (que vaza tinta), para usar na sala de aula não seria tratado como destinatário final desse produto. ${ }^{115}$

De outra banda, a maximalista não se mostra totalmente oportuna quando exige apenas a retirada do produto ou do serviço do mercado, aproximando a figura do destinatário final a do destinatário fático. Sua irrestrita objetividade também pode causar injustas distorções. ${ }^{116}$

Adverte, de modo ímpar, James Marins, “(...) que havendo no direito positivo conceito preciso de consumidor - como em verdade ocorre com o art. $2^{\circ}$ aqui objeto de análise - e que albergue conceito próprio induvidoso, não se pode pretender submetê-lo às teorias jurídicas informadoras de sistemas alienígenas, teorias essas ora textualmente recebidas pelo legislador, ora textualmente afastadas em prol de um sistema próprio". 117

Daí a precisa intervenção de Cláudia Lima Marques:

"O destinatário final é o Endverbraucher, o consumidor final, o que retira o bem do mercado ao adquirir ou simplesmente utilizá-lo (destinatário final fático), aquele que coloca um fim na cadeia de produção (destinatário final econômico) e não aquele que utiliza o bem para continuar a produzir, pois ele não é o consumidor-final, ele está transformando o bem, utilizando o bem para oferecê-lo por sua vez ao seu cliente, seu consumidor.

Portanto, em princípio, estão submetidos às regras do Código os contratos firmados entre o fornecedor e o consumidor não-profissional, e entre o fornecedor e o consumidor, o qual pode ser um profissional, mas que, no

\footnotetext{
${ }^{114}$ Guilherme Ferreira da Cruz. Princípios constitucionais..., cit., p. 167/170.

${ }^{115}$ Cf., o perfeito exemplo de Luiz Antonio Rizzatto Nunes. Comentários..., cit., p. 101/103.

${ }^{116}$ Cf., o exemplo do usineiro dado por Luiz Antonio Rizzatto Nunes. Comentários..., cit., p. 96/101.

${ }^{117}$ Responsabilidade da empresa pelo fato do produto (os acidentes de consumo no Código de Proteção e Defesa do Consumidor). São Paulo: RT, 1993, p. 64.
} 
contrato em questão, não visa lucro, pois o contrato não se relaciona com sua atividade profissional, seja este consumidor pessoa física ou jurídica."118

Impunha-se traçar um norte para o intérprete. Fê-lo com sabedoria Luiz Antonio Rizzatto Nunes:

"O Código de Defesa do Consumidor regula situações em que produtos e serviços são oferecidos ao mercado de consumo para que qualquer pessoa os adquira, como destinatária final. Há, por isso, uma clara preocupação com bens típicos de consumo, fabricados em série, levados ao mercado numa rede de distribuição, com ofertas sendo feitas por meio de dezenas de veículos de comunicação, para que alguém em certo momento os adquira.

Aí está o caminho indicativo para a solução. Dependendo do tipo de produto ou serviço, aplica-se ou não o Código, independentemente de o produto ou serviço estar sendo usado ou não para a 'produção' de outros."119

E conclui: “(...) a Lei 8.078 regula o pólo de consumo, isto é, pretende controlar os produtos e serviços oferecidos, postos à disposição, distribuídos e vendidos no mercado de consumo e que foram produzidos para ser vendidos, independentemente do uso que se vá deles fazer. (...) Dessa maneira, repita-se, toda vez que o produto e/ou serviço puderem ser utilizados como bem de consumo, incide na relação as regras do CDC". ${ }^{120}$

Leva-se em conta, em rigor de raciocínio, a natureza dos produtos e dos serviços oferecidos no mercado de consumo; se acessíveis a qualquer pessoa, na opção do próprio risco assumido no exercício da atividade explorada, independentemente do destino que lhes for dado, a relação será de consumo. Corrobora este pensamento a idéia do consumidor equiparado por mera exposição às praticas comerciais (infra, 2.2.3).

\subsection{Consumidor equiparado}

Afirma Luiz Antonio Rizzatto Nunes que “(...) a definição de consumidor do CDC começa no individual mais concreto (art. $2^{\circ}$. Caput) e termina no

\footnotetext{
${ }^{118}$ Contratos..., cit., p. 279/280.

${ }^{119}$ Comentários..., cit., p. 100.

${ }^{120}$ Idem, p. 102.
} 
geral mais abstrato (art. 29). Isto porque, logicamente falando, O caput do art. $2^{\circ}$ aponta para aquele consumidor real que adquire concretamente um produto ou um serviço, e o art. 29 indica o consumidor tipo-ideal, um ente abstrato, uma espécie de conceito difuso, na medida em que a norma fala da potencialidade, do consumidor que presumivelmente exista, ainda que possa não ser determinado". ${ }^{21}$

Segundo Cláudia Lima Marques, "o ponto de partida desta extensão do campo de aplicação do CDC é a observação de que muitas pessoas, mesmo não sendo consumidores stricto sensu, podem ser atingidas ou prejudicadas pelas atividades dos fornecedores no mercado. (...) instituiu o legislador brasileiro três normas de extensão do campo de aplicação pessoal do CDC, três disposições legais conceituando os agentes que considera equiparados a consumidores (parágrafo único do art. $2^{\circ}$, arts. $17 \mathrm{e}$ 29)". 122

São três, pois, os equiparados:

a) equipara-se a consumidor a coletividade de pessoas, conquanto que indetermináveis, que haja intervindo nas relações de consumo (art. $2^{\circ}$, par. ún.);

b) para fins desta seção (responsabilidade pelo fato de produto e do serviço) equiparam-se aos consumidores todas as vítimas do evento (art. 17);

c) para fins deste Capítulo (das práticas comerciais) e do seguinte (proteção contratual), equiparam-se aos consumidores todas as pessoas determináveis ou não, expostas às práticas nele previstas (art. 29).

Conforme ensina Roberto Senise Lisboa, “(...) resultam da implementação do Estado Social do Direito, consagrando-se a proteção dos interesses da massa de consumidores considerados socialmente relevantes pelo legislador. Os interesses difusos, coletivos e individuais homogêneos dos consumidores são protegidos em face da contratação em massa. Não há mais tão-somente a tutela individual do adquirente direito ou o usuário final, mediante o equilíbrio da relação jurídica. Defende-se os interesses sociais da massa de consumidores que intervém nas relações de consumo (interesse difuso e coletivo), das vítimas de acidentes de consumo ao menos atentatórios à vida, à saúde ou à segurança do consumidor e das pessoas expostas às práticas decorrentes de oferta e

\footnotetext{
${ }^{121}$ Comentários..., cit., p. 95.
}

${ }^{122}$ Contratos..., cit., p. 290/291. 
publicidade, mesmo que não venham a adquirir o produto ou o serviço veiculado pela mídia (interesses difusos)", 123

Há que se esclarecer: a terminologia empregada pelo Código no sentido de "equiparar-se" a consumidor a coletividade de pessoas, as vítimas do evento e todas as pessoas expostas às práticas comerciais (abusivas), não significa nenhuma diferença de ordem prática ou jurídica entre os consumidores próprios e seus equiparados. $^{124}$

\subsubsection{Coletividade de pessoas}

Equiparam-se a consumidor a coletividade de pessoas, ainda que indetermináveis, que intervenha nas relações de consumo (art. $2^{\circ}$, par. ún.).

Ressalta Mirella D’Angelo Caldeira:

“(...) o legislador confere à coletividade o mesmo tratamento conferido ao consumidor individual. Isto é, a coletividade que tenha intervindo na relação de consumo tanto poderá ter seu direito tutelado no âmbito individual quanto no âmbito coletivo. Equiparam-se, pois, o indivíduo e a coletividade. Toda proteção deferida ao indivíduo isoladamente poderá ser invocada pela coletividade - determinável ou não - em igualdade de posição.

\section{(...)}

Por outro lado, poderíamos imaginar uma hipótese em que a coletividade não é determinável, como, por exemplo, uma indústria farmacêutica que coloca no mercado um remédio falso. Nesse caso, impossível é identificar todos os lesados com o fato, porém é certo que todos os que adquiriram o produto sofreram danos, quer econômicos, quer físicos, ou ambos. Desse modo, com fundamento no mesmo preceito (art. $2^{\circ}$, parágrafo único), é possível a reparação dos danos individualmente sofridos por essa coletividade." 125

Observa Roberto Senise Lisboa que se reconhece a existência dos interesses de uma coletividade de pessoas, ainda que indetermináveis, que tenham atuado na relação de consumo. Com isso, a viabilizar a tutela dos interesses difusos e

\footnotetext{
${ }^{123}$ Responsabilidade civil nas relações de consumo. São Paulo: RT, 2001, p. 165.

${ }^{124}$ Antônio Carlos Efing. Contratos..., cit., p. 56.
} 
coletivos da massa de pessoas que participam das relações de consumo, cujas necessidades podem ser defendidas preventiva ou repressivamente pelos órgãos legitimados por lei para tal mister". 126

Assim, a regra do parágrafo sub examine permite o enquadramento de universalidade ou conjunto de pessoas, mesmo que não se constituam em pessoa jurídica. Por exemplo, a massa falida pode figurar na relação de consumo como consumidora ao adquirir produtos, ou então, o condomínio, quando contrata serviços. ${ }^{127}$

Imagine-se um condomínio que contrate uma empresa de limpeza de fachada. Durante a prestação dos serviços, a fornecedora acaba danificando as pastilhas do revestimento externo pelo uso demasiado de ácido na solução utilizada, causando danos às partes comuns e a determinadas unidades autônomas (serviço defeituoso).

Ressai, pois, à evidência, que a controvérsia será resolvida pela Lei 8.078/90, pois o condomínio, consumidor equiparado, aglutina os interesses de todos os condôminos (consumidores próprios).

Essencial, aqui, é que a coletividade intervenha nas relações de consumo, adquirindo ou utilizando produtos e serviços; ao contrário das outras duas figuras equiparadas que são estranhas ao vínculo consumerista originário, apenas suportando ou assimilando seus reflexos.

\subsubsection{Vítimas do evento}

Para os fins de responsabilidade pelo fato de produto e do serviço se equiparam a consumidores todas as vítimas do evento (CDC, art. 17).

Além do próprio consumidor, o terceiro prejudicado recebeu a atenção do legislador, ante o dano sofrido decorrente da relação de consumo da qual não participou. Nesse caso, a vítima pode pleitear a reparação da ofensa com base na responsabilidade objetiva do fornecedor. ${ }^{128}$

Com propriedade, elucida James Marins:

\footnotetext{
${ }^{125}$ O conceito de consumidor no parágrafo único do art. $2^{\circ}$ do Código de Defesa do Consumidor. Artigos de doutrina: Saraiva, disponível em www.saraivajur.com.br.

${ }^{126}$ Responsabilidade civil..., cit., p. 163.

${ }^{127}$ Luiz Antonio Rizzatto Nunes. Comentários..., cit., p. 107.

${ }^{128}$ Roberto Senise Lisboa. Responsabilidade civil..., cit., p. 163.
} 
Exatamente para solucionar possíveis distorções desta natureza, o Código, em seu art. 17 equipara as vítimas do fato do produto e do serviço a consumidores, o que significa estar nessas condições o intermediário (comerciante, v.g.) e outras vítimas (terceiros) mesmo que não participem da relação de consumo, denominados pela doutrina e jurisprudência americanas de bystanders, autorizados a acionar o fornecedor pela responsabilidade civil pelo fato do produto ou do serviço, na qualidade de consumidores, e com as mesmas prerrogativas a estes deferidas pelo Código de Proteção e Defesa do Consumidor.

A proteção ao denominado bystander, ou seja, aquelas pessoas (físicas ou jurídicas, já que a lei não restringe) que mesmo sem serem partícipes da relação de consumo - seja na qualidade de adquirentes como de meros usuários - foram atingidas em sua saúde ou segurança em virtude do defeito do produto, sendo irrelevante que se trate de destinação final ou não."129

Protege-se a figura do terceiro, conhecida nos países da common law como bystander, isto é, aquele que não participou da circulação jurídica do bem nem do seu uso. O bystander, via de regra, não se encontra em melhor posição que aquela ocupada pelo consumidor. Ele não pode escolher o produto mais seguro ou exercer a devida diligência no uso do produto, como pode fazer o consumidor. Por essa razão é que se costuma afirmar que a lei deve assegurar ao bystander uma tutela objetiva. ${ }^{130}$

Logo, basta ser "vítima" de um produto ou serviço para ser privilegiado com a posição de consumidor legalmente protegido pelas normas sobre responsabilidade objetiva pelo fato do produto presentes no CDC. ${ }^{131}$

Frise-se, todavia, que a proteção é para o terceiro prejudicado (bystander), estranho à relação de consumo geradora do dano. Trata-se de uma descrição alargada que, em última ratio, na verdade protege todos aqueles que vierem a ser vítimas. $^{132}$

Entre os exemplos mais sugestivos de propagação dos danos materiais ou pessoais, surgem as hipóteses de acidentes de trânsito, do uso de agrotóxicos

\footnotetext{
${ }^{129}$ Responsabilidade da empresa..., cit., p. 70.

${ }^{130}$ Silvio Luís Ferreira da Rocha. Responsabilidade civil..., cit., p. 70.

${ }^{131}$ Cláudia Lima Marques. Contratos..., p. 292.

${ }^{132}$ Artur Marques da Silva Filho. Código do Consumidor..., cit., p. 38.
} 
ou fertilizantes, com a consequente contaminação dos rios, ou da construção civil, quando há comprometimento dos prédios vizinhos. ${ }^{133}$

\subsubsection{Vítima e vício do produto e do serviço}

A equiparação de todas as vítimas do evento aos consumidores, consubstanciada no art. 17, que resulta na extensão legal da abrangência do Código, justifica-se em função da potencial gravidade que pode atingir o fato do produto ou do serviço. Tal extensão não alcança o vício do produto ou do serviço (arts. 18 e ss), pois aí disciplina o Código lesões de menor gravidade ao consumidor. ${ }^{134}$

Para Silvio Luís Ferreira da Rocha, "o alargamento do conceito de consumidor não ocorre na responsabilidade por vícios do produto. Nesta, aplicável o conceito previsto no art. $2^{\circ}$ do Código de Defesa do Consumidor, de modo que o comerciante e intermediário não poderão utilizar-se dos meios previstos no Código de Defesa do Consumidor contra o fabricante ou produtor, quando se tratar de vícios de qualidade ou quantidade, devendo, para tanto, recorrer à disciplina prevista no Código Civil e no Código Comercial". ${ }^{135}$

Essa convicção decorre do próprio texto legal, que faz expressa referência à Seção II, do seu Capítulo IV, ou seja, aquela que regulamenta a responsabilidade pelo fato do produto e do serviço.

Entretanto, poder-se-ia cogitar desta extensão conceitual (consumidor-vítima) também para as hipóteses de vício do produto e do serviço, disciplinados em outra Seção (III) do mesmo Capítulo, em razão do princípio da confiança e com base na teoria da qualidade da produção voltada, em última análise, para o consumo?

A resposta depende da distinção entre vício e defeito.

\subsubsection{Vício e defeito: distinção}

\footnotetext{
133 Zelmo Denari et alii. Código Brasileiro de Defesa do Consumidor, comentado pelos autores do anteprojeto. $4^{\mathrm{a}}$ ed. São Paulo: Forense Universitária, 1996, p. 126.

${ }^{134}$ Arruda Alvim et alii. Código do Consumidor comentado..., cit., p. 141.

${ }^{135}$ Responsabilidade civil..., cit., p. 71.
} 
Não se ignora que os vícios (CDC, art. 18) podem ser de qualidade e quantidade (impropriedade ou inadequação), enquanto os defeitos (CDC, art. 12) se encontram atrelados à idéia de periculosidade (criação, produção e informação), seja ela inerente aos produtos e aos serviços (v.g., agrotóxicos) - dês que normal e previsível, ligada às informações - seja ela adquirida (CDC, arts 12 a 17) ou presumida (CDC, art. 10 e $\left.18, \S 6^{\circ}\right)$.

Ocorre que o defeito, na sua essência, representa um plus em relação ao vício, ou, em outras palavras, é o vício qualificado pela ocorrência de dano, material ou moral, que extravasa o próprio produto ou serviço retirado do mercado (aquisição ou utilização), alcançando tanto o consumidor próprio quanto eventuais terceiros estranhos à relação consumerista primária.

Vêm a talho de foice, na espécie, os ensinamentos do insigne Arruda Alvim. Ei-los: "o fato do produto, desta forma, não corresponde estritamente ao dano nem ao defeito. Em primeiro lugar porque o mero defeito constatado não caracteriza fato do produto, mas apenas vício, regulado na forma dos artigos 18 e seguintes, somente configurando-se fato do produto quando do defeito decorrerem prejuízos, danos, que não a mera desvalorização ou impossibilidade de uso, estando estes vícios regulados na seção subsequente, não autorizando a reparação nos termos do art. 12 que não pode prescindir do dano e do nexo causal". ${ }^{136}$

E prosseguem os lúcidos comentadores: "se verificado o defeito do serviço, sem que este tenha ocasionado dano ao consumidor que não seja maior que a mera desvalorização ou inservibilidade, a matéria é tratada pelos artigos 20 e seguintes, referentes, referentes ao vício do serviço". ${ }^{137}$

Todavia, essa projeção externa lesiva não desqualifica a inicial essência de vício do problema; logo, mesmo no caso de defeito, as possibilidades asseguradas nos arts. $18, \S 1^{\circ}, 19$ e 20 da Lei 8.078/90 permanecem à disposição do consumidor, pena de se mitigar o direito básico à ampla reparação do prejuízo (CDC, art. $\left.6^{\mathrm{o}}, \mathrm{VI}\right)$, a permitir, com isso, até, se cogite de prazos distintos para o exercício dessas pretensões frente às possíveis perdas e danos advindas do episódio. ${ }^{138}$

\footnotetext{
${ }^{136}$ Et alii. Código do Consumidor comentado..., cit., p. 118.

${ }^{137}$ Idem, p. 137.

138 "Em realidade, o prazo decadencial a que alude o art. 26, II, é aplicável na hipótese de reclamação pelo defeito no serviço prestado (na verdade vício), circunstância não verificada na espécie. O que se pretende com a presente ação é a indenização por danos materiais e morais decorrentes da má prestação do serviço,
} 
Distinguem-se, pois, pela ocorrência - ou não - de dano, ainda que moral; no entanto, essa verificação abstrata depende do pedido concretamente deduzido pelo consumidor vítima, titular da esfera de direitos violada. ${ }^{139}$

"O defeito é o vício acrescido de um problema extra, alguma coisa extrínseca ao produto ou serviço, que causa um dano maior que simplesmente o mau funcionamento, o não-funcionamento, a quantidade errada, a perda do valor pago - já que o produto ou serviço não cumpriram o fim ao qual se destinavam. O defeito causa, além desse dano do vício, outro ou outros danos ao patrimônio jurídico material e/ou moral e/ou estético e/ou à imagem do consumidor.

Logo, o defeito tem ligação com o vício, mas, em termos de dano causado ao consumidor, é mais devastador.

Temos, então, que o vício pertence ao próprio produto ou serviço, jamais atingindo a pessoa do consumidor ou outros bens seus. $\mathrm{O}$ defeito vai além do produto ou do serviço para atingir o consumidor em seu patrimônio jurídico mais amplo (seja moral, material, estético ou da imagem). Por isso, somente se fala propriamente em acidente, e, no caso, acidente de consumo, na hipótese de defeito, pois é aí que o consumidor é atingido." $" 140$

Impende frisar que o paralelismo proposto, embora com certo dissenso $^{141}$, já foi consagrado pela jurisprudência. ${ }^{142}$

demanda de natureza condenatória, sequer sujeita a prazo decadencial, mas sim prescricional. (...) Com efeito, escoado o prazo decadencial de 90 (noventa) dias previsto no art. 26, II, do CDC, não poderá o consumidor exigir do fornecedor do serviço as providências previstas no art. 20 do mesmo Diploma reexecução do serviço, restituição da quantia paga ou o abatimento proporcional do preço -, porém, a pretensão de indenização dos danos por ele experimentados pode ser ajuizada durante o prazo prescricional de 5 (cinco) anos, porquanto rege a hipótese o art. 27 do CDC" (STJ, REsp. 683.809/RS, rel. Min. Luis Felipe Salomão, j. 20.04.2010).

139 "A questão a ser decidida refere-se à ocorrência de vício ou fato do produto, para posteriormente decidir a respeito da decadência. (...) Em matéria de prescrição, isto é, de perda do direito de ação, é preciso ver como identificada a ação pela petição inicial, consolidados os termos desta pela sentença, que julgou procedente a ação, fornecendo, ambas as peças, o balizamento à apelação, que restou provida. A ação movida pelos autores não dizia respeito a vício do produto, mas, sim, como aqui sustentam, a fato do produto, como se vê do exame detido do pedido e da causa de pedir da inicial e do dispositivo da sentença que julgou a ação procedente. (...) Deve-se, pois, julgar alegação da inicial de que houve danos causados por fato do produto, e não por vício do produto, aplicável, pois, o prazo prescricional de 5 (cinco) anos, previsto no art. 27 do Código de Defesa do Consumidor" (STJ, REsp. 953.187/MT, rel. Min. Sidnei Beneti, j. 23.06.2009). Em igual sentido e da mesma Corte: REsp. 567.333/RN, rel. Min. Fernando Gonçalves, j. 02.02.2010.

${ }^{140}$ Luiz Antonio Rizzatto Nunes. Curso de direito do consumidor. $2^{\mathrm{a}}$ ed. São Paulo: Saraiva, 2005, p. 167.

141 “(...) a causa de pedir não versa sobre defeito (art. 12, $\S 1^{\circ}, \mathrm{CDC}$ ), pois ausente risco à segurança do consumidor ou terceiro. A lide versa sobre vício de qualidade do serviço ou produto, supostamente inadequados à finalidade esperada pelo consumidor (art. 18). Respeitados os entendimentos contrários, a 
Além disso, outro aspecto reforça a presente construção, é que o CDC, ao tratar da decadência e da prescrição, divisou os institutos pelo interesse almejado, reservando a prescrição à reparação pelos danos causados por fato do produto ou do serviço (art. 27). A decadência, por sua vez, limita no tempo o direito de reclamar pelos vícios (art. 26).

Fixadas essas premissas, a resposta à pergunta anteriormente formulada (supra, 2.2.2.1) há de ser negativa, pois somente o fato do produto ou do serviço (defeito) é capaz de projetar seus reflexos (danos) na esfera jurídica de terceiro, daí o porquê da equiparação legal $(\mathrm{CDC}$, art. 17). $\mathrm{O}$ vício, ao revés, permanece restrito à pessoa do consumidor próprio.

\subsubsection{Pessoas expostas às práticas comerciais}

Em relação às práticas comerciais e à proteção contratual, equiparam-se aos consumidores todas as pessoas determináveis ou não, a elas expostas.

Confira-se a abordagem da professora Cláudia Lima Marques

sobre a matéria:

“(...) O art. 29 é uma disposição especial, que abre o capítulo V do Código sobre 'Práticas Comerciais', aplicável, portanto, a todas as seções do capítulo, quais sejam: a seção sobre a oferta (arts. 30 a 35), sobre publicidade (arts. 36 a 38), sobre práticas abusivas (arts. 39 a 41), sobre cobrança de dívidas (art. 42), sobre Banco de Dados e Cadastros de Consumidores (arts. 43 a 45) e que se diz aplicável também ao capítulo posterior, o Capítulo VI, dedicado à 'proteção contratual'.

simples existência de dano material não desloca o vício para fato, até porque a própria lei refere que os danos advindos do vício podem ser reparados independentemente da rescisão do contrato (art. 18, §1 $1^{\circ}, \mathrm{II}, \mathrm{CDC}$ )" (TJSP, AC 1.124.160-0/0, rel. Artur Marques, j. 01.10.2007).

142 “(...) Situação fática narrada, ademais, que pleiteia a reparação de dano causado ao patrimônio jurídico material e moral do consumidor em decorrência do vício do produto/serviço alegado - Hipótese de defeito que causa, além do dano do vício, outro ou outros danos ao patrimônio do consumidor - Rejeição da preliminar de decadência mantida - Agravo desprovido" ( $1^{\circ} \mathrm{TacCiv} / \mathrm{SP}$, AI 1.204.169-5, rel. Rizzatto Nunes, j. 13.08.2003). "(...) para o fim de definição de sua responsabilidade objetiva pelo fato do serviço, as diretrizes traçadas pelo Código de Defesa do Consumidor, a saber: de um lado, a aptidão ou idoneidade do produto ou do serviço geram a responsabilidade pelo chamado vício, caso em que o fornecedor só arca com as conseqüências jurídicas do fornecimento de um produto ou serviço imperfeito; de outro lado, a falta de segurança do produto ou serviço acarreta, por sua vez, a responsabilidade do fornecedor pelo fato do produto/serviço (acidente de consumo), especificamente no que diz respeito aos danos produzidos, caso em 


\section{(...)}

O art. 29 supera, portanto, os estritos limites da definição jurídica de consumidor para imprimir uma definição de política-legislativa! Parece-nos que, para harmonizar os interesses presentes no mercado de consumo, para reprimir eficazmente os abusos do poder econômico, para proteger os interesses econômicos dos consumidores-finais, o legislador concedeu um poderoso instrumento nas mãos daquelas pessoas (mesmo agentes econômicos) expostas às práticas abusivas. Estas, mesmo não sendo 'consumidores stricto sensu', poderão utilizar das regras especiais do CDC, de seus princípios, de sua ética de responsabilidade social no mercado, de sua nova ordem pública, para combater as práticas comerciais abusivas!"143

Referidas práticas devem advir de uma relação de consumo paradigma. A equiparação é que dispensa a definição legal de consumidor. ${ }^{144} \mathrm{O}$ que a lei diz é que, uma vez existindo qualquer prática comercial, toda a coletividade de pessoas já está exposta a ela, ainda que em nenhum momento se possa identificar um único consumidor real que pretendia insurgir-se contra ela. ${ }^{145}$

Trata-se da mais importante norma extensiva do campo de aplicação da Lei $8.078 / 90^{146}$, praticamente uma espécie de conceito difuso de consumidor (o mais abrangente, amplo e abstrato), tendo em vista que desde já e desde sempre todas as pessoas são consumidoras por estarem potencialmente expostas a toda e qualquer prática comercial. $^{147}$

E arremata a douta Cláudia Lima Marques: "concluímos, então, afirmando que em virtude do disposto no art. 29 do CDC, assim como foi interpretado pela jurisprudência, o legislador brasileiro, para proteger os interesses econômicos dos consumidores, concedeu um novo e poderoso instrumento (as ações autorizadas pelo CDC e sua ética de boa-fé objetiva nas relações negociais) para que os ‘consumidores-equiparados' (na maioria, também empresários) combatam as práticas

que a imperfeição do serviço recebe o nome de defeito" (TJSP, AC 70.826-4, rel. Antonio Carlos Marcato, j. 29.04.1999).

${ }^{143}$ Contratos..., cit., p. 292/294.

${ }^{144}$ Roberto Senise Lisboa. Responsabilidade civil, cit., p. 165.

${ }^{145}$ Luiz Antonio Rizzatto Nunes. Curso..., cit., p. 85.

${ }^{146}$ Cláudia Lima Marques. Contratos..., cit., p. 293.

${ }^{147}$ Luiz Antonio Rizzatto Nunes. Comentários..., cit., p. 108. 
comerciais abusivas que os lesam diretamente e que, mediatamente, prejudicam os outros consumidores e a harmonia do mercado". ${ }^{148}$

Força é concluir, diante disso, que a mera exposição às práticas comerciais aproxima, e muito, o consumidor equiparado do art. 29 da Lei 8.078/90 da interpretação adotada para o elemento teleológico (destinatário final) do conceito de consumidor próprio (supra, 2.1.3).

\subsubsection{A norma de extensão e os bancos}

Ressalte-se, a propósito, o magistério de Antônio Carlos

Efing:

"A norma do art. 29 da Lei 8.078/90 incide nas relações bancárias de consumo, pelo fato de que quase a totalidade dos contratos bancários são de adesão (art. 54 do CDC), contendo cláusulas abusivas (art. 51 do CDC). Assim, a mera exposição da pessoa física ou jurídica ao contrato de adesão já estabelece a equiparação ao consumidor destinatário final (art. 29 do CDC).

\section{(...)}

Igualmente, não se pode, no caso das relações bancárias, cogitar-se da finalidade da operação como requisito para aplicação da lei, pois, no que respeita o art. 29 e a proteção contratual, o comando legal é claro e o que equipara empresas a consumidores é a presença inaceitável da abusividade nas diversas formas que podem revesti-la, seja a abusividade considerada objetivamente ou subjetivamente."

Quando ainda se controvertia na jurisprudência acerca da sujeição dos bancos ao império do CDC, matéria hoje pacífica (infra, 3.1.2), o extinto Tribunal de Alçada do Rio Grande do Sul concretizou, de modo pioneiro, o comando desta norma de extensão. ${ }^{150}$

\footnotetext{
${ }^{148}$ Contratos..., cit., p. 297.

${ }^{149}$ Contratos..., cit., p. 56.

150 "Contrato de crédito rotativo. Juros e correção monetária. Código de Defesa do Consumidor. Conceito de consumidor para os fins dos capítulos V e VI da Lei 8.078/90. Exegese do art. 29 do CDC. Contrato de adesão. Cláusula abusiva. Controle judicial dos contratos. Ainda que não incidam todas as normas do CDC nas relações entre Banco e empresa, em contrato de crédito rotativo, aplicam-se os Capítulos V e VI, por força do art. 29 do CDC, que amplia o conceito de consumidor possibilitando ao Judiciário o controle das cláusulas contratuais abusivas, impostas em contratos de adesão. Cláusula que permite variação unilateral de taxa de juros é abusiva porque, nos termos do art. 51, X e XIII, possibilita variação de preço e modificação
} 
Infere-se, desse contexto, que se assim for interpretado o art. 29 uma nova série de hipóteses passarão a incluir-se no campo de aplicação das normas dos capítulos V e VI do CDC, permitindo uma tutela protetiva daquele profissional, consumidor-equiparado, justamente no âmbito contratual, de forma a reequilibrar a relação e reprimir o uso abusivo do poder econômico. ${ }^{151}$

\subsection{Consumidor estrangeiro não residente (turista)}

Este tópico remete o intérprete, obrigatoriamente, ao caput, do art. $5^{\circ}$, da $\mathrm{CF}^{152}$, bem assim aos conceitos de soberania e de isonomia.

Com efeito, a viga medular dos direitos e deveres individuais e coletivos, além dos brasileiros (natos e naturalizados), alcançou os estrangeiros residentes no País.

É possível, diante dessa realidade, estender a proteção constitucional ao estrangeiro não residente no Brasil, assim entendido aquele que está em território pátrio, mas na condição de visitante, de turista?

Segundo os professores Luiz Alberto David Araujo e Vidal Serrano Nunes Júnior, “os direitos fundamentais têm um forte sentido de proteção do ser humano, e mesmo o próprio caput do art. $5^{\circ}$ faz advertência de que essa proteção realiza-se 'sem distinção de qualquer natureza'. Logo, a interpretação sistemática e finalística do texto constitucional não deixa dúvidas de que os direitos fundamentais destinam-se a todos os indivíduos, independentemente de sua nacionalidade ou situação no Brasil. Assim, um turista (estrangeiro não residente) que seja vítima de uma arbitrariedade policial, por evidente, poderá utilizar-se do habeas corpus para proteger o seu direito de locomoção". ${ }^{153}$

Enfatiza Luiz Antonio Rizzatto Nunes: "como resolver as questões contratuais em envolvem essas pessoas? E os eventuais danos que elas possam

unilateral dos termos contratados. Possibilidade de controle judicial, visando estabelecer o equilíbrio contratual, reduzindo o vigor do princípio pacta sunt servanda, não tendo a taxa de juros sido convencionada no contrato, prevalece o disposto no art. 1062 do CC e decreto n. 22.626/33, fixando-se a taxa em $0,5 \%$ ao mês. Correção do valor, na ausência de convenção, se fará pela variação da TR, fixada pelo governo para corrigir operações financeiras. Ação declaratória julgada procedente para anular lançamentos feitos abusivamente. Sentença reformada" (AC no 192188076, rel. Paulo Heerdt, j. 24.09.1992).

${ }^{151}$ Cláudia Lima Marques. Contratos..., cit., p. 295.

${ }^{152} \mathrm{CF}$, art. $5^{\circ}$, caput: "todos são iguais perante a lei, sem distinção de qualquer natureza, garantindo-se aos brasileiros e aos estrangeiros residentes no País a inviolabilidade do direito à vida, à liberdade, à igualdade, à segurança e à propriedade, nos termos seguintes". 
sofrer por conta da relação de consumo? Afinal, como se disse, se o estrangeiro gasta seu dinheiro aqui, contribui para o desenvolvimento do mercado nacional, possibilitando distribuição de renda, pagamento de impostos e gerando empregos". 154

Reside o problema em se estabelecer a correta amplitude da expressão estrangeiros residentes no País, que, aliás, já integrava os textos das Constituições de 1946 (art. 141, caput), 1967 (art. 150, caput) e da Emenda 1/69 (art. 153, caput).

Razoável interpretá-la, como sugere Alexandre de Moraes, “(...) no sentido de que a Carta Federal só pode assegurar a validade e gozo dos direitos fundamentais dentro do território brasileiro (RTJ 3/566), não excluindo, pois, o estrangeiro em trânsito pelo território nacional, que possui igualmente acesso às ações, como o mandado de segurança e demais remédios constitucionais". ${ }^{155}$

Em verdade, isto há muito foi proposto pelo Min. José Celso de Mello Filho, para quem "a garantia de inviolabilidade dos direitos fundamentais, salvo as exceções de ordem constitucional, se estende também aos estrangeiros não residentes ou domiciliados no Brasil. O caráter universal dos direitos do homem não se compatibiliza com estatutos que os ignorem. A expressão residentes no Brasil deve ser interpretada no sentido de que a Carta Federal só pode resguardar a validade e o gozo dos direitos fundamentais dentro do território brasileiro (...)". ${ }^{156}$

Parece ser esse o caminho trilhado pelo Supremo Tribunal Federal $^{157}$ e pelo Superior Tribunal de Justiça. ${ }^{158}$

Prestigiam-se, com isso, todos os titulares de direitos humanos fundamentais (residentes ou em trânsito) ${ }^{159}$; portanto, o consumidor turista também é destinatário da Lex Fundamentalis e da Lei 8.078/90.

\footnotetext{
${ }^{153}$ Curso..., cit., p. 87.

${ }^{154}$ Comentários..., cit., p. 33/35.

${ }^{155}$ Direitos humanos fundamentais. $3^{\mathrm{a}}$ ed. São Paulo: Atlas, p. 82.

${ }^{156}$ Constituição Federal..., cit., p. 424.

${ }^{157} \mathrm{HC} \mathrm{n}^{\mathrm{o}} 74051-1 / \mathrm{SC}$, rel. Min. Marco Aurélio, j. 18.06.1996.

${ }^{158} \mathrm{RHC} \mathrm{n}^{\mathrm{o}} 3.729 / \mathrm{SP}$, rel. Min. Edson Vidigal, j. 22.06.1994.

${ }^{159}$ Miguel Ángel Ekmekdjian. Tratado de derecho constitucional. Buenos Aires: Depalma, 1993, p. 473/475.
} 


\section{O FORNECEDOR}

Mais uma vez opta o legislador por definir o instituto (art. $\left.3^{\mathrm{o}^{160}}\right)$

Importante é, assim, centrar a atenção no conceito de atividade, porque, de um lado, ele designará se num dos polos da relação jurídica está o fornecedor, com o que se poderá definir se há ou não relação de consumo. ${ }^{161}$

Nesta quadra, consigne-se que é assegurado a todos o livre exercício de qualquer atividade econômica, independentemente de autorização de órgãos públicos, salvo nos casos previstos em lei ( $\mathrm{CF}$, art. 170, par. ún.).

Pois bem. O texto legal indica “(...) que são compreendidos todos quantos propiciem a oferta de bens e serviços no mercado de consumo, de molde a atender à suas necessidades, pouco importando a que título, tendo relevância a distinção, apenas, como se verá, quando se cuidar da responsabilidade de cada 'fornecedor' em casos de danos aos consumidores, ou então para os próprios fornecedores, na via regressiva e em cadeia dessas responsabilidades, eis que vital a solidariedade para a obtenção efetiva da proteção que se almeja para os consumidores". ${ }^{162}$

Isto quer dizer, sinteticamente, que fornecedor é todo ente que provisiona o mercado ${ }^{163}$. Basta que o ato de negócio tenha como viga mestra a atividade regular ou eventual para que surja a relação de consumo ${ }^{164}$, cujo protagonista é o responsável pela disponibilização de produtos e de serviços ao consumidor ${ }^{165}$. É ele gênero do qual o fabricante, o produtor, o construtor, o importador e o comerciante são espécies. ${ }^{166}$

Para Cláudia Lima Marques, “(...) o critério caracterizador é desenvolver atividades tipicamente profissionais, como a comercialização, a produção, a importação, indicando também a necessidade de uma certa habitualidade, como a

\footnotetext{
${ }^{160} \mathrm{CDC}$, art. $3^{\circ}$ : “fornecedor é toda pessoa física ou jurídica, pública ou privada, nacional ou estrangeira, bem como entes despersonalizados, que desenvolvem atividades de produção, montagem, criação, construção, transformação, importação, exportação, distribuição ou comercialização de produtos ou prestação de serviços".

${ }^{161}$ Luiz Antonio Rizzatto Nunes. Curso..., cit., p. 86/87.

162 José Geraldo Brito Filomeno. Manual de direitos do consumidor. $5^{\text {a }}$ ed. São Paulo: Atlas, 2001, p. 46.

${ }^{163}$ Arruda Alvim et alii. Código do Consumidor comentado..., cit., p. 32.

${ }^{164}$ Luiz Antonio Rizzatto Nunes. Comentários..., cit., p. 109.

165 José Geraldo Brito Filomeno et alii. Código Brasileiro de Defesa do Consumidor..., cit., p. 35.

${ }^{166}$ Luiz Antonio Rizzatto Nunes. Comentários..., cit., p. 112.
} 
transformação, a distribuição de produtos. Estas características vão excluir da aplicação das normas do Código todos os contratos firmados ente dois consumidores, nãoprofissionais (...)". ${ }^{167}$

E salienta João Batista de Almeida:

“Em princípio, portanto, só estariam excluídos do conceito de fornecedor aqueles que exerçam ou pratiquem transações típicas de direito privado e sem o caráter de profissão ou atividade, como a compra e venda de imóvel entre pessoas físicas particulares, por acerto direto e sem qualquer influência de publicidade.

\section{(...)}

Nesse ponto, portanto, a definição de fornecedor se distancia da de consumidor, pois, enquanto esta há de ser o destinatário final, tal exigência já não se verifica quanto ao fornecedor, que pode ser o fabricante originário, o intermediário ou o comerciante, bastando que faça disso sua profissão ou atividade principal. O Fornecedor é, pois, tanto aquele que fornece bens e serviços ao consumidor como aquele que o faz para o intermediário ou comerciante (...)."168

Destaca José Geraldo Brito Filomeno: "quanto às atividades desempenhadas pelos fornecedores, são utilizados os termos 'produção, montagem, criação, construção, transformação, importação, exportação, distribuição ou comercialização de produtos ou prestação de serviços' ou, em síntese, a condição de fornecedor está intimamente legada à atividade de cada um e desde que coloquem aqueles produtos e serviços efetivamente no mercado, nascendo daí, ipso facto, eventual responsabilidade por danos causados aos destinatários, ou seja, pelo fato do produto". ${ }^{169}$

Cada um dos núcleos de conduta guarda um significado próprio $^{170}$; porém, mister se faz perceber, com Arruda Alvim, “(...) que a enumeração das atividades que caracterizam o fornecedor poderia parecer pretender ser exauriente. Todavia, dadas as características desta lei de proteção ao consumidor, não nos parece que devam ser entendidas como taxativas, mas sim exemplificativas ('numerus apertus') das

\footnotetext{
${ }^{167}$ Contratos..., cit., p. 326/327.

${ }^{168}$ A proteção jurídica do consumidor. $2^{\mathrm{a}}$ ed. São Paulo: Saraiva, 2000, p. 41.

${ }^{169}$ Et alii. Código Brasileiro de Defesa do Consumidor..., cit., p. 36.

${ }^{170}$ José Cretella Júnior et alii. Comentários ao Código do Consumidor. Rio de Janeiro: Forense, 1992, p. 12/14.
} 
atividades que normalmente envolvem as relações de consumo e que possam gerar ao consumidor direitos exercitáveis por meio deste Código, sem que se possa excluir de estar regulada por este Código outra atividade de natureza similar, semelhante ou de natureza equivalente às atividades enumeradas."171

\subsection{Pessoa jurídica}

Aqui, como uma luva cabe a lição de Luiz Antonio Rizzatto Nunes:

“(...) Tanto no caso do conceito de consumidor quanto no de fornecedor, a referência é a 'toda pessoa jurídica', independentemente de sua condição ou personalidade jurídica. Isto é, toda e qualquer pessoa jurídica. O legislador poderia muito bem ter escrito no caput do art. $3^{\circ}$ apenas a expressão 'pessoa jurídica' que o resultado teria sido o mesmo. Não resta dúvida de que toda pessoa jurídica pode ser consumidora e, evidentemente, por maior força de razão, é fornecedora.

Ao que parece, o legislador, um tanto quanto inseguro, tratou a pessoa jurídica como consumidora sem se importar muito com o resultado de sua determinação, e quis garantir-se de que, no caso do fornecedor, nenhuma pessoa jurídica escapasse de se enquadrar na hipótese legal." ${ }^{\text {172 }}$

\subsubsection{Associações civis e cooperativas}

Neste particular, precisa é a intervenção de Roberto Senise

Lisboa:

“Todas as pessoas jurídicas de direito privado podem ser fornecedoras, pouco importando se o seu fim é econômico ou de lucro. Incluem-se na definição de fornecedor, portanto, as sociedades civis e as sociedades comerciais e empresariais.

Mesmo as entidades sem fins econômicos podem, eventualmente, ser consideradas fornecedoras. Deve-se analisar cuidadosamente o

\footnotetext{
${ }^{171}$ Et alii. Código do Consumidor comentado..., cit., p. 35.
} 
caso concreto, a fim de se concluir corretamente sobre a aplicação do Código de Defesa do Consumidor ou não. Para que a entidade sem fins econômicos seja considerada fornecedora, é indispensável que ela forneça alguma atividade em prol de 'filiados', que possuem a obrigação de pagar uma manutenção periódica, mas que não têm qualquer poder deliberativo para influir, fazendo prevalecer a sua vontade nas decisões do ente moral. Em tal caso, torna-se evidente que a entidade procura se acobertar na forma de uma pessoa jurídica sem fins econômicos, porém atua no mercado de consumo como prestadora de serviços remunerados e, por isso, deve ser considerada fornecedora." $" 173$

Imagine-se, a título de exemplo, uma associação civil que tenha em seus estatutos a finalidade de criação, de organização, de manutenção e de direção de escola, dedicando-se ao ensino e à educação, mantendo os mais variados cursos inclusive. Condiciona esse ente fictício o ingresso em seus quadros sociais ao pressuposto específico da matrícula escolar, recebendo, como uma de suas fontes de renda, remuneração pelos serviços prestados.

Pode essa associação civil eximir-se da sua responsabilidade como fornecedora alegando, verbi gratia, que sua atividade não é exercida no mercado, pois restrita aos associados e a seus dependentes?

É claro que não ${ }^{174}$, pois a hipótese abstrata construída revela tentativa de se mascarar o objetivo primordial da pessoa jurídica (associação), qual seja, a exploração de serviços educacionais remunerados.

No concernente às cooperativas, prossegue o referido jurista: “A lei protetiva do destinatário final de bens não se limita a considerar fornecedor tãosomente as entidades comerciais ou empresariais. Pelo contrário. Inclui-se na noção qualquer pessoa física ou jurídica, mesmo a de natureza civil. Para que incida a lei protecionista do consumidor na relação cooperativa e filiado deve-se demonstrar que o cooperativado não possui poder deliberativo suficiente, em conjunto com outros cooperativados, para afastar as decisões tomadas por uma 'cúpula' de dirigentes. Esses diretores, por sua vez, acabam por se aproveitar indevidamente da forma jurídica dessa entidade para obter a remuneração junto aos consumidores cooperativados, cujos interesses

\footnotetext{
${ }^{172}$ Curso..., cit., p. 88.

${ }^{173}$ Responsabilidade civil..., cit., p. 130/131.

${ }^{174}$ No mesmo sentido: TJSP, AC n 369.964/7, rel. Linneu Carvalho, j. 02.06.1998.
} 
devem ser tutelados pela legislação consumerista, já que não podem intervir nas atividades da entidade". ${ }^{175}$

Tome-se o exemplo de uma cooperativa cujo objetivo social seja a aquisição de lotes urbanizados, em condomínio fechado, para implementar a construção de moradias e, para tanto, contrata terceira empresa como administradora do empreendimento.

$\mathrm{Na}$ consecução de seus fins, além de recolher mensalidade, que integra seus recursos econômicos, inclusive descontando taxa de administração na hipótese de cooperado excluído, presta seus serviços a qualquer pessoa ${ }^{176}$, pois, em princípio, o ingresso nas cooperativas é livre a todos que desejarem utilizar os serviços prestados. $^{177}$

Ora, pode a cooperativa se recusar a cumprir o art. $53^{178}$ da Lei 8.078/90 na hipótese de o seu cooperado (consumidor) desistir do negócio, verbi gratia, pelo inadimplemento das prestações ajustadas? Está a cooperativa isenta de devolver as parcelas pagas tão-só pela sua forma de constituição, apartando-se daquilo que faria uma construtora normal (empresa ou sociedade comercial)?

Hão de ser negativas as respostas, pois nesse exemplo imaginário a cooperativa age, flagrantemente, como fornecedora quando vende e presta seus serviços; logo, não pode invocar sua forma de constituição para se furtar às obrigações inerentes à atividade explorada. ${ }^{179}$

De fato, o STJ já aplicou o CDC para resolver caso análogo. $^{180}$

\footnotetext{
${ }^{175}$ Roberto Senise Lisboa. Responsabilidade civil..., cit., p. 131.

${ }^{176}$ Lei 5.764/71, art. $4^{\circ}$, caput: "as cooperativas são sociedades de pessoas, com forma e natureza jurídica próprias, de natureza civil, não sujeitas à falência, constituídas para prestar serviços aos associados, distinguindo-se das demais sociedades pelas seguintes características: I - adesão voluntária, com número ilimitado de associados, salvo impossibilidade técnica de prestação de serviços”.

${ }^{177}$ Lei 5.764/71, art. 29, caput: "o ingresso nas cooperativas é livre a todos que desejarem utilizar os serviços prestados pela sociedade, desde que adiram aos propósitos sociais e preencham as condições estabelecidas no estatuto, ressalvado o disposto no artigo $4^{\circ}$, item I, desta lei".

${ }^{178}$ CDC, art. 53: "nos contratos de compra e venda de móveis ou imóveis mediante pagamento em prestações, bem como nas alienações fiduciárias em garantia, consideram-se nulas de pleno direito as cláusulas que estabeleçam a perda total das prestações pagas em benefício do credor que, em razão do inadimplemento, pleitear a resolução do contrato e a retomada do produto alienado".

${ }^{179} \mathrm{Cf}$., em sentido contrário, entendendo que a natureza civil da cooperativa constitui óbice para a aplicação do CDC: TJDF, $2^{\text {a }}$ T., AC 47.729/98, rel. Nancy Andrighi, DJU de 21.10.1998, p. 84 e TJSP, AI 178.5364/5-00, rel. Júlio Vidal, j. 13.12.2000.

180 “Cooperativa - Desligamento de cooperado - Devolução das parcelas pagas. I - A fim de se evitar enriquecimento injusto de uma das partes, deve a cooperativa reter $10 \%$ do valor total das parcelas pagas, monetariamente corrigido, para pagamento de encargos por ela suportados. II - Agravo regimental
} 


\subsubsection{Instituições financeiras (ADI 2591)}

Quando a Lei 8.078/90 se refere a toda pessoa jurídica (supra, 3.1), por certo, está dirigindo seus comandos também aos bancos, tanto é que, ao definir serviço (art. $3^{\circ}, \S 2^{\circ}$ ), inclui de maneira expressa as atividades de natureza bancária, financeira, de crédito e securitária (infra 4.2 ), até porque intimamente ligadas ao cotidiano da vida moderna.

Lembra Cláudia Lima Marques que, “(...) na sociedade atual os contratos bancários popularizam-se, não havendo classe social que não se dirija aos bancos para levantar capital, para recolher suas economias, para depositar seus valores ou simplesmente pagar suas contas. É o contrato de adesão por excelência, é uma das relações consumidor-fornecedor que mais se utiliza do método de contratação por adesão e com ‘condições gerais' impostas e desconhecidas". 181

A matéria que deveria ser pacífica, até bem pouco tempo, incrivelmente não era ${ }^{182}$, mas como ressalta Antônio Carlos Efing:

“(...) tais argumentos não encontram sequer respaldo no próprio $\mathrm{CDC}$, que em seus preceitos deixa claro o enquadramento das instituições de crédito como fornecedores.

Por outro lado, conforme já argumentado anteriormente, do ponto de vista da conceituação de consumidores, especialmente os expostos às práticas consideradas abusivas pelo $\mathrm{CDC}$, não resta qualquer dúvida de que a Lei 8.078/90 é perfeitamente aplicável às instituições financeiras.

\section{(...)}

Logicamente, quando uma instituição financeira está contratando qualquer espécie de financiamento, posiciona-se na condição de

\footnotetext{
desprovido"180 (AGA 387.392/SP, rel. Min. Antônio de Pádua Ribeiro, j. 04.10.2001). Do V. Aresto extrai-se o seguinte excerto: "finalmente, não se pode ignorar que o contrato em questão está sob a égide do Código de Defesa do Consumidor e que, sendo assim, suas cláusulas deverão ser interpretadas de maneira mais favorável ao cooperado". Em igual sentido: "comprovado o inadimplemento da promitente vendedora. Irrelevância da natureza de cooperativa, que não impede a aplicação da regra do CDC. Retorno das partes ao estado anterior, com devolução imediata das parcelas do preço. Sentença que se mantém. Recurso não provido" (TJSP, AC 405.545-4/4, rel. Francisco Loureiro, j. 02.04.2009).

${ }^{181}$ Contratos..., cit., p. 429.

${ }^{182}$ Arnoldo Wald. O direito do consumidor e suas repercussões em relação às instituições financeiras. $R T$, São Paulo: RT, v. 666, p. 7.
} 
fornecedora, ainda mais que a sua atividade econômica reflete o lucro obtido entre a taxa de captação de dinheiro e a taxa cobrada do consumidor/financiado spread.

Dentro do conceito legal de fornecedor (caput do art. $3^{\circ}$ do CDC) encontramos as atividades comumente desenvolvidas pelas instituições financeiras: comercialização de produtos e prestação de serviços.

Certamente, toda atividade financeira desenvolvida por qualquer banco visa à obtenção de lucro, caracterizando-se em todos os aspectos a remuneração (direta e indireta) dos serviços prestados. Aliás, em momentos de índice inflacionário baixo, todas as instituições financeiras apelam para a cobrança de taxas em decorrência de qualquer serviço prestado ao consumidor."183

Outra não é a postura assumida por Nelson Nery Júnior: "analisado o problema da classificação do banco como empresa e de sua atividade negocial, tem-se que é considerado pelo art. $3^{\circ}$, caput, do CDC como fornecedor, vale dizer, como um dos sujeitos da relação de consumo. O produto da atividade comercial do banco é o crédito; agem os bancos, ainda, na qualidade de prestadores de serviço, quando recebem tributos mesmo de não clientes, fornecem extratos de contas bancárias por meio de computador etc. Podem os bancos, ainda, celebrar contrato de aluguel de cofre, para a guarda de valores, igualmente enquadrável no conceito de relação de consumo. Suas atividades envolvem, pois, os dois objetos das relações de consumo: os produtos e os serviços." 184

A propósito, após qualificar como um "absurdo em termos de hermenêutica jurídica" a não sujeição dos bancos ao CDC, Newton de Lucca conclui que, “(...) parece de todo evidente que, em todas essas hipóteses que vimos mencionando, ultrapassaria os limites do inacreditável fosse alguém sustentar estarem as instituições financeiras à margem de tais disposições legais, podendo expor devedores a ridículo, redigir cláusulas abusivas, fazer propaganda enganosa ou abusiva e assim por diante". ${ }^{185}$

Em que pese à sujeição dos bancos ao império do CDC estivesse pacificada no $\mathrm{STJ}^{186}$, intérprete soberano da legislação federal, a Confederação

\footnotetext{
${ }^{183}$ Contratos..., cit., p. 63/64.

${ }^{184}$ Et alii. Código Brasileiro de Defesa do Consumidor..., cit., p. 313.

${ }^{185}$ O Código de Defesa do Consumidor: discussões sobre o seu âmbito de aplicação. Revista de Direito do Consumidor, São Paulo: RT, v. 6, abr.-jun. 1993, p. 67.

${ }^{186}$ STJ, Súm. 297.
} 
Nacional do Sistema Financeiro (CONSIF), em 26.12.2001), ajuizou perante o STF Ação Direta (ADIN no 2591/DF) visando à declaração de inconstitucionalidade, ex tunc, da expressão: inclusive as de natureza bancária, financeira, de crédito e securitária constante do art. $3^{\circ}, \S 2^{\circ}$, da Lei 8.078/90, por afronta aos arts. 192, caput, e incisos II e IV (então vigentes ${ }^{187}$ ) c.c. $5^{\circ}$, LIV, ambos da Constituição da República. ${ }^{188}$

A autora sustentava sua pretensão exclusivamente num suposto vício formal, ou seja o $\mathrm{CDC}$ - lei ordinária - não poderia regular o Sistema Financeiro Nacional, o que só é factível por lei complementar (CF, art. 192, caput).

Esquecia-se, deliberadamente, que a lógica de proteção da Lei 8.078/90 é de ordem subjetiva, estabelecida pela qualidade da parte; consequentemente (isso é importante), não interfere no regramento abstrato da atividade do fornecedor, apenas na sua exploração no mercado de consumo; logo, em momento algum a Lei 8.078/90 se arvora na regulamentação do Sistema Financeiro Nacional, especialmente quanto àquelas pretéritas hipóteses dos incisos II e IV, do artigo 192 da CF.

Ao revés, garante ao consumidor - materialmente vulnerável - um meio eficaz de repressão aos abusos praticados no mercado, sempre com base na boafé e buscando o equilíbrio nas relações entre consumidores e fornecedores (CDC, art. $4^{\circ}$ e seus incisos).

Luiz Antonio Rizzatto Nunes também doutrina nesse sentido:

“Coloque-se em relevo esse ponto: a lei 8.078/90 regula as relações jurídicas no pólo final de consumo; não estabelece normatização para as outras diversas relações existentes entre os vários agentes econômicos. Assim, por exemplo, o CDC não regula as relações entre o produtor rural e a indústria de alimentos, ou a existente entre a montadora de veículos e suas concessionárias, ou ainda, as relações entre o Banco Central e os agentes financeiros, entre o Estado e o Banco Central etc.

Assim claro está que, a hipótese do art. 192 é a de regulação de matéria bem diversa daquela estabelecida pelo CDC: a existente entre o Estado, o Banco Central, os agentes financeiros, as seguradoras etc. A matéria tratada na

\footnotetext{
${ }^{187}$ Hoje revogados pela EC 40, de 29 de maio de 2003.

$188 \mathrm{CF}$, art. 192: "o sistema financeiro nacional, estruturado de forma a promover o desenvolvimento equilibrado do País e a servir aos interesses da coletividade, será regulado em lei complementar, que disporá, inclusive, sobre: (...) II - autorização e funcionamento dos estabelecimentos de seguro, resseguro,
} 
lei 8.078/90, repita-se, é outra muito diferente: ela regula as relações jurídicas estabelecidas no pólo final de consumo, ente consumidor de um lado, e fornecedor de outro, na transação de produtos e serviços." "189

E saliente-se: não é a defesa do consumidor que deve amoldar-se ao Sistema Financeiro Nacional, mas, sim, o contrário, pois a lei complementar reguladora jamais poderá contrapor-se à defesa do consumidor, um dos princípios gerais da ordem econômica (CF, art. 170, V).

É essa a razoabilidade constitucional; todavia, a investida não era surpreender, pois, até hoje, as instituições financeiras são ditadoras da ordem econômica no Brasil, onde praticam abusos e arbitrariedades inomináveis, sem qualquer punição. ${ }^{190}$

De outra banda, a inconstitucionalidade da expressão guerreada (inclusive as de natureza bancária, financeira, de crédito e securitária), caso fosse julgado procedente do pedido, em nada alteraria a realidade fática suportada pelas instituições financeiras, visto que continuariam fornecedoras ex vi do caput, do art. $3^{\circ}$ do CDC, vinculadas a transações com produtos $\left(\S 1^{\circ}\right)$, imateriais (crédito) inclusive, além de prestadoras de serviço $\left(\S 3^{\circ}\right)$ - assim considerado qualquer atividade fornecida no mercado de consumo, mediante remuneração, salvo as decorrentes das relações de caráter trabalhista (parte restante fora da arguição de inconstitucionalidade).

Observe-se a lição de Luiz Antonio Rizzatto Nunes: "a norma faz uma enumeração específica, que tem razão de ser. Coloca expressamente os serviços de natureza bancária, financeira, de crédito e securitária, antecedidos do advérbio 'inclusive'. Tal designação não significa que exista alguma dúvida a respeito da natureza dos serviços desse tipo. Antes demonstra, mais uma vez, a insegurança do legislador, em especial, no caso, preocupado que os bancos, financeiras e empresas de seguro conseguissem, de alguma forma, escapar do âmbito de aplicação do CDC. Ninguém duvida de que esse setor da economia presta serviços ao consumidor e que a natureza dessa prestação se estabelece tipicamente numa relação de consumo. Foi um reforço acautelatório do legislador. Que, aliás, demonstrou-se depois, era mesmo necessário. Apesar da clareza do texto legal, que

previdência e capitalização, bem como do órgão oficial fiscalizador; (...) e IV - a organização, o funcionamento e as atribuições do Banco Central e demais instituições financeiras públicas e privadas".

${ }^{189}$ O Código de Defesa do Consumidor e o artigo 192 da Constituição Federal: conflito entre lei ordinária e lei complementar? Artigos de doutrina: Saraiva, disponível em www.saraivajur.com.br. 
coloca com todas as letras, que os bancos prestam serviços aos consumidores, houve tentativa judicial de obter declaração em sentido oposto". ${ }^{191}$

Renovou-se, assim e após onze anos de vigência do CDC, o ataque à cidadania; mas o Augusto Pretório, apesar de informado pela maioria do seu plenário, bem decretou a improcedência do pedido. ${ }^{192}$

\subsection{Ente despersonalizado}

Também os entes despersonalizados respondem perante o consumidor, o que inclui as sociedades de fato e quaisquer formas de cooperação ou

${ }^{190}$ Augusto Zenun. Comentários ao Código do Consumidor. 2ª ed. Rio de Janeiro: Forense, 1998, p. 6.
${ }_{191}$ Comentários..., cit., p. 117.
192 "CÓDIGO DE DEFESA DO CONSUMIDOR. ART. 5, XXXII, DA CF/88. ART. 170, V, DA CF/88. INSTITUIÇÕES FINANCEIRAS. SUJEIÇÃO DELAS AO CÓDIGO DE DEFESA DO CONSUMIDOR, EXCLUÍDAS DE SUA ABRANGÊNCIA A DEFINIÇÃO DO CUSTO DAS OPERAÇÕES ATIVAS E A REMUNERAÇÃO DAS OPERAÇÕES PASSIVAS PRATICADAS NA EXPLORAÇÃO DA INTERMEDIAÇÃO DE DINHEIRO NA ECONOMIA [ART. $3^{\circ}, \S 2^{\circ}$, DO CDC]. MOEDA E TAXA DE JUROS. DEVER-PODER DO BANCO CENTRAL DO BRASIL. SUJEIÇÃO AO CÓDIGO CIVIL. 1. As instituições financeiras estão, todas elas, alcançadas pela incidência das normas veiculadas pelo Código de Defesa do Consumidor. 2. "Consumidor", para os efeitos do Código de Defesa do Consumidor, é toda pessoa física ou jurídica que utiliza, como destinatário final, atividade bancária, financeira e de crédito. 3. O preceito veiculado pelo art. $3^{\circ}, \S 2^{\circ}$, do Código de Defesa do Consumidor deve ser interpretado em coerência com a Constituição, o que importa em que o custo das operações ativas e a remuneração das operações passivas praticadas por instituições financeiras na exploração da intermediação de dinheiro na economia estejam excluídas da sua abrangência. 4. Ao Conselho Monetário Nacional incumbe a fixação, desde a perspectiva macroeconômica, da taxa base de juros praticável no mercado financeiro. 5. O Banco Central do Brasil está vinculado pelo dever-poder de fiscalizar as instituições financeiras, em especial na estipulação contratual das taxas de juros por elas praticadas no desempenho da intermediação de dinheiro na economia. 6. Ação direta julgada improcedente, afastando-se a exegese que submete às normas do Código de Defesa do Consumidor [Lei 8.078/90] à definição do custo das operações ativas e da remuneração das operações passivas praticadas por instituições financeiras no desempenho da intermediação de dinheiro na economia, sem prejuízo do controle, pelo Banco Central do Brasil, e do controle e revisão, pelo Poder Judiciário, nos termos do disposto no Código Civil, em cada caso, de eventual abusividade, onerosidade excessiva ou outras distorções na composição contratual da taxa de juros. ART. 192, DA CF/88. NORMA-OBJETIVO. EXIGÊNCIA DE LEI COMPLEMENTAR EXCLUSIVAMENTE PARA A REGULAMENTAÇÃO DO SISTEMA FINANCEIRO. 7. O preceito veiculado pelo art. 192 da Constituição do Brasil consubstancia norma-objetivo que estabelece os fins a serem perseguidos pelo sistema financeiro nacional, a promoção do desenvolvimento equilibrado do País e a realização dos interesses da coletividade. 8. A exigência de lei complementar veiculada pelo art. 192 da Constituição abrange exclusivamente a regulamentação da estrutura do sistema financeiro. CONSELHO MONETÁRIO NACIONAL. ART. 4º, VIII, DA LEI N 4.595/64. CAPACIDADE NORMATIVA ATINENTE À CONSTITUIÇÃO, FUNCIONAMENTO E FISCALIZAÇÃO DAS INSTITUIÇÕES FINANCEIRAS. ILEGALIDADE DE RESOLUÇÕES QUE EXCEDEM ESSA MATÉRIA. 9. O Conselho Monetário Nacional é titular de capacidade normativa - a chamada capacidade normativa de conjuntura - no exercício da qual lhe incumbe regular, além da constituição e fiscalização, o funcionamento das instituições financeiras, isto é, o desempenho de suas atividades no plano do sistema financeiro. 10. Tudo o quanto exceda esse desempenho não pode ser objeto de regulação por ato normativo produzido pelo Conselho Monetário Nacional. 11. A produção de atos normativos pelo Conselho Monetário Nacional, quando não respeitem ao funcionamento das instituições financeiras, é abusiva, consubstanciando afronta à legalidade" (STF, ADI 2591/DF, rel. Min. Eros Grau, j. 29.09.2006). 
atividade comum $^{193}$, ou seja, aquelas que, sem constituir uma pessoa jurídica, desenvolvem, de fato, atividade industrial, comercial, de prestação de serviços etc. A figura do "camelô" está aí inserida. O CDC não poderia deixar de incluir tais "pessoas" pelo simples fato de que elas formam um bem número de fornecedores, que suprem de maneira relevante o mercado de consumo. ${ }^{194}$

São exemplos de entes despersonalizados que podem ser fornecedores: a massa falida, a massa concordatária, o espólio, o condomínio, a herança jacente ou vacante, etc.

\subsection{Pessoa física}

Com acuidade observa Luiz Antonio Rizzatto Nunes:

"No que respeita à pessoa física, tem-se, em primeiro lugar, a figura do profissional liberal como prestador de serviço e que não escapou da égide da Lei 8.078. (...) Há, ainda, outra situação em que a pessoa física será identificada como fornecedora. É aquela em que desenvolva atividade eventual e rotineira de venda de produtos, sem ter-se estabelecido como pessoa jurídica.

\section{(...)}

E também será fornecedora a pessoa física que presta serviços mesmo sem ser caracterizada como profissional liberal, tal como o eletricista, o encanador etc." 195

É o caso do autônomo, que nem sempre se confunde com o profissional liberal. Os termos não se equivalem, embora - de acordo com parte da doutrina - o segundo possa ser classificado como uma espécie do gênero que encerra o primeiro, apenas qualificado por certos requisitos próprios.

Mirella D’Angelo Caldeira e Patrícia Caldeira, v.g., elencam as características próprias ao profissional liberal: “1. conhecimento técnico (científico e/ou manual) sobre certa profissão; 2. conhecimento atestado por meio de diploma, conferido

\footnotetext{
193 Adalberto Pasqualotto. Conceitos fundamentais..., cit., p. 52.

${ }^{194}$ Luiz Antonio Rizzatto Nunes. Curso..., cit., p. 88/89.

${ }^{195}$ Curso..., cit., p. 89/90.
} 
por uma escola capacitada; 3. profissão regulamentada; 4. livre exercício da atividade, e; 5 relação intuito personae". ${ }^{196}$

\footnotetext{
${ }^{196}$ O conceito de profissionais liberais: uma nova proposta. Revista dignidade. Programa de Pós-graduação em direito da Unimes. Ano 1, $\mathrm{n}^{\mathrm{o}}$ 1, 2002, p. 156. Asseveram as autoras, na sequência (p. 158/159), que “(...) profissional liberal não é sinônimo de profissional autônomo. Este último é gênero do qual o primeiro é espécie. Com efeito, o profissional autônomo é aquele que exerce seu trabalho com poder de direção sobre a própria atividade, autodisciplinando-a segundo os seus critérios pessoais, detendo, pois, o poder de direção da própria atividade. Além disso, o profissional autônomo assume a teoria do risco da atividade que exerce, exatamente em razão do poder de direção que assume. Vale dizer, ele não transfere a fiscalização de sua atividade a um superior hierárquico. (...) Assim, o autônomo seria o gênero, porque abarca todo e qualquer tipo de atividade/profissão que seja exercida com poder de direção e com base no risco. O profissional liberal também é autônomo, pois possui autonomia e poder de direção, entretanto, sua atividade requer conhecimento (intelectual ou manual), atestado por escola de nível superior, cuja profissão tem que ser regulamentada. Dessa forma, profissional liberal é espécie do gênero profissional autônomo, pois todo liberal pode ser autônomo, mas nem todo autônomo pode ser liberal".
} 


\section{PRODUTOS E SERVIÇOS}

Identificados os sujeitos (supra, 2 e 3), surgem os produtos e os serviços como os objetos das relações de consumo.

Segundo Roberto Senise Lisboa, “(...) o Código de Defesa do Consumidor procurou distinguir o objeto da relação de consumo, dividindo-o em duas grandes categorias: o produto e o serviço. Considerou-se que o exercício da atividade remunerada é um objeto da relação de consumo distinto do produto. A conduta desenvolvida pelo fornecedor, como objeto da relação de consumo, é o serviço, enquanto que os demais bens são produtos". ${ }^{197}$

\subsection{Produto}

Produto é qualquer bem, móvel ou imóvel, material ou imaterial (CDC, art. $\left.\S 1^{\circ}\right)$.

Por se tratar de definição extremamente abrangente, não se permite ao intérprete a restrição de seu conteúdo, salvo para diferenciar a atividade da pessoa e o produto. Essa é, a bem da verdade, a única distinção feita entre os vários objetos de direito na relação de consumo. ${ }^{198}$

\section{Para o mestre Luiz Antonio Rizzatto Nunes:}

"Esse conceito de produto é universal nos dias atuais e está estreitamente ligado à idéia do bem, resultado da produção no mercado de consumo das sociedades capitalistas contemporâneas. É vantajoso seu uso, pois o conceito passa a valer no meio jurídico e já era usado por todos os demais agentes do mercado (econômico, financeiro, de comunicações etc.).

$\mathrm{Na}$ definição de produto, o legislador coloca então 'qualquer bem', e designa este como 'móvel ou imóvel', e ainda 'material ou imaterial'. Da necessidade de interpretação sistemática do CDC nascerá também a hipótese de fixação do produto como durável e não durável, por previsão do art. 26 (acontecerá o mesmo no que tange aos serviços)."199

\footnotetext{
${ }^{197}$ Responsabilidade civil..., cit., p. 167.

${ }^{198}$ Idem.

${ }^{199}$ Comentários..., cit., p. 113.
} 


\subsubsection{Crédito}

Quanto aos produtos materiais não há dificuldade; entretanto, o Código de Defesa do Consumidor também disciplina as operações com produto imaterial.

Mas poderia esse bem ser oferecido no mercado de consumo para venda pelo fornecedor e, ao mesmo tempo, adquirido pelo consumidor? ${ }^{200}$

Basta voltar às instituições financeiras (supra, 3.1.2) para que a visualização fique mais clara, v.g., o mútuo, as aplicações rentáveis, o crédito, etc.; aliás, "o conceito de mútuo pode ser interpretado em sentido amplo, de molde a integrar a abertura de crédito". 201

Dentre os produtos fornecidos pelos bancos, o mais nobre é o crédito, essencialmente consumível (não durável) ${ }^{202}$, daí o porquê da referência expressa.

Cumpre frisar, com Cláudia Lima Marques, que “(...) a operação envolvendo crédito é intrínseca e acessória ao consumo, utilizada geralmente como uma técnica complementar e necessária ao consumo, seja pela produção com menos possibilidades econômicas e sociais, que utilizam seguidamente as vendas à prestação, seja pelo resto da população para adquirir bens de maior valor, como automóveis ou casas próprias, ou simplesmente para alcançar maior conforto e segurança nas suas compras, utilizando o sistema de cartões de crédito. A massificação do crédito e um pós-moderno entusiasmo pelo consumo com pagamento postergado têm trazido problemas de insolvência em países (pós) industrializados de primeiro mundo, mas também no Brasil". 203

\subsubsection{Durável}

Quanto à durabilidade, o produto pode ser: durável e não durável. Produto durável é aquele cujo consumo não importa sua imediata destruição

\footnotetext{
${ }^{200}$ Luiz Antonio Rizzatto Nunes. Curso ..., cit., p. 91.

${ }^{201}$ Fernando de Gravato Morais. Contratos de crédito ao consumo. Coimbra: Almedina, 2007, p. 51.

${ }^{202}$ Márcio Mello Casado. Proteção do consumidor de crédito bancário e financeiro. São Paulo: RT, 2000, p. $29 / 30$.

${ }^{203}$ Contratos..., cit., p. 430.
} 
física ${ }^{204}$, ou seja, sobrevive a muitos usos. ${ }^{205}$ Exemplos: eletrodomésticos, automóvel, computador, móveis, roupas, etc.

Saliente-se a observação sempre precisa de Luiz Antonio Rizzatto Nunes:

"Produto durável é aquele que, como o próprio nome diz, não se extingue com o uso. Ele dura, leva tempo para se desgastar. Pode - e deve - ser utilizado muitas vezes. Contudo, é preciso chamar a atenção para o aspecto de 'durabilidade' do bem durável. Nenhum produto é eterno. Todos tendem a um fim material. Até mesmo um imóvel construído se desgasta (o terreno é uma exceção, uma vez que dura na própria disposição do planeta). A duração de um imóvel, enquanto tal, comporta arrumações, reformas, reconstruções etc.; com idêntica razão, então, é claro que um terno se desgaste, uma geladeira se desgaste, um automóvel se desgaste etc.

\section{$(\ldots)$}

Nesses casos de desgaste natural não se pode nem se falará em vício do produto. Não há proteção legal contra o desgaste, a não ser que o próprio fabricante tenha assumido certo prazo de funcionamento (conforme permite o CDC: arts. 30, 31, 37, 50 etc.). A norma protege o produto durável, em certo prazo, por vício (arts. 18, 26, II, e 50), para garantir sua finalidade e qualidade." 206

\subsubsection{Produto descartável}

O produto descartável (termo não definido em lei) é o durável de baixa durabilidade, uma subespécie, ou que somente pode ser utilizado uma vez. É uma invenção do mercado contemporâneo, que acaba aproximando o produto durável em sua forma de desgaste ao produto não durável em sua forma de extinção. ${ }^{207}$

\subsubsection{Não durável}

\footnotetext{
${ }^{204}$ Roberto Senise Lisboa. Responsabilidade civil..., cit., p. 173.

${ }^{205}$ Philip Kloter. Administração e Marketing: análise, planejamento e controle. São Paulo: Atlas, 1995, apud, José Geraldo Brito Filomeno et alii. Código Brasileiro de Defesa do Consumidor..., cit., p. 38. ${ }^{206}$ Comentários..., cit., p. 115.

${ }^{207}$ Idem.
} 
Produto não durável é aquele cujo consumo acarreta a sua imediata destruição física ${ }^{208}$, é dizer, bens que normalmente são consumidos em um ou em alguns poucos usos. ${ }^{209}$ Exemplos: gêneros alimentícios, produtos medicinais, sabonete, etc.

Segundo Luiz Antonio Rizzatto Nunes:

“O produto 'não durável', por sua vez, é aquele que se acaba com o uso. Como o próprio nome também diz, não tem qualquer durabilidade. Usado, ele se extingue ou, pelo menos vai-se extinguindo. Estão nessa condição os alimentos, os remédios, os cosméticos etc. Note-se que se fala em extinção imediata, como é o caso de uma bebida, pela ingestão ou extinção consumativa sequencial, como é o caso do sabonete: este se vai extinguindo enquanto é usado.

\section{(...)}

(...) $\mathrm{O}$ fato de todo o produto não se extinguir de uma só vez não lhe retira a condição de 'não durável'. O que caracteriza essa qualificação é sua maneira de extinção 'enquanto' é utilizado.

É exatamente daí que surge a diferença específica do produto durável descartável. Enquanto este permanece quase tal como era após utilizado, o produto 'não durável' perde totalmente sua existência com o uso ou, ao menos, vai perdendo-a aos poucos com sua utilização."210

Vale mencionar a proposta do Eminente Min. Sálvio de Figueiredo Teixeira: “entende-se por produtos não duráveis aqueles que se exaurem no primeiro uso ou logo após sua aquisição, enquanto que os duráveis, definidos por exclusão, seriam aqueles de vida útil não-efêmera". 211

\subsubsection{Produto gratuito (amostra grátis)}

Tendo em vista que a remuneração só foi expressamente mencionada na definição de serviço (infra, 4.2), isso significa que o produto gratuito está incluído nas garantias do CDC. A chamada amostra grátis deve ter todas as características exigidas e

\footnotetext{
${ }^{208}$ Roberto Senise Lisboa. Responsabilidade civil..., cit., p. 173.

${ }^{209}$ Philip Kloter. Administração e Marketing..., cit., idem.

${ }^{210}$ Curso..., cit., p. 93/94.

${ }^{211}$ STJ, REsp. 114.473/RJ, j. 24.03.1997.
} 
está sujeita às regras relativas aos vícios, aos defeitos, aos prazos de garantia, à responsabilidade civil, etc. ${ }^{212}$

Apenas para que não passe despercebido, o produto enviado ou entregue e o serviço prestado sem prévia solicitação do consumidor, além de encerraram prática abusiva típica, equiparam-se às amostras grátis, o que elide a obrigação de pagamento (CDC, art. 39, III, c.c. seu par. ún.).

\subsection{Serviço}

Serviço é qualquer atividade fornecida no mercado de consumo, pública ${ }^{213}$ ou privada, mediante remuneração, inclusive as de natureza bancária, financeira, de crédito e securitária, salvo as decorrentes das relações de caráter trabalhista $\left(\mathrm{CDC}\right.$, art. $\left.3^{\circ}, \S 2^{\circ}\right)$.

Ao fixar como serviço qualquer atividade remunerada, o legislador pretendeu fazer com que a norma jurídica consumerista incidisse sobre a mais variada gama de relações, pouco importando a área tradicional do direito na qual elas se formavam, exceção expressa feita às relações trabalhistas. ${ }^{214}$

Há, como se percebe, uma única exceção, de ordem material, prevista na lei: atividades decorrentes das relações de caráter trabalhista.

O critério distintivo básico entre serviço e produto é, destarte, a atividade profissional do fornecedor ser preponderante para a outorga de um bem material ou imaterial. A diferença expressa entre produto e serviço teve como objetivo, indubitavelmente, inviabilizar a incidência do CDC sobre a relação jurídica cujo objeto fosse a atividade humana, porém não remunerada. ${ }^{215}$

A remuneração é, pois, fundamental.

Mas é preciso cautela, visto que, na arguta observação de Luiz Antonio Rizzatto Nunes:

\footnotetext{
${ }^{212}$ Luiz Antonio Rizzatto Nunes. Curso ..., cit., p. 94/95.

213 “Ação de indenização - Direito do consumidor - Furto de veículo em estacionamento da Zona Azul. Lei Municipal 3.434/2007 que obriga pessoas físicas ou jurídicas que exploram estacionamento neste Município, inclusive espaços públicos administrados pela iniciativa privada, a contratar seguro contra danos e sinistros ocorridos aos automóveis. Dever de indenizar. Danos morais configurados. Quantum indenizatório justo. Apelo improvido. Sentença mantida. Decisão Unânime” (TJSE, AC 2008217361, rel. José Alves Neto, j. 02.03.2009).

${ }^{214}$ Roberto Senise Lisboa. Responsabilidade civil..., cit., p. 175.

${ }^{215}$ Roberto Senise Lisboa. Responsabilidade civil..., cit., p. 174/175.
} 
“(...) quando a lei fala em 'remuneração' não está necessariamente se referindo a preço ou preço cobrado. Deve-se entender o aspecto 'remuneração' no sentido estrito de qualquer tipo de cobrança ou repasse, direto ou indireto.

É preciso algum tipo de organização para entender o alcance da norma. Para estar diante de um serviço prestado sem remuneração, será necessário que, de fato, o prestador do serviço não tenha, de maneira alguma, se ressarcido de seus custos, ou que, em função da natureza da prestação do serviço, não tenha cobrado o preço (...)."216

$\mathrm{Na}$ mesma linha de pensamento leciona James Marins: “inicialmente, cremos que se deva entender a expressão 'mediante remuneração' não apenas como representativa da remuneração direta, isto é o pagamento diretamente efetuado pelo consumidor ao fornecedor. Compreende também a remuneração do fornecedor o benefício comercial indireto advindo de prestações de serviços aparentemente gratuitas assim como a remuneração 'embutida' em outros custos". 217

\subsubsection{Durável}

Luiz Antonio Rizzatto Nunes enfrentou o tema com percuciência:

“(...) o mercado acabou criando os chamados serviços tidos como duráveis, tais como os contínuos (por exemplo, os serviços de convênio de saúde, os serviços educacionais regulares em geral etc.). Com isso, o CDC, incorporando essa invenção, trata de definir também os serviços como duráveis e não duráveis, no que andou bem.

\section{(...)}

Serviços duráveis serão aqueles que:

a) tiverem continuidade no tempo em decorrência de uma estipulação contratual. São exemplos a prestação dos serviços escolares, os chamados planos de saúde etc., bem como todo e qualquer serviço que no contrato seja estabelecido como contínuo;

${ }^{216}$ Curso..., cit., p. 98. 
b) embora típicos de não-durabilidade e sem estabelecimento contratual de continuidade, deixarem como resultado um produto. Por exemplo, a pintura de uma casa, a instalação de um carpete, o serviço de buffet, a colocação de um Box, os serviços de assistência técnica e de consertos (o conserto de um veículo) etc. Nesses casos, embora se possa destacar o serviço do produto deixado (o que gerará diferenciais no aspecto de responsabilidade, como se verá), o produto faz parte do serviço - às vezes até com ele se confundindo, como acontece, por exemplo, com a pintura de uma parede." ${ }^{218}$

\subsubsection{Não durável}

Partindo-se da idéia de que serviço é tipicamente uma atividade, ação humana dirigida a determinado fim, via de regra, sua projeção se esgota tão logo praticada aquela conduta em si mesma; logo, serviço não durável será aquele que, de fato, se exaure assim que prestado, v.g., transportes, diversões públicas, hospedagem, etc. $^{219}$

Interessante notar, a partir da precisa distinção feita pela doutrina, que em determinadas situações, forte no princípio da vinculação (infra, Cap. V, 2.1) inerente à obrigatória oferta (CDC, art. 30), que o fornecedor pode converter um serviço ontologicamente não durável em durável.

A justificativa para esse proceder pode estar em inúmeros motivos, no entanto, como revela a experiência comum, o fornecedor que assim age visa a uma forma mais eficiente de captação de clientela, lídimo diferencial de atuação no mercado; daí porque, como corolário do risco proveito, ao gerar legítimas expectativas no íntimo do consumidor, há de suportar os reflexos do inadimplemento se não alcançar o resultado prometido.

Observe-se, por oportuno, que toda venda de produto implica a simultânea prestação de serviço, embora a recíproca não seja verdadeira; aliás, tal qual ocorre em uma consulta médica onde existe apenas o serviço. ${ }^{220}$

\footnotetext{
${ }^{217}$ Responsabilidade da empresa..., cit., p. 82.

${ }^{218}$ Comentários..., cit., p. 121/122.

${ }^{219}$ Luiz Antonio Rizzatto Nunes. Curso..., cit., p. 96.

${ }^{220}$ Luiz Antonio Rizzatto Nunes. Curso..., cit., p. 97.
} 


\title{
CAPÍTULO III \\ POLÍTICA NACIONAL DAS RELAÇÕES DE CONSUMO
}

\author{
SUMÁRIO: 1. CONSIDERAÇÕES GERAIS - 2. VULNERABILIDADE - 3. AÇÃO \\ GOVERNAMENTAL - 4. HARMONIA E EQUILÍBRIO - 5. SERVIÇOS PÚBLICOS.
}

\section{CONSIDERAÇÕES GERAIS}

Segundo Fabio Nusdeo, “a palavra 'política' empregada no contexto do Código de Defesa do Consumidor, inclui-se, à evidência, no campo vasto da Política Econômica, uma vez que o ato de consumir e a relação de consumo dele decorrente constituem atividade tipicamente econômica, caracterizada pela utilização de bens escassos para o atendimento de necessidades. Ora, a política corresponde a um enfoque da realidade, no caso econômica, dentro do qual algumas variáveis são encaradas como meios para que outras variáveis, tidas como fins, assumam determinados níveis ou valores. Essa a essência de qualquer atividade dita 'política': o seu finalismo, a sua vetorização, o seu endereçamento a um resultado ou a uma meta preestabelecida. Ação política é, portanto, aquela ordenada a um fim. Fala-se - sempre no campo da economia em política de produção, política de desenvolvimento, política comercial e, mesmo, em política de consumo".221

E prossegue o destacado professor, ao anotar que não se trata de mera política de consumo, mas de política das relações de consumo, ressaltando o endereçamento desse novo campo econômico "é outro: visa não ao consumo em si, mas às relações de consumo, ou seja, àquelas em que se envolvem todos quantos procuram bens e serviços para o atendimento de suas necessidades e aqueles que lhe fornecem os bens para tal. A lei pretende imprimir determinadas características a tais relações, a fim de que elas possam apresentar um nível de qualidade tido como favorável, principalmente a uma das partes nelas envolvidas: o consumidor. Isto não significa, é claro, que a contrario sensu tal relação deva ser desfavorável à outra parte: o fornecedor. Este dela derivará a sua remuneração própria: o lucro, condicionado porém ao atendimento de certos requisitos,

\footnotetext{
${ }^{221}$ Et alii. Comentários ao Código de Defesa do Consumidor. Rio de Janeiro: Forense, 1992, pág. 20.
} 
cujo espaço é, precisamente, o de evitar seja ele obtido com o sacrifício injustificado do consumidor". 222

Pretende-se, com isso, uma política que privilegie as necessidades da demanda e não as conveniências da oferta. Ao se planejar um produto, há de se indagar o que o mercado precisa, e não mais o que o mercado aceita. A ótica da oferta deve ceder lugar à ótica da demanda. ${ }^{223}$

Não é por outra razão que a Lei 8.078/90 deixa clara sua intenção. Eis o espectro outorgado à matéria pelo texto legal: "art. $4^{\circ} \mathrm{A}$ Política Nacional das Relações de Consumo tem por objetivo o atendimento das necessidades dos consumidores, o respeito à sua dignidade, saúde e segurança, a proteção de seus interesses econômicos, a melhoria da sua qualidade de vida, bem como a transparência e harmonia das relações de consumo, atendidos os seguintes princípios:".

Essa política protecionista, imposta pelo Estado, parte da constatação da fragilidade do consumidor, disperso, sem organização frente às empresas e da consequente necessidade da sua intervenção no sentido de proteger o consumidor, ou por iniciativa direta ou mediante o fomento à criação e ao desenvolvimento das associações de consumidores, ou por sua presença no mercado. ${ }^{224}$

Mas não se pode olvidar a ressalva do aplaudido mestre Arruda Alvim sobre mencionado artigo: "o 'caput' deste art. $4^{\circ}$, ao definir objetivos que norteiam a política de relações de consumo, e não simplesmente, o que poderia ser chamado de 'política de defesa do consumidor', pretende ter um alcance substancialmente mais longo do que apenas o regramento dos preceitos que orientam o presente Código. Colima, em verdade, estabelecer parâmetros que devem nortear todo e qualquer ato do Governo, seja de âmbito legislativo, como executivo e judiciário, quando do tratamento das 'relações de consumo', expressão evidentemente mais ampla do que apenas 'defesa do consumidor'. Desta forma, parece pretender este art. $4^{\circ}$, desde já, estabelecer limitações a qualquer ato governamental futuro, que possa ser infringente nas relações de consumo $(\ldots))^{225}$

\footnotetext{
${ }^{222}$ Idem.

${ }^{223}$ Adalberto Paqualotto. Conceitos fundamentais..., cit., p. 50.

${ }^{224}$ Francisco de Queiroz Bezerra Cavalcanti. Comentários ao Código de Proteção e Defesa do Consumidor. Belo Horizonte: Livraria Del Rey, 1991, p. 25.

${ }^{225}$ Et alii. Código do Consumidor comentado..., cit., p. 42.
} 
Afinal, a defesa do consumidor não pode ser encarada como instrumento de confronto entre produção e consumo, senão como meio de compatibilizar e harmonizar os interesses envolvidos. ${ }^{226}$

$\mathrm{Na}$ busca desse equilíbrio, a Política Nacional das Relações de Consumo funciona como norma-objetivo, ou seja, possibilita a introdução no universo normativo dos fins perseguidos pelo sistema mediante a análise de padrões teleológicos perfeitamente definidos, in casu: o atendimento das necessidades dos consumidores, o respeito à sua dignidade, saúde e segurança, a proteção do seus interesses econômicos, a melhoria da sua qualidade de vida, bem como a transparência e a harmonia das relações de consumo.

O professor e Min. do STF Eros Roberto Grau, no sentido de que o intérprete deve repudiar qualquer solução interpretativa que não seja adequada à realização daqueles fins inscritos na norma-objetivo do art. $4^{\circ}$, enfatiza:

“(...) o art. $4^{\mathrm{o}}$ do Código do Consumidor é uma normaobjetivo, porque define os fins da política nacional das relações de consumo, quer dizer, ela define resultados a serem alcançados. Todas as normas de conduta e todas as normas de organização, que são as demais normas que compõem o Código do Consumidor, instrumentam a realização desses objetivos, com base nos princípios enunciados no próprio art. $4^{\circ}$. (...) Assim, todas as normas de organização e conduta, contidas no Código do Consumidor, devem ser interpretadas teleologicamente, finalisticamente, não por opção do intérprete, mas porque essa é uma imposição do próprio Código. (...) A circunstância de existirem normas-objetivo que determinem a interpretação de normas de organização e conduta estreita terrivelmente a possibilidade dessa opção, porque a única interpretação correta é aquela que seja adequada à instrumentação da realização dos fins, no caso, os fins estipulados no art. $4^{\circ}$ do Código do Consumidor."227

Isto não significa o comprometimento da liberdade econômica, ao contrário, resta ela estimulada enquanto atuação socialmente responsável de ambos os polos envolvidos, ou seja, o princípio da intervenção mínima necessária impede

\footnotetext{
${ }^{226}$ João Batista de Almeida. A proteção jurídica..., cit., p. 15.

${ }^{227}$ Interpretando o Código de Defesa do Consumidor; algumas notas. Revista de Direito do Consumidor, São Paulo: RT, v. 5, 1993, p. 188/189.
} 
que os economicamente mais fortes reduzam ou anulem a liberdade dos fracos (consumidores). ${ }^{228}$

${ }^{228}$ Luiz Amaral. O código, a política e o sistema nacional de defesa do consumidor. Revista de Direito do Consumidor, São Paulo: RT, v. 6, 1993, p. 71. 


\section{VULNERABILIDADE}

A vulnerabilidade é a espinha dorsal da proteção ao consumidor, onde se assenta toda a linha filosófica do movimento consumerista ${ }^{229}$, podendo ser apontada como basilar e consequente de todos os outros princípios informadores do sistema protetivo. ${ }^{230}$ Daí porque a Lei 8.078/90 parte da fraqueza manifesta do consumidor no mercado, conferindo-lhe certos instrumentos para melhor defender-se. ${ }^{231}$

Nas sociedades de massa, o consumidor não se encontra individualmente preparado para a aquisição de um produto ou de um serviço, por não conhecer o mercado como o fornecedor, com quem, via de regra, somente se relaciona indiretamente, através de empregados, representantes ou prepostos. ${ }^{232}$

Pode-se dizer que o CDC é todo uma emanação do princípio da vulnerabilidade e, em certo sentido, justifica-se em função dele. ${ }^{233}$ Afinal, a própria Constituição da República é expressa em reconhecer no consumidor um sujeito que precisa de defesa (art. $5^{\circ}$, XXXII), e quando impõe ao Estado o dever de protegê-lo nada mais faz do que concretizar o princípio da isonomia tratando desigualmente os desiguais.

$\mathrm{O}$ art. $4^{\circ}$ impõe, como elenca o seu primeiro princípio (I), seja reconhecida a vulnerabilidade do consumidor no mercado de consumo.

Para Luiz Antonio Rizzatto Nunes, isso significa a imposição de um tratamento diferenciado, veja-se:

“(...) o consumidor é a parte fraca da relação jurídica de consumo. Essa fraqueza, essa fragilidade, é real, concreta, e decorre de dois aspectos: um de ordem técnica e outro de cunho econômico.

O primeiro está ligado aos meios de produção, cujo conhecimento é monopólio do fornecedor. E quando se fala em meios de produção não se está apenas referindo aos aspectos técnicos e administrativos para a fabricação de produtos e prestação de serviços que o fornecedor detém, mas também ao elemento fundamental da decisão: é o fornecedor que escolhe o que,

\footnotetext{
${ }^{229}$ João Batista de Almeida. A proteção jurídica..., cit., p. 16.

${ }^{230}$ James Marins. Responsabilidade da empresa..., cit., p. 38.

${ }^{231}$ José Geraldo Brito Filomeno et alii. Código Brasileiro de Defesa do Consumidor..., cit., p. 44.

${ }^{232}$ Roberto Senise Lisboa. Responsabilidade civil..., cit., p. 84.

${ }^{233}$ Fabio Nusdeo et alii. Comentários ..., cit., p. 27.
} 
quando e de que maneira produzir, de sorte que o consumidor está à mercê daquilo que é produzido.

É por isso que, quando se fala em 'escolha' do consumidor, ela já nasce reduzida. O consumidor só pode optar por aquilo que existe e foi oferecido no mercado. E essa oferta foi decidida unilateralmente pelo fornecedor, visando seus interesses empresariais, que são, por evidente, a obtenção de lucro.

$\mathrm{O}$ segundo aspecto, o econômico, diz respeito à maior capacidade econômica que, via de regra, o fornecedor tem em relação ao consumidor. É fato que haverá consumidores individuais com boa capacidade econômica e às vezes até superior à de pequenos fornecedores. Mas essa é a exceção da regra geral." ${ }^{234}$

2.1 Vulnerabilidade como conceito de ordem material

Entende a professora Cláudia Lima Marques, “(...) que a pessoa jurídica ou o profissional não se beneficia da presunção de vulnerabilidade, mas pode prová-la, sempre que destinatário final econômico do produto ou serviço". ${ }^{235}$ E mais: “isto não significa que o Judiciário não possa tratar o profissional de maneira 'equivalente' ao consumidor, se o profissional efetivamente provar a sua vulnerabilidade, que levou ao desequilíbrio contratual. Trata-se, porém, de exceção e não da regra". ${ }^{236}$

Sem embargo do respeito que merece a douta jurista da UFRGS, data venia, esse enquadramento não há de prevalecer.

Com efeito, a vulnerabilidade não é pressuposto da condição de consumidor, nem elemento do seu conceito; é, isto sim, direito material outorgado a todos os que a lei considera consumidores (supra, Cap. II, 2), pessoa jurídica inclusive. ${ }^{237}$

$\mathrm{Ou}$, em outras palavras, não é o vulnerável que será, per se, consumidor; mas todo consumidor é materialmente vulnerável, conquanto se trate ou não de pessoa física, jurídica ou profissional. Evidenciado o elemento teleológico (destinatário final), ressai ex vi legis a vulnerabilidade.

Precisa é a observação de Roberto Senise Lisboa:

\footnotetext{
${ }^{234}$ Comentários..., cit., p. 128.

${ }^{235}$ Contratos..., cit., p. 291.

${ }^{236}$ Contratos..., cit., p. 276.
} 
“A vulnerabilidade, conforme consta do Código de Defesa do Consumidor, não se submete ao critério da razoabilidade para ser identificada no caso concreto, uma vez que o legislador presumiu iure et de iure a sua existência em uma relação de consumo, fixando-se que o destinatário final de produtos e serviços é a parte que necessita ser amparada de forma mais favorável pela legislação.

\section{$(\ldots)$}

Para se caracterizar a vulnerabilidade pouco importa a situação econômica ou a classe social do consumidor, bem como o seu grau de instrução ou mesmo se a aquisição do produto ou do serviço se deu para o exercício da atividade profissional do consumidor, ou não. A vulnerabilidade é qualidade indissociável do destinatário final do produto e serviço pelas considerações anteriormente expendidas. É adjetivo que se encontra sempre ligado ao consumidor no sistema jurídico brasileiro, sem que qualquer ressalva tenha sido expressamente feita pelo legislador.",238

Perfilha a mesma linha o insigne Arruda Alvim, para quem, “a vulnerabilidade do consumidor é incindível do contexto das relações de consumo e independe de seu grau cultural ou econômico, não admitindo prova em contrário, por não se tratar de mera presunção legal. É, a vulnerabilidade, qualidade intrínseca, ingênita, peculiar, imanente e indissociável de todos que se colocam na posição de consumidor, em face do conceito legal, pouco importando sua condição social, cultural ou econômica, quer se trate de consumidor-pessoa jurídica ou consumidor-pessoa física". ${ }^{239}$

\subsection{Vulnerabilidade $\mathrm{x}$ hipossuficiência}

De fato, a vulnerabilidade do consumidor não se confunde com a hipossuficiência, característica restrita àqueles que, além de vulneráveis, vêem-se agravados nessa situação por sua individual condição de carência cultural, material ou, como ocorre com frequência, ambas. ${ }^{240}$

\footnotetext{
${ }^{237}$ Antonio Carlos Morato. Pessoa jurídica consumidora. São Paulo: RT, 2009, p. 152.

${ }^{238}$ Responsabilidade civil..., cit., p. 85/86.

${ }^{239}$ Et alii. Código do Consumidor comentado..., cit., p. 45.

${ }^{240}$ Arruda Alvim et alii. Código do Consumidor comentado..., cit., p. 45, n. 7.
} 
Percebe-se, por conseguinte, que a hipossuficiência é um plus em relação à vulnerabilidade. Esta é aferida objetivamente, ope legis. Aquela, mediante um critério subjetivo, consumidor a consumidor. ${ }^{241}$

E Salienta Roberto Senise Lisboa:

“Ordinariamente, vulnerabilidade é expressão sinônima de hipossuficiência uma vez que não encontra precedentes de importância na história do direito brasileiro. Entretanto, o legislador consumerista conferiu um tratamento nitidamente diferenciado para os dois vocábulos, motivo pelo qual eles não devem ser compreendidos como sinônimos.

\section{(...)}

Em outras palavras: não é sempre que o consumidor pode ser considerado hipossuficiente, mas ele sempre é vulnerável. O consumidor vulnerável pode ser hipossuficiente ou não. A lei não entende que a hipossuficiência equivale à vulnerabilidade. Pelo contrário. Do microssistema jurídico em questão pode-se concluir que todo consumidor é vulnerável, porém nem todo consumidor é hipossuficiente." 242

Observe-se que a hipossuficiência ganha especial relevo em sede consumerista, pois a Lei 8.078/90 a erigiu em um dos requisitos para a inversão do ônus da prova no processo civil (art. $6^{\circ}$, VIII $\left.^{243}\right)$.

Assim, força é concluir, que a vulnerabilidade é um conceito de ordem material, inerente à figura de qualquer consumidor; enquanto a hipossuficiência é ontologicamente processual e, por isso, sua presença deve ser verificada caso a caso com o escopo de viabilizar seu único efeito: a inversão do ônus da prova.

\subsection{Espécies de vulnerabilidade}

Conquanto sua essência material impeça gradações, há sólida e respeitável corrente doutrinária que estabelece parâmetros de vulnerabilidade: a técnica, a jurídica e a fática (sócio-econômica).

\footnotetext{
${ }^{241}$ Antônio Herman de Vasconcellos e Benjamin et alii. Código Brasileiro de Defesa do Consumidor, comentado pelos autores do anteprojeto. $4^{\mathrm{a}}$ ed. São Paulo: Forense Universitária, 1996, p. 230.

${ }^{242}$ Responsabilidade civil..., cit., p. 85/88.
} 
$\mathrm{Na}$ técnica, o consumidor não possui conhecimentos específicos sobre o objeto que está adquirindo e, portanto, é mais facilmente enganado quanto às características do bem (ou serviço) ou quanto à sua utilidade. A jurídica é a falta de conhecimentos legais específicos (v.g., dos seus próprios direitos, de contabilidade, de economia, etc.), além de não estar acostumado a litigar. A fática concentra-se no outro polo da relação, o fornecedor que por sua posição preponderante, aliada ao seu grande poder econômico e/ou à essencialidade do serviço, impõe sua superioridade a todos que com ele contratam. $^{244}$

E mais. Newton de Lucca, sob o título: as três grandes vulnerabilidades do consumidor, elenca os principais inimigos da defesa do consumidor: a publicidade enganosa ou abusiva, as cláusulas contratuais abusivas e os preços abusivos. ${ }^{245}$

Invocando a linha de raciocínio adotada neste estudo (supra, 2.1 e 2.2), parece razoável relegar à hipossuficiência essas distinções (e os conceitos serão retomados), para aí, sim, melhor visualizar sua presença (infra, Cap. V, 5.2.2).

\footnotetext{
${ }^{243} \mathrm{CDC}$, art. $6^{\text {o: }}$ "são direitos básicos do consumidor: (...) VIII - a facilitação da defesa de seus direitos, inclusive com a inversão do ônus da prova, a seu favor, no processo civil, quando, a critério do juiz, for verossímil a alegação ou quando for ele hipossuficiente, segundo as regras ordinárias de experiência".

${ }^{244}$ Cláudia Lima Marques. Contratos..., cit., p. 270.

${ }^{245}$ Direito do Consumidor. Aspectos práticos - perguntas e respostas. São Paulo: RT, 1995, p. 43.
} 


\section{AÇÃO GOVERNAMENTAL}

Esse princípio é, de certa forma, corolário da vulnerabilidade do consumidor, pois, se há reconhecimento dessa fragilidade e desigualdade de uma parte em relação a outra, está claro que o Estado deve intervir para proteger a mais fraca, por meios legislativos e administrativos, de sorte a garantir o respeito aos seus interesses. ${ }^{246}$

Trata-se da responsabilidade atribuída ao Estado, enquanto ente máximo organizador da sociedade (via poder de polícia), de prover o consumidor dos mecanismos que propiciem sua efetiva proteção, seja por iniciativa direta, seja através do impulso e amparo oficial a ser dado à entidades representativas dos consumidores ou até mesmo de fornecedores ${ }^{247}$, das mais diversas faixas e interesses nas relações de consumo. $^{248}$

No campo da ação efetiva no mercado, cabe ainda ao Estado regulá-lo, quer mediante a assunção de faixas de produção não atingidas pela iniciativa privada, quer intervindo quando haja distorções, sem falar-se no zelo pela qualidade, segurança, durabilidade e desempenho dos produtos e serviços oferecidos ao público consumidor. $^{249}$

Observe-se: no fomento da defesa do consumidor (CF, arts. $5^{\circ}$, XXXII c.c. $\left.170, \mathrm{~V}\right)$ e na realização da dignidade da pessoa humana (CF, art. $\left.1^{\circ}, \mathrm{III}\right)$, o Estado, invocando a correta noção de liberdade, há de concretizar os valores sociais da livre iniciativa (CF, art. $1^{\circ}$, IV) conforme os ditames da justiça social (CF, art. 170, caput), fazendo-se presente no mercado de consumo sempre que necessário $\left(\mathrm{CF}\right.$, arts. $173, \S 4^{\circ}$, c.c. 174).

Constante, pois, a intervenção e, para tanto, existem instrumentos ( $\mathrm{CDC}$, art. $\left.5^{\circ}\right)$, sancionatórios inclusive (CDC, art. 55 e ss), que serão usados, se necessário, dentro do Sistema Nacional de Defesa do Consumidor (CDC, arts. 105 c.c. 106).

\footnotetext{
${ }^{246}$ João Batista de Almeida. A proteção jurídica..., cit., p. 16/17.

${ }^{247}$ Cf., Fabio Nusdeo (Et alii. Comentários..., cit., p. 27/28): “não diz a lei quem estariam representando tais associações. Infere-se, porém, que devam ser basicamente de consumidores, nada impedindo, no entanto, possam ser também de fornecedores, desde que voltadas ao estudo e à implementação de medidas de proteção dos consumidores e de atendimento de seus interesses, como tais".

${ }_{248}$ Arruda Alvim et alii. Código do Consumidor comentado..., cit., p. 46.

${ }^{249}$ José Geraldo Brito Filomeno et alii. Código Brasileiro de Defesa do Consumidor..., cit., p. 45.
} 
Por este prisma, a ação governamental não se esgota nas formas previstas no art. $4^{\mathrm{o}}$, II, do CDC, ao contrário, vincula-se inexoravelmente a outras, sejam no mesmo dispositivo sejam esparsas no Código.

Anote-se, verbi gratia, a educação e a informação de fornecedores e consumidores, quanto aos seus direitos e deveres, com vistas à melhoria do mercado de consumo ${ }^{250}$; o incentivo à criação pelos fornecedores de meios eficientes de controle de qualidade e segurança de produtos e serviços, assim como de mecanismos alternativos de solução de $\operatorname{conflitos}^{251}$; e a coibição e repressão eficientes de todos os abusos praticados no mercado de consumo, inclusive a concorrência desleal e utilização indevida de inventos e criações industriais das marcas e nomes comerciais e signos distintivos, que possam causar prejuízos aos consumidores. ${ }^{252}$

Quanto ao estudo constante das mudanças do mercado de consumo (CDC, art. $4^{\circ}$, VIII), decorre da imposição de o Estado estar sempre apto a utilizar os instrumentos legais necessários a estimular a criação, manutenção e ampliação de mercados através de mecanismos, tais como, concessão de incentivos, exercício de poder de polícia, alteração do disciplinamento legal, etc. ${ }^{253}$

\subsection{Fornecedor e autocontrole (CONAR e recall)}

Afora sua natural intervenção, o Estado deve incentivar os fornecedores a criarem meios eficientes de controle de qualidade e segurança de produtos e serviços, assim como de mecanismos alternativos de solução de conflitos de consumo $\left(\mathrm{CDC}\right.$, art. $\left.4^{\mathrm{o}}, \mathrm{V}\right)$, sempre por eles mesmos custeados.

Um exemplo bem sucedido dessa experiência é a autorregulamentação da publicidade pelos próprios agentes do mercado, que caminham lado a lado, sem que se possam excluir mutuamente, com a fiscalização estatal. Trata-se de um sistema misto de gerência dos eventuais abusos publicitários.

\footnotetext{
${ }^{250} \mathrm{CDC}$, arts. $4^{\mathrm{o}}, \mathrm{IV}$, c.c. $6^{\mathrm{o}}$ c.c. $9^{\circ}$ c.c. 12 c.c. 14 c.c. 18 c.c. 19 c.c. 20 c.c. 30 c.c. 31 c.c. 36 c.c. 37 c.c. 38 c.c. 40 c.c. 43 c.c. 46 c.c. 52 c.c. 55 , $\S 4^{\circ}$, c.c. 106 , III e IV.

${ }^{251} \mathrm{CDC}$, arts. $4^{\mathrm{o}}$, caput, e V, c.c. $5^{\mathrm{o}}$, IV e V, c.c. $6^{\mathrm{o}}$, I, c.c. $8^{\mathrm{o}}$ c.c. $9^{\mathrm{o}}$ c.c. 10 c.c. $12, \S 1^{\mathrm{o}}$, c.c. 13 , III, c.c. $14, \S$ $1^{\circ}$, c.c. $18, \S 6^{\circ}$, c.c. $19, \S 2^{\circ}$, c.c. $20, \S 2^{\circ}$, c.c. 22 c.c. 23 c.c. 24 c.c. 51 , I, c.c. $55, \S \S 1^{\circ}$ e $3^{o}$, c.c. 56 c.c. 106 , VIII.

${ }^{252} \mathrm{CDC}$, art. $4^{\mathrm{o}}$, VI, c.c. $5^{\circ}$, I, II e III, c.c. $6^{\circ}$, IV e V, c.c. 10 c.c. 25 c.c. 28 c.c. 30 usque 60 c.c. 61 usque 80 c.c. 81 usque 102 c.c. 106, II, V a IX.

${ }^{253}$ Francisco Cavalcanti. Comentários..., cit., p. 27.
} 
Nessa temática o autocontrole é exercido pelo Conselho Nacional de Autorregulamentação Publicitária (CONAR) ${ }^{254}$, responsável pelo Código Brasileiro de Autorregulamentação Publicitária (CBARP).

Lucia Ancona Lopez Magalhães Dias ressalta que "havendo a veiculação de publicidade em violação às normas do seu Código Ético (CBARP), o Conselho de Ética poderá aplicar as seguintes sanções: a) advertência ao anunciante e sua agência; b) recomendação de alteração ou correção do anúncio; c) recomendação aos veículos no sentido de que sustem a divulgação do anúncio; e d) divulgação pública (na mídia) da posição do CONAR em relação ao anunciante, agência e ao veículo, na hipótese do acatamento das medidas e providências recomendadas (art. 50, CBARP e art. 61 do Estatuto Social). A sustação do anúncio pelo membro do Conselho de Ética, ad referendum da Câmara ou do Plenário, poderá se dar por medida liminar, nas hipóteses do art. 30 do Regimento Interno do Conselho de Ética - RICE". ${ }^{255}$

João Batista de Almeida, por sua vez, aponta três formas de implementação desse autocontrole: a efetiva atenção à qualidade e à segurança dos produtos defeituosos no mercado (preventivo), o recall e a criação de centros ou serviços de atendimento ao consumidor (reparatório). ${ }^{256}$

No que tange ao recall, que funciona como agente minimizador de danos ${ }^{257}$, da mesma forma dotado de essência preventiva, o abalizado jurista traduz sua ratio como sendo: “(...) a convocação dos consumidores de bens produzidos em série e que contenham defeitos de fabricação que possam atentar contra a vida e a segurança dos usuários, arcando o fornecedor com as despesas de substituição das

\footnotetext{
${ }^{254}$ Destaca Lucia Ancona Lopez Magalhães Dias (Publicidade e direito. São Paulo: RT, 2010, p. 41/42) que “(...) foi constituído o CONAR, sociedade civil sem fins lucrativos, fundada por associações de anunciantes, agências de publicidade e veículos de comunicação, com a finalidade de executar e fiscalizar as suas normas éticas. Incumbe ao CONAR, dentre outras finalidades, 'zelar pela comunicação social, sob todas as formas de propaganda' e 'funcionar como órgão judicante nos litígios éticos que tenham por objeto a indústria da propaganda ou questões a ela relativas' (art. $5^{\circ}$ do seu Estatuto Social). É a instituição privada por excelência que fiscaliza a ética na propaganda comercial veiculada no Brasil, norteando-se pelas disposições contidas no seu Código Brasileiro de Autorregulamentação Publicitária”.

${ }^{255}$ Idem, p. 42.

${ }^{256}$ A proteção jurídica..., cit., p. 18/19.

${ }^{257}$ Lembra Aurisvaldo Melo Sampaio (As novas tecnologias e o princípio da efetiva prevenção de danos ao consumidor. Revista de Direito do Consumidor, São Paulo: RT, v. 49, jan.-mar. 2004, p. 155) que: “caso o conhecimento da periculosidade apresentada pelo produto ou serviço seja posterior à sua introdução no mercado de consumo, deverá o fornecedor efetuar o recall (art. $10, \S \S 1^{\circ}$ e $2^{\circ}$ ), comunicando o fato imediatamente às autoridades competentes e aos consumidores, mediante anúncios publicitários, sujeitandose, em caso de omissão, a sanções administrativas (art. 13, II e III, do Dec. 2.181, de 20.03.1999) e criminais (art. 64), além de responsabilidade civil. Conforme seja o grau da periculosidade, deverá ainda, como é curial, retirar o produto do mercado de consumo".
} 
peças defeituosas. Há o reconhecimento do defeito, mas ao mesmo tempo ele é sanado pelo próprio fabricante, sem prejuízo ou custo para o consumidor. A indústria automobilística utilizou-se largamente do recall, notando-se que, a partir de 1991, cresceu enormemente no País o número de convocações dirigidas aos consumidores, por montadoras nacionais e estrangeiras, o que pode ter ocorrido pela maior conscientização do fabricante como pelo efeito da vigência do CDC. Outras indústrias dos ramos de eletrodomésticos e computadores seguiram o mesmo caminho". ${ }^{258}$

Funciona o recall como inteligente e eficaz instrumento de comunicação positiva entre fornecedor e consumidor ${ }^{259}$, em especial quanto ao conhecimento de periculosidade ínsita posterior à introdução do produto ou do serviço no mercado (CDC, art. 10, $\S 1^{\mathrm{o}^{260}}$ ); daí já se tendo uma idéia do encargo de transparência imposto tanto pela precaução quanto pela prevenção ao titular do processo produtivo (infra, Cap. VI, 3.4). ${ }^{261}$

Entretanto, sem nenhuma interferência na disciplina estruturante da responsabilidade civil, ou seja, mesmo na circunstância de o adquirente não levar o produto para conserto, em atenção a recall, não se isenta o fornecedor da obrigação indenizar os danos advindos do fato da coisa transacionada. ${ }^{262}$

\subsection{Inviabilidade de abuso no mercado}

Propõe-se o Estado, de maneira eficiente, a coibir e a reprimir todos os abusos praticados no mercado de consumo (CDC, art. $\left.4^{\circ}, \mathrm{VI}\right)$, e essa atuação deve abranger todas as esferas de governo: Executivo, Legislativo e também o Judiciário.

\footnotetext{
${ }^{258}$ Idem.

259 José Geraldo Brito Filomeno. Manual..., cit., p. 51.

${ }^{260} \mathrm{CDC}$, art. 10, $\S 1^{\circ}$ : “o fornecedor de produtos e serviços que, posteriormente à sua introdução no mercado de consumo, tiver conhecimento da periculosidade que apresentem, deverá comunicar o fato imediatamente às autoridades competentes e aos consumidores, mediante anúncios publicitários".

261 A vinculação do fornecedor ao recall há tempos foi apreciada, de certo modo, pela jurisprudência: "RESPONSABILIDADE CIVIL - Incêndio de automóvel estacionado em frente da residência de seu proprietário - Responsabilidade do fabricante ex vi do art. 12 do CDC (Lei 8.078/90) - Ação improcedente Apelação provida, para inversão do julgado" (1 ${ }^{\circ}$ TacCiv/SP, Apel. 811.851-3, rel. Jorge Farah, j. 13.04.1999). Do V. Aresto extrai-se o seguinte excerto: "o incêndio ocorrido, realmente não é um fato natural, ou melhor, tal evento não se encontra dentro da previsibilidade. $\mathrm{O}$ acontecimento em exame, não pode ser considerado simples incidente de percurso. É que os modelos como o do veículo em questão, estavam sofrendo reparos, tendo sido chamados para a efetivação do conhecido recall. A prova é robusta em tal sentido".

${ }^{262}$ STJ, REsp. 1.010.392/RJ, rel. Min. Humberto Gomes de Barros, j. 24.03.2008.
} 
Como já se registrou em obra doutrinária ${ }^{263}$, o Estado, incumbido de defender o consumidor, não pode, em hipótese alguma, desrespeitá-lo. Se o desrespeito parte do próprio Estado, faltar-lhe-á legitimidade para cobrar o respeito por parte de outrem.

Observa, a propósito, João Batista de Almeida: “deve garantir-se não só a repressão aos atos abusivos, como a punição de seus autores e o respectivo ressarcimento, mas também a atuação preventiva tendente a evitar a ocorrência de novas práticas abusivas, afastando-se aquelas que podem causar prejuízos aos consumidores (...)". ${ }^{264}$

O correr frouxo do mercado ${ }^{265}$, indutor da impunidade, deve ceder à firme, eficiente e implacável atuação, preventiva e repressiva, no combate aos abusos, autêntico desestímulo a prováveis violações.

Esse abuso, em geral, materializa-se em práticas ou em cláusulas contratuais e nas cobranças de dívidas.

\subsubsection{Práticas abusivas}

O contexto das práticas comerciais, onde estão reguladas a oferta e a publicidade, abarca também as práticas abusivas, que correspondem a comportamentos, tanto na esfera contratual como à margem dela, que abusam da boa-fé ou da situação de inferioridade econômica ou técnica do consumidor. ${ }^{266}$

Originam-se do abuso do poder econômico.

São ações e/ou condutas que, uma vez existentes, caracterizam-se como ilícitas, independentemente de se encontrar ou não algum consumidor lesado ${ }^{267}$. Verdadeiras condições irregulares de negociação nas relações de

\footnotetext{
${ }^{263}$ Guilherme Ferreira da Cruz. Princípios constitucionais..., cit., p. 176/177.

${ }^{264}$ A proteção jurídica..., cit., p. 17.

265 Já no primeiro ano de vigência do CDC, com propriedade, afirmava Newton de Lucca (A proteção contratual no Código de Defesa do Consumidor. Revista de Direito do Consumidor, São Paulo: RT, v. 5, p. 75): “(...) mais do que um mero 'dirigismo contratual', para usar uma expressão da moda, impunha-se uma verdadeira intervenção do Estado no princípio da autonomia da vontade das partes - basilar da teoria geral dos contratos, em sua concepção clássica - com o propósito de coibir os abusos mais escandalosos de que nossa República foi pródiga em revelar exemplos".

${ }_{266}$ Antônio Carlos Efing. Contratos..., cit., p. 96/97.

${ }^{267}$ Luiz Antonio Rizzatto Nunes. Comentários ..., cit., p. 493.
} 
consumo $^{268}$, que sujeitam o fornecedor a sanções civis, administrativas e penais ${ }^{269}$, sem que se possa falar em bis in idem, mesmo no âmbito da tutela da ordem econômica. ${ }^{270}$

Infere-se, portanto, que o dano não é elemento essencial das práticas abusivas. $\mathrm{Na}$ verdade, pretende o legislador alterar a conduta do fornecedor, atingindo objetiva e diretamente circunstâncias que poderiam resultar em danos ao consumidor, dada a magnitude a que chegaram esses problemas nas relações de consumo. $^{271}$

Como práticas, representam gênero do qual a publicidade e as cláusulas abusivas são espécie. Um conceito fluído e flexível. Mas prática abusiva no Código é apenas aquela que, de modo direto e no sentido vertical da relação de consumo (do fornecedor ao consumidor), afeta o bem-estar do consumidor. Manifestam-se através de uma série de atividades, pré e pós-contratuais. ${ }^{272}$

Essa flexibilidade atribui um caráter meramente exemplificativo (numerus apertus) às hipóteses positivadas no art. 39 do $\mathrm{CDC}$, não podendo, na prática, haver restrições quanto ao enquadramento de outras práticas consideradas abusivas - adotadas pelos fornecedores em detrimento do consumidor ou em afronta aos princípios protetivos insculpidos. ${ }^{273}$

Ressalta, nesse sentido, Antônio Herman de Vasconcellos e Benjamin que, "não podia o legislador, de fato, listar, à exaustão, as práticas abusivas. O mercado de consumo é de extremada velocidade e as mutações ocorrem da noite para o dia. Por isso mesmo é que buscamos, no seio da Comissão, deixar bem claro que a lista do art. 39 era meramente exemplificativa, uma simples orientação ao intérprete". 274

As práticas abusivas, portanto, podem ser típicas ou atípicas.

Imagine-se uma empresa que explore, no mesmo local (shopping center), duas atividades: a prestação de serviços de projeção cinematográfica e a venda de produtos alimentícios. No exercício do seu mister, a fornecedora só permite o

\footnotetext{
${ }^{268}$ Gabriel A. Stiglitz. Protección jurídica del consumidor. $2^{\mathrm{a}}$ ed. Buenos Aires: Depalma, 1990, p. 81.

${ }^{269}$ Cláudia Lima Marques. Contratos..., cit., p. 685/686.

${ }^{270}$ Roberto Augusto Castellanos Pfeiffer. Proteção do consumidor e defesa da concorrência: paralelo entre práticas abusivas e infrações contra a ordem econômica. Revista de Direito do Consumidor, São Paulo: RT, v. 76, out.-dez. 2010, p. 138.

${ }^{271}$ Antônio Carlos Efing. Contratos..., cit., p. 98.

272 Antônio Herman de Vasconcellos e Benjamin et alii. Código Brasileiro de Defesa do Consumidor..., $4^{\mathrm{a}}$ ed., cit., p. 237.

${ }^{273}$ Antônio Carlos Efing. Contratos..., cit., p. 98.

${ }^{274}$ Et alii. Código Brasileiro de Defesa do Consumidor..., 4 ${ }^{\mathrm{a}}$ ed., cit., p. 239.
} 
ingresso nas salas de projeção de produtos adquiridos em seu estabelecimento, muito embora existam outras tantas lojas que negociam produtos assemelhados (mesmo gênero e espécie) nas proximidades (v.g., praça de alimentação). Justifica a postura adotada na alegação de que seu sistema de limpeza é adequado tão-só aos produtos que vende, não aos demais (lojas vizinhas).

Clara como o sol que reluz a prática abusiva ${ }^{275}$, concorrência desleal inclusive (reserva de mercado).

Mesmo sem condicionar o fornecimento do serviço de projeção cinematográfica à aquisição dos seus produtos alimentícios (CDC, art. 39, I) venda casada expressamente proibida, note-se que é possível o ingresso nas salas para assistir aos filmes sem comer nem beber nada ${ }^{276}$ - a fornecedora interfere decisivamente na escolha do consumidor, restringindo sua liberdade de atuação no mercado.

Assim já se pronunciou o TJSP, embora não tenha se referido textualmente à prática abusiva ${ }^{277}$; enquanto parte da jurisprudência, contudo sem razão, identifica nesse proceder a venda casada típica. ${ }^{278}$

275 "Responsabilidade civil - Danos materiais e morais - Consumidores que foram retirados da sala de cinema, sem devolução dos bilhetes de entrada, por portarem bebidas e alimentos diversos dos fornecidos pelo próprio cinema - Ilegalidade - Inteligência do art. 39 do Código de Defesa do Consumidor Estabelecimento já, anteriormente, multado pelo PROCON São Paulo e Rio de Janeiro - Devolução do valor dos bilhetes - Dano moral provado - Recurso parcialmente provido" (TJSP, AC 337.814.4/2-00, rel. José Luiz Gavião de Almeida, j. 04.11.2008).

${ }^{276}$ Roberto Augusto Castellanos Pfeiffer (Proteção do consumidor..., cit., p. 142/143) entende que não se trata "propriamente de venda casada. Isto porque não existiu a figura do 'condicionamento', ou seja, não se condicionou a venda do ingresso à aquisição de alimentos. Na realidade o que havia era a imposição de uma exclusividade: apenas os alimentos vendidos pela empresa cinematográfica poderiam ser consumidos no interior do cinema (...)".

277 "LIMINAR - Empresa que exibe projeções cinematográficas - Exclusividade de consumo dos produtos vendidos pela autora em suas dependências - Hipótese que fere a liberdade de escolha do consumidor, que se sobrepõe ao direito de contratação da agravante - Inteligência dos artigos $5^{\circ}$, XXXII, CF c.c. $6^{\circ}$, II, CDC Hipótese em que o prejuízo engloba os consumidores e demais empresas alimentícias próximas ao estabelecimento, dada a multiplicidade dos consumidores lesados - Liminar mantida - Agravo improvido" (TJSP, AI 195.256.4/1-00, rel. Ribeiro dos Santos, j. 08.08.2001).

278 "A denominada 'venda casada', sob esse enfoque, tem como ratio essendi da vedação a proibição imposta ao fornecedor de, utilizando de sua superioridade econômica ou técnica, opor-se à liberdade de escolha do consumidor entre os produtos e serviços de qualidade satisfatório e preços competitivos. Consectariamente, ao fornecedor de produtos ou serviços, não é lícito, dentre outras práticas abusivas, condicionar o fornecimento de produto ou de serviço ao fornecimento de outro produto ou serviço (art. 39,I, do CDC). Na hipótese, a prática abusiva revela-se patente se a empresa cinematográfica permite a entrada de produtos adquiridos na suas dependências e interdita o adquirido alhures, engendrando por via oblíqua a cognominada 'venda casada', interdição inextensível ao estabelecimento cuja venda de produtos alimentícios constituiu a essência da sua atividade comercial como, verbi gratia, os bares e restaurantes" (STJ, REsp. 744.602/RJ, rel. Min. Luiz Fux, j. 01.03.2007). “Apelação Cível - Anulatória - Multa aplicada pelo Procon - Proibição de entrada dos espectadores portando alimentos e refrigerantes, adquiridos em outro estabelecimento, nas salas de cinema do autor - Ação julgada improcedente. Recurso voluntário do autor - Alegação de inexistência de violação aos direitos do consumidor - Inadmissibilidade - Violação do artigo 39,1 do CDC. R. Sentença 


\subsubsection{Cláusulas abusivas}

Inicia-se esse tópico com o lúcido magistério de Cláudia Lima Marques:

"O Código de Defesa do Consumidor inova consideravelmente o espírito do direito das obrigações, e relativa a máxima pacta sunt servanda.

A nova lei vai reduzir o espaço antes reservado para a autonomia da vontade, proibindo que se pactuem determinadas cláusulas, vai impor normas imperativas, que visam proteger o consumidor, reequilibrando o contrato, garantindo as legítimas expectativas que depositou no vínculo contratual.

A proteção do consumidor, o reequilíbrio contratual vem $a$ posteriori, quando o contrato já está perfeito formalmente, quando o consumidor já manifestou a sua vontade, livre e refletida, mas o resultado contratual ainda está inequitativo. As normas proibitórias de cláusulas abusivas são normas de ordem pública, normas imperativas, inafastáveis pela vontade das partes. Estas normas do CDC aparecem como instrumentos do direito para restabelecer o equilíbrio, para restabelecer a força da 'vontade', das expectativas legítimas, do consumidor, compensando, assim, sua vulnerabilidade fática. (...) passamos a aceitar no Brasil, com o advento do Código de Defesa do Consumidor, a existência de valores jurídicos superiores ao dogma da vontade, tais como a equidade contratual, os quais permitem ao Poder Judiciário um novo e efetivo controle do conteúdo dos contratos de consumo." 279

Em rigor, a edição de normas protetoras do sujeito vulnerável provém exatamente da necessidade, percebida pelo legislador, de se remediar os abusos perpetrados pela inserção de cláusulas contratuais que reflitam a prepotência do contratante economicamente mais forte ${ }^{280}$; isto porque "a abusividade da cláusula contratual é o

mantida - Recurso voluntário desprovido" (TJSP, AC 409.060-5/3-00, rel. Sidney Romano dos Reis, j. 28.09.2009).

${ }^{279}$ Contratos..., cit., p. 766.

${ }^{280}$ João Bosco Leopoldino da Fonseca. Cláusulas abusivas nos contratos. Rio de Janeiro: Forense, 1993, p. 60. 
descompasso de direitos e obrigações entre os contratantes, direitos e obrigações típicos daquele tipo de contrato, é a unilateralidade excessiva, é o desequilíbrio contrário à essência, ao objetivo contratual, aos interesses básicos presentes naquele tipo de relação, é a autorização da atuação desleal, maliciosa, de má-fé subjetiva, que esta cláusula, se cumprida, irá ocasionar". ${ }^{281}$

De outra banda, irrelevante para a caracterização da abusividade de uma cláusula a boa ou má-fé subjetiva do fornecedor que a impôs ao consumidor. A tendência hoje é conectar a abusividade das cláusulas a um paradigma real: o princípio da boa-fé objetiva. Com isso, observa-se mais seu efeito (resultado) e abandona-se uma investigação sobre eventual conduta maliciosa subjetiva. ${ }^{282}$

É dizer: o CDC sanciona e afasta apenas o resultado, o desequilíbrio objetivo, não exige um ato reprovável (má-fé intencional) do fornecedor. A cláusula pode ter sido aceita conscientemente pelo consumidor, mas se traz vantagem excessiva para o fornecedor (abusiva), seu efeito será contrário às novas normas da ordem pública protetiva e, assim, não prevalecerá a autonomia da vontade. ${ }^{283}$

Quanto à sanção, anota Nelson Nery Júnior:

“O CDC adotou um sistema próprio de enumeração e de proteção contra as cláusulas abusivas. Conferiu-lhe o regime da 'nulidade de pleno direito', não estabelecendo graus de invalidade entre elas, tampouco as tratando como causas de ineficácia da relação jurídica de consumo.

\section{$(\ldots)$}

Do mesmo modo, não há lugar para falar-se, no sistema do CDC, em nulidade absoluta e nulidade relativa de cláusulas contratuais abusivas. No regime jurídico do $\mathrm{CDC}$ as cláusulas abusivas são nulas de pleno direito porque contrariam a ordem pública de proteção ao consumidor. Isso quer dizer que as nulidades podem ser reconhecidas a qualquer tempo e grau de jurisdição, devendo o juiz ou tribunal pronunciá-las ex officio, porque normas de ordem pública insuscetíveis de preclusão."284

\footnotetext{
${ }^{281}$ Cláudia Lima Marques et alii. Comentários ao Código de Defesa do Consumidor. $3^{\mathrm{a}}$ ed. São Paulo: RT, 2010 , p. 255.

${ }^{282}$ Cláudia Lima Marques. Contratos..., cit., p. 774.

${ }^{283}$ Cláudia Lima Marques. Contratos..., cit., p. 742.

${ }^{284}$ Et alii. Código Brasileiro de Defesa do Consumidor..., cit., p. 307/308.
} 
Por isso, não se valida cláusula abusiva. Embora implantada no contrato, ela será sempre nula, desde seu nascimento; logo, em função desse caráter, não está o consumidor obrigado a cumprir obrigação dela decorrente ${ }^{285}$. Todavia, há uma autorização excepcional (CDC, art. $\left.6^{\circ}, \mathrm{V}\right)$, a critério do consumidor, para modificar essas cláusulas originalmente desproporcionais (infra, Cap. V, 4.1).

\subsubsection{A expressão cláusula abusiva}

Entende-se que o sentido da expressão cláusula utilizada pela lei (CDC, art. 51, caput) é mais amplo do que o de simples cláusula contratual.

Preleciona, neste particular, Luiz Antonio Rizzatto Nunes que, “(...) o sentido estrito de 'cláusula contratual' está previsto. Mas deve-se entender o vocábulo 'cláusula' da norma na sua acepção mais ampla, de todo e qualquer pacto ou estipulação contratual, escrito ou verbal, de todas as formas possíveis de fazerem nascer relações jurídicas de consumo". ${ }^{286}$

Comunga do mesmo entendimento o ilustre professor Nelson Nery Júnior: “as cláusulas abusivas não se restringem aos contratos de adesão, mas a todo e qualquer contrato de consumo, escrito ou verbal, pois o desequilíbrio contratual, com a supremacia do fornecedor sobre o consumidor, pode ocorrer em qualquer contrato, concluído mediante qualquer técnica contratual. O CDC visa proteger o consumidor contra as cláusulas abusivas tout court e não somente o aderente do contrato de adesão. Daí a razão de as cláusulas abusivas estarem tratadas pelo $\mathrm{CDC}$ em seção diversa do regulamento do contrato de adesão, significando terem abrangência para além dessa forma de contratação em massa". ${ }^{287}$

Trata-se, na verdade, de uma expressão valorativa moderna, mas de certa maneira paradoxal. Só pode ser abusivo o que excedeu os limites e, na visão tradicional da autonomia da vontade (plena liberdade de contratar), limites na fixação de cláusulas contratuais praticamente não existem. Denominar, portanto, uma cláusula do contrato como abusiva é pressupor a reação do direito contratual, é aceitar a imposição de novos limites ao exercício do direito subjetivo da livre contratação. A ingerência do Estado

\footnotetext{
${ }^{285}$ Luiz Antonio Rizzatto Nunes. Comentários..., cit., p. 584.

${ }^{286}$ Comentários..., cit., p. 588.

${ }^{287}$ Et alii. Código Brasileiro de Defesa do Consumidor..., cit., p. 340.
} 
nos negócios privados e a imposição de limites ao dogma da autonomia da vontade vão caracterizar a atual concepção do contrato. ${ }^{288}$

\subsubsection{Rol exemplificativo}

Tende-se para essa conclusão. ${ }^{289}$

Com efeito, é princípio medular da Política Nacional das Relações de Consumo a coibição e a repressão eficientes de todos os abusos praticados no mercado (CDC, art. $\left.4^{\circ}, \mathrm{VI}\right)$, sendo direito básico do consumidor a proteção contra as cláusulas abusivas ou impostas no fornecimento de produtos e serviços (CDC, art. $\left.6^{\circ}, \mathrm{IV}\right)$.

A cláusula meramente imposta pelo fornecedor, percebe-se, já nasce impregnada de vício determinante da sua invalidade.

Não bastasse isso, o próprio art. 51, caput, da Lei 8.078/90 indica que as hipóteses expressas em seus dezesseis incisos são apenas algumas entre outras. Existem, ainda, duas cláusulas (ou condições) gerais: as que estabeleçam obrigações consideradas iníquas, abusivas, que coloquem o consumidor em desvantagem exagerada $^{290}$, ou sejam incompatíveis com a boa-fé ou a equidade (CDC, art. 51, IV) e as que estejam em desacordo com o sistema de proteção ao consumidor (CDC, art. 51, XV).

Por fim, há a cláusula abusiva específica dos contratos de compra e venda de móveis ou de imóveis mediante pagamento em prestações, bem como nas alienações fiduciárias em garantia (CDC, art. 53, caput).

Infere-se daí que toda e qualquer condição contratual que afronte o princípio da boa-fé, em tese, é cláusula abusiva, a ser atingida pela nulidade absoluta, nos termos do CDC. ${ }^{291}$

\footnotetext{
${ }^{288}$ Cláudia Lima Marques. Contratos..., cit., p. 768/769.

${ }^{289}$ Cf., Luiz Antonio Rizzatto Nunes. Curso..., cit., p. 627; Arruda Alvim et alii. Código do Consumidor comentado..., cit., p. 250; Nelson Nery Júnior et alii. Código Brasileiro de Defesa do Consumidor..., cit., p. 342; Cláudia Lima Marques. Contratos..., cit., p. 780 e Valéria Silva Galdino. Cláusulas Abusivas. São Paulo: Saraiva, 2001, p. 49.

290 "Um dos princípios fundamentais do Código de Defesa do Consumidor, estampado em seu art. $6^{\circ}$, III, é o dever de informação adequada e clara sobre os diferentes produtos e serviços colocados à disposição do consumidor. A cláusula contratual de seguro que exime de cobertura os sinistros ocorridos em residência de madeira coloca o consumidor em desvantagem exagerada, uma vez que restringe o direito fundamental inerente à natureza do citado contrato, qual seja, a proteção do patrimônio do segurado. Inteligência do art. 51, inciso IV c.c. o seu $\S 1^{\circ}$, inciso II, da Lei Consumerista. Deve ser presumida a boa-fé do segurado ante a ausência de comprovação de sua má-fé quando da celebração do negócio jurídico" (TJMS, AC 2006.0139086/0000-00, rel. Paschoal Carmello Leandro, j. 30.09.2008).

${ }^{291}$ Antônio Carlos Efing. Contratos..., cit., p. 103.
} 


\subsubsection{Oportunidade de reconhecimento e prazo}

Ressalte-se que a nulidade da cláusula abusiva pode (deve) ser reconhecida judicialmente por meio de ação direta, de reconvenção, de exceção substancial alegada em defesa (contestação), de embargos ou, ainda, por ato ex officio do juiz ${ }^{292}$, não se colocando no oblívio - aqui - a Súm. 381 do $\mathrm{STJ}^{293}$.

A despeito da evidente afronta - num primeiro momento - ao caráter inderrogável da Lei 8.078/90 (supra, Cap. I, 1), o fato é que, mesmo sem justificar o discrimen (por que só nos contratos bancários?), o intérprete soberano da legislação federal acabou reconhecendo - em leitura inversa do preceito - que tal agir do magistrado é plenamente lícito e possível em qualquer outro contrato de consumo.

Nada obstante o choque entre os interesses dos bancos e a disciplina constitucional e legal da sua atividade continue gerando distorções como esta, perceptíveis cada vez mais na jurisprudência ${ }^{294}$, a busca da segurança jurídica nos negócios acaba submetendo a técnica aos seus efeitos colaterais.

Isto porque: se é verdade que o julgador não está preso à orientação do seu tribunal - afirmação correta do ponto de vista da lógica formal abstrata também é verdadeiro que, no campo da política judiciária, essa afirmação transforma a distribuição da justiça em jogo de azar, convertendo o resultado de um processo em loteria, fazendo com que uma certa tese jurídica receba tratamentos diferentes na mesma Corte, ao sabor da composição de cada turma e dependendo da sorte dos números sorteados.

Quanto às projeções do reconhecimento, embora de nulidade se trate, há divergência sobre o caráter principal da sentença que a reconhece: se declaratória ou se desconstitutiva (constitutiva negativa). A primeira melhor se afina ao efeito ex tunc inerente a situações como a da espécie, apensar de a segunda encontrar amparo em vozes ressonantes da doutrina nacional. ${ }^{295}$

\footnotetext{
${ }^{292}$ Cf., Luiz Antonio Rizzatto Nunes, Curso..., cit., p. 622/623 e Nelson Nery Júnior et alii. Código Brasileiro de Defesa do Consumidor..., cit., p. 341.

${ }^{293}$ STJ, Súm. 381: "nos contratos bancários, é vedado ao julgador conhecer, de ofício, da abusividade das cláusulas".

294 "Não cabe ao juízo, como se estivera em um garimpo, debulhar os contratos celebrados entre as partes, à caça de identificar concretamente e proclamar eventuais vícios que pudessem se amoldar às relações jurídicas deles decorrentes" (TJSP, AC 7.278.544-1, rel. Edgard Jorge Lauand, j. 18.11.2008).

${ }^{295}$ Luiz Antonio Rizzatto Nunes, Comentários..., cit., p. 584.
} 
Viável um temperamento caso se entenda que a sentença ao decretar a nulidade declara essa situação preexistente e desconstitui a juridicidade do ato $^{296}$. Quer dizer que, em relação ao ato ou ao negócio nulo em si, a sentença tem conteúdo meramente declaratório; no tocante à juridicidade do ato ou negócio, a sentença é desconstitutiva. $^{297}$

Afinal, adverte Pontes de Miranda, luminar da ciência jurídica, que toda sentença possui natureza condenatória, constitutiva, declaratória e mandamental, dependendo a classificação do seu tônus prevalecente. Segundo ele, "para que o acima exposto fosse destruído, fora preciso que se apontasse, pelo menos, 'uma' sentença pura de condenação, outra de declaração, outra de constituição, outra de mandamento, outra de execução. Não há. Nem nunca houve. A qualidade de cada uma resulta, apenas, da quantidade ou intensidade de um dos elementos (declaratividade, constitutividade, condenatoriedade, mandamentalidade, execução)". ${ }^{298}$

No atinente ao prazo, a Lei 8.078/90 inspirou-se, confessadamente, no critério de Agnelo Amorim Filho para distinguir prescrição e decadência. Segundo ele, as ações condenatórias têm prazo de prescrição para o seu exercício; as ações constitutivas com prazo na lei encerram hipótese de decadência; as ações declaratórias e as ações constitutivas sem prazo previsto na lei para serem ajuizadas são imprescritíveis. ${ }^{299}$

Destarte, quer seja considerada meramente declaratória, ou desconstitutiva, a ação não está sujeita à prescrição nem à decadência: é imprescritível ${ }^{300}$ (lato sensu), conquanto o STF já tenha reconhecido que, mesmo nessas hipóteses, o prazo máximo para exercício da pretensão é o maior previsto no sistema jurídico.

\subsubsection{Cobrança de dívidas $\mathrm{x}$ repetição do indébito}

\footnotetext{
${ }^{296}$ Kazuo Watanabe. Breve reflexão sobre a natureza jurídica da sentença de nulidade de casamento. $R T$, São Paulo: RT, v. 542, p. 25/28.

${ }^{297}$ Nelson Nery Júnior et alii. Código Brasileiro de Defesa do Consumidor..., cit., p. 341, n. 119.

${ }^{298}$ Comentários ao Código de Processo Civil. Atual. Legislativa de Sergio Bermudes. $5^{\text {a }}$ ed. Rio de Janeiro: Forense, 1997, t. I, p. 111.

${ }^{299}$ Critério científico para distinguir a prescrição da decadência e para identificar as ações imprescritíveis. RT. São Paulo: RT, v. 300, p. 7/37.

${ }^{300}$ Cf., Luiz Antonio Rizzatto Nunes. Comentários..., cit., p. 587 e Nelson Nery Júnior et alii. Código Brasileiro de Defesa do Consumidor..., cit., p. 341, n. 119.
} 
O Código é peremptório neste ponto, haja vista estabelecer que, "na cobrança de débitos, o consumidor inadimplente não será exposto a ridículo, nem será submetido a qualquer tipo de constrangimento ou ameaça" (art. 42, caput), o que forçosamente nos remete, sem embargo dos reflexos penais desse abuso (CDC, art. 71), por certo sem esgotar o tema, à análise do consumidor inadimplente no âmbito da prestação de serviço público essencial (infra, 5.2).

Interessa agora, todavia, verificar a disciplina da repetição do indébito, sobretudo diante da regra de direito comum prevista no art. 940 do Código Civill $^{301}$. Dispõe o art. 42, par. ún., do CDC que "o consumidor cobrado em quantia indevida tem direito à repetição do indébito, por valor igual ao dobro do que pagou em excesso, acrescido de correção monetária e juros legais, salvo hipótese de engano justificável".

A despeito da divergência doutrinária que permeia o tema $s u b$ examine $^{302}$, a repetição dobrada do indébito na forma prevista pela Lei 8.078/90 exige a conjugação de três pressupostos: a) a cobrança de dívida de consumo; b) o seu efetivo pagamento pelo consumidor e c) o engano injustificável do fornecedor. Percebe-se, assim, que os dois primeiros são de ordem objetiva, enquanto o último encerra tônus subjetivo.

\subsubsection{Cobrança de dívida de consumo}

Certamente a disciplina do art. 42, par. ún., do CDC exige, como elemento fundamental da sua incidência, que a relação controvertida de débito/crédito tenha sido gerada de um vínculo primário de consumo. O discrínem se dá em razão da matéria, a afastar, forte na especialidade, as normas civis ordinárias.

O núcleo de conduta do tipo é cobrar, gênero do qual se apresenta a espécie cobrar em juízo ou simplesmente demandar. O legislador de 1990 deixou claro, com isso, na sua linha protecionista, ao contrário das demais pessoas

\footnotetext{
${ }^{301}$ CC, art. 940: “aquele que demandar por dívida já paga, no todo ou em parte, sem ressalvar as quantias recebidas ou pedir mais do que for devido, ficará obrigado a pagar ao devedor, no primeiro caso, o dobro do que houver cobrado e, no segundo, o equivalente do que dele exigir, salvo se houver prescrição".

302 Cf., Luiz Antonio Rizzatto Nunes. Curso..., cit., p. 546/547 e Antônio Herman de Vasconcellos e Benjamin et alii. Código Brasileiro de Defesa do Consumidor, comentado pelos autores do anteprojeto. Direito Material. 10a ed. Rio de Janeiro: Forense, 2011, p. 407/410.
} 
(naturais ou jurídicas), que o consumidor tem hipotético direito de repetição dobrada se, de qualquer maneira $^{303}$, for cobrado de modo indevido.

A sistemática do Código Civil, nesse ponto, tem espectro reduzido, pois apenas as cobranças judiciais, as conhecidas demandas, ensejam discussão sobre indébito repetível ${ }^{304}$, o que não autoriza se possa dela aqui cogitar (supra, Cap. I, 2.6). O art. $941^{305}$, ao integrar o 940, usando os termos desistir da ação e contestada a lide, dúvida não deixa quanto a essa disciplina.

\subsubsection{Efetivo pagamento pelo consumidor}

\section{O direito à repetição do indébito se realiza por valor igual ao}

dobro do que pagou em excesso. Deve o consumidor, portanto, ter pago algo injusto, no todo ou em parte. ${ }^{306}$

A expressão dobro, tal qual os civilistas bem estudaram acerca das $\operatorname{arras}^{307}$, não é adequada. Melhor seria, como fez o Código Civil de 2002 (arts.

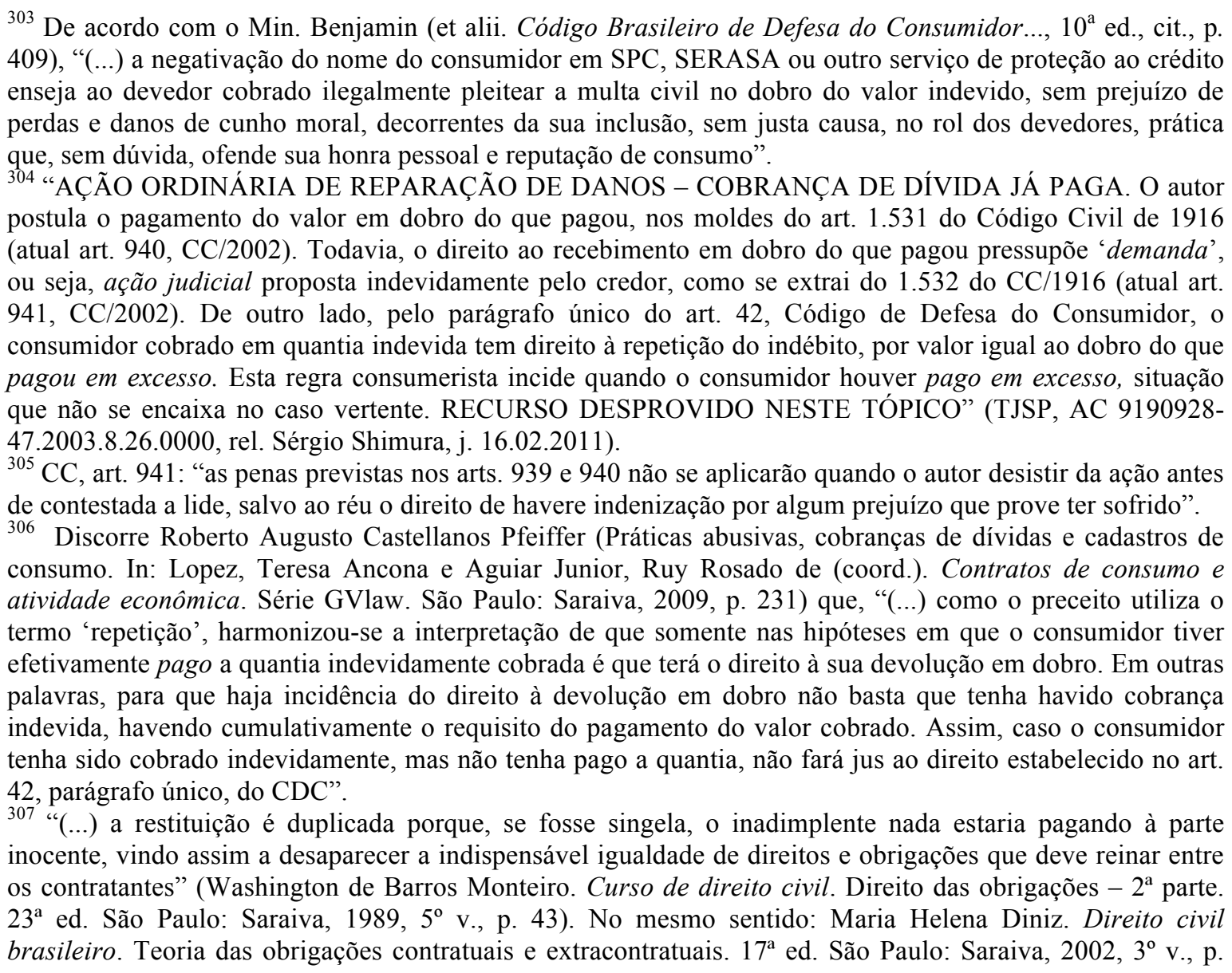


418 e 420), uma redação que desse à matéria o sentido de devolver o que foi pago mais o equivalente. A soma desses valores representa duas vezes o indevidamente exigido.

Mas e se o consumidor, posto que cobrado, não cede à conduta abusiva do fornecedor. Tem ele algum direito se nada pagou?

A resposta, afirmativa, depende da boa compreensão da eficácia condicionante da Parte Geral da Lei 8.078/90, notadamente do diálogo das fontes imposto pelo seu art. $7^{\circ}$, caput. Isto porque o $\mathrm{CDC}$, ao revés do direito privado comum, não previu essa hipótese.

Pois bem. O art. 940 do Código Civil abarca duas situações autônomas, com consequências distintas: a) demandar por dívida quitada implica pagamento do dobro que houver sido cobrado e b) pedir mais do que for devido traz como preceito sancionador o equivalente do que se exigiu.

Ora, se o direito entre iguais assegura ao injustamente cobrado, ainda que sem nada pagar, receber o equivalente que dele se exigiu, razão muito maior autoriza resultado análogo em benefício do consumidor. Conquanto não se trate de repetição, porque não houve pagamento, sem prejuízo da efetiva reparação de outros danos causados $^{308}$, a sanção pelo equivalente injusto atua como importante medida de desestímulo à conduta abusiva do fornecedor, muitas vezes relapso por si ou por seus prepostos.

\subsubsection{Engano injustificável do fornecedor}

Não bastassem suas elementares objetivas, o art. 42, par. ún., do $\mathrm{CDC}$ atrela sua disciplina à inexistência de engano justificável daquele que cobra o consumidor, circunstância atrativa, nesse processo, a despeito do viés objetivo do Código, da análise do elemento subjetivo do fornecedor.

138; Sílvio de Salvo Venosa. Direito civil. Teoria geral das obrigações e teoria geral dos contratos. $3^{\mathrm{a}}$ ed. São Paulo: Atlas, 2003, v. II, p. 538/542; Álvaro Villaça Azevedo. Teoria geral das obrigações e responsabilidade civil. $11^{\mathrm{a}}$ ed. São Paulo: Atlas, 2008, p. 237/239; Silvio Rodrigues. Direito civil. Parte geral das obrigações. $30^{a}$ ed. São Paulo: Saraiva, 2002, v. 2, p. 283/284.

308 "A cobrança abusiva de serviços televisivos por assinatura, culminando na solução de continuidade dos serviços contratados, gera não só a devolução em dobro do valor cobrado abusivamente (art. 42, parágrafo único, da Lei 8.078/90) como também dano moral, indenização que ganha aspecto punitivo, que deve ser considerado na fixação do quantum devido" (1 TacCiv/SP, Ap. 783.839-1, rel. Rizzatto Nunes, j. 18.08.1999). 
Em que pese a todo engano na cobrança de consumo ser, em princípio, injustificável $^{309}$, forte no necessário equilíbrio que deve reger essa especial relação jurídica (infra, 4), estabeleceu o legislador de 1990, por opção, uma espécie de rota de fuga em prol do fornecedor ${ }^{310}$, talvez inspirado na Súm. 159 do $\mathrm{STF}^{311}$, cuja edição graduava o art. 1.531 do CC/1916, hoje substituído pelo art. 940 do Estatuto vigente.

Com razão, ao imputar a prova da justificabilidade ao fornecedor $^{312}$, sustenta o Min. Benjamin que "o engano é justificável exatamente quando não decorre de dolo ou de culpa ${ }^{313}$. É aquele que, não obstante todas as cautelas razoáveis exercidas pelo fornecedor-credor, manifesta-se" ${ }^{, 314}$, o que retoma a clássica moldura da responsabilidade aquiliana (in lex aquilia levissima culpa venit) ${ }^{315}$, que também não afasta a verificação de concreta, mas não exclusiva, má-fé. ${ }^{316}$

Quanto às instituições financeiras, embora se tenha consagrado que na abertura de crédito em conta a repetição do indébito não exige prova do erro (STJ, Súm. 322), porque os lançamentos feitos pelo próprio credor elidem a ideia de pagamento voluntário $^{317}$, a má-fé como pressuposto da devolução em dobro ${ }^{318}$ - na esteira da Súm. 159 do STF - nas relações de consumo, repita-se, cede ao exame da culpabilidade mais abrangente do engano injustificável, como o inadmissível erro aritmético para quem é senhor absoluto das técnicas da matemática financeira.

O STJ, intérprete soberano da legislação federal, aqui, hoje em $\mathrm{dia}^{319}$, tem se orientado no sentido de que a robusta controvérsia judicial que permeia o

\footnotetext{
${ }^{309}$ Cláudia Lima Marques. Comentários..., cit., p. 805.

${ }^{310}$ Luiz Antonio Rizzatto Nunes. Curso..., cit., p. 547.

311 STF, Súm. 159: “cobrança excessiva, mas de boa-fé, não dá lugar às sanções do art. 1.531 do Código Civil",

312 “(...) O art. 42, par. ún., do CDC, embora exclua a responsabilidade objetiva predominante nesse Estatuto, por aceitar o engano justificável, não exclui a responsabilidade subjetiva. A locução 'salvo engano justificado', do art. 42, par. ún., in fine, torna a excludente de culpa matéria de defesa. Não realizada por quem cobrou indevidamente, a culpa se presume" (TJSC, AC 99.014591-3, rel. Pedro Manoel Abreu, j. 01.11.2001).

${ }^{313}$ STJ, REsp. 1.079.064/SP, rel. Min. Herman Benjamin, j. 02.04.2009. Em igual sentido, dente outros, e da mesma Corte: REsp. 1.084.815/SP, rel Min. Denise Arruda, j. 23.06.2009 e AgRg. no REsp. 1.151.496/SP, rel. Min. Arnaldo Esteves de Lima, j. 23.11.2010.

${ }^{314}$ Et alii. Código Brasileiro de Defesa do Consumidor..., $10^{\text {a }}$ ed., cit., p. 410.

${ }^{315}$ STJ, REsp. 1.085.947/SP, rel. Min. Francisco Falcão, j. 04.11.2008.

${ }^{316}$ STJ, REsp. 1.127.72'/RS, rel. Min. Nancy Andrighi, j. 03.12.2009.

317 STJ, REsp. 184.237/RS, rel. Min. César Asfor Rocha, j. 05.10.2000. Ou seja: não se pode considerar voluntário o pagamento realizado "para evitar possíveis constrangimentos" (STJ, REsp. 187.717/RS, rel. Min. Carlos Alberto Menezes Direito, j. 14.10.1999).

${ }^{318}$ STJ, AgRg. no REsp. 1.064.772/SE, rel. Min. Fernando Gonçalves, j. 04.08.2009.

319 O Min. Ruy Rosado de Aguiar Júnior, em situação análoga, proferiu voto diametralmente oposto a esse raciocínio: "nessas condições, fica evidente o comportamento ilícito da credora, que sobrepôs parcelas para o
} 
tema da cobrança de juros e de encargos pelas instituições financeiras arreda os pressupostos autorizantes da devolução em dobro ${ }^{320}$, diretriz que já encontra ressonância na Corte Bandeirante. ${ }^{321}$

De qualquer forma, o engano justificável ganha relevo tão-só na análise de pertinência da parcela do equivalente, pois aquilo que sem causa foi pago será, a todo modo, pena de enriquecimento ilícito do fornecedor ${ }^{322}$, repetível. ${ }^{323}$

\subsubsection{Os bancos de dados e seus prazos}

Uma das práticas comerciais previstas pelo Código, que também pode se revelar fonte de abusos, é o manejo, pelo fornecedor, dos bancos de dados e dos cadastros de consumidores, agora também positivos ${ }^{324}$, legalmente tidos como entidades de caráter público (art. $43, \S 4^{\circ}$ ), o que esvaziou o veto presidencial ao art. 86 da Lei 8.078/90, cujo texto previa a aplicação do "habeas data à tutela dos direitos e interesses dos consumidores", per se, viável a partir do art. 5, LXXII, da Constituição da República.

fim deliberado de aumentar as quantias correspondentes às parcelas mensais do financiamento, e assim elevar o saldo devedor. $\mathrm{O}$ fato de estar no contrato a previsão dessa conduta não afasta a incidência da regra que ordena a repetição do indébito pelo dobro, nos precisos termos do art. 42 do CDC, pois a cláusula nula de pleno direito não justifica o enriquecimento indevido. Se a existência do contrato de adesão bastasse ao comportamento abusivo e à cobrança ilícita, ficaria sem aplicação a regra legal, uma vez que, no Brasil, sem qualquer controle eficaz do Estado, os contratos de adesão contemplam de ordinário disposições somente favoráveis à estipulante. Porém, como muito bem ficou realçado no r. acórdão, nem tudo o que se contém no contrato pode ser aceito diante do ordenamento jurídico. Logo, o comportamento fundado em contrato nulo é ilícito, e os valores auferidos a maior devem ser restituídos em dobro. Esse valor deve ser aquele reconhecido no r. acórdão como cobrado indevidamente" (STJ, REsp. 328.338/MG, j. 15.04.2003). A controvérsia foi levada à $2^{\text {a }}$ Seção do STJ e reformada em sede de divergência, quando se entendeu que "o pagamento resultante de cláusula contratual mais tarde declarada nula em sede judicial deve ser devolvido de modo simples, e não em dobro; age no exercício regular de direito quem recebe a prestação prevista em contrato" (STJ, EREsp. 328.338/MG, rel. Min. Ari Pargendler, j. 26.10.2005).

${ }^{320}$ STJ, AgRg. no Ag 932.894/RS, rel. Min. Sidnei Beneti, j. 16.09.2008.

321 "Não deve ser acolhido o requerimento de restituição em dobro dos valores indevidamente pagos a maior, pois esta C. Câmara vem entendendo que a cobrança excessiva dos encargos não representa resultado da máfé do banco-credor, mas tão-somente de uma interpretação equivocada das leis e do contrato existente entre as partes" (TJSP, AC 7.082.593-9, rel. J. B. Franco de Godoi, j. 24.09.2008).

${ }^{322}$ STJ, REsp. 200/267/RS, rel. Min. Sálvio de Figueiredo Teixeira, j. 03.10.2000.

${ }^{323}$ Esse é o pensamento de Luiz Antonio Rizzatto Nunes (Curso..., cit., p. 547): “(...) ser for aceito algum engano justificável na cobrança indevida, ainda sim remanesce, obviamente, o direito de o consumidor repetir o valor singelo, acrescido de correção monetária e juros legais".

${ }^{324}$ Lei 12.414 , de 09 de junho de 2011. 
Conquanto se possa, na teoria, estabelecer uma distinção entre essas duas figuras, notadamente acerca da fonte e do destino da informação ${ }^{325}$ - nos cadastros as informações partem do consumidor e se dirigem a fornecedor certo e determinado; já nos banco de dados, no seu próprio interesse, a informação é obtida pelos fornecedores no intuito de alimentar o mercado - o certo é que todos eles estão submetidos às normas do $\mathrm{CDC} .{ }^{326}$

Dessa natureza pública dos registros avulta a possibilidade de o consumidor, com amplo acesso ${ }^{327}$, sempre que encontrar inexatidão nos seus dados e cadastros, exigir a sua imediata correção, quando o arquivista terá o prazo de cinco dias úteis para comunicar as mudanças aos seus potenciais destinatários (CDC, art. 43, $\S 3^{\circ}$ ).

O prazo de cinco dias úteis é para informar as correções já feitas, as quais devem ser promovidas de imediato após solicitadas pelo consumidor, pena de o arquivista incidir no crime previsto no art. 73 do $\mathrm{CDC}^{328}$. Há uma tendência de se interpretar o advérbio imediatamente como o lapso razoável mínimo, caso a caso, para que seja corrigido o registro. ${ }^{329}$

\footnotetext{
${ }^{325}$ Destaca Leonardo Roscoe Bessa (et alii. Manual de direito do consumidor. São Paulo: RT, 2008, p. 240) que "(...) dois aspectos se destacam na distinção entre bancos de dados e cadastros de consumo: a origem da informação (fonte) e seu destino. Nos cadastros, muito comuns nas lojas que comercializam roupas, é o próprio consumidor, independemente de a compra ser a crédito, que oferece seus dados pessoais para o estabelecimento. Objetiva-se, com a coleta de dados, estabelecer uma comunicação maior entre fornecedor e consumidor, principalmente oferecer informações sobre promoções, chegada de novos modelos de roupas, etc. A fonte da informação é o próprio consumidor e o destino é um fornecedor específico. De outro lado, nos bancos de dados de consumo, cuja principal espécie são justamente as entidades de proteção ao crédito, a informação advém, em regra, dos fornecedores (e não mais do consumidor). O destino final da informação, embora ela permaneça armazenada na entidade, é o mercado, ou seja, os fornecedores".

${ }^{326}$ Luiz Antonio Rizzatto Nunes. Curso..., cit., p. 552.

${ }^{327} \mathrm{CDC}$, art. 72: "impedir ou dificultar o acesso do consumidor às informações que sobre ele constem em cadastros, banco de dados, fichas ou registros: Pena - detenção de seis meses a um ano ou multa".

${ }^{328}$ CDC, art. 73: "deixar de corrigir imediatamente informação sobre consumidor constante de cadastro, banco de dados, fichas ou registros que sabe ou deveria saber ser inexata: Pena - detenção de um a seis meses ou multa".

${ }^{329}$ Ressalta Leonardo Roscoe Bessa (et alii. Manual..., cit., 373) que, "o propósito da norma é que, logo após a constatação da necessidade de corrigir a informação, o responsável realize os atos necessários para alterar ou apagar o registro. Um excelente indicativo é verificar o tempo máximo para realizar um registro contra o consumidor. Um dia? Doze horas? Qual o prazo, por exemplo, que o SPC, após pedido de negativação de determinado fornecedor, utiliza para fazer a inscrição? Como a atividade desenvolvida para incluir, excluir ou retificar informação é semelhante, o prazo deve ser o mesmo. Atualmente, ao menos em relação aos bancos de dados de proteção ao crédito, o registro, quando não é realizado pelo próprio fornecedor que tem acesso direto e eletrônico à base de dados da entidade de proteção ao crédito, não demora, em regra, mais do que vinte e quatro horas. O interesse é que a informação de dívida vencida esteja, o quanto antes, no mercado para proteção dos fornecedores. O mesmo interesse deve existir para excluir ou corrigir a informação, por duas razões: 1) o mercado não deseja informações inverídicas; 2) o tratamento de dado inexato constitui ofensa ao direito à privacidade". Para Antônio Herman de Vasconcellos e Benjamin (et alii. Código Brasileiro de Defesa do Consumidor..., $10^{\mathrm{a}}$ ed., cit., p. 486), "o vocábulo imediatamente quer dizer o
} 
Mas para que o consumidor tenha acesso às restritivas, inclusive no intuito de aquilatar a veracidade dos seus termos, é preciso que saiba da existência da anotação ${ }^{330}$, por isso a lei impôs ao arquivista $^{331}$, não ao credor, o dever de comunicá-lo por escrito e previamente (STJ, Súm. $359^{332}$ ) sobre a abertura do registro (CDC, art. 43, $\left.\S 2^{\circ}\right)$.

Pouco importa ao espírito da norma protetiva a origem da dívida. É dizer: em qualquer hipótese cabe à entidade mantenedora a obrigação de comunicar.

Não se desconhece que as duas Turmas integrantes da $2^{\mathrm{a}}$ Seção do STJ se orientaram no sentido de dispensar a comunicação se o cadastro é aberto a partir de informes de domínio público ${ }^{333}$, como os pertencentes a cartórios de protesto de títulos e de distribuição judicial ${ }^{334}$; contudo, a prevalecer esse raciocínio, nem mesmo os bancos de dados mantidos por capital privado (v.g., Serasa, SCPC, etc.) deveriam cumprir o art. $43, \S 2^{\circ}$, do CDC, pois os seus registros também são de caráter público $\left(\S 4^{\circ}\right)$.

Além disso, data venia, é de todo despiciendo investigar a origem das informações, visto que o destinatário natural da norma cogente é o administrador do arquivo creditício, de onde quer que tenham vindo as notícias registráveis ${ }^{335}$, pois quaisquer delas, as de fonte pública inclusive, no mínimo, "podem ser transcritas de maneira incorreta, estarem viciadas pelo decurso de um dos prazos previstos

seguinte: a emenda é feita pelo arquivista logo após ter os elementos caracterizadores da incorreção ou, de outra maneira, lhe faltarem subsídios para a sua manutenção”.

${ }^{330}$ Luiz Antonio Rizzatto Nunes alerta (Curso..., cit., p. 562): "é garantia que decorre diretamente do texto constitucional de preservação da privacidade do consumidor (art. $5^{\circ}, \mathrm{X}$ ). Vale tanto para abertura de cadastros ditos positivos quanto negativos. Dessa forma, estão os serviços de proteção ao crédito obrigados a avisar, por escrito, previamente o consumidor de que irão fazer a anotação. Tal aviso deve ser remetido com a antecedência de, no mínimo, 5 dias úteis. É que, na falta de regra específica sobre o prazo, aplica-se a hipótese do $\S 3^{\circ}$ por analogia, preenchendo-se a lacuna existente".

${ }^{331}$ STJ, REsp. 1.092.765/MT, rel. Min. Aldir Passarinho Júnior, j. 17.03.2011, orientação pacificada na $2^{\mathrm{a}}$ Seção dessa Corte Superior a partir do julgamento do REsp. 1.061.134/RS, rel. Min. Nancy Andrighi, j. 10.12.2008.

332 STJ, Súm. 359: “cabe ao órgão mantenedor do Cadastro de Proteção ao crédito a notificação do devedor antes de proceder à inscrição".

${ }^{333}$ STJ, AgRg. no Ag 1.339.328/SP, rel. Min. Sidnei Beneti, j. 19.10.2010.

${ }^{334}$ STJ, EDcl. no REsp. 1.080.009/DF, rel. Min. Luís Felipe Salomão, j. 21.10.2010.

335 "Os órgãos mantenedores de cadastros possuem legitimidade passiva para as ações que buscam a reparação dos danos morais e materiais decorrentes da inscrição, sem prévia notificação, do nome de devedor em seus cadastros restritivos, inclusive quando os dados utilizados para a negativação são oriundos do CCF do Banco Central ou de outros cadastros mantidos por entidades diversas” (STJ, REsp. 1.061.134/RS, rel. Min. Nancy Andrighi, j. 10.12.2008). 
no $\mathrm{CDC}$, ou, o que é pior, serem insustentáveis em arquivos de consumo, conquanto privilegiadas (informações médicas, por exemplo)",336

Observa, a propósito, Leonardo Roscoe Bessa que, “o dever de comunicação refere-se a qualquer novo registro no banco de dados. Não importa se a fonte da informação seja acessível a todos. Os efeitos decorrentes de um protesto de título em cartório são absolutamente diversos das consequências de estar negativado em serviços de proteção ao crédito. Ademais, a lei, no art. $43, \S 2^{\circ}$, não faz qualquer ressalva". 337

O STJ, a cumprir sua tarefa de intérprete maior da legislação federal, com a sua Súm. $404^{338}$, pacificou a pendenga sobre a necessidade, ou não, de o consumidor assinar o aviso de recebimento para que se pudesse outorgar validade à notificação. Basta, assim, sob o ônus exclusivo do arquivista, a prova da remessa do expediente ao endereço constante no título originário da dívida ou em outra referência objetiva (v.g., lista telefônica, etc.).

A dúvida, por certo, forte nos princípios protetivos insculpidos na Parte Geral do Código, há de ser resolvida em benefício do consumidor.

\subsubsection{Irregularidade no registro $\mathrm{x}$ dano moral}

Se nenhum abuso é tolerado (supra, 3.2), mesmo sendo legítima a hipotética inscrição do seu nome em serviços de proteção ao crédito, tem o consumidor o direito básico de só ser negativado de acordo com o modelo legal e em razão de verdadeira pendência financeira.

Logo, a restritiva pode gerar danos extrapatrimoniais se inadequada, tanto do ponto de vista formal (v.g., falta ou falha de comunicação prévia ${ }^{339}$, limites temporais, etc.) quanto do material (v.g., débito inexistente ${ }^{340}$ ou excessivo ${ }^{341}$ ).

\footnotetext{
${ }^{336}$ Antônio Herman de Vasconcellos e Benjamin et alii. Código Brasileiro de Defesa do Consumidor..., $10^{\mathrm{a}}$ ed., cit., p. 473.

${ }^{337}$ O consumidor e os limites dos bancos de dados de proteção ao crédito. São Paulo: RT, 2003, p. 194.

${ }^{338}$ STJ, Súm. 404: "é dispensável o aviso de recebimento (AR) na carta de comunicação ao consumidor sobre a negativação de seu nome em bancos de dados e cadastros".

339 "SERASA. Comunicação prévia. Falta. Indenização. A falta de comunicação da inscrição do nome do devedor no banco de dados de inadimplência gera direito à indenização pelo dano extrapatrimonial que daí decorre. Recurso conhecido e provido" (STJ, REsp. 448.010/SP, rel. Min. Ruy Rosado de Aguiar, j. 06.02.2003). “Consumidor. Recurso Especial. Inscrição no cadastro de inadimplentes. Comunicação prévia do devedor. Necessidade. Dano moral. Configuração. A inscrição do nome do devedor no cadastro de inadimplentes sem a sua prévia comunicação por escrito ocasiona-lhe danos morais a serem indenizados pela entidade responsável pela manutenção do cadastro. Nesse caso, demonstra-se o dano moral pela simples
} 
Embora se possa sustentar, com um silogismo coerente (infra, Cap. V, 5.4), a existência de solidariedade entre os bancos de dados e os credores $^{342}$, notadamente se material o vício da restritiva ${ }^{343}$, o cumprimento imperfeito do art. $43, \S 2^{\circ}$, do CDC, por representar ato próprio do arquivista, em princípio ${ }^{344}$, segundo a orientação jurisprudencial predominante ${ }^{345}$, não vincula o credor originário, muito embora

comprovação da inclusão indevida. Precedentes" (STJ, REsp. 442.051/RS, rel. Min. Nancy Andrighi, j. 07.11.2002).

340 “Já assentou a Corte, em monótona jurisprudência, que provado o fato que gerou o dano moral, no caso, a inscrição indevida em cadastro negativo, impõe-se a condenação" (STJ, REsp. 436.850/RO, rel Min. Carlos Alberto Menezes Direito, j. 05.12.2002).

341 "Em se tratando de indenização decorrente da inscrição irregular no cadastro de inadimplentes, a exigência de prova do dano moral (extrapatrimonial) se satisfaz com a demonstração da existência da inscrição irregular nesse cadastro" (STJ, REsp. 165.727/DF, rel. Min. Sálvio de Figueiredo Teixeira, j. 16.06.1998).

${ }^{342}$ Cf. Leonardo Roscoe Bessa (et alii. Manual..., cit., p. 257/258): “(...) não há como pretender excluir a responsabilidade civil dos bancos de dados de proteção ao crédito perante o consumidor. Todos os pressupostos legais (veracidade, comunicação prévia, clareza, objetividade limites temporais etc.) que legitimam o registro são dirigidos a todos que participam do tratamento das informações, especialmente aos bancos de dados de proteção ao crédito. Os arquivos promovem a circulação das informações como se verdadeiras fossem. Se o banco de dados registra - ou permite que o fornecedor registre diretamente informação sem qualquer exigência ou cautela quanto à demonstração da veracidade dos dados, deve, naturalmente, arcar com as sanções civis decorrentes de sua conduta. A entidade pode - e deve - estipular, na sua relação com as fontes, a responsabilidade final delas, caso se verifique, posteriormente, a inverdade da informação. Todavia, a relação entre o solicitador do registro e o arquivo de proteção ao credito é estranha ao consumidor. Portanto, há concorrência entre fornecedor (lojista, instituição financeira) e banco de dados na realização do ato ilícito: ambos devem responder perante o consumidor. $\mathrm{O}$ fornecedor apresentou, desatendendo o disposto no art. $43, \S 1^{\circ}$, informação inverídica. A entidade arquivista aceitou como verdadeira a informação e a colocou à disposição de terceiros".

${ }^{343} \mathrm{Cf}$., em sentido oposto: "reconhecida a responsabilidade exclusiva da empresa pela inclusão injustificada do nome da autora em cadastro negativo de crédito, caracterizadora do dano moral, a esta cabe a legitimidade passiva para a demanda e não à associação mantenedora do serviço de proteção ao crédito" (STJ, REsp. 748.561/RS, rel. Min. Aldir Passarinho Júnior, j. 22.08.2006). "A orientação iterativa nesta Corte é a de que cabe aos bancos de dados e cadastros de inadimplentes apenas a anotação das informações passadas pelos credores, não sendo de sua alçada a confirmação dos dados fornecidos" (STJ, AgRg. no Ag. 727.440/RJ, rel. Min. Paulo Furtado, Des. convocado do TJBA, j. 04.06.2009). E ainda: AgRg. no Ag. 1.107.240/RJ, j. 04.06.2009.

${ }^{344}$ Há precedente entendendo que, "não sendo a parte notificada previamente da inscrição, tanto a empresa que solicitou a inclusão do nome no rol dos inadimplentes (suposto credor), como o órgão mantenedor do cadastro podem ser sujeitos passivos na respectiva ação de indenização por danos morais” (STJ, AgRg. nos EDcl. no Ag. 881.401/RS, rel. Min. Maria Isabel Gallotti, j. 10.05.2011).

345 "Compete ao banco de dados notificar o devedor sobre a inscrição de seu nome no cadastro respectivo, de sorte que a instituição financeira credora é parte ilegitimidade ad causam, para responder por tal omissão" (STJ, REsp. 595.170/SC, rel. Min. Aldir Passarinho Júnior, j. 16.11.2004). "Igualmente pacífico é o entendimento de que a comunicação compete ao órgão responsável pelo cadastro, e não ao credor ou à instituição financeira, afigurando-se inviável, na espécie, imputar responsabilidade ao recorrente pela ausência de aviso prévio sobre a inclusão do nome do devedor em cadastro de inadimplentes" (STJ, REsp. 849.223/MT, rel. Min. Hélio Quaglia Barbosa, j. 13.02.2007). “A legitimidade para responder por dano moral resultante da ausência da comunicação prevista no art. 42, $\S 3^{\circ}$, do CDC, pertence ao banco de dados ou à entidade cadastral a quem compete, concretamente, proceder à negativação que lhe é solicitada pelo credor. Precedentes do STJ" (STJ, AgRg. nos EDcl. no REsp. 1.152.089/SP, rel. Min. Sidnei Beneti, j. 25.05.2010). Em igual sentido e da mesma Corte: REsp. 695.902/AM, j. 10.04.2007; REsp. 818.218/MG, j. 27.03.2007; REsp. 759.244/RS, j. 05.09.2006; REsp. 642.590/RS, j. 15.08.2006; REsp. 744.888/PB, j. 03.08.2006; REsp. 807.132/RS, j. 21.02.2006; REsp. 622.609/RS, j. 16.11.2004. 
atraia para a cadeia de causadores do dano os demais órgãos de proteção ao crédito que do registro falho se valeram no intuito de disseminar a informação no mercado. ${ }^{346}$

Contudo, a matéria está a exigir uma maior reflexão. Se o credor responde solidariamente pelos abusos dos seus prepostos cobradores (CDC, art. 34), e isso não se discute ${ }^{347}$, por que não se vincularia ao exercício formalmente inadequado, portanto também abusivo, do arquivista escolhido? Estar-se-ia, inclusive, diante de uma espécie de culpa in eligendo.

A pedra de toque, parece, está em perquirir como foi colhida a informação pelo serviço de proteção ao crédito, se do credor, seu parceiro negocial, ou se diretamente do mercado. No primeiro caso, sem dúvida, de acordo com a eficácia condicionante dos princípios protetivos da Parte Geral do Código, a responsabilidade solidária é inafastável; porém, no segundo, ante a falta de nexo causal apto a evidenciar coligação de interesses, apenas o arquivista responderá pela falta da específica comunicação prévia.

Não se ponha no oblívio, todavia, que uma negativação pode nascer regular e depois, por conta de fato novo (v.g., pagamento da dívida), se converter em ato abusivo. Nesse caso, há dano moral na indevida manutenção do nome do consumidor nos serviços de crédito? Quem deve levantar a restritiva, o devedor, que

\footnotetext{
346 “(...) inegavelmente, a recorrente se beneficia das informações lançadas por ela mesma e por outras entidades de outras cidades ou Estados. Esse benefício, aliado à necessidade de facilitar a defesa do consumidor em juízo (Art. $7^{\circ}$, caput, primeira parte, CDC), cria nexo suficiente para justificar a legitimidade passiva. Além disso, a recorrente potencializa a ofensa ao patrimônio moral do inscrito, porque amplia a publicidade da negativação que não obedeceu ao requisito do Art. 43, $\S 2^{\circ}$, do CDC (notificação prévia). Enquadra-se, portanto, entre os autores do dano, o que chama a incidência do Art. $7^{\circ}$, parágrafo único, do CDC: (...). O consumidor, posto pela Lei em condição de hipossuficiência, teria grande dificuldade em identificar exatamente a qual associação ou câmara de dirigentes seu credor está filiado, para só então buscar a reparação em juízo. Por isso a solução da Lei: havendo solidariedade, o consumidor pode demandar quem lhe pareça mais adequado, de forma a facilitar a defesa de seus interesses em juízo (Art. 275 do novo Código Civil). Se todas as associações ou câmaras de dirigentes se servem do cadastro (banco de dados) no qual foi inscrito irregularmente o consumidor, sobre todas elas, solidariamente, devem recair os ônus da reparação dos prejuízos causados pela falta de notificação prévia. A recorrente é parte legítima, ainda que não seja dela o dever de notificar" (STJ, REsp. 974.212/RS, rel. Min, Humberto Gomes de Barros, j. 08.02.2008). "É parte legítima para a causa a entidade que se utiliza de cadastro aberto por outro banco de dados, porque dele aufere vantagens na sua área de atuação, devendo a inscrição ser comunicada com antecedência do devedor, nos termos do art. 43, $\S 3^{\circ}$, do CPC" (STJ, REsp. 793.926/RS, rel. Min. Aldir Passarinho Júnior, j. 23.09.2008).

347 "Dano moral Cheque oriundo de falsidade Responsabilidade indenizatória solidária cio comerciante que o recebe e da empresa de cobrança. Atuação culposa e defeituosa Indenização devida em decorrência do protesto indevido Arbitramento adequado Sucumbência fixada com moderação Recurso improvido" (TJSP, AC 1.334.803-3, rel. Hamid Charaf Bdine Júnior, j. 18.09.2008). Em igual sentido e da mesma Corte: AC 9238612-89.2008.8.26.0000, j. 01.06.1011; AC 0053369-54.2010.8.26.0002, j. 06.07.2011; AC 991.07.082039-6, j. 10.02.2010; AC 991.07.051426-6, j. 10.11.2009.
} 
resgata sua obrigação, ou o credor, que recebe - diretamente ou pelas mãos de prepostos cobradores - o montante devido, sem dúvida com os acréscimos da mora?

A despeito de orientação divergente (STJ, Súm. 385 $5^{348}$ ), considerando os princípios medulares da confiança e da boa-fé objetiva (mínimo ético exigível), à semelhança da inscrição sem causa, a simples manutenção indevida de registro depreciativo em serviço de proteção ao crédito basta para firmar a obrigação de indenizar.

Isto porque, segundo Antônio Carlos Efing, "a conduta desabonadora praticada pelo arquivo de consumo, qual seja a de inscrever, manter ou divulgar, de maneira imprecisa ou desatualizada, dados a respeito de qualquer pessoa, assume caráter de infração à ordem extrapatrimonial do arquivado, e somente dele. Este ato se configura, inclusive, forma de cobrança desabonadora rechaçada pelo art. 42 do Código do Consumidor, justamente em virtude do ataque à esfera extrapatrimonial do arquivado caracterizado pela conduta indevida ou abusiva do arquivo de consumo". 349

É dizer, a mesma diligência adotada para a negativação deve permear a conduta dos credores e dos arquivistas no sentido inverso, cancelando a restritiva quando a sua causa geradora não mais exista no mundo jurídico ${ }^{350}$, até porque essa informação há de ser corrigida imediatamente (CDC, art. 73).

Irrelevantes, ainda, ao menos para a formação da obrigação de indenizar, eventuais outras anotações em nome do consumidor, visto que o STJ, em inúmeras oportunidades, de modo não unânime é verdade ${ }^{351}$, já proclamou que a existência de vários registros, na mesma época, de débitos diversos em cadastros de inadimplentes não afasta a presunção de existência do dano moral. ${ }^{352}$

\footnotetext{
${ }^{348}$ STJ, Súm. 385: “da anotação irregular em cadastro de proteção ao crédito, não cabe indenização por dano moral, quando preexistente legítima inscrição, ressalvado o direito ao cancelamento".

${ }^{349}$ Bancos de dados e cadastro de consumidores. São Paulo: RT, 2002, p. 180, i. 5.3.2, g.n..

350 "Cabe às entidades credoras que fazem uso dos serviços de cadastro de proteção ao crédito mantê-los atualizados, de sorte que uma vez recebido o pagamento da dívida, devem providenciar, em breve espaço de tempo, o cancelamento do registro negativo do devedor, sob pena de gerarem, por omissão, lesão moral, passível de indenização" (STJ, REsp. 432.062/MG, rel. Min. Aldir Passarinho Junior, j. 03.10.2002). "Responsabilidade civil. Danos Morais. Inclusão no cadastro de inadimplentes. Exclusão não providenciada após a quitação. Indenização devida. Responsabilidade indenizatória da loja em que efetuada a compra, da financeira e da empresa de cobrança. Contratos coligados. Solidariedade dos responsáveis pelo dano causado \{Parágrafo Io do artigo 25 do CDC). Recurso provido" (TJSP, AC 210.146-4/7-00, rel. Hamid Charf Bdine Júnior, j. 27.10.2005). "RESPONSABILIDADE CIVIL - Dano moral - Permanência do nome da apelante no rol dos inadimplentes após o pagamento da dívida - Inadmissibilidade - Banco credor e empresa de cobrança que respondem solidariamente pela falha nos serviços prestados - Indenização devida - Recurso provido" (TJSP, AC 9084269-38.2008.8.26.0000, rel. J. B. Franco de Godoi, j. 04.05.2011).

${ }^{351}$ STJ, AgRg. no REsp. 1.046.881/RS, rel. Min. João Otávio de Noronha, j. 09.12.2008.

${ }^{352}$ REsp. 196.024/MG, j. 02.03.1999; REsp. 234.592/MG, j. 16.11.1999; REsp. 323.356/SC, j. 11.06.2002.
} 
Interessa que o consumidor tem solarmente claro o direito de só ser negativado por débitos reais e concretos. E a reparação moral deve ser medida por esse parâmetro, ainda que se voltem os olhos à inicial inadimplência (CC, art. $945^{353}$ ), não à sua vida pregressa.

Além disso, será muito difícil imprimir um exame minucioso da causa fundamentadora de cada restritiva em aberto (todas podem ser ilegítimas, v.g.), o que afasta tanto a tese da legitimidade primária da anotação inexata quanto a Súm. 385 do $\mathrm{STJ}^{354}$; afinal, não se sabe ao certo se o adendo explicativo "quando preexistente legítima inscrição" está a se referir à legitimidade da mesma restritiva, a da dívida paga após o registro, ou de outras que também incidam sobre o nome do consumidor.

\subsubsection{Vida útil da restritiva}

De fato, agora, cumpre definir a inteligência (amplitude e alcance) de dois parágrafos do art. 43 do Código: "os cadastros e dados de consumidores devem ser objetivos, claros, verdadeiros e em linguagem de fácil compreensão, não podendo conter informações negativas referentes a periodo superior a cinco anos" $\left(\S 1^{\circ}\right.$, g.n.) e "consumada a prescrição relativa à cobrança de débitos do consumidor, não serão fornecidas, pelos respectivos Sistemas de Proteção de Crédito, quaisquer informações que possam impedir ou dificultar novo acesso ao crédito junto aos fornecedores” ( $§ 5^{\circ}$, g.n.).

\footnotetext{
${ }^{353}$ CC, art. 945: "se a vítima tiver concorrido culposamente para o evento danoso, a sua indenização será fixada tendo-se em conta a gravidade de sua culpa em confronto com a do autor do dano".

${ }^{354}$ Cláudia Lima Marques (et alii. Comentários..., cit., 833) entende “(...) que esta orientação sumular não foi a melhor interpretação do sistema do CDC, que impõe ao fornecedor o dever de regularidade de todos os seus cadastros, frente a todos os consumidores. A Súmula 385 acabou por criar excludente para o fornecedor que efetivamente erra e ainda uma excusa de antemão de todos os erros dos fornecedores e da abertura de cadastros irregulares (que ficam sem qualquer punição), caso o consumidor tenha um - e somente um problema anterior, em que se considerou 'legítima' a inscrição 'preexistente'. O foco do CDC é na regularidade do cadastro e pressupõe - parece-me - que mesmo o consumidor superendividado ou com os anteriores e preexistentes problemas de cadastro negativo tem honra (ou quid) e sofre dano moral (o quantum é que poderia ter sido diminuído), ou teria feito esta exceção. A Súmula ressalvou o direito de cancelar o erro do fornecedor, mas não trouxe qualquer incentivo para que os fornecedores cuidem com os 'registros irregulares' que fazem e denigrem a imagem do consumidor. Também não contribui para que os fornecedores respeitem e cooperem com o consumidor superendividado, por exemplo, que perderia sua 'honra' já na primeira 'legítima inscrição'. Qualquer erro do fornecedor com relação ao consumidor superendividado passa a ficar impune. Fica a pergunta, se o consumidor supeendividado restabelecerá sua honra ao final dos 5 anos previstos como tempo máximo no CDC, ou a perde para sempre. (...)”.
} 
Sem embargo do que se possa sustentar a partir do paralelo entre as elementares não podendo conter e não serão fornecidas ${ }^{355}$, a controvérsia interpretativa neste tópico sempre foi intensa. O próprio STJ, pelas vozes das suas $3^{\mathrm{a} 356} \mathrm{e}$ $4^{\mathrm{a} 357}$ T. julgadoras, apresentava orientação divergente sobre, v.g., o que se deveria entender por prescrição relativa à cobrança de débitos.

Coube à doutrina equacionar o impasse, tal qual se infere das palavras de Reynaldo Andrade da Silveira, para quem “(...) a prescrição é da ação de cobrança como um todo, não de eventual prescrição de ação de execução". 358

Também esse o pensamento de Leonardo Roscoe Bessa: “(...) $\mathrm{O} \mathrm{CDC}$, ao se referir à 'prescrição relativa a cobrança de débitos do consumidor', não deixou espaço para o intérprete concluir que, no caso de dívidas representadas, também, por títulos de crédito, a prescrição refere-se à ação de execução. Ao contrário, o objetivo da norma, ao aludir à cobrança de débitos, parece ter sido justamente explicitar que a prescrição aludida não é a da ação cambial". 359

Essa é a melhor corrente, até porque em harmonia com a diretriz do STJ cristalizada na Súm. 299 ${ }^{360}$; assim, com facilidade, conclui-se que o limite temporal estabelecido pelo art. $43, \S 5^{\circ}$, da Lei $n^{\circ} 8.078 / 90$ dependerá da análise, caso a

\footnotetext{
${ }^{355}$ Diz Leonardo Roscoe Bessa (et alii. Manual..., cit., p. 273): "há outra sutil distinção na redação dos dois dispositivos que merece observação. $\mathrm{O} \S 1^{\circ}$ determina que os bancos de dados não podem conter informações negativas referentes a período superior a cinco anos; o $\S 5^{\circ}$ estabelece que, consumada a prescrição, não serão fornecidas informações. Interpretação meramente literal poderia levar à conclusão de que há dois regimes: no primeiro caso, a informação deve ser retirada; no segundo, a informação é mantida nos arquivos, mas com o óbice de ser transferida a terceiros. Não é o que deve ocorrer. Os bancos de dados de proteção ao crédito não coletam informação para uso próprio. Sua atividade está voltada para o fornecimento das informações armazenadas para terceiros. Manter o dado sem poder transferi-lo é o mesmo que não possuir a informação. Assim, por questão de segurança, é melhor que toda informação que extrapole seu limite temporal, seja em decorrência do $\S 1^{\circ}$ ou do $\S 5^{\circ}$, seja definitivamente excluída dos arquivos dos bancos de dados".

356 "Nome inscrito na SERASA. Prazo de prescrição. Código de Defesa do Consumidor. Precedentes da Corte. 1. Já decidiu a Corte em outras oportunidades que o prazo de prescrição é o da ação de execução relativa ao título, não o geral, como pretende o especial. 2. Recurso especial não conhecido (REsp. 533.916/RS, T3, rel. Min. Carlos Alberto Menezes Direito, j. 28.10.2003). Em semelhante sentido: REsp..528.398/RS, j. 02.12.2003.

357 "CIVIL. BANCO DE DADOS. SERASA. REGISTRO. PRAZO. ARTIGO 43, §§ $1^{\circ}$ E $5^{\circ}$, DO CÓDIGO DE DEFESA DO CONSUMIDOR. A "prescrição relativa à cobrança de débitos", cogitada no $\S 5^{\circ}$ do artigo 43, CDC, não é da ação executiva, mas de qualquer ação de cobrança. O registro de dados negativos em serviços de proteção ao crédito deve ser cancelado a partir do quinto ano ( $\$ 1^{\circ}$ do artigo 43 , CDC). Recurso conhecido e provido" (REsp. 541.413/RS, T4, rel. Min. César Asfor Rocha, j. 14.10.2003). Na mesma linha: REsp. 535.645/RS, j. 23.09.2003.

${ }^{358}$ Práticas mercantis no direito do consumidor. Curitiba: Juruá, 2000, p. 229.

${ }^{359}$ O consumidor..., cit., p. 212, i. 8.6.2.

${ }^{360}$ STJ, Súm. 299: "é admissível ação monitória fundada em cheque prescrito".
} 
caso, dos vários prazos de prescrição possíveis: a) gerais (CC/02, arts. 205 c.c. $206, \S 3^{\circ}$, VIII, c.c. seu $\S 5^{\circ}$, I, c.c. 2.028 c.c. CC/16, art. 177); b) especiais (v.g., Lei $n^{\circ} 7.357 / 85$ ).

Contudo, em todas as hipóteses, há de se observar a impossibilidade de os registros conterem informações negativas referentes a período superior a cinco anos $\left(\mathrm{CDC} \text {, art. } 43, \S 1^{\circ}\right)^{361}$. Percebe-se, portanto, que os prazos disciplinados pelos $\S \S 1^{\circ}$ e $5^{\circ}$ do art. 43 do CDC se inter-relacionam.

Lembra Antônio Carlos Efing: “(...) conjugando-se os dois parágrafos que normatizam a prescrição em matéria de arquivos de consumo, conclui-se que o prazo máximo para a manutenção de dados negativos em arquivos de consumo é cinco anos (art. 43, $\S 1^{\circ}$ ), podendo ser 'desarquivados' em momento anterior no caso de adimplemento da dívida cadastrada ou por força da prescrição da ação de cobrança relativa ao débito cadastrado (art. $43, \S 5^{\circ}$ ), quando este for menor que cinco anos". 362

Ocorre que o legislador não indicou, claramente, qual o dies a quo do quinquênio limite previsto no art. $43, \S 1^{\mathrm{o}}$, do Código: a) se o vencimento da obrigação ou b) se a abertura efetiva do registro.

Certos estudiosos se inclinaram pela primeira corrente, mais restritiva e benéfica ao consumidor, com destaque para Antônio Carlos Efing, para quem: "analisando ambos os termos, em consonância com os princípios norteadores da Política Nacional de Relações de Consumo, em especial o dispositivo que determina que as normas do CDC deverão ser interpretadas de forma mais favorável ao consumidor, entende-se que o termo inicial de contagem do prazo prescricional para fins de exclusão dos dados dos arquivos de consumo é o fato que enseje a inscrição dos mesmos. Ou seja, a partir do vencimento de obrigação cambial; a partir do vencimento de estipulação contratual etc. que certamente ocorrerá com antecedência ao registro da informação em repositório. A partir

\footnotetext{
${ }^{361}$ Ressalta Leonardo Roscoe Bessa ( $O$ consumidor..., cit., p. 215, i. 8.6.3), que: “(...) expirado o prazo para ajuizamento da ação executiva, pode o credor, por exemplo, promover ação ordinária de cobrança do débito, na qual o título de crédito servirá apenas como meio de prova concernente ao negócio jurídico realizado. No CC/1916, o prazo prescricional para ação de cobrança era de 20 anos (art. 177). O CC/2002 estabelece, ao lado do prazo ordinário de 10 anos (art. 205), o prazo de 5 anos para 'cobrança de dívidas líquidas constantes de instrumentos público ou particular' (art. 206, § $5^{\circ}$, I). As reduções, todavia, não alteram os limites temporais dos registros em bancos de dados de proteção ao crédito, pois não são menores do que o qüinqüênio previsto no $\S 1^{\circ}$ do art. 43 do CDC".

${ }^{362}$ Bancos de dados..., cit., p. 142, i. 3.9.3.
} 
daí, alcançando-se os cinco anos máximos previstos pelo Código do Consumidor deve ser excluída a informação referente a este inadimplemento". ${ }^{363}$

Mas não é só, como arremata Bertram Antônio Stürmer: “(...) o termo inicial da contagem não pode ser o da data do registro, eis que a lei, no $\S 1^{\circ}$ do art. 43, menciona as informações referentes a período superior a cinco anos, ou seja, informações relacionadas, relativas, referentes a fatos pertencentes a período superior a cinco anos. Logo, o termo inicial de contagem do prazo deve ser o da data do ato ou fato que está em registro e não a data do registro, eis que, se assim fosse, aí sim, a lei estaria autorizando que as anotações fossem perpétuas. Bastaria que elas passassem de um banco de dados para outro ou para um banco de dados novo. E, em segundo lugar, não haveria e não há finalidade nenhuma na lei em fazer com que o dado, depois de prescrito o débito, ficasse mantido sem poder ser usado para, somente após o decurso dos 5 anos, ser cancelado". 364

O Min. Benjamin, na última edição CDC comentado pelos autores do anteprojeto, retomou sua orientação primeira ${ }^{365}$ para sustentar, “(...) no que se

${ }^{363}$ Banco de dados..., cit., p. 139, i. 3.9.2. Leonardo Roscoe Bessa (O consumidor..., cit., p. 210, i. 8.6.1) perfilha idêntica orientação: "o termo inicial da contagem do prazo deve coincidir com o momento em que é possível efetuar a inscrição da informação nos bancos de dados de proteção ao crédito: um dia após o vencimento da dívida. $\mathrm{O}$ critério é objetivo, pois não deve ficar submetido à vontade do banco de dados ou do fornecedor, sob pena de esvaziar, por completo, o propósito legal de impedir consequências negativas, como a denegação do crédito, em decorrência de dívidas consideradas - legalmente - antigas e irrelevantes. Assim, vencida a obrigação e não havendo pagamento, inicia-se a respectiva contagem do prazo de cinco anos, independentemente da efetiva inscrição nos arquivos de consumo". Bruno Miragem (Direito do consumidor. São Paulo: RT, 2008, p. 212/213), por sua vez, entende “(...) que o prazo de cinco anos deve dizer respeito à causa que justifica e fundamenta eventual inclusão do consumidor no banco de dados. Nesse sentido, a causa da inclusão é a ocorrência do evento a que a informação faz referência, que no caso é a inadimplência do consumidor. Até porque, ao se entender que o prazo devesse contar desde a data do registro, se estaria deixando ao arbítrio do fornecedor-credor a possibilidade de controlar o período da contagem, inclusive com a postergação ad aeternum da inclusão como espécie de ameaça ao consumidor. Esta manipulação do prazo, de sua vez, é flagrantemente contrária à lógica de limitação temporal da restrição ao crédito determinada pelo CDC, ao reconhecer a possibilidade de inclusão em banco de dados, assim como viria em contrário aos próprios princípios que limitam no âmbito de todo o direito, o tempo para o exercício do direito, em homenagem à segurança jurídica, fundada na máxima do direito romano dormientibus non sucurrit ('o direito não socorre aos que dormem'). Assim, há de se considerar como termo inicial do prazo de cinco anos estabelecido no artigo 43, $\S 1^{\circ}$, do CDC, o dia seguinte ao vencimento da dívida, tempo em que ela se torna exigível e, ocorrendo a violação do direito de crédito do fornecedor, nasce para ele a pretensão de cobrança (artigo 189 do CC)".

364 Banco de dados e habeas data no código do consumidor. Revista de Direito do Consumidor, São Paulo: RT, v. 1, mar. 1992, p. 74.

365 “(...) nenhuma informação negativa pode ter idade superior a cinco anos. É o lapso que o Código considera razoável para que uma conduta irregular do consumidor seja esquecida pelo mercado. Se até os crimes mais graves prescrevem, não há razão para que o consumidor fique com sua 'folha de antecedentes de consumo' maculada ad eternum. Note-se que o prazo de cinco anos é contado não da inserção da informação no cadastro, mas da data do fato que deu origem ao dado depreciador (4 ${ }^{\text {a }}$ ed. São Paulo: Forense Universitária, 1996, p. 276/277, n. 11 ao art. 43). 
refere ao quinquênio, sua computação toma por base a data da ocorrência que deu origem ao dado depreciador (= fato gerador), não tendo qualquer relevância o momento em que a informação é arquivada; ou, dito de outra forma, o lapso 'começa a fluir após o vencimento da obrigação, sendo indiferente o prazo de comunicação do SPC ou registro nele lançado",. 366

E explica na sua nota de rodapé $\mathrm{n}^{0}$ 466: “em edições anteriores defendi posição diversa, pensando melhor, resolvi modificar. Ao vedar a inclusão de 'informações negativas referentes a período superior a cinco anos', o CDC, que deve ser sempre interpretado de forma mais favorável ao consumidor, já que lei de ordem pública (art. $1^{\circ}$ ), deixou de indicar o termo inicial do período de cinco anos. Duas possibilidades são abertas: a) o termo a quo é aquele do momento em que a informação é incorporada ao banco de dados; b) o termo a quo é o do fato gerador que deu origem à informação, afinal arquivada. Ora, a interpretação sistemática do CDC nos leva à conclusão de que o legislador quis, em verdade, fixar um teto - máximo e genérico - para a vida útil da informação arquivada ou arquivavél em bancos de dados de consumo. Se assim é, só pode ser ele contado a partir do fato gerador material da informação (=a obrigação) e não do fato gerador formal da informação (= o registro)".

No entanto, seguindo precedentes que entenderam que "as informações restritivas de crédito devem cessar após o quinto ano do registro" ${ }^{\text {"367 }}$, com isso a dar prevalência à data da negativação no banco de dados e/ou da abertura do cadastro, o STJ editou sua Súm. $323^{368}$, que passou longe de pacificar a quaestio.

\footnotetext{
${ }^{366}$ Et alii. Código Brasileiro de Defesa do Consumidor..., $10^{\mathrm{a}}$ ed., cit., p. 471.

367 STJ, REsp. 676.678/RS, j. 18.11.2004; REsp. 648.528/RS, j. 16.09.2004; REsp. 472.203/RS, j. 23.06.2004; REsp. 631.451/RS, j. 26.08.2004; REsp. 615.639/RS, j. 28.06.2004.

${ }^{368}$ STJ, Súm. 323: "a inscrição de inadimplente pode ser mantida nos serviços de proteção ao crédito por, no máximo, cinco anos".
} 


\section{HARMONIA E EQUILÍBRIO}

Observe-se, prima facie, que a relação de consumo deve ser harmônica e justa, a fim de que o vínculo entre o fornecedor e o consumidor seja constituído de maneira tal que se estabeleça o equilíbrio econômico da equação financeira e das obrigações jurídicas pactuadas ou contraídas pelos interessados. Esse equilíbrio econômico e jurídico é princípio informativo da relação de consumo que possui por fundamento a justiça distributiva, harmonizando-se os interesses legítimos das partes. ${ }^{369}$

Assim, o objetivo da Política Nacional das Relações de Consumo é a harmonização dos interesses envolvidos e não o confronto ou o acirramento de ânimos. Interessa às partes (consumidores e fornecedores) o implemento das relações de consumo como um todo, atendidas as necessidades do destinatário final sem prejuízo de estar o mercado abastecido de bens e de serviços ${ }^{370}$. Não se trata, portanto, de uma cruzada anti-empresa, mas, ao contrário, de uma forma de aperfeiçoamento do sistema empresarial, inclusive com a finalidade de dotá-lo de maior competitividade e eficiência. ${ }^{371}$

Ou, em outras palavras, a tensão entre a liberdade econômica e a igualdade social há de ser resolvida pela exigência de qualidade, de produtividade, de melhor preço (concorrência plena), de transparência e de responsabilidade no exercício dos negócios. $^{372}$

Quadra ressaltar, in casu, que o ponto de partida é o reconhecimento da desigualdade nas relações de consumo. ${ }^{373}$

\footnotetext{
${ }^{369}$ Roberto Senise Lisboa. Responsabilidade civil..., cit., p. 108.

${ }^{370}$ João Batista de Almeida. A proteção jurídica..., cit., p. 17.

${ }^{371}$ Fabio Nusdeo et alii. Comentários..., cit., p. 28.

${ }^{372}$ Luiz Amaral. O código..., cit., p. 74.

${ }^{373}$ Para José Geraldo Brito Filomeno (Et alii. Código Brasileiro de Defesa do Consumidor..., cit., p. 48/49), "a filosofia imprimida pelo Código do consumidor, como já asseverado, aponta no sentido de uma busca da harmonia das relações de consumo, harmonia essa não apenas fundada no tratamento das partes envolvidas, como também na adoção de parâmetros até de ordem prática. Assim é que, se é certo que o consumidor é a parte vulnerável nas sobreditas relações de consumo, não se compreendem exageros nessa perspectiva a ponto, por exemplo, de obstar-se o progresso tecnológico e econômico. O chamado 'interesse difuso' é por si só e intrinsecamente conflituoso, devendo sempre buscar-se o equilíbrio, baseado na natureza das coisas e no bom senso. (...) Referida harmonização tem como caminhos dois grandes instrumentos: a) o 'marketing' de defesa do consumidor, consubstanciado pelas já centenas de departamentos de atendimento do consumidor criados pelas próprias empresas e diversificadas técnicas de abordagem, como a possibilidade de contato telefônico ou postal, por exemplo; b) a 'convenção coletiva de consumo', assim definidos os pactos estabelecidos entre as 'entidades civis de consumidores' e 'as associações de fornecedores ou sindicatos de categoria econômica' de molde a regularem relações de consumo que tenham por objeto estabelecer condições relativas ao preço, à qualidade, à garantia e características de produtos e serviços, bem como à reclamação e composição de conflito de consumo (art. 107 do Código do Consumidor)".
} 
De um lado, situa-se o fornecedor de bens e serviços, geralmente uma empresa, estruturada não apenas para atender a uma finalidade precípua, como também apta a prover o resguardo dos seus interesses comerciais por via de recursos diversos, desde o poder de barganha até departamentos jurídicos especializados. De outro, tem-se o consumidor, em regra uma pessoa física isolada, desconhecedora dos seus próprios direitos ou impossibilitada de acioná-los, impotente diante da lesão aos seus interesses legítimos, confrontada com a necessidade de consumir bens ou serviços imprescindíveis à manutenção da sua própria existência e dignidade. ${ }^{374}$

José Geraldo Brito Filomeno, neste passo, identifica um novo caminho para o marketing: a defesa do consumidor. Entretanto, não basta investir em publicidade, é preciso orientar internamente as pessoas de uma empresa para aprenderem a respeitar e tratar bem aquele que lhes paga o salário: o consumidor. ${ }^{375}$

E prossegue o ex-Procurador Geral da Justiça de São Paulo discorrendo sobre os departamentos ou sistemas de atendimento aos consumidores: “(...) em verdade, demonstram ter duas mãos: ao mesmo tempo em que recolhem reclamações/queixas contra determinados produtos ou serviços, igualmente captam valiosas sugestões dos consumidores para que as empresas possam ainda melhor servirlhes, certamente maneira inteligente para o desenvolvimento e progresso das próprias atividades empresariais". 376

No que concerne à harmonia e ao equilíbrio, há de não se perder de vista os postulados constitucionais da justiça, da solidariedade e da isonomia, pois, na lição de Teresa Ancona Lopez, o princípio do equilíbrio "encontra sua razão de ser na justiça contratual, e apresenta-se antagônico ao princípio clássico da obrigatoriedade dos contratos - pacta sunt servanda - que é consequência imediata e lógica da autonomia da vontade. Portanto, limita, na busca do direito justo, os dois últimos". 377

\subsection{Transparência}

\footnotetext{
${ }^{374}$ Adalberto Pasqualotto. Conceitos fundamentais do Código de Defesa do Consumidor..., cit, p. 49.

${ }^{375}$ Et alii. Código Brasileiro de Defesa do Consumidor..., cit., p. 52.

${ }^{376}$ Idem. O mesmo autor arremata a quaestio em outra oportunidade (Manual..., cit., p. 51, item 5): “o marketing é meio de defesa do consumidor dos mais eficientes, ao mesmo tempo em que se reveste de forma do próprio marketing o processo comunicativo/informativo praticado modernamente pelas empresas, não só na satisfação do consumidor como também na própria qualidade dos bens e serviços pelas suas sugestões".

377 Princípios contratuais. In: Fernandes, Wanderlei (coord.). Fundamentos e princípios dos contratos empresariais. Série GVlaw. São Paulo: Saraiva, 2009, p. 25.
} 
Transparência é clareza qualitativa e quantitativa da

informação que incumbe às partes conceder reciprocamente na relação jurídica, contratual ou extracontratual (v.g., publicidade, vitrines, marketing, etc. $)^{378}$. É objetivo implícito em quase todos os dispositivos do CDC e supõe a boa-fé e a reta intenção dos fornecedores, dos anunciantes e dos financiadores. ${ }^{379}$

Para Luiz Antonio Rizzatto Nunes ela, “(...) se traduz na obrigação do fornecedor de dar ao consumidor a oportunidade de conhecer os produtos e serviços que são oferecidos e, também, gerará no contrato a obrigação de propiciar-lhe o conhecimento prévio de seu conteúdo". 380

Sem embargo desse caráter genérico (CDC, art. $4^{\circ}$, caput, e IV), e às vezes específico ${ }^{381}$, a transparência como efeito imediato do direito básico à correta informação (CDC, art. $6^{\circ}$, III) ganha relevo, sem sombra de dúvida, no âmbito da proteção contratual, com destaque para o art. 46 da Lei $8.078 / 90^{382}$, até porque constitui direito do consumidor apenas arcar com os custos do produto e do serviço que lhe são previamente informados (CDC, art. $39, \mathrm{VI})^{383}$ e efetivamente fornecidos. ${ }^{384}$

\footnotetext{
${ }^{378}$ Roberto Senise Lisboa. Responsabilidade civil..., cit., p. 101 e Cláudia Lima Marques, Contratos..., cit., p. $594 / 595$.

${ }^{379}$ Fabio Nusdeo et alii. Comentários..., cit., p. 26.

${ }^{380}$ Curso..., cit., p. 125.

${ }^{381}$ É que o art. 55 do CDC permite que "a União, os Estados, o Distrito Federal, em caráter concorrente e nas suas respectivas áreas de atuação administrativa, baixarão normas relativas à produção, industrialização, distribuição e consumo de produtos e serviços". Contudo, há de se ter em mente a sempre atual advertência de Rui Geraldo Camargo Viana (Rotulagem dos alimentos geneticamente modificados. Matéria federal. In: Marques, Cláudia Lima e Miragem, Bruno (org.). Doutrinas essenciais. Direito do consumidor. Teoria de qualidade e danos. São Paulo: RT, 2011, v. V., p. 265) quanto aos limites lógicos estabelecidos pela Constituição Federal nos seus arts. 22, VIII, e 24, V e VIII: “(...) o direito à informação, outorgado ao consumidor por meio de lei federal, não tem o condão de infirmar a distribuição constitucional de competências legislativas, que encontra o seu fundamento no princípio federativo. Ou seja, a lei editada com base na competência concorrente do Estado-membro limita-se à sua circunscrição territorial, pois deverá atender, necessária e exclusivamente, às suas peculiaridades, sendo inconstitucional qualquer norma legal ou infralegal que irradie efeitos fora desse limite".

${ }^{382} \mathrm{CDC}$, art. 46: "os contratos que regulam as relações de consumo não obrigarão os consumidores se não lhes for dada oportunidade de tomar conhecimento prévio de seu conteúdo, ou se os respectivos instrumentos forem redigidos de modo a dificultar a compreensão de seu sentido e alcance". Para Newton de Lucca (A proteção..., cit., p. 78), “(...) estamos diante de uma figura de contrato singular que se caracteriza pela sua não vinculação entre as partes. Um contrato que não gera efeitos é um contrato ineficaz e contrato ineficaz não deixa de ser uma contradição nos seus termos".

${ }^{383}$ Constitui prática abusiva típica a execução de "serviços sem a prévia elaboração de orçamento e autorização expressa do consumidor, ressalvadas as decorrentes de práticas anteriores entre as partes" (CDC, art. 39, VI); no entanto, em alguns casos, como no de tratamento médico de emergência, já se entendeu ser dispensável o orçamento prévio (TJDFT, AC 20060110708575, rel. Sandoval Oliveira, j. 11.03.2009).

384 TJRJ, AC 9258/2009, rel. Ricardo Couto de Castro, j. 01.04.2009.
} 
A grande maioria dos contratos (paritários ou de adesão) hoje firmados no Brasil é redigida unilateralmente pela parte economicamente mais forte e, por isso, além da necessária clareza intrínseca (CDC, art. 54, $\S \S 3^{\circ}$ e $4^{0385}$ ), o Código relegou ao fornecedor um dever especial quando da elaboração desses instrumentos, dificultando a exploração da vulnerabilidade do consumidor. ${ }^{386}$

Invoca-se, aqui, o magistério preciso de Nelson Nery Júnior:

“O fornecedor deverá ter a cautela de oferecer oportunidade ao consumidor para que, antes de concluir o contrato de consumo, tome conhecimento do conteúdo do contrato, com todas as implicações consequenciais daquela contratação no que respeita aos deveres e direitos de ambos os contratantes, bem como das sanções por eventual inadimplemento de alguma prestação a ser assumida pelo contrato. Não sendo dada essa oportunidade ao consumidor, as prestações por ele assumidas no contrato, sejam prestações que envolvam obrigação de dar como de fazer ou não fazer, não o obrigarão.

Dar oportunidade de tomar conhecimento do conteúdo do contrato não significa dizer para o consumidor ler as cláusulas do contrato de comum acordo ou as cláusulas contratuais gerais do futuro contrato de adesão. Significa, isto sim, fazer com que tome conhecimento efetivo do conteúdo do contrato. Não satisfaz a regra do artigo sob análise a mera cognoscibilidade das bases do contrato, pois o sentido teleológico e finalístico da norma indica dever o fornecedor dar efetivo conhecimento ao consumidor de todos os direitos e deveres que decorrerão do contrato, especialmente sobre as cláusulas restritivas de direitos do consumidor, que, aliás, deverão vir em destaque nos formulários de contrato de adesão (art. 54, § $\left.4^{\circ}, \mathrm{CDC}\right) .{ }^{, 387}$

Muito mais que um simples elemento formal, a transparência afeta diretamente o conteúdo do contrato ${ }^{388}$, pois as informações prestadas o integram ${ }^{389}$ e,

\footnotetext{
385 CDC, art. 54: “contrato de adesão é aquele cujas cláusulas tenham sido aprovadas pela autoridade competente ou estabelecidas unilateralmente pelo fornecedor de produtos ou serviços, sem que o consumidor possa discutir ou modificar seu conteúdo". (...) $\S 3^{\circ}$ : "os contratos de adesão escritos serão redigidos em termos claros e com caracteres ostensivos e legíveis, de modo a facilitar sua compreensão pelo consumidor". $\S 4^{\circ}$ : "as cláusulas que implicarem limitação de direito do consumidor deverão ser redigidas com destaque, permitindo sua imediata e fácil compreensão".

${ }^{386}$ Cláudia Lima Marques. Contratos..., cit., p. 667.

${ }^{387}$ Et alii. Código Brasileiro de Defesa do Consumidor..., cit., p. 323/324.

388 "Fundamento do Juízo a quo de que houve agravamento do risco pela embriaguez do condutor do veículo no momento do acidente. Cláusula limitativa de Direito do Consumidor. Ausência de destaque. Inteligência
} 
em regra, o vinculam (infra, Cap. V, 2.1), mesmo se fornecidas por prepostos (CDC, art. $\left.34^{390}\right){ }^{391}$

É essa a sistemática introduzida pela Lei 8.078/90 (arts. $30^{392}$

c.c. $\left.35, \mathrm{I}^{393}\right)$.

Segundo a emérita professora Cláudia Lima Marques:

“(...) o ideal de transparência no mercado acaba por inverter os papéis tradicionais, aquele que se encontrava na posição ativa e menos confortável (caveat emptor), aquele que necessitava atuar, informar-se, perguntar, conseguir conhecimentos técnicos ou informações suficientes para realizar um bom negócio, o consumidor, passou a confortável posição de detentor de um direito subjetivo de informação (art. $6^{\circ}$, III), enquanto aquele que se encontrava na segura posição passiva, o fornecedor, passou a ser sujeito de um novo dever de informação (caveat vendictor), dever de conduta ativa (informar), o que significa, na prática, uma inversão de papéis (arts. 46, 51, IV e 54), e um início de inversão ex vi lege de ônus da prova.

Se esta inversão de papéis ocasionada pelo ideal de transparência e lealdade imposto pelo CDC pode ser considerada renovadora, o sentido e o fim (Sinn und Zweck) do mandamento, como denominam os alemães a ratio legis, pode ser reduzida à tradicional procura da 'verdadeira e livre vontade do consumidor'. Visto deste ângulo, o ideal de transparência seria apenas uma nova (e sem dúvida importante) pré-condição para que o consumidor possa se manifestar sem medo e livremente sua vontade, e realizar (ao fim) as suas expectativas legítimas, aquelas que o levaram a - informado devidamente sobre o

do art. $54, \S 4^{\mathrm{o}}$, do CDC. Irrelevante o estado de embriaguez do motorista do veículo segurado. Necessidade de prova cabal de dolo ou culpa por parte do segurado. Recurso provido" (TJPR, AC 573.960-4, rel. Denise Krüger Pereira, j. 03.09.2009”.

389 Cláudia Lima Marques. Contratos..., cit., p. 598.

${ }^{390}$ CDC, art. 34: "o fornecedor do produto ou serviço é solidariamente responsável pelos atos de seus prepostos ou representantes autônomos".

391 "Sob a égide do Código de Defesa do Consumidor, as informações prestadas por corretor a respeito de contrato de seguro-saúde (ou plano de saúde) integram o contrato que vier a ser celebrado e podem der comprovadas por todos os meios probatórios admitidos" (STJ, REsp. 531.281/SP, rel. Min. Nancy Andrighi, j. 10.08.2004).

392 CDC, art. 30: "toda informação ou publicidade, suficientemente precisa, veiculada por qualquer forma ou meio de comunicação com relação a produtos e serviços oferecidos ou apresentados, obriga o fornecedor que a fizer veicular ou dela se utilizar e integra o contrato que vier a ser celebrado".

393 CDC, art. 35: "se o fornecedor de produtos ou serviços recusar cumprimento à oferta, apresentação ou publicidade, o consumidor poderá, alternativamente e à sua livre escolha: I - exigir o cumprimento forçado da obrigação, nos termos da oferta, apresentação ou publicidade”. 
produto ou serviço, ciente de seus futuros direitos e deveres contratuais - escolher aquele fornecedor como seu parceiro contratual."394

Deve se ter em mente, ainda, neste ponto, como destaca Antonio Junqueira de Azevedo ${ }^{395}$, que "o dever de informar tem graus; conforme a situação, há simples dever de esclarecer ou, mais fortemente, o de aconselhar ou, até mesmo, se houver riscos, o de advertir" ${ }^{396}$, e do fornecedor, titular absoluto do processo produtivo, ao optar livremente pela exploração econômica do mercado (infra, Cap. VI, 1), se exige o cumprimento desses três graus.

\subsection{Confiança}

Leciona a professora Cláudia Lima Marques que "a manifestação de vontade do consumidor é dada almejando alcançar determinados fins, determinados interesses legítimos. A ação dos fornecedores, a publicidade, a oferta, o contrato firmado criam no consumidor expectativas, também, legítimas de poder alcançar estes efeitos contratuais. (...) No sistema do CDC leis imperativas irão proteger a confiança que o consumidor depositou no vínculo contratual, mais especificamente na prestação contratual, na sua adequação ao fim que razoavelmente dela se espera, irão proteger também a confiança que o consumidor deposita na segurança do produto ou do serviço colocado no mercado."397

Dessa confiança inerente às relações de consumo, decorrência direta da boa-fé objetiva (infra, Cap. IV) mesmo na esfera extracontratual, decorrem três deveres anexos fundamentais: o de informar, o de cooperar e o de cuidado (segurança). O primeiro, afora a disciplina constitucional aplicável à espécie, guarda estreita ressonância com o que foi dirigido à transparência (supra, 4.1).

Conquanto não expresso, o dever de cooperar pode ser inferido da sistemática protetiva, v.g., pela dicção do art. $51, \S 1^{\circ}$, do Código ${ }^{398}$. Sua força

\footnotetext{
${ }^{394}$ Cláudia Lima Marques. Contratos..., cit., p. 596/598.

${ }^{395}$ Estudos e pareceres de direito privado. São Paulo: Saraiva, 2004, p. 179.

${ }^{396}$ TJRS, AC 70030952246, rel. Tasso Caubi Soares Delabary, j. 09.12.2009.

${ }^{397}$ Contratos..., cit., p. 979.

${ }^{398} \mathrm{CDC}$, art. 51, § $1^{\text {o: }}$ "presume-se exagerada, ente outros casos, a vantagem que: I - ofende os princípios fundamentais do sistema jurídico a que pertence; II - restringe direitos ou obrigações fundamentais inerentes à natureza do contrato, de tal modo a ameaçar seu objeto ou o equilíbrio contratual; III - se mostra excessivamente onerosa para o consumidor, considerando-se a natureza e conteúdo co contrato, o interesse das partes e outras circunstâncias peculiares ao caso".
} 
é tamanha que pode chegar até a impor uma renegociação das obrigações assumidas pelo consumidor. $^{399}$

Já o dever de cuidado (segurança) projeta-se em dois níveis medulares: o da pessoa do consumidor (v.g., saúde, dignidade, patrimônio, etc.) e o dos objetos da relação de consumo - o produto e o serviço - (v.g., materiais e métodos utilizados no fornecimento).

Apesar de anexos, ou secundários, esses deveres, enquanto contratuais, representam verdadeiras obrigações (acessórias) a indicar que a relação contratual obriga não somente ao cumprimento da obrigação principal (a prestação), mas também ao cumprimento das várias obrigações acessórias ou dos deveres anexos àquele tipo de contrato. ${ }^{400}$

Essa vinculação é tão forte que o STJ já firmou a responsabilidade do fornecedor decorrente da quebra da confiança do consumidor ${ }^{401}$. Segundo Nelson Nery Júnior:

“(...) grande é a responsabilidade dos produtores ou fornecedores no sentido de:

a) bem informar os seus consumidores sobre os riscos que apresentem seus produtos ou serviços, além, certamente, de suas características;

b) retirar do mercado os produtos que apresentem riscos constatados após seu lançamento, assim como comunicar às autoridades competentes tais circunstâncias;

c) preventivamente, ainda, estabelecer canais de comunicação com o público consumidor, quer para informações, quer para ouvir sugestões, quer para reparar danos já causados, e para que outros não ocorram, mediante mecanismos de solução conciliatória." 402

\footnotetext{
${ }^{399}$ CDC, arts. 39 c.c. 40 c.c. 51 c.c. 52 c.c. 53.

${ }^{400}$ Cláudia Lima Marques. Contratos..., cit., p. 185.

401 “O princípio da boa-fé se aplica às relações contratuais regidas pelo $\mathrm{CDC}$, impondo, por conseguinte, a obediência aos deveres anexos ao contrato, que são decorrência lógica deste princípio. O dever anexo de cooperação pressupõe ações recíprocas de lealdade dentro da relação contratual. A violação a qualquer dos deveres anexos implica o inadimplemento contratual de quem lhe tenha dado causa" (STJ, REsp. 595.631/SC, rel. Min. Nancy Andrighi, j. 08.06.2004).

${ }^{402}$ Et alii. Código Brasileiro de Defesa do Consumidor..., cit., p. 53.
} 
E a legítima expectativa de o direito ser regularmente exercido também integra a confiança depositada. ${ }^{403}$

Lembra Teresa Ancona Lopez, ao anuir à necessidade de se revalorizar a pessoa como centro das preocupações do ordenamento jurídico, que, "a teoria da confiança, que tem como fundamento a boa-fé entre as partes, encontrou na cláusula geral do abuso do direito um abrigo seguro na defesa e efetivação dessa relação de confiança. (...) Sem duvida, o abuso do direito como fruto da teoria da confiança tem como finalidade a proteção das pessoas que dele possam ser vítimas. As limitações do exercício do direito quando há abuso nesse exercício têm como foco as pessoas e suas relações intersubjetivas". 404

$\mathrm{Na}$ sequência serão examinados dois casos de autêntica limitação ao exercício de direitos subjetivos (infra, Cap. IV, 6.2) imposta pela teoria da confiança: o cheque pós-datado e a troca imotivada de mercadorias.

\subsubsection{Cheque pré-datado (pós-datado)}

Com efeito, o cheque pré-datado é prática normal incorporada à vida das pessoas, funcionando no comércio como método eficaz de captação de clientela, já que sugere (e promete) uma maior facilidade no pagamento do preço.

\footnotetext{
403 "Infringentes - Danos morais - Apontada inocorrência - Produto que embora vencido, não chegou a ser consumido - Inconsistência - Comerciante que responde pela segurança do produto que vende - A mera conduta se revela suficiente ao ensejo da reparação, independentemente de danos físicos - Prestigiado entendimento esposado no acórdão recorrido - Embargos rejeitados" (TJSP, EI 522.084.4/5-01, rel. Joaquim Garcia, j. 18.11.2009). "BEM MÓVEL - Indenização por danos morais - Compra e venda de produto alimentício - Prazo de validade expirado - Responsabilidade pelo produto vendido - Conduta negligente que, por si só, gera o dever de indenizar - Reparação que se impõe, aliás, como medida de caráter pedagógico-punitivo, para evitar reincidência - Indenização devida - Fixação - Proporcionalidade e razoabilidade - Observância - Ação parcialmente procedente - Recurso provido" (TJSP, AC 992.08.0283399, rel. Melo Bueno, j. 20.09.2010). "Hipótese em que o filho da demandante, ao mastigar uma bolacha presente em pacote recém-adquirido para consumo conjunto, encontrou um parafuso tipo estrela incrustado em uma das unidades. Responsabilidade civil. Irrelevância do fato de o menor ter ou não ingerido o produto. Dano moral in re ipsa" (TJRS, AC 70023003627, rel. Íris Helena Medeiros Nogueira, j. 30.04.2008). "RESPONSABILIDADE CIVIL - DANOS MORAIS - Demanda que busca reparação por danos advindos da aquisição de 'pão de pizza' fabricado pela ré e por ela comercializado impróprio para o consumo (presença de vermes) - Co-autora que chegou a introduzir o produto em sua boca, mas ao notar algo estranho, expeliu-o, sem chegar a ingerir - Conjunto probatório que confirma a versão narrada pelos autores - Dano moral caracterizado pela quase ingestão e pelo sentimento de repugnância e nojo experimentados pela co-autora - Relação de consumo - Responsabilidade objetiva - Nexo de causalidade e danos comprovados - Sentença mantida - Recurso improvido" (TJSP, AC 559.635-4/7, rel. Salles Rossi, j. 12.11.2008).
} 
Representa, em verdade, um financiamento direto do lojista (ou credor) ao consumidor, encontrando previsão no direito positivo (Lei 7.357/85, art. 32, par. ún. ${ }^{405}$ ) que permite seja o cheque sacado em data diversa daquela constante na cártula.

Anote-se a ponderação do professor Luiz Antonio Rizzatto

Nunes:

"Ora, se a própria lei prevê que o cheque pode ser apresentado antes da data de emissão, significa logicamente que ela sabe que o cheque foi emitido para data posterior. A questão é de lógica básica.

Portanto, a interpretação do artigo 32 com seu parágrafo único, nos diz que não só o cheque pré-datado pode ser admitido, como se for apresentado ao banco antes, ele vale, só que neste caso a data da apresentação passa a ser considerada como se a data da emissão fosse." ${ }^{.406}$

Ganha relevo, nesta quadra, precisar a consequência jurídica para a quebra da confiança daquele (consumidor) que acreditou, tal qual prometido e aceito pelo fornecedor, fosse o cheque levado a pagamento tão-só na data futura convencionada.

Assume o cheque pré-datado, pois, uma natureza contratual e, por isso, sujeita ao inadimplemento de ambas as partes.

Está se desenvolvendo a orientação de que o comerciante, ao aceitar pagamento com cheque pré-datado, assume obrigação de não fazer, consistente em abster-se de apresentar o título ao sacado antes da data avençada com o consumidor. De modo que, se descumprida, haveria o dever de indenizar o emitente. ${ }^{407}$

Nessa linha de raciocínio vem se posicionando o STJ. ${ }^{408}$

Isso ocorre porque, na lição de Luiz Antonio Rizzatto Nunes:

“(...) o pagamento com cheque pré, normalmente é, do ponto de vista jurídico, um contrato verbal onde o comprador, adquirindo um produto ou

\footnotetext{
${ }^{404}$ Exercício do direito e suas limitações: abuso do direito. In: Nery, Rosa Maria de Andrade e Donnini, Rogério (coord). Responsabilidade civil. Estudos em homenagem ao professor Rui Geraldo Camargo Viana. São Paulo: RT, 2009, p. 551/552.

${ }^{405}$ Lei 7.357/85, art. 32: “o cheque é pagável à vista. Considera-se não escrita qualquer menção em contrário". Par. ún.: "o cheque apresentado para pagamento antes do dia indicado como data de emissão é pagável no dia da apresentação”.

${ }^{406} \mathrm{O}$ cheque pré-datado e o direito do consumidor. Lex - Jurisprudência dos Tribunais de Alçada Civil de São Paulo, São Paulo: Lex Editora, 1999, ano 33, v. 176, p. 9.

${ }^{407}$ Fábio Ulhoa Coelho. Código Comercial e legislação complementar anotados. $3^{\mathrm{a}}$ ed. São Paulo: Saraiva, 1997, p. 538.
} 
serviço, paga o preço com um ou mais títulos (cheques), sendo certo que o vendedor se compromete a somente resgatar o título (isto é, apresentar o cheque pré ao banco) nas datas acertadas entre ele e o comprador. Tudo verbal, mas tudo rigorosamente legal (por vezes, acompanhado de recibo ou pedido discriminando os cheques e/ou nota fiscal, fazendo o mesmo).

\section{$(\ldots)$}

Como a oferta é parte integrante do contrato por força expressa de lei, isto é, pelo estabelecido no artigo 30 do $\mathrm{CDC}$, e como tanto o preço quanto a forma de pagamento são parte da oferta do vendedor, eles integram o negócio realizado. Daí conclui-se que, se o vendedor oferece ao comprador como forma de pagamento a entrega de cheque que ele (vendedor) só vai levar ao banco em determinado dia futuro, isso é verdadeira cláusula contratual, que não pode ser por ele (vendedor) quebrada, sem que seja responsabilizado pelo rompimento."409

Com o saque de cheque pré-datado ocorre mera ampliação real do prazo de apresentação ${ }^{410}$, que vincula em concreto o fornecedor, seja porque expressamente ofertou essa forma de pagamento (CDC, art. 30), seja porque simplesmente a aceitou; logo, se quebrar a legítima confiança que lhe foi depositada pelo consumidor (autêntica ruptura do contrato), responderá objetivamente pela violação.

\subsubsection{Troca imotivada de mercadorias}

Eis outra prática usual e corriqueira no mercado de consumo, tanto para as trocas imotivadas quanto para as motivadas e, por isso, trata-se de mais uma decorrência direta do princípio da confiança que rege toda a relação entre fornecedor e consumidor, o que acaba determinando, em ambas as hipóteses, observância obrigatória.

De fato, a simples troca imotivada (sem vício ou defeito) é praxe consagrada e, por isso, pode o consumidor que adquire uma mercadoria (v.g., roupas, calçados, jóias etc.), sem qualquer motivo, após decorrido um pequeno lapso de tempo

\footnotetext{
408 “A devolução de cheque pré-datado, por insuficiência de fundos, apresentado antes da data ajustada entre as partes, constitui fato capaz de gerar prejuízos de ordem moral" (STJ, REsp. 213.940/RJ, rel. Min. Eduardo Ribeiro, j. 29.06.2000).

${ }^{409} \mathrm{O}$ cheque..., idem.

${ }^{410}$ STJ, REsps nos 195.748/PR, j. 15.06.1999; 223.486/MG, j. 08.02.2000 e 237.376/RJ, j. 24.05.2000.
} 
(depende de valoração concreta), simplesmente procurar o comerciante e lhe solicitar a troca. O comércio em geral utiliza essa prática como um plus em suas vendas, pois o consumidor, ao efetuar uma troca, pode, eventualmente, adquirir outros produtos. ${ }^{411}$

Interessa saber que o fornecedor, dentro da normalidade das coisas, mas sempre partindo da boa-fé do consumidor, não pode recusar a troca. É mais um risco inerente à liberdade de empreender e de explorar o mercado. Com muito mais razão se se tratar de presente, algo que o consumidor recebeu de terceiro (v.g., aniversário) e, assim, sequer teve oportunidade de escolher, de experimentar, etc.

Nos Estados Unidos da América, berço do capitalismo, a política de respeito à confiança depositada pelo consumidor é tão intensa que chega a prestigiar não só a troca de mercadorias, mas também a própria devolução - total ou parcial - do dinheiro.

É comum o fornecedor reduzir os preços por força de uma superveniente promoção; contudo, sabedores que o consumidor respeitado sempre volta, dentro de um lapso variável de tempo ${ }^{412}$ (até 30 dias inclusive) e sem nenhuma burocracia (apenas o original do recibo de compra é exigido), os americanos devolvem a diferença entre o que foi pago e o atual custo do produto adquirido, mesmo aberto e/ou usado.

Trata-se do que se conhece como price adjustment.

No que respeita à troca motivada (vício aparente ou oculto), dúvidas não há. A matéria integra a garantia legal de adequação.

\subsection{Prescrição e decadência}

Transcreve-se, aqui, a distinção proposta pelo douto Min. Ruy Rosado de Aguiar, no sentido de que, "a diferença entre uma e outra dessas figuras (arts. 26 e 27), para o que nos interessa, deve ser feita a partir da distinção entre Direito subjetivo propriamente dito (Direito formado, fundamental ou bastante em si), que contém poderes sobre bens da vida, permite ao seu titular dispor sobre eles, de acordo com a sua vontade e nos limites da lei, e está armado de pretensão dirigida contra quem se encontra no pólo passivo da relação (devedor), para que efetue a prestação a que está obrigado (ex.:

\footnotetext{
411 Mário Cerveira Filho. Mercadorias: trocá-las ou não? Artigos de doutrina. Saraiva, disponível em www.saraivajur.com.br.
} 
direito de propriedade, direito de crédito), e direito formativo (dito de configuração ou potestativo), que atribui ao seu titular, por ato unilateral, formar relação jurídica concreta, a cuja atividade a outra parte simplesmente se sujeita. Esse direito formativo é desarmado de pretensão, pois o seu titular não exige da contraparte que venha efetuar alguma prestação decorrente exclusivamente do direito formativo; apenas exerce diante dela o seu direito de configurar uma relação. $\mathrm{O}$ efeito do tempo sobre os direitos armados de pretensão atinge a pretensão, encobrindo-a, e a isso se chama de prescrição. Os direitos formativos, porque não têm pretensão, são afetados diretamente pelo tempo e extinguem-se: é a decadência". 413

Acompanha-o Zelmo Denari, para quem, "a decadência significa a extinção do direito subjetivo que não chega a se constituir, pela inatividade de seu titular, enquanto que a prescrição significa, pelas mesmas razões, a extinção do direito subjetivo plenamente constituído". 414

Colorido diverso, como se percebe, foi outorgado à clássica diferença dos institutos fundada nos efeitos do decurso do tempo: a decadência extingue o direito e a prescrição a ação. Ganha força, por sua vez, o critério científico de Agnelo Amorim Filho (supra, 3.2.2.3).

Fixados esses conceitos preliminares, passa-se à análise da relevante matéria pertinente à temática sub examine.

\subsubsection{Garantia}

A garantia legal de adequação do produto ou do serviço independe de termo expresso, vedada a exoneração contratual do fornecedor (CDC, art. 24), bem como a estipulação de cláusula que impossibilite, exonere ou atenue a obrigação de reparar em decorrência dos defeitos e/ou dos vícios encontrados (CDC, art. 25, caput). ${ }^{415}$

\footnotetext{
${ }^{412}$ Dados disponíveis no site http://abclocal.go.com/kgo/story?section=news/7_on_your_side\&id=4381488, acesso em 24.10.2010.

${ }^{413}$ Aspectos do Código de Defesa do Consumidor. Revista Ajuris, Porto Alegre: Ajuris, v. 52, 1991, p. $183 / 184$.

${ }^{414}$ Et alii. Código Brasileiro de Defesa do Consumidor..., cit., p. 148.

${ }^{415} \mathrm{CDC}$, art. 51: "são nulas de pleno direito, entre outras, as cláusulas contratuais relativas ao fornecimento de produtos e serviços que: I - impossibilitem, exonerem ou atenuem a responsabilidade do fornecedor por vícios de qualquer natureza dos produtos e serviços ou impliquem renúncia ou disposição de direitos".
} 
Trata-se do sistema legal da garantia de adequação, o que significa qualidade para o atingimento do fim a que se destina o produto ou o serviço, segurança para não causar danos ao consumidor, durabilidade e desempenho. ${ }^{416}$

No sistema do CDC a garantia de adequação é mais do que a dos vícios redibitórios ${ }^{417}$, ela é implícita ao objeto do contrato, à prestação principal (produto ou serviço), assegurando sua funcionabilidade, ou seja, que atingirá tanto o fornecedor direto quanto outros fornecedores da cadeia de produção. Quanto ao produto, o acompanhará durante sua vida útil, mesmo se transmitido a sucessivos consumidores. Essa garantia não pode ser condicionada ou restringida. ${ }^{418}$

Realidade essa que implica a sua incidência também sobre os produtos usados, o qual não sofre distinção ou restrição pelo CDC. Entretanto, a garantia legal há de ser verificada em face das reais especificidades do objeto adquirido, assim como das condições da oferta dirigida. ${ }^{419}$

\subsubsection{Prazos de decadência}

Definidos os produtos e os serviços em razão de suas vidas úteis (supra, Cap. II, 4.1 e 4.2), revela-se simples a fórmula legal ${ }^{420}$; porém, a essa disciplina se deve dar aplicação restrita. ${ }^{421}$

\footnotetext{
${ }^{416}$ Luiz Antonio Rizzatto Nunes. Comentários..., cit., p. 342.

417 Ensina José Fernando Simão (Vícios do produto no novo Código Civil e no Código de Defesa do Consumidor. Responsabilidade civil. São Paulo: Atlas, 2003, p. 188, i. 22 e 33): "a questão do vício aparente do bem no Código Civil é resolvida pela presunção segundo a qual o adquirente que, constatando o vício aparente, recebe o bem, só o faz porque quis receber o bem defeituoso. Se depois viesse reclamar, estaria agindo contra a boa-fé objetiva, em nítido venire contra factum proprium; nas relações de consumo, a questão do vício ser aparente ou oculto tem menor relevância, pois apenas altera o início do prazo para a propositura das demandas, mas, em ambos os casos, os direitos conferidos aos consumidores são os mesmos".

${ }^{418}$ Cláudia Lima Marques. Contratos..., cit., p. 1009/1012 e 1018.

${ }^{419}$ Luiz Antonio Rizzatto Nunes. Comentários..., cit., p. 346/349.

${ }^{420}$ CDC, art. 26: "o direito de reclamar pelos vícios aparentes ou de fácil constatação caduca em: I - 30 (trinta) dias, tratando-se de fornecimento de serviço e de produto não duráveis; II - 90 (noventa) dias, tratando-se de fornecimento de serviço e de produto duráveis. $\S 1^{\circ}$ Inicia-se a contagem do prazo decadencial a partir da entrega efetiva do produto ou do término da execução dos serviços. (...) $\S 3^{\circ}$ Tratando-se de vício oculto, o prazo decadencial inicia-se no momento em que ficar evidenciado o defeito".

421 "A questão aqui está circunscrita ao prazo para repetir o pagamento indevido de taxas e tarifas bancárias por serviço não prestado. É impossível, no entanto, enquadrar o pedido de repetição do indébito nas hipóteses arroladas nos arts. 20 e 26, CDC. Repetir o pagamento indevido não equivale, nem pode ser equiparado, à reexecução, à redibição e ao abatimento do preço, porque, na verdade, não se trata de má-prestação do serviço, mas de flagrante e inequívoco enriquecimento sem causa do recorrido, que cobrou por serviço jamais prestado. Nessa linha, os precedentes desta Corte impedem que a instituição financeira cobre valores indevidos, mesmo que tais quantias não tenham sido reclamadas pelos consumidores nos prazos decadenciais
} 
Não se perca de vista que os prazos são os mesmos para os vícios de fácil constatação (aparente) ou ocultos, fixando o legislador a diferença pela durabilidade, ou não, do produto ou do serviço.

Percebe-se que o termo inicial da contagem também é distinto (entrega efetiva do produto ou execução do serviço para um e quando ficar evidenciado o problema para o outro), mas prevalece a intenção comum, ou seja, quer a lei que o consumidor usufrua de um período no qual nenhum vício pode surgir e, para isso, é necessário um contato real e concreto com o produto ou com o serviço. A garantia legal pressupõe a sua concreta aferição da adequabilidade. ${ }^{422}$

Quanto ao vício oculto, a garantia legal não pode se eternizar. O início do prazo de decadência há de equilibrar-se com a durabilidade natural dos bens de consumo, ou seja, sua vida útil ${ }^{423}$, o que afasta a aplicação subsidiária automática (se prejudicial) - até porque quase sempre mais restritivos ao consumidor - dos prazos do art. $445, \S 1^{\text {o }}$, do Código Civil: 180 dias para bens móveis e 01 ano para imóveis ${ }^{424}$. Cabe ao Poder Judiciário avaliar, casuisticamente, se o fornecedor se desincumbiu a contento do dever de qualidade (durabilidade e adequação). ${ }^{425}$

\subsubsection{Vício: fácil constatação e oculto}

$A b$ initio, com indiscutível lucidez, assinala Luiz Antonio Rizzatto Nunes que o termo vícios aparentes, “(...) não é bom semanticamente falando. É que a palavra 'aparente' tem sentido de 'aparência', daquilo que não é real. E o vício, ao contrário, é bem real. O legislador quis aproveitar do vocábulo o sentido de aparecimento, do que aparece, mas ele não se presta a isso. Por isso, preferimos abandonar seu uso e ficar

do art. 26, CDC. Diante desta conclusão, de forma análoga, não se pode impedir a repetição do indébito tal como fez o Tribunal de origem" (STJ, REsp. 1.094.270/PR, rel. Min. Nancy Andrighi, j. 02.12.2008).

${ }^{422}$ Luiz Antonio Rizzatto Nunes. Comentários..., cit., p. 344.

${ }^{423}$ TJMG, AC 1.0145.07.390109-5/001, rel. Marcelo Rodrigues, j. 09.04.2008.

${ }^{424}$ Na palavras de Leonardo Roscoe Bessa (Vícios dos produtos: paralelo entre o CDC e o Código Civil. In: Pasqualotto, Adalberto e Pfeiffer, Roberto Augusto Castellanos (coord). Código de Defesa do Consumidor e $o$ Código Civil de 2002. Convergências e assimetrias. RT: São Paulo, 2005, p. 293), "o dispositivo possibilita que a garantia legal se estenda, conforme o caso, a três, quatro ou cinco anos. Isso é possível porque não há, de propósito, disposição indicando o prazo máximo para o aparecimento do vício oculto, a exemplo da disciplina do CC/2002 ( $§ 1^{\circ}$, art. 445). O critério para delimitação do prazo máximo de aparecimento do vício oculto passa a ser o da vida útil do bem, o que, além de conferir uma flexibilidade ao julgador, revela a importância de análise do caso concreto".

${ }^{425}$ Cláudia Lima Marques. Contratos..., cit., p. 1022. 
apenas com a outra expressão: 'de fácil constatação'. Essa sim diz respeito ao sentido desejado pela norma". 426

Pois bem. A constatação é fácil pelo singelo uso e consumo regular do produto e do serviço, enquanto o oculto, mesmo sem provocar impropriedade ou inadequação, não se mostra acessível. Escapa ao mero exame superficial, ou seja, não se visualiza de pronto.

Dependendo do vício, pode ficar mais ou menos clara a sua identificação. Dúvida existindo, competirá ao Poder Judiciário, atendendo ao princípio geral da vulnerabilidade do consumidor e ao caso concreto, determinar a correta qualificação. $^{427}$

\subsubsection{Garantias: legal x contratual}

Assevere-se, de plano, que a garantia contratual deriva da vontade do fornecedor direto ou indireto, conquanto facultativa (um plus ou anexo voluntário), é complementar à legal $\left(\mathrm{CDC}\right.$, art. $\left.50^{428}\right)$; logo, mister se faz definir o seu alcance, mormente em relação aos prazos estabelecidos.

Duas posições exsurgem bem definidas da doutrina, ambas plenamente sustentáveis dada a envergadura dos seus interlocutores. Para Cláudia Lima Marques a garantia legal se refere ao funcionamento do produto, à adequação do produto ou serviço, sendo portanto total; a garantia contratual, por sua vez, pode ser total ou parcial, pois depende da manifestação de vontade do fornecedor, que a restringe aos limites oferecidos quando da formação do contrato ou mesmo durante a sua execução. Assim, a garantia contratual pode não ser tão ampla quanto à legal, instituída pelo CDC, porém é mais fácil de ser utilizada pelo consumidor. ${ }^{429}$

"Como podemos observar, o regime da garantia contratual e da garantia legal são diversos. Na garantia contratual não se pergunta se o vício é

\footnotetext{
${ }^{426}$ Comentários..., cit., p. 345/346.

${ }^{427}$ Arruda Alvim et alii. Código do Consumidor comentado..., cit., p. 172.

${ }^{428}$ CDC, art. 50: "a garantia contratual é complementar à legal e será conferida mediante termo escrito". Par. ún.: "o termo de garantia ou equivalente deve ser padronizado e esclarecer, de maneira adequada, em que consiste a mesma garantia, bem como a forma, o prazo e o lugar em que pode ser exercitada e os ônus a cargo do consumidor, devendo ser-lhe entregue, devidamente preenchido pelo fornecedor, no ato do fornecimento, acompanhado de manual de instrução, de instalação e uso de produto em linguagem didática, com ilustrações".

${ }^{429}$ Contratos..., cit., p. 1018/1022.
} 
oriundo de mau uso, ou de culpa exclusiva do consumidor ou de terceiro, não se pergunta pela vida útil do bem. Se a garantia contratual existe, se a garantia prevista abrange aquele detalhe do produto e se não transcorreu o seu prazo, o fornecedor conserta ou substitui o produto e o devolve ao consumidor. Já a garantia legal é de adequação, de funcionalidade do produto ou serviço, só poderá ser usada se a causa da inadequação é o próprio produto ou serviço, não abrangendo os casos de mau uso ou de caso fortuito posterior ao contrato, que tornem o bem inadequado ao uso. $\mathrm{O}$ fornecedor tem o dever legal de entregar um produto em perfeitas condições, adequado para o seu uso, que resista ao uso normal, que dure o tempo ordinário da vida útil deste tipo de produtos.

Luiz Antonio Rizzatto Nunes, a seu turno, destaca que não se deve confundir prazo de reclamação com garantia legal de adequação. A disputa em torno de posições jurídicas nesse tema decorre da circunstância de a lei não ter fixado claramente um lapso para a garantia legal. O legislador se restringiu a estabelecer tempo de reclamação (30 e 90 dias) ${ }^{431}$. A garantia legal, portanto, é de adequação, mas sem prazo. O que o consumidor tem é tempo para apresentar reclamação contra essa garantia a partir do recebimento do produto ou do término do serviço. ${ }^{432}$

\subsubsection{Contagem dos prazos}

Aqui se contrapõem referidos doutrinadores, cada um a identificar momento próprio para o início da contagem dos prazos previstos no art. 26 do CDC. Segundo Cláudia Lima Marques, "hoje, a interpretação mais favorável ao consumidor é aquela da garantia legal implícita de adequação. Assim, se há garantia contratual (express warranty) e esta foi estipulada para vigorar a partir da data do contrato (termo de garantia), as garantias começam a correr juntas, pois a garantia legal nasce necessariamente com o contrato de consumo, com a entrega do produto, sua colocação no mercado de consumo. Ao consumidor é que cabe escolher qual delas fará uso. Pode usar a

\footnotetext{
${ }^{430}$ Cláudia Lima Marques. Contratos..., idem.

431 "O prazo decadencial de trinta ou noventa dias estabelecido ao consumidor diz respeito ao seu 'direito de reclamar' por vício no fornecimento de produto ou de serviço não durável ou durável (CDC, art. 26). Reclamar pressupõe a idéia de obter o afastamento do vício e, pois, a de concluir o contrato, a de obter o produto ou o serviço, sem o vício que o contamina" (TJSP, AC 992.05.009342-7, rel. S. Oscar Feltrin, 12.05.2010).

${ }^{432}$ Curso..., cit., p. 363.
} 
garantia contratual, porque lhe é mais vantajosa, no sentido de não ter de arguir que o vício já existia à época do fornecimento. Mas pode usar a garantia legal, porque, por exemplo, o vício se localiza no motor do produto (geladeira), que não está incluído na garantia contratual, ou porque o consumidor se interessa em redibir o contrato e adquirir outro produto de marca diferente. Logo, com a aplicação imperativa dos arts. 18 e 50 do CDC parece-nos superada a jurisprudência que afirmava começar a garantia legal só após o fim do prazo contratual. Era uma interpretação pró-consumidor, baseada na falta de legislação específica, que procurava, adaptar normas superadas à realidade moderna. As novas normas do CDC são, porém, imperativas, não havendo possibilidade do consumidor ou do fornecedor dispor sobre elas; os limites temporais são outros". 433

Diverge Luiz Antonio Rizzatto Nunes, para quem, se houver um termo aditivo, o prazo para reclamar continua o mesmo, mas o seu dies a quo é postergado para o final desse acréscimo de tempo, o que dá o sentido de complementar utilizado pelo CDC; assim, com o término da garantia contratual têm início os prazos legais para o consumidor apresentar sua reclamação.

"Se o fornecedor dá prazo de garantia contratual (até a próxima Copa, um ou dois anos etc.), dentro do tempo garantido até o fim (inclusive último dia) o produto não pode apresentar vício. Se apresentar, o consumidor tem o direito de reclamar, que se estende até 30 ou 90 dias após o término da garantia.

Se o fornecedor não dá prazo, então os 30 ou 90 dias correm do dia da aquisição ou término do serviço."434

Em que pesem às sólidas vigas que amparam as conclusões adotadas pela jurista da UFRGS, destacam-se duas: a) a garantia contratual pode ser total ou parcial e b) a garantia legal nasce necessariamente com o contrato de consumo, se discorda da fórmula de contagem proposta, inclusive por força da diretriz que vem trilhando, sobre o tema, embora sem anuir à soma de prazos, o intérprete soberano da legislação federal. ${ }^{435}$

${ }^{433}$ Contratos..., cit., p. idem. Com entendimento similar cf., Zelmo Denari et alii. Código Brasileiro de Defesa do Consumidor..., cit., p. 150/151.

${ }^{434}$ Curso..., cit., p. 363.

435 “'(...) a doutrina e a jurisprudência divergem quanto ao sentido dado à expressão 'complementar' utilizada pelo legislador, isto é, se, havendo a dilação do prazo da garantia legal, deve este ser incluído ou somado ao prazo da garantia contratual. Em verdade, a confusão decorre do fato da lei não ter fixado expressamente um prazo de garantia legal. $\mathrm{O}$ art. 24 do CDC limita-se a dispor que 'a garantia legal de adequação do produto 
E mais: a garantia de adequação prevista no comando do art.

24 da Lei 8.078/90 é irrestrita e incondicional; logo, está o fornecedor obrigado, em princípio independentemente de prazo (o oculto relaciona-se com a vida útil ${ }^{436}$ ), a assegurar que o produto vendido ou o serviço prestado atinja o fim determinante da aquisição, respeitadas a dignidade, a saúde e a segurança do consumidor (CDC, arts. $4^{\circ}$, caput, c.c. $6^{\circ}$, I, c.c. $\left.8^{\circ}\right)$.

Assim, mesmo que a livre iniciativa permita ao fornecedor conceder garantia parcial, facultando a definição da sua forma e do seu prazo (CDC, art. 50, par. ún.), jamais poderá atenuar a obrigação primitiva (CDC, arts. $4^{\circ}, \mathrm{II}, d$, c.c. 25 , caput, c.c. $51, \mathrm{I})$.

Consequentemente, força é inferir que a garantia legal de adequação nasce mesmo com a contratação, mas seu dies ad quem (se de fácil constatação) é deslocado no exclusivo interesse do fornecedor (v.g., captação de clientela), permitindo o exercício do direito de reclamar nos prazos estabelecidos (CDC, art. 26, I e II), mas a partir

ou serviço independe de termo expresso, vedada a exoneração contratual do fornecedor'. Como se vê, a garantia legal é de adequação e segurança, mas sem prazo. O que há é prazo para reclamar contra o descumprimento dessa garantia, o qual, em se tratando de vício de adequação, está previsto no art. 26 do CDC, sendo de 90 (noventa) ou 30 (trinta) dias, conforme seja produto ou serviço durável ou não. Em suma, não se deve confundir garantia de adequação e segurança com prazo de reclamação. Ocorre que, diferentemente do que acontece com a garantia legal contra vícios de adequação, cujos prazos de reclamação estão contidos no art. 26 do $\mathrm{CDC}$, a Lei não estabelece prazo de reclamação para a garantia contratual. Nessas condições, uma interpretação teleológica e sistemática do CDC permite integrar analogicamente a regra relativa à garantia contratual, estendendo-lhe os prazos de reclamação atinentes à garantia legal, inclusive para preservar a coerência com a estrutura de proteção idealizada pelo legislador. Incidindo sobre a garantia contratual os mesmos prazos de reclamação da garantia legal, mantém-se inalterado o fiel da balança que pondera os direitos e obrigações entre fornecedores e consumidores, ou seja, a partir do término da garantia contratual, o consumidor terá 30 (bens não duráveis) ou 90 (bens duráveis) dias para reclamar por vícios de adequação surgidos no decorrer do período desta garantia. Ademais, evita-se, de um lado, o tolhimento do direito de reclamação e, de outro, a criação de direito objetivo de poder reclamar a qualquer tempo pela garantia contratual. Note-se que, ao contrário do que sustenta parte da doutrina e da jurisprudência, não se trata de somar o prazo legal ao contratual. Ainda que se possa atingir, conforme a hipótese, o mesmo resultado prático, tal solução implicaria em diferir o início da contagem do prazo decadencial do art. 26, $\S 1^{\circ}$, do CDC, para depois do encerramento da garantia contratual, circunstância que não encontra nenhum subsídio ou respaldo legal” (STJ, REsp. 967.623/RJ, rel. Min. Nancy Andrighi, j. 16.04.2009).

${ }^{436}$ No caso dos vícios ocultos, assevera Leonardo Roscoe Bessa (Et alii. Manual..., cit., p. 169), que “o CDC, como se demonstrou, foi extremamente favorável ao possibilitar a contagem do prazo decadencial com base no critério da vida útil do produto. Ora, tal critério, que tem forte apoio da doutrina, é mais do que suficiente para tutelar os interesses do consumidor. Portanto, para garantir a 'efetiva prevenção e reparação de danos patrimoniais e morais' do consumidor (art. $6^{\circ}$, VI, do CDC), não se faz necessário recorrer à soma dos prazos de garantia contratual e legal: basta considerar que, se o vício oculto surgiu no período de vida útil do produto, é possível, no prazo de 90 dias (produtos duráveis) após a manifestação do defeito, o exercício das alternativas indicadas nos incisos do $\S 1^{\circ}$ do art. 18 do CDC”. “(...) pela interpretação do at. 24 do Código de Defesa do Consumidor, o termo a quo dos prazos decadenciais dispostos no art. 26, consubstanciado o direito de reclamar pelos vícios aparentes e ocultos do produto, ocorre após expirado o prazo de garantia legal, que 
do término da garantia complementar contratual (CDC, art. 50, caput $)^{437}$, o que encontra ressonância na moldura contida no art. $446,1^{\text {a }}$ parte, do Código Civil. ${ }^{438}$

Se complementar, é porque o fornecedor quis dar mais do que tinha já o consumidor ex vi legis; daí porque a garantia contratual traz inexoravelmente consigo a legal até o seu termo ${ }^{439}$, dilatando-a e, em razão disso, o direito de reclamar ultrapassa os prazos limites de 30 e de 90 dias contados da entrega efetiva do produto ou do término da execução do serviço (fácil constatação) e do momento em que ficar evidenciado o defeito (oculto).

Cogite-se de um automóvel zero km comprado por um senhor de 80 anos para seu neto de 18 anos. O modelo é esporte e muito veloz, porém há ínsita uma falha de produção nos freios que só se manifesta quando o sistema é acionado numa velocidade superior a $40 \mathrm{~km} / \mathrm{h}$. Preocupado com seus reflexos, o avô deixa a concessionária e conduz o carro até sua casa sem ultrapassar $30 \mathrm{~km} / \mathrm{h}$ e, por isso, nada de errado percebe. O neto só vem buscar seu presente 95 dias depois da entrega, pois estava em viagem ao exterior, constatando a inadequação do equipamento na primeira quadra rodada. A garantia contratual, embora de 3 anos, não alcança o sistema de freios, assim, nega a concessionária a reparação sem ônus ao consumidor.

Entende a fornecedora que o produto é durável e o vício de fácil constatação - pois a velocidade de $40 \mathrm{~km} / \mathrm{h}$ poderia ser ordinariamente atingida pelo

independe de termo expresso e não admite exoneração contratual pelo fornecedor" (TJMG, AC 1.0024.05.660743-5/001, rel. José Flávio de Almeida, j. 28.04.2010).

437 "1. Constatados vícios que se repetiram após o término do prazo de garantia contratual e persistiram durante o prazo de garantia legal, não cabe reconhecer o transcurso do prazo decadencial previsto no art. 26 do Código de Defesa do Consumidor. 2. 'É inadmissível a substituição da garantia legal pela contratual. Aquela é obrigatória e inderrogável; esta é complementar àquela, constituindo-se num plus em favor do consumidor'. 3. Na questão de que se cuida - impermeabilização e vazamento em piscina - não se pode querer certeza absoluta, contundente, havendo de se aceitar juízo de alta probabilidade, tal qual enunciado pelo perito oficial e não contrariado por qualquer elemento convincente. Do contrário, ficará indene toda execução de serviço como a os autos, defeituosa e imperfeita, a dano do consumidor" (TJSP, AC 992.09.032264-8, rel. Reinaldo Caldas, j. 15.09.2010).

${ }^{438} \mathrm{CC}$, art. 446: "não correrão os prazos do artigo antecedente (de decadência dos vícios redibitórios) na constância de cláusula de garantia; mas o adquirente deve denunciar o defeito ao alienante nos trinta dias seguintes ao seu descobrimento, sob pena de decadência”. A segunda parte, por ser incompatível com o sistema protetivo do CDC, não pode servir de paradigma.

439 "Ocorre que o art. 50 do mesmo Código estabelece que a 'garantia contratual é complementar à legal e será conferida mediante termo escrito'. E a interpretação oferecida pelo Acórdão recorrido está de acordo com o sistema de proteção ao consumidor. Na verdade, se existe uma garantia contratual de um ano tida como complementar à legal, o prazo de decadência somente pode começar da data em que encerrada a garantia contratual, sob pena de submetermos o consumidor a um engodo com o esgotamento do prazo judicial antes do esgotamento do prazo de garantia. E foi isso que o art. 50 do Código de Defesa do Consumidor quis evitar" (STJ, REsp. 225.859/SP, voto do Min. Carlos Alberto Menezes Direito, j. 15.02.2001). 
homem médio - conseguintemente, o prazo para reclamar era de 90 dias contados da entrega efetiva do bem (CDC, art. 26, $\left.\S 1^{\circ}\right)$, já ultrapassados. É correta a postura adotada pela concessionária fornecedora?

Data venia, não. O vício era mesmo de fácil constatação; entretanto, falha no sistema de freio de qualquer veículo, ainda mais esporte, compromete, à evidência, a funcionalidade do bem. É, pois, matéria garantida ex vi legis (CDC, art. 24). Ninguém pode vender um carro cujos freios não funcionam! O elemento de segurança é básico. Ora, por este prisma, a adequação passa a ser amparada durante toda a garantia contratual, dispondo o neto, e mesmo o avô, de 90 dias para o exercício de seu direito de reclamar contados após os 3 anos complementares previstos.

Necessário, porém, se trate de vício de adequação e que tenha origem dentro do prazo ajustado.

De outra banda, se o fornecedor, atuando livremente no mercado, garantir mais do que a adequação (v.g., mau uso do consumidor que errou a voltagem indicada e ligou aparelho 110 em voltagem 220), o acréscimo será regido exclusivamente pela garantia contratual, inclusive com possibilidade de reduzido prazo de reclamação, no silêncio ou no abuso prevalece a regra positiva (30 ou 90 dias), ou de dupla fluência de lapsos, o que pode gerar certa perplexidade:

“(...) admitindo-se a soma das garantias, o prazo decadencial, por questão lógica, só não correria em relação a direitos amparados tanto pela garantia contratual como pela legal. Se a garantia legal não cobre determinada parte do produto (parte elétrica de um veículo, por exemplo), não há falar em soma de prazos em relação aos vícios surgidos no sistema elétrico do carro. Tal fato conduzirá o consumidor a ter de analisar minuciosamente ambas as garantias para verificar em que medida são coincidentes e, ainda, em quais aspectos poderá se valer de uma ou de outra. A dificuldade será inevitável e, muitas vezes, irá levar o consumidor a perder o seu direito, em face de um exame equivocado dos temos, condições e limites da garantia contratual. Este é um outro fator prático que deve também ser considerado na interpretação de norma que objetiva justamente o conhecimento dos direitos, a facilitação de sua defesa e a prevenção de danos ao consumidor (art. 6º, II, VI e VIII)."440

\footnotetext{
${ }^{440}$ Leonardo Roscoe Bessa et alii. Manual..., cit., p. 170.
} 
In casu, a garantia voluntária funciona tal qual um seguro concedido pelo fornecedor, que pode, inclusive, ajustar-se com empresa especializada nesse tipo de cobertura: seguradora típica, assegurando ao consumidor, sujeito a ser seduzido e convencido no mercado, maior segurança.

\subsubsection{Garantia estendida}

Como anota Leonardo Roscoe Bessa ${ }^{441}$, "tem sido cada vez mais frequente no comércio, no momento de aquisição de bens duráveis, principalmente eletrodomésticos e eletroeletrônicos, o oferecimento do que se tem denominado garantia estendida. Pagando-se determinado valor, o estabelecimento comercial estende a garantia de fábrica, normalmente de um ano, para dois ou três anos".

Antes de mais nada há que se visualizar esse instituto como uma espécie de garantia contratual, portanto, além da sua essência de seguro ${ }^{442}$, ex vi legis, complementar à legal (CDC, art. 50); assim, nada obstante a proteção assegurada ante os vícios ocultos durante a vida útil do produto ou do serviço, pode o consumidor optar - dês que atue num ambiente de plena transparência ${ }^{443}$ - por este adendo no ajuste.

Não se vislumbra, per se, abusividade na conduta do fornecedor que oferece a garantia estendida, sobretudo porque o consumidor - se a adquirir - ficará livre, durante o prazo da avença, de discussões sobre a origem temporal do vício oculto, se antes ou se depois da vida útil do bem da vida adquirido ou utilizado.

Abuso poderia estar presente se a garantia estendida abrangesse prazo incapaz de romper a notória exigência de mínima vida útil para certos

\footnotetext{
${ }^{441}$ Idem.

442 "Justifica-se a restituição integral do preço pago pelo autor, porquanto na ocasião em que o aparelho celular foi enviado à assistência técnica a exigência do pagamento para substituição de peças mostrou-se inaceitável. Consequentemente, após a contratação de seguro (garantia estendida) com a vendedora, e apresentado novo problema no produto adquirido, houve negativa de solução pelas empresas rés" (TJSP, AC 0218223-90.2009.8.26.0005, rel. Adílson de Araújo, j. 31.05.2011).

443 "Ação de indenização por danos moral e material - bem móvel - conjunto estofado - garantia estendida e contrato de seguro com cartão de crédito não requeridos - venda casada - ônus da fornecedora de provar que o consumidor tinha ciência do que estava contratando - devolução da quantia indevidamente cobrada - danos morais evidenciados - sucumbência integral da ré - apelação provida em parte" (TJSP, AC 000514426.2009.8.26.0038, rel. Eros Piceli, j. 14.03.2011). O extinto $1^{\circ} \mathrm{TacCiv} / \mathrm{SP}$, por sua vez, liberou o aderente desse encargo contratual, pois considerou que: "não há prova, igualmente, de que ao consumidor foram prestadas todas as informações necessárias sobre o serviço que lhe foi vendido (garantia estendida), nem tão pouco que lhe tenha sido prestadas as informações necessárias sobre o procedimento no uso do seguro contratado" (AC 853.023-6, rel. Paulo Roberto de Santana, j. 20.05.2004).
} 
bens de consumo ${ }^{444}$, o que deve ser avaliado em cada caso concreto, a partir da hipossuficiência técnica do consumidor e das obrigações fundamentais inerentes à natureza e ao conteúdo do contrato, jamais se apartando o intérprete - nesse processo - do amplo espectro de incidência da adequação legalmente imposta.

\subsubsection{O sentido de obstar}

Inovou, quando promulgada ${ }^{445}$, mais uma vez, a Lei 8.078/90 ao admitir interferência no curso do prazo decadencial (CDC, art. $26, \S 2^{\mathrm{o} 446}$ ), e o fez com o uso da inédita expressão "obstam”. Com isso, o legislador afastou-se da controvérsia que certamente envolveria os conceitos de interrupção e de suspensão nessa espécie de contagem.

Há dissensões na doutrina acerca da natureza jurídica das consequências geradas no prazo decadencial obstado, introduzindo alguns um outro novo conceito: o impedimento.

Nesse sentido é a intervenção de Roberto Senise Lisboa, para quem, "o impedimento não confere sequer a oportunidade de se iniciar a contagem do prazo decadencial. É o contrário do que sucede na suspensão da prescrição, em que a contagem prossegue de onde parou, a partir do momento em que cessa o evento. E nem se trata de interrupção, pois no impedimento não ocorre o reinício da contagem do prazo". ${ }^{447}$

Ora, e se o prazo já começou a fluir? O que fazer com o tempo contado quando a decadência não estiver mais obstada?

Não convence, pois, a teoria do impedimento.

Saliente-se que as duas hipóteses legais previstas admitem a retomada da fluência regular do prazo decadencial após: (I) a resposta negativa,

\footnotetext{
${ }^{444}$ Imagine-se uma montadora que assegure garantia de fábrica aos seus veículos por um ano, mas uma das usas concessionárias oferece, a certo custo, garantia estendida por mais seis meses. Ora, a garantia legal de adequação não se harmoniza com um carro que apresente problemas de funcionalidade em um ano e meio, daí o abuso do complemento contratual (CDC, arts. $4^{\circ}$, VI, c.c. $6^{\circ}$, IV, c.c. 39 , IV e V, c.c. 51, I, IV, XV, c.c. seu $\S 1^{\circ}$, I, II e III).

445 Hoje, com o novo Código Civil, o sistema comum de direito privado também admite, se legalmente imposta, a solução de continuidade do prazo decadencial. CC, art. 207: "salvo disposição legal em contrário, não se aplicam à decadência as normas que impedem, suspendem ou interrompem a prescrição".

${ }^{446} \mathrm{CDC}$, art. 26, $\S 2^{\circ}$ : "obstam a decadência: I - a reclamação comprovadamente formulada pelo consumidor perante fornecedor de produtos e serviços até a resposta negativa correspondente, que deve ser transmitida de forma inequívoca; II - (Vetado.) III - a instauração de inquérito civil, até seu encerramento".

${ }^{447}$ Responsabilidade civil..., cit., p. 277.
} 
inequívoca, do fornecedor em face da reclamação comprovadamente formulada pelo consumidor $^{448}$ e (II) o encerramento do inquérito civil instaurado pelo Ministério Público ou, se for o caso, a decisão final de arquivamento ou, ainda, em diálogo de fontes (supra, Cap. I, 2.6), do último ato (trânsito em julgado) do processo que se seguiu à investigação do parquet (CDC, art. $7^{\circ}$, caput, c.c. CC, art. 202, par. ún.).

Luiz Antonio Rizzatto Nunes, em edição anterior dos seus comentários, sustentava que se assemelhavam as ações de obstar e de suspender, aplicando “(...) por analogia ao conceito de suspensão o mesmo regime para o de obstaculização: no ato obstativo estanca-se a contagem do prazo decadencial, que recomeça de onde parou, logo após a cessação do efeito do fato obstaculizador" ${ }^{\text {"49; }}$; no entanto, evoluiu para considerar que a reclamação do consumidor constitui um direito novo para o consumidor, o de pleitear aquilo que a lei subsequentemente lhe garante, o que afasta o efeito suspensivo ou interruptivo ante a diversa sistemática. ${ }^{450}$

Oscila a doutrina neste pormenor ${ }^{451}$, optando Zelmo Denari $^{452}$ e Arruda Alvim ${ }^{453}$ por atribuir eficácia suspensiva ao regime da obstaculização; enquanto Héctor Valverde Santana, afirmando que o CDC não acolheu as interpretações

448 Segundo Luiz Antonio Rizzatto Nunes (Curso..., cit., p. 375/376): “é evidente que uma norma protecionista que tenha conferido prazos curtos (30 e 90 dias) para o consumidor agir e não decair de seu direito tenha de ser interpretada da maneira mais ampla e abrangente possível em relação à forma de constituição dessa garantia".

${ }^{449}$ Comentários ao Código de Defesa do Consumidor. Direito Material (arts. $1^{o}$ a 54). São Paulo: Saraiva, 2000 , p. 341.

${ }^{450}$ Curso..., cit., p. 373/374. E quanto ao prazo para o exercício desse novo direito, não previsto na Lei 8.078/90, assevera que: "primeiro, percebe-se que se trata de direito de ação e todas as hipóteses de exercício (as três do $\S 1^{\circ}$ do art. 18, as quatro do art. 19 e as três do art. 20) dizem respeito a perdas e danos. Logo, o primeiro passo é examinar o art. 27 , que regula o prazo prescricional para a propositura da ação relativa à reparação de danos. O problema é que o art. 27 faz referencia expressa à Seção II do Capítulo IV e esta trata da Responsabilidade pelo Fato do Produto e do Serviço (arts. 12 a 17). A outra hipótese de solução seria buscar na regra geral do novo Código Civil o prazo, e este seria de 10 anos. Como já pudemos observar, os vícios guardam intrínseca relação com os defeitos, sendo que mesmo no caso dos vícios, há previsão expressa do direito a pleitear perdas e danos (inciso II, do $\S 1^{\circ}$ do art. 18; inciso IV do art. 19 e inciso II do art. 20), além do fato de que o não saneamento do vício implica per si perda material. Por isso que este novo direito subsequente é indenizatório. Visto tudo isso, então, entendemos que o prazo para o ingresso da ação é de 5 anos, por aplicação do art. 27 ao caso. Não há que se falar em 30 ou 90 dias, das hipóteses previstas no art. 26, porque não apontam sequer para uma analogia viável. É que no art. 26 o prazo é para constituição do direito material. Prazo para ingresso da ação é do art. 27”.

${ }^{451}$ Paulo Jorge Scartezzini Guimarães (Vícios do produto e do serviço por qualidade, quantidade $e$ insegurança. Cumprimento imperfeito do contrato. $2^{\text {a }}$ ed. São Paulo: RT, 2007, p. 309-314) entende que o art. 26 do CDC trata de duas situações distintas, a criar para cada qual um reflexo próprio na fluência subsequente do prazo decadencial. Ou seja, “(...) o Código de Defesa do Consumidor, ao prever duas situações nas quais o prazo fica obstado, criou uma hipótese de interrupção e outra de suspensão". Para o autor, o inc. I, que depende de um comportamento ativo do consumidor (a reclamação), encerraria caso de interrupção; enquanto o inc. II, desprendido da vontade do consumidor, implicaria suspensão.

${ }^{452}$ Et alii. Código Brasileiro de Defesa do Consumidor..., cit., p. 147 e 151. 
que procuram determinar efeitos suspensivo ou interruptivo às causas obstativas nele previstas, conclui que, “(...) a solução que o subsistema das relações de consumo apresenta para o caso é iniciar a contagem de novo prazo extintivo de direito material, podendo ser prescricional se a postulação buscar provimento jurisdicional condenatório, ou decadencial se manejar uma ação constitutiva". 454

Não se pode perder de vista que a decadência tem um prazo a cumprir, ou seja, uma vez superada a causa obstativa ele vai, sem alterar sua natureza (e isso é importante), fluir novamente (o que põe de lado a ideia de mero limite de tempo para o exercício de direito subjetivo potestativo ${ }^{455}$ ), daí porque não é possível alçar a inicial decadência à prescrição do art. 27 , muito menos permitir que assuma tônus de uma ou de outra a depender da pretensão subsequente deduzida pelo consumidor. Além disso, a reclamação só é, em tese, obrigatória ${ }^{456}$ nas hipóteses de vício de qualidade do produto $\left(\mathrm{CDC}\right.$, art. 18, $\left.\S 1^{\circ}\right)$; logo, pode não existir nos demais casos de vício (qualidade de produto essencial e/ou caso de problema de grande extensão a comprometer as características originárias do bem ou diminuir-lhe o valor, quantidade do produto e qualidade do serviço) e nem por isso o consumidor estaria impossibilitado de exercer, diretamente, os direitos previstos nos arts. $18, \S 3^{\circ}, 19,20$ e 21 do Código.

Pensar-se o contrário, data venia, seria a consagração de prérequisito não estabelecido pelo $\mathrm{CDC}$, em nítida afronta ao primado da legalidade $(\mathrm{CF}$, art. $5^{\circ}$, II).

${ }^{453}$ Et alii. Código do Consumidor comentado..., cit., p. 176.

${ }^{454}$ Prescrição e decadência nas relações de consumo. São Paulo: RT, 2003, p. 127/128.

${ }^{455}$ Alerta Cláudia Lima Marques (Comentários..., cit., p. 592), identificando um prazo de decadência para o direito de reclamar judicialmente, que: “(...) se a decadência fosse efetivamente do direito de reclamar, este já teria sido usado, exercitado como direito; logo, não poderia morrer, decair, caducar, como se queria".

${ }^{456}$ Atente-se ao fato de que parte da doutrina diverge dessa obrigatoriedade. Segundo Leonardo Roscoe Bessa (Vícios dos produtos..., cit., p. 291/292): "a melhor solução é na linha de interpretação restritiva da exigência do prazo de 30 dias: somente para situações excepcionais, poderá ser invocado o prazo de 30 dias. Para tanto, as hipóteses previstas no $\S 3^{\circ}$ do art. 18 , que permitem o afastamento do referido prazo, devem ser visualizadas com atenção ao princípio da efetiva proteção aos interesses materiais e morais do consumidor (art. $6^{\circ}, \mathrm{VI}$ ), ou seja, a regra é considerar, em princípio, que todos os produtos são essenciais e, ainda, que a substituição das partes viciadas compromete a qualidade do produto ou diminui o seu valor. Nem o CC/16, nem o atual - que não se preocupam em oferecer proteção diferenciada ao comprador como faz o CDC exigem qualquer prazo prévio para que o adquirente do bem possa exigir a devolução ou abatimento proporcional do preço. Assim, a perplexidade é inevitável, pois em relação a esse aspecto específico, a disciplina do Código Civil parece ser mais vantajosa ao comprador. Surge, portanto, mais um argumento em favor da interpretação da matéria pró-consumidor. Se o CC/2002, que, teoricamente, reflete a preocupação do legislador moderno com o tema, não impõe qualquer prazo preliminar para o exercício dos direitos de redibição ou abatimento proporcional do preço, o prazo de 30 dias só pode ser invocado em situações absolutamente excepcionais, incapazes de gerar qualquer dano material ou moral ao consumidor. O diálogo 
A identificar o que fazer com o prazo já percorrido até a reclamação (se existente), ponto nuclear da desnecessária controvérsia ${ }^{457}$, no meu sentir, forte na eficácia condicionante dos princípios protetivos da Parte Geral, a razão está com Leonardo Roscoe Bessa, “em que pese à dificuldade que a matéria comporta, a melhor posição, considerando a finalidade de proteção ao consumidor, e que os prazos decadenciais do CDC são bastante exíguos, é no sentido de se reiniciar a contagem dos prazos decadenciais a partir da resposta negativa do fornecedor (inciso I) ou da data em que se promove o encerramento do inquérito civil (inciso III). Obstar, portanto, tem o sentido de invalidar o prazo já transcorrido, o que se assemelha ou se aproxima das hipóteses de interrupção". ${ }^{458}$

\subsubsection{Prescrição}

Prescreve em cinco anos a pretensão à reparação dos danos causados por fato do produto ou do serviço (defeito), iniciando-se a contagem do prazo a partir do conhecimento do dano e da sua autoria (CDC, art. 27).

Para Arruda Alvim, “(...) caso o vício não cause dano, correrá para o consumidor o prazo decadencial, para que proceda à reclamação, previsto neste artigo 26. No entanto, vindo a causar dano, ou seja, concretizando-se a hipótese do artigo 12, deste mesmo Código, deve-se ter em mente o prazo quinquenal, disposto pelo art. 27, sempre que se quiser pleitear indenização". 459

Ou seja, toda e qualquer situação danosa originada de defeito (supra, Cap. II, 2.2.2.2) em relação jurídica de consumo está subsumida à regra do art. 27 da Lei $8.078 / 90^{460}$, ainda que tenha sua gênese em primário vício. ${ }^{461}$

das fontes entre os dois diplomas reforça, sem a menor dúvida, a idéia de excepcionalidade da concessão do prazo de 30 dias".

${ }^{457}$ É que o par. ún. do art. 27 do CDC, que acabou vetado pelo Presidente da República por força de um erro de redação, aludia ao $\S 1^{\circ}$ ao invés do $\S 2^{\circ}$, e só por conta disso advirta-se, estabelecia - na sua verdadeira ratio - ser possível interromper a prescrição nas hipóteses do $\S 2^{\circ}$ do art. 26; daí a essência interruptiva declarada pela própria lei, caso tivesse sido sancionada e publicada em seu inteiro teor.

${ }^{458}$ Et alii. Manual..., cit., p. 165.

${ }^{459}$ Et alii. Código do Consumidor comentado..., cit., p. 172/173.

${ }^{460}$ Luiz Antonio Rizzatto Nunes. Comentários..., cit., p. 371.

461 "DIREITO DO CONSUMIDOR. AÇÃO DE INDENIZAÇÃO POR DANOS MATERIAIS E MORAIS DECORRENTES DE VÍCIOS NO SERVIÇO. PRESCRIÇÃO. CINCO ANOS. INCIDÊNCIA DO ART. 27 DO CDC. 1. Escoado o prazo decadencial de 90 (noventa) dias previsto no art. 26, II, do CDC, não poderá o consumidor exigir do fornecedor do serviço as providências previstas no art. 20 do mesmo Diploma reexecução do serviço, restituição da quantia paga ou o abatimento proporcional do preço -, porém, a 
Em que pese à realidade instalada, mormente por força do texto expresso da lei de regência, existe entendimento no sentido de que o comando sub examine encerra prazo decadencial e não prescricional. ${ }^{462}$

Quanto ao prazo, não basta o conhecimento do dano, visto que o marco inicial da contagem exige a identificação do nexo de causalidade com o produto ou o serviço defeituoso.

Exatos os comentários de Luiz Antonio Rizzatto Nunes no sentido de que, “a norma se utiliza adequadamente da conjuntiva 'e' para determinar o início do prazo, porque pode acontecer de o consumidor sofrer dano e não conseguir de imediato identificar o responsável por ele ou pelo menos, todos os responsáveis, uma vez que, como se viu, a Lei 8.078 estabelece ampla solidariedade entre os fornecedores.” ${ }^{463}$

\subsubsection{Ações coletivas}

À luz do que se abordou no início do trabalho (supra, Cap. I, 3), não se ponha no oblívio que a indivisibilidade gradua os direitos difusos e coletivos, a ponto de, por falta de titulares previamente identificados, colocá-los em posição segura fora do espectro de incidência dos efeitos do decurso do tempo (prescrição e decadência) ${ }^{464}$, o que não ocorre com os individuais homogêneos, divisíveis na origem.

Percebe-se, portanto, que a prescrição das demandas coletivas deveriam guardar ressonância com a espécie de direito metaindividual por elas tutelado; daí porque a pretensão ligada aos individuais homogêneos se sujeitaria às mesmas regras da tutela individual de direitos disponíveis. ${ }^{465}$

pretensão de indenização dos danos por ele experimentados pode ser ajuizada durante o prazo prescricional de 5 (cinco) anos, porquanto rege a hipótese o art. 27 do CDC. 2. Recurso especial conhecido e provido" (STJ, REsp. 683.809/RS, rel. Min. Luis Felipe Salomão, j. 20.04.2010).

${ }^{462}$ Zelmo Denari et alii. Código Brasileiro de Defesa do Consumidor..., cit., p. 149.

${ }^{463}$ Curso..., cit., p. 385/386. No mesmo sentido Arruda Alvim et alii. Código do Consumidor comentado..., cit., p. 178.

${ }^{464}$ Cf., v.g., o comando constitucional que qualifica como imprescritíveis as ações de ressarcimento dos prejuízos causados ao erário $\left(\mathrm{CF}\right.$, art. $\left.37, \S 5^{\circ}\right)$. E mais: "não há prescrição, seja em relação às obrigações de fazer e não fazer, seja em relação à pretensão de ressarcimento. Como anotou o agravado, reportando-se a julgado desta Câmara, a tutela da ordem urbanística e do meio ambiente diz respeito a direitos transindividuais indisponíveis e imprescritíveis, até porque o dano ambiental não está confinado no tempo, mas é permanente; portanto, seja para cessação da degradação, seja para recomposição do meio ambiente, seja para ressarcimento econômico de danos ambientais, não há que falarem prescrição" (TJSP, AI 010160776.2011.8.26.0000, rel. Antonio Celso Aguilar Cortez, j. 02.06.2011).

${ }^{465}$ Héctor Valverde Santana. Prescrição..., cita., p. 109. 
No entanto, o E. STJ tem se inclinado a reconhecer um lapso extintivo autônomo para as demandas não individuais, embora em sede de ação civil pública, que não se confunde com as coletivas previstas no CDC em razão da diversidade de objetos tuteláveis, com isso aplicando a elas analogicamente o prazo prescricional de cinco anos da ação popular (Lei 4.717/65, art. 21), independentemente da natureza dos direitos nelas debatidos. ${ }^{466}$

É bem verdade que em matéria consumerista (reparação de danos advindos de fato do produto ou do serviço) isto teria pouco, quiçá nenhuma, relevância prática diante do art. 27 do CDC, que adota o mesmo lapso quinquenal, mas o estudioso deve ficar atento à fundamentação adotada pela mais alta Corte infraconstitucional do país.

\subsubsection{Direito comum como norma supletiva}

São duas as perguntas que devem ser respondidas neste tópico: a) superados os prazos de decadência ou de prescrição, pode ainda o consumidor acionar o fornecedor invocando o lapso temporal maior eventualmente previsto pelo direito comum (Código Civil)? e b) o prazo prescricional do art. 27 da Lei 8.078/90 pode ser obstado, suspenso ou interrompido?

466 “CIVIL E PROCESSUAL CIVIL. AÇ̃̃O CIVIL PÚBLICA DECORRENTE DE DIREITOS INDIVIDUAIS HOMOGÊNEOS. POUPANÇA. COBRANÇA DOS EXPURGOS INFLACIONÁRIOS. PLANOS BRESSER E VERÃO. PRAZO PRESCRICIONAL QUINQUENAL. 1. A Ação Civil Pública e a Ação Popular compõem um microssistema de tutela dos direitos difusos, por isso que, não havendo previsão de prazo prescricional para a propositura da Ação Civil Pública, recomenda-se a aplicação, por analogia, do prazo quinquenal previsto no art. 21 da Lei n. 4.717/65. 2. Embora o direito subjetivo objeto da presente ação civil pública se identifique com aquele contido em inúmeras ações individuais que discutem a cobrança de expurgos inflacionários referentes aos Planos Bresser e Verão, são, na verdade, ações independentes, não implicando a extinção da ação civil pública, que busca a concretização de um direto subjetivo coletivizado, a extinção das demais pretensões individuais com origem comum, as quais não possuem os mesmos prazos de prescrição. 3. Em outro ângulo, considerando-se que as pretensões coletivas sequer existiam à época dos fatos, pois em 1987 e 1989 não havia a possibilidade de ajuizamento da ação civil pública decorrente de direitos individuais homogêneos, tutela coletiva consagrada com o advento, em 1990, do CDC, incabível atribuir às ações civis públicas o prazo prescricional vintenário previsto no art. 177 do $\mathrm{CC} / 16$. 4. Ainda que o art. $7^{\circ}$ do CDC preveja a abertura do microssistema para outras normas que dispõem sobre a defesa dos direitos dos consumidores, a regra existente fora do sistema, que tem caráter meramente geral e vai de encontro ao regido especificamente na legislação consumerista, não afasta o prazo prescricional estabelecido no art. 27 do CDC. 5. Recurso especial a que se nega provimento" (STJ, REsp. 1.070.896/SC, rel. Min. Luis Felipe Salomão, j. 14.04.2010). Em sentido contrário, parte da jurisprudência se inclina a reconhecer uma autonomia e independência da ação civil pública em face da ação popular (TJSP, AC 115.019-5/9, rel. Paulo Dimas Mascaretti, j. 20.06.2000). 
Quadra logo ressaltar que os direitos previstos no CDC não excluem outros decorrentes da legislação interna ordinária, bem como os que derivem dos princípios gerais de direito, analogia, costumes e equidade (CDC, art. $7^{\circ}$, caput $^{467}$ ), na exata medida diálogo das fontes (supra, Cap. I, 2.6).

Fixada tal premissa, aclaram-se as indagações.

Como já visto (supra, 4.3), fluente na concepção tradicional o resultado da decadência: a morte do direito; enquanto a prescrição arreda apenas a possibilidade de exercitar a pretensão. Assim, para certos autores, a resposta da primeira pergunta dependeria da espécie de prazo.

Se de decadência, nada mais haveria se fazer ante a perda do direito material do consumidor ${ }^{468}$; entretanto, a se aplicar o diálogo das fontes, o direito do consumidor só se extinguiria após consumado o maior prazo decadencial previsto no sistema $^{469}$, visto ser inadmissível que ao sujeito especialmente tutelado pela Constituição Federal fosse reservada proteção jurídica reduzida.

Leonardo Roscoe Bessa defende a possibilidade de “(...) haver a aplicação de regime misto, decorrente de utilização simultânea de institutos do Código Civil e do CDC? A idéia do diálogo das fontes, reforçada pelo disposto no caput do art. $7^{\circ}$, aponta para uma resposta positiva. Pode-se, desse modo, invocar prazo decadencial mais vantajoso ao consumidor, previsto no Código Civil, tratado internacional do qual o Brasil seja signatário ou outra lei ordinária (art. $7^{\circ}$, caput, do CDC) e, simultaneamente, ser obstado o prazo decadencial pelas hipóteses indicadas no $\S 2^{\circ}$ do art. 26, e, ainda, obter a inversão do ônus da prova (art. $6^{\circ}$, VIII). Este é o sentido do diálogo das fontes!" 470

\footnotetext{
${ }^{467} \mathrm{CDC}$, art. $7^{\circ}$, caput: "os direitos neste Código não excluem outros decorrentes de tratados ou convenções internacionais de que o Brasil seja signatário, da legislação interna ordinária, de regulamentos expedidos pelas autoridades administrativas competentes, bem como dos que derivem dos princípios gerais do direito, analogia, costume e equidade".

${ }^{468}$ Roberto Senise Lisboa. Responsabilidade civil..., cit., p. 277 e Arruda Alvim et alii. Código do Consumidor comentado..., cit., p. 176.

${ }^{469}$ Tal qual ocorre em relação às pretensões edilícias (redibição ou abatimento do preço) no caso de vício constatado em imóvel, produto durável se o contrato aquisitivo for de consumo. $\mathrm{O}$ art. 445, caput, do Código Civil prevê para essa hipótese dois prazos: 01 ano contado da entrega efetiva ou, se o adquirente já se encontrava no exercício da posse, 06 meses contados da alienação. Tanto um quanto outro superam o prazo de reclamação de 90 dias previsto no art. 26, II, do CDC, por isso aqueles prevalecem na hipótese sub examine.

${ }^{470}$ Leonardo Roscoe Bessa et alii. Manual..., cit., p. 166.
} 
A prescrição, da mesma forma, se rege pelo prazo mais elástico $^{471}$, embora parte da doutrina - sem razão, anote-se - entenda que, uma vez ultrapassado o prazo do art. 27, impossibilitada estará a ação reparatória como prevista no sistema protetivo da Lei 8.078/90, mas não impede sejam utilizadas as regras de direito comum, se mais favoráveis. ${ }^{472}$

No referente à segunda questão, cumpre lembrar que o art. 27, par. ún. $^{473}$, da Lei 8.078/90 foi vetado pelo Presidente da República.

Infere-se que o propósito era estender as hipóteses do $\S 2^{\circ}$ (supra, 4.3.5), e não do $\S 1^{\circ}$ (dies a quo do prazo de decadência), à prescrição, alterando-se o termo obstam por interrompe-se; contudo, esse erro de redação determinou o veto presidencial.

Da forma como hoje está, o comando gera dissenso na doutrina. Parte sustenta que nada há ser feito, assinalando o prazo contínuo de 5 anos para o consumidor pleitear seus direitos ${ }^{474}$, outros preferem manter a sistemática original (antes do veto), mas propõem a suspensão (obstar) e não a interrupção do $\operatorname{prazo}^{475}$. Por fim, sustentam alguns seja a matéria regulada pelas normas gerais, disciplinadoras da prescrição, constantes no Código Civil: tanto para a suspensão quanto para a interrupção. ${ }^{476}$

\footnotetext{
471 "Uso do prazo mais favorável ao consumidor. Art. $27 \mathrm{c} / \mathrm{c}$ art. $7^{\circ}$ : O sistema de responsabilidade sem culpa e solidária do CDC é rápido e eficaz, mas, em caso de prescrição, a jurisprudência tem utilizado o art. $7^{\circ}$ do CDC (abertura do sistema) para utilizar o prazo geral, de 20 anos do CC/1916, ou agora (art. 205 do CC/2002), de 10 anos para beneficiar o consumidor, bem ao espírito do CDC. A jurisprudência também atuou para considerar muito sabiamente que diversos pedidos referentes ao defeito do produto e serviço, mesmo que conectados a contratos - mas abrindo a possibilidade de danos morais - sejam tratados pelo art. 27 do CDC. E ainda esclareceu que o art. 26 do CDC restringe-se ao inadimplemento parcial, sendo o art. 27 do CDC o prazo em caso de inadimplemento total, pois há apenas a possibilidade de indenização pelos danos materiais e morais" (Cláudia Lima Marques et alii. Comentários..., cit., p. 607). No mesmo sentido é Leonardo Roscoe Bessa (Et alii. Manual..., cit., p. 167), para quem "a conclusão, portanto, é no sentido da possibilidade de mistura de regime entre direitos previstos no Código Civil e no Código de Defesa do Consumidor para conferir proteção maior ao consumidor. Esta interpretação atende ao comando constitucional de defesa do consumidor (art. $5^{\circ}$, XXXII) e, ao mesmo tempo, confere coerência ao ordenamento jurídico, pois não se pode conceber a existência de tutela mais vantajosa ao comprador nas relações jurídicas entre iguais (entre dois empresários, por exemplo) do que aquela constante no CDC (relação entre desiguais: consumidor e fornecedor)".

${ }^{472}$ Roberto Senise Lisboa. Responsabilidade civil..., cit., p. 278.

${ }^{473} \mathrm{CDC}$, art. 27, par. ún.: "interrompe-se o prazo de prescrição do direito de indenização pelo fato do produto ou serviço nas hipóteses previstas no $\S 1^{\circ}$ do artigo anterior, sem prejuízo de outras disposições legais".

${ }^{474}$ Luiz Antonio Rizzatto Nunes. Comentários..., cit., p. 372.

${ }^{475}$ Zelmo Denari. Código Brasileiro de Defesa do Consumidor..., cit., p. 153.

476 Arruda Alvim. Código do Consumidor comentado..., cit., p. 178 e Roberto Senise Lisboa, Responsabilidade civil..., cit., p. 278.
} 
Induz a sistemática em vigor da Lei 8.078/90 (art. $7^{\circ}$, caput), aparelhada nos seus princípios protetivos e no diálogo das fontes, a correção da terceira corrente, sem embargo das razões em sentido contrário alinhadas pela primeira. Impossível é a analogia com dispositivo vetado ou com hipótese ontologicamente distinta (decadência).

Nesse sentido, após analisar com percuciência a disciplina dos efeitos do decurso do tempo nas duas esferas de direito privado sub examine, é a ponderação de Fábio Siebeneichler de Andrade: “(...) o exame da influência do regime geral da prescrição e da decadência sobre os preceitos da Lei de defesa do consumidor fortalece a convicção de que, na atualidade, não se pode conceber os dois sistemas em uma relação de oposição ou de polaridade. Por força da oxigenação proporcionada pelos novos preceitos do Código Civil, houve uma aproximação entre este regime e o da Lei de Defesa do Consumidor. Estabelece-se, portanto, um sistema complementar no âmbito das relações jurídicas de Direito Privado, que deve estar direcionado à defesa do consumidor, tendo em vista sua condição de contratante mais fraco, relativamente ao fornecedor de produtos e serviços. Trata-se, portanto, de atender a princípio constitucional fixado no art. 170, V, da Constituição Federal". 477

\footnotetext{
${ }^{477}$ Considerações sobre o regime da prescrição no Código Civil de 2002 e seus efeitos quanto à lei de defesa do consumidor. In: Pasqualotto, Adalberto e Pfeiffer, Roberto Augusto Castellanos (coord). Código de Defesa do Consumidor e o Código Civil de 2002. Convergências e assimetrias. RT: São Paulo, 2005, p. 324.
} 


\section{SERVIÇOS PÚBLICOS}

Em face dos serviços públicos, o CDC exige: a) sua racionalização e melhoria (art. $\left.4^{\circ}, \mathrm{VII}\right)$, b) sua adequada e eficaz prestação (art. $6^{\circ}, \mathrm{X}$ ) e c) que sejam eles adequados, eficientes e seguros, enquanto contínuos os essenciais (art. 22).

Ressalte-se logo a respeito: qualquer pessoa jurídica pode ser considerada fornecedora (supra, Cap. II, 3.1), a pública inclusive (CDC, art. $3^{\circ}$, caput); logo, o serviço público também está inserido no objeto das relações de consumo (supra, Cap. II, 4.2), mas sempre vinculado às suas características fundamentais: a adequação e a eficiência (CF, arts. 37 c.c. 175 , par. ún., IV). ${ }^{478}$

Fácil é, pois, nesta matéria, perceber as razões pelas quais a Lei 8.078/90 impõe rígidos padrões de comportamento à Administração (direta ou indireta), com especial destaque no que tange à continuidade exigida, como um plus, para os serviços públicos essenciais.

\subsection{Serviço essencial}

\footnotetext{
${ }^{478} \mathrm{Na}$ verdade, a eficiência foi erigida, expressamente, em princípio básico da Administração Pública pela EC 19, de 04.06.1998, visto que não constava da redação primitiva do art. 37, caput, da Carta da República. Apesar disso, a doutrina mais abalizada sempre afirmou a necessidade de os serviços públicos serem eficientes (Hely Lopes Meirelles. Direito administrativo brasileiro. 16a ed. São Paulo: RT, 1991, p. 294): "Requisitos do serviço e direitos do usuário - Os requisitos do serviço público ou de utilidade pública são sintetizados, modernamente, em cinco princípios que a Administração deve ter sempre presentes, para exigilos de quem os preste: o princípio da permanência impõe continuidade no serviço; o da generalidade impõe serviço igual para todos; o da eficiência exige atualização do serviço; o da modicidade exige tarefas razoáveis; e o da cortesia se traduz em bom tratamento para com o público". E mais: faltando qualquer desses requisitos em um serviço público ou de utilidade pública, é dever da Administração intervir para restabelecer o seu regular funcionamento, ou retomar a sua prestação (Magalhães Colaço. Concessões de serviços públicos. Lisboa, 1928, p. 61 e ss). Daí a precisa intervenção de Luiz Alberto David Araújo e Vidal Serrano Nunes Júnior (Curso..., cit., p. 267): "O princípio da eficiência tem partes com as normas de 'boa administração', indicando que a Administração Pública, em todos os seus setores, deve concretizar atividade administrativa predisposta à extração do maior número possível de efeitos positivos ao administrado. Deve sopesar relação de custo-benefício, buscar a otimização dos recursos, em suma, tem por obrigação dotar da maior eficácia possível todas as ações do Estado". Já a obra atualizada do jurista Hely Lopes Meirelles continua a trazer a eficiência como um dever imposto ao administrador público (Direito Administrativo Brasileiro. $20^{\mathrm{a}}$ ed. Atual. por Eurico de Andrade Azevedo, Délcio Balestero Aleixo e José Emanuel Burle Filho. São Paulo: Malheiros, 1995, p. 90): “(...) é o que se impõe a todo agente público de realizar suas atribuições com presteza, perfeição e rendimento funcional. É o mais moderno princípio da função administrativa, que já não se contenta em ser desempenhada apenas com legalidade, exigindo resultados positivos para o serviço público e satisfatório atendimento das necessidades da comunidade e de seus membros". A premissa da Carta sempre foi a do serviço adequado (art. 175, par. ún., IV), posteriormente, em 1995, a norma regulamentadora qualificou a adequação constitucional, dentre outros, com o atributo da eficiência (Lei 8.987/1995, art. $6^{\circ}, \S 1^{\circ}$ ), e só então, pela Emenda 19/1998, a eficiência foi alçada a princípio geral da Administração Pública (art. 37, caput). Conclui-se, portanto, que em matéria de serviços públicos, a eficiência é um atributo da adequação.
} 
De fato, como o CDC protege as relações de consumo, ontologicamente explicada pela contextualização social em que se insere, é natural sejam essenciais todos os serviços indispensáveis em uma sociedade de consumo. ${ }^{479}$

Contudo, é mister se investigue a quaestio pelo prisma da essencialidade do serviço público, onde há um aspecto real e concreto de urgência determinante da prestação contínua.

À míngua de definição precisa na Lei 8.078/90, há de o intérprete valer-se de outros ramos do direito para dirimir tal pendência.

Essa é a ponderação do jurista Newton de Lucca:

“Infelizmente, porém, parece que o CDC não se aprofundou muito em determinados conceitos de que se utilizou, sendo necessário, por exemplo, nós irmos procurar na Lei de Greve o conceito de serviços essenciais, no Direito Administrativo, o conceito de serviços públicos e assim por diante.

Parece-me, pois, que algumas considerações a respeito da matéria deverão ser feitas a partir da importação de conceitos de outros ramos do Direito que somos forçados a fazer na interpretação do próprio CDC."480

Pois bem. A Constituição Federal, ao assegurar o direito de greve, relegou à lei a definição dos serviços ou atividades essenciais e o disciplinamento das necessidades inadiáveis da comunidade (art. $\left.9^{\circ}, \S 1^{\circ}\right)^{481}$; daí a promulgação da Lei $7.783 / 89 .{ }^{482}$

Segundo o percuciente doutor Luiz Antonio Rizzatto Nunes:

“(...) nenhum desses serviços pode ser interrompido. O CDC é claro, taxativo e não abre exceções: os serviços essenciais são contínuos. E digase em reforço que essa garantia decorre de texto constitucional.

\footnotetext{
${ }^{479}$ Adalberto Pasqualotto. Os serviços públicos no Código de Defesa do Consumidor. Revista de Direito do Consumidor, São Paulo: RT, v. 1, 1992, p. 139.

${ }^{480}$ Direito do consumidor. Aspectos práticos..., cit., p. 133.

${ }^{481} \mathrm{CF}$, art. $9^{\circ}$ : "é assegurado o direito de greve, competindo aos trabalhadores decidir sobre a oportunidade de exercê-lo e sobre os interesses que devam por meio dele defender. $\S 1^{\mathrm{o}}$ : A lei definirá os serviços ou atividades essenciais e disporá sobre o atendimento das necessidades inadiáveis da comunidade".

${ }^{482}$ Lei 7.783/89, art. 10: "são considerados serviços e atividades essenciais: I - tratamento e abastecimento de água; produção e distribuição de energia elétrica, gás e combustíveis; II - assistência médica e hospitalar; III - distribuição e comercialização de medicamentos e alimentos; IV - funerários; V - transporte coletivo; VI captação e tratamento de esgoto e lixo; VII - telecomunicações; VIII - guarda, uso e controle de substâncias radioativas, equipamentos e materiais nucleares; IX - processamento de dados ligados a serviços essenciais; X - controle de tráfego aéreo; XI - compensação bancária”.
} 
Com efeito, conforme examinamos no início deste trabalho, a legislação consumerista deve obediência aos vários princípios constitucionais que dirigem suas determinações. Entre esses princípios encontram-se os da intangibilidade da dignidade da pessoa humana (art. $1^{\circ}$, III), da garantia à segurança e à vida (caput do art. $5^{\circ}$ ), que tem de ser sadia e de qualidade, em função da garantia do meio ambiente ecologicamente equilibrado (caput do art. 225) e da qual decorre o direito necessário à saúde (caput do art. $6^{\circ}$ ) etc." ${ }^{483}$

E note-se: nem todas as atividades definidas como essenciais pela Lei 7.783/89 são serviços públicos. A lei regulamenta dispositivo constitucional que trata da greve em geral. Nada obstante, a maior parte dessas atividades é exercida através da administração pública direta ou indireta, ou, ainda, por meio de concessão, autorização ou permissão. Outros serviços podem ser públicos ou privados, como os de assistência médica e hospitalar. Já os serviços funerários (exceto os de cemitério) são privados. ${ }^{484}$

Força é inferir, portanto, que a continuidade é inerente a todo serviço público essencial ${ }^{485}$, assim considerado pela Lei 7.783/89, independentemente do agente prestador, verdadeiro pressuposto basilar inviolável.

\subsection{Continuidade $\mathrm{x}$ inadimplemento}

Saliente-se, como acima exposto, que a continuidade é ínsita aos serviços públicos essenciais; porém como fazer se o particular (consumidor) não paga pela prestação? É legítimo o corte do fornecimento como forma de cobrança?

Há de se ressaltar, prima facie, que a Constituição Federal impõe à Administração, na forma da lei, a prestação do serviço público (art. $175^{486}$ ), ao mesmo tempo que não assegura ao usuário nenhuma possibilidade de negociação ou de escolha; ao revés, o usuário é compelido a aceitar o fornecimento tal qual lhe é outorgado, ainda mais se se tratar de serviço essencial (necessário).

Em rigor, portanto, não são o preço e o seu pagamento que determinam a prestação do serviço público, mas a lei. Ou seja, com ou sem pagamento do

\footnotetext{
483 Comentários..., cit., p. 330.

${ }^{484}$ Adalberto Pasqualotto. Os serviços públicos..., cit., p. 139.

485 "A interrupção indevida da prestação de serviços de telefonia gera danos morais que devem ser reparados”. (TJSP, AC 992.05.138362-3, rel. Emanuel Oliveira, j. 02.02.2010).
} 
preço (tarifa), o Estado não pode eximir-se de prestar o serviço público, como determina a lei. $^{487}$

Irrepreensível, neste passo, o magistério do saudoso e genial publicista Geraldo Ataliba no sentido de que, “(...) se o serviço é público, deve ser desempenhado por força da lei, seu único móvel. O pagamento (taxa) é-lhe logicamente posterior e acidental". 488

Diversa não poderia ser a conclusão, pois, se para a manutenção do meio ambiente, da saúde, e da vida sadia do indivíduo hão de ser fornecidos serviços públicos essenciais, eles só podem ser ininterruptos. Ressai, pois, à evidência, que esses bens maiores não podem ser sacrificados em função de um bem de categoria inferior: suposto direito de crédito, sob pena de se legitimar a proliferação de problemas de saúde pública. ${ }^{489}$

Sem embargo dessas ponderáveis razões, alguns autores ${ }^{490}$ e parte da jurisprudência ${ }^{491}$ insistem na legalidade do corte do fornecimento de serviço público essencial como decorrência direta da inadimplência do usuário consumidor.

Até certo ponto, aparentemente, têm eles razão, visto que a Lei 8.987/95, ao disciplinar o regime de concessão e permissão dos serviços públicos, não considera descontínuo o serviço ante o inadimplemento do usuário, considerando o interesse da coletividade (art. $6^{\circ}, \S 3^{\circ}$ ).

Todavia, o interesse da coletividade que permite a interrupção do fornecimento do serviço público essencial - garantido constitucionalmente - só pode ser a fraude praticada pelo usuário, único compatível com a dignidade da pessoa humana, com a justiça, com a solidariedade e com a defesa do consumidor. O importante, neste tema, é esclarecer a confusão entre o direito de crédito que tem o fornecedor (vinculado ao risco da sua atividade) e o direito que ele não tem de cessar a prestação do serviço. ${ }^{492}$

\footnotetext{
${ }^{486} \mathrm{CF}$, art. 175: "incumbe ao Poder Público, na forma da lei, diretamente ou sob regime de concessão ou permissão, sempre através de licitação, a prestação de serviços públicos”.

${ }^{487}$ Luiz Antonio Rizzatto Nunes. Comentários..., cit., p. 335.

${ }^{488}$ Hipótese de incidência tributária. $2^{\mathrm{a}}$ ed. São Paulo: RT, 1975, p. 180.

${ }^{489}$ Luiz Antonio Rizzatto Nunes. Comentários ..., cit., p. 330/334.

490 José Geraldo Brito Filomeno e Zelmo Denari et alii. Código Brasileiro de Defesa do Consumidor..., cit., p. 56 e 141 e Jorge Alberto Quadros de Carvalho Silva, Código de Defesa do Consumidor anotado. São Paulo: Saraiva, 2001, p. 82.

${ }^{491}$ TJSP, AC 163.347-1, j. 21.05.1992 e $1^{\text {o }}$ TacCiv/SP, Apel. 725.643-5, j. 18.11.1998.

${ }^{492}$ Luiz Antonio Rizzatto Nunes. Comentários ..., cit., p. 331.
} 
Com sabedoria e argúcia, adverte e elucida o professor doutor Luiz Antonio Rizzatto Nunes:

"Não se pretende simplesmente tirar-lhe o direito de receber o quantum relativo ao fornecimento do serviço. Ele pode, é claro, receber seu crédito. Mas esse crédito, para ser cobrado, está também submetido às regras instituídas no CDC.

A cobrança não pode ser abusiva (art. 42, c/c o art. 71). E, como se verá, nos comentários ao art. 42, exatamente uma ameaça ilegal de cobrança é a do corte do serviço essencial. E pior: o corte efetivo com o intuito de forçar o consumidor inadimplente ao pagamento é uma concreta violação. Em ambos os casos, tipificado como crime no art. 71.

A nosso ver só há um caminho para o prestador do serviço essencial suspender o fornecimento do serviço essencial: é ele propor ação judicial para cobrar seu crédito e nessa ação comprovar que o consumidor está agindo de má-fé ao não pagar as contas. Pode haver, inclusive, pedido de antecipação de tutela ou pedido de liminar em cautelar, se o fornecedor-credor puder demonstrar a má-fé do consumidor."493

Exige o Estado Democrático de Direito que o prestador de serviço público essencial, como qualquer outra pessoa, peça autorização ao Poder Judiciário para promover o corte, caso contrário, manifesta será a ilegalidade do ato e o constrangimento do consumidor.

Essa foi, de início, a postura adotada pelo $\mathrm{STJ}^{494}$, que mesmo alterando sua jurisprudência para permitir a sustação desse fornecimento essencial, se não pagas as contas atuais e dês que prévia e adequadamente notificado o consumidor ${ }^{495}$, acabou definindo que tal conduta é impossível caso se trate de dívida pretérita, ou seja, apenas diferenças de consumo ${ }^{496}$, no que vem sendo acompanhado pelo TJSP. ${ }^{497}$

\footnotetext{
${ }^{493}$ Curso..., cit., p. 111.

494 STJ, REsps. 353.796/MA, j. 11.12.2001; 122.812/ES, j. 05.12.2000; 223778/RJ, j. 07.12.1999; 209.652/ES, j. 19.10.1999; 201112/SC, j. 20.04.1999; AGREsp. 298017/MG, j. 03.04.2001; AGA 307.905/PB, j. 10.10.2000 e ROMS 8.915/MA, j. 12.05.1998.

495 STJ, REsps. 1.065.323/RS, j. 05.08.2010; 962.366/RS, 27.10.2009; 805.113/RS, j. 23.09.2008; 800.586/RS, j. 23.09.2008; 783.575/RS, j. 09.09.2008 e AgRg nos EDcl no REsp. 1.078.096/MG, 28.04.2009.

496 “ 1 . Discute-se, na presente controvérsia, da possibilidade de corte no fornecimento de energia elétrica, em face de dívida decorrente de diferenças de consumo que geraram a fiscalização, e a constatação unilateral de irregularidades no aparelho de medição. 2. Há ilegalidade na interrupção no fornecimento de energia elétrica
} 


\subsection{Consumidor $\mathrm{x}$ contribuinte}

Duas posições exsurgem bem definidas da doutrina nesta temática: a) qualquer serviço público, em tese, pode ser objeto de uma relação de consumo e b) apenas aqueles serviços públicos especificamente remunerados encontram disciplina na Lei 8.078/90.

Para Adalberto Pasqualotto, “(...) não são abrangidos no CDC os serviços públicos próprios, prestados uti universi diretamente pelo Estado, mantido pelos tributos gerais, porque lhes falta, sob a ótica do Código do Consumidor, o requisito da remuneração específica. Segundo esse mesmo critério, os serviços públicos impróprios, prestados direta ou indiretamente pelo Estado ou, ainda, por meio de concessão, autorização ou permissão, estão sob a tutela do CDC, porque remunerados pelo pagamento específico de taxas ou tarifas". 498

\section{Contrapõe-se o douto Luiz Antonio Rizzatto Nunes,} reconhecendo que se pode: “(...) é verdade, objetar que, se o consumidor não paga diretamente pelo serviço, a lei está excluída da relação, porque o $\S 2^{\circ}$ do art. $3^{\circ}$ fala que o serviço é prestado mediante remuneração. Mas, como tivemos oportunidade de demonstrar quando da análise daquela norma, o fato de não existir pagamento direto (por exemplo, estacionamento grátis do shopping center) não exclui a norma da relação, pois o que vale é

nos casos de dívidas contestadas em Juízo - decorrentes de suposta fraude no medidor do consumo de energia elétrica -, uma vez que o corte configura constrangimento ao consumidor que procura discutir no Judiciário débito que considera indevido. Precedentes. 3. Para solucionar tal controvérsia existem meios ordinários de cobrança, razão pela qual a interrupção do serviço implica infringência ao disposto no art. 42, caput, do Código de Defesa do Consumidor" (STJ, REsp. 708.176/RS, rel. Min. Humberto Gomes de Barros, j. 21.08.2007). "Assentando o aresto recorrido que 'o que está em debate é se a agravada praticou ato ilícito, ou seja, violação de lacre. Nesse passo, forçoso convir que o caso em exame não é de inadimplência pelo não pagamento de fatura mensal de consumo de energia elétrica e, sim, de discussão sobre a procedência dos lançamentos das diferenças apuradas pela agravante, o que impede, ao menos por ora, a interrupção do fornecimento de energia elétrica' (...) Deveras, nesse particular, não merece reparo a decisão objurgada. Isto porque, a situação sub judice não versa sobre inadimplemento de conta regular, mas antes de cobrança de diferença de tarifa, relativa a débitos antigos não-pagos, para os quais há meios ordinários de cobrança, por isso que a estagnação do serviço implica infringência ao disposto no art. 42, caput, do Código de Defesa do Consumidor” (STJ, EDcl no REsp. 765.591/DF, rel. Min. Luiz Fux, j. 29.06.2006).

497 “Antecipação de tutela. Proibição da suspensão do fornecimento de energia elétrica. Cabimento no tocante ao débito decorrente de diferenças consequentes à apuração de fraude na marcação do consumo, mas não quanto ao originado da falta de pagamento das faturas regulares. Recurso parcialmente provido" (TJSP, AI 1.008.480-0/9, rel. Arantes Theodoro, j. 16.03.2006).

498 Os serviços públicos..., cit., p. 145. Cf., no mesmo sentido Newton de Lucca. Direito do consumidor. Aspectos práticos..., cit., p. 133/134. 
o conceito de custo para a oferta do serviço e este é repassado direta ou indiretamente para o consumidor final". 499

Orienta-se, no entanto, a jurisprudência do $\mathrm{STJ}^{500}$, negando a equivalência entre o contribuinte e o consumidor ${ }^{501}$, para a primeira corrente e, com isso, reconhece na Ação Civil Pública o remédio jurídico adequado à tutela dos interesses individuais homogêneos tão-só quando seus titulares sofrerem danos como consumidores, não como contribuintes. ${ }^{502}$

Perfilhou o mesmo entendimento a plenária do Augusto STF ao interpretar a quaestio. ${ }^{503}$

5.4 Responsabilidade do agente prestador

É claro que o agente (fornecedor) é responsável, em especial no que toca à natureza da sua atividade, pelos eventuais vícios e defeitos dos serviços públicos por ele prestados, sem embargo do comando específico insculpido no art. $37, \S 6^{\circ}$, da Constituição Federal. ${ }^{504}$

Por este prisma, ainda ficam reservados a eles os mesmos regimes dos arts. 14 e 20 do $\mathrm{CDC}^{505}$; contudo, só para cumprir (total ou parcial) a obrigação inadimplida e/ou para reparar os danos causados, haja vista não existir espaço para restituição ou abatimento.

Salienta, a propósito, Zelmo Denari que, “(...) os órgãos públicos recebem tratamento privilegiado, pois não se sujeitam às mesmas sanções previstas no art. 20 para os fornecedores de serviços. De fato, o parágrafo único somente faz referência ao cumprimento do dever de prestar serviços de boa qualidade, o que afasta

\footnotetext{
${ }^{499}$ Comentários..., cit., p. 340.

500 “Os serviços públicos prestados pelo próprio Estado e remunerados por taxa devem ser regidos pelo CTN, sendo nítido o caráter tributário da taxa. Diferentemente, os serviços públicos prestados por empresas privadas e remuneradas por tarifas ou preço público regem-se pelas normas de Direito Privado e pelo CDC" (STJ, REsp. 463.331/RO, rel. Min. Eliana Calmon, j. 06.05.2004). No mesmo sentido: REsps. 229.526/PR, j. 25.09.2001; 248.281/SP, j. 02.05.2000; 86.381/RS, j. 14.09.1999; 134.744/MG, j. 19.08.1999; 178.408/SP, j. 17.08.1999; 172.558/ES, j. 13.10.1998; 115.500/PR, j. 02.06.1998; 97.455/SP, j. 10.12.1996; EREsps. 106.993/MS, j. 01.09.1999 e 181.892/MG, j. 10.04.2000 e AGREsp. 333.016/PR, j. 23.10.2001.

${ }^{501}$ STJ, REsp. 169.602/SP, rel. Min. Francisco Peçanha Martins, j. 16.08.2001.

${ }^{502}$ STJ, AGREsp. 325.528/MT, rel. Min. José Delgado, j. 11.09.2001.

${ }^{503}$ STF, RE 195.056-1/PR, rel. Min. Carlos Velloso, j. 09.12.1999.

${ }^{504} \mathrm{CF}$, art. $37, \S 6^{\circ}$ : "as pessoas jurídicas de direito público e as de direito privado prestadoras de serviços públicos responderão pelos danos que seus agentes, nessa qualidade, causarem a terceiros, assegurado o direito de regresso contra o responsável nos casos de dolo ou culpa".
} 
as alternativas da restituição da quantia paga e do abatimento do preço, envolvendo somente a reexecução dos serviços públicos defeituosos". ${ }^{506}$

\subsection{A assinatura básica de telefonia}

Conquanto esteja pacificado na jurisprudência infraconstitucional que é legítima a cobrança de tarifa básica pelo uso dos serviços de telefonia fixa ${ }^{507}$, na linha do que já se sustentou em outra oportunidade ${ }^{508}$, acredita-se ainda serem pertinentes algumas observações sobre o tema.

\subsubsection{Dinâmica fático-jurídica proposta pelas operadoras}

A Carta Magna reservou à União a exclusiva competência para explorar, diretamente ou mediante autorização, concessão ou permissão, os serviços de telecomunicações, nos termos da lei, que disporá sobre a organização dos serviços, a criação de um órgão regulador e outros aspectos institucionais (arts. 21, XI c.c. 175, caput).

Sobreveio, por força dessa autorização e sem prejuízo - é claro - do regime geral de concessões previsto na Lei 8.987/95, a Lei 9.472/97, responsável pela criação da Agência Nacional de Telecomunicações (Anatel) e pelo balizamento das suas atribuições, inclusive quanto à estrutura tarifária para cada modalidade de serviço (arts. $8^{\circ}$ c.c. 19 , caput, c.c. seu inciso VII, c.c. 103 , caput, c.c. seu $\S$ $3^{\circ}$, c.c. 105$)$.

Legitimada, portanto, na ótica das operadoras, a criação (com amparo em ato do Ministério das Telecomunicações ${ }^{509}$ ) - pela Anatel - do fato oponível tratado como tarifa ou preço de assinatura, é dizer, "valor de trato sucessivo pago pelo

\footnotetext{
${ }^{505}$ Luiz Antonio Rizzatto Nunes. Comentários..., cit., p. 341.

${ }^{506}$ Et alii. Código Brasileiro de Defesa do Consumidor..., cit., p. 142.

${ }^{507}$ STJ, Súm. 356.

${ }^{508}$ Guilherme Ferreira da Cruz. A ilegalidade da abusiva tarifa de assinatura mensal do serviço de telefonia fixa e o consequente direito à repetição do indébito. Revista de Direito do Consumidor, São Paulo: RT, v. 55, jul.-set. 2005, p. 371/384.

${ }^{509}$ Ports. 216 e 217, ambas de 03.04.1997, do Ministério das Comunicações (Anexo 03, i. 2.2).
} 
Assinante à Prestadora, durante toda a prestação do serviço, nos termos do contrato de prestação de serviço, dando-lhe direito à fruição contínua do serviço". 510

Daí a licitude, nessa linha de pensamento, da viga específica dos contratos de concessão ${ }^{511}$ e de prestação singular.

O raciocínio proposto é aparentemente lógico e deveras sedutor; contudo, per se, faz exsurgir hiato fatal - como se verá adiante - às suas pretensões: é que a tarifa de assinatura não encontra, de modo expresso, base de ressonância na Lei 9.472/97.

À míngua de hipótese legal típica autorizante, não há falar em constitucionalidade do sistema face à política tarifária prevista - de modo abstrato - para os serviços delegados por concessão ou por permissão. ${ }^{512}$

5.5.2 Natureza jurídica da chamada tarifa de assinatura

Mas o que é, então, essa tarifa de assinatura? Duas possibilidades, inconfundíveis ${ }^{513}$, avultam do senso comum neste pormenor: ou taxa ${ }^{514}$ ou tarifa (também conhecida como preço público).

Servindo ambas como forma de remunerar a prestação de serviço público uti singuli (de uso particular e mensurável), apenas a espécie normativa determinante poderá definir, no caso concreto, a natureza do fato oponível.

Alerta Sacha Calmon: “a realidade está em que os serviços públicos de utilidade, específicos e divisíveis, podem ser remunerados por preços (regime contratual) ou por taxas (regime de Direito Público). O dilema resolve-se pela opção do legislador. Se escolher o regime tributário das taxas, ganha a compulsoriedade do tributo, inclusive pela mera disponibilidade do serviço, se prevista a sua utilização compulsória (CTN, art. 79, I, 'b'), mas fica manietado pelas regras de contenção do poder de tributar (...) Se escolher o regime contratual, perde a compulsoriedade da paga pela mera disponibilidade do serviço, mas ganha elasticidade e imediatez na fixação das tarifas, sistema aceito previamente pelo usuário ao subscrever o contrato de adesão, liberando,

\footnotetext{
${ }^{510}$ Res. 85/98, art. $3^{\circ}$, XXI.

${ }^{511}$ Cap. X, cláusula 10.1, caput e seu par. ún., c.c. Anexo 03, i. 2.2.

${ }^{512} \mathrm{CF}$, art. 175 , caput, c.c. seu par. ún., III.

${ }^{513}$ STF, Súm. 545.

${ }^{514} \mathrm{CF}$, art. 145 , II, c.c. CTN, art. 77.
} 
assim, o controle congressual e a incidência das regras constitucionais de contenção ao poder de tributar. Ao jurista, cujo objeto primordial é o Direito posto, cabe distinguir a taxa do preço exatamente pelo regime jurídico de cada qual. O preço é contratualmente acordado. A taxa é unilateralmente imposta pela lei. O primeiro parte da autonomia da vontade. A segunda é heterônoma". 515

Ao negar a natureza tributária da tarifa de assinatura - até porque criada por mera resolução ${ }^{516}$ - as concessionárias intentam fazer em seu único e exclusivo benefício uma espécie de mix entre essas duas modalidades, separando o que cada uma tem de mais vantajoso.

Ou, em outras palavras, querem - a um só tempo - o pagamento compulsório pela mera disponibilidade da taxa e o flexível regime contratual da tarifa, o que é inaceitável. ${ }^{517}$

Bom. Se a assinatura mensal não tem essência tributária ${ }^{518}$ o que afasta a idéia de taxa e com ela a do pagamento compulsório pela mera disponibilidade - resta saber se ela encerra os contornos mínimos indispensáveis à caracterização de tarifa; todavia, por incrível que pareça, a resposta também é negativa.

Isto porque as tarifas - autêntico preço público regido pelo direito privado - dependem da efetiva utilização do serviço pelo consumidor (e não contribuinte) para galgarem exigibilidade; logo, é o serviço que deve ser remunerado e não o direito à sua fruição contínua. ${ }^{519}$

É dizer: o serviço fixo pontual (stricto sensu) já é remunerado - e bem, advirta-se - pelo método de cômputo dos pulsos.

\footnotetext{
${ }^{515}$ Curso de direito tributário brasileiro. Rio de Janeiro: Forense, 1999, p. 415.

${ }^{516}$ Res. 85/98 da Anatel, art. $3^{\circ}$, XXI.

517 Destacam Renato Franco de Almeida e Aline Bayeri Coelho (Assinatura nos serviços de telefonia: ilegalidade. Disponível em http://www1.jus.com.br/doutrina/texto.asp?id=5700): “(...) ao cobrar quantias de forma compulsória e pela simples disponibilidade do serviço através da chamada assinatura, as operadoras auferem vantagens duas vezes: uma, porque cobram valores sem que haja a efetiva utilização do serviço pelo consumidor, ou seja, pela mera disponibilidade, como se verdadeira taxa fosse - o que no caso deste serviço ensejará enriquecimento sem causa para as respectivas operadoras, uma vez que efetivamente não prestaram serviço algum; duas, não arcam com as agruras próprias das taxas como espécie tributária, quais sejam, previsão e majoração somente através de lei em sentido estrito (princípio da legalidade tributária), aumento do valor somente de forma anual (princípio da anuidade), desembaraço das regras constitucionais limitatórias do poder de tributar (limites ao poder de tributar), etc".

${ }^{518}$ Em casos similares (tarifa de energia elétrica) confira-se a orientação do STJ: REsp. 252.915/DF, j. 15.06.2000 e REsp. 168.411/SP, j. 20.08.1998.

${ }^{519}$ Paulo Andreatto Bonfim. Considerações sobre a ilegalidade da tarifa de assinatura mensal de telefone fixo. Disponível em http://www1.jus.com.br/doutrina/texto.asp?id=5701.
} 
Força é concluir, nesta quadra, que a manutenção e a disponibilização da rede de telefonia - sem as quais não seria possível a exploração do negócio proposto, como é óbvio - representam meras atividades preparatórias ao serviço de comunicação, e não o serviço remunerável propriamente dito.

Tanto é assim que as concessionárias não recolhem, a esse título, ICMS. Este é o entendimento do STJ como se infere do REsp. 402.047/MG, de 04.11.2003, da relatoria do Min. Humberto Gomes de Barros. ${ }^{520}$

Desprovida de serviço stricto sensu que lhe outorgue suporte, a assinatura mensal também não é tarifa, encontrando-se fora do âmbito de tutela da Lei Geral das Telecomunicações: o serviço efetivamente prestado $^{521}$, inclusive aqueles adquiridos de modo específico (v.g., identificador de chamadas, despertador, etc.).

\subsubsection{Impossibilidade de cobrança}

Ora, com isso, sua viga de sustentação é tão-só a base contratual encontrada no vínculo estabelecido entre a concessionária e o particularconsumidor (e não contribuinte); entretanto, via de regra, suas cláusulas não obrigam os aderentes (CDC, art. 46), seja porque o acesso ao instrumento padrão é apenas presumido, seja porque nem mesmo neles se lê - de modo claro (CDC, art. 54, caput, c.c. seus $\S \S 3^{\circ} \mathrm{e}$ $4^{\mathrm{o}}$ ) - algo sobre a tarifa de assinatura.

\footnotetext{
520 “A interpretação conjunta dos dispositivos (LC 87/96; art. 2º III c/c art. 12, VI) aponta que o ICMS somente incide sobre os 'serviços de comunicação' propriamente ditos, no momento das respectivas prestações. Há 'serviço de comunicação' quando um terceiro, mediante prestação negocial-onerosa, mantém interlocutores (emissor/receptor) em contato 'por qualquer meio, inclusive a geração, a emissão, a recepção, a transmissão, a retransmissão, a repetição e a ampliação de comunicação de qualquer natureza'. Os meios necessários à consecução deste fim não estão ao alcance da incidência do ICMS-comunicação. A Cláusula Primeira do Convênio ICMS 69/98 diz que 'os signatários firmam entendimento no sentido de que se incluem na base de cálculo do ICMS incidente sobre prestações de serviços de comunicação os valores cobrados a título de acesso, adesão, ativação, habilitação, disponibilidade, assinatura e utilização dos serviços, bem assim aqueles relativos a serviços suplementares e facilidades adicionais que otimizem ou apliquem o processo de comunicação, independentemente da denominação que lhes seja dada'. A Lei faz incidir o ICMS sobre 'serviços de comunicação', em cujo conceito se inserem os de telecomunicações. A interpretação do art. $2^{\circ}$, III, da LC 87/96, indica que só há incidência de ICMS aos serviços de comunicação 'stricto sensu', onde não se incluem os serviços meramente acessórios ou preparatórios à comunicação propriamente dita. A hipótese de incidência do ICMS-comunicação (LC 87/96; art. 2º III) não permite a exigência do tributo com relação a atividades meramente preparatórias ao 'serviço de comunicação' propriamente dito, como são aquelas constantes na Cláusula Primeira do Convênio ICMS 69/98. Tais serviços configuram, apenas, meios de viabilidade ou de acesso aos serviços de comunicação. Assim, estão fora da incidência tributária do ICMS."

521 Vale lembrar que a Lei 9.472/97, em seu art. 103, outorgou à Anatel apenas a competência para estabelecer a estrutura tarifária para cada modalidade de serviço, o que se renova no art. 105.
} 
Irrelevante, da mesma forma, a previsão da tarifa de assinatura em atos administrativos genéricos (resoluções, portarias, etc.), sobretudo porque incapazes de determinar padrões de comportamento positivos e/ou negativos, pena de nítida afronta ao primado da legalidade (CF, art. $\left.5^{\circ}, \mathrm{II}\right)$.

Mas não é só. Ainda que ultrapassados os aludidos obstáculos, essa cobrança - sem a necessária contraprestação - se revela excessivamente onerosa para o tomador dos serviços de telefonia, verdadeira afronta à boa-fé objetiva e à equidade (CDC, art. 51, IV, XV, c.c. seu $\S 1^{\circ}$, I, II e III), notadamente porque a tarifa de habilitação já se presta (junto com o preço dos pulsos), por óbvio, a manter em ordem as redes do STFC.

É que - em sendo o preço formado pelo custo da produção/manutenção do produto/serviço, acrescido de uma margem de lucro - resta inviável às concessionárias a cobrança em separado do consumidor de outros custos (não especificados nem, em geral, provados) decorrentes da mesma prestação de serviços (atos preparatórios), já remunerada pela medição dos pulsos ou por regra específica, se adicionais.

Pensar-se o contrário seria a consagração do bis in idem.

Clara como o sol que reluz, pois, a abusividade de cláusula contratual que obriga pelo pagamento de serviços sem a respectiva prestação ${ }^{522}$, até porque - utilizando ou não o mínimo de pulsos franqueados - o consumidor suportará nova desvantagem exagerada quando do pagamento do preço cheio da tarifa de assinatura (sem compensação do excedente), o que também não se pode admitir.

Observe-se, tal qual visto (supra, 5.1), que o serviço de telecomunicações é do tipo público essencial e, por isso, traz ínsita à sua prestação a continuidade - princípio explícito de atuação, autêntico dever imposto às concessionárias $^{523}$ - sem condicioná-la ao pagamento de nenhuma tarifa (já que ela não é um fim em si mesma) além do preço devido por força da utilização efetiva dos serviços stricto sensu.

Só a partir daí é que se pode definir a exata inteligência da perseguida universalização que, por certo, não se identifica com a paradoxal realidade imposta pelo sistema: o particular que menos utiliza o serviço (custo inferior à franquia)

${ }^{522} 1^{\text {o }}$ TacCiv/SP, Apel. 991.254-7, rel. Massami Uyeda, j. 31.07.2001. 
pagará mais, proporcionalmente, pela infraestrutura montada do que aquele outro que consumiu além dos 90 ou 100 pulsos incluídos na assinatura.

A prevalecer tal raciocínio, data venia, estar-se-ia dando margem para outras - até hoje impensáveis - situações. Confiram-se, verbi gratia, alguns paralelos:

a) como o serviço de transporte público também está à disposição do particular ininterruptamente, possível seria cogitar-se de uma tarifa de assinatura para manter o sistema, sem prejuízo - por óbvio - do preço da passagem quando do uso efetivo, já calculado para cobrir todos os custos da atividade;

b) quem sabe, talvez, até uma tarifa de assinatura decorrente da manutenção e da disponibilização de estradas transitáveis 24 horas por dia, afinal de contas a qualquer tempo o consumidor pode delas precisar, seja para o seu próprio deslocamento (uso direto), seja para o de um parente ou conhecido (uso indireto). O pedágio seria apenas um plus em face da remuneração.

Já que é tão nítida a incongruência proposta nestas bases hipotéticas, por que com o serviço de telefonia fixa seria diferente?

De fato, pretendem as operadoras - esquecendo que foi opção sua, corolário da livre iniciativa ( $\mathrm{CF}$, art. 170, par. ún.), a exploração de atividade pública essencial (onde a disponibilização integra o próprio sistema) - atuar no mercado sem riscos, ou seja, auferindo renda certa e segura mesmo sem prestar o serviço de comunicação típico.

A peculiar situação ganha contornos ainda mais impressionantes se os paradigmas forem pinçados da estrita ação negocial privada, pois não há dúvida que o custo operacional de bancos, de farmácias, de lanchonetes, de pizzarias, de restaurantes, de academias de ginástica, etc. - funcionando ou não 24 horas por dia, com ou sem prestação de serviços - é única e exclusivamente do fornecedor, sendo teratológico supor a legalidade de uma tarifa de assinatura para a divisão desse ônus com os consumidores.

Ora, o risco do empreendedor - independentemente da natureza do serviço fornecido (público ou privado) - é intransferível (CDC, arts. 51, I, III e $\mathrm{XV}$ ), em nada alterando o deslinde da quaestio o fato de serem as operadoras empresas

${ }^{523}$ Lei $9.472 / 97$, arts. 79 , caput, c.c. seu $\S 2^{\circ}$, c.c. 93 , IV, c.c. CDC, art. 22, caput. 
concessionárias (Lei 8.967/95, art. 25), ou os termos do contrato administrativo celebrado, à revelia dos particulares, entre elas e a agência reguladora.

A eventual necessidade de se restabelecer o equilíbrio financeiro do contrato (a equação originária) nem de longe prejudica os interesses dos consumidores, constitucionalmente protegidos.

E se alguém usar o terminal apenas para receber ligações (circunstância improvável), por certo, aquele que as fizer remunerará o serviço consumido; aliás, outro não é o negócio explorado.

\subsubsection{Repetição do indébito}

Com o saneamento da relação jurídica na forma proposta ${ }^{524}$, estariam as operadoras obrigadas a restituir o que receberam indevidamente (CDC, art. 42, par. ún., c.c. CC, art. 876), dispensada a prova do erro, visto que - nos contratos como o da espécie - os lançamentos são efetuados unilateralmente pela fornecedora na fatura mensal. $^{525}$

No entanto, a devolução do indébito - diferença entre aquilo que foi pago a título de tarifa de assinatura e o valor devido por força dos pulsos efetivamente utilizados, será simples e não em dobro, haja vista o engano justificável gerado tanto pelo contrato de concessão quanto pelos atos administrativos autorizantes (resolução da Anatel e portarias do Ministério das Telecomunicações).

Se por um lado é ilegal a cobrança da tarifa de assinatura nos serviços de telefonia fixa, não menos certo é que esta realidade há muito existe em nosso país, não constituindo inovação provocada pelas empresas concessionárias que, de certa forma, acreditaram na política regulamentar do Governo Federal.

Por este prisma, conquanto sua lógica de incidência seja de ordem subjetiva - pela qualidade da parte - isto é, visa à proteção do consumidor, a Lei 8.078/90 reconhece a necessidade do equilíbrio nas relações de consumo (CDC, art. $4^{\circ}$, caput, c.c. seu inciso III), circunstância que acaba garantindo ao fornecedor um certo espaço de proteção.

\footnotetext{
${ }^{524}$ Já acolhida em pelo menos duas oportunidades pelo Min. Herman Benjamin, tal qual se infere dos seus votos vencidos declarados quando dos julgamentos, no STJ, dos REsps. 1.068.944/PB, j. 12.11.2008, e 911.802/RS, j. 24.10.2007.
} 
Daí o equilíbrio permitir às fornecedoras - que tanto investiram e incrementaram o setor de telecomunicações do país - se programem dentro desse quadro, inclusive com nova avaliação do custo operacional - tudo, à evidência, sem nenhuma possibilidade de abuso do poder econômico tendente ao aumento arbitrário dos lucros. $^{526}$

Ou seja: o consumidor é que define - com a propositura da ação de regência - o marco inicial da sua discordância com o pagamento da tarifa de assinatura.

${ }_{525}^{5}$ STJ, REsp. 176.459/RS, rel. Min. Ruy Rosado de Aguiar, j. 23.11.1998.

${ }^{526} \mathrm{CF}$, arts. 170 , V, c.c. 173 , $\S 4^{\circ}$, c.c. CDC, arts. $4^{\circ}$, VI, c.c. $6^{\circ}$, IV. 


\title{
CAPÍTULO IV O MÍNIMO ÉTICO EXIGÍVEL
}

\begin{abstract}
SUMÁRIO: 1. BOA-FÉ (noções gerais) - 2. EVOLUÇÃO HISTÓRICA - 3. OBJETIVAÇÃO DA BOA-FÉ NO DIREITO COMPARADO - 4. EXPERIÊNCICA BRASILEIRA - 5. BOAFÉ SUBJETIVA X OBJETIVA - 6. A BOA-FÉ OBJETIVA E SUAS FUNÇÕES - 7. O CDC E SUAS CLÁUSULAS ESPECÍFICAS - 8. INCIDÊNCIA AMPLA E IRRESTRITA - 9. O SEGURO-SAÚDE E AS FALSAS DECLARAÇÕES - DIREITO DE ARREPENDIMENTO.
\end{abstract}

1. BOA-FÉ (noções gerais)

Com efeito, a inter-relação humana deve se pautar por um padrão ético de confiança e lealdade, indispensável ao próprio desenvolvimento da convivência social. A expectativa de um comportamento adequado por parte do outro é uma postura indissociável da vida de relação, pressuposto da sua viabilidade. Isso significa que as pessoas devem adotar uma conduta leal já na fase que antecede a constituição do contrato (diligência in contrahendo); e que devem assim permanecer no desenvolvimento das relações jurídicas constituídas. Este dever de se comportar segundo a boa-fé se projeta nas direções em que se diversificam todas as relações jurídicas: direitos e deveres. Os direitos devem ser exercitados de boa-fé; as obrigações têm de ser cumpridas de boa-fé. ${ }^{527}$

Ressalte-se que tal exigência, fundada na segurança e na razoabilidade, induz que o comportamento das pessoas há respeitar um conjunto de deveres ligados a uma regra de atuação de boa-fé. Foi crescendo, portanto, uma noção de boa-fé como uma regra de conduta, de ordem geral: em cada situação concreta existe uma idéia, comum inescusável ao homo medio, que - a um só tempo - traça as diretrizes de como ele deve se pautar e cria em seu íntimo uma convicção de previsibilidade sobre o agir dos outros envolvidos. ${ }^{528}$

Mas que boa-fé é essa?

Se o direito privado tradicional foi construído sob duas perspectivas distintas da boa-fé: a boa-fé crença e a boa-fé lealdade (ou probidade), de

\footnotetext{
${ }^{527}$ Ruy Rosado de Aguiar Júnior. Extinção dos contratos por incumprimento do devedor. Rio de Janeiro: Aide, 1991, p. 239.

${ }^{528}$ Bruno Lewicki. Panorama da boa-fé objetiva. In: Tepedino, Gustavo (coord.). Problemas de direito civilconstitucional. Rio de Janeiro: Renovar, 2000, p. 56/57.
} 
conteúdos diametralmente opostos, uma nova concepção - mais antiga do que se pensa irradiou luzes renovadoras ao instituto.

“A boa-fé-crença é aquela que se baseia no erro ou ignorância da verdadeira situação jurídica. É a Guten Glauben dos alemães. (...)

(...) o erro ou ignorância são os pressupostos da convicção ou crença da legalidade ou validade do ato ou da conduta humana. Em outras palavras, a boa-fé é aí precisamente a crença na legalidade da conduta; o erro ou ignorância, que apenas os pressupostos psicológicos desta crença, às vezes são erroneamente identificados com a boa-fé.

De outro lado, essa primeira forma de boa-fé parece, a alguns juristas, ser simplesmente psicológica, mas na realidade é ética no fundo. Pondere-se que nela há sempre a consideração da vontade da pessoa baseada na crença da validade ou legalidade da conduta.

Passemos à segunda forma com que apresenta o fato da boafé na vida jurídica e social - a lealdade, honestidade ou probidade. Nesta feição, o elemento ético (boa intenção que acompanha a conduta leal, honesta) é tão evidente que não necessita ser demonstrado.

A boa-fé-lealdade é, assim, a honestidade e a sinceridade que devem existir no comércio jurídico. É a Treu und Glauben dos tedescos. ${ }^{.529}$

Bem entender a boa-fé hoje é fundamental para transitar por uma teoria do negócio jurídico cada vez mais impregnada pela ética da confiança ${ }^{530}$, pois é ela, como princípio, que dará o critério para a valoração judicial do comportamento. ${ }^{531}$

Neste capítulo, além da amplitude do instituto, ver-se-á sua aplicação direta sobre duas situações da vida muito caras ao consumidor: a) os contratos médicos e b) as chamadas falsas declarações no seguro saúde.

\footnotetext{
${ }^{529}$ Alípio Silveira. A boa-fé no Código Civil. $3^{\mathrm{a}}$ ed. São Paulo: Editora Universitária de Direito, $1972,1^{\text {o }}$ v., p. $07 / 08$.

${ }_{530}$ Paulo da Mota Pinto. Declaração tácita e comportamento concludente no negócio jurídico. Coimbra: Almedina, 1995, p. 29-31.

${ }^{531}$ Clóvis V. do Couto e Silva. A obrigação como processo. São Paulo: Bushatsky, 1976, p. 42.
} 


\section{EVOLUÇÃO HISTÓRICA}

Para uma resposta segura, impõe-se investigar mais profundamente o instituto, sobretudo por ser o direito um produto histórico-social em constante mutabilidade em razão do fluxo inexorável dos fenômenos socioculturais.

O princípio romano da fides, que impunha a abstenção de todo comportamento que pudesse tornar a execução do contrato mais difícil ou onerosa, sem dúvida, marca a remota preocupação dos juristas com a lealdade entre os sujeitos obrigacionalmente envolvidos.

Ressalta Flávio Alves Martins que a estrutura da boa-fé moderna se encontra mesmo na fides romana, ou fid quod dicitur à Cícero, onde se pressupunha saber o que se disse, cumprir o que se diz ou o que se promete; uma nítida exigência de respeito. ${ }^{532}$

Menezes Cordeiro, por sua vez, identificava aí a representação concreta de uma garantia, uma confiança, permeada de objetividade, que atuava como ponto de referência inescusável no cumprimento das obrigações, "a fides bona teria revestido, no período clássico, a natureza de norma jurídica objetiva de comportamento honesto e correto, respeitador da lealdade dos costumes do tráfego". 533

Lógico o raciocínio, pois o causador de uma situação aparente garante e afiança a sua existência ${ }^{534}$. Percebe-se, com isso, que a noção de boa-fé nasceu graduada por elementos de cognição não puramente subjetivos.

"No direito civil, porém, durante a Idade Média, sob a influência do direito canônico, conferiu-se à boa-fé uma tonalidade ética que se equiparava à ausência de pecado, traduzindo-se em um desvio de aplicação; faltar com a palavra empenhada ou não agir de boa-fé era pecado.

Influenciando toda a vida social da Idade Média, o direito canônico, de moral mais severa que o direito romano, somente concedia os benefícios de boa-fé àquele que a tivesse conservado desde o momento do ato inicial até o instante em que a inovasse. Se, nesse ínterim, viesse a saber do erro

\footnotetext{
${ }^{532}$ A boa-fé objetiva e sua formalização no direito das obrigações brasileiro. Rio de Janeiro: Lúmen Juris, 2000, p. 34.

${ }^{533}$ Da boa-fé no direito civil. Coimbra: Almedina, 1984, p. 105.

${ }^{534}$ Otávio Moreira Guimarães. A boa-fé no direito civil brasileiro. São Paulo: RT, 1938, p. 41.
} 
em que incorrera a princípio, não mais poderia se proteger da escusabilidade dos que erravam bona fides. ${ }^{, 535}$

Com a chegada da Idade Moderna acabou ganhando corpo, forte no dogma da supremacia da autonomia da vontade, a face subjetiva da boa-fé; aliás, consagrada no Code Napoléon de 1804, diploma que sem dúvida influenciou sensivelmente uma série de ordenamentos jurídicos, do Brasil inclusive, pois - segundo Caenagem - marca uma ruptura decisiva na evolução gradual do direito. ${ }^{536}$

Essa filosofia perdurou durante o século XIX, amparada na chamada Escola da Exegese ${ }^{537}$, que buscava preservar o legalismo e a codificação a todo custo, circunstância impeditiva tanto do desenvolvimento do caráter objetivo da boa-fé quanto da atividade criadora do juiz, reduzindo seu espectro de incidência praticamente ao campo dos direitos das coisas (v.g., usucapião ${ }^{538}$, frutos ${ }^{539}, \operatorname{posse}^{540}$, retenção e indenização por benfeitorias $^{541}$, etc.).

"A Escola da Exegese, re-elaborando o princípio da completude de antiga tradição romana medieval, levou às últimas consequências o mito do monopólio estatal da produção legislativa, de tal sorte que o direito codificado esgotava o fenômeno jurídico, em todas as suas manifestações. Assinale-se o fetichismo da lei e, mais ainda, o fetichismo do Código Civil para as relações de direito privado (...).,"542

Para Norberto Bobbio, “(...) o caráter peculiar da escola da exegese é a admiração incondicional pela obra do legislador por meio da codificação, uma confiança cega na suficiência das leis, em definitivo a crença que o Código, uma vez emanado, basta completamente a si próprio. A miragem da codificação é a completude:

\footnotetext{
${ }^{535}$ Flávio Alves Martins. A boa-fé objetiva..., cit., p. 40-41.

${ }^{536}$ R. C. Van Caenagem. Uma introdução histórica ao direito privado. Trad. Carlos Eduardo Machado. São Paulo: Martins Fontes, 1995, p.1.

${ }^{537}$ Escola de interpretação jurídica surgida na França, na qual o intérprete é um escravo da lei. Segundo seu conteúdo, os códigos não deixavam nada ao arbítrio do intérprete, que não tinha a missão de elaborar o direito, pois este já estava pronto em textos autênticos.

${ }^{538} \mathrm{CC} / 16$, arts. 551 c.c. 618 .

${ }^{539} \mathrm{CC} / 16$, arts. 510 usque 513.

${ }^{540} \mathrm{CC} / 16$, arts. 490 c.c. 491.

${ }^{541} \mathrm{CC} / 16$, arts. 516 c.c. 517.

542 Gustavo Tepedino. O Código Civil, os chamados microssistemas e a Constituição: premissas para uma reforma legislativa. In: Tepedino, Gustavo (coord.). Problemas de direito civil..., cit., p. 01/02.
} 
uma regra para cada caso. O Código é para o juiz um prontuário que lhe deve servir infalivelmente e do qual não pode se afastar". 543

Foi o Código Civil alemão $(B G B)$, fundamentado no seu tríplice alicerce (o direito romano, a ética cristã e o direito germânico), que inovou ao reavivar a concepção romana de boa-fé, agora endereçada ao juiz, como se antigo pretor fosse, que terá no seu processo intelectual interpretativo de criação um valor autônomo não relacionado com a vontade dos sujeitos envolvidos.

Com pena de mestre, elucida o jurista Wanderlei de Paula Barreto que, "a redação do $\S 242$ formalmente restringente ao sujeito passivo da relação obrigacional não exaure o âmbito de aplicação da norma. Ao contrário, dirige-se o seu comando, em combinação com os $\S \S 133,157$ e 826 BGB, a todo aquele que exercer direitos ou cumprir obrigações e deveres jurídicos, impondo-lhes fazê-lo segundo exige o princípio Treu und Glauben, vale dizer, levando em consideração os interesses legítimos da contraparte". 544

Todavia, não se pode perder de vista a correta observação de Flávio Tartuce no sentido de que, “dentro do conceito de boa-fé objetiva reside a boa-fé subjetiva, já que uma boa atuação presume, inexoravelmente, uma boa intenção. Portanto, toda vez que há previsão da boa-fé objetiva, também está prevista a subjetiva, pela relação de mutualismo que os conceitos mantêm". 545

A boa-fé subjetiva, nesta quadra, é componente indissociável da boa-fé objetiva.

\footnotetext{
${ }^{543}$ Teoria generale del diritto. Torino: Giappichelli, 1993, p. 242.

${ }^{544}$ O principio da boa-fé na experiência alemã. Palestra proferida no II Congresso Nacional de Direito Civil. Desafios e perspectivas da nova codificação: contratos, responsabilidade civil e relações de consumo. Em homenagem ao Ministro Sálvio de Figueiredo Teixeira. CIETP: Curitiba, Paraná, setembro/2004.

${ }^{545}$ Flávio Tartuce. O princípio da boa-fé objetiva em matéria contratual. Apontamentos em relação do novo Código Civil e visão do Projeto 6.902/02. Disponível em http://www.flaviotartuce.adv.br/secoes/artigos.asp.
} 


\section{OBJETIVAÇÃO DA BOA-FÉ NO DIREITO COMPARADO}

Aqui tomaremos por base a pesquisa realizada por Flávio Alves Martins, que bem analisou o fenômeno em certos sistemas jurídicos ocidentais. ${ }^{546}$

\subsection{França}

Embora o Code Napoléon tenha definido com precisão o princípio da boa-fé (art. 1.135 $5^{547}$ ), impondo que as convenções deveriam ser por ele regidas (art. 1.134, al. $3^{\text {a } 548}$ ), a irrestrita autonomia da vontade pregada pela Escola da Exegese impediram o aprofundamento de questões como a responsabilidade pré-contratual; no entanto, com arrimo nessas normas, as cortes francesas passaram a exigir a boa-fé tanto do devedor (debiteur), na execução das suas obrigações, como do credor (creaucier), no exercício das suas prerrogativas.

\subsection{Alemanha}

O $B G B$ foi o primeiro a separar, com clareza, a boa-fé subjetiva da objetiva, não apenas no âmbito jurídico, mas também, no linguístico (Guter Glauben e Treu und Glauben), o que não foi possível nos outros ordenamentos cujos idiomas derivam do latim (boa-fé, buena fe, bonne foi, buena fede). O código alemão deu uma dupla dimensão à boa-fé. Em sentido subjetivo, exprime a consciência de não prejudicar a outro. Em sentido objetivo, corporiza-se numa regra de conduta a ser observada pelas partes no cumprimento das obrigações.

"A boa fé guter Glauben reveste conteúdo subjetivo e tem seu principal campo de aplicação em matéria possessória ( $\S 990$ ss. $B G B$ ), aquisição de coisas móveis ( $\S 926$ ss. $B G B)$, prescrição ( $\S 937$ e $945 B G B)$,

\footnotetext{
${ }^{546}$ A boa-fé objetiva..., cit., p. 47/71.

${ }^{547}$ Art. 1.135: "les conventions obligent non seulement à ce qui y est exprimé, mais encore à toutes les suites qui l'équité, l'usage ou la loi donnent à l'abligation d'après as nature". Trad.: as convenções obrigam não somente ao que está expresso, mas ainda ao que a equidade, os usos e a lei atribuírem à obrigação pela sua natureza.

${ }^{548}$ Art. 1.134, al. 3: "les conventions doivent être executée de bonne foi". Trad.: as convenções devem ser executadas de boa-fé.
} 
aquisição de frutos e partes de coisas ( $\S 955$ ss. $B G B)$, usufruto $(\S 1.058 B G B)$, aquisição do penhor ( $\S 1.208 B G B)$, posse da herança ( $\S \S 2.024$ ss. $B G B)$.

Denomina-se psicológica a boa-fé quando presente ignorância pura a respeito de determinada circunstância fática, desimportando eventual falta de diligência do agente. Defendeu-a na Alemanha, Carl Georg von Wächter.

A seu turno, a boa-fé ética pressupõe certo grau de diligência. Reputa-se de má-fé quem, por culpa sua, desconhece o vício por ter faltado com o cuidado usual para averiguação das circunstâncias contrárias à aquisição ou ao exercício lídimo do direito ou da posição jurídica. Profligou-a, na Alemanha, Carl Georg Bruns.

\section{$(\ldots)$}

A orientação da jurisprudência alemã aponta para um critério da verificação in concreto do grau de diligência do agente, o que parece conduzir a uma objetivização da boa-fé subjetiva." ${ }^{, 549}$

O $B G B$ ensejou a retomada de uma concepção objetiva da boa-fé, constituindo $\S 242$ em uma cláusula geral capaz de flexibilizar, de dar mobilidade ao sistema fechado antes concebido, aproximando o conceito de obrigação da moldura vigente no common law.

Mas é preciso não perder de vista, aqui, a advertência do professor Wanderlei de Paula Barreto, para quem, "o § 242 BGB não se constitui em uma cláusula de equidade, que autorizasse ao juiz extrapolar as valorações legais a fim de chegar a uma solução por ele considerada equânime, porquanto uma tal concessão viria de encontro à segurança jurídica, subtraindo qualquer previsibilidade às decisões judiciais. Isto não significa, no entanto, que se possa sobrever a obrigação do controle de conteúdo dos contratos que impende aos juízes, obrigação esta deduzida da própria norma constitucional que consagra a garantia da autonomia privada do art. 2, $1^{\text {a }}$ alínea, $G G$ (Grundgesetz, a Lei Fundamental Alemã)". 550

\subsection{Itália}

\footnotetext{
${ }^{549}$ Wanderlei de Paula Barreto. O princípio da boa-fé..., idem.
} 
Entre as disposições gerais em matéria de obrigações, o legislador italiano colocou em evidência a regra da correttezza ${ }^{551}$, que é um critério de valoração do comportamento de ambas as partes: não apenas do devedor, bem como do credor. $^{552}$

O princípio da buona fede oggetiva, consagrado no Código Civil, se projeta desde as tratativas e a formação do contrato (art. $1.337^{553}$ ), passando pela sua interpretação (art. $1.366^{554}$ ), até a execução (arts. $1.375^{555}$ c.c. 1.175).

"Do início das negociações preliminares até a execução do contrato, o juízo sobre o comportamento dos interessados dispõe não apenas da aplicação da norma legal como também da observância da regra de correção, a qual tem uma função integradora, mas poderá assumir uma função corretiva em qualquer hipótese (...) o seu conteúdo não apenas se baseia na prudência ou na diligência, mas também na honestidade: o juiz fecha-se num juízo mais complexo do que o normal, enquanto busca a lealdade entre as partes."

\subsection{Portugal}

No ordenamento jurídico português existem determinações de incidência da boa-fé objetiva nos arts. 227/1 ${ }^{557}$ (culpa in contrahendo), $239^{558}$ (integração dos negócios), 272 e 334 (abuso de direito) e 437/1 e 762/2559 (complexidade

\footnotetext{
${ }^{550}$ Idem.

${ }^{551}$ Ou correção, exatidão, honestidade.

${ }^{552}$ Umberto Breccia. Le Obrigazioni (Trattato do direito privado). Milano: Giuffré, 1991, p. 230.

553 Art. 1.337: "le parti, nello svolgimento delle trattative e nella formazione del contratto, devono comportarsi secondo buona fede". Trad: as partes, no desenvolvimento das tratativas e na formação do contrato, devem se comportar conforme a boa-fé.

554 Art. 1.366: "il contratto deve essere interpretato secondo buona fede". Trad.: o contrato deve ser interpretado segundo a boa-fé.

555 Art. 1.375: "il debitore e il creditore devono comportarsi secondo lê regole della correttezza". Trad.: o devedor e o credor devem se comportar segundo as regras da correção.

${ }^{556}$ Giuseppe Stolfi. Il principio di buona fede. Rivista del diritto commercialle. Milano, 1964, v. LXII, p. 163 e ss.

${ }^{557}$ Art. 227/1: “quem negoceia com outrem para conclusão de um contrato deve, tanto nas preliminares como na formação dele, proceder segundo as regras da boa-fé, sob pena de responder pelos danos que culposamente causar à outra parte".

${ }_{558}$ Art. 239: "na falta de disposição especial, a declaração negocial deve ser integrada de harmonia com a vontade que as partes tenham tido se houvessem previsto o ponto omisso, ou de acordo com os ditames da boa-fé".

${ }^{559}$ Art. 762/2: "no cumprimento da obrigação, assim como no exercício do direito correspondente, devem as partes proceder de boa-fé".
} 
intra-obrigacional); daí restar cumprida a tríplice finalidade protetiva desse princípio: na integração, na formação e na execução dos negócios jurídicos.

Para Orlando Gomes, "sob o aspecto filosófico, a inovação do Código acolhendo o princípio da boa-fé nas suas diversas projeções significa o abandono do formalismo, do logicismo, do conceitualismo dominantes na ciência jurídica do século passado, que fizeram dos juristas simples autômatos e, na sua ambição de tratar o direito como se fora geometria, não se aperceberam seus corifeus de que é 'um aspecto da cultura e um espelho de uma época'. Emancipando-se da Pandecktologia, o codificador português acertou o passo com a tendência dominante na ciência jurídica dos novos tempos e demonstrando atualização de conhecimentos". 560

\subsection{Espanha}

Após a reforma de 1974, o Código Civil espanhol consagrou o caráter informador da boa-fé objetiva (arts. $7^{\circ}, 1^{561}$, e $1.258^{562}$ ), reconhecendo que esse princípio atua como limite ao exercício de direitos em qualquer relação jurídica.

\subsection{Suíça}

Por sua formação histórico-cultural, os cantões suíços são bem mais influenciados pela Alemanha que pela França, o que da mesma forma se projetou sobre o pensamento jurídico e, por isso, o estudo da boa-fé - a partir do paradigma germânico - se desenvolveu também bipartindo no Código Civil a concepção em subjetiva (art. $3^{\circ}$ ) e objetiva (art. $2^{\text {o563 }}$ ).

\footnotetext{
${ }^{560}$ O princípio da boa-fé no Código Civil Português. Revista Jurídica, Rio de Janeiro, 1980, p.177.

${ }^{561}$ Art. $7^{\circ}, 1$ : "los derechos deben ejercitarse conforme a las exigencias de la buena fe". Trad.: os direitos devem ser exercidos conforme as exigências da boa-fé.

${ }^{562}$ Nesse artigo aspira-se a que o desenvolvimento das relações jurídicas, o exercício dos direitos e o cumprimento das obrigações se produzam conforme uma série de princípios que a consciência social considera como necessários, ainda que não tenham sido formulados pelo legislador, nem estabelecidos pelo costume ou pelo contrato. Em sua aplicação no regime de uma relação contratual, a boa-fé constitui um critério de determinação do alcance das prestações contratuais e da forma e modalidades do cumprimento, e uma fonte de criação de deveres acessórios do dever principal da prestação. A regra se dirige também ao credor ou titular de direito subjetivo em virtude da relação contratual, impondo-lhe formas e modalidades do ato de exercício de seu direito e estabelecendo limites que, se ultrapassados, o converterão em abusivo, podendo ser repelido pelo obrigado.

${ }_{563}$ Art. $2^{\circ}$ : "chacun est tenu d'exercer sés droits e d'exécuter sés obligations selon les règles de la bonne foi". Trad.: cada um tem que exercer seus direitos e cumprir suas obrigações conforme as regras da boa-fé.
} 


\subsection{Argentina}

O Código Civil argentino, após a reforma introduzida pela Lei 17.711/68, elegeu a boa-fé como critério de interpretação objetivo fundado na conduta cuidadosa e diligente (previsora), ou seja, aquela que as partes entenderam ou puderam entender (art. $1.198^{564}$ ); privilegia-se o processo comunicativo dos sujeitos, os quais reciprocamente - devem compreender que suas relações são regidas por normas de honra e fidelidade.

\subsection{Outros ordenamentos}

Assevera Fernando Noronha ${ }^{565}$ que a boa-fé não ficou restrita aos ordenamentos de origem romano-germânica, porquanto alguns países praticantes do common law adotaram normas reguladoras do comportamento dos contratantes, como a fair dealing (atuação correta) do Reino Unido.

Nos Estados Unidos há uma sensível preocupação com a Good Faith no Uniform Commercial Code, adotado em todos os estados da federação, exceto a Luisiana, que - por ser de origem francesa - utiliza seu próprio Código Civil sem perder semelhante diretriz (art. $1.759^{566}$ ).

Podem ser citados, ainda, o Código Civil grego (arts. $281^{567} \mathrm{e}$ $388^{568}$ ), o holandês (art. $1.374^{569}$ ), o turco (art. $2^{\text {o570 }}$ ), que reproduz o art. $2^{\circ}$ do Código

\footnotetext{
${ }^{564}$ Art. 1.198: "os contratos devem ser celebrados, interpretados e executados de boa-fé e de acordo com o que verossimilmente as partes entenderam ou puderam entender, tratando com cuidado e previsão".

${ }^{565} \mathrm{O}$ direito dos contratos e seus princípios fundamentais (autonomia privada, boa-fé, justiça contratual). São Paulo: Saraiva, 1994, p. 127.

${ }_{566}$ Art. 1.759: "good faith shall govern de conduct of the obligor and the oblegee in whatever pertains to the obligation". Trad.: a boa-fé governa a conduta do credor e do devedor em tudo aquilo que concerne à obrigação.

${ }^{567}$ Art. 281: "o exercício de um direito está proibido se evidentemente transgride os limites marcados pela boa-fé, ou os bons costumes ou o fim social ou econômico do direito".

${ }^{568}$ Art. 388: “(...) se as condições sobre as quais as partes, tendo em conta a boa-fé e os usos do tráfego, basearam principalmente a celebração do contrato bilateral, e mudaram posteriormente por razões extraordinárias, que não poderiam ser previstas pelas partes".

${ }^{569}$ Adota a fórmula do art. 1.134 do Código Francês.

${ }^{570}$ Reproduz o art. $2^{\circ}$ do Código Suíço.
} 
Suíço, o austríaco $\left(A B G B\right.$, art. $\left.83^{571}\right)$ e, tal qual orienta Maria Paz Garcia Rubio ${ }^{572}$, o mexicano (art. 1.796) e o chileno (art. 1.546 e 1.603), ambos com semelhante conteúdo. ${ }^{573}$

${ }^{571}$ Art. 83: "para significação e os efeitos dos atos e abstenções, deve atender-se aos hábitos e usos normais nas relações de boa-fé".

${ }^{572}$ La responsabilidade precontratual en el derecho español. Madrid: Tecnos, 1991, p. 286.

573 “Os contratos (...) a partir da celebração, obrigam os contratantes não só ao cumprimentos do expressamente pactuado, mas também às consequências que, segundo sua natureza, sejam compatíveis com a boa-fé, aos costumes e à lei." 


\section{EXPERIÊNCIA BRASILEIRA}

Fruto de em um momento histórico marcado pelo apogeu das codificações, o Código Civil de 1916 tinha uma vocação de completude, verdadeiramente exclusivista e auto-suficiente, o que afastava o manejo de fontes integrativas heteronômicas; daí porque não se tinha como certo o reflexo da boa-fé, como regra geral de hermenêutica, somente a partir do art. $4^{\mathrm{o}}$ da LICC. ${ }^{574}$

Para Caio Mário da Silva Pereira, "a maior crítica que certamente se podia fazer ao Código Civil de 1916 era o fato de que nele não se tinha consagrado expressamente o princípio da boa-fé como cláusula geral, falha imperdoável diante da consagração do princípio nos Códigos a ele anteriores, como o francês (art. 1.134) e o alemão (par. 242)".575

É verdade que na parte especial se identificavam dois dispositivos (arts. $1.404^{576}$ e $1.443^{577}$ ), para referir apenas os mais importantes, capazes de romper o modelo subjetivista da boa-fé; no entanto, neste particular, não se colocando no oblívio o art. $131^{578}$ do Código Comercial de 1850 e a importante moldura típica trazida pela Lei das Sociedades Anônimas ${ }^{579}$, é inegável que o grande passo inovador do direito positivo pátrio decorreu da Lei 8.078/90.

Com a vigência do Código Civil de 2002, regido pelo princípio da eticidade, também no direito civil se passou a contar com o expresso reconhecimento da boa-fé como elemento muito mais abrangente do que a simples investigação do aspecto anímico do sujeito de interesses e deveres. O Min. José Augusto

\footnotetext{
${ }^{574}$ LICC, art. 4: "quando a lei for omissa, o juiz decidirá o caso de acordo com a analogia, os costumes e os princípios gerais de direito".

${ }^{575}$ Instituições de direito civil. Contratos. Rio de Janeiro: Forense, 1993, v. III, p. 20.

${ }^{576}$ Art. 1.404: "a renúncia de um dos sócios só dissolve a sociedade (art. 1.399, V), quando feita de boa-fé, em tempo oportuno, e notificada aos sócios 2 (dois) meses antes”.

577 Art. 1.443: "o segurado e o segurador são obrigados a guardar no contrato a mais estrita boa-fé e veracidade, assim a respeito do objeto, como das circunstâncias e declarações a ele concernentes".

578 Art. 131: "sendo necessário interpretar as cláusulas do contrato, a interpretação, além das regras sobreditas, será regulada sobre as seguintes bases: $1^{\circ}-$ a inteligência simples e adequada, que for mais conforme à boa-fé, e ao verdadeiro espírito e natureza do contrato, deverá sempre prevalecer à rigorosa e restrita significação das palavras".

579 A Lei 6.404/76, art. 157 e seus $\S \S .$, como lídimo exemplo de regra de conduta esperada, atribui aos administradores das companhias abertas certos especiais deveres de informar, v.g., sobre: a) as opções de compra de ações que tiver contratado ou exercido no exercício anterior, b) os benefícios ou vantagens, indiretas ou complementares, que tenha recebido ou esteja recebendo da companhia e de sociedades coligadas, controladas ou do mesmo grupo, c) as condições dos contratos de trabalho que tenham sido firmados pela companhia com os diretores e empregados de alto nível, d) quaisquer atos ou fatos relevantes nas atividades da companhia.
} 
Delgado informa que, “o tipo de Ética buscado pelo Novo Código Civil é defendido pela corrente kantiana: é o comportamento que confia no homem como um ser composto por valores que o elevam ao patamar de respeito pelo semelhante e de reflexo de um estado de confiança nas relações desenvolvidas, quer negociais, quer não negociais. É, na expressão kantiana, a certeza do dever cumprido, a tranquilidade da boa consciência". 580

Essa linha de raciocínio, impulsionada pelo novo paradigma estabelecido para as relações de direito privado contemporâneas, ganhou corpo com o estudo do art. $422^{581}$; todavia, a cumprir suas três funções medulares, tal qual a seguir se verá, não podem ser esquecidos os arts. $113^{582}$ e $187 .^{583}$

Parte da doutrina se orienta, e com razão, anote-se, no sentido de identificar a justiça ${ }^{584}$ e a solidariedade ${ }^{585}$ constitucional (art. $3^{\circ}$, I) como fontes fundamentadoras dessa concepção objetivada da boa-fé, que também se projeta a partir da tutela indeclinável da pessoa humana (art. $1^{\circ}$, III $)^{586}$ e da exigência de acesso à ampla informação (art. $\left.5^{\circ}, \mathrm{XIV}\right)^{587}$.

\footnotetext{
${ }^{580}$ A ética e a boa-fé no novo Código Civil. Questões controvertidas do novo Código Civil. São Paulo: Método, 2003, p. 177.

581 Art. 422: "os contratantes são obrigados a guardar, assim na conclusão do contrato, como em sua execução, os princípios de probidade e boa-fé”.

582 Art. 113: "os negócios jurídicos devem ser interpretados conforme a boa-fé e os usos do lugar de sua celebração".

${ }^{583}$ Art. 187: "também comete ato ilícito o titular de um direito que, ao exercê-lo, excede manifestamente os limites impostos pelo seu fim econômico ou social, pela boa-fé ou pelos bons costumes".

584 Alberto do Amaral Júnior. A boa-fé e do controle das cláusulas contratuais abusivas nas relações de consumo. Revista de Direito do Consumidor, São Paulo: RT, v. 6, abr.-jun. 1993, p. 32.

${ }^{585}$ Regis Fichtner Pereira. A responsabilidade pré-contratual: teoria geral e responsabilidade pela ruptura das negociações contratuais. Rio de Janeiro: Renovar, 2001, p. 64.

586 Teresa Negreiros. Teoria do contrato. Novo paradigma. Rio de Janeiro: Renovar, 2003, p. 117.

${ }^{587}$ Flávio Tartuce. O princípio da boa-fé objetiva..., idem.
} 


\section{BOA-FÉ SUBJETIVA X OBJETIVA}

De fato, apresenta a boa-fé dois sentidos diferentes: de estado psicológico do agente (subjetiva) e de regra de conduta (objetiva), este sim encerra conteúdo de princípio. ${ }^{588}$

Segundo Bruno Miragem, “(...) quando se trata do princípio da boa-fé, faz-se referência, necessariamente à boa-fé objetiva. Isto porque a boa-fé subjetiva não se trata de princípio jurídico, mas tão-somente de um estado psicológico que se reconhece à pessoa e que constitui requisito o suporte fático presente em certas normas jurídicas, para produção de efeitos jurídicos", 589

A boa-fé subjetiva, assim, corresponde ao estado psicológico da pessoa, à sua intenção, ao seu convencimento - individual e equivocado - de estar agindo de forma a não prejudicar outrem na relação jurídica. Já a boa-fé objetiva significa uma regra de conduta de acordo com os ideais de honestidade e lealdade, isto é, as partes contratuais devem agir conforme um modelo de conduta social (com honestidade, retidão, lealdade e probidade), sempre respeitando a confiança e os interesses do outro. ${ }^{590}$

A teoria subjetiva leva em consideração a vontade do titular do direito ter agido com o propósito único de prejudicar o lesado (ato emulativo). A teoria objetiva, como princípio geral, averigua o alcance objetivo da conduta, com base no critério da consciência pública, não se interessando pela intenção do agente. Esta verificação se dá quando há um contraste nítido entre o fim próprio do direito e a sua atuação no caso concreto. ${ }^{591}$

$\mathrm{Ou}$, em outras palavras, a cláusula geral da boa-fé objetiva contém implícita uma regra de direito judicial, dirigida à atuação do juiz ${ }^{592}$, que lhe impõe, ao examinar o caso, primeiramente fixar a norma de dever de acordo com a realidade do fato e o princípio a que a cláusula geral adere, para somente num segundo momento

\footnotetext{
${ }^{588}$ Fernando Noronha. $O$ direito dos contratos..., cit., p. 132.

${ }^{589}$ Direito..., cit., p. 71.

${ }^{590}$ Alinne Arquette Leite Novais. Os novos paradigmas da teoria contratual: o princípio da boa-fé objetiva e o princípio da tutela do hipossuficiente. In: Tepedino, Gustavo (coord.). Problemas de direito civil..., cit., p. $22 / 23$.

${ }^{591}$ Maria Cristina Cereser Pezzella. O princípio da boa-fé objetiva no direito privado alemão e brasileiro. Revista de Direito do Consumidor, São Paulo: RT, v. 23-24, jul.-dez. 1997, p. 215.

${ }^{592}$ Enunciado 26 da I Jornada de Direito Civil promovida pelo Conselho da Justiça Federal: "a cláusula geral contida no art. 422 do novo Código Civil impõe ao juiz interpretar e, quando necessário, suprir e corrigir o contrato segundo a boa-fé objetiva, entendida como a exigência de comportamento leal dos contratantes".
} 
confrontar a conduta efetivamente realizada com aquela que as circunstâncias recomendavam. Na cláusula geral há uma delegação, atribuindo ao juiz a tarefa de elaborar o juízo valorativo dos interesses em jogo. Ela é uma realidade jurídica diversa das demais normas (princípios e regras), e seu conteúdo somente pode ser determinado na concretude do caso. ${ }^{593}$

É ferramenta de aplicação, se projetando como regra (objetiva) de conduta $^{594}$, autêntico standard que não depende de forma alguma da verificação da má-fé subjetiva dos contratantes ${ }^{595}$, protegendo as partes contra exigências impertinentes que colidam com o direito e/ou com a equidade ${ }^{596}$ e que possam ensejar o abuso de uma sobre a outra ${ }^{597}$, lídimo estado de espírito que conduz a parte negocial a agir dentro das regras da ética e da razão. ${ }^{598}$

Até porque a boa-fé pode chegar a se apresentar como um conceito básico para determinar o exercício normal ou abusivo de direitos. ${ }^{599}$

Ou seja, "a boa-fé objetiva impõe ao contratante um padrão de conduta, de modo que deve agir como um ser humano reto, vale dizer, com probidade, honestidade e lealdade. Assim, reputa-se celebrado o contrato com todos esses atributos que decorrem da boa-fé objetiva. Daí a razão pela qual o juiz, ao julgar demanda na qual se discuta a relação contratual, deve dar por pressuposta a regra jurídica (lei, fonte de direito, regra jurígena criadora de direitos e de obrigações) de agir com retidão, nos padrões do homem comum, atendidas as peculiaridades dos usos e costumes do lugar". 600

Retoma-se, assim, a moldura da objetividade do injusto ${ }^{601}$, assegurando o acolhimento do que é lícito e a repulsa ao ilícito. ${ }^{602}$

\footnotetext{
${ }^{593}$ Ruy Rosado de Aguiar Júnior. A boa-fé na relação de consumo. Revista de Direito do Consumidor, São Paulo: RT, v. 14, abr.-jun. 1995, p. 20.

${ }^{594}$ Antonio Junqueira de Azevedo. A boa fé na formação dos contratos. Revista de Direito do Consumidor, São Paulo: RT, v. 3, set.-dez. 1992, p. 78/79.

${ }_{595}^{5}$ Luiz Antonio Rizzatto Nunes. Curso..., cit., p. 128.

${ }^{596}$ Maria Cristina Cereser Pezzella. O princípio da boa-fé objetiva..., cit., p. 205.

${ }^{597}$ Alberto do Amaral Júnior. A boa-fé e do controle..., cit., p. 31.

${ }^{598}$ Flávio Tartuce. O principio da boa-fé objetiva..., idem.

${ }^{599}$ José Manuel M. Bernal. El abuso del derecho. Madrid: Montecorvo, 1982, p. 199.

${ }^{600}$ Nelson Nery Junior e Rosa Maria de Andrade Nery. Código Civil comentado. $6{ }^{\mathrm{a}}$ ed. São Paulo: RT, 2008, p. 506, n. 12 .

${ }_{601}^{6}$ Otávio Moreira Guimarães. A boa-fé..., cit., p. 43.

${ }^{602}$ Álvaro Villaça Azevedo. Teoria geral dos contratos típicos e atípicos. São Paulo: Atlas, 2002, p. 26.
} 


\section{A BOA-FÉ OBJETIVA E SUAS FUNÇÕES}

Cláudio Luiz Bueno de Godoy, citando Denis Mazeaud ${ }^{603}$, alude a uma nova era do contrato, moralmente diferenciada, e de alguma forma a garantir contratações mais justas e solidárias, em que, por imperativo da boa-fé, o contrato deva ser sociável e solidário. ${ }^{604}$

A despeito de a nossa doutrina há muito preconizar a responsabilidade pré-contratual ${ }^{605}$, o que se consolidou a partir da mudança de leitura do sistema $^{606}$, a objetivação da boa-fé implicou fosse mais bem compreendido o alcance da lealdade e da probidade sobre todas as fases do negócio jurídico, desde a formação (tratativas, publicidade, etc.) até o pós-contrato, numa espécie de projeção simétrica de responsabilidade (culpa post factum finitum ${ }^{607}$, a garantir a plena fruição do ajuste, como um processo social dinâmico, corolário do comportamento razoável esperado entre as partes $^{608}$, lídima atuação refletida tendente a respeitar os interesses legítimos do parceiro contratual.

Karl Larenz entende que, “o princípio da boa-fé significa que cada um deve guardar fidelidade com a palavra dada e não frustrar a confiança ou abusar dela, já que esta forma a base indispensável de todas as relações humanas"609 ${ }^{~}$ Como ensina Almeida Costa, "o reconhecimento da responsabilidade pré-contratual reflecte a preocupação do direito de proteger a confiança depositada por cada um dos contratantes nas expectativas legítimas que o outro the crie durante as negociações, não só quanto à validade e eficácia do negócio, mas também quanto à sua futura negociação". 610

Eis o espaço de incidência das suas principais funções: a) fonte autônoma de deveres especiais de conduta (supplendi ou ativa); b) limite ao exercício

\footnotetext{
${ }^{603}$ Loyauté, solidarité, fraternité: la nouvelle devise contractuelle? In L'avenir du droit: mélanges em hommage à François Terré, Paris: PUF, 1999, p. 609/623.

${ }^{604}$ Função social do contrato. $3^{\mathrm{a}}$ ed. São Paulo: Saraiva, 2009, p. 75.

${ }^{605}$ Antônio Chaves. Responsabilidade pré-contratual. Rio de Janeiro: Forense, 1959, p. 138/140.

${ }^{606}$ Antonio Junqueira de Azevedo. Responsabilidade pré-contratual no Código de Defesa do Consumidor: estudo comparativo com a responsabilidade pré-contratual no direito comum. Revista de Direito do Consumidor, São Paulo: RT, v. 18, abr.-jun. 1996, p. 23/31.

${ }^{607}$ Antônio Manoel da Rocha e Menezes Cordeiro. Da boa-fé..., cit., v. 1, p. 625.

${ }^{608}$ Roberto Senise Lisboa. Responsabilidade civil..., cit., p. 104.

${ }^{609}$ Derecho de obligaciones, t. I. Trad. Jaime Santos Brinz. Madrid: Editorial Revista de Derecho Privado, 1958, p. 142.

${ }^{610}$ Direito das obrigações. Coimbra: Almedina, 1979, p. 224.
} 
de direitos subjetivos (corrigendi gratia ou reativa) e c) critério de interpretação e concreção dos negócios jurídicos (adjuvandi ou interpretativa). ${ }^{611}$

\subsection{Fonte autônoma de deveres especiais de conduta}

Foi a jurisprudência alemã, a partir da combinação dos princípios-norma sobre o cumprimento da obrigação $(B G B, \S 242)$ e sobre a interpretação dos contratos em consonância com a Treu und Glauben e com os costumes do tráfego $(B G B, \S 157)$, que inaugurou a dogmática dos deveres acessórios ${ }^{612}$, como denominam os franceses, também chamados anexos ou secundários ${ }^{613}$ ou ainda instrumentais ou laterais. ${ }^{614}$

Independentemente da nomenclatura utilizada, não se ignorando a proposta de Antunes Varela, para quem não se confundem os deveres principais (ou típicos) e os secundários (ou acidentais) de prestação e os acessórios de conduta $^{615}$, nem a advertência de Antonio Junqueira de Azevedo, no sentido de que após celebrado o contrato seriam eles obrigações e não meros deveres ${ }^{616}$, essas imposições anexas decorrem da função supletiva do instituto.

Segundo a emérita professora da UFRGS, “esta visão dinâmica e realista do contrato é uma resposta à crise da teoria das fontes dos direitos e obrigações, pois permite observar que as relações contratuais durante toda a sua existência (fase de execução), mais ainda, no seu momento de elaboração (de tratativas) e no seu momento posterior (de pós-eficácia), fazem nascer direitos e deveres outros que os resultantes da obrigação principal. Em outras palavras, o contrato não envolve só a obrigação de prestar, mas envolve também uma obrigação de conduta!". 617

Daí porque o ajuste obriga não somente ao cumprimento do seu componente principal (a prestação), mas também das várias obrigações acessórias ou

\footnotetext{
611 Gustavo Tepedino et alii. Código Civil interpretado conforme a Constituição da República. Rio de Janeiro: Renovar, 2006, v. II, p. 17.

${ }^{612}$ Wanderlei de Paula Barreto. O princípio da boa-fé..., idem.

${ }^{613}$ Clóvis V. do Couto e Silva. A obrigação como processo..., cit., p. 111/119.

${ }^{614}$ Judith Martins-Costa. A boa-fé no direito privado. $2^{\text {a }}$ tir. São Paulo: RT, 2000, p. 438.

${ }^{615}$ João de Matos Antunes Varela. Das obrigações em geral. $10^{\mathrm{a}}$ ed. Coimbra: Almedina, 2000, v. 1, p. $121 / 125$.

${ }^{616}$ A boa-fé..., cit., p. 79.

${ }^{617}$ Cláudia Lima Marques. Contratos..., cit., p. 183.
} 
dos deveres anexos àquele tipo de ajuste ${ }^{618}$, revertendo a inobservância de qualquer deles em quebra positiva do contrato ${ }^{619}$, passível de reparação específica independentemente de culpa $^{620}$, que se identifica no direito à saúde, e. g., com o não esclarecimento adequado sobre a existência de técnica procedimental menos agressiva.

Há, portanto, uma multiplicação de deveres voltada à satisfação dos interesses globais das partes e não só daqueles inerentes à obrigação principal $^{621}$, que, se não cumpridos, tendo em vista o inadimplemento agora com suporte fático ampliado, podem da mesma forma ensejar a recusa da prestação com base na exceptio non adimpleti contractus, a sua execução específica e, em última análise, até a resolução do contrato $(\mathrm{CC} \text {, arts. } 475 \text { e 476) })^{622}$, visto que o silêncio aqui atua como condição irregular de contratação. São eles:

\subsubsection{Informar}

Essa informação é qualificada pela necessidade de uma ampla transparência no conduzir das partes, de modo que cada uma tenha a exata noção do sinalagma originário, única medida da legítima e esperada confiança. Na fase précontratual também positiva a antiga idéia que proíbe o venire contra factum proprium. ${ }^{623}$

Contudo, o fluxo informacional há de estar presente até na etapa do pós-contrato, sobretudo nos chamados contratos relacionais ou cativos de longa duração; sendo possível identificar nesse processo duas modalidades: a) o esclarecimento e b) o aconselhamento.

O dever de esclarecimento obriga a parte mais forte (ou o fornecedor) a informar sobre os riscos, a forma de utilização do objeto contratado e a qualidade da prestação; daí atuar como fonte de expectativas legítimas. O dever de aconselhamento é mais intenso e só existe nas relações entre um profissional e um não

\footnotetext{
${ }^{618}$ Cláudia Lima Marques. Contratos..., cit., p. 185.

${ }^{619}$ Roberto Senise Lisboa. Responsabilidade civil..., cit., p. 104.

${ }^{620}$ Enunciado 24 da I Jornada de Direito Civil promovida pelo Conselho da Justiça Federal: "em virtude do princípio da boa-fé, positivado no art. 422 do novo Código Civil, a violação dos deveres anexos constitui espécie de inadimplemento, independente de culpa".

${ }^{621}$ Mário Júlio de Almeida Costa. Direito das obrigações. $9^{\mathrm{a}}$ ed. Coimbra: Almedina, 2004, p. 66/67.

${ }^{622}$ Gustavo Tepedino et alii. Código Civil interpretado..., cit., p. 18.

${ }^{623}$ Franz Wieacker. El princípio general de la buena fé. Madri: Civitas, 1977, p. 60.
} 
especialista, o que permite ao contratante despreparado optar, de modo mais consciente ${ }^{624}$, por um dos vários caminhos possíveis ${ }^{625}$; entretanto, sem descaracterizar a responsabilidade daquele que detém o domínio do processo produtivo e da técnica oferecida. $^{626}$

No âmbito do direito à saúde esse inadimplemento formal, por assim dizer, a partir da falha de informação, representa gênese autônoma de culpa porque agride a liberdade e os direitos da personalidade do paciente, passível de reparação autônoma independentemente dos resultados ${ }^{627}$, também lesivos, que venham a surgir do tratamento não esclarecido de modo satisfatório, por insuficiência total ou parcial ${ }^{628}$, dês que vinculada à ocorrência de dano pela sua adoção, a ser demonstrada pela vítima ${ }^{629}$ ou desconstituída pelo médico (CDC, art. $6^{\circ}$, VIII). ${ }^{630}$

"INDENIZAÇÃO - Danos materiais decorrentes de intervenção cirúrgica - Ausência de demonstração de culpa do médico em relação às sequelas sofridas pelo paciente - Responsabilização, entretanto, pela falta de

624 "DANO MORAL - Responsabilidade Civil - Cobrança de tarifas relativas à manutenção de conta corrente sem movimentação financeira - Irregularidade - Orientação do consumidor acerca da necessidade de encerramento formal da conta não demonstrado - Ausência, ainda, de comunicação da existência do débito e do envio do nome da autora aos cadastros do SERASA - Dever de indenizar configurado Consideração do caráter reparatório e repressivo da condenação na fixação do montante reparatório Indenizatória procedente - Recurso provido" (TJSP, AC 7.370.805-9, rel. Melo Colombi, j. 19.08.2009).

${ }^{625}$ Cláudia Lima Marques. Contratos..., cit., p. 192/194.

626 “A responsabilidade do profissional médico perante seu paciente é a subjetiva, prevista no art. $14, \S 4^{\circ}$, do CDC, requerendo, portanto, a demonstração de culpa para a configuração do dever de reparar. Situação em que a médica não se desincumbiu do dever de informação, na medida em que não informou à paciente as possíveis reações alérgicas que poderiam advir do tratamento ministrado. Falha do dever de informação que acarreta o dever de reparar pelo dano moral sofrido. Orientação doutrinária e jurisprudencial” (TJRS, AC 70030952246, rel. Tasso Caubi Soares Delabary, j. 09.12.2009).

627 “A Santa Casa, apesar de ser instituição sem fins lucrativos, responde solidariamente pelo erro do seu médico, que deixa de cumprir com a obrigação de obter consentimento informado a respeito de cirurgia de risco, da qual resultou a perda da visão do paciente" (STJ, REsp. 467.878/RJ, rel. Min. Ruy Rosado de Aguiar, j. 05.12.2002).

${ }^{628}$ Lembra a professora Teresa Ancona Lopez, aula proferida no curso de Pós-graduação da Faculdade de Direito da Universidade de São Paulo, em 09.09.2009, que na Espanha, mesmo com o resultado final obtido, responde o médico pelos reflexos lesivos não informados do tratamento.

${ }^{629}$ Fernando Campos Scaff. As relações jurídicas privadas no direito à saúde. Tese de Livre Docência apresentada ao Departamento de Direito Civil da Faculdade de Direito da Universidade de São Paulo (USP), 2006, p. 134/135.

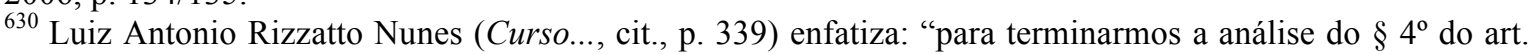
14 é preciso ainda indagar sobre o ônus da produção da prova do dano, do nexo de causalidade do dano com o serviço e da indicação do profissional liberal que o prestou. E, também, do ônus da prova da culpa do profissional. De quem é o ônus da prova? A resposta primeira, como sempre, é simples. O ônus da prova incumbe a quem alega. Logo, é do consumidor. O que acontece, também, como sempre, é que o consumidor goza dos benefícios da inversão do ônus da prova, instituída no inciso VIII do art. $6^{\circ}$. A rigor, no caso, serão dois os momentos de produção de prova e, portanto, dois os momentos da averiguação da possibilidade - e necessidade, como vimos - de inversão. O primeiro é o da prova do dano, do nexo de causalidade entre o 
adequada cientificação do operado, quanto aos efetivos riscos do procedimento operatório - Teoria do consentimento informado - Dever de indenizar - Sentença de parcial procedência mantida - Recurso desprovido."631

Observa, com moderação, Fernando Campos Scaff que, “caso o resultado pretendido com o tratamento seja obtido - a despeito do inadimplemento de se buscar, antes, o consentimento expresso e consciente do destinatário -, é evidente que o pleito de indenização não poderá ser formulado como se os piores e maiores danos tivessem ocorrido por um erro de conduta no procedimento clínico, cirúrgico ou laboratorial prestado, mas sim limitados a outra ordem de valores, em especial aquela dos danos morais". 632

\subsubsection{O consentimento informado}

Reflexo direto da confiança depositada pelo paciente na idoneidade do profissional da área de saúde ${ }^{633}$, compreendido como um princípio que visa a proteger o destinatário desse especial serviço, altamente técnico, da passividade que em regra qualifica sua posição contratual. ${ }^{634}$

É essa concreção de transparência que se espera em respeito ao sujeito desprovido da arte do serviço disponibilizado, seja ele qual for, também pelo

dano e o serviço, com a indicação do profissional responsável. O segundo o da culpa do profissional liberal, prestador do serviço. Em ambos os casos a inversão poderá dar-se".

631 TJSP, AC 296.012-4/5-00, rel. De Santi Ribeiro, j. 04.11.2008. No mesmo sentido e da mesma Corte: "Indenização - Erro médico - Inadmissibilidade de causa de pedir baseada em obrigação de resultado para correção de miopia - Ausência de ato culposo do médico para o procedimento adotado - Viabilidade da causa de pedir lastreada em falta de esclarecimento sobre o risco da cirurgia - Dever do médico em esclarecer sobre os possíveis riscos antes de obter o consentimento para procedimento médico invasivo não urgente - Inteligência do art. 46 do Código de Ética Médica, Resolução 1.246/1988 do Conselho Federal de Medicina, com força vinculadora conforme Lei 3.268/1957, art. 5o, 'd' - Precedentes do Conselho Federal de Medicina sobre a necessidade de esclarecimento anterior dos riscos do procedimento como dever do médico - Ocorrência de nexo causal entre o resultado da piora da visão não esclarecido e as cirurgias efetivadas Deferimento de dano material no valor estimado do transplante de córneas e dano mora não por erro médico culposo ou obrigação de resultado, mas por decorrência possível de procedimento médico sem esclarecimento ao paciente para sopesar o risco e capacidade de consentir de forma plena, omissão de dever médico - Recurso provido, em parte, para julgar procedente, em parte, a ação" (AC 497.193-4/5-00, j. 16.04.2008) e "Responsabilidade civil - Erro médico - Inocorrência - Caso em que o procedimento cirúrgico se mostrou adequado - Hipótese, no entanto, em que o médico deixou de avisar o paciente e seus pais de que seria operado o outro olho - Pânico - Cirurgia que merece ser indenizada - Recurso do hospital provido, e recursos do autor e do réu improvidos" (AC 390.175-4/3-00, rel. José Luiz Gavião de Almeida, j. 03.06.2008).

${ }^{632}$ As relações jurídicas..., cit., p. 135.

${ }^{633}$ Alfredo Jorge Kraut. Los derechos de los pacientes. Buenos Aires: Abeledo-Perrot, 1997, p. 149/150.

${ }^{634}$ Fernando Campos Scaff. As relações jurídicas..., cit., p. 80. 
médico. Afinal, a regra da doutrina francesa no sentido de que cada contratante deve se informar per se, corolário do adágio emptore debet esse curiosis ${ }^{635}$, não tem mais lugar no estado social que se formou a partir do declínio do liberalismo, que converteu a obrigação de se informar em obrigação de informar ${ }^{636}$; aliás, como preconizado pela professora Cláudia Lima Marques (supra, Cap. III, 4.1).

É o que Álvaro da Cunha Gomes Rodrigues associa à informação razoável (reasonable disclosure) da jurisprudência americana, segundo a qual o critério tradicionalmente seguido para aferir o quantum informativo necessário, que era do reasonable doctor, cede ao do reasonable patient. ${ }^{637}$

Parte da doutrina ${ }^{638}$ sustenta que a expressão consentimento informado, haurida do signo anglo-americano informed consent, melhor modularia sua essência se lida como consentimento esclarecido ou consentimento livre e esclarecido; como se infere, no âmbito nacional ${ }^{639}$, da Resolução n ${ }^{\circ} 196$, de 10 de outubro de 1996, do Conselho Nacional de Saúde, que dispõe sobre as Diretrizes e Normas Regulamentadoras de Pesquisas envolvendo seres humanos, cujo item IV disciplina a temática. ${ }^{640}$

A divergência é meramente formal, pois o que interessa é a base estruturante do exercício desse consentimento informado, termo amplamente admitido no tráfego, a abranger uma ampla, leal, concreta e eficiente informação, única capaz - dês que adotada uma linguagem acessível ao destinatário leigo (como na maior das vezes acontece $)^{641}$ - de lhe permitir a plena cognição das alternativas terapêuticas que lhe são apresentadas.

"Representa a obtenção do consentimento informado, portanto, o dever do agente de saúde de informar, confirmar o esclarecimento e de

\footnotetext{
${ }^{635} \mathrm{O}$ comprador deve ser curioso.

${ }^{636}$ Eva Sônia Moreira da Silva. Da responsabilidade pré-contratual por violação dos deveres de informação. Coimbra: Almedina, 2003, p. 17 e ss.

${ }^{637}$ Consentimento informado e intervenção médica. Direito da medicina I. Coimbra: Ed. Coimbra, 2002, p. 39 e ss.

638 Álvaro da Cunha Gomes Rodrigues. Idem, p. 31.

${ }^{639}$ Estabelece o art. 60, "a", da Declaração Universal sobre Bioética e Direitos Humanos de 2005: "qualquer intervenção médica preventiva, diagnóstica e terapêutica só deve ser realizada com o consentimento prévio, livre e esclarecido do indivíduo envolvido, baseado em informação adequada. O consentimento deve, quando apropriado, ser manifestado e poder ser retirado pelo indivíduo envolvido a qualquer momento e por qualquer razão, sem acarretar desvantagem ou preconceito".

640 "Respeito devido à dignidade humana exige que toda pesquisa se processe após consentimento livre e esclarecido dos sujeitos, indivíduos ou grupos que por si e/ou por seus representantes legais manifestam anuência à participação na pesquisa."

${ }^{641}$ João Álvaro Dias. Procriação assistida e responsabilidade médica. Coimbra: Ed. Coimbra, 1996, p. 282.
} 
obter o consentimento do paciente para a realização de cada um dos diversos procedimentos indicados.

Envolvem a abrangência dessa noção tanto as relações do paciente com o médico, com o enfermeiro ou com qualquer outro agente de saúde, como também aquelas estabelecidas entre o paciente e as pessoas jurídicas relacionadas com o atendimento médico, sejam elas operadoras de planos de saúde, hospitais, clínicas ou qualquer outra entidade assemelhada."642

Apesar de secundária, a obrigação de se recolher o consentimento informado revela lídimo direito inato à personalidade do paciente (que se atrela à sua intimidade $)^{643} \mathrm{e}$, por isso, independe de base contratual específica ${ }^{644}$, muito embora se exija, em razão da essência do procedimento eleito, a forma escrita em especiais e determinadas situações (v.g., esterilização ${ }^{645}$, pesquisas envolvendo seres humanos ${ }^{646}$, etc.); uma vez obtido, coliga o exercício da liberdade ao direito à saúde. ${ }^{647}$

${ }^{642}$ Fernando Campos Scaff. As relações jurídicas..., cit., p. 123.

${ }^{643}$ A preocupação é tamanha que o Código de Ética Médica, no seu art. 46, ao tratar dos direitos humanos, estabelece ser vedado ao médico: "efetuar qualquer procedimento médico sem o esclarecimento e consentimento prévios do paciente ou de seu responsável legal, salvo iminente perigo de vida", proibição que se renova no art. 59, agora no capítulo das relações com pacientes e familiares: "deixar de informar ao paciente o diagnóstico, o prognóstico, os riscos e objetivos do tratamento, salvo quando a comunicação direta ao mesmo possa provocar-lhe dano, devendo, nesse caso, a comunicação ser feita ao seu responsável legal"; enquanto o Conselho Federal de Medicina, pela voz do seu Tribunal Superior de Ética Médica, em várias oportunidades, tem reconhecido como infração disciplinar a falta dessa transparência, inclusive impondo a pena de cassação do exercício profissional, vejam-se exempli gratia: "comete infração ética o médico que. descuidando de seu desempenho profissional, provoca atos danosos ao paciente, negligenciando nos cuidados necessários e imediatos Também comete infração ao CEM quando não esclarece de maneira clara os procedimentos a serem realizados, seus riscos e conseqüências e não obtém o consentimento especifico com o paciente, não exercendo o livre direito de decisão" (REC 1174-039/2003, Origem: CRM/RS, DOU de 05.09.2003, sec. 01, p. 134) e "comete infração ética o medico que deixa de informar o diagnóstico, prognóstico e os riscos ao paciente ou a seu representante legal, efetuando procedimento sem o esclarecimento e o consentimento prévios, vulnerando os artigos 46 e 59 do Código de Ética Medica" (REC 111/1997, Origem CRM/DF, j. 03.10.2000, DOU de 14.12.2000, sec. 01, p. 75).

${ }^{644}$ Guilherme de Oliveira. Temas de direito da medicina. Coimbra: Ed. Coimbra, 1999, p. 63.

${ }^{645}$ A Lei 9.263/96, que regula o art. $226, \S 7^{\circ}$, da CF e trata do planejamento familiar, disciplina no seu art. $10, \S 1^{\circ}$ : "é condição para que se realize a esterilização o registro de expressa manifestação da vontade em documento escrito e firmado, após a informação a respeito dos riscos da cirurgia, possíveis efeitos colaterais, dificuldades de sua reversão e opções de contracepção reversíveis existentes".

${ }^{646}$ O item IV.2 da Res. 196, de 10 de outubro de 1996, do Conselho Nacional de Saúde, que dispõe sobre as Diretrizes e Normas Regulamentadoras de Pesquisas envolvendo seres humanos, impõe seja o consentimento livre e esclarecido veiculado em termo específico, com o seguinte conteúdo mínimo: "a) ser elaborado pelo pesquisador responsável, expressando o cumprimento de cada uma das exigências acima; b) ser aprovado pelo Comitê de Ética em Pesquisa que referenda a investigação; c) ser assinado ou identificado por impressão dactiloscópica, por todos e cada um dos sujeitos da pesquisa ou por seus representantes legais; e d) ser elaborado em duas vias, sendo uma retirada pelo sujeito da pesquisa ou por seu representante legal e uma arquivada pelo pesquisador".

${ }^{647}$ Guido Alpa. Esercizio del diritto e abuso del diritto. In: Alpa, Guido; Ruffolo, U.; Zencovich, V. Zeno (coord.). Casi e questioni di diritto privato. v. 9 - Atto illecito e responsabilità civile. $8^{\mathrm{a}}$ ed. Milão: Giuffrè, 2000, p. 248. 
Porém, forte em razões variadas (v.g., éticas, religiosas ${ }^{648}$, medo do risco ${ }^{649}$ esclarecido, etc.), ao paciente lúcido e autônomo é possível a negativa de

${ }^{648}$ Esta, sem dúvida, é uma questão controvertida, notadamente por força da garantia constitucional da liberdade de crença religiosa (CF, art. $5^{\circ}$, VI e VIII). O exemplo clássico é o do paciente "Testemunha de Jeová" que se recusa a receber transfusão de sangue. Se de um lado há quem entenda que o médico e a instituição hospitalar, ao prestarem seus serviços, têm o dever de realizar todo e qualquer procedimento técnico necessário para a manutenção da vida, incumbindo ao paciente e a seus familiares a propositura de medida judicial para evitar a conduta médica, caso entendam haver relevantes fundamentos a prestigiar a postura assumida (TJRS, AC 70020868162, rel. Umberto Guaspari Sudbrack, j. 22.08.2007). "Indenizatória Reparação de danos - Testemunha de Jeová - Recebimento de transfusão de sangue quando de sua internação - Convicções religiosas que não podem prevalecer perante o bem maior tutelado peta Constituição federal que é a vida - Conduta dos médicos, por outro lado, que se pautou dentro da lei e ética profissional, posto que somente efetuaram as transfusões sanguíneas após esgotados todos os tratamentos alternativos Inexistência, ademais, de recusa expressa a receber transfusão de sangue quando da internação da autora Ressarcimento, por outro lado, de despesas efetuados com exames médicos, entre outras, que não merece acolhido, posto não terem sido os valores despendidos pela apelante - Recurso improvido" (TJSP, AC 123.430-4/4-00, rel. Flávio Pinheiro, j. 07.05.2002); de outro, alguns sustentam que não existe a obrigação de viver e o respeito a essa opção não implica omissão de socorro, mas respeito à individualidade do paciente, que tem inclusive tem o direito de morrer sem ser violentado em sua crença; cabendo ao médico adotar todos os recursos técnicos e científicos para proteger sua saúde, no entanto, sem contrariar a vontade expressa do religioso (CREMESP, Parecer $\mathrm{n}^{\circ}$ 27.278/96, aprovado na $2.020^{\mathrm{a}} \mathrm{RP}$, em 07.10.1997). O paciente, aqui, teria o direito de aceitar, ou não, a transfusão de sangue com base na sua crença, religião ou qualquer outro fator inerente à sua vontade. O Código de Ética Médica estabelece proíbe seja alguém constrangido a se submeter à terapêutica que não queira, bastando que tenha capacidade de decidir; o que nem mesmo se altera quando houver risco de morte, pois essa hipótese pode ser interpretada como uma autorização e não como dever absoluto de o médico intervir. De qualquer forma, tem ele o dever de esclarecer o paciente, se isso ocorrer, a lei ampara a possibilidade de ministrar hemoderivados até contrariamente à sua vontade, transparência essa que permitirá antever a futura reação do paciente caso o possível se torne concreto (CREMESP, Parecer $\mathrm{n}^{\circ}$ 19.123/94, aprovado na $1.626^{\mathrm{a}} \mathrm{RP}$, em 08.11.1994). Respeitar as convicções religiosas do paciente adulto e capaz equivale respeitar a autonomia e a autodeterminação individual, elementos que se fundamentam no princípio da dignidade da natureza humana e pressupõem a aceitação do pluralismo social. Se assim é, considerando a importância que essa temática tem para as "Testemunhas de Jeová", a recusa às transfusões de sangue constitui regra de conduta a ser observada, ainda que a sociedade a ignore ou a menospreze. Não se trata do exercício de um suposto direito de morrer, mas do direito de escolha do tipo de tratamento a que se submeterão. Por isso que o respeito à autonomia do paciente deve se estender aos seus valores religiosos, que não podem ser desconsiderados ou minimizados por outrem, sobretudo pelos profissionais da saúde (Zelita da Silva Souza e Maria Izabel Dias Miorim de Moraes. A ética médica e o respeito às crenças religiosas. Revista Bioética, Brasília: Conselho Federal de Medicina, v. 6, $\mathrm{n}^{\circ}$ 1, 1998. disponível em $\mathrm{http}: / / \mathrm{www}$.portalmedico.org.br/revista/ind $1 \mathrm{v} 6 . \mathrm{htm})$. O consentimento informado, em certos casos, portanto, além de um conceito jurídico, encerra acentuado panorama ético e moral, o que pode gerar conflito entre as convicções pessoais do médico e as religiosas do paciente; daí porque, salvo na falta de outro profissional, pode ser invocada escusa de consciência para não participar de um tratamento que ele discorde profundamente. Parece, contudo, existir certa harmonia em sendo menor o paciente. Discorre, sobre esse especial quadro, Jurandir Sebastião (Responsabilidade médica civil, criminal e ética. $3^{\mathrm{a}}$ ed. Belo Horizonte: Del Rey, 2003, p. 248/249): "no tocante ao menor de 16 anos de idade (filho de pais que professam, por exemplo, a religião denominada 'Testemunha de Jeová', internado e necessitando de transfusão de sangue, nem é necessário que se instale o estado de iminente perigo de vida. Invariavelmente os pais discordam da transfusão, mas suas vontades não têm amparo legal. A criança não é propriedade dos pais. Ao contrário, o menor é pessoa de direito, integrante da humanidade e com interesses distintos, cuja vida na sua inteireza e com saúde, deve ser preservada pelo Estado. (...) quando a questão envolve paciente com capacidade civil relativa (entre 16 e 18 anos de idade), a vontade desse menor, em não receber transfusão de sangue, deverá ser respeitada se coincidir com a vontade do tutor e desde que não haja iminente perigo de vida. Em caso de iminente perigo de vida, prevalecem as obrigações estatuídas nos arts. 46 e 56 do CEM, ou seja, o médico deve agir de acordo com a sua convicção profissional. Não sendo o caso de perigo de vida, mas ocorrendo divergência entre a vontade do paciente menor e a de seu tutor, deve prevalecer a indicação médica, pouco importando qual dos dois (tutor ou tutelado) tenha se manifestado a favor da transfusão. Por derradeiro, não é 
intervenção $\left(\mathrm{CC}\right.$, art. $\left.15^{650}\right)$, o que retira a legitimidade do ato médico ${ }^{651}$; logo, se real, efetivo e válido, materializa condição sine qua non para o início do tratamento ${ }^{652}$ e, enquanto não pronunciado, viável e lícita se mostra a recusa de agir. ${ }^{653}$

No entanto, como identifica Ricardo Luís Lorenzetti ${ }^{654}$, essa negativa pode gerar um conflito entre a vontade individual e o valor coletivo vida e saúde; daí porque, em determinadas situações, especiais certamente, dispensa-se a obtenção do consentimento informado.

Eis algumas delas: a) no caso de intervenção compulsória determinada pelo interesse público e imposta pela autoridade competente, se contagiosa a doença, por exemplo, a determinar a prevalência do direito coletivo à saúde; b) se a

demais lembrar que o ser humano é uma entidade complexa, misto de adesão consciente e de vulnerabilidade ais valores sociais. Dentre estes, avulta-se a religião, cuja liberdade de engajamento é assegurada pela $\mathrm{CF} / 88$ (art. $5^{\circ}$, inciso VI). Assim, em caso de razoável dúvida quanto à necessidade imperiosa ou apenas boa conveniência terapêutica a indicar a transfusão de sangue, o médico deve ceder à vontade do paciente e seus familiares. Não se pode esquecer que, em caso de fanatismo ou convicção religiosa, o paciente pode perder a saúde mental ou se atormentar pelo resto da vida, pela lembrança contínua de que dentro de seu corpo corre um sangue impuro! O inconcebível é o médico fanatizar-se em religião e deixar de indicar a transfusão de sangue nos casos de adequação terapêutica. Neste caso, sim, será responsabilizado pelos eventuais danos, sem que possa invocar a seu favor a crença religiosa (CF/88, art. $5^{\circ}$, inciso VIII)". Se o núcleo intangível da Carta Magna tende a assegurar a vida digna (CF, art. $1^{\circ}$, III), seria possível impor a alguém uma vida não digna? E a vida, em última análise, per se, pode ser considerada indigna? A controvérsia, percebe-se, está longe de se pacificar; porém, mister se faz uma maior reflexão sobre essa realidade, fonte inesgotável daquilo que se conhece como hard choices. "O direito à vida não se resume ao viver (...). O Direito à vida diz respeito ao modo de viver, a dignidade do viver. Só mesmo a prepotência dos médicos e a insensibilidade dos juristas pode desprezar a vontade de um ser humano dirigida a seu próprio corpo. Sem considerar os aspectos morais, religiosos, psicológicos e, especialmente, filosóficos que tão grave questão encerra. A liberdade de alguém admitir, ou não, receber sangue, um tecido vivo, de outra (e desconhecida) pessoa" (TJRJ, AI 2004.002.13229, voto vencido do Des. Marcos Antônio Ibrahim, j. 05.10.2004).

${ }^{649}$ Sobre risco confira-se a Res. 196 do Conselho Nacional de Saúde (CNS), que abrange a possibilidade de danos físicos, psíquicos, morais, intelectuais, sociais, culturais ou espirituais do homem, seja por riscoprocesso: a que são expostos os participantes de uma pesquisa, incluídos os próprios pesquisadores, seja por risco-produto: decorrente de projeto, aquele que atinge a sociedade de forma indistinta.

${ }^{650} \mathrm{CC}$, art. 15: "ninguém pode ser constrangido a submeter-se, com risco de vida, a tratamento médico ou a intervenção cirúrgica".

${ }^{651}$ Alfredo Jorge Kraut. Los derechos..., cit., p. 180.

${ }_{652}^{65}$ Fernando Campos Scaff. As relações jurídicas..., cit., p. 128.

653 "Plano de saúde. Ação de rescisão contratual, cumulada com perdas e danos materiais e morais, precedida de medida cautelar inominada. Cirurgia no joelho direito do autor agendada. Não realização pela ausência de assinatura pelo responsável pelo paciente do 'Termo de Consentimento Esclarecido'. Ato que implica na falta de autorização para a realização do ato cirúrgico. Licitude, ademais, da exigibilidade da assinatura do termo de consentimento. Obrigação do médico na obtenção prévia do consentimento do paciente. Razoabilidade da obtenção do consentimento pela forma escrita. Prática, ademais, que não é vedada pelo Conselho Regional de Medicina do Estado de São Paulo. Falta de realização da cirurgia, motivada pelo autor, que não se erige em causa eficiente para a rescisão do contrato que, em princípio, ainda remanesce. Ausência do dever de indenizar por parte das rés. Recusa que reflete exercício regular de um direito (artigo 188, inciso I, do Código Civil). Improcedência da ação reconhecida" (TJSP, AC 543.765-4/5-00, rel. Donegá Morandini, j. 12.05.2009).

${ }^{654}$ Responsabilidad civil de los médicos. Buenos Aires: Rubinzal-Culzoni, 1997, t. II, p. 92 e ss. 
hipótese revelar situação de absoluta emergência, com perigo de morte inclusive ${ }^{655}$, não estando o destinatário do serviço em condições de exprimir uma vontade consciente ${ }^{656}$ o que se robustece se a necessidade de intervenção surgir no curso de um procedimento já instalado; c) sendo contra-indicado, segundo a lex artis, que o paciente tome conhecimento da doença; d) se houver impossibilidade de consentir, seja por limitações de idade, seja por afetações psíquicas, ainda que transitórias; e) a renúncia voluntária ao direito de ser informado. $^{657}$

Sobre a possibilidade dessa renúncia, invariavelmente advinda da confiança depositada no profissional da saúde, com pena de mestre, pondera Fernando Campos Scaff, “outra hipótese de desconsideração legítima do prévio consentimento poderá ocorrer nos casos em que o paciente, de modo voluntário, outorgue ao seu médico plena autonomia e discricionariedade para a realização das medidas por ele julgadas convenientes ao tratamento de sua saúde, recusando informações que pretendesse o agente de saúde fornecer e negando-se, enfim, a obter qualquer esclarecimento acerca da moléstia que o aflige". ${ }^{658}$

O desejo do paciente, não ao uso de determinada técnica ou material, cujas específicas nuances por óbvio não domina, mas ao próprio tratamento indicado pelo médico, é elemento de singular importância nessa qualificada relação jurídica; assim, deve ser colhido dentro de um quadro de plena capacidade, sem que isso implique - de modo inexorável - aquele componente indispensável aos negócios válidos em geral (CC, art. 104, I).

Destaque-se, como visto (supra, Cap. II, 2.1), que a capacidade não foi erigida em elementar do conceito jurídico de consumidor (CDC, art. $2^{\circ}$ ), porquanto conhece o sistema que vínculos dessa natureza podem muito bem se aperfeiçoar via contratação de fato ou mediante um comportamento concludente ${ }^{659}$; entretanto, tormentosa a análise, a busca da plena compreensão dos riscos ${ }^{660}$ acaba

\footnotetext{
${ }^{655}$ Elididas, aqui, as infrações penal (CP, art. 143, § $3^{\circ}$, I) e administrativa (CEM, art. 56).

${ }^{656}$ Fernando Campos Scaff. As relações jurídicas..., cit., p. 136/137.

${ }^{657}$ Alfredo Jorge Kraut. Los derechos..., cit., p. 187 e ss.

${ }^{658}$ As relações jurídicas..., cit., p. 137.

659 Paulo da Mota Pinto. Declaração tácita e comportamento concludente no negócio jurídico. Coimbra: Almedina, 1995.

${ }^{660}$ Alfredo Jorge Kraut (Los derechos..., cit. p. 150 e ss.) sustenta que essa plena compreensão há de representar a capacidade de decidir "por si", tida como aptidão cognoscitiva para entender a informação e poder eleger autônoma e racionalmente o conveniente aos seus interesses (aceitar ou rechaçar uma intervenção médica com fundamento em dita informação disponível).
} 
desaguando na autodeterminação para a prática dos atos da vida civil, suprida a sua falta, tanto pela inconsciência quanto pela imaturidade, via de regra, mediante o concurso dos familiares ou responsáveis legais ou, até mesmo, como última ratio, por decisão judicial.

Não se pode desconsiderar, todavia, a doutrina do menor amadurecido (mature minor doctrine) do direito anglo-americano ${ }^{661}$. Para ela, considera-se menor amadurecido aquele paciente que, embora não tendo atingido a maioridade civil, é dotado de capacidade de tomar decisões independentes, compreendendo a natureza e as consequências do tratamento médico proposto, podendo aceitá-lo ou recusá-lo. ${ }^{662}$

"O facto de uma criança ser competente para consentir ou dar o seu assentimento a determinada terapêutica, não implica que seja competente para recusá-la e vice-versa: o consentimento para um procedimento de baixo risco e seguro benefício por uma criança saudável requer um nível mínimo de competência, enquanto que a recusa do mesmo, necessita do mais elevado nível de competência.

\section{$(\ldots)$}

Se a criança discorda das recomendações do médico ou desejos e preferências dos pais, impõe-se o diálogo esclarecedor das causas de tal discórdia. Em caso de desacordo persistente quer com o clínico, quer com os pais ou com ambos, o médico deve procurar avaliar, com o rigor possível, a competência da criança relativamente a capacidade de decisão, na matéria em apreciação.

Se concluir pela sua competência, deve assumir o compromisso de interceder junto dos pais com a finalidade de conseguir que as preferências e desejos da criança sejam ouvidos e respeitados."

Assim, o médico deve perquirir a capacidade de avaliação do paciente menor sobre o seu próprio problema, considerando a gravidade do quadro clínico

\footnotetext{
${ }^{661}$ Cláudio da Silva Leiria. Transfusões de sangue contra a vontade de paciente da religião Testemunhas de Jeová: uma gravíssima violação dos direitos humanos. Disponível em http://jusvi.com/artigos/39291.

${ }^{662}$ Segundo o art. 12 da Convenção das Nações Unidas sobre os Direitos das Crianças, de 20.11.1989, aprovada pelo Decreto Legislativo 28, de 14 de setembro de 1990 e promulgada pelo Decreto 99.710, de 21 de novembro de 1990: “os Estados Partes assegurarão à criança que estiver capacitada a formular seus próprios juízos o direito de expressar suas opiniões livremente sobre todos os assuntos relacionados com a criança, levando-se devidamente em consideração essas opiniões, em função da idade e da maturidade da criança".
} 
apresentado; na tentativa de evitar, ainda, o possível dano advindo da não revelação dos fatos, em princípio guarnecidos pelo sigilo profissional (CEM, art. $103^{664}$ ), aos seus pais ou responsáveis $^{665}$. Nessa análise, ganha sensível relevo a circunstância de o menor ter, ou não, condições de se conduzir por seus próprios meios, na forma prescrita, para solucionar o mal que o aflige. ${ }^{666}$

$\mathrm{Ou}$, em outras palavras, o adolescente que procura atendimento médico sem acompanhante deve ser atendido sem restrições ${ }^{667}$, preservandose o direito à sua intimidade, garantido a qualquer pessoa independentemente de critérios etários; porém, caso o paciente não possua condições de compreender a extensão do seu problema de saúde, ou não possa por meios próprios se conduzir na forma da orientação médica, seus pais ou responsáveis devem acompanhar a consulta e/ou o tratamento ministrado. ${ }^{668}$

${ }^{663}$ Maria do Carmo Vale e Guilherme de Oliveira. Consentimento informado em menores. Disponível em http://www.ceic.pt/portal/page/portal/CEIC/Documentos/DOCUMENTOS_REFLEXAO/Consent $\% 20$ Inf $\% 2$ 0Menores.pdf.

664 É vedado ao médico: "art. 103 - Revelar segredo profissional referente a paciente menor de idade, inclusive a seus pais ou responsáveis legais, desde que o menor tenha capacidade de avaliar seu problema e de conduzir-se por seus próprios meios para solucioná-lo, salvo quando a não revelação possa acarretar danos ao paciente".

${ }^{665}$ CREMESP, Parecer 15.996/94, aprovado na $1.646^{\mathrm{a}} \mathrm{RP}$, em 14.02.1995.

${ }^{666}$ CREMESP, Parecer 1.800-76/87, aprovado na $1.286^{\mathrm{a}} \mathrm{RP}$, em 01.03.1988.

${ }^{667}$ CREMESP, Parecer 15.633/94, aprovado na 1.612 RP, em 16.08.1994.

668 "Com algumas exceções, os jovens de idade inferior a 18 anos não têm autoridade ou competência legal para prestar consentimento informado, assumindo os pais ou os tutores essa função. Enquanto o doente adulto é considerado competente para prestar consentimento e em caso de incapacidade ter-se-á que provar o contrário, o doente pediátrico é a priori incompetente para tal, sendo necessários determinados requisitos para ser competente, quer do ponto de vista ético, quer do ponto de vista legal. Deve ser dada à criança toda a informação que esta for capaz de compreender, o que naturalmente dependerá da sua maturidade e da natureza da investigação. Importante é não repousar unicamente em fórmulas de assentimento, mas providenciar uma cuidadosa informação entre investigadores, pais e criança, correndo-se o risco de não prestar a informação que se impõe sempre que o protocolo não contemple o assentimento. Os investigadores não devem subestimar a curiosidade e a capacidade destas crianças de fazer escolhas informadas. Os préadolescentes devem ser tratados praticamente como adultos porque lhes é particularmente caro o respeito pela sua autonomia e competência. A principal informação e compreensão que as crianças necessitam para grande parte das decisões terapêuticas refere-se ao impacto que as alternativas terão na sua vida e não a dados técnicos médicos. O pediatra deve manifestar solidariedade e respeito com a visão parental, não descurando ou abdicando do seu dever prioritário em face da criança que trata. A comunicação entre o médico e a criança se pautará, sobretudo, pelo paternalismo e beneficência, dado que a criança não pode nunca ser tratada ou abordada como um adulto e deverá ter em conta a idade, o desenvolvimento cognitivo, o desenvolvimento moral e o estatuto moral da criança no interior do contexto social e cultural dela e família. Também a experiência e a perspectiva da criança deverão ser contempladas e, sempre que possível, valorizadas segundo pressupostos elaborados individualmente, sobretudo em crianças com antecedentes de doença aguda ou crônica, em que o crédito a atribuir à sua opinião dependerá da questão envolvida: quanto mais seguro e cientificamente demonstrado um tratamento, menor intervenção, deliberação e protagonismo será dado à criança e naturalmente predominará o princípio da beneficência e o paternalismo. Pelo contrário, quanto mais grave a situação clínica e desequilibrada a relação custo-benefício de um procedimento diagnóstico ou terapêutico, maior peso, protagonismo e autonomia poderão ser dados à criança, atendendo ao duvidoso benefício e seguro sofrimento, provavelmente inútil, daí decorrente. Deve o médico evitar, à exaustão, o 


\subsubsection{Colaboração (lealdade ou cooperação)}

A obrigação de colaborar permeia toda a execução do contrato, impondo a lealdade pelo não obstruir, não impedir ou não dificultar a atuação do contratante mais fraco. ${ }^{669}$

É um dever ético de não frustrar as expectativas recíprocas, utilizando todos os meios possíveis para que prevaleça a satisfação dos interesses da outra parte ${ }^{670}$; inclusive acatando ou promovendo as alterações necessárias, no caso de quebra da base objetiva do negócio, para garantir a realização do intuito comum pactuado, por meio da adaptação das condições primitivas, ainda que de modo compulsório, a um só tempo, preservando o equilíbrio contratual e evitando a ruína econômica do sujeito desprotegido. ${ }^{671}$

\subsubsection{Cuidado}

Aqui a preocupação se esparze sobre a integridade pessoal (moral ou física) e patrimonial dos contratantes, reciprocamente considerados. É uma obrigação de segurança da mesma forma dirigida a realizar o objetivo do contrato, o que se evidencia ainda mais se de saúde a relação jurídica. ${ }^{672}$

Discorrendo sobre a matéria no âmbito do CDC, assim se pronuncia Bruno Miragem, "no que se refere aos deveres de proteção e cuidado com relação à pessoa e ao patrimônio da outra parte, o CDC igualmente prevê este efeito decorrente do princípio da boa-fé ao consagrar os direitos do consumidor à saúde e segurança, e ao estabelecer, em consequência, o dever do fornecedor de respeitá-los

conflito entre a criança e a sua família. Se não puder ser resolvido, terão que ser analisados criteriosa e objetivamente os detalhes do caso e questionar designadamente a existência de benefício direto para a criança e, nesse caso, ponderar os motivos e competência de quem se opõe à inclusão da criança na investigação" (Maria do Carmo Vale e Guilherme de Oliveira. Consentimento informado..., idem).

${ }^{669}$ Cláudia Lima Marques. Contratos..., cit., p. 195.

${ }^{670}$ Roberto Senise Lisboa. Responsabilidade civil..., p. 106-107.

${ }^{671}$ Cláudia Lima Marques. Contratos..., cit., 198.

672 "Plano de Saúde. Necessidade de tratamento de hemodiálise em domicílio para a tentativa de preservação da vida do segurado. Reconhecimento do caráter abusivo de cláusula que exclui a cobertura do tratamento. Custos da cobertura diluídos na receita obtida dos demais usuários que pouco utilizam o plano de saúde. Custo inserido na atividade desenvolvida pela recorrida. Atenuação do princípio pacta sunt servanda. 
(artigos $8^{\circ}$ a 10 do CDC). A própria estrutura da relação de responsabilidade civil no CDC reflete esta idéia, ao distinguir entre a responsabilidade pelo fato do produto ou do serviço, e a responsabilidade pelo vício do produto ou do serviço, em razão do interesse tutelado do consumidor. No primeiro caso, protegendo-se a segurança do consumidor (artigos 12 a 14), e no segundo a finalidade pretendida por ele na realização do contrato de consumo (artigos 18 a 20)". ${ }^{673}$

\subsubsection{Sigilo}

Pelo dever de sigilo (omissão ou segredo) se exige reserva da parte sobre o que tenha sabido em razão do processo contratual e cuja divulgação lhe possa frustrar o objetivo ou trazer prejuízo a seu desenvolvimento e, por conseguinte, ao parceiro do negócio. ${ }^{674}$

Lembra, ainda, o professor Fernando Campos Scaff que essa garantia se projeta sobre as particularidades do paciente, ligadas à sua intimidade, exceto se necessária a comunicação aos órgãos públicos da presença de moléstia com potencial epidêmico. $^{675}$

6.2 Limite ao exercício de direitos subjetivos

Ao identificar no contrato um caráter social que se distancia daquela antiga concepção de mera forma de exteriorizar a vontade declarada, relega-se à boa-fé objetiva a função de obstar comportamentos que contrariem os pressupostos da lealdade e da probidade ${ }^{676}$ ou, nas palavras de Menezes Cordeiro, o exercício inadmissível de posições jurídicas. ${ }^{677}$

Observe-se, a propósito: o Código Civil deixa bem claro que o abuso de direito equivale a ato ilícito (art. 187) ${ }^{678}$, enquanto a política nacional das

Incidência do disposto no artigo 421 do Código Civil. Sentença mantida. Recurso improvido" (TJSP, AC 595.265-4/9, rel. Donegá Morandini, j. 23.06.2009).

${ }^{673}$ Direito..., cit., p. 73.

${ }^{674}$ Cláudio Luiz Bueno de Godoy. Função social..., cit., p. 80.

${ }^{675}$ As relações jurídicas..., cit., p. 123.

${ }^{676}$ Judith Martins-Costa. A boa-fé..., cit., p. 457.

${ }^{677}$ Da boa-fé..., cit., v. 2, p. 661.

678 "O art. 187, CC, ao tratar da definição de ato ilícito, reconhece que a violação da boa-fé objetiva pode corresponder ao exercício inadmissível ou abusivo de posições jurídicas. Isto é, a figura do abuso de direito é 
relações de consumo exige - como norma-objetivo - a coibição e a repressão eficientes de todos os abusos praticados no mercado ( $\mathrm{CDC}$, art. $\left.4^{\mathrm{o}}, \mathrm{VI}\right)$, regra que outorga fundamento de validade às outras existentes nesse microssistema protetivo, seja na parte geral (art. $6^{\circ}$, IV e V), seja na parte especial (capítulos V - práticas comerciais e VI - proteção contratual).

$\mathrm{Na}$ Alemanha, por sua vez, a produção jurisprudencial alargou a aplicabilidade da objeção ao exercício abusivo do direito criando dois grupos de casos: a) quando por meio do exercício do direito não são realizados os interesses protegidos pelo contrato ou pela lei e b) quando o titular do direito, ao exercê-lo, se põe em contradição com seu comportamento anterior (venire contra factum proprium) ${ }^{679}$

Eis as vertentes dessa limitação, aí não incluída - por depender da subjetividade do agente - a exceptio doli ${ }^{680}$ :

\subsubsection{Doutrina dos atos próprios}

Para Judith Martins-Costa, essa teoria propõe “(...) que a ninguém é lícito fazer valer um direito em contradição com a sua anterior conduta interpretada objetivamente segundo a lei, segundo os bons costumes e a boa-fé, ou quando o exercício posterior se choque com a lei, os bons costumes e a boa-fé. O seu efeito primordial é impedir que a parte que tenha violado deveres contratuais exija o cumprimento pela outra parte, ou valha-se do seu próprio incumprimento para beneficiarse de disposição contratual ou legal". ${ }^{6} 1$

Nelson Nery Junior e Rosa Maria de Andrade Nery, a propósito do tema, comentam que, "a cláusula geral de boa-fé objetiva obriga as partes a não agirem em contradição com atos e comportamentos anteriores, praticados antes da conclusão do contrato, durante a execução ou depois de exaurido o objeto do contrato. Em outras palavras, a parte não pode venire contra factum proprium. A proibição incide objetiva e unilateralmente, independentemente do comportamento ou da atitude da contraparte, porque é dever de conduta de cada um dos contratantes isoladamente

associada à violação do princípio da boa-fé objetiva e, nessa função, ao invés de criar deveres laterais, a boafé restringe o exercício de direitos, para que não se configure abusividade” (STJ, REsp. 1.096.639/DF, rel. Min. Nancy Andrighi, j. 09.12.2008).

${ }^{679}$ Wanderlei de Paula Barreto. O princípio da boa-fé..., idem.

${ }^{680}$ Faculdade potestativa de paralisar o comportamento da outra parte na hipótese de dolo. 
considerados. A proibição do venire também se caracteriza quando a parte, por seu comportamento pré-contratual ou manifestado durante a execução do contrato, gerou expectativa de legítima confiança na contraparte, que pratica atos e espera resultados de acordo com o que vinha demonstrando o outro contratante". ${ }^{62}$

São, conforme ensina a boa doutrina, quatro os pressupostos do venire: a) um comportamento; b) a geração de uma expectativa; c) o investimento nesse estado anímico causado, não necessariamente econômico e d) a conduta contraditória à inicial, referência da confiança depositada. ${ }^{683}$

É dizer: aquele que praticou determinado ato (em regra conduta positiva) não pode, posteriormente, alegar circunstância que se contraponha àquelas posturas iniciais a que ele mesmo dera causa ${ }^{684}$; ou seja, o obrar incoerente que lesiona a confiança suscitada na outra parte da relação e impõe aos sujeitos um comportamento probo nas relações jurídicas. ${ }^{685}$

Adita Anderson Schreiber que, “(...) a tutela da confiança atribui ao venire um conteúdo substancial, no sentido de que deixa de se tratar de uma proibição à incoerência por si só, para se tornar um princípio de proibição à ruptura da confiança, por meio da incoerência" ${ }^{686}$. O que se preserva é a confiança da contraparte ${ }^{687}$, a expectativa legítima criada, núcleo estruturante da regra do venire, sendo desinfluente perquirir tanto a culpa quanto a licitude ou ilicitude do factum proprium. ${ }^{688}$

No direito à saúde essa teoria ganha espaço em duas situações bem definidas. A primeira como sentido inverso do postulado da transparência, antes estudada apenas como dever secundário de aconselhamento imposto ao titular da arte, do processo produtivo, agora dirigida à honestidade da conduta do paciente, sem a

\footnotetext{
${ }^{681}$ A boa-fé..., cit., p. 460.

${ }^{682}$ Código Civil comentado..., cit., p. 507.

${ }^{683}$ Luciano de Camargo Penteado. Figuras parcelares da boa-fé objetiva e venire contra factum proprium. Disponível em http://www.flaviotartuce.adv.br/secoes/artigosc.asp.

${ }^{684}$ Nelson Nery Junior e Rosa Maria de Andrade Nery. Código Civil comentado..., cit., p. 507.

${ }^{685}$ Rúben Héctor Compagnucci de Caso. La doctrina de los próprios actos y la declaración tácita de la voluntad. In La Ley, t. 1985-A, Buenos Aires, 1985, p. 1.001.

${ }^{686}$ A proibição do comportamento contraditório. Tutela da confiança e venire contra factum proprium. Rio de Janeiro: Renovar, 2005, p. 95.

${ }^{687}$ Enunciado 362 da IV Jornada de Direito Civil promovida pelo Conselho da Justiça Federal: "a vedação do comportamento contraditório (venire contra factum proprium) funda-se na proteção da confiança, tal qual se extrai dos arts. 187 e 422 do Código Civil".

${ }^{688}$ Enunciado 363 da IV Jornada de Direito Civil promovida pelo Conselho da Justiça Federal: “os princípios da probidade e da confiança são de ordem pública, estando a parte lesada somente obrigada a demonstrar a existência da violação".
} 
qual fica impossível ou pouco provável, no mínimo, a escolha da melhor técnica e do mais eficaz tratamento.

Aquele consentimento informado tem, de fato, duas representações, também se irradiando sobre a pessoa do paciente, a quem cabe prestar todas as informações ao profissional da saúde, permitindo possa ele - a um só tempo formular corretamente as hipóteses diagnósticas e sugerir o procedimento adequado. ${ }^{69}$

Trata-se de vínculo recíproco inerente a essa especial relação, pois o direito de o médico obter informações claras tem como pressuposto o dever esclarecer ao máximo o destinatário dos seus serviços a ponto de lhe gerar, no espírito, a confiança indispensável à decisão de colaborar.

Contudo, se optar pela omissão de dados essenciais ao seu tratamento, de modo deliberado ou não, o paciente poderá induzir em erro o prestador de serviços que, nessas situações, não deverá ter a si atribuída a responsabilidade que decorreria de suposta e inexistente culpa advinda da conduta adotada. ${ }^{690}$

João Vaz Rodrigues aponta que, "entre as conseqüências da falta de colaboração do doente, ou da sua colaboração deficiente, situam-se a impossibilidade de responsabilizar o agente médico por uma atuação técnica incorreta e a possibilidade de o médico recusar a assistência ou a prática de um ato médico, desde que não esteja em causa perigo para a vida, ou para a integridade física do paciente, ou inviabilizado o regular acompanhamento profissional do paciente por outro médico, pois nestas circunstâncias a recusa do médico não é possível sem consequências". ${ }^{691}$

Tal impossibilidade de responsabilização, nesses casos, nada mais é do que o venire contra factum proprium a impedir seja o médico questionado por não ter se conduzido de certa forma, que somente lhe seria possível antever se o paciente tivesse lhe proporcionado ampla cognição acerca do real espectro da moléstia e/ou dos sintomas que o acometiam.

A segunda, a seu turno, como elemento inviabilizador das chamadas falsas declarações, cujos reflexos nos contratos de saúde serão adiante analisados.

\footnotetext{
${ }^{689}$ Fernando Campos Scaff. As relações jurídicas..., cit., p. 128.

${ }^{690}$ Idem, p. 93.

691 O consentimento informado para o ato médico no ordenamento jurídico português. Coimbra: Ed. Coimbra, 2001, p. 224/225.
} 
Ainda como representação dessa doutrina, na voz de Menezes Cordeiro, tem-se o tu quoque, que se caracteriza pela regra segundo a qual a pessoa que transgride uma norma jurídica não pode, sem que se caracterize abuso, exercer a situação jurídica que esta mesma norma violada lhe tenha atribuído. ${ }^{692}$

Não é possível, portanto, em respeito à ética, a parte recorrer a normas por ela própria infringidas ${ }^{693}$, o que estrutura - no âmbito contratual - a principiologia da exceptio non adimpleti contractus $^{694}$ e demonstra uma eficácia vinculativa para além dos limites da autonomia privada do negócio. ${ }^{695}$

Ninguém pode adquirir direitos de má-fée ${ }^{696}$, beneficiando-se de uma espécie de invocação de dois pesos e duas medidas, ou seja, "o emprego, desleal, de critérios valorativos diversos para situações substancialmente idênticas". 697

\subsubsection{Suppressio $\mathrm{x}$ surrectio}

A boa-fé objetiva, por via da suppressio, impede o exercício de um direito subjetivo não exercido em certas circunstâncias e durante um determinado lapso de tempo (conduta negativa em regra). É o abandono de uma posição jurídica que impossibilita - ainda que momentaneamente - a realização de um direito ${ }^{698}$, agora desprovido de eficácia. ${ }^{699}$

Ressalta Fernando Noronha, após afastar qualquer afinidade do instituto com os efeitos do decurso do tempo gerados pela prescrição e pela decadência e a relevância do estado anímico do titular do direito não exercido, que, "no protraimento desleal é imprescindível que o titular do direito tenha tido um comportamento deslealmente

\footnotetext{
${ }^{692}$ Da boa-fé..., cit., v. 2, p. 837.

${ }^{693}$ Franz Wieacker. El princípio..., cit., p. 67.

${ }^{694}$ Cláudio Luiz Bueno de Godoy. Função social..., cit., p. 88.

${ }^{695}$ Luciano de Camargo Penteado. Figuras parcelares..., idem.

${ }^{696}$ José Fernando Simão. A boa-fé e o novo Código Civil - Parte III. Disponível em http://www.professorsimao.com.br/artigos_simao_a_boa_fe_03.htm.

${ }_{697}$ Anderson Schreiber. A proibição do comportamento contraditório..., cit., p.175.

${ }^{698}$ STJ, REsp. 1.096.639/DF, rel. Min. Nancy Andrighi, j. 09.12.2008.

699 "Tenho como admissível a teoria da suppressio, segundo a qual o comportamento da parte, que se estende por longo período de tempo ou se repete inúmeras vezes, porque incompatível com o exercício do direito, pode levar a que se reconheça a extinção desse direito, com base na boa-fé objetiva” (STJ, REsp. 207.509/SP, voto do Min. Ruy Rosado de Aguiar, j. 27.11.2001).
} 
contraditório, criando na pessoa contra quem o direito se dirigia uma situação de justificada confiança em que ele nunca seria exercido", 700

Dessa inação surge a surrectio, uma nova posição jurídica (tida como presente) gerada pela expectativa legítima - da mesma forma o verdadeiro objeto da tutela protetiva - de que o direito antagônico não será exercido.

Uma variante concreta desses institutos no âmbito das relações que a este estudo interessam pode ser identificada se um seguro coletivo (de saúde ou de vida), após renovar anual e sequencialmente sua apólice, por mais de trinta anos em certos casos, com base em cláusula permissiva de resilição unilateral, embora nula de pleno direito (CDC, arts. 51, IV, XI e XV, c.c. seu $\S 1^{\mathrm{o}}$, I, II e III, c.c. 54, $\left.\S 2^{\circ}\right)^{701}$, pretende cancelar - por si só - o contrato com arrimo no término do prazo cíclico de vigência.

Esse proceder, na verdade, ultrapassa o exercício regular para se converter em abuso, pois o ajuste obrigacional não pode ser mantido apenas enquanto bom para uma das partes, notadamente porque a teoria do adimplemento substancial impede seja ele desfeito pelo mais forte - lídimo ato que beira a potestatividade pura quando a ele começam a recair maiores riscos.

Tais condutas, por óbvio, frustram a expectativa legítima do segurado de ser ressarcido em razão dos sinistros cobertos ${ }^{702}$; sendo que apenas e tãosomente a ele se reconhece o direito de manter ou não a contratação, faculdade exclusiva do aderente ${ }^{703}$ beneficiado pela suppressio.

\subsubsection{Teoria do adimplemento substancial}

Essa função limitativa atribui eficácia liberatória (eximente ou absolutória) ao devedor confrontado por um credor inflexível. O direito que se restringe, ainda formativo, é o de resolver o contrato.

Mesmo diante de uma obrigação não cumprida, conquanto haja cláusula resolutiva expressa, cabe perquirir a relevância e a gravidade do inadimplemento sobre a esfera de interesses leais e razoáveis do sujeito, em tese, prejudicado pela ruptura do sinalagma originário.

\footnotetext{
${ }^{700}$ O direito dos contratos..., cit., p. 186/187.

${ }^{701}$ TJSP, AC 936.582-0/5, rel. Ruy Coppola, j. 23.03.2006.

702 TJSP, AC 1.076.655-0/2, rel. Clóvis Castelo, j. 02.03.2009.
} 
Caso o adimplemento, mesmo incompleto, se aproxime do resultado final pretendido quando do ajuste, sob o crivo das legítimas expectativas criadas e da reciprocidade das prestações assumidas, possível não mais será a resolução do vínculo; reservando-se ao credor apenas a busca de perdas e danos. ${ }^{704}$

"O adimplemento substancial, conforme o definiu o Prof. Clóvis do Couto e Silva, constitui 'um adimplemento tão próximo do resultado final, que, tendo em vista a conduta das partes, exclui-se o direito de resolução, permitindo-se tão somente o pedido de indenização' e/ou de adimplemento, de vez que aquela primeira pretensão viria a ferir o princípio da boa-fé.

\section{(...)}

O inadimplemento ou o adimplemento inútil são causas de desequilíbrio porque privam uma das partes da contraprestação a que tem direito. Por isso se lhe concede o direito de resolução, como medida preventiva.

Mas, para que haja efetivamente um desequilíbrio, algo que pese na reciprocidade das prestações, é necessário que tal inadimplemento seja significativo a ponto de privar substancialmente o credor da prestação a que teria direito., 705

Preservado o núcleo da base objetiva do negócio, à míngua de relevante comprometimento da comutatividade primária, a resolução - direito prima facie potestativo - passa a ser entendida como medida inútil e desproporcional e, por isso, cede ao princípio da preservação dos contratos.

Nas relações jurídicas privadas no direito à saúde, por exemplo, aufere vantagem manifestamente exagerada, de forma abusiva e em contrariedade à boa-fé objetiva, o segurador que, após longo período recebendo os prêmios devidos pelo segurado, nega a cobertura, sob a alegação de que se trata de doença preexistente. $^{706}$

Ressalte-se, por oportuno, que o adimplemento substancial pode ser quantitativo e/ou qualitativo, de acordo com a importância - em todos os seus contornos - que tiverem as prestações dentro do espectro unitário do negócio; como a

\footnotetext{
${ }^{703}$ TJSP, AC 1.078.705-0/8, rel. Júlio Vidal, j. 17.02.2009.

${ }^{704}$ Gustavo Tepedino et alii. Código Civil interpretado..., cit., p. 21.

${ }^{705}$ Anelise Becker. A doutrina do adimplemento substancial no direito brasileiro e em perspectiva comparativista. Revista da Faculdade de Direito da Universidade Federal do Rio Grande do Sul. Porto Alegre: Livraria dos Advogados, n. 1, v. 9, nov. 1993, p. 60 e 65.
} 
irrelevante mora de uma ou de algumas mensalidades, dentro da economia de um contrato de plano de saúde pago regularmente durante longos anos, não poderia ensejar - per se - a negativa de cobertura. ${ }^{707}$

O exercício desequilibrado de direitos, segundo a doutrina de Fernando Noronha ${ }^{708}$, Menezes Cordeiro ${ }^{709}$ e Franz Wieacker ${ }^{710}$, lembra o romano inciviliter agere, procedimento claramente iníquo; quadro que se revela se o exercício do direito desconsidera a contraparte em razão de interesses desproporcionais, o que evidencia falta de equidade e de solidariedade na relação entre os sujeitos.

\subsection{Critério de interpretação e concreção dos negócios jurídicos}

A interpretação é dirigida à vontade contratual, não àquela que cada um dos sujeitos aderentes pura e simplesmente declararam; importante é o consenso a partir da intenção comum que se revelou de modo objetivo no ajuste, afastando-se a força vinculante das palavras que constaram do instrumento, agora relativizadas. Alguns princípios ganham especial relevo nesse processo: a) o da boa-fé objetiva; b) o da preservação dos contratos e c) o do equilíbrio proporcional entre os compromissos assumidos e as vantagens esperadas. ${ }^{711}$

A confiança e as expectativas legítimas também norteiam essa função, haja vista tentarem reconstituir a intenção presumida dos contratantes ${ }^{712}$; daí porque as cláusulas devem ser entendidas de acordo com seu sentido objetivo e aparente, regidas por um significado que o standard de conduta leal aponte ser o mais razoável. ${ }^{713}$

Segundo Renan Lotufo, "a função interpretativa da boa-fé, que deverá nortear os destinatários do negócio jurídico, visando conferir o real significado que as partes lhe atribuíram, procedendo com lisura, ou, na hipótese de cláusulas ambíguas, conferir preferência ao significado que a boa-fé aponte como mais razoável". 714

\footnotetext{
${ }^{706}$ STJ, REsp. 1.080.973/SP, rel. Min. Nancy Andrighi, j. 09.12.2008.

${ }^{707}$ TJSP, AC 612.729.4/9-00, rel. Francisco Loureiro, j. 25.06.2009.

${ }^{708}$ O direito dos contratos..., cit., p. 179.

${ }^{709}$ Da boa-fé..., cit., v.2, p. 859.

${ }^{710}$ El princípio..., cit., p. 72.

${ }_{711}^{71}$ Cláudio Luiz Bueno de Godoy. Função social..., cit., p. 76/77.

712 Alessandro Somma. Autonomia privata e struttura del consenso contrattuale. Milão: Giuffrè, 2000, p. 427/428.

${ }^{713}$ Fernando Noronha. $O$ direito dos contratos..., cit., p. 152.

${ }^{714}$ Comentários ao novo Código Civil. São Paulo: Saraiva, 2003, v. I, p. 315.
} 
No sistema alemão, paradigma natural na temática sub examine, como ensina Wanderlei de Paula Barreto, segue-se a mesma diretriz, pois, "a imposição da norma de conduta segundo Treu und Glauben dirige-se tanto ao devedor quanto ao credor no que pertine à determinação da espécie da prestação e do seu modo de adimplemento e encontra aplicação limitada à função interpretativa, nas hipóteses de existência de normas positivas específicas sobre a situação fática, e, por outro lado, aplicação integrativa, no caso de existência de lacunas normativas". ${ }^{715}$

Tanto o Código Civil quanto o CDC trazem dispositivos orientadores de interpretação contratual (CC, arts. 112, 113 e 423 c.c. CDC, arts. $4^{\circ}$, III, e 47) e outros que encerram típica cláusula geral para definição de regras de conduta (CC, art. 422 c.c. CDC, art. 51, IV); assim entendida como autêntico vetor do mínimo ético exigível.

Assevere-se, uma vez mais, que a boa-fé objetiva representa um limite à liberdade de contratar, haja vista suas exigências éticas submeterem e restringirem a autonomia da vontade ${ }^{716}$, permitindo a construção de um sistema aberto, que evolui e se perfaz dia a dia pela incorporação dos variados casos apresentados pela prática social. $^{717}$

É, neste passo, um importante referencial na conciliação de interesses conflitantes. $^{718}$

\footnotetext{
715 O princípio da boa-fé..., idem.

${ }^{716}$ Heloísa Carpena Vieira de Mello. A boa-fé como parâmetro da abusividade no direito contratual. In: Tepedino, Gustavo (coord.). Problemas de direito civil..., cit., p. 316.

717 Judith Martins-Costa. Sistema e cláusula geral: a boa-fé objetiva no processo obrigacional. Tese de Doutorado apresentada à Universidade de São Paulo (USP), setembro/1996, p. 465.

718 Agathe E. Schmidt da Silva. Cláusula geral de boa-fé nos contratos de consumo. Revista de Direito do Consumidor, São Paulo: RT, v. 17, jan.-mar. 1996, p. 146.
} 


\section{O CDC E SUAS CLÁUSULAS ESPECÍFICAS}

7.1 Art. $4^{\mathrm{o}}$, III

Para o Min. Ruy Rosado de Aguiar Júnior, com sua acurada

visão:

"O princípio da boa-fé está mencionado no texto do art. $4^{\circ}$, III, como critério auxiliar para a viabilização dos ditames constitucionais sobre a ordem econômica (art. 170 da CF). (...) Isso quer dizer que a boa-fé não serve tãosó para a defesa do débil, mas também atua como fundamento para orientar interpretação grandiosa da ordem econômica, compatibilizando interesses contraditórios, onde eventualmente poderá prevalecer o interesse contrário ao do consumidor, ainda que a sacrifício deste, se o interesse social prevalente assim o determinar. (...) O que está conforme o ensinamento de Rodotá: 'a escolha deverá ser feita de modo a assegurar prevaleça o interesse que se apresenta mais vantajoso em termos de custo social.'

A aproximação dos termos ordem econômica - boa-fé serve para realçar que esta não é apenas um conceito ético, mas também econômico, ligado à funcionalidade econômica do contrato e a serviço da finalidade econômico-social que o contrato persegue. (...) $\mathrm{O}$ art. $4^{\mathrm{o}}$ do Código se dirige para o aspecto externo e quer a intervenção na economia contratual, para a harmonização dos interesses, se dê com base na boa-fé, isto é, com superação dos interesses egoísticos das partes e com a salvaguarda dos princípios constitucionais sobre a ordem econômica através de comportamento fundado na lealdade e na confiança." ${ }^{, 719}$

Há de se concretizar essa harmonia, pois o sujeito materialmente vulnerável precisa ser compatibilizado com o princípio da autonomia da vontade e com o desenvolvimento econômico e tecnológico; por conseguinte, é imprescindível manter o equilíbrio entre as partes na relação de consumo e, para isso, atua a boa-fé como eficaz ferramenta do dirigismo contratual. ${ }^{720}$

${ }^{719}$ A boa-fé..., cit., p. 21-22. 
Impende frisar que a Lei 8.078/90 (art. 51, $\mathrm{IV}^{721}$ ) consagrou autêntica cláusula geral de boa-fé, facultando sua utilização como instrumento de controle daquelas abusivas, assim consideradas pelo seu critério definidor, exigindo do juiz uma atividade criadora fulcrada numa postura teleológica ou finalista do sistema protetivo. ${ }^{722}$

Quanto a esse pormenor, acrescenta o Min. Ruy Rosado de Aguiar Júnior:

“A boa-fé é uma cláusula geral cujo conteúdo é estabelecido em concordância com os princípios gerais do sistema jurídico (liberdade, justiça e solidariedade, conforme está na Constituição da República), numa tentativa de 'concreção em termos coerentes com a racionalidade global do sistema.'

\section{(...)}

A boa-fé se constitui numa fonte autônoma de deveres, independentemente da vontade, e por isso a extensão e o conteúdo da 'relação obrigacional já não se mede somente nela (vontade), e, sim, pelas circunstâncias ou fatos referentes ao contrato, permitindo-se construir objetivamente o regramento do negócio jurídico, com a admissão de um dinamismo que escapa ao controle das partes'. A boa-fé significa a aceitação da interferência de elementos externos na intimidade da relação obrigacional, com poder limitador da autonomia contratual, pois através dela pode ser regulada a extensão e o exercício do direito subjetivo."723

Adverte Paulo Luiz Neto Lôbo que esse dispositivo também se refere à equidade, ou seja, “(...) a boa-fé sempre se entroncou historicamente com a equidade. O juízo de equidade conduz o juiz às proximidades do legislador, porém limitado à decidibilidade do conflito determinado na busca do equilíbrio dos poderes contratuais, tendo de um lado o predisponente e de outro o aderente típico. Não atua no campo da política legislativa. Apesar de trabalhar com critérios objetivos, com 'standards' valorativos e com o efeito 'erga omnes' da decisão, a equidade é entendida no sentido

\footnotetext{
${ }^{720}$ Agathe E. Schmidt da Silva. Cláusula geral..., cit., p. 146.

721 Art. 51: "são nulas de pleno direito, entre outras, as cláusulas contratuais relativas ao fornecimento de produtos e serviços que: (...) IV - estabeleçam obrigações consideradas iníquas, abusivas, que coloquem o consumidor em desvantagem exagerada, ou sejam incompatíveis com a boa-fé ou a equidade".

${ }^{722}$ Agathe E. Schmidt da Silva. Cláusula geral..., cit., p. 146/147 e 156.
} 
aristotélico de justiça do caso concreto. No caso, a equidade surge como corretivo ou impedimento das condições gerais iníquas ou que provocam vantagem injusta ao predisponente em relação a qualquer aderente. A idéia da lei é que existam critérios definidos referenciáveis em abstrato e que o juiz-intérprete não os substitua por mera apreciação discricionária". 724

Conclui-se, em rigor, que é uma ferramenta à disposição do juiz para manter ou restabelecer o equilíbrio - e aqui reside o núcleo do princípio da boa-fé objetiva $^{725}$ - entre os deveres e as obrigações das partes envolvidas nos contratos de consumo $^{726}$; porém, equilíbrio das posições contratuais, não econômico, uma vez que, em sede de relação de consumo, a regra é o desequilíbrio de forças, dependendo a composição real da análise de todo o ajuste. ${ }^{727}$

\footnotetext{
${ }^{723}$ A boa-fé..., cit., p. 24.

${ }^{724}$ Condições gerais dos contratos e cláusulas abusivas. São Paulo: Saraiva, 1991, p. 147.

${ }^{725}$ Alberto do Amaral Júnior. A boa-fé e do controle..., cit., p. 31.

${ }^{726}$ Agathe E. Schmidt da Silva. Cláusula geral..., cit., p. 160.

${ }^{727}$ Luiz Antonio Rizzatto Nunes. Curso..., cit., p. 128.
} 


\section{INCIDÊNCIA AMPLA E IRRESTRITA}

Mesmo antes da sua positivação no sistema de direito privado comum (e isto também serve para todas as demais relações jurídicas), notadamente por força da sua base constitucional (justiça ${ }^{728}$ e solidariedade $^{729}$ ), o princípio da boa-fé objetiva poderia incidir, porquanto constitui o resultado de necessidades éticas essenciais a qualquer sistema normativo, em que pese tal utilização se tornar difícil caso não haja uma norma positiva de referência. ${ }^{730}$

Maria Cristina Cereser Pezzella prossegue asseverando que, "pelo fato da boa-fé objetiva estar contida expressamente em lei para as relações de consumo, isto não significa que o princípio deva ser aplicado apenas no âmbito restrito destas relações, pois ele estende-se para todos os setores do ordenamento jurídico". 731

E arremata, com perspicácia, nos idos de 1995, o Min. Ruy

Rosado de Aguiar Júnior:

“(...) é importante realçar dois aspectos. A boa-fé é limitadora do direito subjetivo, angustia o âmbito da liberdade contratual, flexibiliza a estrutura material do contrato e gera certa insegurança quanto ao seu conteúdo, mas a sua finalidade principal é de manutenção e conservação do vínculo, aperfeiçoado pelos princípios da confiança, da lealdade, da honestidade e da verdade.

\section{(...)}

Em segundo lugar, a recepção do princípio da boa-fé objetiva e a previsão legislativa de tantos deveres incluídos no âmbito da boa-fé constitui o maior avanço do sistema de Direito Civil legislado e vai influir de modo decisivo em todos os setores do nosso direito obrigacional, apesar de estarem tais normas inseridas num microssistema."

A dúvida, no entanto, persiste em relação às fases pré e póscontratual, pois o Código Civil (em especial) - nesses pontos - afastou-se dos modelos

\footnotetext{
${ }^{728}$ Alberto do Amaral Júnior. A boa-fé e do controle..., cit., p. 32.

${ }^{729}$ Regis Fichtner Pereira. A responsabilidade pré-contratual..., cit. p. 64.

${ }^{730}$ Maria Cristina Cereser Pezzella. O princípio da boa-fé objetiva..., cit., p. 210.

${ }^{731}$ Idem, p. 217.

${ }^{732}$ A boa-fé..., cit., p. 27.
} 
português (art. 227/1 ${ }^{733}$ ) e italiano (art. $1.337^{734}$ ), daí uma falha sensível, mas que pode ser facilmente sanada.

É o que se pretende com o Projeto de Lei 276/2007, cujo texto propõe uma nova redação para o art. $422 .{ }^{735}$

A vingar essa proposta de alteração, consagrar-se-ia aquilo que a doutrina há certo tempo vem insistindo, notadamente a consumerista, tal qual se infere dos específicos enunciados aprovados nas Jornadas de Direito Civil promovidas, com o apoio do STJ, pelo Conselho da Justiça Federal:

“25 - O art. 422 do Código Civil não inviabiliza a aplicação pelo julgador do princípio da boa-fé nas fases pré-contratual e póscontratual."

“170 - A boa-fé objetiva deve ser observada pelas partes na fase das negociações preliminares e após a execução do contrato, quando tal exigência decorrer da natureza do contrato.”

O reflexo disso no âmbito do direito à saúde é a consagração que o consentimento informado do paciente, pedra angular de equilíbrio desse especial vínculo jurídico, sob todos os aspectos protetivos da sua completude, deve se renovar a partir do início de cada fase do tratamento (pós-operatório ou de convalescença inclusive), mesmo após a alta; o que também abrange a autorização para qualquer procedimento de diagnose utilizado, sobretudo os aptos a gerar efeitos colaterais indesejáveis e/ou a provocar sequelas relevantes ${ }^{736} \mathrm{ou}$, ainda, que sejam per se arriscados. ${ }^{737}$

\footnotetext{
${ }^{733}$ Art. 227/1: "quem negoceia com outrem para conclusão de um contrato deve, tanto nas preliminares como na formação dele, proceder segundo as regras da boa-fé, sob pena de responder pelos danos que culposamente causar à outra parte".

734 Art. 1.337: "le parti, nello svolgimento delle trattative e nella formazione del contratto, devono comportarsi secondo buona fede". Trad: as partes, no desenvolvimento das tratativas e na formação do contrato, devem se comportar conforme a boa-fé.

735 "Os contratantes são obrigados a guardar, assim nas negociações preliminares e conclusão do contrato, como em sua execução e fase pós-contratual, os princípios de probidade e boa-fé e tudo mais que resulte da natureza do contrato, da lei, dos usos e das exigências da razão e da equidade."

${ }^{736}$ Fernando Campos Scaff. As relações jurídicas..., cit., p. 130.

${ }^{737}$ Carla e Ettore Prodetti. Medici e biologici nella giurisprudenza. Milão: Giuffrè, 1998, p. 194.
} 


\section{O SEGURO-SAÚDE E AS FALSAS DECLARAÇÕES}

Embora a República Federativa do Brasil tenha adotado, ao menos no plano formal, modelo aparentemente centralizador ao estabelecer que a saúde é direito de todos e dever do Estado ( $\mathrm{CF}$, art. 196), o fato é que a prévia ciência da impossibilidade de a estrutura assim se manter, no âmbito material, a efetivar a universalidade pretendida, fez com que a Constituição de 1988 permitisse, conquanto sob a regulamentação, a fiscalização e o controle governamental, a execução dos serviços de saúde por terceiros (CF, art. 197).

Ou seja, como atividade econômica, ainda que complementar ao sistema único, a assistência à saúde é livre à iniciativa privada ${ }^{738}$, dês que se observem três regras mínimas: a) as entidades filantrópicas e sem fins lucrativos preferem às demais; b) é defeso destinar recursos públicos para auxílios ou subvenções a essas instituições, se empresariais e c) salvo previsão legal, direta ou indiretamente, empresas ou capitais estrangeiros não podem disso participar (CF, art. 199).

Pois bem. Excluídos os meros atos jurídicos médicos, aqueles praticados em situação emergencial, que prescindem do prévio ajuste das partes envolvidas na relação, apesar de atraírem consequências lícitas ou ilícitas, reparação de danos inclusive, as intervenções no direito à saúde se aperfeiçoam, fora da rede pública, mediante um contrato - bilateral, comutativo, consensual e oneroso - atípico ${ }^{739}$ de prestação de serviços, de execução tanto imediata (v.g., consultas, visitas, exames, procedimento único, etc.) quanto continuada (e.g., vínculos de longa duração). ${ }^{740}$

\footnotetext{
${ }^{738}$ Identifica o professor Fernando Campos Scaff (As relações jurídicas..., cit., p. 58) que “a justificativa racional da contratação de seguros ou de planos de saúde funda-se também no seu chamado caráter mutualístico, ou seja, aquele que almeja a dispersão dos custos dos eventos ocasionais de tratamentos médicos a um grupo considerável de pessoas, como ocorre em planos de previdência pública ou privada, pecúlios etc.".

${ }^{739}$ Esse é o entendimento de Antonio Joaquim Fernandes Neto (Plano de saúde e direito do consumidor. Belo Horizonte: Del Rey, 2002, p. 128), que assim ampara seu raciocínio: "posto que as expressões 'contratos atípicos' e 'contratos inominados' sejam frequentemente utilizadas como sinônimas, o estudo da regulamentação dos planos de saúde exige que seja apontada a diferença existente entre elas. No direito romano, o contrato nominado tinha um nome e um modelo previamente definidos. Nos dias de hoje, há casos em que um determinado contrato é mencionado ou reconhecido pelo sistema jurídico, mas não tem um modelo ou tipo definido pela lei". E conclui com Pedro Pais de Vasconcelos: "há contratos que têm um nomem na lei e que, não obstante, não encontram aí um modelo regulativo típico. A distinção entre contratos nominados e inominados deve ser reservada, no direito atual, para os casos em que o contrato tem, ou não tem, um nomem na lei. A distinção para os contratos típicos e atípicos dever ser reservada para os casos em que o contrato tenha, na lei ou na prática, um modelo típico de disciplina própria” (idem, p. 132/133).

${ }^{740}$ Fernando Campos Scaff. As relações jurídicas..., cit., p. 35/38.
} 
Tais contratos não ficaram imunes aos efeitos da nova moldura das relações jurídicas imposta pela economia de massa do estado liberal, o que determinou cedessem os pactos individuais aos coletivos ${ }^{741}$, seja para o tratamento, seja para a prevenção de doenças, na tentativa de viabilizar que a atuação médica se fizesse de modo mais expandido e generalizado. ${ }^{742}$

É possível afirmar que se está, “(...) longe dos tempos em que esses serviços podiam em regra ser prestados a custos relativamente reduzidos, circunscritos basicamente aos honorários médicos de profissionais generalistas prestadores da eficiente e saudosa medicina de família e ao custo de medicamentos em regra manipulados em farmácias singelas. O moderno instrumental e a necessidade de especialização profissional, produtos típicos do progresso da ciência, agravam custos e exigem divisão de tarefas, mediante organização sistemática do trabalho, que repercute na organização sistemática do sistema de saúde. O Direito acompanha a exigência científicosocial e organiza instrumentos jurídicos para gerar todas as prestações legais e contratuais exigidas pelo sistema" 743

9.1 Distinção entre plano de saúde e seguro-saúde

A atuação privada aqui, sem desprezar a existência das $\operatorname{cooperativas}^{744}$ e das empresas de autogestão ${ }^{745}$, basicamente, está dividida em duas

\footnotetext{
${ }^{741}$ Lembra Irany Novah Moraes (Erro médico e a lei. $4^{\mathrm{a}}$ ed. São Paulo: Lejus, 1998, p. 100 e ss.): "Kimball, em 1929, verificava que, nos Estados Unidos, os hospitais não estavam ao alcance dos bolsos dos professores das escolas onde seus filhos estudavam e que, nas ocasiões em que eles adoeciam, usavam seu hospital e não tinham condições de pagar. Foi então que idealizou um sistema de pré-pagamento das despesas eventuais com doença. Diferia esse processo do seguro comum pois, em lugar de oferecer indenização em moeda para ressarcir dos prejuízos decorrentes da enfermidade, oferecia cuidados para a cura da enfermidade. Assim, se criou a Blue Cross americana, em 20.12.1929". No Brasil, nas palavras de Arnaldo Rizzardo (Planos de assistência e seguros de saúde. Porto Alegre: Livraria do Advogado, 1999, p. 16), "a medicina de grupo surgiu e desenvolveu-se nos anos 60, no ABC Paulista, em virtude da precariedade dos serviços públicos da região e dos altos preços da medicina liberal. Visava a atender basicamente as necessidades de assistência médico-hospitalar da classe trabalhadora, mediante sistema de convênio-empresa, financiado pelos empregadores".

${ }^{742}$ Fernando Campos Scaff. As relações jurídicas..., cit., p. 39/42.

${ }^{743}$ Sidnei Agostinho Beneti e Sidnei Agostinho Beneti Filho. In: Teixeira, Sálvio de Figueiredo (coord.). Direito \& Medicina. Aspectos jurídicos da medicina. Belo Horizonte: Del Rey, 2000, p. 315/316.

744 “.(...) Para fixação do regime jurídico do contrato, o que importa é a sua causa, sendo irrelevante a forma societária pela qual se organizou a prestadora de serviços. Entender o contrário seria admitir que por ato unilateral da fornecedora, mediante simples alteração de seu objeto social, cambiasse do regime jurídico do Código de Defesa do Consumidor para o Código Civil, em manifesta fuga das normas protetivas cogentes do consumidor" (TJSP, AC 398.899.4/5-00, rel. Francisco Loureiro, j. 22.09.2005).
} 
modalidades organizacionais de empresas: as de plano de saúde e as seguradoras, que envolvem "a transferência onerosa e contratual de riscos futuros à saúde do consumidor e de seus dependentes, mediante a paga de um prêmio, que dá origem ao pagamento direto ou ao reembolso dos gastos e serviços médico-hospitalares", 746

Para Adalberto Pasqualloto, "o sistema de trabalho dessas organizações pode ser totalmente fechado, quando o organizador impõe ao beneficiário um médico clínico de cabeceira, que em caso de necessidade fará o encaminhamento aos distintos especialistas (pouco frequente no Brasil), a um sistema totalmente aberto no qual o beneficiário procura os serviços de sua livre escolha, obrigando-se o organizador tãosomente a reembolsar as despesas comprovadas (modalidade de seguro). A esses dois sistemas extremos podem ser agregados outros, mistos, em que o organizador fornece uma lista de prestadores de serviços, ficando o beneficiário adstrito a escolher limitadamente um deles. Ou este sistema poderá ser combinado com o da livre escolha" ${ }^{747}$

Distinguem-se, pois, em dois aspectos fundamentais: a) o modo como os serviços de saúde são prestados e b) a forma de remuneração ${ }^{748}$. Enquanto nos planos, via de regra, o atendimento médico é feito por profissionais próprios ou credenciados, mediante custo pago diretamente pela empresa; as seguradoras agem por terceiros, reembolsando as despesas geradas. ${ }^{749}$

O mecanismo, contudo, não desconhece o possível trânsito

\footnotetext{
${ }^{745}$ Segundo Adalberto Pasqualotto (A regulamentação dos planos e seguros de assistência à saúde - Uma interpretação construtiva. São Paulo: RT, 1999, p. 39): “a Lei 9.656 também se aplica à autogestão (art. $1^{\circ}, \S$ $2^{\circ}$ ), mas de modo parcial, dispensando, v.g., cobertura universal das doenças relacionadas na Classificação Internacional (art. 10). A autogestão é realizada pelas entidades ou empresas que mantêm sistemas próprios de assistência à saúde. São grupos fechados, de acesso restrito aos empregados, funcionários ou associados da entidade promotora. As cooperativas de serviços médicos, praticando medicina de grupo mediante prépagamento, tecnicamente enquadram-se na classificação do art. $1^{\circ}, \S 1^{\circ}$, I, da Lei 9.656 como operadores de planos privados de assistência à saúde". Alerta, no entanto, Maria Stella Gregori (Planos de saúde. A ótica da proteção do consumidor. São Paulo: RT, 2007, p. 140) que "somente estão excluídas de sua competência as pessoas físicas, que estão proibidas de operar nesse mercado, e as jurídicas de direito público. Ela permite também, a possibilidade da entrada de capital estrangeiro para operar planos de assistência à saúde".

${ }^{746}$ Cláudia Lima Marques. Planos privados de assistência à saúde. Desnecessidade de opção do consumidor pelo novo sistema. Opção a depender da conveniência do consumidor. Abusividade de cláusula contratual que permite a resolução do contrato coletivo por escolha do fornecedor. Revista de Direito do Consumidor, São Paulo: RT, v. 31, jul.-set. 1999, p. 134.

${ }^{747}$ A regulamentação..., cit., p. 38.

748 “(...) tanto o seguro saúde como o plano de saúde tem a mesma finalidade: pagamento de prestação para ser assegurado acesso a serviços médicos/hospitalares cujas despesas ou são reembolsadas ou já assumidas pela seguradora ou plano. Logo, fundamentalmente o contrato é o mesmo, difere apenas quanto ao momento em que as despesas são pagas ao prestador de serviços médicos/hospitalares” (TJSP, AI 1.011.283-0/1, rel. Luiz Felipe Nogueira Junior, j. 17.05.2006).

${ }^{749}$ E no exercício dessa atividade típica não geram as seguradoras a hipótese de incidência do ISS, ínsito aos planos de saúde (STF, AI 576.787/DF, decisão monocrática do Min. Sepúlveda Pertence, j. 29.03.2006).
} 
nessa atuação; é dizer: ao mesmo tempo que os planos podem manter serviços próprios ou para este fim contratar ou credenciar terceiros, reembolsando os beneficiários das despesas feitas, às seguradoras também é permitido reembolsar o segurado ou pagar, à sua ordem, diretamente aos prestadores.

Com isso, “(...) fica mantida a essência funcional de cada operador, que é a de prestar diretamente serviços especificados (planos) ou de reembolsar despesas (seguros). As opções de prestar os serviços através de terceiros (planos) ou de pagar diretamente ao prestador de serviços livremente escolhido pelo segurado (seguros) são apenas modos alternativos de cumprimento da obrigação principal dos operadores, que em nada os descaracteriza". 750

A proximidade entre elas é tanta, que a própria Lei 9.656/98 ${ }^{751}$, com a dimensão que lhe foi dada por sucessivas Medidas Provisórias ${ }^{752}$, acabou tratando-as indistintamente pelo gênero operadoras ${ }^{753}$, lídima categoria contratual única $^{754}$, pois ambas atuam de modo semelhante nas chamadas, pelos ingleses, relações

\footnotetext{
${ }^{750}$ Adalberto Pasqualotto. A regulamentação..., cit., p. 42 e ss.

${ }^{751}$ Destacam Sidnei Agostinho Beneti e Sidnei Agostinho Beneti Filho (Direito \& Medicina..., cit., p. 323) que "a Lei 9.656/98 teve tramitação bastante complicada, durando mais do que sete anos entre a entrada do projeto e a sanção pela Presidência da República, acabando por transpor período em que os planos de saúde eram os recordistas em reclamações perante os Procons e outras entidades de defesa do consumidor. Daí, aliás, a marca extremamente protetiva".

752 “Art. $1^{\mathrm{O}}$ Submetem-se às disposições desta Lei as pessoas jurídicas de direito privado que operam planos de assistência à saúde, sem prejuízo do cumprimento da legislação específica que rege a sua atividade, adotando-se, para fins de aplicação das normas aqui estabelecidas, as seguintes definições: I - Plano Privado de Assistência à Saúde: prestação continuada de serviços ou cobertura de custos assistenciais a preço pré ou pós estabelecido, por prazo indeterminado, com a finalidade de garantir, sem limite financeiro, a assistência à saúde, pela faculdade de acesso e atendimento por profissionais ou serviços de saúde, livremente escolhidos, integrantes ou não de rede credenciada, contratada ou referenciada, visando a assistência médica, hospitalar e odontológica, a ser paga integral ou parcialmente às expensas da operadora contratada, mediante reembolso ou pagamento direto ao prestador, por conta e ordem do consumidor; II - Operadora de Plano de Assistência à Saúde: pessoa jurídica constituída sob a modalidade de sociedade civil ou comercial, cooperativa, ou entidade de autogestão, que opere produto, serviço ou contrato de que trata o inciso I deste artigo."

${ }^{753}$ Afirma Francisco Eduardo Loureiro (Planos e seguros de saúde. In: Tavares da Silva, Regina Beatriz (coord.). Responsabilidade Civil. Responsabilidade civil na área da saúde. São Paulo: Saraiva, 2007, p. 294) que "tem o preceito redação larga, como o escopo de alcançar todas as pessoas jurídicas, qualquer que seja a forma de sua constituição, incluídas as cooperativas e as entidades ou empresas que mantêm sistemas de assistência à saúde, pela modalidade de autogestão ou administração $\left(\S 2^{\circ}\right.$ do art. $\left.1^{\circ}\right)$. O critério determinante para o enquadramento da atividade empresarial às normas cogentes da Lei 9.656/98 é o da operação econômica, da natureza da atividade, que sempre consiste, com maior ou menor variação, em serviços remunerados de assistência à saúde, sendo irrelevante a questão da forma societária adotada, inclusive para efeito de incidência das normas protetivas do Código de Defesa do Consumidor". No mesmo sentido, cf. TJSP, AC 482.329.4/2-00, rel. Fábio Quadros, j. 07.08.2008.

754 "Para efeito deste artigo, não se faz distinção prática ou jurídica entre plano ou seguro saúde, pela razão de que a MP 1.976, que alterou dispositivos da Lei 9.656/98, passou a definir os planos e os seguros-saúde como uma categoria contratual única, alterando o art. $1^{\circ}$ da referida lei para denominá-los simplesmente de 'plano privado de assistência à saúde (...)" (TJSP, ED 154.745.4/5-01, rel. Joaquim Garcia, j. 20.06.2007).
} 
não $o n e ~ s h o t^{755}$, perseguindo idêntico objetivo: segurança e proteção para prováveis riscos à saúde ${ }^{756}$, transacionando os mesmos produtos ${ }^{757}$, mediante o pagamento de um valor mensal ${ }^{758}$; sendo, na hipótese de listas fechadas de serviços ou de profissionais, responsáveis legítimas ${ }^{759}$ e solidárias $^{760}$ pela reparação dos danos causados por seus prepostos indicados.

\subsection{Os reflexos jurídicos das falsas declarações}

Partindo-se da idéia que o contrato de seguro, como gênero, visa a atribuir os reflexos da ocorrência concreta de um risco, conquanto previsto, mas meramente hipotético e possível (incerto), por via do qual um dos sujeitos, o segurado, transfere a probabilidade de perda financeira para a contraparte, companhia de seguro ${ }^{761}$, mister se faz definir a álea razoavelmente esperada como pedra angular do equilíbrio dessa relação.

\footnotetext{
${ }^{755}$ José Reinaldo de Lima Lopes. Consumidores de seguros e planos de saúde. Saúde e responsabilidade: seguros e planos de assistência privada à saúde. São Paulo: RT, 1999, p. 31.

${ }^{756}$ Para Ricardo Bechara Santos (Direito de seguro no cotidiano. Rio de Janeiro: Forense, 1999, p. 44) "o objetivo do seguro saúde, pois, não é especificamente garantir a saúde do segurado, mas garantir o risco das despesas com a sua saúde, com sua assistência médica, que seriam por ele devidas a médicos, laboratórios e hospitais até os limites máximos estipulados na apólice por escolha do próprio segurado, e observadas as inclusões e exclusões nela previstas".

${ }^{757}$ TJSP, AC 314.468.4/4-00, rel. Maury Ângelo Bottesini, j. 27.03.2006.

${ }^{758}$ Linneu Rodrigues de Carvalho Sobrinho. Seguros e planos de saúde. São Paulo: Juarez de Oliveira, 2001, p. 4.

759 "A empresa prestadora do plano de assistência à saúde é parte legitimada passivamente para ação indenizatória proposta por associado em decorrência de erro médico por profissional por ela credenciado" (STJ, AgRg no Ag 682.875/RJ, rel. Min. Paulo Furtado, j. 15.09.2009).

760 "Responsabilidade Civil - Erro médico - Ação de indenização por danos materiais e morais Transfixação da bexiga da paciente por fios inabsorvíveis em cirurgia para correção de prolapso de cúpula vaginal e de incontinência urinaria - Culpa manifesta do médico que realizou a cirurgia e responsabilidade solidária da operadora de plano de saúde bem configurada - Indenização corretamente arbitrada - Recursos desprovidos" (TJSP, AC 994.02.064345-0, rel. Morato de Andrade, j. 03.08.2010). "DANO MORAL - Erro de diagnóstico laboratorial - Responsabilidade solidária do laboratório que realizou a análise clínica, do hospital que o sedia e do plano de saúde - Código de Defesa do Consumidor - Contratos coligados Diagnóstico equivocado comprovado por perito judicial - Dano indenizável - Autor que já estava na posse de quatro exames favoráveis contra um desfavorável ao seu estado de saúde - Fato que impede a condenação no patamar pleiteado na petição inicial - Minoração - Inversão da sucumbência - Recurso provido" (TJSP, AC 568.839.4/6-00, rel. Francisco Loureiro, j. 16.07.2009). "Obrigação de fazer [concluir contrato] inadmissível, por faltar prova da proposta e do consentimento - Laboratório que pretende impor a uma operadora de planos de saúde seu credenciamento compulsório, o que afronta o elemento fundamental do contrato consensual, qual seja, o acordo de vontades - Hipótese de ser respeitada a liberdade de contratar, inclusive porque o credenciamento cria responsabilidade solidária pelos danos [art. 14, da Lei 8078/90] Provimento do apelo da ré, prejudicado o recurso adesivo do autor" (TJSP, AC 550.296-4/0, rel. Ênio Santarelli Zuliani, j. 16.04.2009).

${ }_{761}$ João Marcos Brito Martins. Direito de seguro. Rio de Janeiro: Forense Universitária, 2002, p. 11.
} 
Lógico o sistema: "ao transferir as consequências financeiras das perdas para a companhia de seguros, os segurados trocam a possibilidade de uma grande perda incerta por um pequeno pagamento certo (prêmio) suportável em seu orçamento. Tal transferência é formalizada através de uma apólice de seguros, documento que materializa o contrato de seguro, explicitando os direitos e deveres da companhia de seguro e do segurado". 762

E a quase comutatividade desse contrato aleatório, representativo de uma lídima garantia, mais acentuada no seguro-saúde, cujo conteúdo não trata de questões verdadeiramente imprevisíveis ${ }^{763}$, só pode ser alcançada se a conduta das partes for dirigida pela boa-fé, tanto a subjetiva quanto a objetiva, no curso de toda a relação jurídica obrigacional (CC, arts. $765^{764}$ c.c. $766^{765}$ ).

\footnotetext{
${ }^{762}$ João Marcos Brito Martins. Idem. Na visão de Celso Marcelo de Oliveira (Contrato de seguro. Campinas: LZN, 2002, p. 11/12), "entendido como técnica de transferência, o seguro é um sistema que permite a uma pessoa, família ou empresa, transferir as consequências financeiras de uma perda para uma companhia de seguros, a qual, por sua vez, indeniza o segurado pelos prejuízos sofridos (desde que cobertos no contato), e distribui os custos entre todos os segurados". E acrescenta Linneu Rodrigues de Carvalho Sobrinho (Seguros..., cit., p. 5) que "os seguradores ou administradores de planos de saúde funcionam como intermediários e gestores. Possuem função distributiva, alocando a cada consumidor parte suficiente da receita capaz de cobrir os riscos contratados. Possuem o caráter de mutualidade, no sentido de solidariedade, dependendo da coletividade na constituição de um fundo, sem o qual não assumiriam os riscos, e lhes permite, simultaneamente, individualizar as relações com os consumidores. É essa a idéia de dispersão dos prejuízos que tem causado, no Brasil como em outros países, a orientação das empresas de seguro no sentido de buscar a contratação de um grupo de pessoas, mais do que a contratação individual". Tais empresas são, portanto, como assinala José Reinaldo de Lima Lopes (Consumidores de seguros..., cit., p. 33), fundamentalmente intermediárias de recursos financeiros.

763 Anota o professor Fernando Campos Scaff (As relações jurídicas..., cit., p. 49/52) que "uma das características usualmente atribuídas ao contrato de seguro genericamente considerado é a sua suposta aleatoriedade, que significa, em suma, que o pagamento do prêmio pelo segurado não corresponde, necessariamente, à realização de uma contraprestação pelo segurador, correspectiva ao ressarcimento ajustado, uma vez que o risco pode não se concretizar durante o prazo de vigência do contrato estabelecido pelas partes. Acontece que, especificamente no contrato de seguro-saúde, tal aleatoriedade não é assim tão evidente, sendo mesmo mais comum, na verdade, que ceda ela lugar a algo mais próximo de uma efetiva comutatividade entre as prestações e contraprestações atribuídas a cada uma das partes. (...) Desse modo, o chamado índice de sinistralidade mantém, por exemplo, uma proporção direta com as diversas faixas etárias em que se situem os indivíduos segurados e, sob essa perspectiva, nada terá de 'aleatória' a concretização do evento futuro tido como sendo o risco previsto no contrato - qual seja, o aparecimento da doença -, revelando-se, na verdade, esperado que tal risco ocorra em um dado grupo de pessoas de idade avançada, os quais muito provavelmente sofrerão os efeitos de específicos problemas que são próprios da maturidade e que não terão, em regra, saúde idêntica àquela gozada na época da juventude. (...) Sendo assim, essa suposta aleatoriedade, entendida como elemento de tal modalidade de contrato, perde muito de seu conteúdo, uma vez que certas moléstias guardam uma relação direta com determinados fatores, cujo surgimento situa-se estritamente nos limites do controle pessoal. Ora, os custos daí derivados - que deverão ser arcados pela seguradora - não se constituem, necessariamente e na mais pura acepção das palavras, de verdadeiros riscos ou sinistros, mas sim decorrem de eventos que certa ou provavelmente ocorrerão, o que retira, efetivamente, a suposta álea do cerne de caracterização desse tipo de contrato".

${ }^{764} \mathrm{CC}$, art. 765: "o segurado e o segurador são obrigados a guardar, na conclusão e na execução do contrato, a mais estrita boa-fé e veracidade, tanto a respeito do objeto como das circunstâncias e declarações a ele concernentes".
} 
No entanto, uma coisa é certa, o risco no contrato de segurosaúde não é o mesmo que caracteriza as outras modalidades de seguro ${ }^{766}$, até porque a doença é uma alteração do estado de higidez qualquer que seja a sua origem: desse modo, a enfermidade traumática (causa acidental) ou a enfermidade patológica são igualmente garantidas. $^{767}$

As falsas declarações, a partir de tais premissas, ganham especial relevo, sobretudo no que concerne às chamadas doenças preexistentes.

\subsection{Doença preexistente}

Estabelecer uma noção jurídica de doença preexistente é fundamental para que os problemas gerados a partir dessa realidade empírica possam ser adequadamente dirimidos, pois justa se mostra a preservação das bases protetivas originárias do contrato de plano ou de seguro-saúde, causas determinantes do próprio ajuste.

É expectativa legítima do aderente ou do segurado, aceito por uma operadora do setor, receber a devida assistência quando necessária e não ser surpreendido com a negativa de cobertura ${ }^{768}$; daí porque a Lei 9.656/98, corretamente, definiu parâmetros mínimos nesta temática. ${ }^{769}$

Mas a expressão preexistente pressupõe um norte objetivo anterior, um elemento fático capaz de definir certo parâmetro referencial, papel atribuído ao contrato de prestação de serviços de saúde; porém, o problema continua diante da

\footnotetext{
${ }^{765} \mathrm{CC}$, art. 766: "se o segurado, por si ou por seu representante, fizer declarações inexatas ou omitir circunstâncias que possam influir na aceitação da proposta ou na taxa do prêmio, perderá o direito à garantia, além de ficar obrigado ao prêmio vencido. Parágrafo único: Se a inexatidão ou omissão nas declarações não resultar de má-fé do segurado, o segurador terá direito a resolver o contrato, ou a cobrar, mesmo após o sinistro, a diferença do prêmio".

${ }^{766}$ Fernando Campos Scaff. As relações jurídicas..., cit., p. 54.

${ }_{767}^{767}$ Yvonne Lambert-Faivre. Droit des assurances. $11^{\mathrm{a}}$ ed. Paris: Dalloz, 2001, p. 842.

${ }^{768}$ Entende Linneu Rodrigues de Carvalho Sobrinho (Seguros..., cit., p. 5), que "o objetivo pretendido pela coletividade ao buscar a segurança num plano de saúde consiste em garantir cobertura para fatos adversos à saúde. Este objetivo quando não atingido, por ações ou omissões do fornecedor, se tornará fraude e representará abusividade, havendo quebra da boa-fé, paradigma das relações de consumo".

769 "Art. 11. É vedada a exclusão de cobertura às doenças e lesões preexistentes à data de contratação dos produtos de que tratam o inciso I e o $\S 1^{0}$ do art. $1^{\underline{0}}$ desta Lei após vinte e quatro meses de vigência do aludido instrumento contratual, cabendo à respectiva operadora o ônus da prova e da demonstração do conhecimento prévio do consumidor ou beneficiário. Parágrafo único. É vedada a suspensão da assistência à saúde do consumidor ou beneficiário, titular ou dependente, até a prova de que trata o caput, na forma da regulamentação a ser editada pela ANS."
} 
dificuldade de se identificar quando teve início o processo de comprometimento do organismo, assim entendida a doença. ${ }^{770}$

Karyna Rocha Mendes da Silveira entende que, "um conceito jurídico não pode ser construído à distância dos demais saberes, pois ao elaborar um conceito jurídico pressupõe-se que o legislador conheça o fenômeno sobre o qual está construindo, criando e delimitando poderes. Espera-se também que, antes de um conceito jurídico ser criado, ele seja cotejado com os diversos saberes, com as diversas ciências, sob pena de mostrar-se inviável e irreal, já que o mundo da lei não constitui um mundo independente". ${ }^{771}$

O existir previamente da moléstia, nesta quadra, no que interessa, passa a ter um espectro limitado e relativo, despido de valor médico, porquanto variável o fato temporal de referência. A preocupação, como se percebe, é com a economia do ajuste dentro da lógica dos lucros. ${ }^{772}$

Contudo, identifica-se no ordenamento o conceito de doença preexistente. Integrando o art. 11 da Lei 9.656/98, o Conselho de Saúde Suplementar (CONSU) editou sua Resolução ${ }^{\circ}$ 02/98, aceita pelo sistema tão-só naquilo que amplia os direitos do consumidor (CDC, art. $7^{\circ}$, caput), pena de afronta ao primado da legalidade ${ }^{773}$

\footnotetext{
${ }^{770}$ Nos termos do Parecer $n^{\circ}$ 16/97 do Conselho Federal de Medicina (CFM), da relatoria do Conselheiro Edson de Oliveira Andrade, aprovado em 07.05.1997, a pedido do Instituto Brasileiro de Defesa do Consumidor (IDEC), que buscava esclarecimento do órgão fiscalizador sobre o conceito de "doenças preexistentes e crônicas": "excetuando-se, talvez, os casos de acidentes e algumas poucas outras situações, é quase sempre muito difícil para o médico identificar com exatidão o momento em que o organismo abandona a higidez e transpassa o portal da doença. Na maioria das vezes, os procedimentos propedêuticos se prestam para detectar algo já em curso e, quando muito, quantificar o grau de comprometimento orgânico decorrente da moléstia. (...) Desta forma, retirando as exceções de praxe, o que normalmente se faz é detectar algo já instalado e quantificar a sua intensidade". E a sua conclusão aponta para as seguintes balizas: "1. O conceito de doença preexistente aplicada às relações contratuais dos planos e seguros de saúde é de natureza relativa e desprovida de valor médico. 2. Sendo a identificação de uma moléstia prévia um fato capaz de alterar os cálculos atuariais na determinação do premium, é legítima a cobrança de um plus sobre o valor básico. 3. A existência de uma doença prévia à assinatura do contrato não pode ser utilizada como justificativa para ação discriminatória, exceto a prevista no item anterior. 4. Havendo solicitação de exames pré-admissionais, estes correrão por conta do plano de saúde ou do seguro, em decorrência de que os mesmos são os principais beneficiários com a sua realização".

${ }_{771}^{771}$ Doença preexistente nos planos de saúde. São Paulo: Saraiva, 2009, p. 179.

${ }^{772}$ Karyna Rocha Mendes da Silveira (idem, p. 183) destaca: "indubitavelmente, o único viés que norteou a criação do conceito de doença preexistente foi o aspecto econômico, pois interessa à iniciativa privada, que maneja o setor da saúde suplementar, construir concepções que, segundo Luiz Antonio Rizzatto Nunes, são apenas economicistas".

${ }^{773}$ Sobre a possibilidade de a doença preexistente implicar a denúncia unilateral do contrato de saúde, na forma do art. $3^{\circ}$ da Resolução $n^{\circ} 02$ do CONSU, assim decidiu o TJSP: "Doença preexistente - Contrato firmado na vigência da lei 9.656/98 - Má-fé do segurado que autoriza apenas a suspensão de cobertura para a enfermidade por 24 meses, mas não a rescisão do contrato - Recurso improvido" (AC 243.730-4/9-00, rel. Eduardo Sá Pinto Sandeville, j. 26.04.2006). Do V. Acórdão extrai-se o seguinte aresto: "A ausência de exame admissional não impede que se afaste cobertura a doenças preexistentes desde que demonstre a
} 
$\left(\mathrm{CF}\right.$, art. $\left.2^{\circ}, \mathrm{II}\right)$, cujo art. $1^{\mathrm{o}}$ define "que doenças e lesões preexistentes são aquelas que o consumidor ou seu responsável, saiba ser portador ou sofredor, à época da contratação de planos ou seguros privados de assistência à saúde, de acordo com o artigo 11 e o inciso XII do artigo 35A da Lei ${ }^{\circ}$ 9.656/98 e as diretrizes" nela estabelecidas.

Necessários, assim, dois requisitos cumulativos: um objetivo, de existência da moléstia ou da lesão no momento da formação do contrato; outro subjetivo $^{774}$, do seu conhecimento por parte do consumidor ou do responsável ${ }^{775}$, inclusive quanto à extensão e à gravidade do problema. ${ }^{776}$

Mas, afinal, quais as consequências jurídicas da doença preexistente? Há relevância, aqui, das chamadas falsas declarações?

\subsubsection{Consequências jurídicas}

A premissa fundamental deve ser a impossibilidade de recusa da contratação. ${ }^{777}$

seguradora que o segurado tinha ciência do mal e o omitiu. Contudo, na vigência da lei 9.656/98 a conseqüência da preexistência da enfermidade, se demonstrado o conhecimento prévio do consumidor é apenas a suspensão de cobertura à enfermidade por 24 meses conforme decorre do disposto em seu artigo 11 que em momento algum autoriza a rescisão do contrato por esse motivo. E nesse passo a resolução do CONSU $n^{\circ} 2$ ao autorizar a suspensão ou denuncia do contrato por esse motivo vai além do que diz a lei incidindo em evidente ilegalidade. Note-se que a preexistência da doença não autoriza a seguradora a recusar a contratação. Pode apenas impor carência ou exigir agravo para sua cobertura. E se não pode recusar-se a contratar também não pode rescindir o contrato por esse motivo, cabendo apenas autorizá-la a aplicar a conseqüência que a lei extrai da existência de doença preexistente. E isto porque a omissão não vicia seu consentimento quanto a contratação, mas apenas quanto a âmbito da cobertura".

${ }^{774}$ É "necessário que o segurado tenha feito declarações inverídicas quando poderia fazê-las verdadeiras e completas" (STJ, REsp. 791.333/PB, rel. Min. Carlos Alberto Menezes Direito, j. 14.11.2006), ou seja, que previamente à celebração do contrato tinha o consumidor autêntico e inequívoco conhecimento do diagnóstico da doença (TJSP, AC 143.767-4/8, rel. Sebastião Carlos Garcia, j. 20.05.2004).

775 TJSP, AC 397.765.4/7-00, rel. Francisco Loureiro, j. 21.05.2009.

776 TJSP, AC 716.370-00/1, rel. Egídio Giacoia, j. 21.11.2005. Em igual sentido e da mesma Corte: AC 741.662-0/0 - j. 06.06.2005.

${ }^{777}$ Bem esclarece Silvio Luís Ferreira da Rocha (Contratos de assistência médica pré-pagos e disciplina prevista na Lei 9.656, de 3 de junho de 1998. In: Marques, Cláudia Lima; Schmitt, Cristiano Heineck; Lopes, José Reinaldo de Lima; Pfeiffer, Roberto Augusto Castellanos (coord.). Saúde e responsabilidade 2. A nova assistência privada à saúde. São Paulo: RT, 2008, p. 238) que: "a existência de doença não impede a pessoa de contratar um plano de saúde. A operadora não pode se recusar a celebrar o contrato com pessoa portadora de doença. A operadora de plano de saúde deve oferecer ao contratante duas alternativas: ou o aceita no plano com uma restrição temporária de cobertura, que não pode ultrapassar 24 meses, ou o aceita no plano sem qualquer restrição, mas, em contrapartida, lhe impõe um encargo financeiro extraordinário decorrente da preexistência e que também não pode ultrapassar o prazo de 24 meses. Decorrido o prazo de 24 meses, a cobertura passa a ser ampla e total, e cessa a cobrança do encargo financeiro extraordinário decorrente da preexistência". 
Primeiro porque, estando submetidas à fiscalização dos Conselhos de Medicina (Lei 6.839/80, art. $1^{0778}$ ), as operadoras de saúde devem respeito ao Código de Ética Médica, cujo art. $1^{\circ}$ qualifica a medicina como "uma profisssão a serviço da saúde do ser humano e da coletividade e deve ser exercida sem discriminação de qualquer natureza", muito menos de ordem econômica. Segundo porque a Lei 9.656/98, quando trata das doenças preexistentes (art. 11), veda a exclusão de cobertura - e consequentemente a negativa de ingresso do aderente ${ }^{779}$ - apenas impondo uma carência especial $^{780}$ de 24 meses para a eficácia plena do contrato.

Essa norma é específica e, no pormenor, afasta o comando do art. 13, par. ún., II, que autoriza a rescisão unilateral do contrato se caracterizada fraude; logo, também por isso, a Resolução n ${ }^{\circ} 02 / 98$ do CONSU, ao permitir a ruptura do ajuste (art. $3^{\mathbf{0}^{781}}$ ), equiparando os dois fenômenos (doença preexistente e fraude), não se sustenta, ainda mais quando ela mesma prevê consequência diversa mais benéfica para o aderente no seu art. $4^{\text {o }} .^{782}$

Observe-se, a propósito, que a norma regulamentar não restringe o momento da constatação por perícia, sendo factível que isso se dê até judicialmente. A dúvida de exegese normativa, à semelhança da contratual (CDC, art. 47), há de ser resolvida em proveito do consumidor.

\footnotetext{
778 “O registro de empresas e a anotação dos profissionais legalmente habilitados, delas encarregados, serão obrigatórios nas entidades competentes para a fiscalização do exercício das diversas profissões, em razão da atividade básica ou em relação àquela pela qual prestem serviços a terceiros."

${ }^{779} \mathrm{Cf}$., nota 616 .

${ }^{780}$ Segundo o professor Luiz Antonio Rizzatto Nunes (Comentários à lei de plano privado de assistência à saúde. $2^{a}$ ed. São Paulo: Saraiva, 2000, p. 30/31), “(...) A maneira como foi redigido o caput do art. 11 faz com que se elabore a idéia de uma 'carência negativa', pois não se trata propriamente de um período em que a cobertura não é assegurada, para posteriormente ser, como ocorre nas carências. É caso de funcionamento similar. Trata-se da possibilidade de suspensão pelo período de vinte e quatro meses, quando, então, nenhuma cobertura poderá ser excluída pelo fato de o consumidor ou beneficiário ter doença preexistente na data de assinatura do contrato".

${ }^{781}$ Art. $3^{\circ}$ : "mos planos ou seguros individuais ou familiar de assistência à saúde contratados após a regulamentação da Lei 9.656/98, fica o consumidor obrigado a informar à contratada, quando expressamente solicitado na documentação contratual, a condição sabida de doença ou lesão preexistente, previamente à assinatura do contrato, sob pena de imputação de fraude, sujeito à suspensão ou denúncia do contrato, conforme o disposto no inciso II do parágrafo único do artigo13 da Lei 9.656/98".

${ }^{782}$ Art. $4^{\circ}$ : "sendo constatada pela operadora por perícia, ou na entrevista através de declaração expressa do consumidor, a existência de lesão ou doença, que possa gerar impacto nos custos, será obrigatório o oferecimento das alternativas previstas nesta regulamentação, ou seja: a cobertura parcial temporária e agravo do contrato".
} 
Interessa é que esses dois únicos efeitos (cobertura parcial ou agravo $^{783}$ do contrato) apenas são oponíveis ao consumidor, à sua escolha, durante os primeiros 24 meses do ajuste, prazo este de natureza decadencial ${ }^{784}$, que uma vez escoados impossibilita qualquer restrição fundada em doença preexistente, volvendo as partes ao sinalagma obrigacional primitivo, ainda que o aderente tenha agido de má-fé. ${ }^{785}$

Alerta Silvio Luís Ferreira da Rocha que, "pode ocorrer, no entanto, que o contratante silencie a respeito da preexistência da doença. A lei, nesse caso, no art. 11, proíbe a exclusão de cobertura às doenças e lesões preexistentes à data de contratação após 24 meses de vigência do contrato, e durante esse prazo impõe à operadora de plano de saúde o ônus da prova da preexistência e do conhecimento prévio do contratante. A operadora do plano, na verdade, é quem deverá provar que a doença preexistia e que o consumidor sabia dessa doença, mas preferiu se omitir". ${ }^{786}$

As operadoras têm, portanto, nesses 24 meses, presumida a boa-fé ${ }^{787}$, o ônus de $\operatorname{provar}^{788}$ os quatro elementos fundamentais ao reflexo liberatório pretendido: a) existência da moléstia ou da lesão quando da contratação (objetivo); b) o seu

\footnotetext{
${ }^{783}$ Assim entendido como qualquer acréscimo no valor da contraprestação paga ao plano ou seguro de saúde (CONSU-Res. 02/98, art. $2^{\circ}$, III).

785 “A boa-fé a que alude o art. 11 da L. 9.656/98 é outra, a subjetiva, ou crença, um estado de ignorância dos vícios que atingem uma determinada situação jurídica. No caso específico dos planos de saúde, é a ignorância da existência da moléstia ou lesão no momento da contratação. Vê-se que a figura é concebida de modo negativo, como ignorância e não como convicção. Má-fé tem aquele que conhece a moléstia ou lesão, aquele que tem a consciência da ilegitimidade de seu direito à dispensa da carência. Discute-se sobre a caracterização da boa-fé subjetiva, se basta a ignorância do vício (concepção psicológica), ou, ao invés, é exigível que o estado de ignorância seja desculpável (concepção ética). No caso dos planos de saúde, a lei se inclinou pelo acolhimento da concepção psicológica, criando uma série de mecanismos para que as operadoras apurem a existência das doenças e lesões antes da formação do contrato. $\mathrm{O}$ art. $3^{\circ}$ da Res. CONSU 2 dispõe que nos planos ou seguros individuais ou familiares de assistência à saúde o consumidor está obrigado a informar ao fornecedor, desde que expressamente solicitado na documentação contratual, a condição sabida de doença ou lesão preexistente. Disso decorre que confere a norma de regência ao fornecedor o dever de indagar, inexistindo a obrigação de revelação espontânea da doença ou lesão" (TJSP, AC 560.138.4/9-00, rel. Francisco Loureiro, j. 30.10.2008).

${ }^{786}$ Contratos de assistência médica..., cit., p. 238.

${ }^{787}$ Impossível é, dentro do sistema constitucional vigente (CF, arts. 5º, XXXII, c.c. 170, V), presumir-se situação em prejuízo do consumidor, sobretudo se considerados o equilíbrio e a boa-fé objetiva (vigas medulares das relações de consumo), nem de longe arranhados por meras conjecturas ou ilações. "Não é possível presumir-se a má-fé da segurada sobre a pré-existência da doença sem respaldo em prova técnica e, ainda, neste caso, sem que sequer tenha sido alegada e demonstrada pela seguradora" (STJ, REsp. 617.239/MG, rel. Min. Carlos Alberto Menezes Direito, j. 14.04.2004). "Inobstante a omissão do de cujus sobre ser portador da AIDS ao tempo da contratação do seguro, não se é de presumir a má-fé se o mesmo sobreviveu, por longos anos mais, renovando sucessivamente a apólice, demonstrando que possuía, tanto à época, como ainda por bastante tempo, estado de saúde e vida praticamente normais" (STJ, REsp. 399.455/RS - rel. Min. Aldir Passarinho Junior, j. 19.12.2002).

${ }^{788}$ Lei $9.656 / 98$, art. 11, par. ún., c.c. CONSU-Res. 02/98, art. $7^{\circ}$, c.c. CDC, art. $6^{\circ}$, VIII.
} 
conhecimento por parte do consumidor ou do responsável (subjetivo) ${ }^{789}$; c) o nexo etiológico entre o problema passado conhecido e a atual necessidade do aderente (causal), este como decorrência direta dos deveres laterais de colaboração e de cuidado; d) a relevância da omissão, o que se descaracteriza caso a doença não se manifeste por longo período de adimplemento do contrato. ${ }^{790}$

Não basta, percebe-se, a simples existência de qualquer mal conhecido antecedente, há que se ter - a partir dele - uma evolução natural, concreta e científica que deságue, como causa direta ${ }^{791}$, na doença cuja cobertura se nega, sendo irrelevante uma possível atuação como mero fator de risco, pena de se admitir, no contrato, hipótese de vantagem exagerada capaz de comprometer obrigações fundamentais inerentes à sua natureza, ameaçando o objeto e o equilíbrio determinantes da confiança depositada (CDC, art. 51, IV e XV, c.c. seu $\S 1^{\text {o }}$, I, II e III). ${ }^{792}$

De toda sorte, estas discussões só vêm à tona porque, no exercício pleno da sua liberdade negocial (CF, art. 170, par, ún. ${ }^{793}$ ), agravando deliberadamente o risco do negócio que administram ${ }^{794}$, as operadoras optam pela exploração agressiva do mercado, sobretudo no que concerne à captação de clientela, circunstância incompatível com a prévia submissão do consumidor a exames admissionais $^{795}$, que acaba sujeito somente a questionários, na maior das vezes, vagos e imprecisos.

Sendo inviável auferir apenas os bônus, apartando-se dos ônus, tudo que se projetar desse quadro, incertezas inclusive, representa lídima res inter

\footnotetext{
789 "É ilícita a recusa da cobertura securitária, sob a alegação de doença preexistente à contratação do segurosaúde, se a Seguradora não submeteu a segurada a prévio exame de saúde e não comprovou má-fé. Precedentes" (STJ, AgRg no Ag. 973.265/SP, rel. Min. Humberto Gomes de Barros, j. 12.02.2008). "A orientação da Corte está firmada no sentido de que a seguradora deve provar a má-fé do segurado, sendo certo que quando não realizado o prévio exame, não pode escusar-se do pagamento ao argumento de que haveria doença preexistente" (STJ, REsp. 651.713/PR, rel. Min. Carlos Alberto Menezes Direito, j. 12.04.2005).

790 “Excepcionalmente, a omissão do segurado não é relevante quando contrata seguro e mantém vida regular por vários anos, demonstrando que possuía, ainda, razoável estado de saúde quando da contratação da apólice” (STJ, REsp. 1.080.973/SP, rel. Min. Nancy Andrighi, j. 09.12.2008).

791 TJSP, AC 750.468-0/2, rel. Carlos Giarusso Santos, j. 14.02.2006 e TJSP, AC 836.966-0/4, rel. Marcondes D’Angelo, j. 14.02.2006.

${ }^{792}$ TJSP, AC 591.689-4/4-00, rel. De Santi Ribeiro, j. 09.12.2008.

${ }^{793} \mathrm{CF}$, art. 170, par. ún.: "é assegurado a todos o livre exercício de qualquer atividade econômica, independentemente de autorização de órgãos públicos, salvo nos casos previstos em lei."

${ }^{794}$ STJ, REsp. 244.841/SP, rel. Min. Carlos Alberto Menezes Direito, j. 03.08.2000.

795 Afirmam François Couilbault, Constant Eliashberg e Michel Latrasse (Les grands principes de l'assurance. $5^{\text {a }}$ ed. Paris: Dalloz, 2002, p. 82): “(...) a seguradora se remete inteiramente à lealdade do
} 
alios frente ao consumidor e, assim, por receberem o prêmio ${ }^{796}$, só às fornecedoras interessam $^{797}$, o que eventualmente pode alcançar seus prepostos omissos. ${ }^{798}$

Certo é que se poderia opor o argumento de que as condutas de má-fé ${ }^{799}$ não identificadas ou, se identificadas, não expostas por algum motivo (v.g., término da carência especial, contrato celebrado antes da Lei 9.656/98, etc.) à cobertura temporária ou ao agravo, em última análise, se admitidas como fontes geradoras de efeitos contratuais regulares, poderiam elidir o equilíbrio mutualístico ${ }^{800}$ que estrutura a exploração privada da saúde em prejuízo dos outros tantos consumidores leais.

No entanto, nada obstante a logicidade do raciocínio, data venia, dele se discorda. É que se assim for, quando chamada à sua responsabilidade, a operadora sempre buscará abrigo na existência dos demais aderentes, com quem não divide lucros, para obter uma espécie de desculpa pela falta de cuidado em gerir o negócio explorado. Quando muito, a seu exclusivo ônus, há de evidenciar que a restrição de determinada cobertura, supostamente indevida, é indispensável para se manter o próprio sistema que patrocina.

Vem a talho de foice, neste passo, as ponderações sempre autorizadas de Cláudia Lima Marques no sentido de que, "expectativas de prestação de um serviço seguro, previsível e de adequada qualidade no tratamento dos problemas de saúde do consumidor e sua família são despertadas no mercado através das atuais vendas

segurado: ela se refere a essas declarações sem estar obrigada, de maneira geral, a verificar todos os elementos declarados".

796 "A empresa que explora plano de seguro-saúde e recebe contribuições de associado sem submetê-lo a exame, não pode escusar-se ao pagamento da sua contraprestação, alegando omissão nas informações do segurado" (STJ, REsp. 229.078/SP, rel. Min. Ruy Rosado de Aguiar, j. 09.11.1999). Em igual sentido e da mesma Corte: AgRg no Ag. 653.720/RS, j. 29.03.2005.

797 "Consoante entendimento desta Corte, a seguradora que não exigiu exames médicos previamente à contratação não pode eximir-se do pagamento da indenização, sob a alegação de que houve omissão de informações pelo segurado" (STJ, AgRg no Ag. 1.062.383/RS, rel. Min. Sidnei Beneti, j. 02.10.2008). "SEGURO-SAÚDE. Doença preexistente. AIDS. Omissa a seguradora tocante à sua obrigação de efetuar o prévio exame de admissão do segurado, cabe-lhe responder pela integralidade das despesas médicohospitalares havidas com a internação do paciente, sendo inoperante a cláusula restritiva inserta no contrato de seguro-saúde. Recurso conhecido em parte e parcialmente provido" (STJ, REsp. 234.419/SP, rel. Min. Ruy Rosado de Aguiar, j. 15.05.2001).

798 "É solidária a responsabilidade pelo cumprimento do seguro-saúde se o corretor omite informações sobre o verdadeiro estado de saúde da segurada e a seguradora não realiza exames prévios de admissão" (STJ, REsp. 534.675/SP, rel. Min. Humberto Gomes de Barros, j. 20.04.2004).

799 "Age de má-fé tanto aquele que afirma boa saúde e não a tem, quanto aquele que não a tem, mas silencia a respeito" (TJSP, AC 875.924-0/0, rel. Marcondes D’Angelo, j. 31.01.2006).

${ }^{800}$ Destaca, a propósito, Arnaldo Rizzardo (Planos de assistência..., cit., p. 15): “o seguro-saúde é uma forma de financiamento das despesas médico-hospitalares com suporte na legislação e nos princípios do mútuo. A seguradora compromete-se, face à ocorrência de determinados eventos previstos no contrato, a ressarcir as despesas realizadas pelo segurado, respeitados os limites estabelecidos". 
agressivas do massivo uso da publicidade comercial, sem que estas expectativas (agora) legítimas sejam, cumpridas na prática e sem que direitos correspondentes sejam assegurados nos contratos destes planos de saúde e nos contratos de prestação de assistência médica. Ao contrário, tais textos contratuais massificados procuram exonerar o fornecedor de ter que assumir seu risco próprio profissional, qual seja ter que realizar com adequação e qualidade o objeto do próprio contrato, isto é, cobrir os riscos de saúde de seus associados, conveniados e clientes". 801

9.4 Dos contratos anteriores à Lei 9.656/98

Uma vez definido que, sob a égide da Lei 9.656/98, a doença preexistente só pode gerar uma de duas consequências jurídicas: cobertura parcial temporária $o u$ agravamento do contrato, afastadas a recusa de ingresso e a exclusão, passa a ser importante perquirir se tais reflexos também disciplinam os pactos que se aperfeiçoaram antes dessa inovação legislativa.

Ou, em outras palavras, é possível - de modo singelo aplicar o art. 766 do Código Civil à hipótese? Qual a utilidade do CDC nesse processo?

Pois bem. No âmbito do direito intertemporal a orientação pretoriana diverge, analisadas as balizas gerais do sistema consumerista (supra, Cap. I, 2).

Apesar de a histórica posição do Supremo Tribunal Federal ${ }^{802}$ não admitir o fenômeno da retroatividade mínima ${ }^{803}$, avaliando o trato sucessivo que via de regra permeia a contratação de consumo de massa, essa diretriz tem sido adotada com tranquilidade pelo Superior Tribunal de Justiça quando o foco da discussão é a incidência da Lei 8.078/90 ${ }^{804}$ e/ou o Estatuto do Idoso. ${ }^{805}$

${ }^{801}$ Expectativas legítimas dos consumidores nos planos e seguros privados de saúde e os atuais projetos de
lei. Revista de Direito do Consumidor, São Paulo: RT, v. 20, out.-dez. 1996, p. 72.
802 ADI 493-0, rel. Min. Moreira Alves, j. 25.06.1992.
${ }^{803}$ Vale lembrar, aqui, a proposta de Matos Peixoto (Limite temporal..., cit., p. 468) quanto à graduação da
retroatividade pela sua intensidade: "dá-se a retroatividade máxima (também chamada restitutória, porque em
geral restitui as partes ao 'statu quo ante'), quando a lei nova ataca a coisa julgada e os fatos consumados
(transação, pagamento, prescrição). (...) A retroatividade é média quando a lei nova atinge os efeitos
pendentes de ato jurídico verificados antes dela, exemplo: o decreto no 22.626 , de 7 de Abril de 1933 (lei da
usura), o qual limitou a taxa de juros e se aplicou aos contratos existentes, inclusive os ajuizados. Enfim a
retroatividade é mínima (também chamada temperada ou mitigada), quando a lei nova atinge apenas os
efeitos dos atos anteriores produzidos após a data em que ela entrou em vigor".
804 "Embora o CDC não retroaja para alcançar efeitos presentes e futuros de contratos celebrados
anteriormente à sua vigência, a legislação consumerista regula os efeitos presentes de contratos de trato
sucessivo e que, por isso, foram renovados já no período de sua vigência. Dada a natureza de trato sucessivo 
Interessante é que à Lei 9.656/98 se nega essa modalidade de eficácia imediata, qual seja, a de regular efeitos atuais advindos da execução continuada de contratos celebrados no passado, tão-só diante da possível adaptação ${ }^{806}$, pelo consumidor, dos vínculos antigos à nova sistemática prevista (art. $35^{807}$ ).

“As disposições da Lei 9.656/98 só se aplicam aos contratos celebrados a partir de sua vigência, bem como para os contratos que, celebrados anteriormente, foram adaptados para seu regime. A Lei 9.656/98 não retroage para atingir o contrato celebrado por segurados que, no exercício de sua liberdade de escolha, mantiveram seus planos antigos sem qualquer adaptação."808

do contado de seguro saúde, o CDC rege as renovações que se deram sob a sua vigência, não havendo que se falar aí em retroação da lei nova" (STJ, REsp. 735.168/RJ - rel. Min. Nancy Andrighi, j. 11.03.2008).

805 “(...) tem-se a controvérsia instaurada porque os fatos nascidos na lei antiga, a partir, portanto, da pactuação, produzem efeitos sob a égide da Lei nova. Tal ocorre porque a previsão de reajuste contida na cláusula depende de um elemento básico prescrito na lei, isto é, o direito está dependendo, conforme já mencionado, da ocorrência de um fato futuro e incerto exigido pela lei, e o contrato só poderá operar seus efeitos no tocante à majoração das mensalidades pretendida pela recorrente, quando satisfeita a condição contratual e legal, qual seja, completar o segurado do plano de saúde a idade de 60 anos. Assim, se o implemento da idade, que confere à pessoa a condição jurídica de idosa, realizou-se sob a égide da Lei nova, não estará o consumidor usuário do plano de saúde sujeito ao reajuste estipulado no contrato e permitido pela lei antiga. Estará amparado, portanto, pela Lei nova. Por isso, não há violação aos arts. $6^{\circ}$ da LICC, e 15 , § $3^{\circ}$, da Lei $10.741 / 2003$, porque a aplicação da Lei nova, na hipótese sob julgamento, não prejudica o ato jurídico perfeito ou o direito adquirido. Prosseguindo-se, pela relevância da questão posta em julgamento, para adentrar na seara da Lei que não está sob discussão, porque não prequestionada, mas apenas para fins de reforço argumentativo, ressalte-se que o art. 15 da Lei 9.656/98 faculta a variação das contraprestações pecuniárias estabelecidas no contrato de planos de saúde em razão da idade do consumidor desde que estejam previstas no contrato inicial as faixas etárias e os percentuais de reajuste incidentes em cada uma delas, conforme normas expedidas pela ANS. No entanto, o próprio parágrafo único do aludido dispositivo legal veda tal variação para consumidores com idade superior a 60 anos. E mesmo para os contratos celebrados anteriormente à vigência da Lei $9.656 / 98$, qualquer variação na contraprestação pecuniária para consumidores com mais de 60 anos de idade está sujeita à autorização prévia da ANS (art. 35-E da Lei 9.656/98). Sob tal encadeamento lógico, o consumidor que atingiu a idade de 60 anos, quer seja antes da vigência do Estatuto do Idoso, quer seja a partir de sua vigência ( $1^{\circ}$ de janeiro de 2004$)$, está sempre amparado contra a abusividade de reajustes das mensalidades dos planos de saúde com base exclusivamente no alçar da idade de 60 anos, pela própria proteção oferecida pela Lei dos Planos de Saúde e, ainda, por efeito reflexo da Constituição Federal que estabelece norma de defesa do idoso no art. 230" (REsp. 809.329/RJ, rel. Min. Nancy Andrighi, j. 25.03.2008).

806 "Embora a Lei tenha previsto a possibilidade de adaptação a cargo do consumidor, tal escolha não foi realizada em grande número, ante a oneração dos contratos com a ampliação da cobertura. Tal fato,, porém, multiplicou o ajuizamento de demandas judiciais, além do alto número de reclamações perante órgãos de defesa do consumidor, tendo em vista a insatisfação dos consumidores, dentre outros aspectos, com as exclusões contratuais de cobertura" (Bruno Lemos Rodrigues. Aspectos legais dos contratos de segurosaúde. São Paulo: Thomson IOB, 2006, p. 38).

${ }^{807}$ Art. 35: "aplicam-se as disposições desta Lei a todos os contratos celebrados a partir de sua vigência, assegurada aos consumidores com contratos anteriores, bem como àqueles com contratos celebrados entre 2 de setembro de 1998 e $1^{\circ}$ de janeiro de 1999 , a possibilidade de optar pela adaptação ao sistema previsto nesta Lei".

${ }^{808}$ STJ, REsp. 1.080.973/SP, rel. Min. Nancy Andrighi, j. 09.12.2008. Em igual sentido e da mesma Corte: REsps. 1.011.331/RJ, j. 17.04.2008 e 889.406/RJ, j. 20.11.2007. 
Certamente o intérprete soberano da legislação federal trilharia a mesma linha principiológica ${ }^{809}$ caso a Lei $9.656 / 98$ não tivesse previsto, expressamente, em benefício do consumidor (e isso é importante), a possibilidade de adaptação de regimes; logo, o que é para beneficiar o sujeito constitucionalmente protegido (CF, art. $5^{\circ}$, XXXII) não pode ser usado para prejudicá-lo.

A dinâmica de incidência deve ser a mesma, pois - no particular - em nada diferem a norma estruturante dos planos e dos seguros privados de saúde, o CDC e o Estatuto do Idoso; daí porque, conquanto anterior o contrato à Lei 9.656/98, a doença preexistente não pode levar à exclusão de cobertura ${ }^{810}$, até porque seus

\footnotetext{
${ }^{809}$ Partindo-se da proteção constitucional que ampara o consumidor, exsurge viável adotar-se a teoria da retroatividade mínima para aqueles casos em que a causa autorizante do exercício do direito litigioso atrativa da proteção específica - surge no mundo jurídico já na vigência da Lei 8.078/90. Observe-se, a propósito, como ensina José Celso de Mello Filho (Constituição Federal..., cit., p. 431) que a incidência imediata das normas constitucionais, todas elas revestidas de eficácia derrogatória das regras e dos atos dotados de positividade jurídica inferior, não permite que se invoque contra elas qualquer situação juridicamente consolidada. Assim, o ato jurídico perfeito, a coisa julgada e o direito adquirido, embora imunes à ação legislativa ordinária, que não poderá afetá-los, mostram-se irrelevantes em face da inquestionável supremacia formal e material das regras constitucionais. Vem a talho de foice, por oportuna, a lição de Gustavo Tepedino (As relações de consumo..., cit., p. 214): “(...) é imperioso interpretar restritivamente a noção de direito adquirido, de molde a não abranger os efeitos futuros de negócios jurídicos que, posto praticados legalmente no passado, são hostilizados pela lei nova. Até a entrada em vigor desta, há de se proteger os efeitos produzidos pelo ato jurídico perfeito, sempre que definitivamente incorporados ao patrimônio de alguém. Cuidando-se, entretanto, de relações de trato sucessivo, pretender fazer prevalecer por anos a fio, projetada para o futuro, a produção de efeitos e a incorporação de novos efeitos no patrimônio individual, por força de comportamento ou atividade que a sociedade considera nocivos ao convívio social, parece-nos excessivo. Mais que excessivo, parece-me deliberada subversão da vontade constitucional". Ou, nas palavras de Cláudia Lima Marques (Contratos..., cit., p. 578), esta nova linha de interpretação relativa necessariamente a mencionada noção de ato jurídico perfeito, ou haverá violação de outro princípio constitucional, que é a defesa do consumidor, ao negar-se o juiz a examinar a licitude da imposição contratual face ao novo mandamento de maior lealdade no mercado e relativização do dogma absoluto da autonomia da vontade. E conclui, com a pena de mestre que lhe é peculiar, a brilhante professora (idem, p. 581): “(...) A aceitação desta tese, quanto ao que se refere à aplicação do CDC como lei mais benéfica ao consumidor, mesmo aos contratos anteriores, significa a aceitação da mudança dos princípios orientadores do direito civil - talvez por influência mesmo constitucional - e da possibilidade de intervenção e dirigismo contratual estatal. Esta nova visão desloca a importância do corolário da autonomia da vontade e da obrigatoriedade do pactuado, para o problema da função social do direito privado, para considerar que a eficácia dos atos decorre da lei, a qual os sanciona porque são úteis, com a condição de serem justos tanto no momento de sua formação, quanto de sua execução".

810 "Plano de saúde - Miopia - Cirurgia refrativa - Procedência - Contrato firmado em 1996 - Avença de execução continuada - Aplicabilidade da Lei ${ }^{\circ}$ 9.656/98 - Intervenção que se mostra como procedimento altamente eficaz no tratamento de miopias - Restrição contida na Resolução $n^{\circ} 10 / 98$ abusiva - Sequer pode ser discutida a preexistência da doença, já passados mais de 24 meses da contratação, conforme dispositivo contido no caput do art. 11 da Lei dos Planos de Saúde - Sentença mantida - Recurso improvido" (AC 260.336.4/5-00, rel. Joaquim Garcia, j. 30.07.2008). Do V. Aresto extrai-se o seguinte excerto: "embora anterior à Lei $n^{\circ} 9.656 / 98$, o contrato em exame é de execução continuada ou diferida no tempo, pois firmado pelo prazo de 24 meses, com renovação automática; assim, a lei nova atinge os efeitos e os fatos ocorridos após sua vigência. Verificando-se que, apesar de o contrato ter sido firmado em 1996, a cirurgia foi solicitada apenas em 2001, quando já vigente a lei do setor de saúde”. Em igual sentido e da mesma Corte: AC 424.994-4/1-00, j. 06.04.2009.
} 
custos - inseridos na atividade desenvolvida pela operadora - são diluídos na receita obtida dos demais usuários que pouco acionam o sistema. ${ }^{811}$

É que, como adverte o Min. Cezar Peluso, ainda quando judicava no TJSP, “(...) não se pode reduzir tais contratos aos padrões dos negócios governados apenas pela lógica dos lucros. É preciso ir além, enxergar um pouco mais alto, no sistema jurídico-normativo, e deixar-se iluminar pelos princípios que se radicam na dignidade da pessoa humana, hoje sublimada à condição constitucional de fundamento da República (artigo $1^{\circ}$, caput, III, da Constituição), e perante a qual devem justificar-se as normas jurídicas e toda a juridicidade". 812 


\section{DIREITO DE ARREPENDIMENTO}

Quando o espírito do consumidor não está preparado para uma abordagem mais ousada, com técnicas de venda incisivas, não terá ele discernimento suficiente para contratar ou deixar de contratar, dependendo do poder de convencimento empregado nessas práticas agressivas. Para essa situação é que o CDC prevê o direito de arrependimento. ${ }^{813}$

Trata-se de um prazo legal de reflexão (CDC, art. $\left.49^{814}\right)$, um certo período de decantação ${ }^{815}$ em que o consentimento do consumidor se exercita em câmera lenta. ${ }^{816}$

A configuração e o exercício desse direito dependem da presença simultânea de quatro elementos: a) relação de consumo (sujeitos e objeto); b) aperfeiçoada fora do estabelecimento comercial do fornecedor ${ }^{817}$; c) especialmente por telefone ou a domicílio; e d) observância do prazo de sete dias.

Percebe-se, prima facie, que a lei não qualifica nem exclui certos produtos ou serviços, ao contrário, é genérica e a todos alcança (e.g., venda de

\footnotetext{
${ }^{813}$ Nelson Nery Júnior et alii. Código Brasileiro de Defesa do Consumidor..., cit., p. 332.

${ }^{814} \mathrm{CDC}$, art. 49: "o consumidor pode desistir do contrato, no prazo de 7 dias a contar de sua assinatura ou do ato de recebimento do produto ou serviço, sempre que a contratação de fornecimento de produtos e serviços ocorrer fora do estabelecimento comercial, especialmente por telefone ou a domicílio". Par. ún.: "se o consumidor exercitar o direito de arrependimento previsto neste artigo, os valores eventualmente pagos, a qualquer título, durante o prazo de reflexão, serão devolvidos, de imediato, monetariamente atualizados".

${ }^{815}$ Geraldo de Faria Martins da Costa. O direito do consumidor endividado e a técnica do prazo de reflexão. Revista de Direito do Consumidor, São Paulo: RT, v. 43, jul.-set. 2002, p. 266.

${ }^{816}$ Ricardo Luis Lorenzetti. Consumidores. Santa Fé: Rubinzal-Culzoni, 2003, p. 204.

817 “Além das aquisições fora do estabelecimento comercial há inúmeras situações em que os negócios, mesmo os realizados dentro do estabelecimento, são firmados sem a necessária reflexão por parte do consumidor. É o caso do consumidor que visita a loja e é instigado pelo vendedor a adquirir um determinado produto que está em uma 'promoção irresistível' ou que tem, supostamente, disponibilidade em estoque extremamente baixas ('últimas peças'). Nas aquisições feitas nestas situações, é muito possível que o consumidor, ao chegar a casa e refletir melhor sobre a compra que fez, arrependa-se. Caso o produto ainda não tenha sido entregue ou, se retirado pelo consumidor, não tenha sido utilizado, é bastante razoável que se lhe permita o direito de se arrepender, observando-se, logicamente, o prazo estabelecido pelo art. 49 do CDC (sete dias da celebração do contrato ou do recebimento da mercadoria) e o pressuposto de vedação ao enriquecimento sem causa" (Fernando Büscher Von Teschenhausen Eberlin. Contratação refletida na sociedade de consumo: o direito de arrependimento como proteção do consentimento do consumidor. Revista de Direito do Consumidor, São Paulo: RT, v. 76, out.-dez. 2010, p. 66). Com base em constatação empírica, destaque-se que tal prática é bem aceita nos Estados Unidos, notadamente nos estados da Flórida, de Nova Iorque, de Nova Jersey, de Illinois e de Massachussetts. A entender que a aquisição de produto mediante escolha por catálogo, mas realizada em uma das lojas da fornecedora, não autoriza o direito de arrependimento, cf. TJSP, AC 992.09.069103-1, rel. Arantes Theodoro, j. 05.11.2009; enquanto para a mera insatisfação com o produto adquirido no estabelecimento comercial, cf. TJPR, AC 645.675-1, rel. Hamilton Mussi Corrêa, j. 10.02.2010).
} 
imóvel, negócios comumente celebrados dessa forma, crédito ${ }^{818}$, etc.); logo, inviável ao intérprete restringir onde a lei não $\mathrm{o} \mathrm{fez}^{819}$. E não o fez porque o legislador sabe que o consumidor é materialmente vulnerável e que o ônus da atividade economicamente lucrativa explorada no mercado é exclusivo do fornecedor, isto é, se atuar fora do seu estabelecimento, está assumindo o risco que a lei atribui ao negócio: arrependimento do consumidor.

Visando a assegurar a boa-fé e a lealdade nas relações contratuais de consumo, protegendo a declaração de vontade do consumidor despreparado (pouco tempo para decidir, impossibilidade de comparar o produto com outros, dependência total das informações prestadas pelo vendedor ou pelo catálogo, impossibilidade de examinar o produto ou de testar o serviço, etc.), para que esta possa ser decidida e refletida com calma, desprestigiando aquela fundada no mero impulso, a Lei $8.078 / 90$ instituiu um prazo de reflexão obrigatório e um direito de arrependimento. ${ }^{820}$

A medida se justifica em virtude da circunstância de que, fora do estabelecimento comercial, sem dúvida, o consumidor tem menos condições de avaliar o objeto adquirido (produto ou serviço), pois esse tipo de negócio é nitidamente mais agressivo, imprimindo à relação de consumo um desequilíbrio acentuado. ${ }^{821}$

Luiz Antonio Rizzatto Nunes, a abordar que a lei não exige nenhuma explicação, bastando a objetiva desistência (pura e simples), sem necessidade de serem anunciadas suas razões determinantes, que se fala: “em prazo de 'reflexão' porque

\footnotetext{
${ }^{818}$ Entende a professora Cláudia Lima Marques (Contratos..., cit., p. 731) que o art. 49 do CDC, “ (...) não engloba um prazo de reflexão em caso de contrato envolvendo crédito". Entretanto, data venia, discorda-se dessa postura, pois o crédito nada mais é do que um serviço como outro qualquer (supra, Cap. II, 4.1.1 c.c. $\mathrm{CDC}$, art. $3^{\circ}, \S 2^{\circ}$ ).

819 "Consumidor. Recurso Especial. Ação de busca e apreensão. Aplicação do CDC às instituições financeiras. Súmula 297/STJ. Contrato celebrado fora do estabelecimento comercial. Direito de arrependimento manifestado no sexto dia após a assinatura do contrato. Prazo legal de sete dias. Art. 49 do CDC. Ação de busca e apreensão baseada em contrato resolvido por cláusula de arrependimento. Improcedência do pedido. - O Código de Defesa do Consumidor é aplicável às instituições financeiras. Súmula 297/STJ. - Em ação de busca e apreensão, é possível discutir a resolução do contrato de financiamento, garantido por alienação fiduciária, quando incide a cláusula tácita do direito de arrependimento, prevista no art. 49 do CDC, porque esta objetiva restabelecer os contraentes ao estado anterior à celebração do contrato. - É facultado ao consumidor desistir do contrato de financiamento, no prazo de 7 (sete) dias, a contar da sua assinatura, quando a contratação ocorrer fora do estabelecimento comercial, nos termos do art. 49 do CDC. - Após a notificação da instituição financeira, a cláusula de arrependimento, implícita no contrato de financiamento, deve ser interpretada como causa de resolução tácita do contrato, com a consequência de restabelecer as partes ao estado anterior. - O pedido da ação de busca e apreensão deve ser julgado improcedente, quando se basear em contrato de financiamento resolvido por cláusula de arrependimento. Recurso especial conhecido e provido" (STJ, REsp. 930.351/SP, rel. Min. Nancy Andrighi, j. 27.10.2009).

${ }^{820}$ Cláudia Lima Marques. Contratos..., cit., p. 703/704.
} 
se pressupõe que, como a aquisição não partiu de uma decisão ativa, plena, do consumidor, e também como este ainda não 'tocou' concretamente o produto ou testou o serviço, pode querer desistir do negócio depois que o avaliou melhor. Ou, em outros termos, a lei dá oportunidade para que o consumidor, uma vez tenha recebido o produto ou testado o serviço, possa, no prazo 7 dias, desistir da aquisição feita". ${ }^{822}$

Tem, pois, caráter de arbítrio absoluto (prerrogativa do consumidor), não se podendo, sob pretexto algum, limitar o exercício de tal direito, potestativo $^{823}$, que vale pela só exteriorização dessa vontade ${ }^{824}$, ou seja, independe de justificativa de ordem subjetiva ${ }^{825}$. Representa autêntica denúncia vazia do contrato de consumo. $^{826}$

\subsection{Natureza jurídica}

Após discorrer sobre as doutrinas alemã (aceitação apta, em tese, a constituir o vínculo obrigacional, mas ineficaz durante o prazo reflexivo) e a francesa (não existência do contrato ficando o consumidor como mero depositário do bem transacionado), a professora Cláudia Lima Marques, pressupondo a existência do contrato nessas hipóteses, repele os conceitos tradicionais das condições suspensiva e resolutiva para propor uma nova vertente de cláusula resolutiva tácita (ex tunc). Segundo ela, "seria uma faculdade unilateral do consumidor de resolver o contrato no prazo legal de reflexão, sem ter que arcar com os ônus contratuais normais da resolução por inadimplemento (perdas e danos etc.). (...) A resolução opera, então, de pleno direito, não necessitando a manifestação do Judiciário, bastando a simples manifestação de vontade do consumidor em desistir do contrato (...) operando retroativamente para restabelecer o statu quo ante" ${ }^{827}$

Essa recondução das partes ao estado anterior, à evidência, depende do estado do produto, que deve ser devolvido ${ }^{828}$; entretanto, data venia, não há

\footnotetext{
${ }^{821}$ Arruda Alvim et alii. Código do Consumidor comentado..., cit., p. 243.

${ }^{822}$ Comentários..., cit., p. 572/573.

${ }^{823}$ Fernando Büscher Von Teschenhausen Eberlin. Contratação refletida..., cit., p. 63.

${ }^{824}$ Arruda Alvim et alii. Código do Consumidor comentado..., cit., p. 243.

${ }^{825}$ Luiz Antonio Rizzatto Nunes. Comentários..., cit., p. 572.

${ }^{826}$ Nelson Nery Júnior et alii. Código Brasileiro de Defesa do Consumidor..., cit., p. 334. No mesmo sentido: TJSP, Apel. 991.04.014898-0, rel. Mário de Oliveira, j. 10.08.2010.

${ }^{827}$ Contratos..., cit., p. 710.

828 'CONTRATO - Resolução - Compra de computador tipo 'notebook' - Acolhida a pretensão à antecipação da tutela requerida pelo autor para o restabelecimento da situação anterior à aquisição, devendo
} 
como se exigir esteja ele realmente intacto (não experimentado, não manuseado, etc.). Observe-se: é justamente esse uso, o primeiro contato, que pode ter sido o fator determinante do arrependimento.

Tome-se o exemplo de um xampu. O consumidor, que obtém o produto fora do estabelecimento comercial do fornecedor, adota a conduta razoavelmente esperada para a hipótese: toma banho e usa o xampu. Não gosta do resultado e desfaz o negócio dentro do prazo legal. Outra situação, de igual maneira, o consumidor compra o mesmo xampu. Experimenta e gosta; gosta tanto que em seis dias quase todo o produto foi exaurido. Sabedor da regra do art. 49 da Lei 8.078/90, o adquirente pleiteia a incidência dos seus efeitos.

Ora, é a boa-fé objetiva, como norma de comportamento, que vai resolver a questão.

$\mathrm{Na}$ primeira hipótese outra coisa não se poderia esperar do consumidor e, por isso, seu arrependimento não lhe acarretará nenhum ônus, que, dentro da normalidade das coisas, é exclusivo daquele que se predispõe a explorar o mercado fora do seu estabelecimento comercial. Ao revés, no segundo exemplo, a conduta do consumidor desviou-se do padrão normal imposto pela boa-fé objetiva para beirar o abuso.

Conquanto preservado o arrependimento, para que não enriqueça sem causa $^{829}$, há de ressarcir o fornecedor pela perda exagerada do produto.

Raciocínio idêntico é reservado aos serviços.

Sublinhe-se que o arrependimento independe da possibilidade física da volta ao status quo, o direito é assegurado para liberar o consumidor do vínculo contratual, sem ônus. Questionável seria o interesse em desistir daqueles serviços de execução imediata, os quais, pela sua essência, são quase sempre ajustados e prestados no domicílio do consumidor (v.g., de consertos gerais, de pintura, etc.). ${ }^{830}$

ele entregar à ré o computador, competindo a esta, em contrapartida, a devolução do dinheiro, devidamente corrigido, desde o seu recebimento, eis que verificada a presença dos pressupostos autorizadores, quais sejam, o fundado receio de dano irreparável ou de difícil reparação, caso o pedido fosse atendido somente a final, certo que o bem em causa torna-se obsoleto em curto espaço de tempo, e a verossimilhança das alegações do comprador quanto ao descumprimento, pela vendedora, não só da obrigação principal, como também das acessórias, tendo ele, inclusive, manifestado, em tempo hábil, sua desistência do negócio, nos termos do Código de Defesa do Consumidor - Agravo provido" (1 ${ }^{\circ}$ TacCiv/SP, AI 1.196.624-4, rel. Itamar Gaino, j. 09.09.2003).

${ }^{829}$ Fernando Büscher Von Teschenhausen Eberlin. Contratação refletida..., cit., p. 62.

${ }^{830}$ Claudia Lima Marques. Contratos..., cit., p. 715. 
Demais, não se perca de vista que a simples chamada voluntária do fornecedor (produtos ou serviços) não inviabiliza o exercício posterior do direito de desistência, porquanto se deve esquadrinhar de modo objetivo as condutas realizadas (e esperadas) pelas partes, verificando, em concreto, as formas e as técnicas do próprio fornecimento.

\subsection{Elenco exemplificativo}

Esclarece Nelson Nery Júnior que o advérbio especialmente utilizado pelo Código deixa claro que a contração por telefone ou a domicílio são apenas algumas das formas pelas quais o vínculo obrigacional pode se aperfeiçoar nessas específicas condições; e ao destacar esse caráter de numerus apertus conclui: "toda relação de consumo que for celebrada fora do estabelecimento comercial está sujeita ao regime do direito de arrependimento. Assim as contratações por telefone, telex, fax, videotexto, mala direta, reembolso postal, catálogo, prospectos, lista de preços, a domicílio etc.". 831

Todo o sistema legal consumerista está estruturado sobre conceitos e cláusulas gerais, visto que as inovações do mercado - cada vez mais sedutor e em constante evolução tecnológica - jamais poderiam ser alcançadas pela produção legislativa ou regulamentar.

Sem sombra de dúvida, àquele rol podem ser incluídos os negócios realizados por meio eletrônico (internet ${ }^{832}$ ) e pela televisão. ${ }^{833}$

\subsection{Prazo (contagem e manifestação)}

Com efeito, o prazo legal (mínimo) para o consumidor se arrepender é de sete dias, podendo ampliar-se no exclusivo interesse do fornecedor (v.g., captação de mercado), observada a regra ordinária de contagem: exclui-se o dia do

\footnotetext{
${ }^{831}$ Et alii. Código Brasileiro de Defesa do Consumidor..., cit., p. 333.

832 "BEM MÓVEL - Ação de rescisão de contrato cumulada com indenização por dano moral - Ação julgada improcedente - Cerceamento de defesa e nulidade da sentença - Não ocorrência - Compra feita pela Internet - Direito de arrependimento exercitado no prazo legal - Rescisão decretada - Artigo 49, do Código de Defesa do Consumidor - Desídia e ineficiência do serviço da ré que superaram os limites do que se entende tolerável - Dano moral caracterizado - Ação procedente - Recurso provido" (TJSP, AC 992.08.031261-5, rel. Sá Duarte, j. 10.05.2010).

${ }^{833}$ Luiz Antonio Rizzatto Nunes. Comentários..., cit., p. 571.
} 
começo, mas inclui-se o do vencimento ${ }^{834}$. Do intérprete exige-se atenção para os distintos termos iniciais: assinatura do contrato ${ }^{835}$ ou ato de recebimento do produto ou serviço.

Salienta, a propósito, Luiz Antonio Rizzatto Nunes:

"Se se tivesse referido à assinatura do contrato de compra e venda do produto ou serviço que iria ser entregue, então nada diria, uma vez que a norma cuida das vendas fora do estabelecimento e a proteção tem início quando o consumidor recebe efetivamente o produto ou o serviço. É isso o que importa, e não o documento emitido para sua compra e venda, que pode ser - na maior parte dos casos é - apenas a nota fiscal de compra e venda.

A lei, na verdade, pressupõe que, além da aquisição do produto ou serviço, existem outras transações firmadas por contrato fora do estabelecimento comercial, que merecem a guarida do prazo de reflexão. E de fato existem. São por exemplo, assinaturas de revistas e jornais; a contratação de serviços de TV a cabo feita por vendedores em domicílio; a aquisição de seguros em geral e planos de saúde também feita em domicílio etc. São casos típicos de contratos cuja importância está mais no contrato do que no serviço ou na entrega do produto (...). ${ }^{\Perp 836}$

Caso o fornecimento de produtos ou a prestação de serviços tragam inerente também a assinatura de contrato (ainda que em momentos distintos), prevalece a contagem mais benéfica para o consumidor ${ }^{837}$, haja vista sua acentuada vulnerabilidade pela submissão às técnicas agressivas de venda fora do estabelecimento comercial. $^{838}$

\footnotetext{
${ }^{834} \mathrm{CC}$, art. 132.

835 "É facultado ao consumidor desistir do contrato de compra, no prazo de 7 (sete) dias, a contar da sua assinatura, quando a contratação ocorrer fora do estabelecimento comercial, nos termos do art. 49 do CDC" (STJ, AgRg. no REsp. 1.189.740/RS, rel. Min. Sidnei Beneti, j. 22.06.2010).

${ }^{836}$ Comentários..., cit., p. 575.

837 "PRESTAÇÃO DE SERVIÇOS - ARREPENDIMENTO - Admissibilidade - Desistência, através de regular notificação, que se deu anteriormente à vigência do próprio contrato - Artigo 49 do Código de Defesa do Consumidor - Teleologia da norma que leva em consideração sempre o pleno início das relações - No caso, tratando-se de prestação de serviço, este só tem vigência quando efetivamente prestado - Devolução do preço pago e de qualquer despesa efetuada - Efeito ex tunc da desistência - Procedência do pedido - Apelo provido para esse fim" (1 ${ }^{\circ} \mathrm{TacCiv} / \mathrm{SP}$, Apel. 797.271-8, rel. Rizzatto Nunes, j. 24.05.2000).

${ }^{838}$ O STJ já se manifestou contrário a essa posição ao enfrentar o direito de arrependimento em sede de promessa de venda e compra de imóvel: "o direito de arrependimento previsto no artigo 49 do Código de Defesa do Consumidor se esgota decorridos sete dias da celebração do negócio, ainda que a entrega do bem dependa da conclusão do prédio. Extensão indevida a regra destinada a proteger o consumidor de uma prática comercial na qual ele não desfruta das melhores condições para decidir sobre a conveniência do negócio, circunstâncias essas que não persistem depois de prolongada execução do contrato" (REsp. 57.789/SP, rel. Min. Ruy Rosado de Aguiar, j. 25.04.1995).
} 
Ou, nas palavras de Nelson Nery Júnior, "se o produto ou serviço for entregue ou prestado no dia da assinatura do contrato, a partir daí é que se conta o prazo para o exercimento do direito de arrependimento. Caso o contrato seja assinado num dia e o produto ou serviço entregue ou prestado em época posterior, o prazo de reflexão tem início a partir da efetiva entrega do produto ou prestação do serviço. Isso porque, no mais das vezes, as compras por catálogo ou por telefone são realizadas sem que o consumidor esteja preparado para tanto, e, ainda, sem que tenha podido ter acesso físico ao produto. Quando recebe o produto encomendado, verifica que está aquém de suas expectativas, pois, se o tivesse visto e examinado, não o teria comprado". ${ }^{839}$

No que tange à manifestação de vontade, tem o consumidor ex vi legis sete dias para refletir; assim, a desistência do contrato e o consequentemente direito de arrependimento podem ser externados ao fornecedor até o último momento desse lapso, circunstância que induz um caráter não receptício, ou seja, basta a remessa da prova da intenção. Se veiculada por telefone, a matéria de fato será dirimida durante a instrução processual, observadas as peculiaridades do caso concreto.

Para tanto há de estar cumprida a regra específica de oferta insculpida no comando do art. 33 do CDC. ${ }^{840}$

Lembra o insigne Arruda Alvim que, “(...) seu exercício não pode ser objeto de qualquer ulterior repasse de informação depreciativa, a teor do disposto no artigo 39, VII, deste Código". ${ }^{841}$ A lei protege o consumidor que exercita seus direitos contra essa prática abusiva.

Ultrapassado esse prazo de sete dias, subsiste a possibilidade de se discutir todos os abusos constantes do contrato, invocando o consumidor, para tanto, os vários dispositivos da Lei 8.078/90. ${ }^{842}$

\footnotetext{
${ }^{839}$ Et alii. Código Brasileiro de Defesa do Consumidor..., cit., p. 331. No mesmo sentido, Arruda Alvim et alii. Código do Consumidor comentado..., cit., p. 242/243. E Newton de Lucca (A proteção..., cit., p. 83) adita que o art. 49 do CDC: “(...) contempla duas situações distintas. Não se trata, à evidência, de duas formas de contar um mesmo prazo para a mesma situação jurídica, mas sim de duas hipóteses diversas nas quais esse prazo será contado em função da característica de cada uma delas. Entendo que só faz sentido falar-se em prazo de 7 dias a contar da assinatura quando, ao mesmo tempo desta, tiver o consumidor recebido o produto. É o caso, p. ex., das vendas feitas no próprio domicílio. Nas vendas por correspondência, é evidente que o prazo de 7 dias só poderá começar a fluir após o recebimento do produto e não após a assinatura do contrato, pois poderá passar os 7 dias sem que o consumidor tenha sequer recebido o produto".

${ }^{840} \mathrm{CDC}$, art. 33: "em caso de oferta ou venda por telefone ou reembolso postal, devem constar o nome do fabricante e endereço na embalagem, publicidade e em todos os impressos utilizados na transação comercial",

${ }_{841}^{84}$ Et alii. Código do Consumidor comentado..., cit., p. 243.

${ }^{842}$ Maria Cristina Cereser Pezzella. O princípio da boa-fé objetiva..., cit., p. 211.
} 
10.4 Vendas emocionais

$\mathrm{O}$ art. 39 proíbe uma série de práticas abusivas (supra, Cap. III, 3.2.1), dentre as quais pode ser incluído o método de venda que impede uma decisão racional e refletida do consumidor, corolário da livre escolha assegurada pelo art. $6^{\circ}$, II, do CDC. $^{843}$

Tal modalidade tem ocorrido com certa frequência nos chamados contratos de venda time-sharing ou multipropriedade ${ }^{844}$. Neles, como preleciona Cláudia Lima Marques, “(...) o consumidor é convidado (por telefonemas, com sorteios e premiações) a comparecer no estabelecimento comercial do vendedor ou representante, especialmente organizado para tal, onde então, em uma festa, coquetel ou recepção, onde se servem mesmo bebidas alcoólicas e onde o clima de sucesso, realização e prazer é oferecido através de vídeos, aplausos, brincadeiras e jogos, onde o consumidor é (des)informado sobre o contrato e o assina, assim como o seu pagamento, garantido com a assinatura de vários boletos de cartão de crédito, tudo em um clima 'emocional' de consumo e prazer que costuma arrefecer até mesmo advogados e juízes". ${ }^{845}$

Pois bem. Como a Lei 8.078/90 resguarda a vontade do consumidor apenas nos contratos celebrados fora do estabelecimento comercial, estaria o consumidor desprotegido nessa hipótese, em que ele é atraído intencionalmente pelo fornecedor?

Responde a professora da UFRGS que, “(...) pela intenção do legislador do CDC de proteger a 'vontade racional' nos contratos fora do estabelecimento comercial, é necessário interpretar esta norma do art. 49 do CDC de forma aberta, para poder incluir os mais variados métodos de contratação emocional em matéria de timesharing e o marketing direto. Muitos destes métodos agressivos de convencimento e estratégias de venda são executados dentro do 'pretenso' ou aparente estabelecimento

\footnotetext{
${ }^{843}$ Cláudia Lima Marques et alii. Comentários..., cit., p. 912.

${ }^{844}$ Segundo Cristiano Heineck Schmitt e Fabiana Pietros Peres (Contrato de time-sharing: nuances acerca da proteção do consumidor no direito comunitário e no direito brasileiro. Revista de Direito do Consumidor, São Paulo: RT, v. 76, out.-dez. 2010, p. 204/205), “as origens do time-sharing apontam o mesmo como se tratando de uma solução para o turismo na Europa. No pós-guerra, as origens do sistema viabilizaram pequenos grupos familiares reunirem-se parar adquirir e compartilhar um imóvel de férias. Tal prática beneficiava os hoteleiros, porque assim garantiam a lotação necessária para a subsistência do negócio".

${ }^{845}$ Contratos..., cit., p. 716.
} 
comercial do organizador de vendas ou do projeto de lazer, em festas, em reuniões, e com distribuições de pretensos prêmios gratuitos". ${ }^{846}$

Isto porque o consumidor, comparecendo em local indicado pelo fornecedor, a convite seu, em razão da estratégia adotada, é submetido à forte pressão psicológica que o coloca em situação desvantajosa ${ }^{847}$, que o impede de refletir e de manifestar livremente sua vontade, ao mesmo passo que o incentiva a assinar o contrato. ${ }^{848}$ Em resumo: o consumidor, vítima da sua própria incapacidade crítica ou suscetibilidade emocional, dócil objeto de exploração de uma publicidade obsessora e obsidional, passa a responder ao reflexo condicionado da palavra mágica, sem resistência. Compra um objeto ou paga por um serviço, não porque a sua marca ateste a boa qualidade, mas simplesmente porque ela evoca todo um reino de fantasias ou devaneio de atração irresistível. ${ }^{849}$

${ }^{846}$ Contratos..., cit., p. 719.

847 "NEGÓCIO JURÍDICO - Contrato - Direito de arrependimento - Incidência do Código de Defesa do Consumidor - Hipótese em que o contraio foi firmado dentro do estabelecimento comercial - Art. 49 do CDC que não deve ser interpretado restritivamente - Método agressivo de 'marketing' que permite o direito de arrependimento - Caso em que a consumidora foi premiada após participação de jogo, ganhando direito a conhecer hotel, onde foi convencida a contratar, em duna emocional - Vontade maculada pelo entusiasmo temporário, causado pelo estímulo repentino e de ansiedade de contratação, derivado do método de apresentação do produto ou serviço - Direito de arrependimento que deve ser garantido em homenagem à boa-fé contratual, evitando-se que a venda emocional possa legitimar contratações maculadas pela ausência de transparência e respeito aos interesses do contratante mais fraco - Recurso não provido" (TJSP, AC 1.224.228-5, rel. Melo Colombi, j. 09.05.2007).

${ }^{848}$ TARS, AC 196115299, rel. Maria Isabel de Azevedo Souza, j. 10.09.1996,

${ }^{849}$ Fábio Konder Comparato. A proteção do consumidor na Constituição brasileira de 1988. Revista de Direito Mercantil, São Paulo: RT, v. 80, out.-dez. 1990. 


\title{
CAPÍTULO V \\ DIREITOS BÁSICOS DO CONSUMIDOR
}

\begin{abstract}
SUMÁRIO: 1. CONSIDERAÇÕES GERAIS - 2. OFERTA (informação adequada) - 3. PUBLICIDADE - 4. REVISÃO CONTRATUAL - 5. ACESSO À JUSTIÇA.
\end{abstract}

\section{CONSIDERAÇÕES GERAIS}

À semelhança dos precedentes internacionais, mormente da Organização das Nações Unidas (ONU - Res. 39/248) e das diretivas editadas pela Comunidade Econômica Européia (CEE), o legislador de 1990 preocupou-se em fixar uma série de direitos básicos do consumidor (CDC, art. $\left.6^{\circ}\right)$.

Em certa medida, o elenco de princípios do artigo $4^{\circ}$ da Lei 8.078/90 transporta-se aos direitos básicos dos consumidores num processo lógico de explicitação. A base, entretanto, continua a mesma: a) a vulnerabilidade; b) o dever governamental; c) a adequação; d) a boa-fé objetiva; e) a informação; e f) o acesso à justiça. ${ }^{850}$

Na síntese de Thierry Bourgoignie, “(...) ele (o direito do consumidor) vale pelo reconhecimento de um sem número de direitos ao consumidor e pela elaboração de um conjunto normativo específico, para a realização dos objetivos do movimento que visa assegurar a promoção dos interesses do consumidor. ${ }^{851}$

\footnotetext{
${ }^{850}$ Arruda Alvim et alii. Código do Consumidor comentado..., cit., p. 59/60.

${ }^{851}$ Revue Internacionale de Droit Compare, v. 3, 1982, apud, José Geraldo Brito Filomeno et alii. Código Brasileiro de Defesa do Consumidor..., cit., p. 79.
} 


\section{OFERTA (informação adequada)}

Com efeito, o direito à ampla informação, inexoravelmente derivado do princípio da transparência (supra, Cap. III, 4.1), se projeta em várias oportunidades na Lei 8.078/90, mas uma das suas principais vertentes, sem dúvida, por força das consequências que encerra, está na nova concepção de oferta (publicidade).

Observa João Batista de Almeida que, "a evolução das relações de consumo conduziu à necessidade de novo tratamento do tema atinente à oferta e publicidade. As disposições do direito comum (CC, art. 1.087, e CCom, arts 121 e s.) mostraram-se insuficientes e inadequadas para regular a nova realidade, por duas razões principais: (a) como a oferta e a publicidade eram desconhecidas ou incipientes no fim do século XIX e começo do século XX, os Códigos Comercial e Civil, de 1850 e 1917, respectivamente, regularam minimamente a matéria; e, (b) ainda sim, a escassa regulamentação pressupunha a igualdade das partes e tinha presente o entendimento de que a oferta se dava entre pessoas determinadas, pressupondo a bilateralidade proponenteaceitante". ${ }^{852}$

E prossegue o referido autor: “(...) a regulamentação da matéria mostrava-se de suma importância para o consumidor à constatação de que seus direitos básicos de informação, livre escolha e proteção contra métodos desleais e práticas comerciais (art. $6^{\circ}$, II, III e IV) só estariam efetivamente garantidos se lhe fosse permitido atuar com liberdade e consciência na fase da oferta, sem sofrer influência de oferta inverídica e de publicidade enganosa ou abusiva, deturpadoras de sua manifestação de vontade. Atento à circunstância de que o consumidor atua no mercado de consumo influenciado pela oferta e seduzido pela publicidade, optou o legislador por disciplinar a matéria na via legislativa, com isso pretendendo depurar o mercado de práticas condenáveis e proporcionar proteção, preventiva e repressiva, ao consumidor". ${ }^{853}$

Por isso o dispositivo de regência considera que toda informação ou publicidade, suficientemente precisa, veiculada por qualquer forma ou meio de comunicação com relação a produtos e serviços oferecidos ou apresentados, obriga o fornecedor que a fizer veicular ou dela se utilizar e integra o contrato que vier a ser celebrado (CDC, art. 30).

${ }^{852}$ A proteção jurídica..., cit., p. 105. 
Pode-se dizer, então, que a oferta é um veículo de mensagens, integradas por informação e por publicidade, onde o fornecedor é o emissor e o consumidor é o receptor ${ }^{854}$. Atua como instrumento para assegurar maiores lealdade e veracidade nas informações fornecidas no mercado de consumo. ${ }^{855}$

Se na concepção tradicional a oferta já era criadora de vínculos, na do CDC este poder de vinculação - declaração negocial voltada ao consumo é ampliado ${ }^{856}$, até porque toda informação, mesmo em forma de publicidade, suficientemente precisa constitui uma oferta (uma proposta contratual), vinculando o fornecedor. $^{857}$

Pode-se dizer, assim, que ambas formam quase uma unidade semântica, atuando a publicidade como meio de comunicação e de divulgação da oferta. ${ }^{858}$

Para Cláudia Lima Marques, “o art. 30, ao ampliar a noção de oferta e ao afirmar que as informações dadas integram o futuro contrato, revoluciona a idéia de invitatio ad offerendum. Agora, qualquer informação ou publicidade veiculada que precisar, por exemplo, os elementos essenciais da compra e venda: res (objeto) e pretium (preço), será considerada como uma oferta vinculante, faltando apenas a aceitação (consensus) do consumidor ou consumidores em número indeterminado". 859

Essa opção legislativa decorreu da constatação de que “(...) nas relações massificadas do mercado capitalista, as ofertas já não se dirigiam a pessoas certas, mas ao público, fazendo com que os produtos chegassem a destinatários autônomos" ${ }^{\$ 60}$. O art. 30 do CDC tenta resolver o impasse, criando um novo regime legal para a oferta, generalizando como proposta contratual quase todas as manifestações, mesmo a publicidade, oriundas do fornecedor. Estas manifestações, uma vez vinculativas e obrigatórias para o profissional, passam a integrar o conteúdo do futuro contrato". ${ }^{861}$

Trata-se do princípio da vinculação.

\subsection{Princípio da vinculação}

\footnotetext{
${ }^{853}$ A proteção jurídica..., cit., p. 107.

${ }^{854}$ Luiz Antonio Rizzatto Nunes. Comentários ..., cit., p. 388.

${ }^{855}$ Cláudia Lima Marques. Contratos..., cit., p. 605.

${ }^{856}$ TJSP, AC 992.07.059462-6, rel. Antonio Maria, j. 20.04.2010.

${ }^{857}$ Cláudia Lima Marques. Contratos..., cit., p. 602.

${ }^{858}$ Adalberto Pasqualotto. Oferta e publicidade..., cit., p. 35.

${ }^{859}$ Contratos..., cit., p. 603.

${ }^{860}$ Adalberto Pasqualotto. Oferta e publicidade..., cit., p. 37.

${ }^{861}$ Cláudia Lima Marques. Contratos..., cit., p. 605/606.
} 
A preocupação de defesa do consumidor conduziu, igualmente, a um alargamento da noção de compra e venda privada, no quadro mais realista de uma economia de empresa. Passou-se, assim, a entender que os processos de publicidade comercial, pela sua importância decisiva no escoamento da produção por um consumo em massa, integravam o próprio mecanismo do contrato e deveriam, por conseguinte, merecer uma disciplina de ordem pública análoga às das estipulações contratuais. $^{862}$

Esse princípio, apesar de inserido na seção da oferta, aplicase igualmente à publicidade, ou seja, abrange todas as formas de manifestação do marketing. É a resposta que o direito dá ao relevante papel que este fenômeno assume na sociedade de consumo. ${ }^{863}$

Representa mais um mandamento de proteção da segurança e da harmonia social, pois impõe àqueles que utilizarem da publicidade riscos profissionais mais elevados, uma vez que visam ao lucro (direta ou indiretamente), uma vez que participam de sua atividade negocial (esfera de necessário controle do empresário) e atingem um número indeterminado, em grau ou não controlável, de pessoas (grupo a tutelar). ${ }^{864}$

E citando Johannes Köndgen, na sua Tese de Habilitação na Universidade de Tübingen ${ }^{865}$, prossegue Cláudia Lima Marques asseverando que, “(...) a atividade de comunicar-se por publicidade é uma opção do fornecedor (livre determinação), e que, por suas características de atividade profissional (risco próprio) e por seus importantes e irreversíveis efeitos na sociedade, faz nascer vínculos obrigacionais, tornando-se hoje de relevância jurídica indiscutível". 866

Oferecida a mensagem, por qualquer meio (CDC, art. $48^{867}$ ), fica o fornecedor a ela vinculado ${ }^{868}$, podendo o consumidor, inclusive, exigir seu

\footnotetext{
${ }^{862}$ Fábio Konder Comparato. A proteção do Consumidor: Importante Capítulo do Direito Econômico. Defesa do Consumidor - Textos Básicos, Brasília: MJ/CNDC, 1987.

${ }^{863}$ Antônio Herman de Vasconcellos e Benjamin et alii. Código Brasileiro de Defesa do Consumidor..., cit., p. 176 .

${ }^{864}$ Cláudia Lima Marques. Contratos..., cit., p. 609/610.

${ }^{865}$ Selbstbindung ohne Vertrag: zur Haftung aus geschätsbezogenem Handeln, Tübingen, Mohr, 1981.

${ }^{866}$ Contratos..., cit., p. 610.

${ }^{867}$ CDC, art. 48: "as declarações de vontade constantes de escritos particulares, recibos e pré-contratos relativos às relações de consumo, vinculam o fornecedor, ensejando inclusive execução específica, nos termos do art. 84 e parágrafos".
} 
cumprimento forçado, pois o caráter objetivo da oferta impede, via de regra, a retratação $^{869}$. É uma subordinação irresistível (verdadeiro estado de sujeição) que consiste na necessidade de suportar as consequências jurídicas da atuação do outro (consumidor) que titula um poder potestativo. ${ }^{870}$

A oferta é vinculativa por si só. O CDC, diferentemente, atribui direito, pretensão e ação ao consumidor desde que seja veiculada a oferta, ainda antes da formação do ajuste, sem necessidade de aceitação declarada; daí porque o fornecedor fica imediatamente adstrito ao dever de prestar, em congruência com a oferta que fez anunciar ${ }^{871}$, caracterizando prática abusiva típica a conduta de "recusar a venda de bens ou a prestação de serviços diretamente a quem se disponha a adquiri-los mediante pronto pagamento" (CDC, art. 39, IX).

É possível, contudo, a retratação, se veiculada da mesma forma (v.g., destaque), que a oferta; porém, seus efeitos serão ex nunc, ou seja, o fornecedor suportará a vinculação até que os consumidores em potencial sejam adequadamente informados da retratação.

2.2 Exclusão ou limitação da obrigatoriedade

Conferindo profundidade à análise da matéria sub examine, Silvio Luís Ferreira da Rocha elenca cinco hipóteses mitigadoras da força obrigatória da oferta: a) a interrupção do processo de formação; b) as reservas; c) o termo; d) o caso fortuito e a força maior; e) a falência do ofertante. ${ }^{872}$

A essas acrescente-se uma sexta: a diversidade entre o anunciante e o fornecedor.

\subsubsection{Interrupção do processo de formação}

Para o referido jurista, “(...) pode ocorrer a interrupção do processo de formação da oferta. Nessa hipótese, uma nova declaração de vontade do

\footnotetext{
${ }^{868}$ Segundo Newton de Lucca (A proteção..., cit., p. 81), “agora, com efeito, não poderá mais o fornecedor utilizar-se de uma desculpa qualquer para safar-se de sua vinculação contratual".

${ }^{869}$ Luiz Antonio Rizzatto Nunes. Comentários..., cit., p. 389.

${ }^{870}$ Cláudia Lima Marques. Contratos..., cit., p. 612.

${ }^{871}$ Adalberto Pasqualotto. Oferta e publicidade..., cit., p. 38/40.
} 
ofertante, contrária à primeira, impede a realização da oferta. O CDC não proibiu a interrupção do processo criador da oferta, hipótese distinta da revogação. É importante, nesse caso, definirmos o exato momento da realização da oferta. A oferta, declaração de vontade receptícia, deve ser comunicada à pessoa determinada ou indeterminada para produzir seus efeitos jurídicos" ${ }^{873}$

Observe-se: a declaração será eficaz pelo fato de o destinatário poder percebê-la, ainda que não o faça efetivamente ${ }^{874}$. A oferta pública tornase perfeita com sua divulgação ${ }^{875} \mathrm{e}$, por isso, inexiste vinculação se não houver exposição ${ }^{876}$. Ou, em outras palavras, a mensagem (oferta) deve ser oferecida ${ }^{877}$ : veiculada ou utilizada pelo fornecedor. ${ }^{878}$

Por este prisma, não se comunga do entendimento proposto, pois se a mensagem (informação ou publicidade) ainda está em processo de formação é porque não foi exposta; logo, de oferta não se trata. Caso haja exposição (e com isso a oferta propriamente dita), a obrigatoriedade ressai ex vi legis, deslocando-se a controvérsia para a possibilidade de aceitar-se a revogação ou o erro.

Cabe, agora, por oportuna, a distinção entre a oferta ao público (negócio bilateral receptício) e a promessa ao público (negócio unilateral) proposta por Adalberto Pasqualotto, no sentido de que na promessa “(...) a declaração é feita a todos (indeterminação inicial), mas se concretizará em alguém em particular (unus ex publico): a indeterminação é provisória. Na oferta ao público a indeterminação é definitiva, porque não visa a distinguir um entre o público, mas muitos e quantos se apresentarem como aceitantes, identificados ou interminados na massa". 879

${ }^{872}$ A oferta no Código de Defesa do Consumidor. São Paulo: Lemos Editorial, 1997, p. 105/124.

${ }^{873}$ Silvio Luís Ferreira da Rocha. A oferta..., cit., p. 105/106.

${ }^{874}$ Nicola Distaso. I contratti in generale. Torino: Unione tipográfico - editrice torinese (UTET), 1980, v. I, p. 409.

875 Silvio Luís Ferreira da Rocha. A oferta..., cit., p. 106.

${ }^{876}$ Antônio Herman Vasconcellos e Benjamin et alii. Código Brasileiro de Defesa do Consumidor..., $4^{\mathrm{a}}$ ed., cit., p. 177.

${ }^{877}$ Luiz Antonio Rizzatto Nunes. Comentários..., cit., p. 389.

${ }^{878}$ Arruda Alvim et alii. Código do Consumidor comentado..., cit., p. 189.

${ }^{879}$ Oferta e publicidade..., cit., p. 53. E prossegue: "a coletividade é considerada diferentemente na promessa e na oferta. Na promessa, a coletividade não é importante; na verdade é elemento perturbador da finalidade da promessa, porque o promitente pretende identificar quem, dentre os membros indefinidos da coletividade, poderá satisfazer o seu interesse. Na oferta, a coletividade é virtualmente a soma dos interesses do ofertante, porque ele se dirige a todos como potenciais aceitantes" (idem, p. 53/54). Isto porque: "a oferta é o fato que passou a ser valorado pelo direito para dar nascimento ao vínculo jurídico. A oferta (dirigida ao público) outorga aos consumidores em geral (na passagem do coletivo para o individual) o direito formativo (a cada um em particular) de adjudicação do crédito correspondente. E simultaneamente com o crédito vem a pretensão (a mesma simultaneidade que se verifica para o lesado nos atos ilícitos), permitindo a exigibilidade 


\subsubsection{Reservas}

Impende frisar que a teoria dos limites ou das reservas procurou compatibilizar a indeterminação dos destinatários (oferta ao público) com sua obrigatoriedade.

Salienta, neste pormenor, Silvio Luís Ferreira da Rocha que: “a reserva é uma restrição feita pelo ofertante e essa restrição pode estar relacionada a um ato de vontade do ofertante ou não. Na primeira hipótese temos a chamada reserva de consentimento, que autoriza o ofertante a não contratar com o aceitante com base no seu exclusivo arbítrio, subtraindo da oferta realizada toda sua obrigatoriedade. $\mathrm{Na}$ segunda hipótese, a restrição reporta-se a acontecimento que independe da vontade do ofertante, como, p.ex., o término dos estoques". 880

No que tange à reserva de consentimento - fundadas na vontade exclusiva do ofertante - a sistemática objetiva da Lei 8.078/90 arreda sua materialização, até porque assegura aos consumidores o direito básico da igualdade nas contratações $\left(\mathrm{CDC}\right.$, art. $\left.6^{\circ}, \mathrm{II}\right)$, considerando prática abusiva a recusa ao atendimento das demandas, na exata medida das disponibilidades de estoque do fornecedor (CDC, art. 39, II).

É, assim, mais uma projeção da isonomia constitucional (CF, art. $5^{\circ}$, caput), apenas com possibilidade de restritos discrímens.

Objeta, contudo, Silvio Luís Ferreira da Rocha afirmando que se admitem, (...) as chamadas reservas de consentimento tão somente nos contratos em que as qualidades morais e a capacidade econômica do consumidor sejam fundamentais para sua conclusão, como nos contratos de crédito. Nesse caso a conclusão do contrato não depende exclusivamente da concordância do ofertante, mas também de acontecimento que escapa à sua alçada, razão pela qual tal condição, classificada de simplesmente potestativa, é aceita pelo nosso ordenamento jurídico". 881

Data venia do ilustre professor, o crédito - serviço como outro qualquer $\left(\mathrm{CDC}\right.$, art. $\left.3^{\circ}, \S 2^{\circ}\right)$ - não reclama proteção especial do intérprete, até

imediata de cumprimento da oferta (com a necessária adaptação se a prestação do fornecedor for de cumprir a prazo)" (idem, 51/52).

${ }^{880}$ A oferta..., cit., p. 107. 
porque a lei nada nesse sentido lhe concede. É preciso acabar, de uma vez por todas, com esse pensamento submisso - fruto de um imperialismo econômico calcado numa suposta globalização - tendente a outorgar privilégios àqueles que exploram o mercado negociando crédito, tal qual estivessem eles à margem do império da lei.

Exemplifica-se: a título de suposição, apenas, cogite-se de uma empresa (aqui chamada de supercrédito) que, agressiva e ostensivamente em todo território nacional (publicidade veiculada de modo intenso nos mais variados meios de comunicação, inclusive em popular programa domingueiro de televisão), oferece crédito fácil ao consumidor sob o seguinte slogan: "está precisando de dinheiro, passa na supercrédito que dá. Basta sua carteira de identidade que a supercrédito dá”.

Ora, será possível admitir que o consumidor necessitado, mas portanto sua carteira de identidade - atraído pela publicidade intensa e ostensiva veiculada durante grande parte do domingo, quase sempre dia de descanso semanal do trabalho - seja discriminado pela fornecedora no momento de contrair o mútuo com base em elemento não integrante da oferta (v.g., negativação na serasa, título protestado, etc.)?

Há de ser negativa a resposta.

Quanto às reservas tácitas (segunda hipótese), sem embargo da sólida estrutura construída pela doutrina civilista tradicional, sua aceitação pode comprometer a proteção jurídica do consumidor, pois ele nunca saberá, efetivamente, se está sendo enganado. Veja-se: oferta de produto implicitamente vinculada ao número de unidades existente no estoque.

É possível a utilização desse procedimento como manto protetor de conhecida prática abusiva: anunciam-se produtos (que o fornecedor já sabe serem poucos em quantidade) a preços bem menores que os praticados no mercado e, com isso, os consumidores são atraídos ao comércio e, à míngua de suficiência do estoque para atender a demanda gerada pela oferta, acabam adquirindo outros, similares, porém mais caros.

Precisa, aqui, a conclusão de Silvio Luís Ferreira da Rocha no sentido de que, “(...) os princípios da transparência e da boa-fé exigem da oferta ao público a expressa menção da quantidade dos bens em estoque. Não se admite a reserva tácita do término dos estoques. E mais: o número de bens em estoque, indicados na oferta,

${ }^{881}$ A oferta..., cit., p. 111. 
deve ser compatível com o meio escolhido para a divulgação da proposta, sob pena de caracterizar a intenção do fornecedor de apenas atrair os consumidores ao seu estabelecimento, cometendo prática comercial abusiva, e não de realizar uma oferta ao público". 882

In casu, a obrigatoriedade estaria mitigada apenas com a correta e a precisa informação acerca do número das unidades disponíveis para aquisição na forma anunciada, caso contrário (na omissão) restará configurada prática abusiva e o fornecedor estará obrigado a cumprir a oferta, mesmo sem estoque suficiente.

\subsubsection{Termo}

A oferta será obrigatória para o fornecedor durante o tempo nela fixado, que, evidentemente, deve estar claro e preciso aos olhos quase sempre desatentos do consumidor.

Todavia, o silêncio do anúncio não implica numa vinculação perpétua do fornecedor ao cumprimento da oferta, o que seria, por certo, contrário ao equilíbrio e à harmonia estimulados pelo CDC.

Força é concluir, portanto, que a força obrigatória da oferta estará, se omissa quanto ao seu temo, subordinada a um prazo razoável, assim entendido de acordo com as particularidades do caso concreto e do produto ou do serviço proposto.

Incide, por analogia, o comando insculpido no art. 32, par. ún., da Lei 8.078/90. ${ }^{883}$

Nesse sentido pontifica Walter Ceneviva:

“É, pois, adequado, resolver o problema exegético através da aplicação extensiva do art. 32, parágrafo único, do CDC que estende a validade da oferta 'por período razoável de tempo, na forma da lei', salvo se ela for expressamente limitada pelo fornecedor.

Período razoável de tempo é aquele no qual - feita a oferta ou publicado o anúncio - decorra o prazo ou seja satisfeito o termo, sendo a

\footnotetext{
${ }^{882}$ A oferta..., cit., p. 113/114.

${ }^{883}$ CDC, art. 32: "os fabricantes e importadores deverão assegurar a oferta de componentes e peças de reposição enquanto não cessar a fabricação ou importação do produto". Par. ún.: "cessadas a produção ou importação, a oferta deverá ser mantida por período razoável de tempo, na forma da lei”.
} 
razoabilidade referente ao produto ou serviço, aos usos e costumes ou a eventuais determinações legais a respeito de qualidades e característicos exigidos." $\$ 84$

\subsubsection{Caso Fortuito e força maior}

Segundo a doutrina de Silvio Luís Ferreira da Rocha, “o Código de Defesa do Consumidor, ao tratar do instituto da oferta, não instituiu a responsabilidade objetiva do ofertante, obrigando-o a cumprir com a oferta, mesmo demonstrada a inevitabilidade do evento responsável pelo inadimplemento. O ofertante, nas situações em que a impossibilidade absoluta do cumprimento da oferta não foi causada por culpa sua, ou então, resulte de caso fortuito ou força maior, está exonerado do dever de cumpri-la". 885

Entretanto, diverge-se em parte da linha sugerida, pois todo o sistema protetivo instituído pela Lei 8.078/90 é informado pela teoria do risco proveito (infra, Cap. VI, 2.3.2) e, por isso, o fornecedor quando ingressa (atua) no mercado de consumo assume, e de modo absoluto, toda a responsabilidade inerente à exploração lucrativa que se propõe.

Irrelevantes, assim, como ocorre no sistema de responsabilidade civil, o caso fortuito e a força maior internos (ínsitos ao empreendimento), mormente se excluídos da oferta.

É essa a postura do STJ, “quando o fornecedor faz constar de oferta ou mensagem publicitária a notável pontualidade e eficiência de seus serviços de entrega, assume os eventuais riscos de sua atividade, inclusive o chamado risco aéreo, com cuja consequência não deve arcar o consumidor" 886

De outra banda, se absolutamente externos, ou seja, alheios à atividade produtiva do fornecedor, o caso fortuito e a força maior, de modo excepcional, serão aptos a desconstituir o nexo de causalidade, visto que não houve assunção de risco dessa categoria quando da veiculação da oferta.

\subsubsection{Falência do ofertante}

\footnotetext{
${ }^{884}$ Publicidade e Direito do Consumidor. São Paulo: RT, 1991, p. 57.

${ }^{885}$ A oferta..., cit., p. 118/119.

${ }^{886}$ REsp. 196.031/MG, rel. Min. Antônio de Pádua Ribeiro, j. 24.04.2001.
} 
Basicamente, essa hipótese reside em se dirimir a controvérsia entre os art. 117 da Lei $11.111 / 05^{887}$ e 35, I, da Lei 8.078/90, se e quando declarada a falência do fornecedor.

O primeiro confere ao administrador judicial a faculdade de analisar a conveniência, ou não, do cumprimento dos contratos bilaterais celebrados antes da quebra; enquanto o segundo, como se verá (infra, 2.5), permite ao consumidor exigir compulsoriamente a realização da oferta.

Sem dúvida alguma prevalece o $\mathrm{CDC}$, lei principiológica (supra, Cap. II, 1), essência a prevalecer no conflito de normas, que traz uma proteção específica para esse sujeito especial, que não pode - sendo ainda possível a prestação - ser relegado a uma indenização representativa de crédito quirografário.

Precisa, neste ponto, em que pese à nova sistemática falimentar, a observação de Silvio Luís Ferreira da Rocha, para quem, “(...) a criação do direito do consumidor e a incidência das regras protetivas do direito do consumidor nos chamados atos de consumo subtraiu do campo de ação do direito comercial um número indeterminado de atos jurídicos. Os atos de consumo passaram a ser regrados pelo direito do consumidor e não mais pelas normas do direito civil ou comercial. Neste caso, na hipótese de ocorrer a falência do ofertante, devem ser aplicadas às ofertas até então realizadas as regras do Código de Defesa do Consumidor, que também são de ordem pública, não se reconhecendo ao síndico a faculdade de descumprir a oferta anunciada pelo falido e aceita pelo consumidor", 888

\subsubsection{Diversidade entre o anunciante e o fornecedor}

Cogite-se de uma grande indústria de cerveja, "a $n^{\circ} 1$ ", que numa manobra extremamente agressiva lança promoção inédita no mercado de consumo

\footnotetext{
${ }^{887}$ LF, art. 117: “os contratos bilaterais não se resolvem pela falência e podem ser cumpridos pelo administrador judicial se o cumprimento reduzir ou evitar o aumento do passivo da massa falida ou for necessário à manutenção e preservação de seus ativos, mediante autorização do Comitê. $\S 1^{0} \mathrm{O}$ contratante pode interpelar o administrador judicial, no prazo de até 90 (noventa) dias, contado da assinatura do termo de sua nomeação, para que, dentro de 10 (dez) dias, declare se cumpre ou não o contrato. $\S 2^{\underline{0}}$ A declaração negativa ou o silêncio do administrador judicial confere ao contraente o direito à indenização, cujo valor, apurado em processo ordinário, constituirá crédito quirografário".

${ }^{888}$ A oferta..., cit., p. 124.
} 
oferecendo seu produto no varejo, em garrafas, ao preço de $\mathrm{R} \$ 0,50$ a unidade. $\mathrm{O}$ pequeno comerciante (v.g., dono de um modesto botequim), que em nada contribuiu nesse processo e que pagou os valores antigos ao seu fornecedor, estará obrigado a atender a demanda nessas bases?

Quadra ressaltar que, como regra, o terceiro - assim considerado aquele que não participou da elaboração ou da veiculação do anúncio - não pode ser obrigado a cumprir a oferta.

Entretanto, persiste a vinculação se o terceiro mantém com o anunciante vínculo jurídico obrigando esse cumprimento (v.g., contrato de franquia ou de distribuição exclusiva) ou se de alguma maneira (v.g., captação de clientela, venda de outros produtos ou serviços, etc.) obtiver proveito da atividade promocional anunciada.

Essa última é a situação daquele pequeno comerciante (dono do botequim); logo, sofrerá os efeitos vinculantes da oferta, assegurado o direito de regresso que o sistema jurídico autorizar.

Adalberto Pasqualotto, sobre o tema, assevera que, "os efeitos da oferta, no CDC, não se cingem aos eventuais figurantes do contrato. A amplitude do seu conceito alcança também os que dela se beneficiam, como os concessionários, revendedores, franqueados etc., impondo a obrigatoriedade de cumprir o que foi comunicado publicamente pelo fabricante, pelo importador ou por qualquer outro agente econômico que tenha veiculado mensagem de promoção de venda, embora o contrato venha a ser realizado por terceiro integrante da mesma cadeia de fornecimento. A extensão dos efeitos da oferta a todos os elos econômicos da cadeia de fornecimento realiza a função social da proteção ao consumidor na sociedade de consumo". 889

\subsection{Erro na oferta}

Cumpre assentar que o CDC reduziu a importância da vontade na formação dos contratos e concentrou-se na proteção jurídica dos seus efeitos objetivos, pois o direito deve visar antes à certeza do que à verdade e, com isso, empresta

\footnotetext{
${ }^{889}$ Oferta e publicidade..., cit., p. 50/51.
} 
valor à aparência da vontade, se não é destruída por circunstâncias que indiquem má-fé do destinatário (aquele que supostamente acreditou ser verdadeira). ${ }^{890}$

Pontifica a respeito a professora Cláudia Lima Marques:

“(...) Segundo essa nova espécie da teoria da declaração, havendo divergência (provada) entre a vontade interna e a vontade declarada, prevalece em princípio a vontade declarada, se (e na medida) em que despertou a confiança. Em outras palavras, na medida em que criou expectativas legítimas no outro contratante, na população atingida pela declaração (standard objetivo), a vontade declarada prevalecerá, porém, se o outro contratante sabia ou podia saber razoavelmente no mesmo momento da declaração que aquela não era a vontade interna de seu parceiro, poderá a declaração ser anulada. Procura-se assim, um equilíbrio entre os valores envolvidos e as dificuldades de prova, preservando prioritariamente a segurança das relações, mas também combatendo a (eventual) má-fé subjetiva.

\section{$(\ldots)$}

A confiança serve assim a esta teoria como um parâmetro, um dado objetivo, que uma vez atingido traz a impossibilidade de anular-se por erro a declaração já veiculada; enquanto que a possibilidade de anulação da declaração serve de exceção justa, a ser permitida somente quando a declaração foi tal que (objetivamente) não despertou a confiança no homem médio ou quando, individualmente, aquele consumidor tiver consciência, no momento da declaração, que ela não era a vontade do fornecedor (logo, a declaração nunca pode despertar a confiança subjetiva daquele indivíduo)." 891

Para Luiz Antonio Rizzatto Nunes:

“(...) é de se aceitar o erro como escusa do cumprimento da oferta, se a mensagem, ela própria, deixar patente o erro, pois caso contrário o fornecedor sempre poderia alegar que agiu em erro para negar-se a cumprir a oferta.

\section{(...)}

Conforme já se colocou ao analisar o inciso III do art. $4^{\circ} \mathrm{e}$ ainda se fará quando do exame da proteção contratual (arts. 46 e s.), dois dos

${ }^{890}$ Silvio Luís Ferreira da Rocha. A oferta..., cit., p. 161/162. 
princípios sobre os quais está fundada a relação jurídica de consumo são a boa-fé e o equilíbrio. Eles são pressupostos de toda relação estabelecida. Seria impossível propugnar por uma relação jurídica, como a do exemplo da oferta da TV por apenas R \$ 5,00, na qual o bom senso não imperasse e se quisesse fundá-la nos princípios da boa-fé e do equilíbrio." 892

Trata-se da teoria da confiança, fundada na aparência de seriedade da oferta (erro despercebido), onde será observada a boa-fé objetiva (regra de conduta) do consumidor (aceitante), sem comprometer a análise de seu elemento subjetivo (má-fé) no caso concreto.

Tome-se como exemplo um anúncio de uma concessionária, amplamente divulgado em horário nobre da televisão, dirigido à venda de automóveis BMW, ano 2011 e zero quilômetro, pelo menor preço do mercado: R \$ 7.000,00 (sete mil reais).

Essa oferta é evidentemente falha (critério objetivo), e contraria qualquer padrão regular e usual de preço em negócios análogos; logo, viável a recusa do fornecedor em cumpri-la, sob pena de violação dos princípios do equilíbrio e da harmonia nas relações de mercado. $\mathrm{O}$ consumidor que exigir seu cumprimento terá conduta dissociada do padrão esperado (boa-fé objetiva), circunstância indicativa de nítida má-fé (elemento subjetivo) tendente ao proveito sem causa ${ }^{893}$. Sua confiança não pode ter sido despertada por um negócio dessa natureza.

De qualquer forma, a escusa fundada no erro é excepcional e sempre objetiva para o fornecedor, sendo irrelevante se causado pela atuação determinante de terceiro (v.g., empresa de publicidade, anunciante, empregado, etc.), pois, tratando-se de risco profissional (responsabilidade própria), terá o fornecedor de suportar sua falha e

${ }^{891}$ Contratos..., cit., p. 630/631.

${ }^{892}$ Comentários..., cit., pág. 389/390.

893 "CIVIL. CONSUMIDOR. PUBLICIDADE. PÁGINA ELETRÔNICA. VINCULAÇÃO. VEÍCULO. PREÇO MANIFESTAMENTE IRRISÓRIO. BOA FÉ OBJETIVA. VIOLAÇÃO. ENRIQUECIMENTO ILÍCITO. INADMISSIBILIDADE. I. o princípio da vinculação não pode ser invocado para, em atenção aos preceitos da boa-fé e cooperação, retirar de publicidade manifestamente equivocada, proveito econômico indevido ao consumidor, sob pena de converter-se em fonte de enriquecimento ilícito, o que é dedado no Direito Civil brasileiro. II. Anúncio disponibilizado no endereço eletrônico da ré, consistente na oferta de um automóvel pelo irrisório valor de vinte e dois reais, constitui manifesto erro material e não vincula o fornecedor, sendo perceptível por qualquer pessoa de diligência primária. III. Se não há publicidade abusiva ou enganosa, mas erro material, não prospera a pretensão de compelir o fornecedor ao cumprimento forçado da obrigação, sob pena de enriquecimento ilícito, razão pela qual o pedido devia mesmo ser julgado improcedente. IV. Negou-se provimento ao recurso" (TJDFT, AC 20080310024195APC, rel. José Divino de Oliveira, j. 18.11.2009). 
responderá pela informação mal transmitida, seja pelo inadimplemento contratual seja pelo ato ilícito eventualmente dela resultante. ${ }^{894}$

Basta a publicidade, externada de modo soberano e profissional pelo fornecedor e sob o risco da sua atuação no mercado (tem o dever de conhecer o que oferece e fornece ao público), em caso de falha, erro, ou culpa de terceiro da cadeia organizada ou contratada (fornecedores-auxiliares). Contudo, o fornecedor responsável pela falha tem direito de regresso contra seu auxiliar que efetivamente cometeu o erro. $^{895}$

Em hipótese análoga o extinto $1^{\mathrm{o}} \mathrm{TacCiv} / \mathrm{SP}$ decidiu que, "não se trata de erigir o consumidor em ditador das relações de consumo. O que o legislador procurou foi fornecer meios jurídicos mais eficazes àqueles que, em tese, são economicamente mais fracos, os consumidores. Cabe ao fornecedor produzir com responsabilidade. Atentar para a perfeição de seus serviços. Se a apelante contratou e orientou mal seu preposto, que honre o compromisso social que tem com o consumidor, resolvendo a pendenga contra quem, em tese, lhe teria trazido prejuízos. Não se pode carrear essa questão interna corporis para a relação de consumo. Se o fornecedor teve prejuízos com ato de seu preposto, que atinja padrão de excelência nos futuros negócios para ele mesmo não se desacreditar no mercado. Olvida-se o apelante que o comércio sobrevive da fidúcia". 896

Protege-se, como visto, a confiança e a legítima expectativa depositadas pelo consumidor na oferta, respondendo perante ele o fornecedor e seus prepostos (representantes) solidariamente (CDC, art. $34^{897}$ ).

Liberado do cumprimento, mesmo assim haverá para o fornecedor, em tese, o dever de recompor o statu quo ante por força da teoria do interesse negativo, ou seja, hão de ser ressarcidas, no mínimo, as despesas geradas pelo deslocamento inútil do consumidor.

\subsection{Informação e seus caracteres}

\footnotetext{
${ }^{894}$ Cláudia Lima Marques. Contratos..., cit., p. 629.

${ }^{895}$ Cláudia Lima Marques. Contratos..., cit., p. 629/630.

${ }^{896}$ Ap. 562.425-3, rel. Silvio Venosa, j. 06.07.1994.

${ }^{897}$ CDC, art. 34: “o fornecedor do produto ou serviço é solidariamente responsável pelos atos de seus prepostos ou representantes autônomos".
} 
Como um dos reflexos da transparência (supra, Cap. III, 4.1), ressai o dever de informar imposto ao fornecedor pela Lei 8.078/90, que, inicialmente, concentra-se nas características do produto ou do serviço oferecido no mercado de consumo. $^{898}$

Não é qualquer informação que vincula o fornecedor, mister se faz a precisão $\left(\mathrm{CDC}\right.$, art. $\left.31^{899}\right)$. Dispensa-se a essência absoluta, mas não pode gerar dúvida no íntimo do destinatário. A Lei 8.078/90 se contenta com uma precisão suficiente (descrever o bem e indicar o preço). Essa precisão mínima há de conter um potencial persuasivo, afastando-se do simples exagero. ${ }^{900}$

Força é concluir que o objeto dessa informação é o próprio produto ou serviço que realmente está sendo oferecido, esclarecendo sua finalidade com todos os dados necessários para seu efetivo uso e consumo, diminuindo ao máximo o risco à saúde e/ou à segurança do consumidor. E essa obrigação é exclusiva do fornecedor, titular do indeclinável dever de informar. ${ }^{901}$

Como uma luva cabe à espécie a síntese elaborada pelo insigne mestre Arruda Alvim:

“Todavia, revela notar, como de especial importância, nessa oportunidade, que não se faz essencial que toda a publicidade veiculada, de qualquer modo, aos consumidores, seja assim precisa, específica e completa. O que determina o Código do Consumidor é que, sendo ela precisa, nos termos do previsto no artigo 30, passa a ser considerada como oferta e esta vincula o ofertante, que deverá dar cumprimento à mesma, sob pena de incidência do artigo 35, do Código do Consumidor.

Este artigo 31 estabelece que a oferta e a apresentação devem ser 'precisas', (na forma do artigo 30), e, para isto é necessário sejam seguidas as especificações nele elencadas, a fim de que o consumidor possa, por esse meio, já ter conhecimento do objeto de consumo e suas características." 902

\footnotetext{
${ }^{898}$ Cláudia Lima Marques. Contratos..., cit., p. 646.

${ }^{899}$ CDC, art. 31: "a oferta e apresentação de produtos ou serviços devem assegurar informações corretas, claras, precisas, ostensivas e em língua portuguesa sobre suas características, qualidade, quantidade, composição, preço, garantia, prazos de validade e origem, entre outros dados, bem como sobre os riscos que apresentam à saúde e segurança dos consumidores".

${ }^{900}$ Antônio Herman de Vasconcellos e Benjamin et alii. Código Brasileiro de Defesa do Consumidor..., $4^{\mathrm{a}}$ ed., cit., p. 177.

${ }^{901}$ Luiz Antonio Rizzatto Nunes. Comentários..., cit., p. 397.

902 Et alii. Código do Consumidor comentado..., cit., p. 191/192.
} 
Apesar de meramente exemplificativo o rol de características destacado pela norma de regência (uso da expressão entre outros dados) ${ }^{903}$ - até porque deflui da natureza das coisas que muitos produtos e serviços ofertados não comportam especificação de todas as características enumeradas por esse artigo, por não lhes serem próprias ou por exigirem maiores esclarecimentos ${ }^{904}$-, sem uma informação útil e completa, o consumidor não pode fazer uma escolha livre. ${ }^{905}$

Para o Min. e coautor do anteprojeto da Lei 8.078/90, Antônio Herman de Vasconcellos e Benjamin:

"Não é qualquer modalidade informativa que se presta para atender os ditames do Código. A informação deve ser correta (verdadeira), clara (de fácil entendimento), precisa (sem prolixidade), ostensiva (de fácil percepção) e em língua portuguesa.

\section{(...)}

Os dados objeto do dever de informar são os mais variados, dependendo sempre do produto ou serviço oferecido. De qualquer modo, o Código fixa, de plano, algumas informações que, necessariamente, devem constar de produtos ou serviços: características (produtos e serviços), qualidades (produtos e serviços), quantidade (de regra só produto), composição (mais para produtos do que para serviços), preço (produto e serviços), garantia (produto e serviços), prazos de validade (produtos e serviços), origem (mais para produtos) e riscos (produtos e serviços).

Há, entretanto, um amálgama: a língua portuguesa.

Prossegue, neste pormenor, o referido jurista:

“As informações prestadas devem ser apresentadas em língua portuguesa. Em alguns casos, quando absolutamente inexistente similar na nossa língua, o fornecedor pode utilizar a palavra estrangeira, explicando-a, contudo, sempre que necessário.

\section{(...)}

\footnotetext{
${ }^{903}$ Luiz Antonio Rizzatto Nunes. Comentários..., cit., p. 396; Cláudia Lima Marques. Contratos..., cit., p. 648; e Antônio Herman de Vasconcellos e Benjamin et alii. Código Brasileiro de Defesa do Consumidor..., $4^{\text {a }}$ ed., cit., p. 180 .

${ }^{904}$ Arruda Alvim et alii. Código do Consumidor comentado..., cit., p. 191.

905 Antônio Herman de Vasconcellos e Benjamin et alii. Código Brasileiro de Defesa do Consumidor..., cit., $4^{\mathrm{a}}$ ed., p. 179.

${ }^{906}$ Idem, p. 180 e 182.
} 
A regra aplica-se também aos bens importados. Afinal, não faria sentido criar mais uma hipótese de concorrência desleal entre os fornecedores nacionais e os estrangeiros. O Código, realmente, não faz qualquer distinção entre bens brasileiros e bens importados. As normas, em particular as de informação e segurança, têm por referencial o consumidor, sendo irrelevante o origem do bem." $" 907$

E na leitura de Luiz Antonio Rizzatto Nunes, "talvez se explique que a norma em comento o tenha feito por ter percebido a invasão do País por produtos importados, vendidos sem a necessária tradução e para impedir que se pudesse construir uma teoria às avessas sobre imperialismo e globalização, de forma a dizer que é o consumidor brasileiro que tem de aprender a traduzir e não o fornecedor que deve informálo em português!"908

Tal realidade, por sua vez, não inviabiliza use o fornecedor, excepcionalmente, termo estrangeiro, dês que incorporado à linguagem nacional (v.g., hotdog, flat, etc.) e, assim, possa ser entendido e compreendido em toda a sua extensão e significado pelo consumidor.

À regra geral somam-se os comandos específicos destinados à proteção à saúde e à segurança do consumidor (CDC, arts. $8^{\circ}, 9^{\circ}$ e 10).

Ressalta a professora Cláudia Lima Marques:

"No caso de produtos perigosos ou que possam trazer algum risco à saúde e à segurança do consumidor, o dever geral de informar sobre as características do produto, instituído pelo art. 31, é complementado pelo dever de informar ostensiva e adequadamente a respeito da nocividade ou periculosidade do produto, como dispõe o art. $9^{\circ}$ do CDC.

\section{(...)}

$\mathrm{O}$ art. 10 do CDC impõe também ao fornecedor um típico dever de vigilância, qual seja o dever do fornecedor do produto, cuja periculosidade afora descoberta, de informar à população e às autoridades competentes. O dever de informar dos consumidores sobre 'a periculosidade e nocividade' que se descobriu em um produto ou serviço colocado no mercado (art. $6^{\circ}$, III, c/c art. 8 e art. $10, \S 1^{\circ}$, do CDC) e o consequente dever de retirar,

${ }^{907}$ Idem, p. 181. 
trocar ou consertar este produto ou serviço de forma a prevenir danos aos consumidores é denominado recall, que foi agora regulamentado pelo Ministério da Justiça (Portaria 789909, de 24.08.2001)." ${ }^{910}$

Enseja, ainda, uma das vertentes do recall (supra, Cap. III, 3.1), atuando como forma de autocontrole de qualidade e de segurança realizado pelo fornecedor.

\subsection{Descumprimento e opções}

De fato, o comando do art. 31 da Lei 8.078/90 concretiza todo o princípio da informação em benefício do consumidor; logo, o descumprimento de suas bases pelo fornecedor não é suficiente para reduzir a oferta à condição de mero convite ao contrato.

Explica-se: a parceria entre o direito e a comunicação mercadológica com o consumidor evoluiu de uma proteção pré-contratual (frágil) para uma tutela (efetiva) na fase da formação do contrato e, a partir desta, para um regime especial de execução do documento contratual. ${ }^{911}$

Por isso a lei assegurou (CDC, art. 35), no caso de recusa do cumprimento da oferta, da apresentação ou da publicidade, à livre escolha do consumidor, três opções: a) exigir o cumprimento forçado da obrigação (I); b) aceitar outro produto ou prestação de serviço equivalente (II) e c) rescindir o contrato, com direito à restituição de quantia eventualmente antecipada, monetariamente atualizada, e perdas e danos (III).

Está claro que não pode haver recusa, isto é, o que a lei pretende de modo imediato é proibir que o fornecedor se recuse a cumprir a oferta, a apresentação e/ou a publicidade ${ }^{912}$. Quanto às duas últimas (apresentação e publicidade), dês que consubstanciem oferta. ${ }^{913}$

Conclui-se, portanto, que o novo sistema proibiu a livre revogação ou a retratação da oferta pelo fornecedor, rejeitando a idéia da impossibilidade

\footnotetext{
${ }^{908}$ Comentários..., cit., p. 401.

${ }^{909}$ Texto completo na Revista de Direito do Consumidor, v. 40, p. 298/300.

${ }^{910}$ Contratos..., cit., p. 649 e 652.

911 Antônio Herman Vasconcellos e Benjamin et alii. Código Brasileiro de Defesa do Consumidor..., $4^{\mathrm{a}}$ ed., cit., p. 187.

${ }_{912}^{9}$ Luiz Antonio Rizzatto Nunes. Comentários ..., cit., p. 414.

${ }^{913}$ Arruda Alvim et alii. Código do Consumidor comentado..., cit., p. 201.
} 
de o contrato poder formar-se contra a vontade de uma das partes. Evidenciado, pois, o caráter obrigatório e irrevogável da oferta. ${ }^{914}$

Protege-se o consumidor, que poderá livremente, com exclusividade de direito e sem justificativa ou explicação, optar pela hipótese mais atrativa e conveniente: exigir, aceitar ou rescindir.

Basta um querer objetivo. ${ }^{915}$

Quanto à possibilidade de se exigir o cumprimento forçado da oferta (I), tem-se que o fornecedor se encontra verdadeiramente obrigado a contratar até porque existe o direito básico que assegura a igualdade nas contratações (CDC, art. $6^{\circ}$, II) - nos termos da oferta, mesmo se feita a um público indeterminado, sob pena de restar caracterizada prática abusiva (CDC, art. 39, II).

Aqui ganha especial relevo o instrumento da execução (ou tutela) específica (CDC, art. $84^{916}$ ), pois fatalmente o exercício dessa prerrogativa levará o consumidor a um processo judicial. ${ }^{917}$

É também possível aceitar outro produto ou serviço equivalente (II), assegurando-se ao consumidor, se for do seu interesse, alcançar a prestação contratual $^{918}$, não pela entrega do seu objeto originário, mas de outro que também atenda às necessidades anteriormente buscadas, ou simplesmente ao seu desejo atual.

Viável ao consumidor, ainda, rescindir o contrato, com direito à restituição de quantia eventualmente antecipada e perdas e danos (III). Observese, desde já, que a oferta integra o contrato (CDC, art. 30), que estará concretizado com a simples aquiescência do seu destinatário. É por isso que a recusa do fornecedor enseja a resolução contratual. ${ }^{919}$

\footnotetext{
${ }^{914}$ Silvio Luís Ferreira da Rocha. A oferta..., cit., p. 134.

${ }^{915}$ Luiz Antonio Rizzatto Nunes. Comentários..., cit., p. 414/415. No mesmo sentido: Silvio Luís Ferreira da Rocha. A oferta..., cit., p. 144.

${ }^{916}$ CDC, art. 84, caput: "na ação que tenha por objeto o cumprimento da obrigação de fazer ou não fazer, o juiz concederá a tutela específica da obrigação ou determinará providências que assegurem o resultado prático equivalente ao do adimplemento".

${ }_{917}$ Luiz Antonio Rizzatto Nunes. Comentários ..., cit., p. 415.

918 Cláudia Lima Marques. Contratos..., cit., p. 644.

${ }^{919}$ Luiz Antonio Rizzatto Nunes. Comentários..., cit., p. 417.
} 
Ao rigor desse raciocínio, só resta ao fornecedor brasileiro limitar a sua oferta ao estoque, ao que ele pode efetivamente cumprir, ao preço que pretende, cuidando para veicular somente informações corretas e que possa adimplir. ${ }^{920}$

Por fim, em que pese à abusividade da cláusula que autorize o fornecedor a cancelar o contrato unilateralmente (CDC, art. 51, XI), não basta a singela previsão de igual direito em benefício da outra parte, há de se garantir e respeitar a escolha consumidor (CDC, arts. $51, \S 2^{\circ}$, c.c. $\left.54, \S 2^{\circ}\right)$, ainda que a opção seja pela continuidade do vínculo (CDC, art. 35, I e II).

É direito exclusivo do consumidor dar ou não fim ao contrato. $^{921}$

\subsection{Contratos de adesão}

Em princípio, cumpre ressaltar que a Lei 8.078/90 não restringe o conceito de contrato de adesão às fórmulas escritas do estipulante. Ao contrário, o elemento formador do conceito é a estipulação unilateral prévia pelo fornecedor, o que também alcança os vínculos aperfeiçoados verbalmente ${ }^{922}$, assim como as cláusulas gerais afixadas em cartazes ou similares ${ }^{923}$. Ou seja, apesar de se dirigirem primordialmente aos contratos escritos, essas regras, sem exceção, aplicam-se a todo tipo de contrato, seja escrito seja verbal. $^{924}$

Define o CDC o contrato de adesão como aquele cujas cláusulas tenham sido aprovadas pela autoridade competente ou estabelecidas unilateralmente pelo fornecedor de produtos ou serviços, sem que o consumidor possa discutir ou modificar substancialmente seu conteúdo (art. 54).

Prima facie, a inserção de cláusula no formulário (específica de uma particular relação de consumo) não desfigura a natureza adesiva do ajuste (CDC, art. 54, $\S 1^{\circ}$ ); e quanto à transparência, os escritos hão de ser redigidos em termos claros, com o mínimo possível de linguagem técnica, e com caracteres ostensivos (não miúdos) e legíveis (não apagados ou adequadamente manuscritos), de modo a facilitar sua imediata e

\footnotetext{
${ }^{920}$ Cláudia Lima Marques. Contratos..., cit., p. 644.

${ }^{921}$ Luiz Antonio Rizzatto Nunes. Comentários ..., cit., p. 635.

${ }^{922}$ Nelson Nery Júnior et alii. Código Brasileiro de Defesa do Consumidor..., cit., p. 384.

${ }^{923}$ Cláudia Lima Marques. Contratos..., cit., p. 670.

${ }^{924}$ Luiz Antonio Rizzatto Nunes. Comentários..., cit., p. 640.
} 
fácil compreensão $\left(\mathrm{CDC}\right.$, art. 54, § $\left.3^{\circ}\right)$, além do necessário destaque - a ser aferido claramente no contexto - se implicarem limitação de direito do consumidor (CDC, art. 54, $\S 4^{\circ}$ ), sendo irrelevante a origem pública da estipulação ou a prévia aprovação por autoridade competente (condições gerais).

Salienta, a propósito, o professor Luiz Antonio Rizzatto Nunes a ratio desses dispositivos: "o que vale é o telos legal: o contrato está caracterizado pelo conteúdo e forma de estipulação e não por estar impresso de tal ou qual maneira; quer seja pré-impresso, com espaços a serem preenchidos ou feito integralmente no microcomputador, ainda assim é contrato de adesão"925, o que esvazia a controvérsia jurídica sobre uma possível distinção entre os conceitos de contratos de adesão e por adesão, este reservado às hipóteses de monopólio do fornecimento.

Exige-se, com isso, que ao consumidor seja viável tomar conhecimento do conteúdo do contrato pela simples leitura (realce físico), sem prejuízo do inerente dever de esclarecimento (CDC, art. 46) ${ }^{926}$. Todavia, tal dever de destaque não exime o fornecedor do controle judicial do conteúdo do contrato. ${ }^{927}$

Colorido próprio ganha a informação neste particular.

É por isso que a obscuridade das cláusulas é interpretada contra o estipulante ou disponente ${ }^{928}$ (CDC, art. $47^{929}$ ), pois se presume que o fornecedor tem em suas mãos meios técnicos suficientes para conferir ao contrato uma redação clara e sem ambiguidades. ${ }^{930}$

Idêntica solução adota-se caso exista divergência entre a oferta e o contrato efetivamente celebrado ${ }^{931}$, porquanto a primeira integra o segundo; logo, forte na principiologia normativa até aqui estudada, há de prevalecer a disposição que melhor atenda aos interesses do consumidor. ${ }^{932}$

\footnotetext{
925 Comentários..., cit., p. 634/635. No mesmo sentido Arruda Alvim et alii. Código do Consumidor comentado..., cit., p. 264.

${ }^{926}$ Nelson Nery Júnior et alii. Código Brasileiro de Defesa do Consumidor..., cit., p. 384 e 385/386.

${ }^{927}$ Cláudia Lima Marques. Contratos..., cit., p. 669.

${ }_{928}$ João Batista de Almeida. A proteção jurídica..., cit., p. 156.

${ }^{929}$ CDC, art. 47: "as cláusulas contratuais serão interpretadas de maneira mais favorável ao consumidor".

${ }^{930}$ Arruda Alvim et alii. Código do Consumidor comentado..., cit., p. 267.

${ }^{931}$ TJSP, AC 992.05.008046-5, rel. Ricardo Pessoa de Mello Belli, j. 23.03.2010.

932 TJSP, AC 994.07.118338-0, rel. Sebastião Carlos Garcia, j. 27.05.2010.
} 


\section{PUBLICIDADE}

A publicidade e a oferta, tal qual acima exposto (supra, 2), caminham lado a lado na disciplina jurídica do CDC, ambas são - em conjunto com as práticas abusivas (supra, Cap. III, 3.2.1) - algumas das práticas comerciais tratadas pelo Código. Sem embargo do princípio da vinculação ${ }^{933}$, da exigência de clara apresentação dos produtos e serviços e das consequências da sua inobservância (CDC, arts. 30, 31 e $35)^{934}$, todos já estudados, os arts. 36 a 38, 55, XII e 60 da Lei 8.078/90 veiculam institutos específicos que receberam, em seção própria, regramento autônomo e apartado.

Isto decorreu, como assevera Walter Ceneviva, ao abordar os aspectos históricos da publicidade, porque a transformação da economia capitalista provocou a necessidade imperiosa de mecanismos dinâmicos aptos a instrumentarem as relações mercantis transformadas. O processo se desenvolveu tendo em vista o atingimento eficaz dos interesses do comércio e da indústria em relação a toda a cidadania, em particular nos últimos decênios, quando se tornou notória a influência da propaganda no reforço dos mesmos interesses. A partir daí a publicidade comercial passou a interferir fortemente nas relações de consumo e, assim, na vida de todos os cidadãos. A interferência observada foi um dos fenômenos geradores da economia de massa, terminando por provocar a conveniência de estabelecer especial proteção para interesses coletivos, desligados da atuação individual dos componentes da sociedade. Esse estado de coisas provocou antes das mudanças legislativas, a reação da sociedade contra os abusos da propaganda, a partir do momento em que se passou da mídia impressa (acessível a número relativamente pequeno de pessoas, embora com maior permanência na memória) para o predominante uso da mídia eletrônica, em particular a televisão, enquanto grande promotora da massificação do consumo de bens e de serviços. À medida que aumentava a concorrência, tanto no segmento industrial, quanto no dos publicitários, o rebaixamento ético ficou mais evidente, como subproduto da massificação da economia, dificultando o discernimento dos consumidores quanto aos produtos e serviços fornecidos. ${ }^{935}$

\footnotetext{
${ }^{933}$ STJ, REsp. 341.405/DF, rel. Min. Nancy Andrighi, j. 03.09.2002.

934 "EMBARGOS À EXECUÇÃO - Multa por infração ao Código de Defesa do Consumidor - Mercadoria exposta sem informação do preço - Aposição de etiqueta com código de referência e afixação de listas no interior da loja com os preços associados a cada código - Insuficiência - Recurso não provido" (TJSP, AC 730.031-5/8-00, rel. Mauro Iuji Fukumoto, j. 22.08.2008).

${ }^{935}$ Publicidade..., cit., p. 20/25.
} 
Infere-se, portanto, que o poderio econômico - no processo de dominação do mercado ${ }^{936}$, a impor a ideia de consumismo ${ }^{937}$ - orientou-se por instrumentos que visavam a dificultar, cada vez mais, a identificação clara da verdade na mensagem publicitária, símbolo próprio e verdadeiro da sociedade moderna ${ }^{938}$, a arte de criar necessidades ${ }^{939}$ amparada no seu caráter persuasivo. ${ }^{940}$

"A função persuasiva da linguagem publicitária consiste em tentar mudar a atitude do receptor. Para isso, ao elaborar o texto publicitário leva em conta o receptor ideal da mensagem, ou seja, o público para o qual a mensagem está sendo criada. O vocabulário é escolhido no registro referente a seus usos. Tomando por base o vazio interior de cada ser humano, a mensagem faz ver que falta algo para completar a pessoa: prestígio, amor, sucesso, lazer, vitória. Para completar esse vazio utiliza palavras adequadas, que despertam o desejo de ser feliz, natural de cada ser. Por meio de palavras, o receptor 'descobre' o que faltava, embora logo após a compra sinta a frustração de permanecer insatisfeito."941

\footnotetext{
936 “ “(...) a Constituição Federal, ao contemplar o princípio da livre iniciativa e, como desdobramento deste, o da livre concorrência, empalmou implicitamente o direito dos empreendedores conquistarem espaços no mercado, valendo-se, para tanto, de todos os meios legalmente permitidos, entre eles, a publicidade comercial" (Vidal Serrano Nunes Júnior. A publicidade comercial dirigida ao público infantil. Constituição Federal. Avanços, contribuições e modificações no processo democrático brasileiro. In: Martins, Ives Gandra e Rezek, Francisco (coord.). São Paulo: coedição Centro de Extensão Universitária e RT, 2008, p. 842).

${ }^{937}$ Marília Mazon (O controle e a prevenção do dano ao consumidor perante a publicidade abusiva. Revista de Direito do Consumidor, São Paulo: RT, v. 78, abr.-jun. 2011, p. 229) assevera que "a comunicação em massa viabiliza o consumo em massa, a diversidade e o desenvolvimento dos meios de comunicação e seu fácil acesso ao público contribuem para o fenômeno publicitário e o consumo, levando até mesmo ao consumismo, momento em que o consumidor deixa de adquirir bens e serviços apenas para a satisfação de suas necessidades e passa a ser incentivado pelo sistema à aquisição de bens de consumo desnecessários. Verificamos que, o objetivo da publicidade no mundo globalizado é vender mais, sua finalidade específica é atrair o consumidor através dos meios de comunicação, despertando seu interesse pelo produto ou serviço anunciado e seu desejo e necessidade de compra, persuadindo-o e induzindo-o a consumir mais e assim movimentar o mercado econômico de produção capitalista". No mesmo sentido Vidal Serrano Nunes Júnior (A publicidade comercial..., cit., p. 845).

${ }_{938}$ Guido Alpa. Diritto privato dei consumi. Bologna: Il Mulino, 1986, p. 123.

939 Paulo Vasconcelos Jacobina. A publicidade no direito do consumidor. Rio de Janeiro: Forense, 1996, p. 95. Vidal Serrano Nunes Júnior (A publicidade comercial..., cit., p. 843), ao identificar o consumidor como um verdadeiro refém da publicidade comercial, “ (...) chama a atenção que o objetivo de promover a venda fez com que as técnicas de publicidade fossem gradativamente aprimoradas, de tal modo que de uma virtude informativa, a publicidade rapidamente caminhou para uma feição de sedução do consumidor, sem que houvesse uma marca clara dos limites éticos que a tal instrumento devessem ser opostos". E prossegue referido autor, agora citando Josué Rios (A defesa do consumidor como instrumento de mobilização social, $\mathrm{p}$. 13), a afirmar os fornecedores “(...) investem, com suas mãos sem luvas, no fundo d'alma do consumidor. Mexem com seus recônditos desejos, sentimentos de amor, de poder, de segurança, de ansiedade, de esperança, de riqueza fácil, em seus anseios sexuais e em outros que povoam o imaginário das pessoas". ${ }_{940}$ Adalberto Pasqualotto. Oferta e publicidade..., cit., p. 61.

${ }^{941}$ Nelly de Carvalho. Publicidade: a linguagem da sedução. $3^{\text {a }}$ ed. São Paulo: Ática, 2004, p. 18/19.
} 
Quadro que não passou despercebido do legislador de 1990. Essa contínua fiscalização, nada obstante o poder de polícia estatal específico (CDC, arts. 56, XII, c.c. 60), também é exercida por uma parcela de autocontrole do fornecedor (supra, Cap. III, 3.1), a exemplo do Conselho Nacional de Autorregulamentação Publicitária (CONAR) e do seu Código.

\subsection{Publicidade x propaganda}

Como já anotei em outra oportunidade ${ }^{942}$, segundo Walter Ceneviva, pretendida que fosse uma distinção terminológica, a propaganda seria espécie do gênero publicidade, consistente na arte ou ciência de indução do consumidor a preferir produto ou serviço cujas qualidades proclama. ${ }^{943}$

Para Antônio Herman de Vasconcellos e Benjamin, inversamente, "não se confundem publicidade e propaganda, embora, no dia-a-dia do mercado, os dois termos sejam utilizados um pelo outro. A publicidade tem um objetivo comercial $^{944}$ enquanto que a propaganda visa a um fim ideológico, religioso, filosófico, político, econômico ou social. Fora isso, a publicidade, além de paga, identifica seu patrocinador, o que nem sempre ocorre com a propaganda". ${ }^{945}$

Após investigar a origem etimológica do vocábulo publicidade ${ }^{946}$, Lucia Ancona Lopez de Magalhães Dias trilha o mesmo discrímen ao destacar que "a diferença entre propaganda e publicidade está, portanto, na finalidade de cada uma. A propaganda, historicamente, não almeja um benefício econômico, mas fundamentalmente a difusão de ideias. Ela visa a promover a adesão a certo sistema ideológico (político, social, religioso, econômico, governamental). A publicidade, por seu turno, é a forma clássica de tornar conhecido um produto, um serviço ou uma empresa com mo objetivo de despertar o interesse pela coisa anunciada, criar prestígio ao nome ou à marca do anunciante ou, ainda, difundir certo estilo de vida". ${ }^{947}$

\footnotetext{
${ }^{942}$ Princípios constitucionais..., cit., p. 124/126.

${ }^{943}$ Publicidade..., cit., p. 74.

${ }^{944}$ la finalité d'um rendement économique par lê recrutement d'um public de consommateurs.

${ }^{945}$ Et alii. Manual de direito do consumidor. São Paulo: RT, 2008, p. 195.

946 A palavra "publicidade" está ligada ao termo latino publicus, mas, distante da conhecida dicotomia entre plublicus/privatus, tão própria ao direito público para diferenciar as coisas do Estado daquelas do particular, ela deve ser entendida muito mais no sentido de propagação geral de algo; como "levar a todos"; "tornar de conhecimento geral".

${ }^{947}$ Publicidade..., cit., p. 21 e 23.
} 
Antes de concluir que "o comportamento econômico que se pretende provocar no consumidor (incentivando-o à aquisição de produto ou utilização de serviço) é o elemento-chave que qualifica a informação sujeita ao controle do art. 37 do CDC", prossegue a mesma autora distinguindo-a da mensagem publicitária:

“A mensagem é publicitária quando apresenta o escopo, direto ou indiretamente, de promover a aquisição de bens ou serviços pelo consumidor. Distingue-se da mera informação que é neutra e desinteressada na apresentação dos dados e características do produto ou serviço como são, por exemplo, as informações de conteúdo jornalístico ou científico. Uma matéria elaborada por profissional que informe o consumidor sobre as características de certo (s) produto (s), a partir de pesquisas ou estudos realizados não pode ser confundida com publicidade. Havendo, no entanto, interesse econômico na divulgação do produto, necessário advertir o consumidor de que se trata de um 'Informe Publicitário' e não de uma opinião desinteressada do veículo ou do jornalista." 948

Pondera Maria Elizabete Vilaça Lopes, a seu turno, que "essa distinção doutrinária não foi, de regra, observada pelo direito positivo brasileiro, que, em inúmeros diplomas legais, como p. ex. a Lei 4.680/65, utiliza os termos propaganda e publicidade como sinônimos. O Código do Consumidor incide no mesmo vício, ao referirse à contrapropaganda (arts. 56 e 60), quando deveria aludir à contrapublicidade. De resto, na linguagem vulgar e comercial as expressões são utilizadas indiferentemente". ${ }^{949}$

Na língua portuguesa, Aurélio Buarque de Holanda Ferreira aponta os significados das expressões em análise:

“(...) propaganda [Do lat. propaganda do gerundivo propagare, 'coisas que devem ser propagadas'.] S. f. 4. Prop. Difusão de mensagem, ger. de caráter informativo e persuasivo, por parte de anunciante identificado, mediante compra de espaço em TV, jornal, revista, etc.; publicidade. 5. Prop. A mensagem de propaganda, como, p. ex., reclame, anúncio, spot, etc.

Publicidade [De público + -(i)dade; fr. Publicité.] S. f. 1. Propaganda (4). 4. Qualidade do que é público: a publicidade dum escândalo. 5. Caráter do que é feito em público: a publicidade dos debates judiciais."

${ }^{948}$ Idem, p. 101. 
Assiste, pois, razão a Luiz Antonio Rizzatto Nunes quando afirma que ambos os termos seriam bastante adequados para expressar o sentido desejado pelo anunciante de produto ou serviço, inclusive com a possibilidade de utilização como sinônimos; no entanto, “(...) o mais importante é o fato de que a própria Constituição Federal não faz a distinção. Assim, por exemplo, ela fala em 'propaganda (art. 220, § $3^{\circ}$, II), 'propaganda comercial' (art. 22, XXIX, e $\S 4^{\circ}$ do art. 220), 'publicidade dos atos processuais' (art. $\left.5^{\circ} \mathrm{LX}\right)$, 'publicidade' (art. 37, caput e $\S 1^{\circ}$ )", 950

E adita Newton de Lucca, com arrimo em José Roberto Whitaker, que “(...) das dez maiores agências brasileiras: - 4 possuem a expressão propaganda na razão social; - 5 usam a palavra publicidade; - 1 utiliza o termo comunicações. O nome da associação de classe é Associação Brasileira de Propaganda. Os profissionais do setor, no entanto, não adotam a expressão propagandistas e sim a de publicitários". 951

\subsection{Publicidade $\mathrm{x}$ verdade}

Independentemente da orientação doutrinária a se perfilhar, com ou sem distinção entre os termos propaganda e publicidade, ao menos no âmbito do direito do consumidor, exsurge claro que o ponto de relevo está na finalidade econômica do manejo desses recursos de convencimento pelo fornecedor; daí a preocupação com o instituto, que "deve cumprir suas funções de informar, persuadir e vender produtos e serviços, mas tudo isto, de forma sustentável e responsável, sem incorrer em abusos e enganosidades". 952

Atento deve ficar o intérprete, pois toda publicidade "é de algum modo tendenciosa, na medida em que informa com a finalidade específica de vender, de fixar uma marca ou até mesmo criar estilos de vida (e não desinteressadamente). Na comunicação publicitária sabemos que a informação não se reveste de neutralidade; ela é sempre sugestiva para atingir o seu objetivo de compra, o que, na sociedade moderna,

\footnotetext{
${ }^{949}$ O consumidor e a publicidade. Revista de direito do consumidor, São Paulo: RT, v. 1, p. 149/183.

${ }^{950}$ Curso..., cit., p. 421/422.

${ }^{951}$ Direito do consumidor, aspectos práticos..., cit., p. 49.

${ }^{952}$ Lucia Ancona Lopez de Magalhães Dias. Publicidade..., cit., p. 30.
} 
leva-nos a reconhecer uma certa sobreposição da função persuasiva à informativa, natural dessa técnica de mercado". 953

Mas esse recurso midiático, limitado que é, e a atividade produtiva stricto sensu devem respeito ao sistema constitucional, cujo arcabouço disciplina a publicidade do serviço público $\left(\mathrm{CF}\right.$, art. $37, \S 1^{0954}$ ), dentre outros, pelo princípio da moralidade; enquanto, a do setor privado (de produtos, de práticas e de serviços) vem regulada no capítulo da comunicação social (CF, arts. $220^{955}$ e $\left.221^{956}\right)$.

A ética, que tem como valor fundamental a verdade, deve funcionar como guia permanente de atuação dos agentes interlocutores ${ }^{957}$; logo, como ensina Rizzatto Nunes ${ }^{958}$, “o anúncio publicitário não pode faltar com a verdade daquilo que anuncia de forma alguma, quer seja por afirmação, quer por omissão. Nem mesmo

\footnotetext{
${ }^{953}$ Lucia Ancona Lopez de Magalhães Dias. Publicidade..., cit., p. 28.

${ }^{954} \mathrm{CF}$, art. $37, \S 1^{\circ}$ : "'a publicidade dos atos, programas, obras, serviços e campanhas dos órgãos públicos deverá ter caráter educativo, informativo ou de orientação social, dela não podendo constar nomes, símbolos ou imagens que caracterizem promoção pessoal de autoridades ou serviços públicos".

${ }_{955} \mathrm{CF}$, art. 220: "a manifestação do pensamento, a criação, a expressão e a informação, sob qualquer forma, processo ou veículo não sofrerão qualquer restrição, observado o disposto nesta Constituição. (...) $\S 3^{\circ}$ Compete à lei federal: (...) II - estabelecer os meios legais que garantam à pessoa e à família a possibilidade de se defenderem de programas ou programações de rádio e televisão que contrariem o disposto no art. 221, bem como da propaganda de produtos, práticas e serviços que possam ser nocivos à saúde e ao meio ambiente".

${ }^{956} \mathrm{CF}$, art. 221: "a produção e a programação das emissoras de rádio e televisão atenderão aos seguintes princípios: (...) IV - respeito aos valores éticos e sociais da pessoa e da família”.

957 "A liberdade de expressão é uma das mais importantes garantias constitucionais. Ela é um dos pilares da democracia. Falar, escrever, se expressar é um direito assegurado a todos. Mas, esse direito, entre nós, não só não é absoluto, como sua garantia está mais atrelada ao direito de opinião. Vale dizer, a 'doxa' dos gregos, mero elemento subjetivo é que está garantido. A democracia dá guarida ao direito de opinar, palpitar, lançar a público o pensamento que se tem em toda sua subjetividade. Mas, quando se trata de apontar fatos objetivos, descrever acontecimentos, prestar informações a serviços públicos ou oferecer produtos e serviços no mercado, há um limite ético que controla a liberdade de expressão. Esse limite é a verdade. Com efeito, como diria Sócrates, 'mentir é pensar uma coisa e dizer outra'. A mentira é, pois, simples assim. Examinando a afirmação do famoso grego, vê-se que mentir é algo consciente; é, pois, diferente do erro, do engano, que pressupõe desconhecimento (da verdade), confusão subjetiva do que se expressa ou distorção inocente dos fatos. O sistema jurídico, então, conforme afirmado acima, controla a expressão na sua realidade objetiva, impondo, por exemplo, a testemunha que fale a verdade em juízo. Do mesmo modo impõe aos advogados e às partes, o dever de lealdade processual, proibindo que intencionalmente a verdade dos fatos seja alterada, adulterada, aumentada etc. Esse dever de lealdade - em todas as esferas: administrativa, cível e criminal - é a ética fundamental da verdade imposta a todos. O mesmo se dá no regime de produção capitalista. Não só a Constituição Federal impõe que as informações comerciais (publicidade, apresentação, oferta) sejam verdadeiras como, em conseqüência dessa determinação, o Código de Defesa do Consumidor regula expressamente a informação e a publicidade enganosa, proibindo-a e tipificando-a como crime (artigos 37, § $1^{\circ}$ e $\S 3^{\circ}, 66$ e 67 do Código de Defesa do Consumidor)" (TJSP, AC 7.005.062-7, rel. Rizzatto Nunes, j. 28.05.2008).

${ }_{958}$ Curso..., cit., p. 423.
} 
manipulando frases, sons e imagens para de maneira confusa ou ambígua iludir o destinatário do anúncio". 959

Conquanto seja, na sua origem, irrestrita a liberdade de criação, não se pode tolerar a manipulação dolosa das características essenciais do produto e do serviço oferecidos no mercado, no artifício bem denominado por Vidal Serrano Nunes Júnior, como a verdade bem dita ${ }^{960}$, pois a dificuldade de separar "nas mensagens publicitárias os elementos informativos dos persuasivos, deve pressupor-se que a publicidade respeita a verdade na exaltação da qualidade". 961

Ou seja: é possível algum exagero publicitário ${ }^{962}$, facilmente perceptível, visando a captar a atenção do consumidor, dês que circunstancial às propriedades efetivas do produto ou do serviço anunciado; porém, inaceitável se revela o exagero dirigido às próprias características que se pretende vender ${ }^{963}$, pena de a falta da verdade arranhar, sem sombra de dúvida, a ética constitucionalmente protegida, e com ela a dignidade humana, a justiça, a solidariedade e a boa-fé objetiva.

Bem descortinado por Lucia Ancona Lopez Magalhães Dias, nesta quadra, o desafio que se apresenta: "ao operador do direito incumbe, portanto, o dever de identificar formas de harmonizar as relações de consumo considerando, de um

\footnotetext{
${ }^{959}$ Um pouco diferente é o pensamento de Walter Ceneviva (Publicidade..., cit., p. 94/95): "a liberdade de criação artística da mensagem tem garantia constitucional, que, todavia, é distinta da exigência de fidelidade à verdade, integrada ao princípio da boa-fé nas relações contratuais e de observância do que se tem denominado valores éticos e sociais da pessoa e da família. A boa-fé, todavia, não se desnatura com certos exageros publicitários facilmente perceptíveis pelo homem médio. É contrário ao bom senso partir da incapacidade de avaliação do cidadão brasileiro para restringir a liberdade criadora da arte publicitária. (...) Sendo a produção e a programação das emissoras de rádio e televisão subordinadas, entre outros, ao respeito aos valores éticos e sociais da pessoa e da família, infere-se que também a publicidade nelas divulgada se submete a essa restrição. Liberdade ilimitada não é direito. É impossível e inconveniente, no cotejo com os demais interesses legítimos que movimentam o corpo social. Todavia, restrição à liberdade criadora quando esta é exercida dentro dos limites da lei, também não pode ser tolerada, posto que inconstitucional". 959

${ }^{960}$ Publicidade comercial: proteção e limites na Constituição de 1988. São Paulo: Juarez de Oliveira, 2001, p. 26.

${ }_{961}$ Carlos Ferreira de Almeida. Direito do consumo. Coimbra: Almedina, 2005, p. 141.

${ }^{962}$ Segundo Adalberto Pasqualotto (Oferta e publicidade..., cit., p. 66), "não são atingidos pelo dever de veracidade os apelos fantasiosos da publicidade. Para atrair a atenção do consumidor, a publicidade vale-se geralmente do otimismo, do exagero, do humor, e das emoções. Nada disso é crivado pelo dever de veracidade, nem mesmo os superlativos indeterminados, como 'o melhor produto do mercado"".

${ }_{963}$ Assevera Cláudia Lima Marques (et alii. Comentários..., cit., p. 729) que: "o Código de Defesa do Consumidor introduziu no ordenamento jurídico brasileiro uma série de novos deveres para o fornecedor que se utiliza (patrocina) da publicidade no mercado, como método comercial e de incitação ao consumo. O principal destes deveres é o da 'verdade especial'. A publicidade comunica, logo é forma de informação, mas também é livre para não trazer nenhuma informação precisa ou mesmo nenhum sentido, pura ilusão publicitária; mas, se trouxer alguma informação, seja sobre o preço, sobre qualidade ou quantidade, sobre os riscos e segurança ou sobre características e utilidades do produto e do serviço, esta informação deve ser verdadeira".
} 
lado, a inerente utilização da técnica de convencimento na publicidade (sua sugestividade) e, de outro, os direitos dos consumidores de não serem enganados ou agredidos por certa comunicação publicitária, preservando-lhes direitos básicos neste processo de comunicação". ${ }^{964}$

De qualquer forma, na esteira desse ideal de ética, o art. 38 do CDC estabeleceu, de modo obrigatório ${ }^{965}$, ao contrário da regra geral discricionária (CDC, art. $\left.6^{\circ}, \mathrm{VIII}\right)$, a incidir conjuntamente quanto a outros fatos se o caso, que "o ônus da prova da veracidade e correção da informação ou comunicação publicitária cabe a quem as patrocina"; também por isso que o fornecedor, na publicidade dos seus produtos ou serviços, para informação dos legítimos interessados e para a sua própria garantia, deve manter em seu poder os dados fáticos, técnicos e científicos que dão sustentação à mensagem (CDC, art. 36, par. ún.).

É que, como adverte Rizzatto Nunes, "não basta veicular a verdade. É ainda necessário que a prova da verdade da informação veiculada seja mantida em arquivo para eventual averiguação e checagem"966, pena de responsabilização penal inclusive (CDC, art. 69).

Segundo o Min. Benjamin, “ao fornecedor é lícito fazer prova exoneratória quanto ao caráter enganoso ou abusivo de sua comunicação publicitária"967, o que deixa claro se projetar a disciplina do art. 38 do CDC, como não poderia deixar de ser, até por conta da sua posição topográfica, sobre todas as impropriedades publicitárias. É dizer: a veracidade se relaciona com a não enganosidade, enquanto a correção se afina à não clandestinidade e à não abusividade. ${ }^{968}$

Tal dinâmica podia, sem sombra de dúvida, relegar ao fornecedor anunciante os encargos necessários, econômicos inclusive, à realização de sondagem popular, recurso de grande valia para definir ou afastar o caráter abusivo e/ou

\footnotetext{
${ }^{964}$ Publicidade..., cit., p. 29.

${ }^{965}$ Antônio Herman de Vasconcellos e Benjamin et alii. Manual..., cit., p. 211.

${ }^{966}$ Curso..., cit., p. 505.

${ }^{967}$ Et alii. Código Brasileiro de Defesa do Consumidor..., $10^{\text {a }}$ ed., cit., p. 372.

${ }^{968}$ No mesmo sentido, a regulamentar o CDC, é o art. 14, § 3, do Decreto 2.181, de 20.03.1997: “o ônus da prova da veracidade (não enganosidade) e da correção (não abusividade) da informação ou comunicação publicitária cabe a quem as patrocina".
} 
enganoso da publicidade, diminuindo - com isso - os entraves processuais à sua produção. $^{969}$

\subsection{Os três vícios da publicidade}

Embora mais conhecidas, a enganosidade (objetiva) e a abusividade (subjetiva) não esgotam os vícios da publicidade, que também não pode ser clandestina.

\subsubsection{Publicidade clandestina}

$\mathrm{O}$ art. $36^{970}$, caput, do CDC acolheu o princípio da identificação ${ }^{971}$ da mensagem publicitária, variante da transparência e da boa-fé objetiva, por isso que ela só é lícita quando o consumidor puder, fácil (sem esforço ou capacitação técnica) e imediatamente (no momento da exposição), identificá-la como tal. A publicidade que não quer assumir a sua essência, de uma forma ou de outra, dolosa ou inocentemente, objetiva enganar o consumidor. ${ }^{972}$

E adita Adalberto Pasqualotto que, "por imposição de transparência, a mensagem publicitária deve ser identificável e veraz. Nessa medida, identificação e veracidade são deveres comportamentais do anunciante. Segundo o dever de identificação, a mensagem publicitária tem que se ostentar como tal, não pode ser

\footnotetext{
${ }^{969}$ Lucia Ancona Lopez Magalhães Dias (Publicidade..., cit., p. 199) lembra que "há certamente grandes vantagens na utilização das pesquisas de opinião como forma de avaliação da ilicitude de certa publicidade no âmbito da tutela difusa. No entanto, não são menores as dificuldades para utilização desse meio de prova". $970 \mathrm{CDC}$, art. 36, caput: "a publicidade deve ser veiculada de tal forma que o consumidor, fácil e imediatamente, a identifique como tal".

${ }^{971}$ Após abordar o regramento de direito comparado sobre o tema, com ênfase às disciplinas da Comunidade Européia (1989/252/CEE - art. 10), da Câmara de Comércio Internacional (art. 11), da Lei Geral de Publicidade da Espanha (Ley 34/1988, art. 11), o Código da Publicidade Português (art. 8.1) e o Codice del Consumo Italiano (D. Leg., 206/2005, art. 23.1, parte final), conclui Lucia Ancona Lopez Magalhães Dias (Publicidade..., cit., p. 67): "percebe-se, assim, que a existência da identificação da mensagem publicitária pelo consumidor é tema recepcionado pelas mais diversas legislações do mundo, e nem poderia ser diferente. Com efeito, o mencionado princípio tem como ratio nuclear evitar que o consumidor seja exposto aos efeitos persuasivos da publicidade sem que deles possa se defender. A eventual camuflagem do caráter publicitário da peça veiculada retira do seu destinatário a possibilidade de colocar em prática os naturais mecanismos de defesa em relação a uma publicidade transparente. Ao esconder ilegalmente a sua intenção e natureza, a peça publicitária pode intensificar os efeitos persuasivos sobre o receptor da mensagem. Desse modo, em virtude de sua função persuasiva (promover a aquisição de bens ou serviços), impõe-se que a publicidade seja identificada desde logo (...)".
} 
mascarada. A exigência dessa conduta deve-se ao teor predominantemente persuasivo da publicidade". 973

A conhecida técnica do merchandising ${ }^{974}$ afronta, de modo direto, a vedação legal; contudo, apartada de uma forma aparentemente casual e/ou subliminar $^{975}$, se perceptível a sua prática não haverá - a um só tempo - clandestinidade e ilicitude, pois como afirma Adalberto Pasqualotto, "a lei admite o assédio honesto e declarado ao consumidor, rechaçando a clandestinidade". 976

Entende a doutrina ${ }^{977}$, no entanto, a ponderar a liberdade de criação (expressão) e o princípio da identificação, que o sistema de créditos - antes e

${ }^{972}$ Antônio Herman de Vasconcellos e Benjamin et alii. Código Brasileiro de Defesa do Consumidor..., $10^{\mathrm{a}}$ ed., cit. p. 337.

${ }_{973}$ Oferta e publicidade..., cit., p. $62 / 63$.

${ }^{974}$ Segundo Rizzatto Nunes (Curso..., cit., p. 461/462), “o merchandising é a técnica utilizada para veicular produtos e serviços de forma indireta por meio de inserções em programas e filmes. Dessa maneira, muitos produtos são veiculados sem que os consumidores se dêem conta de que o que eles estão assistindo significa uma prática publicitária, mesmo nos casos mais evidentes. De fato, quando uma personagem importante da novela das 8 entra num bar e pede uma Coca-Cola, o telespectador-consumidor não sabe se aquela demonstração específica é ou não publicidade do produto veiculado. Nem tudo é, mas muitas são".

${ }^{975}$ Adalberto Pasqualotto (Oferta e publicidade..., cit., 65) diferencia a "matéria aqui tratada a publicidade subliminar, porque atua no plano inconsciente do indivíduo, enquanto as formas publicitárias, inclusive as infratoras, agem sobre o consciente, tentando induzir o consumidor a determinado comportamento voluntário. A publicidade subliminar é uma forma de ilicitude que vai além da publicidade, chegando à violação de direito da personalidade, por coatar a autodeterminação. Consiste em estimular a mente de alguém com sinais tão fracos ou efêmeros que escapem à percepção da consciência, mas suficientes para influenciar o comportamento". Informa Antônio Herman de Vasconcellos e Benjamin (et alii. Código Brasileiro de Defesa do Consumidor..., $10^{\text {a }}$ ed., cit. p. 337) que "a eficácia da publicidade subliminar foi testada, experimentalmente, em 1957. Em um cinema dos Estados Unidos, a audiência foi bombardeada com as seguintes frases, na velocidade de 1/3000 de segundo: 'Drink Coca-Cola' e 'Hungry? Eat Popcorn'. O consumo de tais produtos, durante a apresentação, aumentou bastante. Não há, contudo, casos registrados de utilização comercial de publicidade subliminar. Por via das dúvidas, como mera cautela preventiva, a Federal Trade Commission, em 1974, emitiu uma public notice, alertando contra a abusividade da publicidade subliminar”. Marília Mazon (O controle..., cit., p. 246) traz à locação outro exemplo, “(...) o da ração para gatos Wyskas, onde em seu anúncio publicitário televisivo era emitido um ultra-som apenas perceptível e reconhecido pelos gatos, que eram atraídos por tal som durante a transmissão do anúncio comercial, induzindo seus donos a acreditarem ser aquele produto o desejado por seu animal de estimação".

${ }^{976}$ Os efeitos obrigacionais da publicidade no Código de Defesa do Consumidor. São Paulo: RT, 1997, p. 84.

${ }^{977}$ Cf., Antonio Herman de Vasconcellos e Benjamin (et alii. Código Brasileiro de Defesa do Consumidor..., $10^{a}$ ed., cit., p. 338/339): "a melhor delas, sem dúvida, é a utilização de 'créditos', ou seja, a veiculação antecipada de uma informação comunicando que, naquele programa, peça ou filme, ocorrerá merchandising de tais e tais produtos ou serviços. Não vejo aí violação do requisito da imediatidade. Esta tem por ratio evitar a identificação a posteriori. Ora, o crédito simplesmente fornece elementos necessários para que o consumidor, no momento da veiculação do merchandising, possa identificá-lo, de imediato, como publicidade. Por cautela, o crédito, nos programas que são fragmentados, deve ser reapresentado tantas vezes quantos sejam os fragmentos. E para proteger os consumidores que não tenham oportunidade de assistir ao início do programa (ligaram a televisão após a abertura da novela, por exemplo), também se deve exigir que os créditos sejam repetidos no final de cada fragmento". Nesse sentido também é o pensamento de Rizzatto Nunes (Curso..., cit., p. 464): "é preciso lembrar, também, que nesse tema há um outro problema que envolve diretamente o autor do texto ou diretor do programa, filme ou novela. O que se poderá fazer se o autor da novela entender que o personagem X, dadas as suas características, só deva tomar uma caninha específica ou só deva andar num automóvel conhecido como o mais chique? O problema nesse caso é insolúvel, pois a 
depois - do programa onde se explorou a publicidade disfarçada, alertando o consumidor para o seu status de alvo de determinados anúncios, seria suficiente para elidir a clandestinidade, o que parece razoável.

Ao contrário da clandestina, o $\mathrm{CDC}$ não tolera as publicidades enganosa e/ou abusiva (art. 37, caput).

\subsubsection{Publicidade enganosa}

Seguindo idêntica estrutura, na fórmula de cláusula geral, o CDC define publicidade enganosa ${ }^{978}$ como sendo "qualquer modalidade de informação ou comunicação de caráter publicitário, inteira, ou parcialmente falsa, ou, por qualquer outro modo $^{979}$, mesmo por omissão, capaz de induzir em erro o consumidor a respeito da natureza, características, qualidade, quantidade, propriedades, origem, preço e quaisquer outros dados sobre produtos e serviços" (art. 37, § $1^{\circ}$ ).

Apesar da expressa referência do $\S 1^{\circ}$, pois uma não exclui a outra $^{980}$, certamente preocupado, o legislador volta a tratar da enganosidade por omissão no $\S 3^{\circ}$ do art. 37, aclarando que "para os efeitos deste Código, a publicidade é enganosa por omissão quando deixar de informar sobre dado essencial do produto ou serviço", assim entendido como "as informações que têm o condão de levar o consumidor a adquirir", ou não (caso os conheça), esses bens ${ }^{981}$, ou seja, dado "que influi ou pode influir na escolha econômica do consumidor". 982

liberdade de expressão do autor ou diretor não pode ser cerceada. O autor e o diretor têm o direito de criar e mostrar personagens com as características e o modo de vida que bem entenderem. Mas, tirando essa questão, não resta dúvida de que o caput do art. 36 proíbe essa técnica. Como, então, resolver o problema? Uma alternativa de solução que permite, ainda que com algum embaraço, a continuidade de utilização dessa técnica parece ser a inclusão, antes da exibição do filme, programa ou novela, de um aviso de que na programação que se seguirá estará sendo usado o merchandising".

978 Antônio Herman de Vasconcellos e Benjamin (et. alii. Manual..., cit., p. 204) identifica “(...) dois tipos básicos de publicidade enganosa: a por comissão e a por omissão. Na publicidade enganosa por comissão, o fornecedor afirma algo capaz de induzir o consumidor em erro, ou seja, diz algo que não é. Já na publicidade enganosa por omissão, o anunciante deixa de afirmar algo relevante e que, por isso mesmo, induz o consumidor em erro, isto é, deixa de dizer algo que é".

979 Dentro desse "qualquer outro modo" está inserida a publicidade verdadeira, mas ambígua e inexata. O próprio Código Brasileiro de Autorregulamentação Publicitária do CONAR alude a essa possibilidade no seu art. 27.

${ }^{980}$ Lucia Ancona Lopez Guimarães Dias (Publicidade..., cit., p. 100) lembra que: “poderá ainda haver as duas modalidades de enganosidade em uma só publicidade, isto é, caso, ao mesmo tempo, seja veiculada falsa informação e omitido dado essencial sobre o bem ou serviço".

${ }_{981}$ Antônio Herman de Vasconcellos e Benjamin et. alii. Manual..., cit., p. 207.

${ }^{982}$ Lucia Ancona Lopez Guimarães Dias. Publicidade..., cit., p. 140. 
São elas, mas não em rol taxativo, sempre a depender da casuística atrelada ao produto e/ou ao serviço oferecido ${ }^{983}$, as que tiverem como foco os próprios núcleos referidos $\S 1^{\circ}$ do art. 37 do $\mathrm{CDC}^{984}$, e. $g$., informações sobre possíveis vícios e/ou defeitos, reduzido prazo de garantia complementar, exíguo número de assistências técnicas, estoque limitado de peças de reposição, etc.

Marcante, outra vez, a preocupação com a transparência e com os limites impostos pela boa-fé objetiva ${ }^{985}$; aliás, aqui, identificada essa colossal antipatia $^{986}$ ante o engodo, a violar a sanidade do mercado e a distorcer o processo decisório do consumidor ${ }^{987}$, retomamos o que se abordou no paralelo entre a publicidade e a verdade (supra, 3.2).

Sintetiza Luiz Antonio Rizzatto Nunes que "o efeito da publicidade enganosa é induzir o consumidor a acreditar em alguma coisa que não corresponda à realidade do produto ou serviço em si, ou relativamente a seu preço e forma de pagamento, ou, ainda, a sua garantia etc. O consumidor enganado leva, como se diz, 'gato por lebre'. Pensa que está numa situação, mas, de fato, está em outra". ${ }^{988}$

$\mathrm{O}$ erro induzido do consumidor ${ }^{989}$, ou dolo civil do direito privado clássico, também conhecido na modalidade omissiva ${ }^{990}$, que não se esgota na parte

\footnotetext{
983 Antônio Herman de Vasconcellos e Benjamin et alii. Manual..., cit., p. 207.

${ }^{984}$ Adalberto Pasqualotto. Os efeitos..., cit., p. 126.

985 Para Rizzatto Nunes (Curso..., cit., p. 467), “o CDC foi exaustivo e bastante amplo na conceituação do que vem a ser publicidade enganosa. Ele quis garantir - aliás, conforme se viu, como faz em muitos artigos que efetivamente o consumidor não seria enganado por uma mentira nem por uma "meia verdade".

${ }^{986}$ Antônio Herman de Vasconcellos e Benjamin et alii. Manual..., cit., p. 203.

${ }^{987}$ Enganosa é a publicidade que "mediante inexactitudes u ocultamientos, pueda inducir a error, engaño o confusión, respecto de las características o propriedades, naturaleza, calidad, pureza, uso, etc, de bienes o servicios" (Gabriel e Rubén Stiglitz. Derechos y defensa de los consumidores. Buenos Aires: La Rocca, 1994, p. 137).

${ }^{988}$ Idem. E adita Mário Frota no sentido de que a publicidade enganosa é aquela que "por qualquer forma, incluindo a sua apresentação, induz em erro ou é susceptível de induzir em erro as pessoas a quem se dirige ou que afeta e cujo comportamento econômico pode afetar, em virtude de seu caráter enganador ou que, por estas razões, prejudica ou pode prejudicar um concorrente" (Mário Frota. Política de Consumidores na União Européia. O acervo do direito europeu de consumo. Coimbra: Almedina, 2003, p. 210).

989 "Ora, é notório que as frases utilizadas nas capas das revistas se constituem em um chamariz da atenção dos leitores, e acabam funcionando, ainda, como uma espécie de propaganda do conteúdo do periódico. Considerando esse fato e os termos em que proposta a ação, analisados à luz dos arts. 36 e seguintes do CDC, verifica-se que houve propaganda enganosa, posto que a manchete estampada na capa da revista Boa Forma, qual seja, Emagreça $5 \mathrm{~kg}$ em 24 horas, não se coaduna com o conteúdo da matéria, que diz respeito apenas a truques para disfarçar o peso real. Induziu, dessa maneira, a consumidora a erro, pois esta acreditou que realmente encontraria uma fórmula rápida de emagrecimento. (...) Importante frisar que não se questiona, aqui, a veracidade da matéria divulgada. O cerne da questão é a falta de correlação da reportagem à manchete da revista, que consiste em sua propaganda, decorrendo daí o caráter enganoso, pois é, o que, ao cabo, fornece elementos para a vendagem" (TJSP, AC 508.743-4/9-00, rel. Caetano Lagrasta, j. 18.06.2008).
} 
principal da mensagem (captatória), nem se confunde com mera estratégia comercial ${ }^{991}$, exsurge como a grande preocupação do CDC nesse pormenor, sendo imperiosa, como destaca Lucia Ancona, a análise do "nexo causal entre a mensagem e o possível comportamento viciado do consumidor". 992

Cláudia Lima Marques anota que "a característica principal da publicidade enganosa, segundo o CDC, é ser suscetível de induzir ao erro o consumidor, mesmo através de suas 'omissões'. A interpretação dessa norma deve ser necessariamente ampla, uma vez que o 'erro' é a falsa percepção da realidade, falsa noção esta potencial formada na mente do consumidor por ação da publicidade. Parâmetro para determinar se a publicidade é ou não enganosa deveria ser o observador menos atento, pois este representa uma parte não negligenciável dos consumidores e, principalmente, telespectadores". 993

Após divergir para considerar que o consumidor ideal (normalmente informado e razoavelmente atento e advertido ${ }^{994}$ ), o médio ou razoável, é que deve servir de parâmetro para a avaliação da enganosidade, Luiz Antonio Rizzatto Nunes, com precisão, por certo aparelhado na essência objetiva/preventiva do Código, voltado à efetiva proteção do consumidor contra todos os possíveis abusos (supra, Cap. III, 3.2), conclui que "o anúncio é enganoso antes mesmo de atingir qualquer consumidor em concreto; basta ter sido veiculado" ${ }^{995}$, isto porque - como afirma o Min. Benjamin ${ }^{996}$ "não se exige prova de enganosidade real, bastando a mera enganosidade potencial ('capacidade de indução ao erro')", sendo desprovida de relevo nesse processo a boa-fé subjetiva do anunciante. ${ }^{997}$

\footnotetext{
${ }^{990} \mathrm{CC}$, art. 147: "nos negócios jurídicos bilaterais, o silêncio intencional de uma das partes a respeito de fato ou qualidade que a outra parte haja ignorado, constitui omissão dolosa, provando-se que sem ela o negócio não se teria celebrado".

991 "Consumidor e publicidade - Refrigerante Coca-Cola e riscos de obesidade pelo exagerado consumo Não obstante possa incluir a ingestão de refrigerantes calóricos entre as causas que explicam o excesso de peso, já considerado em estudos como epidêmica em alguns países, não se justifica restringir o marketing do fabricante, impedindo que implemente campanhas publicitárias voltadas ao público infantil, pela impossibilidade de caracterizar a estratégia comercial como publicidade enganosa, sendo sensato exigir que investimentos se façam na área da educação para o consumo racional, inclusive dos pais e educadores, ao invés de práticas interditais que, nesse contexto, se aproximam dos atos de censura de atividades licenciadas - Não provimento" (TJSP, AC 566.275.4/7, rel. Ênio Santarelli Zuliani, j. 03.09.2009).

${ }^{992}$ Publicidade..., cit., p. 100.

${ }^{993}$ Et alii. Comentários..., cit., p. 737/738.

${ }^{994}$ Critérios adotados pela Consideranda 18 da Diretiva 2005/29/CE.

${ }_{995}$ Curso..., cit., p. 469.

${ }^{996}$ Et alii. Manual..., cit., p. 203.

${ }^{997}$ Identificada que a abusividade deve ser aferida in abstracto, o dano concreto e o elemento subjetivo do fornecedor terão relevância na esfera penal (CDC, arts. 66 e 67).
} 
Da mesma forma, "a mensagem que não tem aptidão para induzir em erro seus destinatários não pode ser qualificada como enganosa" ${ }^{\text {"998; }}$;uadro a autorizar, ao menos em cognição sumária, mas com o cuidado de não comprometer a essência difusa da publicidade, o que Lucia Ancona chamou de "calibragem ou modulagem do padrão de consumidor médio ao caso concreto". 999

Para ela, é "de fundamental importância para bem avaliar o potencial enganoso da mensagem, está justamente a investigação dos destinatários da publicidade em cujo âmbito a indução em erro deve ser interpretada. Buscando-se evitar a proibição da publicidade enganosa a turbação de uma eventual relação negocial, parecenos claro que a avaliação do potencial lesivo de determinada mensagem não pode se desenvolver de modo alheio à impressão que a publicidade investigada causa entre os possíveis sujeitos da futura relação de consumo. Neste passo, recomendável que a autoridade encarregada de julgar a licitude ou ilicitude de uma mensagem investigue, desde o primeiro momento, o seu público-alvo, isto é, o círculo de destinatários da publicidade ou por ela alcançados". 1000

O perigo dessa corrente, a despeito da sua lógica, data venia, está na possível dispersão de foco pelo intérprete. Se a enganosidade há de ser aferida de modo objetivo, tão-só pelo seu abstrato potencial lesivo, a busca do público-alvo da mensagem publicitária (target group da publicidade ou parâmetro humano ${ }^{1001}$ dos italianos) pode relegar para um segundo plano de proteção aqueles novos consumidores, até então não inseridos como destinatários típicos da campanha, por isso pouco acostumados com as nuances do produto e/ou do serviço anunciado, mas também atingidos pela lesividade difusa propalada, sem distinção, a atraí-los de igual forma.

$\mathrm{Na}$ dúvida, integrando a publicidade o contrato (CDC, art. $30)^{1002}$, a solução há de prestigiar a defesa do sujeito vulnerável (CDC, art. 47), que também se projeta a impedir qualquer abuso no mercado (CDC, art. $\left.4^{\mathrm{o}}, \mathrm{VI}\right)$, publicidade enganosa inclusive (CDC, art. $\left.6^{\circ} \mathrm{IV}\right)$; aliás, a mera dificuldade de compreensão do sentido

\footnotetext{
${ }^{998}$ Lucia Ancona Lopez Guimarães Dias. Publicidade..., cit., p. 101.

${ }^{999}$ Idem, p. 121.

${ }^{1000}$ Idem.

${ }^{1001}$ Maurizio Fusi, Paulina Testa e Pierluigi Cottafavi. La publicità ingannevole. Milano: Giuffrè, 1993, p. 134.

1002 “(...) impressos de publicidade que interam o contrato, gerando uma fonte de obrigação para o fornecedor (art. 30 do CDC) - Abusividade manifesta da cláusula em questão, que deve ser reputada nula (art. 51, IV, do CDC)” (TJSP, AC 994.04.034350-2, rel. Paulo Eduardo Razuk, j. 18.05.2010).
} 
e do alcance da mensagem publicitária já seria apta a desobrigar os consumidores (CDC, art. 46). ${ }^{1003}$

\subsubsection{Publicidade abusiva}

$\mathrm{O}$ art. $37, \S 2^{\circ}$, do CDC, "como verdadeira cláusula geral de não abusividade", na dicção de Lucia Ancona ${ }^{1004}$, qualifica como "abusiva, dentre outras, a publicidade discriminatória de qualquer natureza, a que incite à violência, explore o medo ou a superstição, se aproveite da deficiência de julgamento e experiência da criança, desrespeita valores ambientais, ou que seja capaz de induzir o consumidor a se comportar de forma prejudicial ou perigosa à sua saúde ou segurança”.

O Min. Benjamin, ao reconhecer na publicidade abusiva um contorno próprio, distinto da enganosidade ${ }^{1005}$ antes estudada, afirma que ela encerra "uma noção plástica, em formação. Por um critério residual, em matéria publicitária patológica, pode-se afirmar que abusivo é tudo aquilo que, contrariando o sistema valorativo da

1003 "RESPONSABILIDADE CIVIL - Danos morais e materiais - Titulo de capitalização - Publicidade enganosa que fez o consumidor acreditar que se tratava de contrato para aquisição de imóvel residencial - art. $37, \S 1^{\circ}$, do CDC - Direito do consumidor à informação clara e precisa violado - art. $6^{\circ}$, III e IV e 46 do CDC - Ré que responde por atos dos corretores que oferecem seus produtos aos consumidores - Devolução dos valores pagos devida - art. 34 do CDC - Danos morais caracterizados que devem ser reparados Fixação em R\$ 15 000,00 que atende aos objetivos da reparação civil de danos - Recurso do autor provido e da ré improvido" (TJSP, AC 991.05.002506-7, rel. J. B. Franco de Godoi, j. 10.02.2010). “A propaganda enganosa, na espécie, caracteriza-se pela venda de título de capitalização sem a informação precisa de sua natureza, levando o comprador a crer que adquiria não o título, mas o próprio bem a ele vinculado pelo anúncio da requerida. Assim, embora o contrato seja de investimento financeiro e não de compra e venda, a maneira como veiculada a oferta fez o adquirente presumir o contrário. Esta conduta fere o direito do consumidor à informação clara e adequada sobre produtos e serviços e, portanto, permite a rescisão contrato com a devolução do total dos valores pagos" (TJSP, AC 6.727.084-2, rel. Maia da Cunha, j. 01.10.2009). "No caso, a publicidade, produzida pelo folheto, tem o intuito claro de distorcer e desinformar. Quem para ele olha, acredita que é 'superfácil' adquirir sua casa própria e viver feliz com a família” (TJSP, AC 7.005.062-7, rel. Rizzatto Nunes, j. 28.05.2008).

${ }^{1004}$ Publicidade..., cit., p. 162/163. E destaca a autora que "a análise da publicidade abusiva, por oferecer diversos conceitos jurídicos indeterminados, os quais devem ser preenchidos pelo julgador no caso concreto à luz da peça publicitária, apresenta manejo jurídico mais sensível, tendo em vista a sua possível exposição a uma maior discricionariedade e até subjetividade. Diferentemente da publicidade enganosa, cujos critérios estudados caminham para uma maior objetividade na análise da aptidão lesiva, na publicidade abusiva, exigese uma interação maias intensa do próprio julgador, que procederá a uma análise valorativa dos fatos ali colocados. É importante pontuar, contudo, que essa valoração deverá levar em conta o interesse juridicamente protegido pela norma, que é sempre o interesse social, i.e., coletivo, não se justificando a vedação legal a partir de um grupo isolado de consumidores ou a partir de subjetivismos e posições pessoais de um ou outro. O dano moral difuso deve ser avaliado à luz dos valores e dos usos e costumes que a sociedade, como um todo, está afeita a receber, fundamentando-se o julgador responsavelmente em parâmetros mínimos que deem sustentação à sua análise valorativa".

${ }^{1005}$ Fernando Gherardini Santos. Direito e marketing. São Paulo: RT, 2000, p. 227. 
Constituição e das leis, não seja enganoso"1006; em resumo, segundo Cláudia Lima Marques, é "a publicidade antiética, que fere a vulnerabilidade do consumidor, que fere valores sociais básicos, que fere a própria sociedade como um todo"1007, lídimo "exercício excessivo"1008 do instituto, o qual não se confunde com o mero mau-gosto da campanha. ${ }^{1009}$

Entre eles podem ser listados: a dignidade da pessoa humana, o trabalho, a solidariedade, o repúdio à violência, a impossível discriminação ${ }^{1010}$ (v.g., raça, sexo, cor, orientação sexual, etc.), a valorização da família, a proteção ao idoso, a

${ }^{1006}$ Et alii. Código Brasileiro de Defesa do Consumidor..., $10^{\text {a }}$ ed., cit., p. 355.

${ }^{1007}$ Et alii. Comentários..., cit., p. 738. Como exemplo de publicidade antiética, no final da década de 70, lembre-se da campanha vinculada à marca de cigarros "Vila Rica", cujo "garoto propaganda" era o exjogador de futebol Gerson, integrante da seleção brasileira que ganhou a copa do mundo de 1970, que induzia o consumo desse produto sob o slogan "Gosto de levar vantagem em tudo, certo! Leve vantagem você também. Leve Vila Rica". A sugestão era no sentido de que "brasileiro esperto" é aquele que "gosta de levar vantagem em tudo". Popularmente, a "esperteza" e a "malandragem" ficaram conhecidas como "Lei de Gerson”, para alguns, a "única” lei que pegou no país (http://pt.wikipedia.org/wiki/Lei_de_G\%C3\%A9rson). ${ }^{1008}$ Lucia Ancona Lopez Magalhães Dias. Publicidade..., cit., p. 161.

1009 O TJSP (AC 567.643.5/8-00, rel. Borelli Thomaz, j. 23.04.2008) analisou questão interessante ao perquirir se uma publicidade "em que mostrava egresso saindo da prisão deparando com veículo Pálio para, em seguida, a imagem ficar escura e apenas com a frase Novo Fiat Pálio, ouvindo-se, depois, som de quebra de vidro e som de alarme disparado seguidos da expressão impossível ficar indiferente, teve as características e consequências indicadas na petição inicial" de ação civil pública em que o Ministério Público a taxava de "ofensiva, preconceituosa, discriminatória e apologista de crime". A conclusão foi no sentido de que "é certo haver a explícita referência que o egresso mostrado no filme tornou a delinquir (dano? furto? tentativa de furto?) mal saído da cadeia vista ao fundo, fazendo-o sob escuridão (da tela) e sem resistir ao veículo à sua frente. Sem ferir sensibilidades ou suscetibilidades, que cadeia, cárcere, penitenciária 'recuperam' quem lá esteja e quem de lá saia? Com o máximo respeito aos profissionais que elaboraram todos os estudos e chegaram ao produto final, aprovado pelo cliente, vê-se, isso sim. grosseria, mau-gosto, mau uso de uma idéia ruim, atributos negativos para divulgar produto que até deve ser bom e que, por ser bom, haveria de ser mostrado de forma positiva. Afinal, pouca gente vai querer comprar veículo exibido pela própria fábrica como sujeito a danos e a furto. Criação volta-se contra o criador Ou talvez fosse excelente propaganda para companhia de seguros, onde seria colocado o veículo 'a ser furtado' também poderia ser problema, embora veículos sejam furtados onde quer que estejam. Não é chiste. É argumento para mostrar que o subjetivismo da mensagem pode levar a efeito contrário Esse, aliás, é o grande 'problema' da propaganda, convenhamos, pois o tiro pode sair pela culatra. (...) Em suma, mau-gosto, pouca (ou muita) sutileza, falta de idéias, pouca criatividade e quetais não podem ser impostos ou vedados pela lei. Com o devido respeito, e de novo sem querer ferir sentimentos e suscetibilidades, a propaganda veiculada pelas rés para fazer fama ao NOVO FIAT PÁLIO não é ilícita, ilegal ou irregular. É mesmo de mau-gosto, fato atípico". A ementa desse julgado foi assim redigida: "Ação civil pública. Dano moral difuso. Propaganda vista como ofensiva, preconceituosa, discriminatória e apologista de crime. Legitimidade do Ministério Público. Ilicitudes, no entanto, não ocorrentes. Mau-gosto e pobreza de idéia ferem o intelecto, não a moral, a ética ou os bons costumes. Recurso desprovido".

1010 Entendida como o tratamento desigual dos iguais, em sentido inverso àquele proposto pela isonomia material. Nas palavras de Fábio Ulhoa Coelho ( $O$ empresário e os direitos do consumidor. São Paulo: Saraiva, 1994, p. 260), "a publicidade é discriminatória quando a mensagem veiculada afirma, ou simplesmente sugere, a pertinência de tratamento discriminatório às pessoas. A Constituição Federal assegura a todos, como direito fundamental, o tratamento isonômico (CF, art. $5^{\circ}$, caput, I, XLI e XLII), representando ofensa ao texto constitucional a promoção de produtos ou serviços com desrespeito a esse direito". 
tutela da criança ${ }^{1011}$ e do adolescente ${ }^{1012}$, a saúde ${ }^{1013}$ e a segurança ${ }^{1014}$, a preservação do meio ambiente e do patrimônio histórico, o respeito às instituições e aos símbolos nacionais.

\section{Diferentemente da publicidade enganosa, é possível concluir}

com Rizzatto Nunes que "o caráter da abusividade não tem necessariamente relação direta

1011 “Ação civil pública - Publicidade abusiva - Propaganda de tênis veiculada pela TV - Utilização da empatia de apresentadora - Induzimento das crianças a adotarem o comportamento da apresentadora (Xuxa) destruindo tênis usados para que seus pais comprassem novos, da marca sugerida - Ofensa ao art. 37 , § $2^{\circ}$, do CDC - Sentença condenatória proibindo a veiculação e impondo encargo de contrapropaganda e multa pelo descumprimento da condenação - Contrapropaganda que se tornou inócua ante o tempo já decorrido desde a suspensão da mensagem. Recurso provido parcialmente provido" (TJSP, AC 241.337-1, rel. Ribeiro Machado, j. 30.04.1996). Anota Marília Mazon (O controle..., cit., p. 263) o caso da sandália "Princesas Grendene" apreciado pelas $5^{\text {a }}$ Câm. do Conselho de Ética do CONAR (Rep. 254/09): "o alvo da representação é o comercial veiculado em TV pela Grendene, para divulgar as sandálias Princesas Disney. Ocorreria no comercial, de acordo com a denúncia, sugestão de consumo vocalizada por criança e apelo direto ao público infanto juvenil, por meio de frases como 'vossa majestade vai adorar' e 'tem coisa que só as princesas de verdade podem ter'. Nesse caso, a criança poderia ser induzida a acreditar que o produto lhe assegura algum tipo de superioridade de acordo com os sonhos e universo infantil". Vidal Serrano Nunes Júnior (A publicidade comercial..., cit., p. 845/846), após destacar a impossibilidade de as crianças captarem determinados conteúdos informativos, com base na doutrina da proteção integral, segundo ele incorporada à Constituição Federal no seu art. 227, caput, sustenta que “(...) toda e qualquer publicidade dirigida ao público infantil parece inelutavelmente maculada de ilegalidade", o que parece um pouco de exagero.

${ }^{1012}$ Luiz Antonio Rizzatto Nunes (Curso..., cit., p. 492) anota, neste particular, que na publicidade dirigida às crianças e aos adolescentes: “a) deve-se dar atenção especial às características psicológicas da criança e do jovem; b) deve-se respeitar especialmente a ingenuidade, credibilidade, inexperiência e o sentimento de lealdade dos menores; c) não é admitido que a mensagem transmita expressa ou implicitamente: c.1) sentimento de inferioridade, caso o menor não adquira ou não possa adquirir o produto ou serviço; c.2) estímulo a que o menor constranja seus responsáveis ou terceiros; d) os modelos e comportamentos apresentados especialmente por menores que trabalhem nos anúncios: d.1) não podem sugerir ou apresentar distorções psicológicas ou comportamentos sociais condenáveis; d.2) em qualquer hipótese deve ter a segurança como primeira preocupação, bom como ser elaborado com base em regras de boas maneiras". Como não lembrar, aqui, da campanha publicitária veiculada, na década de 80, principalmente nas proximidades de datas festivas ligadas ao público infantil (v.g., dia da criança, natal, etc.), por uma conhecida fabricante de bicicletas sob os seguintes dizeres: "pai, não esqueça a minha Caloi”, propagando a contínua e insistente perturbação do genitor até a obtenção do produto desejado. Também nessa linha, segundo Marília Mazon (O controle..., cit., p. 250) “(...) o anúncio das tesouras infantis da marca Hércules - Mickey e Minnie, veiculados na mídia eletrônica televisiva com a frase 'Eu tenho... você não tem...!', que leva a criança a sentir-se diminuída, constrangida ou menos importante por não consumir o produto".

1013 Ressalta Lucia Ancona Lopez Magalhães Dias (Publicidade..., cit., p. 194/195), aqui, "caso uma publicidade de medicamentos empregasse imperativos para o seu consumo direto, sem maiores cuidados, inclusive, consulta ao médico, levando os consumidores à automedicação; ou ainda uma publicidade que exaltasse que certo remédio possui qualidades milagrosas, menosprezando o diagnóstico médico". Lembra Marília Mazon (O controle..., cit., p. 263) o caso do Engov apreciado pelas $1^{\mathrm{a}}$ Câm. e Câm. Especial de Recursos do Conselho de Ética do CONAR (Rep. 020/09): “denúncia e alteração do comercial de TV da marca Engov devido ao cometimento de duas infrações: o estímulo ao excesso etílico, sendo o medicamento apresentado como solução para os efeitos negativos de tal conduta, e o estímulo ao uso excessivo de remédio, reforçada na parte final da mensagem, com o emprego da expressão 'Engov 1,2'. Foi determinada a inclusão de um alerta sobre os riscos do consumo indiscriminado e em excesso, assim como foi feito para o caso de anúncio semelhante, bem como a retirada da locução e imagens referentes à expressão '1,2'”.

${ }^{1014}$ Segundo Benjamin (et alii. Código Brasileiro de Defesa do Consumidor..., $10^{\mathrm{a}}$ ed., cit., p. 357), "um dos subprincípios que integram o princípio da não abusividade é o princípio da inofensividade da publicidade. Impede ele qualquer publicidade 'capaz de induzir o consumidor a se comportar de forma prejudicial ou perigosa a sua saúde ou segurança”’. 
com o produto ou serviço oferecido, mas sim com os efeitos da propaganda que possam causar algum mal ou constrangimento ao consumidor", o que implicaria a possibilidade de se "ter numa mesma publicidade um anúncio enganoso e ao mesmo tempo abusivo". 1015

É dizer: "uma publicidade, mesmo absolutamente veraz, pode vir, ainda assim, a ser proibida"1016 por conta de ser abusiva, como no caso da enganosa, de modo apartado do elemento subjetivo do anunciante, como variação do abuso de direito da doutrina clássica ${ }^{1017}$ que é, a partir do seu mero potencial de lesar o consumidor ideal ${ }^{1018}$, mas sempre com os olhos voltados a um certo "padrão social mínimo"1019 admitido coletivamente como aceitável ou não e ao veículo publicitário escolhido ${ }^{1020}$, pouco importando - nessa análise - a "consideração individual do consumidor". ${ }^{1021}$

Adverte Lucia Ancona que, "ao se deparar com uma situação de abusividade, é necessário que o intérprete fundamente sua análise a partir do senso comum, isto é, a partir de parâmetros médios, genericamente vigentes em nossa sociedade, sob pena de admitirmos que qualquer pessoa estará legitimada a falar em nome da coletividade, simplesmente porque certa publicidade se mostra contrária às suas posições individuais. Nessa difícil análise incumbe ao intérprete cobrir-se com o manto da coletividade e não incorporar visões e programas individuais de mundo (ideologias); deverá ele ter em conta o padrão de consumidor minimamente crítico, isto é, daquele que sabe distinguir o verdadeiro do fantasioso; que identifica a manifesta brincadeira da agressão discriminatória, tal qual já expusemos neste Capítulo ao discorrermos sobre o moderno padrão de consumidor na avaliação da licitude da publicidade. Isto porque,

\footnotetext{
1015 Curso..., cit., p. 489.

${ }^{1016}$ Antônio Herman de Vasconcellos e Benjamin et alii. Código Brasileiro de Defesa do Consumidor..., $10^{\mathrm{a}}$ ed., cit., p. 355.

${ }^{1017} \mathrm{CC}$, art. 187: "também comete ato ilícito o titular de um direito que, ao exercê-lo, excede manifestamente os limites impostos pelo seu fim econômico ou social, pela boa-fé ou pelos bons costumes".

1018 Rizzatto Nunes. Curso..., cit., p. 494 e 498. Para Marília Mazon (O controle..., cit., p. 251), trata-se do chamado "dano publicitário".

${ }^{1019}$ Lucia Ancona. Publicidade..., cit., p. 164.

1020 Tome-se emprestado a Lucia Ancona (idem, p. 168) o exemplo da abordagem de questões ligadas à sexualidade: “(...) entre aqueles atingidos pela mensagem publicitária que, a depender do veículo escolhido, podem ser muitos ou poucos, público específico (ex.: revista Playboy), ou massa de consumidores (ex.: televisão). $\mathrm{O}$ padrão de sexualidade de uma publicidade dirigida ao público específico poderá (e deverá) ser diferente quando analisado em revista ou mídia de ampla circulação ou de acesso a crianças".

${ }^{1021}$ Walter Ceneviva. Publicidade..., cit., p. 128. No mesmo sentido Marília Mazon (O controle..., cit., p. 247): “(...) o risco avaliado é sempre coletivo, social, difuso, de interesse da sociedade e da coletividade, de ordem pública. Não há menção ao campo individual, isolado, específico, pois o caráter é muito subjetivo ao verificar a abusividade perante uma só pessoa”.
} 
quanto mais distante estiver o aplicador da norma da realidade e dos parâmetros médios vigentes, mais próximo da censura irracional ele se postará". ${ }^{1022}$

Considerações individuais ${ }^{1023}$ não podem ser a pedra de toque para a tutela da coletividade ${ }^{1024}$, pena de se transformarem em desmedida censura ${ }^{1025}$, a afrontar o equilíbrio tão caro ao Código (supra, Cap. III, 4), considerando que a publicidade, a despeito da sua indeclinável função econômica no processo de circulação de bens e riquezas ${ }^{1026}$, também “encerra manifestação elaborada do intelecto humano em sons e imagens" ${ }^{1027}$ protegida pela liberdade de expressão (CF, arts. 5º IV e IX, c.c. 220).

\subsubsection{Publicidade comparativa}

${ }^{1022}$ Lucia Ancona Lopez Magalhães dias. Publicidade..., cit., p. 165.

1023 Neste precedente o TJSP afastou a pretensão reparatória de danos morais por considerar "que a sensibilidade das autoras se destoa da sensibilidade média". Eis a ementa do julgado: "INDENIZAÇÃO. Dano moral causado por propaganda publicitária, sugerindo que a leitura da revista da apelada tornaria a pessoa mais inteligente, à medida que a mulher da enquête, enquanto foliava a revista, deixava de ser 'loira' e tornava-se 'morena'. Estereótipo da 'loira burra'. Ausência de demonstração do dano. Sentença de improcedência confirmada" (AC 994.05.081591-3, rel. Paulo Alcides, j. 25.03.2010).

${ }^{1024}$ O Des. Unias Silva (TJMG, AC 4585904-26.20000.8.13.0000, j. 02.06.2005), ao relatar a apelação interposta pelo Movimento das Donas de Casa e Consumidores de Minas Gerais, na Ação Civil Pública promovida em face da AMBEV e de empresa de publicidade, contra sentença que não lhe reconheceu, no caso, interesse de agir, ressaltou: “(...) tenho que a questão posta sob apreciação é bastante complexa, já que de caráter absolutamente subjetivo. Isso porque a mensagem que se pretende transmitir depende, na verdade, da interpretação pessoal de cada consumidor, não sendo certo afirmar, com absoluta certeza, que a intenção da empresa que criou o referido comercial seria associar as imagens dos objetos circulares apresentados no filme publicitário ao êxito sexual. Sobre esta questão, esclareceu com acuidade o douto Magistrado, valendo aqui transcrição de trecho da sentença: 'Ora, funciona a arte da publicidade ao sabor da interpretação daquele que a assiste. Agora, dizer que a intenção da empresa que criou o comercial é associar os objetos circulares que apresenta o filme a êxito sexual e ou maior sexualidade é tentar a autora fazer prevalecer o seu entendimento em detrimento de milhões de consumidores que recebem o impacto da publicidade de modo diverso e não vêem nela qualquer conotação de êxito sexual e ou maior sexualidade. (...) Além do mais, gera perplexidade o fato de a autora dar exegese sponte sua daquilo que a propaganda pretende transmitir ao consumidor, porque se sequer conhece ela o briefing que foi passado pela empresa dona do produto à agência detentora de sua conta para determinar a criação da publicidade e, é bom dizer que a propaganda não se confunde com publicidade, posto que aquela visa fim ideológico e esta visa fim comercial'. Junte-se a isso o fato de o pedido formulado ir de encontro ao permissivo constitucional (CF/88) que disciplina a liberdade de expressão (...)"

${ }^{1025}$ Lucia Ancona Lopez Magalhães dias. Publicidade..., cit., p. 178.

1026 Destaca Vital Serrano Nunes Júnior (Publicidade comercial..., cit., p. 161) que "o eventual caráter artístico não desnatura a essência econômica da publicidade comercial, que, enquanto função de venda, tem no mercado de consumo o destinatário de sua atenção. Arredada de sua finalidade econômica, sequer chegaria a existir. Assim, eventual criação artística que nela se encontre nada mais é do que mero instrumento da ação publicitária, que objetiva fazer atual referida finalidade econômica".

${ }^{1027}$ Lucia Ancona Lopez Magalhães dias. Publicidade..., cit., p. 38. 
A abordagem da publicidade abusiva, com frequência, toca o modo comparativo de abordagem publicitária; contudo, per se, esta técnica não é ilícita. ${ }^{1028}$ Esclarece Antonio Herman de Vasconcellos e Benjamin que "a publicidade comparativa, além dos princípios gerais que informam toda a atividade publicitária, tem algumas exigências particulares. Em primeiro lugar, o seu conteúdo deve ser objetivo, não se admitindo a comparação que seja excessivamente geral. A comparação deve ser feita entre elementos essenciais e verificáveis. Em segundo lugar, a comparação deve ser exata (aplicação específica do princípio da veracidade)" ${ }^{1029}$

O Código Brasileiro de Autorregulamentação Publicitária (art. 32, "b") admite a publicidade comparativa, dês que "tenha por princípio básico a objetividade na comparação, posto que os dados subjetivos, de fundo psicológico ou emocional, não constituem uma base válida de comparação perante o Consumidor". É, portando, essa natureza objetiva ${ }^{1030}$ que impede subjetivismos ${ }^{1031}$ desprovidos de sustentação, quase sempre com viés depreciativo. ${ }^{1032}$

1028 “A propaganda comparativa, plenamente admitida, não bastasse alimentar a livre concorrência, sempre salutar e benéfica ao consumidor, seu alvo número um, conta com garantia constitucional (art. 170, IV) e previsão no Código Brasileiro de Auto-Regulamentação Publicitária (art. 32), ostentando, portanto, manto de legalidade. Destarte, enquanto não sugerir ou insinuar ofensa, não denegrir a marca ou produto comparado e observar a ética, não pode ser coarctada em respeito à liberdade publicitária. Gerar experimentação e conhecimento através de divulgação comparativa não impõe afronta ao disposto no artigo 32 do Código de Auto-Regulamentação Publicitária, cujo objetivo maior é esclarecer o consumidor, sem utilizar injustificadamente a imagem comparativa. Prematuro e inoportuno afirmar desde logo prática de concorrência desleal ou desprestígio e ataque à imagem do produto utilizado para comparação da marca. Contudo, presença dos requisitos legais autorizavam a antecipação de tutela deferida, diante da dinâmica da publicidade ilustrada nos autos" (TJSP, AI 490.413.4/0-00, rel. Francisco Casconi, j. 14.02.2007).

${ }_{1029}$ Et alii. Código Brasileiro de Defesa do Consumidor..., $10^{\mathrm{a}}$ ed., cit., p. 361.

1030 "CONCORRÊNCIA DESLEAL - Propaganda comparativa - Produtos apresentados ao público em suposta concorrência, com a colheita de opiniões de consumidores com apoio apenas em opiniões pessoais e juízos de valor sobre gosto ou preferência - Violação dos princípios da livre concorrência - Denegrição do produto concorrente e probabilidade de causar confusão no espírito do consumidor - Pedido de vedação à repetição da publicidade atendido - Danos materiais e morais configurados - Apuração dos primeiros mediante liquidação por artigos, e não mediante cálculo do contador, como ordenado, fixados os segundos na decisão que definir os primeiros - Nulidade da sentença, nesse ponto, inexistente - Sentença parcialmente reformada, com observação" (TJSP, AC 0063180-93.2000.8.26.0000, rel. João Calos Saletti, j. 03.05.2011). 1031 "Os fatos comprováveis distinguem-se das opiniões pessoais e dos juízos de valor. Os primeiros dizem respeito a determinadas circunstâncias de consenso generalizado, por isso, podem ser provados. As opiniões pessoais e os juízos de valor não podem ser comprovados porque não trazem o conteúdo de falsidade ou verdade, assim, exprimem subjetivamente um gosto, uma preferência, uma impressão sem análise mais detida dos fatos, ou na ausência de conhecimento técnico científico, sem apuração efetiva da realidade" (Marco Antonio Marcondes Pereira. Concorrência desleal por meio da publicidade. São Paulo: Juarez de Oliveira, 2001, p. 106/107)

1032 "Esses atos (entre os quais insinuação quanto à qualidade inferior ou a defeitos) assumem, em face do respectivo vulto, ênfase especial no âmbito da publicidade, em que anúncios falsos ou abusivos podem derrear a reputação, o crédito ou a confiança do mercado em relação a determinado produtor, comerciante ou profissional de serviços. Assim, por exemplo, tem sido profligada, em especial, a comparação depreciativa indicada expressamente, ou de forma perceptível - com o nome, com a figura ou com os produtos do 
Para Rizzatto Nunes, à evidência à luz dos princípios informadores e condicionantes da parte geral do $\mathrm{CDC}$, algumas regras devem ser cumpridas pelo anunciante que se vale dessa técnica de abordagem: “a) o fim da comparação deve ser o esclarecimento e/ou a defesa do consumidor; b) a comparação deve ser feita de formam objetiva, evitando o uso de alusões de caráter subjetivo, e deve ser passível de ser comprovada; c) os modelos a serem comparados devem ter a mesma idade, tendo sido produzidos no mesmo ano. A comparação entre modelos de épocas diferentes só é possível se se pretender demonstrar evolução, que deve ficar claramente caracterizada; d) não pode estabelecer confusão entre produtos, serviços e marcas concorrentes; e) não pode caracterizar concorrência desleal nem denegrir a imagem do produto, serviço ou marca concorrente; f) não pode utilizar injustificadamente a imagem corporativa ou o prestígio de terceiros; g) se se tratar de comparação entre produto e serviço cujo preço seja de nível desigual, tal circunstância deve ser claramente indicada". ${ }^{1033}$

E concluiu o Min. Benjamin"1034 que "a tendência atual é no sentido de permitir a publicidade comparativa desde que ela seja objetiva, isto é, que se mostre sem enganosidade ou abusividade, confrontando dados e características que não sejam de apreciação exclusivamente subjetiva". ${ }^{1035}$

\subsection{Contrapropaganda}

$\mathrm{Na}$ sua redação original o art. 37 do CDC trazia um $4^{\circ} \S$, vetado pelo Presidente da República, in verbis: "quando o fornecedor de produtos ou serviços se utilizar de publicidade enganosa ou abusiva, o consumidor poderá pleitear indenização por danos sofridos, bem como a abstenção da prática do ato, sob pena de execução específica, para o caso de inadimplemento, sem prejuízo da sanção pecuniária cabível e de contrapropaganda, que pode ser imposta administrativa ou judicialmente”.

concorrente, desde que, em publicidade, a pregação genérica de superioridade do próprio produto - direta ou indireta - é admitida como natural. Veda-se, pois, a publicidade comparativa depreciativa, com apregoações ou insinuações negativas sobre o concorrente" (Carlos Alberto Bittar. Teoria e prática da concorrência desleal. São Paulo: Forense Universitária, 2005, p. 56/59).

${ }^{1033}$ Curso..., cit., p. 498.

${ }^{1034}$ Et alii. Código Brasileiro de Defesa do Consumidor..., $10^{\text {a }}$ ed., cit., p. 362.

1035 “Ação cominatória por concorrência desleal - Propaganda enganosa. A propaganda comparativa entre escolas de língua inglesa somente se mostra enganosa ou falsa, de modo a configurar a concorrência desleal, quando fornecer informações incorretas ou difamar os concorrentes intencionalmente. Apelação desprovida" (TJRS, AC 599025921, rel. Jorge Luis Dall'Agnol, j. 15.06.1999). 
Interessa, agora, definir se o veto presidencial reservou à contrapropaganda apenas uma essência de medida meramente administrativa (CDC, arts. 56 , XII ${ }^{1036}$, c.c. $\left.60^{1037}\right)$, não judicial. A resposta há de ser negativa.

Antônio Herman de Vasconcellos e Benjamin, qualificando o instituto como "terror de qualquer anunciante", destaca que "seu objetivo é fulminar a força persuasiva da publicidade enganosa ou abusiva, mesmo após a cessação de sua veiculação”. E prossegue: “a expressão é, sem dúvida, inadequada. Dever-se-ia falar em contrapublicidade e não em contrapropaganda. O uso, contudo, impôs em detrimento da técnica. A contrapropaganda nada mais é que uma publicidade obrigatória e adequada que se segue a uma publicidade voluntária, enganosa ou abusiva. Seu objetivo é 'lavar' a informação inadequada da percepção do consumidor, restaurando, dessa forma, a realidade dos fatos". 1038

Sendo quase sempre impossível desfazer todo o mal causado pelo anúncio enganoso e/ou abusivo, é viável remediá-lo com a contrapropaganda ${ }^{1039}$, único instrumento capaz de minimizar/neutralizar a captação residual pretérita consumada e de evitar, eficazmente, enganos ou abusos futuros. ${ }^{1040}$

A problemática sub examine teve seus contornos bem delineados por Cláudia Lima Marques nos seus Comentários:

"Ilícito civil. Sanção. Contrapropaganda: Além da sanção normalmente cominada ao ato ilícito e da imposição de abstenção do ato danoso, o art. 37 continha, em seu $\S 4^{\circ}$, vetado pelo Presidente da República, uma importante inovação, a possibilidade de o Poder Judiciário condenar o fornecedor a fazer veicular uma contrapropaganda, às suas expensas. Com o veto, a contrapropaganda permanece prevista como sanção administrativa, no art. 56, XII, do CDC. A questão não está, porém, resolvida totalmente, pois parte da doutrina

\footnotetext{
${ }^{1036}$ CDC, art. 56, XII: “as infrações das normas de defesa do consumidor ficam sujeitas, conforme o caso, às seguintes sanções administrativas, sem prejuízo das de natureza civil, penal e das definidas em normas específicas: (...) XII - imposição de contrapropaganda”.

${ }^{1037}$ CDC, art. 60: "a imposição de contrapropaganda será cominada quando o fornecedor incorrer na prática de publicidade enganosa ou abusiva, nos termos do art. 36 e seus parágrafos, sempre às expensas do infrator. $\S 1^{\text {o: }}$ "a contrapropaganda será divulgada pelo responsável da mesma forma, frequência e dimensão e, preferencialmente no mesmo veículo, local, espaço e horário, de forma capaz de desfazer o malefício da publicidade enganosa ou abusiva".

${ }^{1038}$ Et alii. Código Brasileiro de Defesa do Consumidor..., $10^{\mathrm{a}}$ ed., cit., p. 370.

${ }^{1039}$ Luiz Antonio Rizzatto Nunes. Curso..., cit., p. 484 e 500.

1040 Antônio Herman de Vasconcellos e Benjamin et alii. Código Brasileiro de Defesa do Consumidor..., 10 ${ }^{\mathrm{a}}$ ed., cit., p. 371.
} 
defende a possibilidade de o Judiciário, em interpretação sistemática do CDC, impor a sanção da contrapropaganda judicialmente. Os efeitos civis da publicidade, como frisamos, são totalmente novos e as reflexões sobre o tema estão apenas começando no Brasil. A importância do tema e o interesse dos profissionais do ramo prometem uma evolução rápida."1041

Ora, da mesma forma que seria insustentável emprestar ao veto presidencial força tamanha a impedir o consumidor submetido à publicidade enganosa e/ou abusiva de pleitear indenização pelos danos que tais práticas lhe impuseram, em nítida afronta à inafastabilidade da jurisdição $\left(\mathrm{CF}\right.$, art. $\left.5^{\circ} \mathrm{XXXV}\right)$, não há como retirar do Poder Judiciário o manejo da contrapropaganda, ferramenta de grande valia na busca da efetividade da tutela protetiva do Código. ${ }^{1042}$

As normas condicionantes dispostas na Parte Geral do CDC, neste tópico, outra vez, ganham especial importância, pois conduzem o operador à única interpretação consentânea com esse especial microssistema, sobretudo em razão do tônus prevalecente cominatório da imposição da contrapropaganda (CDC, art. 84, § $\left.5^{\circ}\right)$.

E adita Rizzatto Nunes: "a imposição dessa penalidade decorre das medidas judiciais à disposição do magistrado para a proteção dos consumidores, uma vez que é intenção da lei consumerista dar ampla tutela para a garantia dos consumidores". 1043

$\mathrm{O}$ veto presidencial, portanto, nada alterou no sistema de proteção do consumidor em juízo, do qual também a contrapropaganda é peça fundamental, até porque "a publicidade leal e sem engodos, dizendo efetivamente o que o produto contém, sem iludir o consumidor, sequer depende de decisão judicial". ${ }^{1044}$

\subsection{Responsabilidade civil}

\footnotetext{
${ }^{1041}$ Et alii. Comentários..., cit., p. 738.

1042 CDC, art. 83: "para a defesa dos direitos e interesses protegidos por este Código são admissíveis todas as espécies de ações capazes de propiciar sua adequada e efetiva tutela".

${ }^{1043}$ Curso..., cit., p. 484.

1044 "RECURSO - Apelação - Agravo contra decisão que recebeu apelações interpostas junto à ação civil pública apenas no efeito devolutivo - Sentença que julgou parcialmente procedente a ação - Cabimento do efeito devolutivo apenas quanto à determinação de se realizar a contrapropaganda - Decisão parcialmente reformada - Recurso parcialmente provido" (TJSP, AI 0046884-10.2011.8.26.0000, rel. Álvaro Passos, j. 15.06.2011). No mesmo sentido: "a contrapropaganda apresenta-se como medida necessária e adequada a restaurar, na mente da massa consumidora e frente à concorrência, a realidade dos fatos. Trata-se, pois, de mecanismo destinado a 'fulminar a força persuasiva da publicidade enganosa ou abusiva, mesmo após a
} 


\section{A premissa desse tópico vem com Lucia Ancona: "a}

configuração da publicidade ilícita, nas suas diferentes modalidades, enganosa ou abusiva, enseja o dever de reparação dos eventuais danos causados. Estes danos podem ser, em relação aos sujeitos que sofrem a lesão, individuais ou coletivos, e no que tange à natureza da lesão, materiais e/ou morais". 1045

Exceção alguma existe aqui ${ }^{1046}$, a prevalecer a essência objetiva que informa todo o microssistema do CDC e, conseguintemente, lembrando que basta o dano potencial em matéria de publicidade ilícita, é o viés da responsabilidade sem culpa do fornecedor-anunciante.

Nessa linha orienta o E. STJ, intérprete soberano da legislação federal, ao considerar que a publicidade enganosa caracteriza dano extrapatrimonial indenizável ${ }^{1047}$, com responsabilidade solidária inclusive. ${ }^{1048}$

cessação de sua veiculação' (idem, p. 314), ou seja, a captação pretérita já consumada" (TJSP, AC 994.07.099802-5, rel. Elcio Trujillo, j. 09.06.2010).

${ }^{1045}$ Publicidade..., cit., p. 279.

1046 "Impossibilidade de efetuar ligações gratuitas no período noturno indicado em promoção publicitária em virtude de congestionamento previsível de serviço. Promoção de Natal a qual irrompe aumento considerável de clientes, à vista das vantagens oferecidas pela concessionária de telefonia móvel, mostra-se hábil a determinar a necessária responsabilidade civil no tocante ao vício do serviço verificado. Problemas previsíveis e que determinaram inadequada prestação do serviço propagandeado. Dever de indenizar patente. Dano 'in re ipsa'. Dano moral evidenciado ante a angústia, frustração e indignação dos clientes aderentes a plano de serviços, cuja prestação mostrou-se notoriamente insatisfatória" (TJRS, AC 70021650627, rel. Odone Sanguiné, j. 20.02.2008).

${ }^{1047}$ STJ, AgRg no Ag 1.045.667/RJ, rel. Min. Aldir Passarinho Junior, j. 17.03.2009. No mesmo sentido: "ora, está evidente que foi divulgada ao público propaganda ao consumidor, que levou o apelante a comparecer ao estabelecimento da recorrida, sendo óbvio que devem existir outros supermercados na região, mas que em razão da promoção foi induzido em lá comparecer para compra dos produtos em promoção e certamente, outras mercadorias o que revela que houve divulgação de propaganda enganosa, já que induziu a erro o consumidor. Registre-se aqui que no exemplar acostados aos autos (fls. 10), ficou categoricamente demonstrado oferta de produtos em promoção, garantindo a quantidade mínima de 5 (cinco) unidades por loja dos produtos anunciados do dia 11 a 13/10/2007 ou enquanto durarem os estoques. O que se verifica, é que estoque do produto, tinha a loja, sendo-lhes negado a permissão para levar a quantidade ofertada no panfleto, o que acarretou o dano, evidenciando o dever de indenizar. Dessa forma, tenho que configurado está o dano. Patente a culpa do réu pelo evento, pois divulgou oferta de produtos em promoção, garantindo a quantidade mínima incutindo na mente do consumidor uma possibilidade inexistente. Os danos morais suportados pelo autor decorrem exatamente dessa total falta de possibilidade de adquirir tais produtos. Suplantam em muito um simples aborrecimento ou frustração. Com panfleto em mãos e poder aquisitivo para adquirir os produtos, ora ofertados, recebeu uma negativa sem justificativa. O sentimento de ver-se enganado, com publicidade enganosa, não poderia acontecer" (TJSP, AC 990.10.017305-7, rel. Salles Rossi, j. 30.06.2010). "Nos termos do Código de Defesa do Consumidor, o fornecedor responde pela propaganda levada ao público, cujos termos vincula. É devida a indenização por danos morais àquele que, em virtude de propaganda enganosa, fui induzido a erro e ludibriado na celebração do contrato, em razão do qual teve, inclusive, seu nome incluído nos cadastros de proteção ao crédito indevidamente" (TJMG, AC 1.0145.08.435047-2/001, rel. Márcia de Paoli Balbino, j. 11.03.2010).

${ }^{1048}$ STJ, REsp n ${ }^{\circ}$ 327.257/SP, rel. Min. Nancy Andrighi, j. 22.06.2004. 
E se a publicidade difundida no mercado se projeta sobre pessoas indeterminadas, titulares de direitos indivisíveis, ligadas apenas pela circunstância fática de terem recebido a informação enganosa, evidente se revela o dano moral difuso. Da mesma forma, segundo Lucia Ancona, "não se vislumbra a possibilidade de um dano moral individual decorrente da simples veiculação da publicidade"1049, efeito liberatório do fornecedor-anunciante que não se identifica na mensagem abusiva, per se, capaz de tisnar a espera extrapatrimonial do consumidor, individualmente considerado, apenas por estar ele submetido à sua abordagem publicitária antiética.

Ter-se-ia, aqui, uma modalidade de dano in re ipsa ${ }^{1050}$, conquanto na análise da sua ocorrência deva o Poder Judiciário ater-se à ponderação dos valores atingidos a partir de um senso coletivo médio, genericamente disperso no âmbito social, não daquele que se diz vítima, ou seja, “demonstrando que a violação da ordem pública, valores éticos, morais, etc., não está apenas em sua opinião isolada, mas na da maioria da comunidade". ${ }^{1051}$

“Observe-se, de outro lado, que quando estamos a tratar de tutela coletiva, a constatação da potencialidade de indução em erro dos destinatários da publicidade ou a demonstração de seu efetivo conteúdo abusivo já se mostra suficiente para ensejar o dano moral difuso. Isto ocorre ainda que não se demonstre ou comprove o exaurimento dos danos sofridos pelos consumidores.

1049 Publicidade..., cit., p. 282.

${ }^{1050} \mathrm{O}$ qual, segundo Carlos Alberto Bittar (Reparação Civil por Danos Morais. 2a Ed. São Paulo: RT, 1994, p. 203/204), despreza “(...) a investigação do subjetivo do ofensor (dolo ou culpa), visto que basta a lesão em si mesma. Evidenciada a conduta lesiva, ou definida objetivamente sua repercussão negativa, surge a obrigação de reparar. $\mathrm{O}$ dano moral existe no próprio fato violador dos direitos da personalidade da vítima (ex facto), impondo a necessidade de resposta, que na reparação se efetiva. É o que se denomina damnum in re ipsa". E do STJ colhem-se os seguintes excertos: "a jurisprudência desta Corte está consolidada no sentido de que na concepção moderna da reparação do dano moral prevalece a orientação de que a responsabilização do agente se opera por força do simples fato da violação, de modo a tornar-se desnecessária a prova do prejuízo concreto (STJ, REsp 196.024/MG, rel. Min. César Asfor Rocha, j. 02.03.1999). "como se trata de algo imaterial ou ideal, a prova do dano moral não pode ser feita através dos mesmos meios utilizados para a comprovação do dano material. Por outras palavras, o dano moral está ínsito na ilicitude do ato praticado, decorrente da gravidade do ilícito em si, sendo desnecessária sua efetiva demonstração, ou seja, como já sublinhado: o dano moral existe in re ipsa. (STJ, REsp 608.918/RS, rel. Min. José Delgado, j. 20.05.2004).

${ }^{1051}$ Paulo Jorge Scartezzini Guimarães. A publicidade ilicita e a responsabilidade civil das celebridades que dela participam. 2a ed. São Paulo: RT, 2007, p. 183. E pensa Lucia Ancona (Publicidade..., cit., p. 283): “não podemos de qualquer modo afastar, a priori, o teor do art. $6^{\circ}$, VI, do CDC para o caso de eventuais danos individuais por publicidade abusiva, embora devamos concordar que não parece fácil demonstrar que certa publicidade violou algum valor da sociedade como um todo, sendo atingido, também e diretamente, o consumidor individual. Poder-se-ia imaginar ainda danos individuais (patrimoniais e/ou morais) em decorrência de publicidade abusiva que incita à adoção de comportamento perigoso ou prejudicial à saúde e à segurança e que venha a ser reproduzido pelo consumidor, provocando danos à sua integridade física". 
São situações em que a verificação de violação da norma proibitiva faz surgir o dano". 1052

É dizer: a simples divulgação de uma mensagem ilícita (clandestina, enganosa ou abusiva) causa, de forma geral e abstrata, dano extrapatrimonial a todos aqueles que a ela foram expostos, fato lesivo autorizante de reparação pecuniária e/ou de publicidade corretora (contrapropaganda). ${ }^{1053}$

Mas quem responde, independentemente da existência de culpa, por esses danos (individuais e/ou coletivos)? Este encargo é exclusivo do fornecedor-anunciante?

Afora a indiscutível responsabilidade objetiva do fornecedoranunciante, exclusiva quanto ao cumprimento compulsório da oferta ${ }^{1054}$, decorrência do princípio da vinculação, cumpre verificar a situação jurídica de outros três sujeitos envolvidos no processo de gênese da publicidade ilícita: a agência, o veículo de comunicação e as celebridades que a apresentam.

Divide-se a doutrina, aqui, em três principais orientações. A primeira corrente, de essência restritiva, como autor do ato de aprovação da campanha, de modo exclusivo, relega ao anunciante essa responsabilidade. ${ }^{1055}$

\footnotetext{
${ }^{1052}$ Lucia Ancona Lopez Magalhães Dias. Publicidade..., cit., p. 283.

${ }^{1053}$ Rui Moreira Chaves. Código da publicidade anotado. $2^{\mathrm{a}}$ ed. Coimbra: Almedina, 2005, p. 162.

1054 "Verifica-se, portanto, que a inserção de propaganda em programas de televisão, particularmente nas apresentações 'ao vivo', é, presentemente, praxe comum, ditada pelas exigências de um mercado dinâmico e mutante. Isso, todavia, não tem absolutamente o condão de modificar a natureza da coisa. Ela é o que é: uma propaganda. E, como tal, há de se distinguir o anunciante, do veículo de mídia que divulga o anúncio. A responsabilidade pelo produto ou serviço anunciado é daquele que o confecciona ou presta, e não se estende à televisão, jornal ou rádio que o divulga. A participação do apresentador, ainda que este assegure a qualidade e confiabilidade do que é objeto da propaganda, não o torna garantidor do cumprimento das obrigações pelo anunciante. A tese sufragada pelo acórdão a quo está em atribuir à emissora de televisão uma parceria, um coempreendedorismo que não existe nem em contrato, nem na lei. Os jornais, revistas, rádio e televisão têm despesas elevadas e auferem sua receita da propaganda que veiculam. Não são instituições bancárias e financeiras, operadoras de cartões de crédito, de telefonia, fábricas de automóveis, de produtos de beleza e vestuário, empresas de aviação, planos de saúde, etc. Esses anunciam, e as empresas de comunicação, por seus veículos, publicam ou transmitem os anúncios. Destarte, a denominada 'publicidade de palco' não implica a corresponsabilidade da empresa de televisão pelo anúncio divulgado. E o apresentador está, ali, como se dizia no passado, atuando como 'garoto-propaganda', e não na qualidade de avalista formal, por si ou pela empresa de comunicação, do êxito do produto ou serviço para o telespectador que vier no futuro a adquiri-los. (...) Verifica-se, portanto, que a alegada falha diz respeito ao produto caracterizado pelo empréstimo e à prestação do serviço de concessão do mútuo, de responsabilidade da $2^{\mathrm{a}}$ ré, Megainvest, que é a instituição financeira contratada, e só ela, para a operação creditícia, atividade, inclusive, inteiramente alheia ao objeto social da $1^{\mathrm{a}}$ ré. A $1^{\mathrm{a}}$ ré, Rádio e Televisão Bandeirantes Ltda, atuou, via 'publicidade de palco', exclusivamente como veiculadora da propaganda, nada além” (STJ, REsp 1.157.228/RS, rel. Min. Aldir Passarinho Júnior, j. 03.02.2011).
}

${ }^{1055}$ Fábio Ulhoa Coelho (O empresário..., cit., p. 291). 
O E. STJ, amparado em três vigas medulares, perfilhou essa linha de raciocínio no julgamento do REsp 604.172/SP: a) os deveres impostos nos capítulos da oferta e publicidade somente atingem os veículos de propaganda, comunicação e anúncios quando estejam eles na condição de fornecedores; b) o art. 38 do CDC exclui a responsabilidade dos veículos de comunicação por eventual publicidade enganosa ou abusiva, pois o ônus de provar a veracidade e correção (ausência de abusividade) é do fornecedor-anunciante, que patrocina a propaganda ou anúncio ${ }^{1056}$ e c) não é dever dos veículos de comunicação apurar, em princípio, a veracidade ou a abusividade do anúncio contratado, pois esse ônus é do fornecedor-anunciante. ${ }^{1057}$

$\mathrm{Na}$ segunda, denominada pelo Min. Benjamin de responsabilidade solidária limitada, só haverá a responsabilização civil da agência e do veículo se e quando agirem com dolo ou culpa ${ }^{1058}$. Se presente o elemento subjetivo, a solidariedade exsurgiria inexoravelmente.

A terceira, com base nos comandos dos arts. $7^{\circ}$, par. ún., e 25 , $\S 1^{\mathrm{o}}$, do CDC, visualiza uma responsabilidade solidária e objetiva entre todos os envolvidos na cadeia do anúncio: o fornecedor, a agência, o veículo e a celebridade que apresenta o produto ou o serviço. ${ }^{1059}$

${ }^{1056}$ A propositura não está inteiramente correta, pois o art. 27 do CBRARP - que integra o arcabouço jurídico de defesa do consumidor (art. $7^{\circ}$, caput) - relega também às agências, quando solicitadas, o ônus de fornecer as comprovações da veracidade de conteúdo da mensagem publicitária.

1057 "O CDC, foi concebido para regular a relação de consumo estabelecida entre aqueles que se enquadrem como consumidores (Art. $2^{\circ}$ e par. único) e fornecedores (Art. $3^{\circ}$ ). Assim, é que o Código, especialmente nos capítulos da oferta e publicidade, impõe deveres ao fornecedor-anunciante (Art. $3^{\circ}$ ) e não aos veículos de comunicação, propaganda e anúncios.

Então, os deveres impostos nos capítulos da oferta e publicidade somente atingem os veículos de propaganda, comunicação e anúncios quando estejam na condição de fornecedores. O Art. 38 do Código protecionista diz que 'os ônus da prova da veracidade e correção da informação ou comunicação publicitária cabe a quem as patrocina'. Portanto, o Art. 38 exclui a responsabilidade dos veículos de comunicação por eventual publicidade enganosa ou abusiva, pois o ônus de provar a veracidade e correção (ausência de abusividade) é do fornecedor-anunciante, que patrocina a propaganda ou anúncio, tanto que o Art. 36 impõe que mantenham, em próprio poder, os dados fáticos, técnicos e científicos que dão sustentação à mensagem para informação dos legítimos interessados. (...) Não é dever dos veículos de comunicação apurar, em princípio, veracidade ou abusividade do anúncio contratado, pois esse ônus é do fornecedor-anunciante, que poderá responder pelo patrocínio da eventual publicidade enganosa ou abusiva, na forma do Art. 38 do CDC. Em suma: os veículos de comunicação não respondem por eventual publicidade abusiva ou enganosa. Tal responsabilidade toca aos fornecedores-anunciantes, que a patrocinaram (CDC, Arts. $3^{\circ}$ e 38 ). O Art. $6^{\circ}$ relaciona direitos básicos do consumidor frente ao fornecedor, o que não vincula os veículos de propaganda perante os consumidores dos produtos ou serviços anunciados. Daí que o consumidor, ou quem o possa representar, deve reivindicar tais direitos perante os fornecedores-anunciantes" (STJ, REsp 604.172/SP, rel. Min. Humberto Gomes de Barros, j. 27.03.2007).

${ }^{1058}$ Et alii. Código Brasileiro de Defesa do Consumidor..., $10^{\mathrm{a}}$ ed., cit., p. 370.

${ }^{1059}$ Paulo Jorge Scartezzini Guimarães. Publicidade ilícita..., cit., p. 170. 
Nenhuma das três - isoladamente - serve, pois não atendem ao complexo e tênue equilíbrio imposto pela condicionante Parte Geral do Código. O adequado ponto de partida para bem compreender a quaestio é identificar "a situação de cada agente envolvido na celebração e divulgação da publicidade de modo a avaliarmos suas diferentes responsabilidades". 1060

O fornecedor-anunciante, no comum das coisas, só aprova campanha estruturada por uma agência ou por um publicitário, profissional técnico da publicidade ${ }^{1061}$, subordinada aos preceitos éticos do Código Brasileiro de Autorregulamentação Publicitária (CBARP) ${ }^{1062}$; daí porque sua atuação no mercado atrai o dever (jurídico e moral) de ser o primeiro juiz da licitude da mensagem ${ }^{1063}$, a qual deu vida e forma ${ }^{1064}$, visto que certamente tem, ou no mínimo deveria ter, instrumentos que isso lhe permitissem, inclusive se negando a trabalhar caso fosse exigida a confecção de mensagem clandestina, enganosa ou abusiva.

Se assim não age, seja por dolo, seja por culpa (é irrelevante perquirir), caracterizado estará o ato próprio autorizante da sua responsabilidade objetiva e solidária com o seu parceiro de negócio, o fornecedor-anunciante.

O veículo de comunicação ${ }^{1065}$, por sua vez, não pode só retirar os bônus da mensagem publicitária (ubi commodum, ibi incommodum ou ubi emolumentum, ibi onus), que dele depende na origem ${ }^{1066}$, como se pudesse ignorar certos

\footnotetext{
${ }^{1060}$ Lucia Ancona Lopez Magalhães Dias. Publicidade..., cit., p. 302.

1061 Lei 4.680/65, art. 3: "pessoa jurídica especializada na arte técnica publicitária, que, através de especialistas, estuda, concebe, executa e distribui a propaganda aos veículos de divulgação, por ordem e cona dos clientes anunciantes, com o objetivo de promover a venda de produtos e serviços, difundir ideias ou informar o público a respeito de organizações ou instituições colocadas a serviço desse mesmo público".

1062 CBARP, art. 45, "b": "a responsabilidade pela observância das normas de conduta estabelecidas neste Código cabe ao Anunciante e a sua Agência, bem como ao Veículo, ressalvadas no caso deste último as circunstâncias específicas que serão abordadas mais adiante, neste artigo: (...) 'b'. a Agência deve ter o máximo cuidado na elaboração do anúncio, de modo a habilitar o Cliente Anunciante a cumprir sua responsabilidade, com ele respondendo solidariamente pela obediência aos preceitos deste Código (...)".

${ }^{1063}$ É que "o anúncio (lato sensu) deve estar inserido harmonicamente nos ditames das leis e das formas secundárias de expressão do direito (costumes, ética, etc.), além de salientarem os princípios da honestidade e da veracidade a que a mensagem publicitária deve se adequar" (Maria Luiza de Sabóia Campos. Publicidade: responsabilidade civil perante o consumidor. São Paulo: Cultural Paulista, 1996, p. 220).

${ }^{1064}$ Lucia Ancona Lopez Magalhães Dias. Publicidade..., cit., p. 302.

1065 Lei 4.680/65, art. 4º: "quaisquer meios de comunicação visual ou auditiva capazes de transmitir mensagens de propaganda ao público, desde que reconhecidos pelas entidades e órgãos de classe, assim considerados as associações civis locais e regionais de propaganda bem como os sindicatos de publicitários". ${ }^{1066}$ Ressalta Marília Mazon (O controle..., cit., p. 239) que: “(...) a publicidade possui dois elementos essenciais para cumprir sua função: a difusão que é seu meio de expressão e a informação, pois deve haver um conteúdo mínimo para atingir o consumidor. Logo, sem a difusão não há que se falar em publicidade, pois sem esta não há por parte do consumidor acesso à informação transmitida, descaracterizando sua finalidade de tornar o produto ou serviço conhecido ao consumidor, persuadindo-o a adquirir tal bem”.
} 
valores morais mínimos e fazer circular qualquer tipo de publicidade. Data venia do entendimento esposado pelo E. STJ, isso não é possível. Tais empresas, com ou sem despesas elevadas, o que só a elas interessa, tem sim - da mesma forma que as agências, com reduzido espectro de excludentes ${ }^{1067}$ - o dever jurídico e moral de não disseminarem à massa dos seus consumidores a ilicitude da campanha, o que atrai a sua responsabilização objetiva.

Noutras palavras: se o custo da publicidade difundida integra sua receita, o veículo de comunicação passa a ser fornecedor ante o destinatário da mensagem, não para cumprimento compulsório da oferta, mas no que tange à garantia de licitude do que encampa com a sua estrutura de penetração social, instrumento de contato com o público ${ }^{1068}$, circunstância atrativa da obrigação de verificar, tecnicamente, o conteúdo do anúncio. ${ }^{1069}$

Esse cuidado, por certo, não se equipara à censura prévia ${ }^{1070}$. Com ele, antes de se extinguir a difusão de mensagens em emissoras de rádio e televisão (e. g.), poder-se-ia contar com um eficiente filtro preventivo, a exigir uma nova concepção de responsabilidade, quase uma precaução, nas campanhas publicitárias. Agora, se o veículo preferir manter o anunciante ${ }^{1071}$, seja qual for o conteúdo da mensagem, a se

${ }^{1067}$ Luiz Antonio Rizzatto Nunes (Curso..., cit., p. 481 e 482), tanto em relação às agências quanto aos veículos de comunicação, anota duas excludentes de responsabilidade: a) se ilicitude não está objetivamente colocada no anúncio em si e b) se enganosidade depende da ação real, concreta e posterior do fornecedoranunciante, de maneira que tais sujeitos tenham atuado apenas como meros coadjuvantes da mensagem.

${ }^{1068}$ Luiz Antonio Rizzatto Nunes. Curso..., cit., p. 482.

1069 Para Maria Elizabete Vilaça Lopes (ob. cit., p. 182): “(...) a culpa do veículo terá de ser grave, como acontecerá na hipótese de divulgação de uma mensagem publicitária cuja falsidade seja evidente. O veículo não precisa se deter na consideração do abuso ou do engano, mas dele se exige um mínimo de cautela, um pouco de diligência".

1070 "O controle legal da publicidade não é forma inconstitucional de censura, mas instrumento eficaz para evitar-se abuso que possa ser cometido em detrimento dos direitos do consumidor" (Nelson Nery Júnior. Os princípios gerais..., cit., p. 67/70).

${ }^{1071}$ Luiz Antonio Rizzatto Nunes (Curso..., cit., 482 e 500) alerta: "mas a questão que se coloca é se o veículo pode negar-se a inserir em seu meio o anúncio que entenda ser enganoso ou abusivo. A resposta é, obviamente, sim. O anunciante e/ou sua agência não podem obrigar o veículo a praticar publicidade enganosa. Não só pelos aspectos civis da questão, mas também pelos morais e criminais. Não se deve esquecer que a prática da publicidade enganosa e abusiva está tipificada como crime na Lei $n^{\circ}$ 8.078/90". E prossegue (idem, p. 482/483 e 500/501) destacando que o veículo pode se negar "a veicular o anúncio em qualquer outro caso de ilegalidade e também naqueles previstos no Código Brasileiro de Autorregulamentação Publicitária, que são: a) quando entender que o seu conteúdo fere, flagrantemente, os princípios e regras da norma autorregulamentares; b) quando fira sua linha editorial, jornalística ou de programação; c) quando não tenha identificação do patrocinador, com exceção do teaser; d) de polêmica ou denúncia sem expressa autorização da fonte conhecida que responda pela autoria da peça". Na mesma linha, ao discorrer sobre o controle preventivo, Marília Mazon (O controle..., cit., p. 255) afirma que "(...) cabe ao anunciante e à agência publicitária seguir as normas de licitude e ainda ao veículo de comunicação, que pode verificar a qualidade e licitude da pela que irá veicular, podendo recusar-se a exibir mensagem de caráter enganoso ou abusivo". 
preocupar com o consumidor, que assuma as consequências do seu ato, pouco importando os supostos entraves que o respeito à ética pudessem causar à sua atividade econômica, lídimos res inter alios frente ao sujeito vulnerável. ${ }^{1072}$

Quanto às personalidades, com as mesmas observações feitas em relação às agências e aos veículos, não é possível admitir-se plena isenção daquele que empresta a sua imagem - geralmente conhecida e capaz de gerar confiança no espírito do consumidor - a uma publicidade que sabia ou deveria saber enganosa e/ou abusiva; contudo, a pedra de toque está no modo da sua atuação no anúncio. Se garantir certo resultado ou assegurar a existência de determinada propriedade do produto ou do serviço, como se testemunha de eficácia fosse, v.g., sem dúvida e sponte propria estará o "garoto propaganda" se erigindo à condição de fornecedor, restrito - é verdade - à ilicitude da mensagem que patrocina.

Mas a terceira corrente não pode ser aceita, aqui, de modo irrestrito. Isto porque essas pessoas, quase sempre artistas ou atletas, ao contrário das agências e dos veículos de informação, não têm na publicidade seu meio de vida, são anunciantes eventuais, não habituais; assim, deles não pode ser exigido um preparo técnico apto a permitir uma minuciosa investigação acerca da ilicitude da mensagem, quadro a ser analisado em cada caso concreto a partir do critério do consumidor razoavelmente atento e advertido, a atrair uma verificação do elemento subjetivo ${ }^{1073}$, afinal eles também integram a coletividade que se visa a proteger.

\subsection{A questão do speedy}

\footnotetext{
1072 Discorda-se, no particular, de Lucia Ancona Lopez Magalhães Dias (Publicidade..., cit., p. 304), para quem: “(...) os veículos são responsáveis em apenas difundir as mensagens publicitárias aos destinatários, não exercendo qualquer controle acerca de seu conteúdo. Trata-se apenas do meio pelo qual a mensagem alcança os consumidores, não havendo uma 'coautoria', no sentido da norma consumerista estudada, para a produção dos danos. Com efeito, podemos afirmar que não mais existiria patrocínio ou publicidade nas emissoras de televisão e demais veículos de comunicação se estes passassem a responder, objetiva e solidariamente, por todas as mensagens que veiculam diariamente. $\mathrm{O}$ argumento que se coloca de que incumbiria aos veículos 'checar e avaliar o conteúdo de cada mensagem' se mostra incompatível com a sua atividade e inexequível, haja vista a dinâmica dos negócios e do mercado concorrencial. Ademais, se admitíssemos um controle prévio por parte dos veículos para que estes avaliassem o conteúdo das mensagens antes de sua difusão, incorreríamos fatalmente na necessidade de censura prévia de determinados conteúdos publicitários, o que seria inadmissível no nosso ordenamento jurídico".

${ }^{1073}$ Sustenta Lucia Ancona Lopez Magalhães Dias (Publicidade..., cit., p. 306) que a responsabilidade dessas personalidades, profissionais liberais, é subsidiária e subjetiva (CDC, art. 14, $\S 4^{\circ}$ ); porém, dependente da prova de dolo ou de culpa grave.
} 
Pode-se dizer que a tecnologia da banda larga trouxe um significativo avanço ao cotidiano do usuário da rede mundial de computadores; no entanto, a um só tempo, como já identificado ${ }^{1074}$, ocasionou um problema jurídico em razão do modelo legal adotado no País para as telecomunicações.

Terceiras empresas, denominadas provedores, a partir de agora, ainda são necessárias?

A matéria sobre a legalidade da imposição desse contrato acessório é extremamente controvertida e abrange a definição do espectro de abrangência do art. $61, \S 1^{\circ}$, da Lei 9.472/97.

Nas linhas seguintes pretende-se demonstrar a ilegalidade e a abusividade desse procedimento, passando-se pelo exame da norma de regência aplicável à espécie, do seu status jurídico e da natureza de uma das suas vertentes: o speedy.

Impende se registre, prima facie, que o ponto medular da controvérsia reside na possibilidade de se estabelecer - ou não - uma diferença entre provedor de acesso e provedor de conteúdo.

\subsubsection{A dinâmica proposta pela fornecedora}

Com efeito, a Carta Magna reservou à União a exclusiva competência para explorar, diretamente ou mediante autorização, concessão ou permissão, os serviços de telecomunicações, nos termos da lei, que disporá sobre a organização dos serviços, a criação de um órgão regulador e outros aspectos institucionais (CF, arts. 21, XI, c.c. 175).

Sobreveio, por força dessa autorização e sem prejuízo - é claro - do regime geral de concessões ${ }^{1075}$, a Lei 9.472/97, que distinguiu o típico serviço de telecomunicações do serviço de valor adicionado ${ }^{1076}$, reservando a exploração do primeiro a empresas exclusivamente criadas para esse fim. ${ }^{1077}$

Impossível, a partir disso, impingir-lhe uma atuação como provedora de acesso à internet, no seu entender, serviço de valor adicionado. Veja-se a

\footnotetext{
${ }^{1074}$ Guilherme Ferreira da Cruz. A internet banda larga e seus provedores: imposição legal ou abusiva venda casada? RT, São Paulo: RT, v. 851, p. 44/62.

${ }^{1075}$ Lei $8.987 / 95$.

${ }^{1076}$ Lei $9.472 / 97$, arts. 60 c.c. 61 .

${ }^{1077}$ Lei $9.472 / 97$, arts. 86 c.c. Contrato de concessão, cláusula 17.1.
} 
síntese do seu argumento: "enquanto o serviço da ré consiste no transporte de dados em alta velocidade (Speedy), o serviço do provedor destina-se a prover o acesso a uma rede de computadores específica: Internet. Daí a designação que recebe: provedor de acesso. $\mathrm{O}$ serviço de Provimento de Acesso à Internet, assim, é indispensável à navegação na rede mundial, constitui serviço de valor adicionado e não é serviço de telecomunicações". ${ }^{1078}$

Legítima, portanto, a intervenção dos chamados provedores de acesso, terceiras empresas que prestam serviços adicionados à estrutura disponibilizada, suporte de alta velocidade inclusive. ${ }^{1079}$

Daí a licitude, no seu entender, da viga específica dos contratos prestação singular.

O raciocínio proposto é aparentemente lógico e muito sedutor; contudo, per se, faz exsurgir hiato fatal - como se verá adiante - às suas pretensões: é que as terceiras empresas - chamadas provedoras de acesso (v.g., UOL, AOL, Terra, Iron, etc.) - em verdade, na banda larga, atuam apenas como provedoras de conteúdo, este sim o autêntico serviço de valor adicionado (Lei 9.472/97, art. 61).

\subsubsection{Natureza do speedy}

Mas o que é, então, o serviço do speedy? A fornecedora afirma que é um serviço de banda larga que permite uma conexão - instantânea e sem discagem - em alta velocidade à Internet por 24 horas $^{1080}$, o que esvazia a necessária intervenção de terceira empresa nessa primeira etapa de deslocamento virtual.

Ou seja: só com o speedy o consumidor já consegue se lançar nos quase infinitos domínios da rede mundial de computadores; o que se constatou em concreto. $^{1081}$

\footnotetext{
${ }^{1078}$ Contestação oferecida nos autos 2005.009387-1 (419/05), $4^{\mathrm{a}}$ Vara Cível de Santos, i. 11, fls. 62.

1079 “(...) ao pretender que a ré preste o Serviço Speedy sem a contratação de provedor de acesso, os autores formulam pedido juridicamente impossível, pois, em decorrência do Contrato de Concessão e da lei, a ré não está autorizada a prestar serviço de valor adicionado, que é, portanto, impossível de ser explorado por esta concessionária" (Idem, i. 19, fls. 69).

${ }^{1080}$ Isto porque, "a ADSL é a tecnologia de banda larga mais usada no mundo. Pode parecer uma simples adaptação de uso da rede de telefone fixo comum, mas por trás existe um verdadeiro milagre da tecnologia, através de sofisticados equipamentos (processadores, roteadores e agregadores de tráfego de dados) instalados em diversos pontos da rede da Telefônica conectando o seu computador à rede mundial com máxima velocidade" (Disponível em http://www1.speedy.com.br/serviços_faqs_speedy_oque.asp.).

1081 “A perícia concluiu que é possível tecnicamente a disponibilização do serviço SPEEDY sem provedor de acesso, pois o provedor não tem controle de acesso à Internet e sim presta serviços de alto nível para seus
} 
Isto porque a fornecedora é quem provê a conectividade ${ }^{1082}$ por meio da sua central pública. ${ }^{1083}$

$\mathrm{O}$ acesso à internet nada tem, pois, com as terceiras empresas provedoras (v.g., UOL, AOL, Terra, Iron, etc.).

\subsubsection{Análise do STJ (provedores de acesso x conteúdo)}

Avaliando a atuação no mercado dessas terceiras empresas provedoras, no desiderato único de identificar o fato oponível determinante da incidência do ICMS (e isto é muito importante, anote-se), vencida a divergência ${ }^{1084}$, definiu o intérprete soberano da legislação federal que essa atividade representa serviço de valor adicionado, que não se amolda ao tipo legal de serviço de telecomunicações (Lei 9.472/97, art. 61 e seu $\left.1^{\circ}\right) .{ }^{1085}$

Pois bem. A partir daí a fornecedora procura impor um silogismo, data venia, equivocado. Ei-lo:

a) se às concessionárias do STFC só é permitida a exploração exclusiva dos serviços de telecomunicações (LGT, art. 86);

usuários. O serviço SPEEDY é vendido ao usuário como sendo um serviço de Banda Larga da Telefônica que oferece uma conexão estável e em alta velocidade à Internet conforme é divulgado em seu site (item 2.1.3.1 figura 1) e portanto entende-se que a TELESP e a REDE DE MULTI SERVIÇOS (TDATA BRASIL) como sendo empresas da Telefônica. Dessa maneira o acesso à Internet estará garantido pela Telefônica, sem necessidade de nenhuma outra empresa para o acesso a Internet". (Conclusão do laudo técnico elaborado durante a instrução da Ação Coletiva, com autos 02.126782-0, proposta pelo IDEC Instituto Brasileiro de Defesa do Consumidor em face da Telecomunicações de São Paulo S/A (Telefônica), que tramitou perante a Egrégia $36^{\mathrm{a}}$ Vara Cível do Foro Central da Comarca de São Paulo).

${ }^{1082}$ No original está “conectivida".

${ }^{1083}$ Quesito 4.2.23 da perícia supra referida.

${ }^{1084}$ STJ, REsp. 323.358/PR, rel. Min. Ministro José Delgado, j. 21.06.2001.

1085 "TRIBUTÁRIO - ICMS - SERVIÇO PRESTADO PELOS PROVEDORES DE INTERNET - LEI 9.472/97. 1. Os serviços prestados pelos provedores de acesso à INTERNET, embora considerados pelo CONFAZ como serviços de telecomunicações, pela definição dada no art. 60 da Lei 9.472/97, que dispôs sobre a organização dos serviços de telecomunicações, não podem ser assim, classificados. 2. O serviço desenvolvido pelos provedores da INTERNET é serviço de valor adicionado (art. 61, Lei 9.472/97), o qual exclui expressamente da classificação de serviços de telecomunicações (§ $1^{\circ}$, art. 61). 3. Se o ICMS só incide sobre serviços de telecomunicações, nos termos do art. $2^{\circ}$ da LC 87/96, não sendo os serviços prestados pela INTERNET serviço de telecomunicações, e sim, SERVIÇO DE VALOR ADICIONADO (art. 61, $\S 1^{\circ}$ da Lei 9.472/97), não há incidência da exação questionada. 4. Recurso especial improvido" (STJ, REsp. 456.650/PR, rel. Min. Eliana Calmon, j. 24.06.2003). Observe-se, a propósito, que a Colenda $1^{\mathrm{a}}$ Seção dessa Excelsa Corte, em 11.05.2005, concluindo o julgamento do EREsp. 456.650/PR, rel. originário Min. José Delgado, relator para o Acórdão Min. Franciulli Netto, firmou orientação no sentido da não-incidência do ICMS sobre os serviços prestados pelos provedores de acesso à Internet, apud, STJ, REsp. 511.390/MG, voto-vista do Min. Teori Albino Zavascki, j. 19.05.2005. 
b) se a atividade desenvolvida pelos provedores da Internet representa serviço de valor adicionado (STJ), excluída - por isso - da classificação típica de serviços de telecomunicações (LGT, art. 61, § $1^{\mathrm{o}}$ );

c) logo, ao usuário do speedy é obrigatória a contratação de um provedor específico.

No entanto, ao contrário do que possa parecer, isto nem de longe foi afirmado pelo STJ; aliás, o detido exame das razões expostas pelos Ínclitos Ministros votantes - elidida a variação terminológica - conduz a resultado diametralmente oposto. Confira-se, aqui, o raciocínio da Ministra Eliana Calmon:

"Mas o que vem a ser a INTERNET, essa utilíssima ferramenta de comunicação? Internet é uma poderosa rede internacional de computadores que, por meio de diferentes tecnologias de comunicação e informática, permite a realização de atividades como correio eletrônico, grupos de discussões, computação de longa distância, transferência de arquivos, lazer, compras etc (Larousse Cultural).

Para ter acesso a essa rede internacional, usa-se os serviços do chamado PROVEDOR DE ACESSO, que funciona como uma espécie de “chave que destranca a porta da internet" (José Wilson Sobrinho, em Direito Tributário, Temas Pontuais, Editora Forense). Assim, tem-se, de um lado, o aparato material que dá suporte à Internet, chamado de 'serviço de meio físico', na linguagem de Pontes de Miranda e, do outro, o serviço que propicia o interessado chegar a esse meio físico, que é a atividade desenvolvida pelo PROVEDOR, não sendo possível unir ambos os serviços, visto que são bem distintos. O provedor nada cria, apenas viabiliza a outrem chegar até as informações. Aliás, é bom destacar que os 'serviços da internet' compreendem variadas prestações, desde a divulgação até o serviço de correspondência entre interlocutores, por via dos EMAILS, passando pelas operações bancárias, serviço de compra e venda etc.

\section{(...)}

O serviço de telefonia, meio de chegar o usuário ao provedor e, a partir daí, conectar ele o usuário à rede, é serviço de telecomunicação, pago de acordo com a quantidade de pulsos utilizados, conforme discriminado na conta telefônica, sobre cujo valor incide o ICMS. 
Em verdade, temos, na espécie, uma multiplicidade de relações desencadeadas por um só toque no computador, e não se pode olvidar que há uma relação jurídica contratual do usuário com a telefônica, pela qual paga ele os serviços de telefonia e o ICMS, serviço que não ser confunde com o estabelecido entre o usuário e o provedor por ele eleito para prestar o serviço de ligação com a rede internacional de computadores. Esses provedores, por seu turno, para desempenharem a atividade precípua, utilizam-se da ligação telefônica por canais especiais.

(...)

Com efeito, agem os provedores como monitores ou facilitadores do usuário, colocando à disposição dos seus clientes equipamentos e softwares que dão acesso e facilitam a utilização do sistema, mas, em verdade, são ambos, provedores e usuários, tomadores do serviço de comunicação, cujo suporte maior e imprescindível é o serviço de telecomunicação." 1086

São dois os momentos de destaque, portanto, nessa complexa relação jurídica:

$1^{\circ}$ ) a disponibilização do aparato técnico para tornar possível o acesso do usuário ao ambiente virtual da conexão, o que integra o típico serviço de telecomunicações, sendo exercido tanto pela linha discada quanto pelo speedy, com incidência do ICMS;

$2^{\circ}$ ) após levar o usuário ao ambiente virtual da conexão, esgota-se o típico serviço de telecomunicação, facultando-se o trânsito pela rede por qualquer meio, o mais comum é por intermédio dos provedores de conteúdo, que prestam serviço de valor adicionado - aproveitando a estrutura material da empresa de telefonia mas, sem gerar ICMS.

Vem a talho de foice, neste passo, o magistério de Luciana Angeiros no sentido de que, “o termo 'provedor', que vem do verbo prover, significa 'abastecer, fornecer, munir'. Ao se falar em provedor, é importante distinguir o que se denomina provedor de serviço de conexão à Internet (PSCI), aquele que providencia o

${ }^{1086}$ STJ, REsp. 456.650/PR, voto-condutor, j. 24.06.2003. 
acesso do usuário, do provedor de serviços de informações (PSI), aquele que abastece a rede com informações". 1087

A partir desse escalonamento - por vezes não muito claro viável é estabelecer uma distinção entre provedor de acesso $\left(1^{\circ}-\mathrm{PSCI}\right)$ e provedor de conteúdo e informação ( $2^{\circ}$ - PSI), ou seja, o que a LGT veda nos seus arts. 61 , $\S 1^{\circ}$, e 86 é que as empresas concessionárias do serviço exclusivo de telecomunicações prestem ainda - serviço de provedor de conteúdo ou informação. ${ }^{1088}$

Força é concluir, nesta quadra, que a fornecedora exaure seu papel quando - seja pela linha discada, seja pelo speedy - lança o internauta no ambiente virtual da conexão, sendo-lhe defeso atuar - também - como provedora de conteúdo ou informação (v.g., UOL, AOL, Terra, Iron, etc.).

O provedor de acesso (PSCI) não se confunde com o provedor de conteúdo ou informação (PSI).

Definidas as esferas de atuação desses provedores, registre-se a palavra do culto Min. Domingos Franciulli Netto:

“(...) conclui-se que o serviço prestado pelo provedor de acesso à internet (em verdade o provedor de conteúdo) ${ }^{1089}$ não se caracteriza como serviço de telecomunicação, porque não necessita de autorização, permissão ou concessão da União.

Tampouco oferece prestações onerosas de serviços de comunicação (art. $2^{\circ}$, III, da LC no 87/96), de forma a incidir o ICMS, porque não oferece as condições e meios para que a comunicação ocorra, sendo um simples usuário dos serviços prestados pelas empresas de telecomunicações.

Trata-se, portanto, de mero serviço de valor adicionado, uma vez que o prestador se utiliza da rede de telecomunicações que lhe dá suporte para viabilizar o acesso do usuário final à Internet, por meio de uma linha telefônica.

Com efeito, os provedores de acesso à Internet (provedor de conteúdo como acima exposto) ${ }^{1090}$ atuam como intermediários entre o usuário final e a Internet. Utilizam-se, nesse sentido, de uma infra-estrutura de

\footnotetext{
${ }^{1087}$ Internet - O Direito na Era Virtual. In: Schoueri, Luís Eduardo (org). $2^{\mathrm{a}}$ ed. Rio de Janeiro: Forense, 2001, p. 238/249.

${ }^{1088}$ TRF-2 ${ }^{\mathrm{a}}$ Região, AI 2003.02.01.001520-3, voto-vencido do Des. Poul Erik Dyrlund, j. 15.10.2003.

1089 É meu o parênteses.

${ }^{1090}$ É meu o parênteses.
} 
telecomunicações preexistente, acrescentando ao usuário novas utilidades relacionadas ao acesso, armazenamento, apresentação, movimentação ou recuperação de informações (artigo 61 da Lei Geral de Telecomunicações)."1091

Desse resultado não discrepa o voto do Ministro Francisco Peçanha Martins:

"Serviço de valor adicionado não constitui serviço de telecomunicações, classificando-se o seu provedor (de conteúdo) ${ }^{1092}$ como usuário dos serviços de telecomunicações, que lhe dá suporte. Esta é a definição da lei. Diz-se, porém, que a provedoria via Internet (de conteúdo) ${ }^{1093}$ não é serviço de valor adicionado.

Penso que é, data venia das opiniões em contrário. A provedoria da Internet (de conteúdo) ${ }^{1094}$ acrescenta informações através das telecomunicações. A chamada comunicação eletrônica, entre computadores, somente ocorre através das chamadas linhas telefônicas de qualquer natureza, ou seja, a cabo ou via satélite. Sem a via telefônica impossível obter acesso à Internet. Cuida-se, pois, de um serviço adicionado às telecomunicações. Assim o diz a lei. Claro que se trava relação de serviço entre o provedor (de conteúdo) ${ }^{1095} \mathrm{e}$ o consumidor isto para enquadrar o usuário dos serviços televisionados (TT e computadores) dentro da definição geral da lei que o protege - Lei 8.078, de 11.9.90, denominada, CDC - Código de Defesa do Consumidor.

Usuários dos serviços de telecomunicações (provedor de acesso) ${ }^{1096}$ serão, pois, os provedores (de conteúdo) ${ }^{1097}$ e as pessoas que se utilizam dos computadores.

\section{(...)}

O pagamento, pelos consumidores, aos provedores de acesso (na verdade de conteúdo) ${ }^{1098}$, justificaria, ao ver de renomados juristas, a tributação, com a incidência do ICMS, em conformidade com a LC n ${ }^{\circ} 87$.

\footnotetext{
${ }^{1091}$ STJ, REsp. 456.650/PR, voto-vista, j. 24.06.2003.

1092 É meu o parênteses.

${ }^{1093}$ É meu o parênteses.

${ }^{1094}$ É meu o parênteses.

${ }^{1095}$ É meu o parênteses.

${ }^{1096}$ É meu o parênteses.

${ }^{1097}$ É meu o parênteses.

${ }^{1098}$ É meu o parênteses.
} 
E com eles concordaria não fosse a regra do art. $61, \S 1^{\circ}$, que expressamente exclui a provedoria (de conteúdo) ${ }^{1099}$ dos serviços de telecomunicações. Os serviços obtidos com a provedoria (de conteúdo) ${ }^{1100}$ são adicionais aos serviços de telecomunicações por força de lei." ${ }^{1101}$

Fixadas tais premissas, finaliza-se com este silogismo:

a) se a empresa de telefonia, como concessionária do STFC, não pode explorar serviços de valor adicionado (LGT, arts. 61 c.c. 86);

b) se ela oferece o speedy - lídimo milagre da tecnologia como serviço de banda larga capaz de estabelecer uma conexão em alta velocidade e instantânea com a internet;

c) logo, o serviço de provedor de acesso (PSCI), que não se confunde com o de provedor de conteúdo (PSI), está inserido no modelo típico dos serviços de telecomunicações, caso contrário não se poderia cobrar tanto pelo acesso quanto pelo aluguel do modem.

\subsubsection{Da prática abusiva e da publicidade enganosa}

E depois que o internauta se encontrar no ambiente virtual da conexão, precisará ele de um provedor de conteúdo para navegar?

Para a fornecedora - mesmo na banda larga - a resposta é afirmativa, pois o "provedor autentica e libera o seu acesso à Internet", ou seja, "sem a assinatura do plano correto, não haverá autenticação e liberação do acesso à Internet com o Speedy". 1102

Segundo a concessionária, ao que parece, fica a cargo do provedor de conteúdo - a um só tempo - a autenticação e a liberação do consumidor. ${ }^{1103}$

\footnotetext{
${ }^{1099}$ É meu o parênteses.

${ }^{1100}$ É meu o parênteses.

${ }^{1101}$ STJ, REsp. 456.650/PR, voto-vista, j. 24.06.2003.

1102 Disponível em http://www1.speedy.com.br/serviços_faqs_speedy_oque.asp.

1103 "Essa iniciativa tem como objetivo fornecer a vocề um ambiente cada vez mais seguro, melhorando o controle de seu acesso. Somente agora foi possível implementar a tecnologia necessária para efetuar a autenticação dos usuários. (...) A autenticação foi desenvolvida pelos provedores de acesso para permitir a identificação de seus clientes e oferecer um melhor controle de seu acesso em banda larga à Internet com a tecnologia ADSL, sua linha Speedy. Dessa forma, somente quem tiver a senha de acesso conseguirá acessar" (Disponível em http://www1.speedy.com.br/serviços_faqs_speedy_oque.asp.).
} 
Todavia, com luz solar e por duas vezes, o concreto e específico exame de engenharia ${ }^{1104}$ alumia a quaestio com precisão técnica:

"Quem efetua o Bloqueio de acesso?

R. O bloqueio de acesso com certeza não é o PROVEDOR quem faz, pois ele não tem acesso aos equipamentos da CENTRAL PUBLICA que pertencem a TELESP e nem aos equipamentos da REDE MULTI SERVIÇOS que pertencem à TELEFONICA. Para um provedor efetuar o bloqueio seria necessário o que está representado no diagrama abaixo, o que não retrata a realidade, conforme a vistoria efetuada item 3.0. ${ }^{1105}$

Quem realiza esta autenticação?

R. No SPEEDY a autenticação confere ao usuário o acesso a REDE DE MULTI SERVIÇOS através do equipamento CISCO 6400 que é um roteador, onde o usuário é identificado com um endereço IP e a partir desse ponto passa a acessar a Internet. Portanto a TELESP confere o gerenciamento e BLOQUEIO do CISCO 6400 e mais nenhuma outra empresa."1106

A tal estória de autenticação e de liberação do usuário, percebe-se, foi criada pela fornecedora - que a arremessou no colo dos provedores de conteúdo - apenas e tão-somente para ludibriar o consumidor, aperfeiçoando seu sistema de imposição de venda casada $\left(\mathrm{CDC}\right.$, art. 39, I ${ }^{1107}$, sem perder de vista a evidente publicidade enganosa (CDC, art. 37, caput, c.c. seu $\left.\S 1^{\circ}\right)$.

É que o inevitável aconteceu: descobriu-se que os provedores de conteúdo são desnecessários, porquanto - com a tecnologia de banda larga ${ }^{1108}$ - "o acesso à Internet estará garantido pela Telefônica, sem a necessidade de nenhuma outra empresa para o acesso a Internet”, tanto é que a primeira versão do contrato nada dispunha sobre isso. ${ }^{1109}$

A concessionária, rapidamente, adotou medidas destinadas à reserva da parcela do mercado exercida pelos provedores de conteúdo (a ratio desse

\footnotetext{
${ }^{1104}$ Cf., nota 769 .

${ }^{1105}$ Quesito 4.1.4 da perícia.

${ }^{1106}$ Quesito 4.2.27, “c”, da perícia.

1107 CDC, art. 39, I: "é vedado ao fornecedor de produtos ou serviços: I - condicionar o fornecimento de produto ou de serviço ao fornecimento de outro produto ou serviço, bem como, sem justa causa, a limites quantitativos".

1108 ADSL - Asymmetric Digital Subscriber Line ou Linha Digital Assimétrica de Assinante.

${ }^{1109}$ Cláusula $4^{\mathrm{a}}$.
} 
proceder será vista adiante) e, com isso, passou a exigir do consumidor - ao menos de modo formal - a contratação desse terceiro sujeito, que deveria "ser compatível aos serviços relacionados". 1110

No entanto, a fornecedora não parou por aí. Aprimorou, ainda mais, sua interferência protetiva quando - além da compatibilidade - reclamava a escolha de um provedor por ela previamente habilitado. ${ }^{1111}$

Qual a necessidade do provedor de conteúdo se o speedy verdadeiro milagre da tecnologia - já permite uma conexão instantânea à internet? ${ }^{1112}$

Se o consumidor - por opção sua - quiser filiar-se a um provedor de conteúdo, por que sua escolha nasce restrita àqueles previamente habilitados pela concessionária?

Após identificar os momentos da relação (supra, $1^{\circ}$ e $2^{\circ}$ ) e quem - de fato - autentica e libera o acesso do internauta, estéreis se mostram as justificativas apresentadas. ${ }^{1113}$

\footnotetext{
${ }^{1110}$ Cláusula 2.4.

1111 Cláusula 6.10.
}

1112 "É mesmo difícil imaginar um motivo para a imposição da contratação de uma empresa cujos serviços são perfeitamente dispensáveis, a não ser o interesse dos próprios provedores de acesso (na verdade de conteúdo), que realmente se encontra ameaçado após a denúncia ganhar os meios de comunicação. O fato é notório, conforme demonstram inúmeras notícias veiculadas pela imprensa" (Pedro Antonio de Oliveira Machado. INTERNET. Acesso via banda larga. Provedores de serviço de acesso. Revista de Direito do Consumidor, São Paulo: RT, v. 47, jul.-set. 2003, p. 236). E ainda: “(...) A questão é importante porque, se assim for determinado nas decisões dessas ações, poderá ocorrer a eliminação das empresas provedoras (de conteúdo) da cadeia de provimento de acesso de alta velocidade na Internet (...)" (Daniela de Oliveira Tourinho. Provimento de acesso de alta velocidade na Internet. Revista do Advogado, São Paulo: AASP, ${ }^{\circ}$ 69, maio de 2003, p. 67).

1113“"Por que preciso adquirir um plano de provedor para acessar a Internet? De acordo com a legislação em vigor, a Telefônica, na condição de concessionária do Serviço Telefônico Fixo Comutado (STFC), não pode prestar serviços de valor adicionado, como prover acesso à Internet. Para acessar a Internet, o assinante do Speedy precisa contratar um provedor habilitado. A Telefônica fornece a tecnologia transmissão de voz/dados através do Speedy e o provedor autentica e libera o seu acesso à Internet". "Tenho acesso discado e meu provedor é habilitado para o Speedy. Por que preciso mudar meu plano de acesso? Os provedores habilitados possuem planos de acesso específicos para o acesso à Internet com o Speedy. Sem a assinatura do plano correto, não haverá autenticação e liberação do acesso à Internet com o Speedy". "Eu já tinha Speedy e mudei para uma nova versão do Speedy. Por que preciso mudar o plano do provedor? Você precisa mudar o plano que usa com a versão anterior do Speedy porque ela não é compatível com o Speedy. Sem a assinatura do plano correto, não haverá autenticação e liberação do acesso à Internet com o Speedy". "Como faço para contratar o plano do provedor para o Speedy com o Speedy antigo? Os provedores habilitados possuem planos de acesso específicos para o acesso à Internet com o Speedy. Sem a assinatura do plano correto, não haverá autenticação e liberação do acesso à Internet com o Speedy". "Meu vizinho/amigo também tem um Speedy, mas ele não precisa autenticar. Por que eu terei? A autenticação está sendo implementada por todos os provedores que oferecem acesso à Internet. Essa alteração tecnológica é um processo gradual, que está sendo realizada pelos provedores e, certamente, o do seu amigo/vizinho será implementado o mais breve possível" (Disponível em http://www1.speedy.com.br/serviços_faqs_speedy_oque.asp). 
O que é isso? A fornecedora usa e abusa da hipossuficiência técnica do consumidor, atuando - conscientemente - de modo a violar a transparência e a boa-fé objetiva, vetor do mínimo ético exigível. ${ }^{114}$

Esse processo de autenticação e de liberação - que não existia antes, por ser desnecessário, registre-se - não está sendo implementado pelos provedores de conteúdo (empresas sem acesso à central pública, à rede multi serviços e ao roteador CISCO 6400), mas sim pela concessionária do serviço de telefonia.

\section{É ela que condiciona o fornecimento do speedy à contratação} de um provedor de conteúdo (venda casada $^{1115}$ ), seu parceiro negocial previamente habilitado, à evidência, por razões de ordem econômica. ${ }^{1116}$

Trata-se de lídima condição irregular de contratação. ${ }^{117}$

${ }^{1114}$ Há notícia de que a Telesp firmou contrato com a Prefeitura Municipal de São Paulo para fornecer o serviço speedy sem a necessidade de provedor de acesso ( $1^{\circ}$ TacCiv/SP, AI 1.119.830-0, rel. Roque Mesquita, j. 18.02.2003).

1115 CDC, art. 39, I. O CADE, Conselho Administrativo de Defesa Econômica, órgão do Ministério da Justiça, define o instituto: "venda casada: Consiste na prática de subordinar a venda de um bem ou serviço à aquisição de outro. O praticante da venda casada produz barreiras à entrada de concorrentes potenciais no mercado ou empecilhos à expansão dos concorrentes já presentes. A subordinação proporcionada pela venda casada gera uma restrição da liberdade de comprar e vender por pressão, por coação, sem que haja qualquer benefício para o consumidor na aquisição vinculada".

1116 “(...) para utilizar esses serviços, os fornecedores estão exigindo que os consumidores contratem terceiro com função meramente figurativa, ao passo que esse terceiro ofereceria a venda de conteúdo webjornalístico ou outros serviços disponíveis que nada tem a ver como o meio físico necessário para se estabelecer conexão à internet via banda larga, conforme se infere dos contratos de prestação de serviços disponibilizados e firmados pelas partes, nos casos que seguem. Fazendo uma interpretação análoga, exigir e colocar como precondição a contratação desnecessária de uma segunda empresa para ter acesso à internet (por exemplo, de conteúdo webjornalístico) seria o mesmo que exigir do consumidor que ao comprar um sanduíche, adquira, também, o refrigerante ou um segundo sanduíche do vendedor conveniado como precondição para a venda do primeiro sanduíche. (...) Portanto, a exigência da contratação de um segundo provedor de acesso considerando que a empresa que faz essa exigência seja o primeiro -, está em descompasso com os preceitos constitucionais e legais brasileiros, na medida em que fere a liberdade de contratação do consumidor, coagindo-o a adquirir serviço prescindível ao objetivo maior que intenta: o acesso à informação via grande rede de computadores" (Renato F. Baccaro. Da Desnecessidade de contratar o segundo provedor de acesso à Internet e as liminares favoráveis ao consumidor. Revista de Direito do Consumidor, São Paulo: RT, v. 48, out.-dez. 2003, p. 271 e 274).

1117 Veja-se, a propósito, como a dinâmica do acerto econômico - à revelia do consumidor - se desdobra dentro de sistema análogo: "a exigência da contratação de um provedor de acesso pela Legislação Geral de Telecomunicações está fundamentada no argumento de que, dessa forma, se estaria protegendo os pequenos provedores, que poderiam ser prejudicados diante da concorrência. Mas, na prática, é justamente isso que está acontecendo. Para ter o direito de autenticar o Velox, além de ter licença, o provedor para uma mensalidade à operadora por usuário, com base no número de clientes Velox autenticados. São os chamados contratos 'revenue share'. Tal valor geralmente fica na casa dos $90 \%$ da taxa paga pelo usuário ao provedor. Somando a taxa da banda larga com a taxa do provedor, o usuário tem que desembolsar, em média, R\$ 100 . Para não ter que cobrar o valor integral aos clientes, o que poderia assustá-los, as operadoras optaram por desmembrar as fontes de recebimento, ao invés do total de $\mathrm{R} \$ 100$, cobra $\mathrm{R} \$ 60$ pelo serviço e usa a lei, que acoberta o contrato com o provedor, para garantir o restante. 'A autenticação é uma coisa que as operadoras criaram para pressionar e obrigar o cliente a contratar o provedor. Então, elas habilitam esses provedores e cobram alto por isso', ressalta o presidente da Abusar.org. A Hotlink é o único provedor local com 
No estado de São Paulo a situação é a mesma, como revela a pesquisa de Pedro Antonio de Oliveira Machado:

“1.7 Recentemente, o Procon-SP assumiu sua posição em favor dos consumidores, na briga com os provedores de acesso por banda larga, como mostra o jornal O Estado de S. Paulo, edição de 20.05.2002, p. 18 (caderno Informática).

1.8 Procurada pelo jornal, a NET, que oferece o serviço Vírtua, confessou a veracidade dos fatos ora expostos, pois 'confirmou que o provedor é responsável por serviços e conteúdo e não participa da estrutura de acesso à internet'. Mas, 'caso o usuário não pague o provedor; o Vírtua é avisado e corta a conexão'."1118

E de modo preciso sobre o speedy, acrescenta o Procurador da República:

"31. Sobre a possibilidade técnica dos serviços de transporte de dados em alta velocidade (Speedy - Tecnologia ADSL - Banda Larga) para acesso à internet, serem prestados pela própria Telefônica, sem necessidade de contratação de um provedor à parte, veja-se a entrevista dada por Roque Abdo, presidente da Associação Brasileira dos Provedores de Acesso, Serviços e Informações da Rede Internet (Abranet):

'A Telefônica não bloqueava quem deixava de pagar o provedor', afirma Abdo, acrescentando que a operadora deve enviar uma correspondência alertando os usuários para acertarem suas contas com o provedor. O presidente da Abranet calcula que os provedores estão perdendo cerca de $\mathrm{R} \$$ 3,5 milhões em faturamento mensal com a situação, que também resulta em perdas para a operadora. Para cada grupo de cem usuários do Speedy, o provedor precisa contratar uma conexão com a Telefônica, que custa, segundo Abdo, R\$ 1.276 por mês. Além disso, a operadora recebe uma participação na mensalidade

autorização da Telemar para autenticar clientes Velox. Segundo Gustavo Pinheiro, diretor técnico do provedor, a Telemar cobra uma taxa de $\mathrm{R} \$ 23,00$ por cada usuário e, que com os impostos, atinge o valor de R \$ 30,00. Atualmente, a Hotlink cobra uma mensalidade de R\$29, que passa para R\$39,90 a partir do quarto mês de serviço. Segundo Pinheiro, no final das contas, o lucro do provedor é praticamente nulo. Questionado sobre o porquê de continuar prestando serviços à operadora, ele afirma ser válido pelo apelo do marketing, pela opção a mais no portfólio de serviços da empresa" (Disponível em http://www.sertaonews.com).

${ }^{1118}$ INTERNET..., cit., p. 238. 
paga ao provedor. O presidente da Abranet afirma que a parcela paga à Telefônica, com os impostos decorrentes, correspondem a $80 \%$ da mensalidade do provedor.'

32. O próprio presidente da associação de provedores, afirma que $80 \%$ (oitenta por cento) do valor da mensalidade desses provedores adicionais é repassado justamente para a Telefônica! Ou seja: o consumidor paga (caro) à Telefônica pelo Speedy, e ainda é obrigado por ela a contratar um provedor adicional também caro, sendo que $80 \%$ do preço deste se destina à primeira!"

Força é concluir - tendo em vista que o usuário é obrigado a contratar novamente o serviço de backbone de um provedor de conteúdo ou PSI ${ }^{1120}$ - que a prática abusiva adotada - à semelhança das outras operadoras da tecnologia de banda larga (ADSL) - amparada em publicidade enganosa, violam em concreto até mesmo os direitos do consumidor mais atento: o Ministro das Telecomunicações. ${ }^{1121}$

\subsubsection{A obrigação de recompor o patrimônio do consumidor}

Percebe-se, após tudo o que foi dito, a olho desarmado, que inexiste embaraço - técnico e/ou jurídico - para a operadora de telefonia lançar o internauta no ambiente virtual da conexão, sem a necessidade da atuação conjunta de um provedor de conteúdo ou informação (PSI).

A opção - como sempre ${ }^{1122}$, aliás - é do consumidor, que não pode ser compelido - a partir de argumentos que não resistem a um sopro do bom direito a contratar terceira empresa para fazer (e o pior é que não faz) o que a concessionária já disponibiliza - como prestadora de serviços típicos de telecomunicações (PSCI) - ao manejar a tecnologia de banda larga (ADSL).

"Recentemente, deu-se um razoável rebuliço dos assinantes de Internet banda-larga, tendo o Procon-SP como porta-voz em uma ação contra

\footnotetext{
${ }^{1119}$ INTERNET..., cit., p. 250.

${ }^{1120}$ Quesito 4.2.25, "a", da perícia.

1121 "Eu não posso obrigar a uma pessoa que tenha um provedor de internet ter um segundo provedor de conteúdo para ter acesso. Eu mesmo descobri recentemente que ao contratar na minha casa um serviço de banda larga de uma empresa ficava obrigado também a fazer um contrato com o seu provedor. Eu não tenho que fazer esse contrato. Eu fiz porque foi uma imposição e me senti um pouco agredido porque tive que fazer uma coisa que não sou obrigado a fazer" (Declarações do Min. das Telecomunicações, Hélio Costa, disponível em http://www1.folha.uol.com.br/folha/dinheiro/ult91u98166.shtml).
} 
as empresas responsáveis pelo serviço. Tudo gira em torno do valor do serviço prestado e a verdadeira tecnologia vendida, que, por sua vez, são regidos por uma legislação tão confusa quanto omissa. ${ }^{123}$

Mas, se o provedor é desnecessário, inútil, por que manda a resolução da Agência reguladora que ele seja contratado? O silêncio cúmplice das prestadoras de banda e dos provedores repousa sobre a legislação, que reza que a Internet não é serviço de telecomunicações. O resultado é tipicamente brasileiro: as operadoras fingem que cumprem a legislação. Os provedores de banda larga credenciados fingem que conectam os internautas. A Anatel finge que fiscaliza. Mas os usuários, mesmo que fingissem achar tudo normal, teriam que pagar pela farsa do mesmo jeito. As questões vieram à tona: Internet é um serviço de valor adicionado ou de comunicações?

O problema, que parece ainda distante de um acordo, coloca a Anatel em situação realmente complicada."1124

O procedimento abusivo da concessionária (venda casada) não encontra amparo sequer na LGT (art. $61, \S 1^{\text {o }}$, c.c. 86 ); contudo, mesmo que tivesse, isto não se esparziria sobre a esfera de direitos do consumidor, constitucionalmente protegido (CF, arts. $5^{\circ}$, XXXII, c.c. $\left.170, \mathrm{~V}\right)$.

Da aparente antinomia ente a LGT e o CDC, como não poderia deixar de ser, avulta intacta a Lei 8.078/90, instrumento de aplicação direta dos princípios constitucionais nas relações de direito privado, visando à preservação da dignidade da pessoa humana.

${ }^{1122} \mathrm{CDC}$, arts. $4^{\circ}$, caput, e seus incisos I, II, “c” e "d", III, IV e VI, c.c. $6^{\circ}$, caput, e seus incisos II, III, IV e VI.

${ }^{1123} \mathrm{O}$ que acontece, tecnicamente, é que os assinantes são obrigados a pagar o serviço duas vezes, sofrendo a conhecida "venda casada". Pagam tanto à prestadora, seja a Telefônica (Speedy), a Telemar (Velox), a NET (Virtua), a TVA (Ajato), seja qualquer outra, bem como ao provedor de acesso, que, em tese, serviria de gateway para alocar e distribuir os IPs destes internautas, como o faz nas ligações normais dial up, ou seja, conectá-los de fato. Isso não acontece, entretanto. A própria prestadora já é quem fornece os IPs, tendo os provedores um papel tão invisível quanto desnecessário no processo. Aliás, para que o provedor fornecesse realmente o IP, tal operação técnica demandaria uma infra-estrutura de valor absurdo, surreal. Além de completamente desnecessária, claro.

${ }^{1124}$ Marco Toledo de Assis Bastos, mestrando em Ciências da Comunicação pela Escola de Comunicação e Artes da USP (ECA), licenciado em História pela Unesp/FCL - Campus de Assis, disponível em www.internetlegal.com.br, apud, Escola Paulista da Magistratura. Cadernos Jurídicos, São Paulo: Imprensa Oficial, $n^{\circ} 23$, set.-out. 2004, p. 19/21. 
Inviável, por todos os ângulos, subordinar-se o serviço de speedy à contratação de um provedor de conteúdo (PSI), o que pode ser elidido com o manejo da tutela cominatória apropriada (obrigação de fazer ou de não fazer).

Irrelevante, da mesma forma, a postura adotada pela Agência Reguladora e pelo Ministério das Telecomunicações em atos administrativos genéricos (resoluções, portarias, normas, ofícios, etc.), sobretudo porque incapazes de determinar padrões de comportamento positivos e/ou negativos, pena de nítida afronta ao primado da legalidade $\left(\mathrm{CF}\right.$, art. $\left.5^{\circ}, \mathrm{II}\right)$.

Viável, assim, a repetição dobrada do indébito.

Ou seja: aquilo que se pagou à terceira empresa - exigível da própria operadora de telefonia por força do princípio da solidariedade ampla em benefício do consumidor ${ }^{1125}$ - pois a contratação do provedor de conteúdo (PSI), juridicamente sem causa, foi imposta aos internautas como conditio sine qua non para a obtenção da banda larga operada pelo serviço speedy.

Não interessa, aqui, perquirir sobre o efetivo receptor (se concessionária ou se provedor de conteúdo), sobretudo porque à fornecedora já foi destinado - no mínimo - $80 \%$ do montante vertido a esse título pelo consumidor, segundo relato de Roque Abdo, Presidente da Associação Brasileira dos Provedores de Acesso, Serviços e Informações da Rede Internet (Abranet). ${ }^{1126}$

Os $20 \%$ restantes, à evidência, serão equacionados na exata medida das íntimas relações que unem a concessionária ao seu parceiro de negócio (v.g., UOL, AOL, Terra, Iron, etc.), autêntica res inter alios frente ao internauta.

A manobra retórica e jurídico-física (elidida por perícia, relembre-se), por óbvio, arreda o engano justificável previsto no art. 42, par. ún., parte final, da Lei 8.078/90, até porque incompatível com a prática deliberada da condição irregular de contratação (venda casada).

Prática abusiva dolosa não equivale a engano justificável.

De fato, uma vez posta às claras a prática abusiva, resta patente a violação tanto da confiança quanto da justa expectativa depositadas pelos

\footnotetext{
${ }^{1125} \mathrm{CDC}$, arts. $7^{\mathrm{o}}$, par. ún., c.c. 34 .

${ }^{1126}$ Pedro Antonio de Oliveira Machado. INTERNET..., cit., p. 250.
} 
consumidores, anotando-se que o STJ já chancelou o dano moral advindo da venda casada. $^{1127}$

${ }^{1127}$ STJ, REsp. 771.827/RJ, rel. Min. Jorge Scartezzini, j. 12.12.2005. 


\section{REVISÃO CONTRATUAL}

Como instrumento de realização dos postulados constitucionais da justiça, da solidariedade e da isonomia, a se sustentar na pretendida justiça distributiva (CF, art. 170, caput), o equilíbrio ou equivalência contratual - tanto econômico da equação financeira quanto jurídico das obrigações pactuadas - alça contornos de princípio informativo de toda a relação de consumo (supra, Cap. III, 4).

Por isso, a identificar um direito subjetivo do consumidor ao equilíbrio contratual ${ }^{1128}$, é que um dos direitos básicos do consumidor permite a "modificação das cláusulas contratuais que estabeleçam prestações desproporcionais ou sua revisão em razão de fatos supervenientes que as tornem excessivamente onerosas" (CDC, art. $\left.6^{\circ}, \mathrm{V}\right)$.

Nada obstante a nulidade de pleno direito que contamina as cláusulas abusivas $^{1129}$, sobretudo aquelas que consagram vantagem exagerada para o fornecedor (CDC, art. 51, $\left.\S 1^{\circ}\right)$, à semelhança da disciplina dos contratos de adesão (CDC, art. 54, $\S 2^{{ }^{1130}}$ ), o sistema jurídico autoriza o consumidor, no seu exclusivo interesse ${ }^{1131}$, ao invés de desconstituí-lo total ou parcialmente, a adequar o vínculo obrigacional a parâmetros equilibrados, que permitam a satisfação econômica dos sujeitos envolvidos ${ }^{1132}$, mas sem a ruína financeira de um deles, por certo a sua própria.

Ou seja, pretende-se resgatar o sinalagma genético ${ }^{1133}$ economicamente justo, visto que nem sempre o originário é equilibrado, pois “(...) a estipulação de cláusulas abusivas é concomitante com a celebração dos contratos, mas a descoberta de sua abusividade é geralmente posterior, é atividade do intérprete do contrato,

\footnotetext{
${ }^{1128}$ Bruno Miragem. Direito..., cit., p. 125.

${ }_{1129}$ Cf., as previstas no art. 51, I, IV, VII, VIII, X, XI, XII, XIII, XV e XVI, do CDC.

${ }^{1130} \mathrm{CDC}$, art. 54, $\S 2^{\circ}$ : "nos contratos de adesão admite-se cláusula resolutória, desde que alternativa, cabendo a escolha ao consumidor, ressalvando-se o disposto no $\S 2^{\circ}$ do artigo anterior"; aliás, são nulas de pleno direito as disposições que "autorizem o fornecedor a cancelar o contrato unilateralmente, sem que igual direito seja conferido ao consumidor" (CDC, art. 51, XI).

${ }^{1131}$ Cláudia Lima Marques (et alii. Manual..., cit., p. 58) anota que, "a onerosidade excessiva e superveniente que permite o recurso a esta revisão judicial é unilateral, pois o art. $6^{\circ}$ do CDC instituiu direitos básicos apenas para o consumidor".

${ }^{1132}$ Lembre-se, aqui, que Enzo Roppo ( $O$ contrato. Coimbra: Almedina, 1988, p. 11) qualifica o contrato como "a veste jurídica de uma operação econômica".

${ }^{1133}$ Bruno Miragem. Direito..., cit., p. 126.
} 
do aplicador da lei, face aos reclamos daquele que, ao executar o contrato, verificou o abuso cometido". 1134

Tem-se, com isso, uma especial faceta do clássico princípio da conservação dos negócios jurídicos ${ }^{1135}$, sempre buscando "assegurar a manutenção do

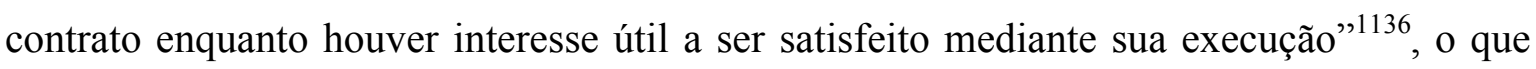
também atrai um exame da teoria do adimplemento substancial (supra, Cap. IV, 6.2.3); daí porque reconheceu específica e expressamente o Código que "a nulidade de uma cláusula contratual abusiva não invalida o contrato, exceto quando de sua existência, apesar dos esforços de integração, decorrer ônus excessivo a qualquer das partes" (CDC, art. 51, § $\left.2^{\mathrm{o}}\right){ }^{1137}$

Esse equilíbrio revisto pode advir de duas situações distintas, a depender da origem do abuso: a) da modificação das cláusulas desproporcionais, se presente desde o nascedouro do contato e b) da revisão, se originado de fatos supervenientes, que tornem excessivamente onerosas as prestações assumidas.

\subsection{Modificação de cláusulas desproporcionais}

Ressalta Luiz Antonio Rizzatto Nunes que, “(...) o inciso V garante a modificação, pelo princípio da conservação do contrato, o magistrado que reconhecer a nulidade deve fazer a integração das demais cláusulas e do sentido estabelecido no contrato, em função de seu objeto, no esforço de mantê-lo em vigor". ${ }^{1138}$ Importante, aqui, nessa espécie de lesão consumerista ${ }^{1139}$, é perceber que a modificação das cláusulas depende exclusivamente da

\footnotetext{
${ }^{1134}$ Cláudia Lima Marques et alii. Comentários..., cit., p. 256.

${ }^{1135} \mathrm{CC}$, art. $157, \S 2^{\circ}$ : "não se decretará a anulação do negócio, se for oferecido suplemento suficiente, ou se a parte favorecida concordar com a redução do proveito". CC, art. 184: "respeitada a intenção das partes, a invalidade parcial de um negócio jurídico não o prejudicará na parte válida, se esta for separável (...)"; CC, art. 479: "a resolução poderá ser evitada, oferecendo-se o réu a modificar equitativamente as condições do contrato". CC, art. 480: "se no contrato as obrigações couberem a apenas uma das partes, poderá ela pleitear que a sua prestação seja reduzida, ou alterado o modo de executá-la, a fim de evitar a onerosidade excessiva". ${ }_{1136}$ Bruno Miragem. Direito..., cit., p. 130.

1137 Segundo Leonardo Roscoe Bessa (et alii. Manual..., cit., p. 295), “(...) o que se pretende destacar é a dupla possibilidade conferida ao juiz: declarar a nulidade (afastando a cláusula) ou promover a revisão. Não há absoluta incompatibilidade entre os dois regimes. Ao contrário, o princípio da conservação do contrato exige esforço judicial de permanência do vínculo. É possível declarar a nulidade de determinada cláusula afastando completamente seus efeitos - e, em seguida, integrar o contrato com base em usos e costumes, com exigências da boa-fé ou expressa disposição normativa sobre o assunto".

${ }^{1138}$ Curso..., cit., p. 569.

${ }^{1139}$ Teresa Ancona Lopez. Princípios contratuais..., cit., p. 31.
} 
desproporcionalidade das prestações estabelecidas, fator permeado de tônus objetivo, ao contrário do que acontece no direito privado dos iguais ${ }^{1140}$; daí porque tem razão Bruno Miragem ao afirmar:

“(...) ao consagrar como direito básico do consumidor a modificação das cláusulas que estabeleçam prestações desproporcionais, independentemente da demonstração de qualquer requisito de natureza subjetiva, o legislador teve por objetivo assegurar o equilíbrio econômico do contrato desde sua celebração, sem a necessidade de sua desconstituição ou invalidação, mas apenas pela correção das mesmas, destacando a finalidade de manutenção do contrato de consumo". 1141

Este poder de modificação, na busca do necessário equilíbrio, de modo direto e no exercício regular da jurisdição, num verdadeiro ato de intervenção estatal $^{1142}$, autoriza o juiz - na verdade um poder dever ${ }^{143}$ - a alterar a economia do contrato antes de desconstituí-lo $\left(\mathrm{CDC} \text {, art. 51, } \S 2^{\circ}\right)^{1144}$; no entanto, sempre a partir do resultado mais interessante para o consumidor, sujeito que quase sempre não participa da elaboração dos seus termos.

Lembre-se que não há direito adquiro ao abuso (supra, Cap. I, 2.4 e 2.5) e a suposta autonomia da vontade cede à justiça distributiva imposta pelo sistema constitucional, também e principalmente, na defesa do consumidor.

4.2 Revisão superveniente $\mathrm{x}$ base do negócio

Prima facie, a ressaltar mais uma vez a importância da principiologia consumerista, lembra Luiz Antonio Rizzatto Nunes que, "a garantia de revisão das cláusulas contratuais em razão de fatos supervenientes que as tornem excessivamente onerosas tem, também, fundamento nos outros princípios instituídos no

\footnotetext{
${ }^{1140}$ Cf., v.g., o estado de perigo (CC, art. 156) e a lesão (CC, art. 157).

${ }^{1141}$ Direito..., cit., p. 126.

1142 João Batista de Almeida. A revisão dos contratos no Código do Consumidor. In: Marques, Cláudia Lima e Miragem, Bruno (org.). Doutrinas essenciais. Direito do consumidor. Contratos de consumo. São Paulo: RT, 2011, v. IV, p. 340.

1143 “A jurisprudência desta Corte é firme no sentido de admitir a revisão ampla dos contratos e a consequente modificação das cláusulas abusivas, à luz do Código de Defesa do Consumidor” (STJ, AgRg. no REsp. 763.245/RS, rel. Min. Fernando Gonçalves, j. 15.09.2005).
} 
CDC citados no item anterior: boa-fé e equilíbrio (art. $4^{\mathrm{o}}$, III), vulnerabilidade do consumidor (art. $\left.4^{\circ}, \mathrm{I}\right)$, que decorre do princípio constitucional maior da isonomia (art. $5^{\circ}$, caput, da CF)". 1145

A Lei 8.078/90, da mesma forma aqui, manteve a filosofia objetivada do seu sistema, apartando-se da tradicional teoria da imprevisão ${ }^{1146}$, que ainda disciplina o trato dos negócios comuns ${ }^{1147}$. Preferiu, com isso, uma revisão pura ${ }^{1148} \mathrm{e}$ unilateral $^{1149}$ em prol do consumidor. É dizer: "mesmo sendo previsível o fato, a sua superveniência aliada à quase impraticabilidade da prestação, permite a revisão do contrato, para adequá-lo ao que foi avençado pelas partes". 1150

Comparando os dois regimes, anota Bruno Miragem que, “(...) a regra do artigo $6^{\circ}, \mathrm{V}$, do $\mathrm{CDC}$, em sua segunda parte, o direito subjetivo do consumidor à revisão do contrato decorre da circunstância de que fato superveniente tenha tornado excessivamente onerosas as prestações. Não faz referência, assim, ao requisito sobre a imprevisibilidade ou não do fato superveniente que tenha dado causa à desproporção. Nesse sentido, o CDC, coerente com a diretriz de impedir a transferência de riscos do negócio ao consumidor, assim como de promover uma maior objetivação do exame e avaliação do comportamento das partes do contrato de consumo, afasta a exigência (e com isso a necessidade de comprovação) de que o fato que tenha dado causa à desproporção fosse imprevisível. O objetivo desta disposição é a proteção do consumidor não apenas com relação a fatos supervenientes que desestruturem o plano do contrato e a possibilidade de adimplemento, mas também uma vedação a que riscos inerentes ao

\footnotetext{
${ }^{1144}$ Destaca João Batista de Almeida (A revisão..., cit., p. 341) que, “(...) em face da regra da conservação dos contratos, deve o juiz rever o contrato, integrando o pacto, de tal modo que este venha a ser implementado, em novas bases, após o reequilíbrio das prestações e o expurgo das cláusulas abusivas".

${ }^{1145}$ Curso..., cit., p. 569.

1146 Lembra Bruno Miragem (Direito..., cit., 127/128): "desenvolvida largamente a partir de então em diversos sistemas jurídicos e, inclusive no direito brasileiro, a teoria da imprevisão exige para dar causa à revisão do contrato, que o fato das prestações seja imprevisível às partes no momento da sua celebração (rebus sic stantibus). (...) Note-se que a imprevisibilidade remete mais uma vez à avaliação sobre a possibilidade ou não das partes de tomarem conhecimento das circunstâncias que envolvem e repercutem na relação contratual. Imprevisivel é qualidade do que não é possível, segundo regras ordinárias e de comportamento diligente e probo das partes, antecipar o conhecimento sobre sua ocorrência. Em matéria contratual, distingue-se do que seja previsível, porquanto este se caracteriza como inerente ao risco normal do adimplemento ou não do contrato".

${ }^{1147}$ CC, art. 317: "quando, por motivos imprevisíveis, sobrevier desproporção manifesta entre o valor da prestação devida e o do momento de sua execução, poderá o juiz corrigi-lo, a pedido da parte, de modo que assegure, quanto possível, o valor real da prestação".

${ }_{1148}^{114}$ Luiz Antonio Rizzatto Nunes. Curso..., cit., p. 569.

${ }^{1149}$ Cláudia Lima Marques et alii. Manual..., cit., p. 58.

1150 João Batista de Almeida. A revisão..., cit., p. 344.
} 
negócio do fornecedor sejam repassados ao consumidor, quando a responsabilidade pelos mesmos seja daquele que desenvolve a atividade negocial". ${ }^{1151}$

A revisão contratual, portanto, está intimamente ligada à mudança das circunstâncias primárias do ajuste e à impossibilidade de divisão de riscos no mercado (infra, Cap. VI, 1), o que o Código não tolera sequer mediante cláusula expressa (CDC, art. 51, I, III e XV).

Segundo Cláudia Lima Marques, "a norma do art. $6^{\circ}$ do CDC avança, em relação ao Código Civil (arts. 478-480 - Da resolução por onerosidade excessiva), ao não exigir que o fato superveniente seja imprevisível ou irresistível - apenas exige a quebra da base objetiva do negócio, a quebra de seu equilíbrio intrínseco, a destruição da relação de equivalência entre prestações, o desaparecimento do fim essencial do contrato. Em outras palavras, o elemento autorizador da ação modificadora do Judiciário é o resultado objetivo da engenharia contratual, que agora apresenta a mencionada onerosidade excessiva para o consumidor, resultado de simples fato superveniente, fato que não necessita ser extraordinário, irresistível, fato que podia ser previsto e não foi. $\mathrm{O} C \mathrm{CDC}$, também, não exige, para promover a revisão, que haja 'extrema vantagem para a outra' parte contratual, como faz o Código Civil (art. 478)". ${ }^{1152}$

Tem-se, nesta quadra, pelo sistema jurídico protetivo do consumidor, a adoção da teoria objetiva ${ }^{1153}$ da base do negócio ${ }^{1154}$, com suas nuances ${ }^{1155}$,

${ }^{1151}$ Direito..., cit., p. 128. Na mesma linha Rizzatto Nunes (Curso..., cit., p. 569): “(...) para que se faça a revisão do contrato, basta que após ter sido firmado surjam fatos que o tornem excessivamente oneroso. Não se pergunta, nem interessa saber, se na data de seu fechamento as partes podiam ou não prever os acontecimentos futuros. Basta ter havido alteração substancial capaz de tornar o contrato excessivo para o consumidor".

${ }^{1152}$ Et alii. Manual..., cit., p. 58.

1153 A teoria subjetiva da base do negócio, segundo Luís Renato Ferreira da Silva (Revisão..., cit., p. 134/135), à semelhança da rebus sic stantibus, permanecia atrelada ao dogma da vontade ao exigir que uma das partes ao menos tivesse conhecimento das expectativas legítimas da outra quanto à existência ou ao surgimento futuro de certas circunstâncias aptas a alterar a vontade negocial primária.

${ }^{1154}$ Aponta Lucia Ancona Lopez Magalhães Dias (Onerosidade excessiva e revisão contratual no direito privado brasileiro. In: Fernandes, Wanderlei (coord.). Fundamentos e princípios dos contratos empresariais. Série GVlaw. São Paulo: Saraiva, 2009, p. 332) que, "Karl Larenz retomou a teoria da base do negócio, atribuindo à mesma um sentido objetivo, assim entendido como o conjunto de circunstâncias e estado geral das coisas, cuja existência ou subsistência é objetivamente necessária para que o contrato, segundo o significado das intenções de ambos os contratantes, possa subsistir como regulamentação dotada de sentido. Segundo esta teoria, haverá a quebra da base objetiva do negócio, possibilitando-se o pedido de revisão ou resolução judicial, quando, em razão de fato superveniente à sua celebração, ocorrer a frustração da finalidade essencial do contrato ou a destruição da sua relação de equivalência econômica". Luís Renato Ferreira da Silva (Revisão dos contratos: do Código Civil ao Código do Consumidor. Rio de Janeiro: Forense, 1998, p. 127) relata que, “(...) a origem da teoria da base negocial é no direito inglês, sendo uma constante a referência aos coronation cases. Porém, o desenvolvimento das obras acerca do tema segue o 
dirigida a manter o contrato válido e economicamente útil às partes ${ }^{1156}$, pouco ou nada importando a subjetiva imprevisibilidade fática. ${ }^{1157}$

A base objetiva se liga ao desaparecimento do fim essencial do contrato ou à destruição da relação de equivalência, elementos cuja análise dependerá, quase sempre, da boa-fé objetiva, que gradua o vínculo obrigacional em todos os seus tempos (supra, Cap. IV, 8), em especial quando da concreta avaliação do nível de desequilíbrio gerado pelo fato superveniente sobre as prestações e da suportabilidade desse dano pelas partes. ${ }^{1158}$

O grande mérito da teoria objetiva da base do negócio está, como destaca Luís Renato Ferreira da Silva, na identificação de “(...) que mesmo fatos previsíveis podem vir a provocar uma 'tensão' entre o querer subjetivo e as circunstâncias concretas. Ignorar que tais fatos merecem um enfoque legal por tudo o que podem provocar no pacto é ignorar o fato de que os contratos desempenham uma função tanto entre as partes (a de manter a justiça comutativa que inspira qualquer contratação) como no meio jurídico (como fator de utilidade nas relações econômicas)". ${ }^{1159}$

rumo da doutrina alemã, que o versou com mais profundidade dogmática que o direito anglo-saxão, não obstante a paternidade reconhecida deste".

${ }^{1155}$ Ressalta João Batista de Almeida (A revisão..., cit., p. 344) que, "para acolher-se pleito fundado nessa teoria é preciso analisar-se se foi atingida a base do negócio, se ocorreu situação anormal (não corriqueira), se a economia contratual foi afetada (tornando insuportável o cumprimento para uma das partes), se a situação adversa não é imputável ao contratante (...). E, por último, se ocorreu a onerosidade excessiva”. Para Lucia Ancona Lopez Magalhães Dias (Onerosidade..., cit., p. 366), “(...) o agravamento superveniente não pode estar coberto pela álea normal do contrato, tal como observado no estudo do art. 478 do CC/2002. Esta condição negativa vem prevista de forma indireta no art. $51, \S 1^{\circ}$, III, do $\mathrm{CDC}$, que determina que para consideração da onerosidade excessiva o juiz deverá levar em conta 'a natureza e conteúdo do contrato, o interesse das partes e outras circunstâncias peculiares ao caso"”.

${ }^{1156}$ Karl Larenz. Base del negocio jurídico y cumplimiento de los contratos. Trad. Carlos Fernández Rodríguez. Madrid: Revista de Derecho Privado, 1956, p. 41.

1157 “O preceito insculpido no inciso $\mathrm{V}$ do art. $6^{\circ}$ do CDC dispensa a prova do caráter imprevisível do fato superveniente, bastando a demonstração objetiva da excessiva onerosidade advinda para o consumidor" (STJ, REsp. 376.877/RS, rel. Min. Nancy Andrighi, j. 06.05.2002).

${ }_{1158}$ Luís Renato Ferreira da Silva. Revisão..., cit., p. 136 e 144.

${ }^{1159}$ Idem, p. 143. 


\section{ACESSO À JUSTIÇA}

O corolário direto da inflexível defesa do consumidor imposta pela Constituição Federal (art. 5, XXXII) é o direito básico à garantia de "acesso aos órgãos judiciários e administrativos, com vistas à prevenção ou reparação de danos patrimoniais e morais, individuais, coletivos ou difusos, assegurada a proteção jurídica, administrativa e técnica aos necessitados" (CDC, art. $6^{\circ}$, VII).

Trata-se de dispositivo que vem a complementar a exigência da criação de certos instrumentos visando à plena execução, pelo Poder Público, da Política Nacional das Relações de Consumo, entre outros: a) a manutenção de assistência jurídica, integral e gratuita ao consumidor carente; b) a instituição de Promotorias de Justiça de Defesa do Consumidor, no âmbito do Ministério Público; c) a criação de delegacias de polícia especializadas no atendimento de consumidores vítimas de infrações penais de consumo; d) a criação de Juizados Especiais de Pequenas Causas e Varas Especializadas para a solução de litígios de consumo; e) a concessão de estímulos à criação e o desenvolvimento das Associações de Defesa do Consumidor, etc. (CDC, art. $5^{\circ}$ ).

Mas não é só. Ao consumidor também é assegurada “a facilitação da defesa de seus direitos, inclusive com a inversão do ônus da prova, a seu favor, no processo civil, quando, a critério do juiz, for verossímil a alegação ou quando for ele hipossuficiente, segundo as regras ordinárias de experiência” (CDC, art. 6º, VIII).

Nessa perspectiva é que serão analisados quatro institutos fundamentais à consecução dos objetivos protetivos traçados pelo sistema: a) o foro de eleição; b) a inversão do ônus da prova; c) a desconsideração da personalidade jurídica e d) a solidariedade ampla.

\subsection{Foro de eleição}

Prima facie, não se desconhecem as regras gerais do Código de Processo Civil que permitem às partes, por escrito e com alusão a determinado negócio jurídico, a modificação da "competência em razão do valor e do território, elegendo foro 
onde serão propostas as ações oriundas de direitos e obrigações" (CPC, art. 111 e seus $\S$ ); disciplina, aliás, que deve ser observada (STF - Súm. $335^{1160}$ ).

Ocorre que o próprio legislador, visando a elidir a indesejada preponderância de um contratante sobre o outro, a mitigar os clássicos princípios da autonomia da vontade e da obrigatoriedade (pacta sunt servanda), na exata compreensão de que entre o forte e o fraco é a liberdade que escraviza e a lei que liberta ${ }^{1161}$, por via da Lei 11.280, de 16 de fevereiro de 2006, nos contratos de adesão, flexibilizou a exigência de exceção $^{1162}$ e previu ser possível, mesmo em matéria territorial, a declaração de nulidade da cláusula de eleição de foro "de ofício pelo juiz, que declinará de competência para o juízo de domicílio do réu" (CPC, art. 112, par. ún.).

A análise do abuso, aqui, será feita em cada caso concreto; no entanto, em sede da relação de consumo primária não há espaço para essa variante ${ }^{163}$, pois a eficácia protetiva tanto constitucional quanto do CDC acabaram por criar uma espécie de competência territorial absoluta $^{1164}$, a sempre facilitar a atuação processual do consumidor $^{1165}$, na exata medida do seu interesse.

${ }^{1160}$ STF, Súm. 335: "é válida a cláusula de eleição de foro para os processos oriundos do contrato".

${ }^{1161} \mathrm{O}$ resultado negativo do exercício da liberdade contratual foi condensado magnificamente nessa frase de LACORDAIRE, Jean-Baptiste-Henri Dominique (religioso dominicano, nascido a 2 de maio $1802 \mathrm{em}$ Receysur-Ource [Côte-d'Or, Borgonha], e falecido a 21 de novembro $1861 \mathrm{em}$ Sorèze [Tarn]. Foi padre, jornalista, educador, deputado e acadêmico, sendo considerado como um precursor do catolicismo moderno e restaurador em França da Ordem dos Pregadores), apud, Orlando Gomes. Contratos. $15^{\mathrm{a}}$ ed. atual. e notas de Humberto Theodoro Júnior. Rio de Janeiro: Forense, 1995, p. 26.

${ }_{1162}$ CPC, art. 112, caput: "argúi-se, por meio de exceção, a incompetência relativa".

${ }^{1163}$ Pois não há sub-rogação desse direito: "efetivamente, a sub-rogação alcança o direito material que a segurada possuía contra a transportadora, mas não a norma processual porventura aplicável àquela, até porque cada qual possui interesses próprios e diversos a tutelar, com significativas implicações na seara da competência (TJSP, AI 7.303.472-1, rel. Correia Lima, j. 02.03.2009)". Com essência similar, do STJ, vejase o CC 21.829/SP, rel. Min. Nancy Andrighi, j. 07.04.2000. Especificamente sobre a impossibilidade de a seguradora, em ação regressiva, se sub-rogar às prerrogativas do consumidor, cf. a decisão monocrática do Min. Ruy Rosado de Aguiar proferida, em 21.02.2001, no AG. 354.783/SP, embora essa Corte Superior também já tenha entendido ser possível a sub-rogação em todos os direitos materiais (mas não processuais) do segurado, inclusive no âmbito da Lei 8.078/90 (AgRg. no REsp. 1.597.702/SP, j. 14.12.2010; AgRg. no AG. 981.968/RJ, j. 14.09.2010; REsp. 802.442/SP, j. 02.02.2010; AgRg. no AG. 957.245/RJ, j. 05.08.2008; REsp. 257.833/SP, 13.03.2001 e REsp. 209.527, j. 17.04.2001).

1164 “(...) 4. O magistrado pode, de ofício, declinar de sua competência para o juízo do domicílio do consumidor, porquanto a Jurisprudência do STJ reconheceu que o critério determinativo da competência nas ações derivadas de relações de consumo é de ordem pública, caracterizando-se como regra de competência absoluta. 5. O microssistema jurídico criado pela legislação consumerista busca dotar o consumidor de instrumentos que permitam um real exercício dos direitos a ele assegurados e, entre os direitos básicos do consumidor, previstos no art. $6^{\circ}$, VIII, está a facilitação da defesa dos direitos privados. 6 . A possibilidade da propositura de demanda no foro do domicílio do consumidor decorre de sua condição pessoal de hipossuficiência e vulnerabilidade (...)" (STJ, REsp. 1.032.876/MG, rel. Min. João Otávio de Noronha, j. 18.12.2008).

1165 "Em se tratando de relação de consumo, tendo em vista o princípio da facilitação de defesa do consumidor, não prevalece o foro contratual de eleição, por ser considerada cláusula abusiva, devendo a ação 
É dizer: a competência do juízo em que reside o consumidor - próprio ou equiparado ${ }^{1166}$ - é absoluta, devendo ser declarada de ofício. ${ }^{1167}$

Ressalte-se, a propósito, que essa orientação está consagrada perante o intérprete soberano da legislação federal há mais de treze anos ${ }^{1168}$, inclusive com expresso afastamento ${ }^{1169}$ do seu enunciado $33^{1170}$ no âmbito consumerista, o que também de certo modo - encontra ressonância junto ao TJSP. ${ }^{1171}$

Força é concluir, portanto, diante da essência principiológica da Lei 8.078/90, de ordem pública e de interesse social, que disciplina e restringe - de modo cogente - a livre iniciativa, amoldando-a aos valores sociais da Carta da República (CF, arts. $1^{\circ}$, IV, c.c. 170 , caput, c.c. seu inc. V), que se houver necessidade de deslocamento para demandar, como mais um reflexo da teoria do risco proveito ${ }^{1172}$, este deve ser relegado aos fornecedores.

Mas o consumidor pode (CDC, art. 101, $\left.\mathrm{I}^{1173}\right)$, no seu exclusivo interesse, optar pela propositura da ação no domicílio do fornecedor, o que esvazia - por parte dele, à míngua de prejuízo ao exercício pleno do contraditório e da sua ampla defesa - qualquer utilidade na arguição de incompetência.

No entanto, em prestígio ao necessário equilibro que deve ser - a todo tempo - concretizado pelo intérprete, essa prerrogativa do consumidor nasce circunscrita a certas bases lógicas inquebrantáveis. Exige-se o nexo etiológico entre o foro

ser proposta no domicílio do réu, podendo o juiz reconhecer a sua incompetência ex officio" (STJ, CC 48.647/RS, rel. Min. Fernando Gonçalves, j. 23.11.2005.

1166 TJMG, AI 1.0701.09.260068-6/001, rel. Alvimar de Ávila, j. 13.05.2009.

${ }^{1167}$ STJ, CC 82.493/PR, rel. Min. Nancy Andrighi, j. 08.08.2007. Em igual sentido e da mesma Corte: AgRg no Ag 644513/RS, j. 24.08.2006.

1168 REsp. 1.089.993/SP, j. 18.02.2010; REsp. 609.237/PB, j. 06.09.2005; REsp. 445.214,, j. 24.09.2002; REsp. 108.666/SP, j. 18.11.1999; REsp. 128.122/SP, j. 18.11.1999; REsp. 205.449/PE, j. 20.05.1999; REsp. 189.170/MG, j. 01.12.1998; CC 18.530/MG, j. 11.11.1998; REsp. 182.258/RS, j. 23.09.1998; REsp. 156.561/SP, j. 24.06.1998; REsp, 154.440/SP, j. 21.05.1998; REsp. 128.144/ SP, j. 21.05.1998; REsp. 154.265/SP, j. 21.05.1998; REsp. 167.918/SP, j. 21.05.1998; CC 19.358/MS, j. 13.05.1998; CC 17.735/CE, j. 13.05.1998; 7CC 18.652/GO, j. 13.05.1998.

${ }^{1169}$ REsp. 196.067/MG, j. 24.08.1999; CC 19.105/MS, j. 11.11.1998; CC 21.331/MG, j. 11.11.1998; CC 21.249/RJ, j. 11.11.1998; REsp. 159.931/SP, j. 21.05.1998; REsp. 156.628/SP, j. 19.05.1998; REsp. 159.702/SP, j. 19.05.1998.

1170 STJ, Súm. 33: "a incompetência relativa não pode ser declarada de ofício".

${ }^{1171}$ CC 133.449.0/4-00, rel. Canguçu de Almeida, j. 27.11.2006; CC 97.586.0/8-00, rel. Luís de Macedo, j. 09.12.2002; CC 094.638.0/4-00, rel. Mohamed Amaro, j. 16.09.2002.

1172 Cf., infra, Cap. VI, 2.3.2.

${ }^{1173}$ CDC, art. 101, I: "na ação de responsabilidade civil do fornecedor de produtos de produtos e serviços, sem prejuízo do disposto nos Capítulos I e II deste Título, serão observadas as seguintes normas: I - a ação pode ser proposta no domicílio do autor". 
pretendido e a amplitude da sua defesa, o que arreda a escolha aleatória em detrimento do fornecedor. $^{1174}$

É que a ninguém, consumidor inclusive, é dado escolher o juízo onde pretende demandar, sequer por cláusula de eleição. ${ }^{175}$

Bons ventos sopram no sentido de ser conveniente a edição de uma súmula sobre o tema, que poderia ter o seguinte enunciado: a competência territorial, no interesse do consumidor, é absoluta.

\subsubsection{Execução x local de pagamento do título}

E para a garantia desse direito básico dos consumidores, pouco importa a natureza jurídica da pretensão deduzida em juízo, se de conhecimento ou se execução ${ }^{1176}$, tese já acolhida - em outra oportunidade - pela C. Câmara Especial do TJSP. ${ }^{1177}$

1174 “A facilitação da defesa dos direitos do consumidor em juízo possibilita que este proponha ação em seu próprio domicílio. Tal princípio não permite, porém, que o consumidor escolha, aleatoriamente, um local diverso de seu domicílio ou do domicílio do réu para o ajuizamento do processo" (STJ, REsp. 1.084.036/MG, rel. Min. Nancy Andrighi, j. 03.03.2009). E do TJSP confira-se: "no caso em exame, o ora apelante, domiciliado na cidade de Pirassununga (fls. 88), propôs a demanda na comarca de Leme, sob a justificativa de existir agência do banco agravado naquela cidade. Todavia, a agência bancária onde o contrato fora firmado também está situada na comarca de Pirassununga e o local do cumprimento da obrigação também é aquela Comarca, de sorte que nada justifica o ajuizamento da demanda em Leme, onde o apelante, repita-se, não mantém domicílio. A escolha aleatória pelo consumidor de comarca para a propositura de demanda, sem justificativa alguma, seja em razão do seu domicílio ou pela existência de cláusula de eleição de foro, não se inclui dentre os direitos garantidos pela legislação consumerista" (AC 990.10.404844-3, rel. Ana de Lourdes Coutinho da Silva, j. 15.12.2010).

1175 “(...) na técnica do direito processual o vocábulo foro significa comarca ou seção judiciária, ao passo que juízo corresponde a órgão judiciário ou vara (cf. Cândido Rangel Dinamarco, Fundamentos do Processo Civil Moderno, p. 140 e segtes. Ed. RT). Destarte, não estando sujeita a competência das Varas Cíveis da Capital a modificações por consenso das partes, visto que estas podem eleger apenas o 'foro', nunca o 'juízo', e como a eleição do Foro Central, no caso em comento, implica na escolha do 'juízo', é que não pode prevalecer o pactuado" (TJSP, AI 7.171.358-5, rel. Mario de Oliveira, j. 27.02.2008).

${ }_{1176}$ Cf., a propósito, o parecer de Nelson Nery Júnior exarado no CC 14.251-0/1-00, j. 13.09.2004, não acolhido pelo TJSP: "a competência é do Juízo suscitante ( $6^{\mathrm{a}}$ Vara Cível de São Vicente). A ação é de execução de notas promissórias derivadas de acordo celebrado entre as partes, em virtude de contrato de prestação de serviços educacionais. A credora, com sede em Santos, ajuizou nessa comarca ação contra os consumidores dos serviços educacionais, que residem em São Vicente. Tratando-se de relação de consumo, é princípio básico positivado no CDC $6^{\circ}$, VIII, que o consumidor tem direito fundamental de ter facilitada sua defesa em juizo. Ainda que haja cláusula de eleição de foro, se for diverso do domicílio do consumidor, ele certamente não estará tendo sua defesa facilitada, razão por que essa cláusula seria nula pleno iure, de acordo com o CDC $51 \mathrm{XV}$ combinado com o CDC $6^{\circ}$ VIII. Assim, deve o juiz proclamar essa nulidade, sem que isso configure ofensa ao preceito estatuído no STJ 33, consoante tem decidido o Egrégio Superior Tribunal de Justiça, como se pode conferir no julgamento da Colenda $4^{\mathrm{a}}$ Turma, rel. Min. Ruy Rosado de Aguiar, que afirma expressamente poder o juiz decidir essa matéria ex officio (RSTJ 153/351). Por essa razão agiu com acerto o juízo de Santos, ao remeter os autos ao juízo do domicílio dos consumidores (São Vicente), que é o verdadeiramente competente para processar e julgar a causa, sendo que esse ato não caracteriza 
Isto se justifica porque a mesma disciplina adotada nas hipóteses de eleição de foro há de incidir quanto ao local de pagamento do título de crédito, a resguardar, com isso, a plenitude da defesa do consumidor.

Sem questiúnculas processuais, simples é a pergunta que exige resposta: qual a diferença entre violar direito do consumidor mediante abusiva eleição contratual de foro e instrumentalizar essa ilegalidade por imposição do lugar de pagamento de título de crédito?

À evidência que a resposta é uma só: nenhuma!

$\mathrm{O}$ consumidor tem ou não tem direito de ser demandado no

seu domicílio?

Tal qual adverte João Batista de Almeida, “deve ser abolida a contradictio in terminis: o Estado, encarregado de defender o consumidor, não pode, em hipótese alguma, desrespeitá-lo. Se o desrespeito parte do próprio Estado, faltar-lhe-á legitimidade para cobrar o respeito por parte de outrem. Por isso, seria bem-vinda uma mudança de mentalidade também nessa área". ${ }^{1178}$

A autonomia principiológica de um título de crédito jamais pode restringir ou esvaziar a força condicionante positiva do texto constitucional.

Por outro lado, para que se perceba a similitude fática das situações (foro de eleição e lugar do pagamento), mister se faz investigar a natureza jurídica da obrigação cambial e, neste pormenor, ressalta Fábio Ulhoa Coelho que "uma obrigação cambial é de natureza quesível, ou seja, cabe ao credor a iniciativa para a obtenção da satisfação do crédito. Deve ele procurar o devedor para receber o valor do título ou avisá-lo do local onde poderá ser feito o pagamento. Ao contrário do que ocorre com o devedor de obrigação portável, ao devedor cambial não cabe a iniciativa para a solução da pendência. De qualquer forma, a inobservância da cláusula quesível ou portável não invalida o pagamento". 1179

reconhecimento de ofício de incompetência relativa, mas é mera decorrência do reconhecimento de matéria de ordem pública $\left(\mathrm{CDC} 1^{\circ}\right)$, consistente na aplicação da garantia do CDC $6^{\circ}$ VIII".

1177 "Conflito negativo de competência - Execução de mensalidade escolar ajuizada fora do domicílio da consumidora - Reconhecimento da competência absoluta, com determinação da remessa dos autos para o foro do domicílio da consumidora com a concordância do fornecedor dos serviços que deixou de recorrer Competência absoluta que pode ser declarada de ofício - Conflito procedente e competente o MM. Juiz suscitante" (TJSP, CC 113.504-0/0, rel. Moura Ribeiro, j. 20.12.2004).

${ }_{1178}$ A proteção jurídica..., cit., p. 283.

${ }^{1179}$ Manual de Direito Comercial. 14a ed. São Paulo: Saraiva, 2003, p. 260. 
Ora, o direito cambiário também é disciplinado pela regra geral do lugar do pagamento, é dizer, à míngua de outros fatores (v.g., convenção das partes, etc.), prevalece a natureza quérable da obrigação e, assim, deve o credor buscar o pagamento no domicílio do devedor. ${ }^{1180}$

E, por certo, a implicar ato de renúncia ${ }^{1181}$, essa convenção da partes exige pleno exercício de vontade livre, o que não ocorre na relação de consumo, marcada por um desnível natural imposto pelas diferentes posições e interesses das partes envolvidas: fornecedor e consumidor.

Impende frisar que o consumidor é, ex vi legis, vulnerável $\left(\mathrm{CDC}\right.$, art. $\left.4^{\circ}, \mathrm{I}\right)$ e, por isso, diferença alguma há na manifestação de vontade aderente à eleição de foro contratual ou ao lugar do pagamento em título de crédito, pois ambos lhe foram impostos.

5.2 Inversão do ônus da prova

Tal qual adverte Rizzatto Nunes: "entender, então, a produção de provas em casos que envolvam as relações de consumo é compreender toda a principiologia da Lei n. 8.078, que pressupõe, entre outros princípios e normas, a vulnerabilidade do consumidor, sua hipossuficiência (especialmente em técnica de informação, mas também econômica, como se verá), o plano geral da responsabilização do fornecedor, que é de natureza objetiva etc.". ${ }^{1182}$

Como direito básico, o art. $6^{\circ}$, VIII, do CDC encerra norma dotada de tônus material, que somente alça contornos processuais se e quando o ônus for efetivamente invertido ${ }^{1183}$, antes disso a abstrata preocupação é com a facilitação da defesa do consumidor e com a garantia da paridade de armas ${ }^{1184}$ em juízo; tanto é assim que são

\footnotetext{
${ }^{1180} \mathrm{CC}$, art. 327: "efetuar-se-á o pagamento no domicílio do devedor, salvo se as partes convencionarem diversamente, ou se o contrário resultar da lei, da natureza da obrigação ou das circunstâncias".

${ }^{1181}$ Segundo Carlos Roberto Gonçalves (Direito civil brasileiro. v. 2. Teoria Geral das Obrigações. $8^{\mathrm{a}}$ ed. São Paulo: Saraiva, 2011, p. 281): “(...) O referido art. 327 constitui, pois, norma supletiva da vontade das partes, caso não concorram os outros fatores mencionados. Sendo o benefício instituído em seu favor, pode o devedor a ele renunciar, efetuando o pagamento no domicílio do credor".

1182 Comentários..., $4^{\mathrm{a}}$ ed., cit., p. 150.

${ }^{1183}$ Claudia Lima Marques et alii. Manual..., cit., 61/62.

1184 Sobre paridade de armas (waffengleichheit), cf., Nelson Nery Júnior. Princípios do processo civil na Constituição Federal. 10 a ed., São Paulo: RT, 2010, p. 244/245, i. 27.
} 
consideradas nulas de pleno direito as cláusulas contratuais que estabeleçam inversão do ônus da prova em prejuizo do consumidor (CDC, art. 51, VI).

A se distinguir de outras previsões dispersas na Parte Especial, a exemplo dos arts. $12, \S 3^{\circ}, 14, \S 3^{\circ}$, e 38 , onde a inversão (ou mera atribuição) opera ex vi legis, o instituto - aqui - só ganha relevo a critério do juiz, segundo as regras ordinárias de experiência ${ }^{1185}$, dês que presentes um dos seus requisitos (não cumulativos): a verossimilhança da alegação ou a hipossuficiência do consumidor, por isso é ope iudicis.

Estruturou-se uma forma de apartar o consumidor das dificuldades impostas pelo direito processual comum, que atribui o ônus da prova do fato a quem o alega ${ }^{1186}$, moldura que poderia se revelar desastrosa nas relações de consumo certamente a ponto de esvaziar a proteção constitucional idealizada - ante a total falta de gerência do consumidor sobre o processo produtivo, cujo único titular é o fornecedor.

Seu espectro de incidência é geral, alcançando todas as situações em que, pela disciplina comum, a prova do fato caberia ao consumidor, inclusive quando o próprio Código faz isso (CDC, art. 14, § $4^{\mathrm{o}^{1187}}$ ).

"A rigor, no caso, serão dois os momentos de produção de prova e, portanto, dois os momentos da averiguação da possibilidade - e necessidade, como vimos - de inversão. O primeiro é o da prova do dano, do nexo de causalidade entre o dano e o serviço, com a indicação do profissional responsável. O segundo o da culpa do profissional liberal, prestador do serviço. Em ambos os casos a inversão poderá dar-se."1188

\subsubsection{Verossimilhança da alegação}

\footnotetext{
${ }^{1185}$ CPC, art. 335: “em falta de normas jurídicas particulares, o juiz aplicará as regras de experiência comum subministradas pela observação do que ordinariamente acontece e ainda as regras da experiência técnica, ressalvado, quanto a esta, o exame pericial".

${ }^{1186} \mathrm{CPC}$, art. 333: "o ônus da prova incumbe: I - ao autor, quanto ao fato constitutivo do seu direito; II - ao réu, quanto à existência de fato impeditivo, modificativo ou extintivo do direito do autor".

$1187 \mathrm{CDC}$, art. 14, $\S 4^{\circ}$ : “a responsabilidade pessoal dos profissionais liberais será apurada mediante a verificação da culpa".

${ }^{1188}$ Luiz Antonio Rizzatto Nunes. Comentários..., $4^{\text {a }}$ ed., p. 233.
} 
Pode-se entender a verossimilhança, no seu efeito prático, como a grande possibilidade - próxima de um juízo objetivo de certeza no caso concreto $^{1189}$ - de terem os fatos se desdobrado do modo descrito pelo consumidor.

É uma valoração de quase mérito, a permitir que o juiz - seja no saneador, seja na sentença - avalie os pontos controvertidos da lide com base naquilo que ordinariamente acontece.

Kazuo Watanabe, no entanto, que nesse caso não haveria propriamente uma inversão do ônus da prova, isto porque "o magistrado, com a ajuda das máximas de experiência e das regras da vida, considera produzida a prova que incumbe a uma das partes. Examinando as condições de fato com base nas máximas de experiência, o magistrado parte do curso normal dos acontecimentos, e, porque o fato é ordinariamente a conseqüência ou o pressuposto de um outro fato, em caso de existência deste, admite também aquele como existente, a menos que a outra parte demonstre o contrário". 1190

\subsubsection{Hipossuficiência}

Já ficou claro que a hipossuficiência não se confunde com a vulnerabilidade (supra, Cap. III, 2.2) ${ }^{1191}$, pois reservada àqueles que, além de vulneráveis, vêem-se agravados nessa situação por sua individual condição de carência cultural, material ou, como ocorre com frequência, ambas. ${ }^{1192}$

\footnotetext{
1189 Para Rizzatto Nunes (idem, p. 154), “(...) a hipossuficiência depende de reconhecimento expresso do magistrado no caso concreto. É que o desconhecimento técnico e de informação capaz de gerar a inversão tem de estar colocado no feito sub judice. São as circunstâncias do problema aventado e em torno do qual o objeto da ação gira que determinarão se há ou não hipossuficiência (que, como vimos, regra geral atinge a maior parte dos consumidores). Pode muito bem ser o caso de consumidor engenheiro que tinha claras condições de conhecer o funcionamento, de modo a ilidir sua presumida hipossuficiência. Como pode também ser engenheiro e ainda assim, para o caso, constatar-se sua hipossuficiência".

${ }^{1190}$ Et alii. Código Brasileiro de Defesa do Consumidor, comentado pelos autores do anteprojeto. Processo Coletivo. $10^{\mathrm{a}}$ ed. Rio de Janeiro: Forense, 2011, p. 8/9.

${ }^{1191}$ Lembre-se de Roberto Senise Lisboa (Responsabilidade civil..., cit., p. 85/88) quando afirma que: "ordinariamente, vulnerabilidade é expressão sinônima de hipossuficiência uma vez que não encontra precedentes de importância na história do direito brasileiro. Entretanto, o legislador consumerista conferiu um tratamento nitidamente diferenciado para os dois vocábulos, motivo pelo qual eles não devem ser compreendidos como sinônimos. (...) Em outras palavras: não é sempre que o consumidor pode ser considerado hipossuficiente, mas ele sempre é vulnerável. O consumidor vulnerável pode ser hipossuficiente ou não. A lei não entende que a hipossuficiência equivale à vulnerabilidade. Pelo contrário. Do microssistema jurídico em questão pode-se concluir que todo consumidor é vulnerável, porém nem todo consumidor é hipossuficiente".

${ }^{1192}$ Arruda Alvim et alii. Código do Consumidor comentado..., cit., p. 45, n. 7.
} 
Percebe-se, por conseguinte, que a hipossuficiência é um plus em ralação à vulnerabilidade. Esta é aferida objetivamente, ope legis. Aquela, mediante um critério subjetivo, consumidor a consumidor. ${ }^{1193}$

$\mathrm{Ou}$, em outras palavras, a vulnerabilidade é um conceito de ordem material, inerente à figura de qualquer consumidor; enquanto a hipossuficiência é ontologicamente processual e, por isso, sua presença deve ser verificada caso a caso com o escopo de viabilizar seu único efeito: a inversão do ônus da prova.

E a hipossuficiência ${ }^{194}$ comumente se projeta no mundo de três formas: a técnica ${ }^{1195}$, a jurídica e a fática (sócio-econômica).

$\mathrm{Na}$ técnica, o consumidor não possui conhecimentos específicos sobre o objeto que está adquirindo e, portanto, é mais facilmente enganado quanto às características do bem (ou serviço) ou quanto à sua utilidade. A jurídica é a falta de conhecimentos legais específicos (v.g., dos seus próprios direitos, de contabilidade, de economia, etc.), além de não estar acostumado a litigar. A fática concentra-se no outro polo da relação, o fornecedor que por sua posição preponderante, aliada ao seu grande poder econômico e/ou à essencialidade do serviço, impõe sua superioridade a todos que com ele contratam. $^{1196}$

\subsubsection{Momento da inversão}

Duas posições avultam bem definidas neste ponto: a primeira, tentando evitar uma possível surpresa aos litigantes ${ }^{1197}$ (e isso é importante), sustenta que

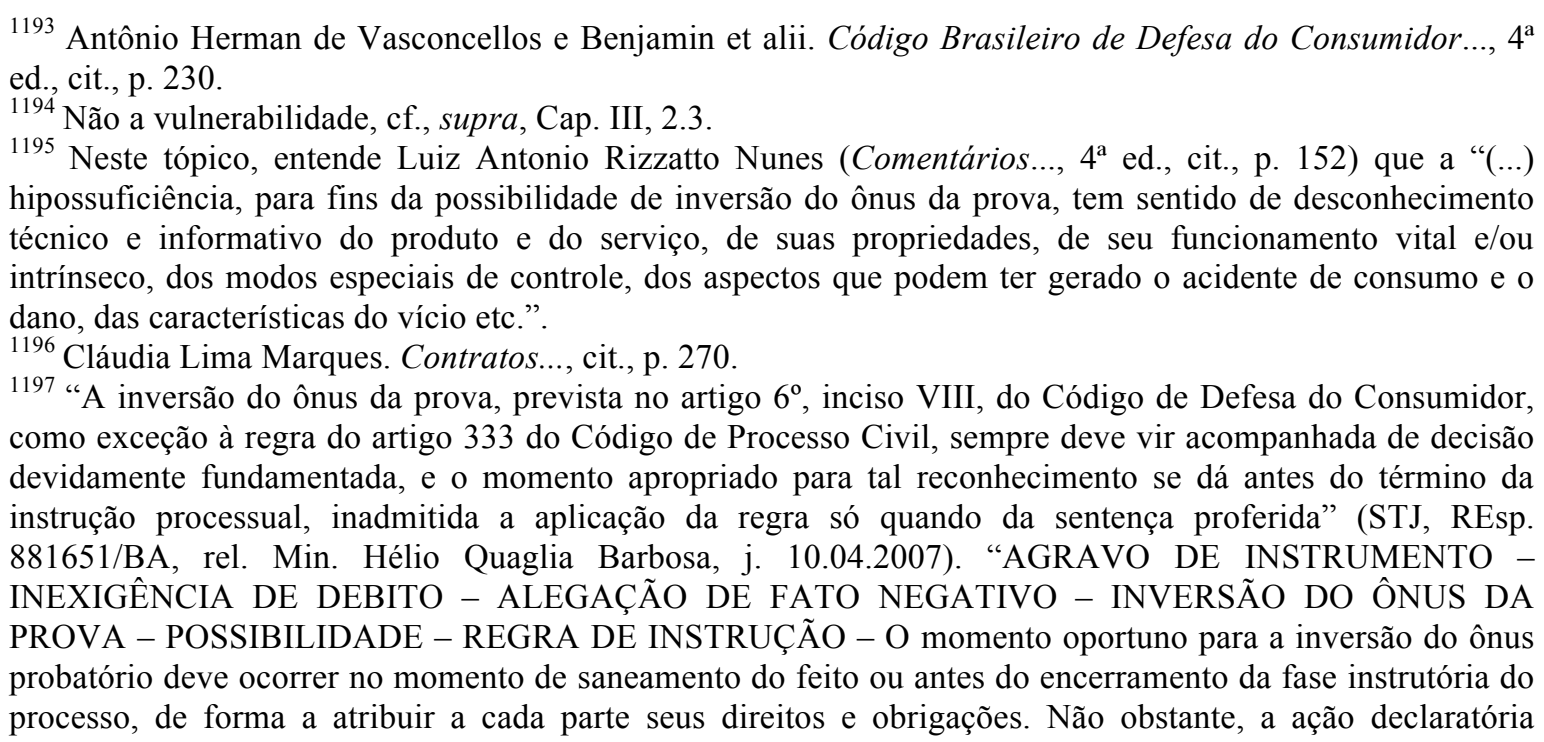


“o momento processual mais adequado para a decisão sobre a inversão do ônus da prova é o situado entre o pedido inicial e o saneador"1198. A segunda, por sua vez, à semelhança da doutrina processual clássica, identifica na hipótese uma regra de julgamento ${ }^{1199}$, mecanismo dirigido a afastar o non liquet em matéria de fato. ${ }^{1200}$

Em que pesem às razoáveis ponderações de uma e de outra corrente, discorda-se de ambas, as quais - na verdade - não se excluem. O importante, aqui, é visualizar que não existe um momento certo ou errado para o juiz inverter o ônus da

negativa de existência de débito e de relação jurídica cabe à recorrida provar o fato constitutivo da dívida, quando a recorrente apenas alega inexistir qualquer relação entre eles. Recurso provido" (TJSP, AI 055781549.2010.8.26.0000, rel. Roberto Mac Cracken, j. 31.03.2011). "DANOS MATERIAIS E MORAIS. Determinação alusiva à produção de provas, observada a 'regra de instrução' quanto à aplicação da inversão do ônus da prova, prevista na Lei Consumerista. Prematura a prolação da sentença, ao inobservar o anterior comando judicial irrecorrido. RECURSO PROVIDO para anular a r. sentença e determinar o retorno dos autos à Vara de Origem para a produção das provas anteriormente determinadas e dar prosseguimento regular à comenda" (TJSP, AC 991.05.024701-9, rel. Elmano de Oliveira, j. 16.06.2011). "PROVA - Ônus Insurgência do recorrente contra decisão que indeferiu o pedido de inversão do ônus da prova Admissibilidade - Hipossuficiência do recorrente configurada - Aplicabilidade da regra de instrução, devendo a inversão ser pronunciada até o saneamento do processo, assegurando-se os direitos constitucionais do contraditório e da ampla defesa - Decisão reformada - Agravo provido" (TJSP, AI 991.07.064144-0, rel. Roque Mesquita, j. 27.11.2007).

${ }^{1198}$ Luiz Antonio Rizzatto Nunes. Comentários..., 4a ed., cit., p. 155). E prossegue: "há, também, a importante questão do destinatário da norma estatuída no inciso VIII do art. $6^{\circ}$. Entendemos, que, muito embora essa norma trate de distribuição do ônus processual de provar dirigido às partes, ela é mista no sentido de determinar que o juiz expressamente decida e declare de qual das partes é o ônus. Como a lei não estipula a priori quem está obrigado a se desonerar e a fixação do ônus depende da constatação da verossimilhança ou hipossuficiência, o magistrado está obrigado a se manifestar antes da verificação da desincumbência, porquanto é ele que dirá se é ou não caso de inversão".

1199 "A inversão do ônus da prova, prevista no art. 6º inciso VIII, do Código de Defesa do Consumidor, é regra de julgamento. Ressalta do entendimento pessoal do Relator, no sentido de que tal solução não se compatibiliza com o Devido Processo Legal" (STJ, REsp. 949.000/ES, rel. Min. Humberto Gomes de Barros, j. 27.03.2008). "INVERSÃO DO ÔNUS DA PROVA. CÓDIGO DE DEFESA DO CONSUMIDOR. REGRA DE JULGAMENTO. INVERSÃO ANTERIOR. IMPOSSIBILIDADE. RECURSO PARCIALMENTE PROVIDO. A norma do artigo $6^{\circ}$, inciso VIII, do CDC, é voltada, não a estabelecer disciplina e conduta das partes, mas de julgamento da causa na hipótese de ausência ou insuficiência de provas Assim, não cabe ao juiz, antes do julgamento, disciplinar a inversão, pois as partes sabem que existe essa possibilidade e lhes cabe atuar com o propósito de trazer os elementos de prova necessários a formação do convencimento" (TJSP, AI 1.208.773-00/8, rel. Adílson de Araújo, j. 11.11.2008). “(...) Prematura a emissão de juízo de inversão do ônus da prova na fase de saneamento do feito, cabendo ao juiz apenas advertir os litigantes a respeito dessa possibilidade, para que o direito ao contraditório possa ser exercido na plenitude pelo réu, nem seja este surpreendido com as conseqüências da não produção de prova que o julgador pode achar que está a cargo de quem está se defendendo" (TJSP, AI 991.09.041027-1, rel. Álvaro Torres Junior, j. 12.04.2010). "INVERSÃO DO ÔNUS DA PROVA - A inversão do ônus da prova, que deve ocorrer por ocasião da prolação de sentença e não durante a instrução da causa, não implica transferir a parte por ela desfavorecida a obrigação de adiantar os honorários periciais - Recurso provido" (TJSP, 0043018-91.2011.8.26.0000, rel. Eduardo Sá Pinto Sandeville, j. 21.06.2011). Em igual sentido e da mesma Corte: AC 0000216-32.2010.8.26.0059, j. 28.06.2011).

${ }^{1200}$ Kazuo Watanabe (et alii. Código Brasileiro de Defesa do Consumidor..., 10 $0^{\mathrm{a}}$ ed., cit., p. 10/11). E adita: “(...) somente após a instrução do feito, no momento da valoração das provas, estará o juiz habilitado a afirmar se existe ou não situação de non liquet, sendo o caso ou não, consequentemente, de inversão do ônus da prova. Dizê-lo em momento anterior será o mesmo que proceder ao prejulgamento da causa, o que é de todo inadmissível". 
prova, seja porque o Código assim não definiu, seja porque cada parte deve tratar a marcha processual cuidando do exercício frutuoso da sua atividade probatória.

Como premissa, em litígio de consumo, forte na principiologia protetiva desse especial microssistema, seu destinatário que é, o juiz pode distribuir o ônus da produção de determinada prova a qualquer tempo, desde a decisão liminar positiva que admite a demanda ${ }^{1201}$ até na própria sentença, quando avalia os fatos provados e os não provados, afinal a possibilidade de inversão está prevista na lei, que a ninguém é dado desconhecer (LICC, art. $3^{01202}$ ), o que afasta o perigo de surpresa. ${ }^{1203}$

1201 “Tome-se emprestado o exemplo de um consumidor que, ao negar ter mantido relação jurídica com certa empresa de telefonia, ingressa em juízo e pede a exclusão do seu nome de cadastros de proteção ao crédito. Na própria antecipação de tutela o juiz pode (e deve) determinar que a ré, na contestação, exiba o contrato, assinado pelo autor, autorizante da restritiva, numa aplicação direta dos arts. $6^{\circ}$, VIII, do CDC e 355 do CPC. A propósito, confira-se: "o cerne da questão está em verificar a existência de relação contratual e sua validade considerado o procedimento adotado pela apelante, a qual afirma que o pedido de instalação é por meio de ligação telefônica com fornecimento de dados pessoais. É certo que a empresa de telefonia deve comprovar a existência do contrato quando negada a relação, tanto à luz do Código de Defesa do Consumidor (art. 6o, VIII) como â vista do disposto no art. 335 do Código de Processo Civil (regras de experiência)" (TJSP, AC 890.087-0/3, rel. José Malerbi, j. 07.08.2006).

${ }^{1202}$ LICC, art. $3^{\circ}$ : "ninguém se escusa de cumprir a lei, alegando que não a conhece".

${ }^{1203}$ Antes da abertura da fase instrutória, porém, como medida de prudência, o juiz deve ouvir as partes sobre as provas hipoteticamente por elas desejadas. É o conhecido despacho "especifiquem provas", que pode ser usado mesmo antes da audiência preliminar (CPC, art. 331, $\left.\S 2^{\circ}\right)$, muitas vezes desnecessária, no intuito de esclarecer a necessidade de saneamento ou de tornar possível, com segurança, a definição antecipada da lide. A extrair um efeito mais útil dessa medida, sugere-se o seguinte formato: "Especifiquem as partes as provas que pretendem produzir ou manifestem expressa concordância com o julgamento antecipado da lide. Prazo: 05 dias, quando também deverão externar interesse na conciliação. Anoto que o silêncio implicará anuência à solução do feito nesta fase". Estando claramente prevista a consequência do silêncio, ao optar pela inércia, a parte estará atraindo, por ato próprio, a preclusão lógica da sua atividade probatória. Assim ensina Miguel Maria de Serpa Lopes ( $O$ silêncio como manifestação de vontade. $3^{\mathrm{a}}$ ed. Rio de Janeiro: Livraria Freitas Bastos, 1961, p. 165): “depois de termos analisado o valor do silêncio, no tríplice ponto de vista da psicologia, sociologia e de Direito, depois de havermos assinalado que o princípio de solidariedade social impõe ao homem, em dadas circunstâncias, o dever de agir e de falar, de modo que o silêncio, em tais momentos, implica necessariamente na produção de efeitos ponderosos; depois de têrmos visto que êsse dever de falar constitui uma obrigação jurídica decorrente da lei, tomada esta na acepção de 'uma relação necessária decorrente da natureza das coisas': não trepidamos em asseverar que o 'silêncio' constitui um elemento capaz de aquisição, modificação e extinção de direito, como o é, igualmente, para formação dos contratos. (...) O silêncio pode então definir-se: 'uma manifestação de vontade, por meio de um comportamento negativo, deduzida de circunstâncias concludentes, caracterizadas pelo dever e possibilidade de falar quanto ao silente e pela convicção da outra parte indicando uma inequívoca direção da vontade incompatível com expressão de uma vontade oposta"”. E mais: "PROCESSUAL CIVIL. ESPECIFICAÇÃO DE PROVAS. MANIFESTAÇÃO A CONSIDERAR. PRECLUSÃO. I. Preclui o direito à especificação de provas se a parte, instada a requerê-la por despacho posterior à contestação, deixa de fazê-lo, dando margem ao julgamento antecipado da lide por se cuidar de matéria de direito. II. Agravo regimental desprovido (STJ, AGA 206.705/DF, rel. Min. Aldir Passarinho Junior, j. 03.02.2000). Do V. Aresto extrai-se o seguinte excerto: “(...) aberta vista às partes para a especificação de provas, em momento posterior à contestação, os recorrentes nada postularam. Ora, se permaneceram inertes, em fase mais adiantada do processo, é porque desistiram da prova inicialmente argüida na inicial da defesa, inexistindo cerceamento algum. Diferente seria, por exemplo, se pedida uma prova na contestação, o MM. Juiz processante houvesse, de inopino, julgado a lide antecipadamente. Mas não foi isso que aconteceu. Como relatado, tomou o cuidado de abrir vista para especificação de provas, recebendo o silêncio preclusivo como resposta". 
Nem de longe isso implica prejulgamento, haja vista ser impossível antever o resultado da prova que teve invertido o ônus da sua produção.

\subsection{4 Ônus econômico x teoria da carga dinâmica}

O próprio sentido da inversão está em relegar a prova à parte que tenha melhores condições - principalmente técnicas, mas também econômicas - de produzi-la; aliás, são esses os contornos da teoria da carga dinâmica.

Segundo Kazuo Watanabe, "para a teoria da carga dinâmica da prova o que importa, em determinadas situações, não é tanto a posição processual das partes ou seu interesse jurídico em ver admitido o fato probando, mas sim a maior facilidade em sua demonstração, pelo domínio de conhecimentos científicos ou técnicos ou pela detenção de informações sobre os fatos da causa. A teoria não desconsidera por completo as regras gerais de distribuição do ônus da prova. O que procura fazer é flexibilizar essas regras, adaptando-as às peculiaridades do caso concreto e às especificidades das partes litigantes, tornando mais efetiva e justa a tutela jurisdicional", 1204

Aqui surge a questão do ônus econômico da prova. Estaria ele abrangido pela inversão? A eficácia condicionante da Parte Geral do Código só admite a resposta afirmativa ${ }^{1205}$, até porque menos gravosa ao fornecedor ${ }^{1206}$, porquanto a prova seria produzida, com possibilidade do seu sucesso inclusive.

\footnotetext{
${ }^{1204}$ Et alii. Código Brasileiro de Defesa do Consumidor..., $10^{\mathrm{a}}$ ed., cit., p. 6.

${ }^{1205}$ Ao enfrentar a mesma indagação, esclarece Luiz Antonio Rizzatto Nunes (Comentários..., $4^{\mathrm{a}}$ ed., cit., p. 155/156): “(...) a resposta salta aos olhos: se o sistema legal protecionista cria norma que obriga à inversão do ônus da prova, como é que se poderia determinar que o consumidor pagasse as despesas ou honorários? Uma vez determinada a inversão, o ônus da produção da prova tem de ser da parte sobre a qual recai o ônus processual. Caso contrário, estar-se-ia dando com uma mão e retirando com a outra. Se a norma prevê que o ônus da prova pode ser invertido, então automaticamente vai junto para a outra parte a obrigação de proporcionar os meios para sua produção, sob pena de - obviamente - arcar com o ônus de sua nãoprodução. Se assim não fosse, instaurar-se-ia uma incrível contradição: o ônus da prova seria do réu, e o ônus econômico do autor (consumidor). Como este não tem poder econômico, não poderia produzir a prova. Nesse caso, sobre qual parte recairia o ônus da não-produção da prova?".

${ }^{1206}$ Orienta Kazuo Watanabe (et alii. Código Brasileiro de Defesa do Consumidor..., 10 a ed., cit., p. 10) que, “(...) sendo o consumidor, em tais condições, economicamente hipossuficiente, será ele dispensado dos gastos com as provas. O mais que o magistrado poderá fazer, tal seja o custo da prova a ser colhida, por exemplo, uma perícia especializada e sua impossibilidade prática de realização gratuita, é determinar que o fornecedor suporte as despesas com a prova. O texto legal em análise permite semelhante interpretação, que conduziria a uma solução menos rigorosa que a de inversão do ônus da prova".
} 


\section{A jurisprudência oscila, ora admitindo o espetro amplo da}

inversão $^{1207}$, ora negando-o ${ }^{1208}$ com base na disciplina geral prevista nos arts. $19^{1209}$ e 33

1207 “1. A inversão do ônus da prova tem por objetivo desobrigar o autor de demonstrar o fato constitutivo de seu direito atribuindo ao réu a responsabilidade de comprovar o quanto deduzido em sua defesa. 2. Se apesar da inversão do ônus da prova o consumidor houvesse de antecipar as despesas processuais, estar-se-ia prejudicando a parte mais fraca da relação processual, pois a aplicação subsidiária dos artigos 19 e 33 do Código de Processo Civil criaria mais dificuldade à defesa de seus direitos em juízo" (TJSP, AG 005078753.2011.8.26.0000/50000, rel. Itamar Gaino, j. 22.06.2011). "A inversão do ônus da prova compreende o ônus financeiro e o dever de arcar com o custeio da prova técnica - Prevalência das normas do CDC sobre os artigos 33 e 333 do Código de Processo Civil - RECURSO DESPROVIDO” (TJSP, AI 006631530.2011.8.26.0000, rel. Sérgio Shimura, j. 18.05.2011). “Antecipação do custo com a realização de perícia que cabe ser imposto ao produtor/fornecedor, para facilitação da defesa dos direitos do consumidor, ante a hipossuficiência técnica e/ou econômica deste" (TJSP, AI 7.032.699-1, rel. Oséas David Viana, j. 26.10.2005). “AGRAVO DE INSTRUMENTO ACIDENTE/SEGURO DE VEÍCULO - COBRANÇA Depósito dos honorários do perito judicial. Tratando-se de relação de consumo em que é cabível a inversão do ônus da prova, não deve o agravado, parte hipossuficiente, custear as despesas com produção de prova pericial. Aplicação do artigo $6^{\circ}$ do Código de Defesa do Consumidor. Decisão mantida. Recurso não provido" (TJSP, AI 992.09.064486-2, rel. Marcondes D’Angelo, j. 17.09.2009). "Lembrando antiga regra de direito material segundo a qual o acessório segue o principal, ocorrendo a inversão do ônus da prova, deve ocorrer igualmente a inversão do ônus de pagar os honorários periciais, sem que se possa afirmar ofensa aos artigos 19, 33 e 333, inciso I, todos do Código de Processo Civil. É que, na hipótese, aplica-se a lei especial que prevalece sobre a geral. Aquela, o Código de Defesa do Consumidor, autoriza a inversão e esta afirma que o ônus do pagamento deve ser assumido pela parte que tem a obrigação de realizar a prova" (TJSP, AI 990.10.228966-4, rel. Roque Mesquita, j. 20.07.2010). "Tratando-se de ônus probatório, caso seja determinada a produção de determinado tipo de prova, por ser reconhecida como necessária, a sua não realização acarretará conseqüências contra quem tem o ônus de produzi-la, no caso presente, a instituição bancária. Em outras palavras, contrariamente ao afirmado pelo agravante, a inversão do ônus da prova importa sim na inversão do ônus econômico, porquanto quem tem o encargo de produzir a prova tida como indispensável ao deslinde da demanda não pode alegar, excludente pela sua não realização" (TJSP, AI 7.348.350-2, rel. Walter Fonseca, j. 17.06.2009). "PROVA - Inversão do ônus - Princípio que abrange tanto a obrigação de custeio da sua produção quanto regra de julgamento - Análise da doutrina e jurisprudência Recurso improvido" (TJSP, AI 7.000.993-7, rel. Jorge Farah, j. 05.04.2005). "Também, decorrente a aplicação, a caso em foco, do Código de Defesa do Consumidor (Lei n ${ }^{\circ}$ 8.078/90), pode o juiz, com fundamento no art. $6^{\circ}$, VIII, do CDC, determinar a inversão do pagamento dos honorários do sr. Perito judicial, considerando-se que a Agravada é hipossuficiente econômica e tecnicamente face da Agravante, estabelecendo-se, assim, a igualdade das partes no processo" ( $1^{\circ}$ TacCiv/SP, AI 1.255.432-2, rel. Paulo Hatanaka, j. 25.11.2003). "PROVA - PERÍCIA CONTÁBIL - Contrato de abertura de crédito em conta corrente - Relação de consumo - Aplicação de oficio das normas do CDC, de ordem pública e interesse social - Artigo $1^{\circ}$ - Insuficiência técnica da correntista-agravante reconhecida - Artigo $6^{\circ}$, VIII, do CDC Inversão do ônus processual e, de conseqüência, do ônus econômico da produção da prova pericial determinados de oficio para dar efetividade à facilitação da defesa da autora em juízo - Custo econômico da prova pericial carreado, de oficio, ao réu-agravado" ( $1^{\circ}$ TacCiv/SP, AI 1.274.184-3, rel. Rizzatto Nunes, $j$. 28.04.2004).

1208 “DESPESAS COM PROVA PERICIAL. CUSTEIO DA PROVA DEVE SER FEITO NOS TERMOS DOS ARTIGOS 19 E 33 DO CÓDIGO DE PROCESSO CIVIL. DECISÃO REFORMADA. 'As regras sobre o ônus da prova no processo não se confundem com as regras disciplinadoras do custeio das despesas processuais. $\mathrm{O}$ dever de pagamento das despesas processuais pelo requerimento de produção de prova pericial incumbirá a quem pediu'. Agravo provido.” (TJSP, AI 0039417-77.2011.8.26.0000, rel. Sandra Galhardo Esteves, j. 08.06.2011). "PROVA - PERÍCIA - Ação revisional - Salários periciais - Inversão dos ônus da prova não implica na necessária imposição de arcar com solvência das despesas de feitura do laudo pericial - Ônus a cargo da parte requerente da feitura da prova pericial - Aplicação da regra do artigo 33 do CPC - Decisão reformada - Agravo de instrumento provido" (TJSP, AI 991.09.012070-2, rel. Ribeiro de Souza, j. 05.08.2009). “Agravo de instrumento - Perícia - Consumidor - Inversão do ônus da prova Honorários provisórios - Determinação de pagamento pela agravante - Prova requerida pelos agravados Aplicação dos artigos 19 e 33 do CPC - A inversão é apenas do ônus da prova e não do seu custeio Obrigação dos agravados, observando-se os benefícios da assistência judiciária - Decisão reformada - 
do Código de Processo Civil ${ }^{1210}$, o que - sem dúvida - coloca à margem o caráter prevalecente da Lei 8.078/90.

Observe-se, a propósito: a inversão econômica não impõe que o fornecedor produza essa ou aquela prova. A essência de ônus permanece intacta; no entanto, tal qual orienta o E. STJ, embora ele não fique obrigado a antecipar os salários do perito, se não o fizer, presumir-se-ão verdadeiros os fatos afirmados pelo consumidor. ${ }^{1211}$

Perfeitamente possível, então, mas sempre preservando a defesa do consumidor, separar essas duas inversões de ônus: o da prova e o do seu encargo econômico; contudo, se o juiz entender indispensável a abertura de específica instrução, notadamente a técnica, para conhecer a plenitude do debate travado no litígio, só ao fornecedor suficiente podem ser atribuídos os percalços da produção probatória.

E conclui-se com Ada Pellegrini Grinover: "trata-se, em suma, da adoção, em matéria de direito do consumidor, da carga dinâmica da prova, superando a velha regra do art. 333 do CPC, para que o 'risco de não provar' recaia sobre quem estiver mais próximo da prova dos fatos e tenha maior facilidade de demonstrá-los, como no caso de hipossuficiência do consumidor". ${ }^{1212}$

\subsection{Desconsideração da personalidade jurídica}

A desconsideração da personalidade jurídica, ou disregard doctrine, a contribuir para a repressão de todos os abusos praticados no mercado (CDC,

Recurso provido" (TJSP, AI 569.242-4/9, rel. Egídio Giacoia, j. 12.08.2008). "Agravo de instrumento Pagamento dos honorários periciais - Prova requerida pelo agravado, que deverá arcar com o seu custeio Aplicação do disposto nos artigos 19 e 33 do CPC - Inversão do ônus da prova - Irrelevância - Inversão é apenas ônus probatório e não do seu custeio - Obrigação exclusiva do agravado, observado o benefício da assistência judiciária - Afastamento da obrigação carreada ao agravante" (TJSP, AI 460.009-4/1, rel. Donegá Morandini, j. 19.09.2006).

${ }^{1209} \mathrm{CPC}$, art. 19: "salvo as disposições concernentes à justiça gratuita, cabe às partes prover as despesas dos atos que realizam ou requerem no processo, antecipando-lhes o pagamento desde o início até a sentença final; e bem ainda, na execução, até a plena satisfação do direito declarado pela sentença. $\S 1^{\circ}$. O pagamento de que trata este artigo será feito por ocasião de cada ato processual. $\S 2^{\circ}$. Compete ao autor adiantar as despesas relativas a atos, cuja realização o juiz determinar de ofício ou a requerimento do Ministério Público".

${ }^{1210} \mathrm{CPC}$, art. 33: "cada parte pagará a remuneração do assistente técnico que houver indicado; a do perito será paga pela parte que houver requerido o exame, ou pelo autor, quando requerido por ambas as partes ou determinado de ofício pelo juiz".

${ }^{1211}$ STJ, AgRg. no REsp. 1.042.919/SP, rel Min. Humberto Martins, j. 05.03.2009. Em igual sentido e da mesma Corte: REsp. 466.604/RJ, j. 07.04.2003; REsp. 435.155/MG, j. 11.02.2003; REsp. 443.208/RJ, j. 11.02.2003; REsp. 437.425/RJ, j. 15.08.2002.

1212 Contratos de consumo e ônus da prova. In: Lopez, Teresa Ancona e Aguiar Junior, Ruy Rosado de (coord.). Contratos de consumo e atividade econômica. Série GVlaw. São Paulo: Saraiva, 2009, p. 359. 
art. $\left.4^{\circ}, \mathrm{VI}\right)$, com isso assegurando a plena reparação dos danos causados aos consumidores $\left(\mathrm{CDC}\right.$, art. $\left.6^{\circ}, \mathrm{VI}\right)$, “(...) tem seu fundamento nos princípios gerais de proibição do abuso de direito, e permite ao Judiciário, excepcionalmente, desconsiderar (ignorar no caso concreto) a personificação societária, como se a pessoa jurídica não existisse, atribuindo condutas e responsabilidades diretamente aos sócios e não à pessoa jurídica. $\mathrm{O}$ reflexo desta doutrina no esforço de proteção aos interesses do consumidor é facilitar o ressarcimento dos danos causados aos consumidores por fornecedores-pessoas jurídicas. No direito tradicional é o patrimônio societário que responde pelas dívidas da sociedade, estando a responsabilidade dos sócios restrita conforme o tipo de sociedade criada (sociedade por quotas de responsabilidade limitada, sociedade anônima, comandita etc.)". ${ }^{1213}$

O direito privado comum ${ }^{1214}$ autoriza essa medida de exceção quando caracterizados o desvio de finalidade ou a confusão patrimonial, elementares da noção de abuso adotada pelo Código Civil no seu art. 50 ${ }^{1215}$; moldura que, de certo modo, também prestigiando o elemento subjetivo do sócio ${ }^{1216}$, se repetiu no art. 28 , caput, do CDC, cujo conteúdo permite ao juiz "desconsiderar a personalidade jurídica da sociedade quando, em detrimento do consumidor, houver abuso de direito, excesso de poder, infração da lei, fato ou ato ilícito ou violação dos estatutos ou contrato social”.

Adita Rizzatto Nunes que a má administração como suporte da desconsideração encerra caso de responsabilidade objetiva; além disso, para ele, "o juiz

${ }^{1213}$ Cláudia Lima Marques. Comentários..., cit., p. 622.

1214 Não se ponham no oblívio outras hipóteses em que a aplicação do instituto é admitida: a) LSA, art. 158; b) CTN, art. 135; c) Lei de Planos de Saúde, art. 26.

${ }^{1215} \mathrm{CC}$, art. 50: "em caso de abuso da personalidade jurídica, caracterizado pelo desvio de finalidade, ou pela confusão patrimonial, pode o juiz decidir, a requerimento da parte, ou do Ministério Público quando lhe couber intervir no processo, que os efeitos de certas e determinadas relações de obrigações sejam estendidos aos bens particulares dos administradores ou sócios da pessoa jurídica".

${ }^{1216}$ Para Bruno Miragem (Direito..., cit., p. 334), "segue a desconsideração da personalidade jurídica, no regime do direito civil, o entendimento da teoria quando de sua recepção no Brasil, exigindo-se para que tenha lugar a limitação imposta pela pessoa jurídica, que tenha havido por parte dos sócios ou administradores confusão patrimonial ou desvio de finalidade. Embora a norma não explicite, é majoritário o entendimento de que tais situações abrangem a motivação geralmente dolosa dos beneficiários. Daí porque se vai exigir, como regra para o deferimento da desconsideração, a existência de má-fé através de fraude ou atos abusivos de parte dos sócios ou administradores. A doutrina mais recente, contudo, vem sustentando a necessidade de uma certa objetivação das hipóteses que autorizam a desconsideração em direito comum, sustentando a necessidade apenas da realização material do resultado concreto da confusão patrimonial ou desvio de finalidade, sem a necessidade de demonstração cabal da atuação dolosa dos sócios e administradores. Pode surgir assim, como mera eficácia de lei, sem vinculação necessária com abuso ou fraude. Entretanto, permanece sustentado por boa parte da doutrina em direito civil, a adoção da teoria subjetiva da desconsideração, ou seja, da exigência da culpa ou dolo como pressuposto da desconsideração da personalidade jurídica, sobretudo em face do caráter excepcional de que se reveste esta providência". 
não tem o poder, mas o dever de desconsiderar a personalidade jurídica sempre que estiverem presentes os requisitos legais". 1217

Cláudia Lima Marques faz interessante paralelo entre a desconsideração da personalidade jurídica e o princípio da confiança (supra, Cap. III, 4.2), “instituído pelo $\mathrm{CDC}$, garantido não só a qualidade dos produtos colocados no mercado, mas assegurando também, como dispõe o art. $6^{\circ}$, VI, a efetiva reparação dos danos sofridos pelos consumidores, mesmo que, para isto, casuisticamente, se deva desconsiderar um dos maiores dogmas do direito comercial e civil". ${ }^{218}$

O fato é que essa preocupação levou o legislador de 1990 a alargar a projeção desse instrumento no $\S 5^{\circ}$ do art. 28 do CDC, quando também estabeleceu a possibilidade de "ser desconsiderada a pessoa jurídica sempre que sua personalidade for, de alguma forma, obstáculo ao ressarcimento de prejuízos causados aos consumidores"1219, ainda que meramente objetivo à justa satisfação desses interesses (v.g., não localização de bens suficientes a satisfazer o crédito), sem que se faça mister demonstrar a prática de ato ilícito dos administradores. ${ }^{1220}$

As hipóteses do caput, portanto, se esvaziaram em rol meramente exemplificativo ${ }^{1221}$ daquilo que pode ser considerada alguma forma de obstáculo à plena reparação dos direitos do consumidor; afinal, o simples agir em desacordo com o sistema que lhe protege já tipifica ato ilegal (CDC, art. 51, XV).

Trata-se da teoria menor da desconsideração da personalidade jurídica $^{1222}$, também reflexo do risco empresarial.

1217 Comentários..., $4^{\mathrm{a}}$ ed., cit., p. 378.

${ }^{1218}$ Et alii. Comentários..., cit., p. 624/625.

${ }^{1219}$ Fábio Ulhoa Coelho (Desconsideração da personalidade jurídica. São Paulo: RT, 1989, p. 63) anota que “(...) não se deve esquecer das hipóteses em que a desconsideração da autonomia da pessoa jurídica prescinde da ocorrência da fraude ou de abuso de direito. Somente diante do texto expresso da lei poderá o juiz ignorar a autonomia da pessoa jurídica, sem indagar da sua utilização com fraude ou abuso de direito".

${ }^{1220}$ TJSP, AI 564.783.4/0-00, rel. Francisco Loureiro, j. 24.04.2008. Em igual sentido e da mesma Corte: AC 975.832-1, j. 21.03.2006; AI 290.722-4/1-00, j. 24.06.2003; AI 207.073-4/6, j. 07.08.2001.

1221 Destaca Luiz Antonio Rizzatto Nunes (Comentários..., 4a ed., cit., p. 381/382) que o intuito do dispositivo é “(...) deixar patente que as hipóteses que permitem a desconsideração da personalidade jurídica estampadas no caput são meramente exemplificativas. Apesar de mais comuns, nada impede que outras espécies de fraude e abusos sejam praticadas, tendo a pessoa jurídica como escudo. Para evitar que, nesses casos, os sócios violadores passem impunes, o parágrafo em comento deixou claro o texto normativo aberto para que em qualquer outra hipótese seja possível desconsiderar a personalidade da pessoa jurídica".

1222 “- A teoria maior da desconsideração, regra geral no sistema jurídico brasileiro, não pode ser aplicada com a mera demonstração de estar a pessoa jurídica insolvente para o cumprimento de suas obrigações. Exige-se, aqui, para além da prova de insolvência, ou a demonstração de desvio de finalidade (teoria subjetiva da desconsideração), ou a demonstração de confusão patrimonial (teoria objetiva da desconsideração). - A teoria menor da desconsideração, acolhida em nosso ordenamento jurídico 
Por fim, os $\S \S 2^{\circ}, 3^{\circ}$ e $4^{\circ}$ do art. 28 não versam regras ontologicamente atreladas à desconsideração da personalidade jurídica, antes representam comandos de atribuição, direta e específica, de responsabilidade civil. ${ }^{1223}$

\subsubsection{Desconsideração inversa x oportunidade de reconhecimento}

Embora no seu formato original a disregard doctrine se volte a atingir bens particulares dos sócios de empresa inadimplente, o sentido contrário do raciocínio, qual seja, a vinculação de patrimônio da sociedade para liquidar dívida dos seus integrantes, passou a ser admitida pela jurisprudência a partir de leading case julgado pelo E. TJSP ${ }^{1224}$. Eis o que se entende como desconsideração inversa da personalidade jurídica, já com ecos no E. STJ. ${ }^{1225}$

excepcionalmente no Direito do Consumidor e no Direito Ambiental, incide com a mera prova de insolvência da pessoa jurídica para o pagamento de suas obrigações, independentemente da existência de desvio de finalidade ou de confusão patrimonial. - Para a teoria menor, o risco empresarial normal às atividades econômicas não pode ser suportado pelo terceiro que contratou com a pessoa jurídica, mas pelos sócios e/ou administradores desta, ainda que estes demonstrem conduta administrativa proba, isto é, mesmo que não exista qualquer prova capaz de identificar conduta culposa ou dolosa por parte dos sócios e/ou administradores da pessoa jurídica. - A aplicação da teoria menor da desconsideração às relações de consumo está calcada na exegese autônoma do $\S 5^{\circ}$ do art. 28 , do CDC, porquanto a incidência desse dispositivo não se subordina à demonstração dos requisitos previstos no caput do artigo indicado, mas apenas à prova de causar, a mera existência da pessoa jurídica, obstáculo ao ressarcimento de prejuízos causados aos consumidores” (STJ, REsp. 279.273/SP, rel. Min. Nancy Andrighi, j. 04.12.2003). “(...) tratando-se de relação de consumo aplica-se a exceção à regra, ou seja, a teoria menor da desconsideração da personalidade jurídica. Com base nesta teoria basta a prova da insolvência da pessoa jurídica para o pagamento de suas obrigações, independentemente da existência de desvio de finalidade ou de confusão patrimonial (TJSP, AI 7.393.813-9, rel. Itamar Gaino, j. 02.09.2009).

1223 "Suas disposições implementam regras gerais de responsabilidade dos vários parceiros que atuam no mercado de consumo em grupos societários, consórcios etc., e que deveriam estar noutra parte (Seção II e/ou III do capítulo presente, junto ao art. 25); estariam bem num capítulo geral de responsabilidade, que, como já observamos, não existe" (Rizzatto Nunes. Comentários..., $4^{\mathrm{a}}$ ed., cit., p. 382/383).

1224 “Agravo de Instrumento. Cumprimento de sentença condenatória. Deferimento de penhora 'on line' de numerário existente em contas bancárias/aplicações do devedor. Frustração da penhora em face da informação da inexistência de saldo nas contas bancárias. Devedor é sócio controlador de sociedades empresárias e considerado o maior revendedor de veículos da América Latina. Pedido de aplicação da desconsideração inversa da personalidade jurídica para que a penhora recaia em saldos bancários das sociedades empresárias controladas pelo devedor. Indeferimento pelo juiz de primeiro grau. Reconhecimento da possibilidade de se declarar a desconsideração da personalidade jurídica incidentalmente na fase de execução da sentença, não se exigindo ação autônoma, mas, observando-se o contraditório, a ampla defesa e o devido processo legal. Prova de que o sócio devedor é, em rigor, 'dono' da sociedade limitada e da sociedade anônima fechada, das quais é o presidente, controlador de fato, e, apesar da participação minoritária de sua esposa, ficam elas caracterizadas como autênticas sociedades unipessoais. Confusão patrimonial entre sócio e sociedades comprovada. Patrimônio particular do sócio controlador constituído de bens que, na prática, mesmo que penhorados, não seriam convertidos em pecúnia para a satisfação do credor. Oferecimento de bens imóveis à penhora, que, por se situarem no Estado da Paraíba, distantes mais de 2.600 $\mathrm{km}$ de São Paulo, onde tramita a execução, com nítido escopo de se opor maliciosamente à execução, empregando ardis procrastinatórios, que configura ato atentatório à dignidade da justiça. Agravo provido, para deferir a desconsideração inversa da personalidade jurídica das sociedades empresárias indicadas 
O instante adequado para a parte cogitar da desconsideração da personalidade jurídica, via de regra, é o da concreta insuficiência do patrimônio societário frente aos seus débitos, matéria a ser enfrentada na fase de cumprimento de sentença ${ }^{1226}$; contudo, no âmbito das relações de consumo, embaraço algum há na prévia identificação de ser a medida necessária desde a inicial, sendo legítimo, portanto, trazer ao polo passivo da demanda - prima facie - os sócios da empresa fornecedora ${ }^{1227}$, com isso, a transpor qualquer obstáculo ao ressarcimento dos prejuízos causados ao consumidor.

\subsection{A solidariedade ampla (a questão do comerciante)}

A cumprir sua diretriz protecionista constitucional, o CDC encerra seu capítulo sobre os direitos básicos do consumidor reconhecendo, de modo expresso $^{1228}$, que "tendo mais de um autor a ofensa, todos responderão solidariamente pela reparação dos danos previstos nas normas de consumo" (art. $7^{\circ}$, par. ún.).

Com os olhos voltados à efetiva recomposição de prejuízos, preocupado (art. 25), após vedar a estipulação contratual de cláusula que impossibilite, exonere ou atenue a obrigação de indenizar (caput), o legislador retomou a ideia da Parte Geral ao dispor que, "havendo mais de um responsável pela causação do dano, todos responderão solidariamente pela reparação prevista nesta e nas Seções anteriores" $\left(\S 1^{\circ}\right)$.

(Limitada e S/A fechada), autorizada a penhora virtual de saldos de contas bancárias” (AI 1.198.103, rel. Manoel de Queiroz Pereira Calças, j. 26.11.2008).

1225 “(...) III - A desconsideração inversa da personalidade jurídica caracteriza-se pelo afastamento da autonomia patrimonial da sociedade, para, contrariamente do que ocorre na desconsideração da personalidade propriamente dita, atingir o ente coletivo e seu patrimônio social, de modo a responsabilizar a pessoa jurídica por obrigações do sócio controlador. IV - Considerando-se que a finalidade da disregard doctrine é combater a utilização indevida do ente societário por seus sócios, o que pode ocorrer também nos casos em que o sócio controlador esvazia o seu patrimônio pessoal e o integraliza na pessoa jurídica, conclui-se, de uma interpretação teleológica do art. 50 do $\mathrm{CC} / 02$, ser possível a desconsideração inversa da personalidade jurídica, de modo a atingir bens da sociedade em razão de dívidas contraídas pelo sócio controlador, conquanto preenchidos os requisitos previstos na norma" (REsp. 948.117/MS, rel. Min. Nancy Andrighi, j. 22.06.2010).

1226 "A despersonalização da pessoa jurídica é efeito da ação contra ela proposta; o credor não pode, previamente, despersonalizá-la, endereçando a ação contra os sócios. Recurso especial não conhecido" (STJ, REsp. 282.266/RJ, rel. Min. Ari Pargendler, j. 18.04.2002).

1227 "Indenização - Responsabilidade civil - Danos morais e materiais - Ajuizamento contra o empreendimento e seus sócios - Imputação de não dispor o empreendimento de lastro imobiliário bastante a suportar o exercício da atividade empresarial - Viabilidade da aplicação da teoria da despersonalização na fase de conhecimento - Inteligência do art. $28, \S 5^{\circ}$, do CDC - Recurso provido para arredar a exclusão dos sócios do pólo passivo da relação processual" (TJSP, AI 360.753-4/7, rel. Waldemar Nogueira Filho, j. 22.02.2005).

${ }^{1228} \mathrm{CC}$, art. 265: "a solidariedade não se presume; resulta da lei ou da vontade das partes". 
No âmbito dos vícios, problemas ontologicamente menos graves (supra, Cap. II, 2.2.2.2), não há dificuldade em se perceber que o Código coloca todos os partícipes do ciclo de produção ${ }^{1229}$ como responsáveis diretos ${ }^{1230}$, de forma que o consumidor poderá escolher e acionar diretamente qualquer dos envolvidos ${ }^{1231}$, exigindo seus direitos. $^{1232}$

O complicador surge quando se analisa a disciplina do fato do produto, em especial no que concerne à responsabilidade do comerciante prevista no art. $13^{1233}$, em princípio subsidiária ${ }^{1234}$, a depender de informação insuficiente (I e II) e/ou de ato próprio (III); porém, o ponto de partida para o pleno entendimento da quaestio deve ser a percepção de que o fabricante, o produtor, o construtor e o importador ${ }^{1235}$ atuam em parceria com os comerciantes, seus lídimos distribuidores, quase sempre numa espécie de

1229 “O comerciante e o fabricante estão inseridos no âmbito da cadeia de produção e distribuição, razão pela qual não podem ser tidos como terceiros estranhos à relação de consumo" (STJ, REsp. 980.860/SP, rel. Min. Nancy Andrighi, j. 23.04.2009).

${ }^{1230}$ Guilherme Ferreira da Cruz. Cadernos Jurídicos. Escola Paulista da Magistratura. São Paulo: Imprensa Oficial do Estado de São Paulo, no 23, ano 5, set.-out. 2004, p. 71/78.

${ }^{1231} \mathrm{CC}$, art. 275: "o credor tem direito a exigir e receber de um ou de alguns dos devedores, parcial ou totalmente, a dívida comum; se o pagamento tiver sido parcial, todos os demais devedores continuam obrigados solidariamente pelo resto".

${ }^{1232}$ Luiz Antonio Rizzatto Nunes. Comentários..., 4 $4^{\mathrm{a}}$ ed., cit., p. 240.

1233 CDC, art. 13: “o comerciante é igualmente responsável, nos termos do artigo anterior, quando: I - o fabricante, o construtor, o produtor ou o importador não puderem ser identificados; II - o produto for fornecido sem identificação clara do seu fabricante, produtor, construtor ou importador; III - não conservar adequadamente os produtos perecíveis. Par. ún.: aquele que efetivar o pagamento ao prejudicado poderá exercer o direito de regresso contra os demais responsáveis, segundo sua participação na causação do evento danoso".

${ }^{1234}$ Para Bruno Miragem (Direito..., cit., p. 295/296), “a responsabilidade do comerciante, no regime do CDC não acompanha a dos demais agentes econômicos expressamente referidos no artigo 12, caput, em matéria de responsabilidade pelo fato do produto. Isto porque a previsão normativa da responsabilidade do comerciante o fez de modo apartado, em artigo próprio - no caso, o artigo 13 do CDC. (...) O caput do artigo 13 ('O Comerciante é igualmente responsável...') induz a pensar-se trata a hipótese de responsabilidade solidária. Todavia, as hipóteses estabelecidas nos incisos I e II da norma, fazendo referência à circunstância de que os responsáveis não possam ser identificados, seja porque esta identificação não existia, seja porque é obscura ou insuficiente, determina a responsabilidade em questão como espécie de responsabilidade subsidiária ou supletiva. Ocorrendo, todavia, qualquer das hipóteses do artigo 13, ele passa a integrar, em conjunto - e portanto, solidariamente - com os demais responsáveis indicados no artigo 12 do $\mathrm{CDC}-\mathrm{o}$ rol de fornecedores que poderão ser demandados pelo consumidor. No caso do inciso III do artigo 13, restando demonstrado que o dano causado aos consumidores decorreu da conservação inadequada de produtos perecíveis, a responsabilidade do comerciante decorre de fato próprio, razão pela qual não se há falar em subsidiariedade, senão de responsabilidade direta, que vincula sua conduta como causa do evento danoso produzido contra o consumidor-vítima". Segundo o Min. Benjamin (et alii. Manual..., cit., p. 131), "a exclusão do comerciante (atacadista ou varejista), por razões de mera política legislativa, não é, contudo, absoluta. Excepcionalmente é ele chamado a responder com base no mesmo regime vigente para aqueles outros agentes econômicos do mercado. Só um fundamento econômico (a não oneração sucessiva de produtos) e outro pragmático (o comerciante, de regra, não tem poder para alterar técnicas de fabricação e produção) é que justificam, de fato, seu afastamento da cadeia de sujeitos responsáveis pelos acidentes de consumo".

${ }^{1235}$ Esse rol é exemplificativo, cf., supra, Cap. II, 3. 
rede contratual conexa ou coligada ${ }^{1236}$, nesse processo de captação de clientela; é dizer, um fornecedor a se valer da reputação comercial do outro.

Ao rigor desse raciocínio, aquele que se aproveita do nome, do conceito e da respeitabilidade dos fabricantes para atrair clientes no mercado de consumo, à evidência, contribui, ainda que tenuamente, para a causação do dano ${ }^{1237}$, pois o consumidor quando adquire um produto (defeituoso ou não) age, também, impulsionado pela confiança depositada no comerciante (v.g., garantia, eficiência na solução de problemas, etc.).

Portanto, na responsabilidade do fornecedor imediato a solidariedade permanece intacta, mesmo na esfera administrativa ${ }^{1238}$, haja vista a regra do artigo $25, \S 1^{\circ}$, da Lei $n^{\circ}$ 8.078/90 aplicar-se não só à seção III (Responsabilidade por Vício do Produto e do Serviço), mas também às seções anteriores, como a II (Responsabilidade pelo Fato do Produto ou do Serviço).

Tal quadro se alumia, e.g., se há dúvida sobre o momento e o local da deterioração de produto perecível - circunstância fática a ser verificada no caso concreto $^{1239}$ - visto que a teleologia do CDC, que envolve a proteção do consumidor e a

${ }^{1236}$ TJSP, AC 584.289.4/2-00, rel. Francisco Loureiro, j. 04.12.2008.

1237 "Se inidôneo o produto cuja comercialização foi autorizada em suas dependências, onde captada a vontade do consumidor de forma viciosa, mediante enganosa propaganda, deve o hipermercado responder pelos danos morais causados, solidariamente ao fabricante ou fornecedor" (TJSP, AC 000943032.2006.8.26.0562, rel. Andrade Neto, j. 29.06.2011).

1238 “(...) 2. As violações a deveres de informação e de transparência quantitativa representam também ilícitos administrativos de consumo que podem ser sancionados pela autarquia em tela. 3. A responsabilidade civil nos ilícitos administrativos de consumo tem a mesma natureza ontológica da responsabilidade civil na relação jurídica base de consumo. Logo, é, por disposição legal, solidária. 4. O argumento do comerciante de que não fabricou o produto e de que o fabricante foi identificado não afasta a sua responsabilidade administrativa, pois não incide, in casu, o $\S 5^{\circ}$ do art. 18 do CDC. Recurso especial provido" (STJ, REsp. 1.118.302/SC, rel. Min. Humberto Martins, j. 01.10.2009).

1239 "1. Inexiste a alegada ilegitimidade passiva do Mercado-Réu, quando se encontra na condição de DISTRIBUIDOR/COMERCIANTE, eis que a responsabilidade daqueles que participam do cenário consumista assumem solidariamente os riscos de sua atividade. Afirmar a ilegitimidade passiva do primeiro réu somente pela ausência da efetiva prova de vinculação entre o dano e o defeito de fabricação é no mínimo descabido; eis que é matéria afeita ao mérito, não à preliminar, eis que é dependente e foi analisado sobre o prisma da prova. Restando provada a compra dos produtos no mercado-réu, este é efetivamente legitimado a responder a demanda. Sentença cassada quando à extinção sem julgamento de mérito para com a $1^{\mathrm{a}}$ Ré; (..) 5. Em não havendo como se fazer saber se a deterioração do produto se deu por má estocagem ou envase, que é o que aparentemente gerou os bolores citados pela Consumidora e confirmados pela autoridade policial, necessário qualificar a solidariedade entre as rés, o que atrai a incidência dos arts. $7^{\circ}$, $\S$ único e 25 , $\S 1^{\circ}$ do Código de Defesa do Consumidor" (TJDFT, AC 20090810024563APC, rel. Alfeu Machado, j. 14.04.2010). "Tanto a apelante quanto a empresa ora parte são solidariamente responsáveis pelos danos causados ao apelado, uma vez que na presente demanda a controvérsia quanto a tal ponto - atribuição de responsabilidade exclusiva do fabricante ou do comerciante - não foi dirimida, por não ser objeto da demanda. Inócuo alegar tal questão sob as excludentes dos artigos $12, \S 3^{\circ}$, e 13 , do $\mathrm{CDC}$, já que a legislação consumerista, ao proteger os interesses do consumidor, garante-lhe a plena facilitação da defesa de seus direitos e a 
garantia da ampla reparação dos danos por ele sofridos, impõe se conclua pela possibilidade de se acionar livremente quaisquer dos fornecedores, tanto o mediato quanto o imediato. ${ }^{1240}$

E nem por isso estar-se-ia esvaziando o espaço de incidência do art. 13 do $\mathrm{CDC}$, que ficaria reservado à posterior equação dos interesses econômicos dos sujeitos envolvidos da cadeia de fornecimento. ${ }^{1241}$

A rápida e eficaz tutela dos direitos do consumidor não se harmoniza com essas discussões sobre amplitude de responsabilidades, as quais melhor se afinam à esfera regressiva.

Além disso, não se pode perder de vista a nova disciplina do defeito prevista no art. 931 do CC, aplicável às relações de consumo (infra, Cap. VI, 2.2.1), que "não estabelece diferença entre os vários agentes da cadeia de fornecimento. Imputa-se responsabilidade objetiva a quem tenha colocado o produto no mercado, o que inclui o comerciante". ${ }^{1242}$

Rizzatto Nunes, com precisão, arremata: "escolhido pelo consumidor o responsável e no processo judicial apurado o verdadeiro responsável, o consumidor será ressarcido de qualquer forma, ainda que não tenha escolhido para colocar no polo passivo da ação o verdadeiro responsável. Depois que o consumidor receber sua indenização, o que pagou poderá ressarcir-se pelo outro responsável ou repartir com ele o quantum pago, uma vez que são, no mínimo, solidários". ${ }^{1243}$

Essa é a solução que a jurisprudência, mutatis mutandis, tem dado aos casos de danos advindos da inadequação de transporte aéreo e/ou de pacote turístico adquirido, a firmar a responsabilidade solidária da agência vendedora desses

responsabilização solidária de todos que contribuíram para a ofensa, nos termos dos artigos $6^{\circ}$, VIII, e $7^{\circ}$, parágrafo único, ambos do CDC. Ressalte-se, por oportuno, que a apelante poderá ingressar com ação autônoma para discutir acerca da responsabilidade com relação à empresa que comercializou seu produto" (TJSP, AC 9197251-58.2009.8.26.0000, rel. Melo Bueno, j. 18.04.2011).

${ }^{1240}$ Luiz Antonio Rizzatto Nunes. Curso..., cit., p. 279.

1241 "O art. 13, caput, e incisos do CDC não exonera a responsabilidade do comerciante, mas sim prevê regras para o exercício do direito de regresso quando o comerciante pagar a indenização. Assim, a exegese que melhor se adapta às finalidades protetivas do $\mathrm{CDC}$, é aquela que confere tanto ao comerciante, como ao fabricante a responsabilidade solidária pelo danos causados ao consumidor" (TJMG, AC 1.0024.07.7661924/001, rel. Tibúrcio Marques, j. 04.06.2009).

${ }^{1242}$ Bruno Miragem. Direito do consumidor..., cit., p. 296.

${ }^{1243}$ Curso..., cit., p. 279. 
específicos produtos ${ }^{1244}$, ainda que se possa tê-la como mera intermediária virtual do ajuste $^{1245}$, por certo também remunerada pela concretização do negócio. ${ }^{1246}$

1244 "A agência de viagens que vende pacote turístico responde pelo dano decorrente da má prestação dos serviços” (STJ, AgRg. no REsp. 850768/SC, rel. Min. Sidnei Beneti, j. 27.10.2009). "A operadora de viagens que organiza pacote turístico responde pelo dano decorrente do incêndio que consumiu a embarcação por ela contratada. Passageiros que foram obrigados a se lançar ao mar, se proteção de coletes salva-vidas, inexistentes no barco. Precedente (REsp. 287.849/SP). Dano moral fixado em valor equivalente a 400 salários minimos" (STJ, REsp. 291.384/RJ, rel. Min. Ruy Rosado de Aguiar, j. 15.05.2001). "A agência de viagens responde pelo dano pessoal que decorreu do mau serviço do hotel contratado por ela para a hospedagem durante o pacote de turismo" (STJ, REsp. 287.849, rel. Min. Ruy Rosado de Aguiar, j. 17.04.2001). "Quando há compra de pacotes de viagem, a relação negocial efetivamente se estabelece entre o cliente e a empresa de turismo, cabendo a esta responder pela adequação de todos os serviços utilizados no mesmo. Eventual inadimplemento de um desses contratos derivados implica no descumprimento de obrigação assumida pela agência ou operadora no ajuste principal, por ela firmado com o seu cliente. Se houve má prestação de serviço por parte da empresa que a agência ou a operadora de turismo elegeu, será esta responsável pelos atos daqueles que contratou" (TJSP, AC 1.090.239-9, rel. Vieira de Moraes, j. 12.06.2008). "A agência de turismo é responsável solidariamente por toda a prestação de serviço. Assim, ela responde não só pelo transporte, como pelas acomodações, serviços prestados no curso da viagem, alimentações incluídas no pacote, enfim, por tudo que faça parte do produto de viagem adquirido pelo consumidor. Assim, fica afastada a tese da agência de que não agiu com culpa no caso dos autos. Sua responsabilidade independe da prova de culpa" (TJSP, AC 998.616-0/0, rel. Rosa Maria de Andrade Nery, j. 23.05.2007). "PRESTAÇÃO DE SERVIÇOS TURÍSTICOS - Overbooking - Deficiência informativa Dever de indenizar turistas que tiveram expectativas frustadas tanto na ida como na volta de viagem Responsabilidade de todos os envolvidos na cadeia de negócios que culminaram com o transporte Procedência - Apelações denegadas" (TJSP, AC 1.137.183-0/7, rel. Sebastião Flávio, j. 16.12.2008). Desse V. Aresto o seguinte excerto: "não importa, assim, quais sejam os limites de atuação de cada qual na cadeia de relações jurídicas envolvidas. Importa apenas é que se criou para o consumidor a expectativa de viajar e encontrar a acomodação tal como inicialmente lhe foi anunciado. É indiferente a tudo quanto se passa nos bastidores desses negócios tumultuados".

1245 "A requerida, embora tente atribuir toda responsabilidade à Companhia Aérea, era parte legítima 'ad causam', visto que foi intermediária na aquisição da passagem e o atraso e a perda do primeiro voo foram decorrentes de falha de comunicação entre as duas empresas, sem culpa da consumidora" (TJSP, AC 990.10.230409-4, rel. Ulisses do Valle Ramos, j. 11.08.2010).

1246 "Muito embora a mercadoria tenha sido adquirida de terceira pessoa, que não integra a lide, o demandado (...) figurou como intermediário da compra e venda realizada, já que, remunerado pela concretização do negócio, foi responsável pela veiculação do anúncio. E uma vez integrando a cadeia de fornecedores que culminou com a compra e venda frustrada, a aplicação das disposições do Código de Defesa do Consumidor à hipótese dos autos é lógica conseqüência. Apelo improvido" (TJRS, AC 70025673856, rel. Paulo Antônio Kretzmann, j. 30.10.2008). 


\title{
CAPÍTULO VI \\ RISCO E RESPONSABILIDADE
}

\begin{abstract}
SUMÁRIO: 1. PANORAMA CONSTITUCIONAL DA RESPONSABILIDADE CIVIL - 2 . OS RISCOS ENVOLVIDOS X PERSPECTIVA CIVIL - 3. PRECAUÇÃO COMO FORMA DE CONTROLE DO RISCO - 4. A RESPONSABILIDADE DAS EMPRESAS FABRICANTES DE CIGARROS.
\end{abstract}

\section{PANORAMA CONSTITUCIONAL DA RESPONSABILIDADE CIVIL}

Nos restritos limites da análise proposta, a expressão livre encontra base constitucional em três momentos distintos: a) como fundamento da República (CF, art. $\left.1^{\circ}, \mathrm{IV}\right)$; b) como seu objetivo (CF, art. $\left.3^{\circ}, \mathrm{I}\right)$; e c) como princípio geral da ordem econômica (CF, art. 170, caput, e IV, c.c. seu par. ún.).

Pois bem.

É necessário fixar, e de modo inquebrantável, a idéia de que o sistema constitucional brasileiro não admite qualquer livre iniciativa, mas apenas aquela fundada em valores sociais (CF, art. $1^{\circ}$, IV); logo, percebe-se, a olho desarmado e ao contrário do que pensam alguns, que a iniciativa não é tão livre assim.

Conclui-se, portanto, que a ordem econômica nacional há de guardar ressonância com os valores sociais da livre iniciativa, porque somente dessa forma poderá assegurar a todos existência digna $(\mathrm{CF}$, art. 170, caput), nova representação da dignidade da pessoa humana já prevista como fundamento da República (CF, art. $\left.1^{\circ}, \mathrm{III}\right)$.

Toda a ordem econômica, portanto, bem assim seus princípios (CF, art. 170), se encontra inexoravelmente vinculada ao propósito de servir de condutor para alcançar-se uma existência digna para todos os seres humanos. Não é ela um fim em si mesma, mas veículo de promoção do primado da dignidade pessoal. ${ }^{1247}$

Fixadas tais premissas, indaga-se: o Estado deve garantir a livre iniciativa e a livre concorrência em benefício dos empreendedores (fornecedores concorrentes) ou do mercado, onde o consumidor é a grande maioria?

${ }^{1247}$ Aurisvaldo Melo Sampaio. As novas tecnologias..., cit., p. 141. 
À evidência que essa noção de liberdade só pode aproveitar ao consumidor, sob pena de se admitir uma exploração irracional, e, até certo ponto, autofágica do mercado, que não pertence exclusivamente aos fornecedores.

Busca-se, em verdade, a realização do social, vale dizer, uma justiça distributiva que permita a construção de uma sociedade livre justa e solidária (CF, art. $3^{\circ}$, I), com prevalência do mandamento jurídico nuclear: dignidade da pessoa humana (piso mínimo normativo ${ }^{1248}$ ).

Referida transmudação está envolta e condicionada pelos anseios resultantes do movimento de massas que domina o mundo atual, ostensivamente desde o limiar do século, para o que vêm sendo idealizados novos instrumentos de realização da justiça. ${ }^{1249}$

$\mathrm{Na}$ assertiva do Min. José Celso de Mello Filho, do STF, “o Estado social é, nitidamente, um Estado intervencionista, que procura, a partir da concretização das liberdades reais ou positivas, realizar a justiça social, prestigiando e fortalecendo, desse modo, os direitos econômicos e sociais reconhecidos em favor das pessoas. Sob a égide do Estado Social - e precisamente em função de suas novas finalidades - surgem as liberdades positivas ou concretas, as quais, projetadas no domínio jurídico, exteriorizam-se nos direitos econômicos e sociais, que constituem realidade importante que emerge do processo de transformação do próprio Estado. O estágio de evolução em que se encontra o Estado contemporâneo é uma consequência direta do processo histórico de sua transformação. $\mathrm{O}$ Estado não pode ser visto como um aparelho destinado a cumprir os desígnios de uma classe dominante. A modernização do Estado reflete, na realidade, as novas tendências que exigem a sua constante atualização. Sem transformações substanciais, que privilegiem a justa solução das graves questões sociais, $\mathrm{o}$ Estado terá, certamente, falhado à sua alta missão institucional". ${ }^{1250}$

Alerta Nelson Nery Júnior, porém, “(...) que a defesa do consumidor é instrumento da livre iniciativa e só existe em países de economia de mercado. As economias estatizadas não se coadunam com a defesa do consumidor. Nos países capitalistas, notadamente os mais industrializados (EUA, Japão, Alemanha, França, Inglaterra, Itália, Suécia, Canadá, Austrália etc) é que se tem desenvolvido com maior

\footnotetext{
${ }^{1248}$ Celso Antonio Pacheco Fiorillo. O direito de antena em face do direito ambiental no Brasil. São Paulo: Saraiva, 2000, p. 14.

${ }^{1249}$ José Manoel Arruda Alvim Neto. Tratado de Direito Processual Civil. São Paulo: RT, 1990, v. I, p. 108.
} 
vigor a defesa do consumidor. O tema não tem, portanto, conteúdo político-ideológico comunista ou socialista". ${ }^{1251}$

Daí surge a precisa noção da liberdade constitucional, ao menos no que tange às relações de consumo. Com perspicácia ímpar, leciona Luiz Antonio Rizzatto Nunes:

"A liberdade de iniciativa é conferida a todos aqueles que decidam, sponte propria, tomando seus bens e constituindo-os em capital, ir ao mercado empreender alguma atividade - qualquer atividade permitida e/ou regulada constitucional e infraconstitucionalmente.

O sentido de 'livre' iniciativa aí, então, significa o direito de escolher correr o risco do empreendimento. A pessoa tem, portanto, o direito garantido de, caso queira, empreender um negócio.

Em relação ao consumidor, a liberdade que o texto lhe garante é objetivo da República, ou seja, o Estado brasileiro tem entre seus objetivos o de assegurar que a sociedade seja livre. Isso significa que, concretamente, no meio social, dentre as várias ações possíveis, a da pessoa designada como consumidora seja livre.

A consequência disso é que o Estado deverá intervir quer na produção, quer na distribuição de produtos e serviços, não só para garantir essa liberdade como para regular aqueles bens que, essenciais às pessoas, elas não possam adquirir por falta de capacidade de escolha. Explica-se.

Primeiramente, como dissemos, o sentido de liberdade da pessoa consumidora, aqui, é o de 'ação livre'. Essa ação é livre sempre que a pessoa consegue acionar duas virtudes: querer + poder. Quando a pessoa quer e pode, diz-se, ela é livre; sua ação é livre.

Assim, a regra básica será a da escolha com possibilidade de aquisição: a pessoa quer algo, tem dinheiro ou crédito para adquiri-lo, então é livre para fazê-lo.

Contudo, haverá casos em que, justamente por não poder escolher, a ação da pessoa não será livre. E nessa hipótese a solução tem de ser outra. Estamo-nos referindo à necessidade. O conceito é clássico: liberdade é o

${ }^{1250}$ STF, ADIN 319/DF, voto do Min. Celso de Mello, em 04.12.1992. 
oposto de necessidade. Nesta não se pode ser livre: ninguém tem ação livre para não comer, não beber, para voar etc. Aplicado o conceito à realidade social, o que se tem é o fato de que o objetivo constitucional da construção de uma sociedade livre significa que sempre que a situação real for de necessidade o Estado pode e deve intervir para garantir a dignidade humana." 1252

No atinente ao fornecedor, a liberdade constitucional encontra sua representação concreta no dispositivo que assegura a todos o livre exercício de qualquer atividade econômica (CF, art. 170, par. ún.).

A opção é, pois, do fornecedor.

Mas saliente-se: a mesma liberdade que assegura ao agente empreendedor (fornecedor) a iniciativa de explorar o mercado, inexoravelmente o vincula aos riscos e aos percalços dessa empreitada, e de maneira exclusiva.

$\mathrm{Ou}$, em outras palavras, o exercício dessa prerrogativa relega ao fornecedor todos os riscos da atividade economicamente lucrativa explorada no mercado $^{1253}$, inviabilizando qualquer tentativa de transferência desse ônus ${ }^{1254}$, inclusive mediante contrato expresso (CDC, art. 51, I, III e XV, c.c. seu $§ 1^{\mathrm{o}}$, I, II e III). ${ }^{1255}$

${ }^{1251}$ Os princípios gerais..., cit., p. 47.

${ }^{1252}$ Curso..., cit., p. 27.

1253 “(...) no momento da contratação, o usuário jamais poderia supor que necessitaria do tratamento de hemodiálise em regime domiciliar, procedimento perfeitamente previsível à apelante, que, certamente, diluiu os custos respectivos na receita obtida de outros usuários que pouco usam o seu plano de saúde, o que, per si, equaciona, com vantagem, o binômio custo $\mathrm{x}$ beneficio, sem dizer, ainda, que a cobertura determinada pela $\mathrm{r}$. sentença amolda-se ao risco da atividade desempenhada pela recorrente, devendo suportar sozinha esse ônus, sem repassá-lo ao autor” (TJSP, AC 595.265-4/9, rel. Donegá Morandini, j. 23.06.2009). “Os Bancos são responsáveis pela segurança do sistema de automatização, principalmente saques e transferências em caixas automáticos, porque são por eles implantados para agilizar o serviço, com redução de custos, o que eleva a lucratividade. Sendo contratos de adesão ou tipo, pouca ou nenhuma chance tem o cliente de discutir cláusulas e condições, de modo que a evolução do direito levou ao abrandamento da força do princípio da pacta sunt servanda e irretratabilidade, justamente para garantir um maior equilíbrio entre as partes. Sendo legítima e necessária a intervenção judicial e a interpretação das cláusulas e condições específicas. E os golpes e prejuízos devem ser suportados pela instituição financeira, por ser parte do risco da sua atividade. Não se desconhece a existência de golpistas, com possibilidade de clonagem (ou furto) de cartão e acesso à senha, sem que o cliente e consumidor tenha qualquer culpa ou responsabilidade. Não poderia singelamente, com raciocínio demasiado simples, dizer que os saques foram efetuados com o cartão e senha secreta, e essa responsabilidade na guarda e manutenção do sigilo da senha, que foram quebrados, só pode ser imputada à vítima. Mesmo a questão do cartão ser retido e os meliantes terem obtido a senha por ardil, fingindo auxiliar por telefone o filho da autora, não transfere toda a responsabilidade ao cliente (consumidor), porque aos Bancos o ônus de proteção do sistema, implantando formas de bloquear ou dificultar a prática. Tanto que hoje, passados os anos, e até em decorrência da evolução tecnológica, várias chaves são necessárias e as máquinas, em geral, já não utilizam o sistema de introduzir os cartões. É a aplicação do art. 14 do CDC, em especial o $\S 1^{\circ}$, quando trata da segurança necessária, pelas condições e circunstâncias relevantes. Somente a culpa exclusiva da vítima, quando se trata de relação de consumo, é que poderia excluir a responsabilidade do fornecedor, como previsto no inciso II, do art. 14 já mencionado" (TJSP, AC 1.061.934-4, rel. Antonio Ribeiro, j. 05.12.2006). "Na verdade, a apelante, de forma inadequada, tenta atribuir a fraude ocorrida na 
Trata-se da teoria do risco do negócio ou do risco da atividade $^{1256}$, que deixa solarmente clara a distinção entre a liberdade do fornecedor e a necessidade do consumidor, condutas de mercado que não se confundem. Básico o fundamento: sem repartição adequada dos lucros, não é possível divisão dos riscos. ${ }^{1257}$

linha telefônica de titularidade da apelada, a terceiro e à própria apelada, alegando, ainda, ser vítima de tal situação. Com o devido respeito, a apelante, uma das maiores empresas de telefonia do país, e, ainda, de caráter multinacional, deveria promover todos os meios necessários para evitar fraudes que, eventualmente, possam ocorrer nas linhas telefônicas de seus usuários, não agindo desta forma, presta serviços de forma irregular, devendo, por consequência, ser responsabilizada pelos prejuízos suportados pela apelada. (...) Assim, forçoso é presumir que a apelante, não dispõe de serviços que possam impedir a clonagem de linhas telefônicas, permitindo, conseqüentemente, que seus clientes fiquem expostos a tais irregularidades e, ainda, à mercê dos prejuízos decorrentes do clone de linhas telefônicas, como in casu. Percebe-se, pelo contexto dos autos, que a apelante resolveu correr o risco empresarial na forma de contratar sem a adequada e indispensável segurança. Assim, deve responder por danos morais evidenciados no caso em exame" (TJSP, AC 7.269.233-4, rel. Roberto Mac Cracken, j. 31.07.2008). "Direito processual civil. Ação de indenização. Saques sucessivos em conta corrente. Negativa de autoria do correntista. Inversão do ônus da prova. - É plenamente viável a inversão do ônus da prova (art. 333, II do CPC) na ocorrência de saques indevidos de contas-correntes, competindo ao banco (réu da ação de indenização) o ônus de provar os fatos impeditivos, modificativos ou extintivos do direito do autor. - Incumbe ao banco demonstrar, por meios idôneos, a inexistência ou impossibilidade de fraude, tendo em vista a notoriedade do reconhecimento da possibilidade de violação do sistema eletrônico de saque por meio de cartão bancário e/ou senha. - Se foi o cliente que retirou o dinheiro, compete ao banco estar munido de instrumentos tecnológicos seguros para provar de forma inegável tal ocorrência. Recurso especial parcialmente conhecido, mas não provido" (STJ, REsp. 727.843/SP, rel. Min. Nancy Andrighi, j. 15.12.2005).

1254 “(...) para justificar o não cumprimento do prazo contratual para a conclusão das obras, aduziu a ré que a demora decorreu de caso fortuito, consistente na dificuldade de obtenção de financiamento imobiliário para custeio da construção em decorrência da chamada "crise Asiática" (fls. 110 e 135). No entanto, esse fato não pode ser admitido como caso fortuito, ou de força maior, uma vez que a obtenção de financiamento para construção de empreendimento imobiliário configura risco do negócio que deve ser assumido por quem se dispõe a comercializar antecipadamente suas unidades, cujo ônus, por óbvio, não pode ser transferido à compradora" (TJSP, AC 264.641-4/6, rel. Galdino Toledo Júnior, j. 12.05.2009).

1255 “(...) o fornecedor do crédito não pode repassar para o consumidor o risco da sua atividade. Cláusula nesse sentido é nula de pleno direito, por violar os princípios constitucionais (art. 170, parágrafo único) e legais (artigos $4^{\circ}$, III; $6^{\circ}$ IV e V; 47; 51 IV; e 51, § 1º, I, II e III, da Lei 8.078/90)" (TJSP, AC 7.292.899-3, rel. Rizzatto Nunes, j. 05.08.2009). Em igual sentido e da mesma Corte: AI 7.125.798-0, j. 28.02.2007 e AC 199.115-4/8-00, j. 21.09.2005, sendo que nesta se afirma “(...) a opção de reduzir o ritmo das obras envolveu transferência de risco ao consumidor que é absolutamente inadmissível no microssistema do Código do Consumidor."

1256 "Precedentes da Corte, de ambas as Turmas da Seção de Direito Privado, assentaram que aceitando a seguradora a 'proposta de adesão, mesmo quando o segurado não fornece informações sobre o seu estado de saúde, assume os riscos do negócio. Não pode, por essa razão, ocorrendo o sinistro, recusar-se a indenizar"” (STJ, REsp. 244.841/SP, rel. Min. Carlos Alberto Menezes Direito, j. 03.08.2000).

${ }^{1257}$ A despeito da lucidez desse raciocínio cartesiano, embora de início tenha decidido ser ilegal a transferência do risco da atividade financeira, no mercado de capitais, próprio às instituições de crédito, ao consumidor violado no seu direito de informação (REsp. 370.598/RS, j. 26.02.2002), em conhecida hipótese fática que assolou nosso País no início do ano de 1999, o Egrégio Superior Tribunal de Justiça firmou-se no sentido da repartição de riscos: "I. Não é nula cláusula de contrato de arrendamento mercantil que prevê reajuste das prestações com base na variação da cotação de moeda estrangeira, eis que expressamente autorizada em norma legal específica (art. $6^{\circ}$ da Lei n. 8.880/94). II. Admissível, contudo, a incidência da Lei n. 8.078/90, nos termos do art. $6^{\circ}, \mathrm{V}$, quando verificada, em razão de fato superveniente ao pacto celebrado, consubstanciado, no caso, por aumento repentino e substancialmente elevado do dólar, situação de onerosidade excessiva para o consumidor que tomou o financiamento. III. Índice de reajuste repartido, a partir de 19.01.99 inclusive, eqüitativamente, pela metade, entre as partes contratantes, mantida a higidez legal da cláusula, decotado, tão somente, o excesso que tornava insuportável ao devedor o adimplemento da 


\section{É essa a viga mestra da responsabilidade independente da}

existência de culpa firmada na Lei 8.078/90; no entanto, a análise do elemento subjetivo não é de todo irrelevante nesta moldura, pois a culpa exclusiva do consumidor ou de terceiro - ao romper o nexo etiológico de causa e efeito - atua como típica excludente (CDC, arts. $12, \S 3^{\circ}$, III, c.c. $14, \S 3^{\circ}$, II).

Se concorrente, todavia, apenas a recomposição dos danos sofrerá, de modo proporcional e ponderado, seus efeitos ${ }^{1258}$; aliás, como disposto no

obrigação, evitando-se, de outro lado, a total transferência dos ônus ao credor, igualmente prejudicado pelo fato econômico ocorrido e também alheio à sua vontade. IV. Recurso especial conhecido e parcialmente provido" (REsp. 472.594/SP, rel. p/Ac. Min. Aldir Passarinho Junior, j. 12.02.2003). Do V. Aresto extrai-se o seguinte excerto: "tais contratos firmados com os consumidores eram derivados de outros - isso é notório, inclusive por inerentes aos primeiros - assumidos pelas financeiras no exterior, daí igualmente vinculados à moeda alienígena. Não parece, pois, razoável que estando autorizada a arrendadora a contratar pela variação cambial e assim acordando o mutuário, tenha de arcar com o ônus integral, já que igualmente vítima da drástica desvalorização do Real. Que há onerosidade excessiva, sem dúvida ela existe, porém não propriamente da cláusula em si, que é legal (art. $6^{\circ}$ da Lei 8.880/94), mas das circunstâncias que advieram a partir de certo momento, quando em curso a relação obrigacional. $\mathrm{O}$ art. $6^{\circ}$, inciso $\mathrm{V}$, do $\mathrm{CDC}$, incide, aqui, porém apenas para retirar a onerosidade que afeta a capacidade de o consumidor adimplir o contrato, em razão de fato superveniente, resguardando-se o pacto e a essência da cláusula, porque, em si mesma, válida e legítima ela o é". "Na linha da jurisprudência firmada na $2^{\mathrm{a}}$ Seção desta Corte, o art. $6^{\circ}$, inciso V, do Código de Defesa do Consumidor incide, apenas, para retirar a onerosidade decorrente de fato superveniente que afeta a capacidade do consumidor adimplir o contrato. Assim, no caso presente, a partir de janeiro de 1999, as prestações do contrato de leasing devem ser reajustadas pela metade da variação cambial verificada" (STJ, AgRg no REsp. 453.662/SP, rel. Min. Carlos Alberto Menezes Direito, j. 13.05.2003).

${ }^{1258}$ No STJ, sem dúvida, o leading case nesse tema foi o REsp. 287.849/SP, j. 17.04.2001, da relatoria do Min. Ruy Rosado de Aguiar, de onde se extrai o seguinte excerto: "sendo a culpa concorrente, estabelece-se a controvérsia. Para Zelmo Denari, 'A doutrina tem sustentado o entendimento de que a lei pode eleger a culpa exclusiva como único causa extintiva de responsabilidade, como fez o Código de Defesa do Consumidor, nesta passagem. Caracterizada, portanto, a concorrência de culpa, persiste a responsabilidade integral do fabricante, e demais fornecedores nominados no caput, pela reparação do dano' (Código Brasileiro de Defesa do Consumidor, $2^{\mathrm{a}}$ ed., pág. 90). Eduardo Arruda Alvim entende que 'o sistema do Código não exclui a culpa concorrente como atenuante de responsabilidade. Até porque a razão de ser que leva a que a culpa concorrente seja considerada como atenuante de responsabilidade é precisa e exatamente a mesma daquela segundo a qual é causa excludente a culpa exclusiva do consumidor' (Responsabilidade Civil pelo fato do produto no CDC, Revista de Direito do Consumidor, 15/130). Adalberto Pasqualotto examinou a Diretiva da União Européia, comparou-a com o nosso CDC e concluiu: 'No CDC, o tratamento dos dois casos é idêntico (intervenção de terceiro e participação culposa da vítima) mas a exoneração do fabricante requer que a culpa do consumidor ou de terceiro seja exclusiva (art. 12, $\S 3^{\circ}$, III). A doutrina tem entendido que, em vista da natureza objetiva da responsabilidade dos fornecedores, não é admissível a divisão do prejuízo. A jurisprudência, porém, admite tradicionalmente a atenuação da responsabilidade objetiva do Estado por participação culposa da vítima' (A Responsabilidade Civil do Fabricante e os Riscos do Desenvolvimento, Adalberto de Souza Pasqualotto, AJURIS, 59, Ano XX, novembro de 1993, fl. 155). Penso que essa última corrente é a melhor. Corresponde à nossa experiência jurisprudencial sobre a responsabilidade objetiva do Estado, para a qual se adota a teoria do risco administrativo, com possibilidade de ser atenuada a condenação do Estado na hipótese de concorrência de culpa da vitima. Além disso, permite ao juiz manter-se junto à realidade dos fatos, avaliar as causas e condições concorrentes, a fim de proferir uma sentença que corresponda às circunstâncias de cada caso. Proibir a ponderação da culpa concorrente é orientação que leva necessariamente a uma perda de justiça, tanto maior quanto maior a culpa da vítima. Por isso, concluo que se pode ponderar, no âmbito do sistema de responsabilidade instituído pelo CDC, a culpa concorrente da vítima”. Em igual sentido e da mesma Corte: REsp. 712.591/RS, rel. Min. Nancy Andrighi, j. 16.11.2006. 
sistema do Código Civil (art. 945 ${ }^{1259}$ ). Pensar-se o contrário, atribuindo indenização completa à vítima que contribuiu para o sinistro, seria a consagração do venire contra factum proprium. ${ }^{1260}$

${ }^{1259} \mathrm{CC}$, art. 945: "se a vítima tiver concorrido culposamente para o evento danoso, a sua indenização será fixada tendo-se em conta a gravidade de sua culpa em confronto com a do autor do dano".

${ }^{1260}$ João Calvão da Silva. Responsabilidade civil do produtor. Coimbra: Almedina, 1999, p. 733/734. 


\section{OS RISCOS ENVOLVIDOS X A PERSPECTIVA CIVIL}

O estudo dos riscos que permeiam a relação de consumo não pode se apartar da disciplina simétrica do Código Civil (CDC, art. $7^{\circ}$, caput), em especial no que concerne ao seu art. 927, par. ún. ${ }^{1261}$; aliás, não só nesse tema (supra, Cap. I, 2.6), é essa a diretriz que vem ganhando corpo no direito moderno a partir da teoria do diálogo das fontes ${ }^{1262}$, muito bem estruturada por Erik Jamye. ${ }^{1263}$

"Na pós-modernidade, o campo de aplicação é necessariamente flexível, pois engloba interesses e direitos difusos, coletivos, individuais homogêneos e individuais simples, ao mesmo tempo, é mutável, pois visa acompanhar as criações da prática contratual, com a nova conexidade dos contratos e vínculos, na sociedade de consumo. Bem se deduz dessas afirmações que delimitar o campo de aplicação de forma fixa para uma revogação é vontade pouco realista, pois a antinomia é tópica, mais aparente do que real, devendo o aplicador dar preferência a uma compatibilização das normas e aplicação simultânea das leis, 'em diálogo', na bela expressão de Erik Jayme. Aqui a preocupação do direito é a legitimidade da solução, pois todas as normas em conflito são 'válidas' e devem ter alguma eficácia, mesmo que auxiliar. O diálogo das fontes é, pois, a aplicação simultânea, compatibilizadora, das normas em conflito, sob a luz da Constituição, com efeito útil para todas as leis envolvidas, mas com eficácias (brilhos) diferenciados a cada uma das normas em colisão, de forma a atingir o efeito social (e constitucional) esperado. $\mathrm{O}$ 'brilho' maior será da norma que concretizar os direitos humanos envolvidos no conflito, mas todas as leis envolvidas participarão da solução concorrentemente."1264

Essa cláusula geral ${ }^{1265}$, standard de conduta, fluído e flexível, aparece no sistema modulada por três elementares (atividade, normalmente desenvolvida e

\footnotetext{
${ }^{1261}$ CC, art. 927, par. ún.: "haverá obrigação de reparar o dano, independentemente de culpa, nos casos especificados em lei, ou quando a atividade normalmente desenvolvida pelo autor do dano implicar, por sua natureza, risco para os direitos de outrem".

${ }^{1262} \mathrm{Na}$ jurisprudência, sem nenhuma pretensão de esgotar a pesquisa, eis alguns exemplos de aplicação da teoria do diálogo das fontes: STJ, REsp. 209.410/MG, j. 09.11.1999; REsp. 235.410/RS, j. 14.12.1999; REsp. 260.892/MG, j. 17.05.2001.

${ }^{1263}$ Identité..., cit., p. 259.

${ }^{1264}$ Claudia Lima Marques. Contratos..., cit., p. 519.

${ }^{1265}$ Estabelecer regra de responsabilidade civil na forma de cláusula geral não é novidade. Cunha Gonçalves (Tratado de direito civil. São Paulo: Max Limonad, 1957, v. 12, t. 2, p. 470) comentando o art. 159 do
} 
risco), estas o verdadeiro objeto de estudo, pois indispensáveis à plena compreensão do sistema privado de responsabilidade sem culpa. ${ }^{1266}$

Com isso, o novo diploma civil afasta a teoria da culpa e expressamente adota a teoria do risco, chamada de objetiva, segundo a qual aquele que em virtude da sua atividade cria um risco de danos a terceiro, fica obrigado a reparar, sendo irrelevante que a ação do agente denote imprudência ou negligência ${ }^{1267}$, deslocando a questão para o viés exclusivo da reparação do dano. ${ }^{1268}$

O fato gerador da responsabilidade, ao rigor desse raciocínio, passa a ser o exercício da atividade permeada de risco.

\subsection{Atividade}

Atividade não se confunde com ato. Segundo Fernando Noronha, “(...) uma atividade é sempre caracterizada por uma série (ou conjunto) de atos praticados com vista à realização de determinado objetivo. Atividade Jurídica é aquela que visa realizar um objetivo juridicamente relevante e, por isso, objeto de tratamento unitário. $\mathrm{Na}$ atividade, o todo é qualitativamente diverso dos atos que a integram e, devido a isso, estes podem produzir consequências jurídicas que não aconteceriam, se não fosse estarem integrados no conjunto". ${ }^{1269}$

É a atividade, portanto, uma sequência coordenada e organizada de $\operatorname{atos}^{1270}$, ou seja, uma série de atos tendentes ao mesmo escopo ${ }^{1271}$, o que

Código Civil de 1916, já alertava que o conceito de culpa é tão vago, metafísico e de difícil concretização que em seu grave levíssimo pode mesmo abarcar até hipóteses sobre as quais construída a teoria da responsabilidade objetiva. $\mathrm{E}$ com os olhos voltados à idealização de um fundamento geral de responsabilidade civil, propõe Giselda Maria Fernandes Novaes Hironaka (Responsabilidade pressuposta. Belo Horizonte: Del Rey, 2005, p. 354) que ele deve se ancorar “(...) para além da pontuação legal casuística de responsabilização objetiva e revelando, como causa final almejada, a concretização dos paradigmas do justo e do equânime".

${ }^{1266}$ O Enunciado 38, aprovado na I Jornada de Direito Civil, promovida pelo Conselho da Justiça Federal com o apoio do Excelso Superior Tribunal de Justiça, estabelece: "a responsabilidade fundada no risco da atividade, como prevista na segunda parte do parágrafo único do art. 927 do novo Código Civil, configura-se quando a atividade normalmente desenvolvida pelo autor do dano causar à pessoa determinada um ônus maior do que aos demais membros da coletividade".

1267 José Fernando Simão. A teoria do risco no novo Código Civil. Disponível em http://www.professorsimao.com.br/artigos_simao_a_teoria_do_risco.htm.

${ }^{1268}$ Alvino Lima. Culpa e risco. $2^{\mathrm{a}}$ ed. Rev. e Atual. por Ovídio Rocha Barros Sandoval. São Paulo: RT, 1998.

${ }^{1269}$ Direito das obrigações. São Paulo: Saraiva, 2003, v. 1, p. 399.

${ }^{1270}$ Giselda Hironaka. Responsabilidade pressuposta..., cit., p. 339. 
firma o caráter do agir normalmente a ponto de excluir do espectro de incidência da norma o ato anormal ${ }^{1272}$, dissociado de contexto.

Não basta a mera repetição de atos, ainda que eventuais, dirigidos a um negócio, perigoso ou de extremo risco ${ }^{1273}$; o exercício de uma atividade pressupõe uma sucessão contínua e repetida de atos que se desencadeiam no tempo e implicam mínimo de continuidade e predisposição dos meios empregados em seu desempenho. $^{1274}$

É importante também fixar que o risco é atributo dessa atividade $^{1275}$, o que distingue atividade de risco e risco da atividade. Ou seja, o fator de imputação da norma é a atividade de risco e não o risco da atividade. O risco deve ser necessário e não, de modo singelo, eventualmente presente; daí porque não se pode afirmar que atividades próprias do lazer, como a mera condução de veículo automotor (geradora de certo risco inerente), implicariam responsabilidade objetiva. ${ }^{1276}$

Para o Min. Ruy Rosado de Aguiar, "o fundamento dessa responsabilização está em que a pessoa que exerce normalmente uma atividade perigosa deve ter um cuidado especial para impedir a ocorrência do dano. Se este acontece, presume-se que os cuidados não foram adequados. É uma regra nova que ainda está dependendo de interpretação e que é preciso que seja lida em seus devidos termos. O perigo deve ser excepcional, porquanto de um modo geral toda a atividade enseja algum tipo de risco; a culpa somente pode ser desconsiderada como elemento da responsabilização quando as circunstâncias evidenciarem que a conduta adotada era inadequada ao risco oferecido pela atividade. Assim, o motorista de táxi, que exerce

${ }^{1271}$ Fábio Konder Comparato e Calixto Salomão Filho. O poder de controle na sociedade anônima. $4^{\mathrm{a}}$ ed. Rio de Janeiro: Forense, 2005, p. 125.

${ }_{1272}$ Caio Mário da Silva Pereira. Responsabilidade civil. $9^{\mathrm{a}}$ ed. Rio de Janeiro: Forense, 1999, p. 285.

${ }^{1273}$ Cláudio Luiz Bueno de Godoy. Responsabilidade pelo risco da atividade. São Paulo: Saraiva, 2009, p. $55 / 56$.

${ }^{1274}$ Giselda Hironaka. Responsabilidade pressuposta..., cit., p. 300.

${ }^{1275}$ Segundo Carlos Alberto Bittar (Responsabilidade civil nas atividades perigosas. Responsabilidade civil Doutrina e jurisprudência. São Paulo: Saraiva, 1984, p. 90), "passou-se de um ato ilícito (teoria subjetiva) para um lícito, mas gerador de perigo (teoria objetiva), para caracterizar-se a responsabilidade civil. Com efeito, inserem-se dentro desse novo contexto atividades que, embora legítimas, merecem, pelo seu caráter de perigosas - seja pela natureza (fabricação de explosivos e de produtos químicos, produção de energia nuclear etc.), seja pelos meios empregados (substâncias, máquinas, aparelhos e instrumentos perigosos, transportes etc.) -, tratamento jurídico especial em que não se cogita da subjetividade do agente para a sua responsabilização pelos danos ocorridos".

${ }^{1276}$ Sergio Cavalieri Filho. Programa de responsabilidade civil. $5^{\mathrm{a}}$ ed. Rio de Janeiro: Malheiros, 2003, p. 170. 
normalmente atividade de risco, não pode ser condenado a reparar todo o dano que causar, com fundamento da responsabilidade objetiva". ${ }^{277}$

\subsection{Normalmente desenvolvida}

O fundamento para se atribuir responsabilidade, sem culpa, com base no risco gerado normalmente por determinadas atividades ${ }^{1278}$, não restritas à mera prestação de serviço para alguns ${ }^{1279}$, visto que os produtos quase sempre equivalem a uma representação concreta e direta do resultado do facere, encontra ressonância nas palavras de Miguel Reale, "se aquele que atua na vida jurídica desencadeia uma estrutura social que, por sua própria natureza, é capaz de pôr em risco os interesses e os direitos alheios, a sua responsabilidade passa a ser objetiva e não mais subjetiva". ${ }^{1280}$

Mas é preciso ter em mente que é a produção o fator de risco e não o produto dela resultante. A regra de responsabilidade objetiva sub examine, portanto restritiva, só terá aplicação se a atividade do agente causador do dano for normalmente

${ }^{1277}$ Ruy Rosado de Aguiar Júnior. Responsabilidade Civil no Novo Código Civil. Revista do Tribunal de Contas do Estado do Rio Grande do Sul, Porto Alegre, v. 36, mai. 2004, p. 86/90, Edição especial.

1278 Ainda sob a égide do Código Civil de 1916, mesmo por maioria, trilhou essa diretriz o Excelso Superior Tribunal de Justiça: "Responsabilidade civil. Teoria do risco (presunção de culpa). Atividade perigosa (transportador de valores). Acidente de trânsito (atropelamento de terceiro). Inexistência de culpa da vítima (indenização). 1. É responsável aquele que causa dano a terceiro no exercício de atividade perigosa, sem culpa da vítima. 2. Ultimamente vem conquistando espaço o princípio que se assenta na teoria do risco, ou do exercício de atividade perigosa, daí há de se entender que aquele que desenvolve tal atividade responderá pelo dano causado. 3. A atividade de transporte de valores cria um risco para terceiros. 'Neste quadro', conforme o acórdão estadual, 'não parece razoável mandar a família do pedestre atropelado reclamar, dos autores não identificados do latrocínio, a indenização devida, quando a vítima foi morta pelo veículo da ré, que explora atividade sabidamente perigosa, com o fim de lucro'. Inexistência de caso fortuito ou força maior. 4. Recurso especial, quanto à questão principal, fundado no art. 1.058 e seu parágrafo único do Cód. Civil, de que a Turma não conheceu, por maioria de votos" (REsp. 185.659/SP, rel. p/Ac. Min. Nilson Naves, j. 26.06.2000).

${ }^{1279}$ Para Cláudio Luiz Bueno de Godoy (Responsabilidade..., cit., p. 85 e 86): “(...) tem-se a aplicação do parágrafo único do art. 927 aos casos de danos produzidos no exercício da atividade, uma ação humana, enquanto o art. 931 ou o Código de Defesa do Consumidor, conforme se cuide ou não de relação de consumo, aplica-se aos casos de danos provocados por produtos postos em circulação, independente do manejo pelo homem, particularmente por quem exerce a atividade de que ele, o produto, é o resultado. (...) Ou seja, para não haver ociosidade de um ou outro, impende a diferenciação entre o dano havido no exercício de uma atividade, num caso, e o dano havido pelo fato da coisa, no outro, já não fosse a diversidade de nexo de imputação, o defeito no art. 931 e o risco da atividade no art. 927, parágrafo único". João Calvão da Silva (Responsabilidade civil..., cit., p. 406), na mesma linha, sustenta que o dano pelo produto provocado "(...) tem origem no ciclo produtivo, em falhas humanas e/ou técnicas da organização produtiva. Consequentemente, ainda sob esse ângulo, pode dizer-se que o dano deriva do desenvolvimento ou exercício da actividade em si”.

${ }^{1280}$ O projeto do Código Civil. São Paulo: Saraiva, 1986, p. 8. 
$\operatorname{arriscada}^{1281}$. Se o elemento de risco ou de perigo estiver - de modo exclusivo - na própria essência do produto (v.g., agrotóxicos, venenos, etc.), não no processo de produção, a reparação do dano, também independentemente de culpa, encontrará regência no art. 931 Código Civil.

2.2.1 Art. 931 do Código Civil: noção ampliada de fato do produto.

É bom lembrar que o art. 931 do Código Civil, à semelhança do art. 12 da Lei 8.078/90, também tipifica o chamado fato do produto nos seguintes termos: "ressalvados outros casos previstos em lei especial, os empresários individuais e as empresas respondem independentemente de culpa pelos danos causados pelos produtos postos em circulação". ${ }^{1282}$

Ao confrontar esses dois dispositivos, na busca de harmonizá-los com a disciplina da atividade de risco, sustenta Cláudio Luiz Bueno de Godoy que: “(...) pese embora sua omissão a propósito, o que pode gerar algum conflito, não se entende que o Código Civil, se afinal não adotou a teoria do risco integral, como já se explicitou no comentário do art. 927, a que ora se remete o leitor, dispense a mesma verificação do defeito do produto, o que levaria, em indesejável contradição sistemática, como se o ordenamento não fosse uno, à admissão de uma responsabilidade mais rigorosa, e em lei incidente na relação entre iguais, que da legislação do consumidor, a qual, não se pode olvidar, é subjetivamente especial porque, justamente, é protetiva de individuo presumidamente vulnerável, destarte envolvido numa relação entre desiguais. Cuida-se, então, do mesmo risco inerente à colocação no mercado de produto com periculosidade adquirida, por causa de defeito de segurança que passa a apresentar, quer ocorrido no processo de sua criação ou de sua produção, quer na correspondente informação. A responsabilidade, nesses casos, estará afeta, como na hipótese do art. 12 do CDC, aos empresários ou empresas aos quais estão incumbidos o fabrico, a produção, a construção

\footnotetext{
${ }^{1281}$ José Fernando Simão. Vícios do produto..., cit., p. 167/169.

1282 De acordo com Bruno Miragem (Direito..., cit., p. 297), “(...) A crítica mais destacada a esta disposição legal, é de que ela fasta o critério da anormalidade do risco do produto, característica da noção de defeito do Código de Defesa do Consumidor, fazendo com a responsabilidade determinada no Código Civil em razão dos danos provocados por produtos colocados no mercado, assume verdadeira caracterítisca de responsabilidade por risco integral".
} 
ou a importação do produto, entendendo-se aplicável a mesma restrição do art. 13 do Código de Defesa do Consumidor quanto à responsabilidade do comerciante". ${ }^{1283}$

Não parece ser esse, data venia, o silogismo hermenêutico adequado, pois se está restringindo o Código Civil a partir de uma tipologia por ele não prevista; ao passo que o correto, na forma do diálogo das fontes (supra, Cap. I, 2.6), sempre na busca do melhor amparo do consumidor, seria ampliar a noção do fato do produto previsto no CDC para, da mesma forma e com maior razão ante os desiguais sujeitos envolvidos, dispensar a existência do defeito em si como pressuposto da responsabilidade sem culpa.

Observe-se, a propósito, que o art. 931 do CC não alude expressamente a esse defeito, tanto que o enunciado 42, aprovado na I Jornada de Direito Civil promovida, com o apoio do Excelso Superior Tribunal de Justiça, pelo Conselho da Justiça Federal, reconheceu que: "o art. 931 amplia o conceito de fato do produto existente no art. 12 do Código de Defesa do consumidor, imputando responsabilidade civil à

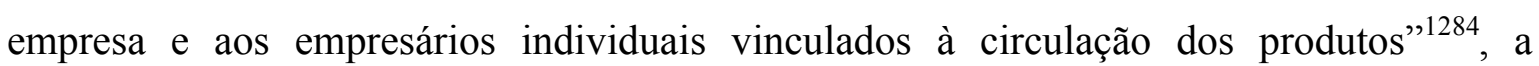
dispensar a ideia do necessário problema agregado.

A impositiva proteção constitucional e a normatividade principiológica condicionante da Parte Geral da Lei 8.078/90 impõem concluir-se com Adalberto Pasqualotto no sentido de que, “(...) a regra do art. 931 do CC/2002 suplantou os limites de imputação do art. 12 do CDC. Enquanto este exige defeito do produto para a imposição da obrigação de indenizar ao fornecedor, o art. 931 do CC/2002 menciona apenas a circulação do produto no mercado" ${ }^{2125}$, sem distinguir, ainda e por exemplo, a responsabilidade do comerciante.

\section{$2.3 \mathrm{O}$ risco e suas variações}

\footnotetext{
1283 Código Civil comentado. Doutrina e jurisprudência. In: Min. Cezar Peluso (coord.). $3^{\text {a }}$ ed. Barueri: Manole, 2009, p. 892/893. Esse também é, ao que parece, o entendimento de José Fernando Simão (Vícios do produto..., cit., p. 169/172).

${ }^{1284}$ Essa ideia foi retomada em 2006, no enunciado 378 da IV Jornada: "aplica-se o art. 931 do Código Civil, haja ou não relação de consumo"; muito embora o enunciado 190 da III Jornada, em 2004, tenha se mostrado tímido e até retrógrado ao dispor: "a regra do art. 931 do novo $\mathrm{CC}$ não afasta as normas acerca da responsabilidade pelo fato do produto ou do serviço previstas no art. 12 do CDC, que continuam mais favoráveis ao consumidor".

1285 Dará a reforma ao Código de Defesa do Consumidor um sopro de vida? Revista de Direito do Consumidor, São Paulo: RT, v. 78, abr.-jun. 2011, p. 19. Em igual sentido Carlos Alberto Menezes Direito; Sérgio Cavalieri Filho. In: Teixeira, Sálvio de Figueiredo (coord.). Comentários ao novo Código Civil. Rio de Janeiro: Forense, 2004, v 13, p. 148.
} 


\subsubsection{Risco integral x risco mitigado}

No risco integral se diz que a causalidade é pura, independe de qualquer elemento valorativo externo, como nas hipóteses de responsabilidade civil do Estado (CF, art. $37 \S 6^{\circ}$ ), ambiental (CF, art. 225 , $\S 3^{\circ}$, e Lei $\left.6.938 / 81\right)$ e por dano nuclear (CF, art. 21, XXIII, e Lei 6.453/77 $7^{1286}$ ), que envolvem tutela de bens essencialmente coletivos; daí a socialização dos riscos que a todos interessa e a necessidade até de reparação do dano involuntário, dispensando o nexo causal.

Para Cláudio Luiz Bueno de Godoy, aqui, “(...) a causalidade substitui a culpa sem nenhum elemento qualificador que a ela se agregue. A configuração do dever reparatório surge do só nexo que há entre o dano e um fato humano, até mesmo independente da vontade ou da consciência do agente. Basta apenas que a conduta humana seja a causa material da eclosão do evento lesivo, como que se a questão indenizatória daí decorrente se resolvesse à luz de um conflito de patrimônios, dessarte a que estranha qualquer cogitação de dado outro da ocorrência ou do causador do dano". ${ }^{1287}$

O risco mitigado, por sua vez, não se contenta com uma causalidade bastante em si mesma. Sem a pureza da teoria anterior, a ela se agrega um elemento qualificativo, externo, que modula o próprio fato danoso ou os sujeitos envolvidos $^{1288}$. É o caso da responsabilidade sem culpa prevista na Lei 8.078/90 que, ao definir a inexistência do defeito como excludente (arts. $12 \S 3^{\circ}$, II, e 14, $\S 3^{\circ}$, I), acabou exigindo um problema, tal qual nela definido, como fator autorizante da obrigação de indenizar.

\subsubsection{Risco criado x risco proveito}

E prossegue o referido autor:

\footnotetext{
${ }^{1286} \mathrm{Em}$ verdade, tal qual se infere dos seus arts. $6^{\circ}$ a $8^{\circ}$, também aqui existem excludentes de responsabilidade: a) culpa exclusiva da vítima (causadora direta do dano), prevalecendo o risco agravado para os demais atingidos $\left(\operatorname{art.} 6^{\circ}\right.$ ), e b) fatos excepcionais de grandes proporções (v.g., conflitos armados, hostilidades, guerra civil, insurreição ou excepcional fato da natureza), se causadores diretos do acidente (art. $\left.8^{\circ}\right)$.

${ }^{1287}$ Cláudio Luiz Bueno de Godoy. Responsabilidade..., cit., p. 65.

${ }^{1288}$ Idem, p. 66.
} 
“(...) Pelo risco criado, responde, independentemente de culpa, quem cria ou expõe outrem a risco. Em diversos termos, quem, com sua atividade, gera risco a terceiros, deve arcar com a responsabilidade consequente. Ainda em outras palavras, cada qual deve suportar os riscos de sua atividade. É a causalidade entre o dano sofrido e uma atividade desempenhada que provoca risco convertido em lesão a direito alheio.

(...) O caso aqui é, antes, de desempenho normal de uma atividade lícita, a qual, porém, cria risco aos direitos de terceiros. Uma atividade que gera risco cuja responsabilidade se atribui a quem a controla e a quem seja de algum modo afeto o interesse no seu desempenho, mesmo que esse interesse não seja econômico."

Agora, se a atividade for dirigida ao lucro tem-se a teoria do risco proveito ${ }^{1290}$, representada pela parêmia segundo a qual cabem os ônus àquele que percebe os bônus (ubi commodum, ibi incommodum ou ubi emolumentum, ibi onus) ${ }^{1291}$. Fernando Noronha ${ }^{1292}$ identifica um desdobramento no risco proveito em face do sujeito passivo do dano: a) o risco de empresa ${ }^{1293}$, atrela o empreendedor a qualquer evento danoso inerente ao processo produtivo ou distributivo e b) o risco profissional, se a vítima for empregado ou preposto do titular da atividade econômica. ${ }^{1294}$

\footnotetext{
${ }^{1289}$ Idem, p. 66-67.

1290 “(...) não restam dúvidas que a atividade bancária resulta em proveito ao agente ao mesmo tempo em que acarreta riscos patrimoniais (e até pessoais) a terceiros. Riscos estes inerentes ao negócio que desenvolve, impedindo, desse modo, que se alce um episódio como este, que ora se aprecia, a categoria de imprevisível ou mesmo inevitável" (TJSP, AC 7.310.169-0, rel. Melo Colombi, j. 04.03.2009).

${ }^{1291}$ A doutrina se divide quanto à teoria adotada pelo novo Código Civil, se a do risco criado ou se a do risco proveito. Talvez o melhor fosse considerar o gênero risco econômico como abrangente das duas modalidades anteriores, pois como ensina Georges Ripert ( $O$ regimen democrático e o direito civil moderno. Trad. J. Cortezão. São Paulo: Saraiva, 1937, p. 330 e ss.) a "democracia não pode admitir uma organização econômica que separa na exploração os benefícios e os riscos".

1292 Direito das obrigações..., cit., p. 486.

${ }^{1293}$ Pietro Trimarchi (Rischio e responsabilità oggettiva. Milano: Giuffrè, 1961, p. 24/25) sustenta que o fato material de organização da empresa, aliado aos ônus daí advindos, bastaria para firmar, também aqui, a causalidade pura. Ou, como entende Carlos Alberto Bittar (Responsabilidade civil nas atividades nucleares. São Paulo: RT, 1985, p. 70) seria a responsabilidade pelo simples fato da exploração da empresa.

1294 “Antes de imputar culpa ao fabricante da máquina, é mister indagar da responsabilidade do empregador, que, pelo visto, havia adquirido recentemente as máquinas (três ou quatro meses antes do acidente) e que ainda pelo que é possível inferir por falta de provas -, não realizou treinamento de seus empregados para que ficassem eles alerta ao risco que as lâminas cortantes representam em caso de desconcentração. Também não consta que manteve supervisores ou chefe de setores para, em ritmo de plantão ou turno, controlar o serviço executado. Igualmente não há, nos autos, prova da manutenção periódica para avaliação de segurança das máquinas, porque nenhum comunicado ou reclamação, nesse sentido, se expediu no período em que as máquinas eram garantidas pelo fornecedor" (TJSP, AC 121.643-4/1, rel. Ênio Santarelli Zuliani, j. 14.05.2002).
} 
Identifica-se, ainda, o risco defeito e o risco perigo. O risco defeito é o possível comprometimento do objeto da circulação de riqueza (vício ou defeito), enquanto o risco perigo ${ }^{1295}$ se vincula à exploração de atividade de risco intrinsecamente perigosa; ou seja, que gera perigo mediante desempenho ordinário e não extraordinário, tolerada apenas por ser socialmente útil. ${ }^{1296}$

Pode-se afirmar, nesta quadra, a partir das classificações propostas, que o microssistema da Lei 8.078/90 apresenta, para a responsabilidade civil, o risco proveito (empresa), defeito ou perigo, com causalidade mitigada.

\subsection{Conteúdo normativo}

A se adotar a premissa de que toda atividade humana implica a possível, embora remota, ocorrência de um dano ${ }^{1297}$, repelidas as teorias da causalidade pura (risco integral), em razão dos complementos integrativos do próprio tipo sub examine (responsabilidade independente de culpa e atividade indutora de risco), e da limitada (risco mitigado), considerando a nova concepção de fato do produto prevista no art. 931 do Código Civil, ponderada se mostra a idéia de um risco especial (destacado ou particular), o que acaba atraindo, mas não por completo, a moldura intermediária do risco perigo.

"Pois a desvinculação da responsabilidade sem culpa do conceito de perigo intrínseco, propiciada pela redação do parágrafo único do art. 927, serve justamente a preencher esse espaço que se aponta. Vale dizer, ampliase a abrangência da cláusula geral da responsabilidade objetiva pela sua adstrição, não ao perigo propriamente, mas ao risco criado pela atividade normalmente desenvolvida, sem que, menos ainda, seja necessário configurar-se um defeito. Muito embora, tal como na tese do risco perigo, esse risco deva ser diferenciado, particular, especial.

\footnotetext{
1295 Que se situa entre a causalidade pura do risco integral e o risco mitigado dependente de um elemento qualificador para aperfeiçoar o nexo etiológico.

${ }^{1296}$ Giselda Hironaka. Responsabilidade pressuposta ..., cit., p. 299.

1297 Pietro Trimarchi. Rischio..., cit., p. 19 e Massimo Franzoni. La responsabilità oggettiva: il danno da cose, da esercizio di attività periculose, da circolazione di veicoli. Padova: CEDAM, 1995, v. 2, p. 143. Por sua vez, Gerd Winter (European Environmental Law - A Corporative Perspective. Aldershot: Dartmouth Publishing Co., 1996, p. 41) afirma que: “os perigos são geralmente proibidos, o mesmo não acontece com os riscos. Os riscos não podem ser excluídos, porque sempre permanece a probabilidade de um dano menor. Os riscos podem ser minimizados".
} 
A diferença, dessarte, é que a opção da legislação brasileira, ao estabelecer a cláusula de responsabilidade objetiva, não foi a de reduzi-la ao perigo intrínseco, mesmo que especial, da atividade desenvolvida. Antes, erigiuse, no ordenamento civil, uma cláusula geral que, ao contrário de outras, próprias de diversos sistemas, ou mesmo ao contrário de outras precedentemente projetadas, no Brasil aludiu não ao perigo, mas ao risco induzido pelo exercício de certa atividade." 1298

Por este prisma, embora não se exija que a atividade seja de risco congênito ${ }^{1299}$, muito menos que revele defeito, critérios estatísticos ${ }^{1300}$, dados técnicos e até mesmo máximas de experiência (CPC, art. 335) poderão ser manejados visando à identificação desse risco especial e particular ${ }^{1301}$, num processo que deve sempre que possível anteceder o dano.

Ganham corpo, neste passo, os princípios da precaução e da prevenção.

${ }^{1298}$ Cláudio Luiz Bueno de Godoy. Responsabilidade..., cit., p. 96.

1299 Admite-se que a periculosidade varia com o tempo, ou seja, uma atividade em princípio sem risco pode alçar contornos de perigosa em momento posterior; bem como o contrário. Leva-se em conta, ainda, o contexto social onde se desenvolve a atividade.

${ }^{1300}$ Segundo Píer Giuseppe Monateri (La responsabilità civile per lo svolgimento di attività pericolose. Disponível em http://www.notiziariogiuridico.it/attpericolose.html): “con formula classica si è detto che ogni attività è per se stessa idonea a cagionare danno ad altri: l'art. 2050 si applica quando la pericolosità rappresenta un dato tipico e immanente. Pertanto la pericolosità deve consistere in una potenzialità lesiva $d i$ grado superiore al normale. Sono qui possibili, allora, due criteri concorrenti: a) tenere conto della quantità di danni abitualmente cagionati dall'attività in questione; b) tener conto anche della gravità dei pregiudizi minacciati. L'attività sarà quindi pericolosa quando statisticamente cagiona molti incidenti, e quando minaccia di cagionarne di molto gravi". Ou em vernáculo (tradução livre): "com a fórmula clássica, se disse que cada atividade é por si mesma idônea a causar dano a outro: o art. 2.050 se aplica quando a periculosidade representa um dado típico e imanente. Portanto, a periculosidade deve consistir em uma potencialidade lesiva de grau superior ao normal. São possíveis aqui, então, dois critérios concorrentes: a) ter em conta a quantidade de danos habitualmente causados pela atividade em questão; b) ter em conta também a gravidade da ameaça de causar danos. Consequentemente, a atividade será perigosa quando estatisticamente causa muitos incidentes, e quando a ameaça de causá-los é muito acentuada”.

${ }^{1301}$ Lembra Carlos Alberto Bittar (Responsabilidade civil nas atividades perigosas..., cit., p. 93/94) que perigosa é "aquela atividade que contenha em si uma grave probabilidade, uma notável potencialidade danosa, em relação ao critério da normalidade média e revelada por meio de estatísticas, de elementos técnicos e da própria experiência comum (...). Embora não seja fácil a determinação da periculosidade, devem ingressar nessa noção aquelas atividades que, pelo grau de risco, justifiquem a aplicação de uma responsabilidade especial. Isso significa que não somente as enumeradas em disposições legais ou em leis especiais merecem essa qualificação, mas aquelas que revelem 'periculosidade intrínseca ou relativa aos meios de trabalho', na fórmula consagrada pela Suprema Corte Italiana”. 


\title{
3. A PRECAUÇÃO COMO FORMA DE CONTROLE DO RISCO
}

\author{
3.1. Delimitação da problemática
}

Muito embora a precaução e a prevenção atuem como elementos de incidência ampla, lídimos paradigmas multidisciplinares fundados no agir prudente e no princípio da solidariedade social, este estudo se baliza na análise dos seus reflexos sobre as relações de consumo, particularmente no que tange à conduta do fornecedor diante dos riscos gerados pela exploração econômica da sua atividade, sejam eles reais e concretos, sejam eles apenas hipotéticos (ainda não definidos de modo científico).

De sensível importância nessa investigação se revela o panorama traçado por Teresa Ancona Lopez ${ }^{1302}$, cujo conteúdo iluminará todo o desenvolvimento do tema sub examine; aliás, como alerta a catedrática, “(...) é preciso esclarecer que a prevenção e a precaução não devem ser aplicadas pelo direito da responsabilidade civil somente diante de catástrofes globais. Esses princípios têm que mostrar a direção correta também individualmente, ou seja, têm que segui-los o médico, o advogado, o administrador de empresas, o motorista, os hospitais, os transportadores aéreos, terrestres e marítimos, os empreiteiros, etc.". ${ }^{1303}$

Ressalte-se, a propósito, que a Política Nacional de Relações de Consumo impõe uma ação governamental também voltada a garantir no mercado produtos e serviços com padrões adequados de qualidade, segurança ${ }^{1304}$, durabilidade e desempenho (CDC, art. 4", II, “d”).

Afora esse natural dirigismo, lídimo programa de intervenção permanente ${ }^{1305}$, o Estado também deve incentivar os fornecedores a criarem meios eficientes de controle dessas mesmas qualidade e segurança, inclusive com os olhos

\footnotetext{
${ }^{1302}$ Princípio da precaução e evolução da responsabilidade civil. Tese para concurso de Professor Titular apresentada ao Departamento de Direito Civil da Faculdade de Direito da Universidade de São Paulo (USP), 2008.

${ }^{1303}$ Princípio da precaução..., cit., p. 76.

1304 A segurança é componente de destaque nessa atuação, tanto que também erigida em objetivo dessa intervenção estatal. Eis o caput, do art. $4^{\circ}$ da Lei 8.078/90: "a Política Nacional de Relações de Consumo tem por objetivo o atendimento das necessidades dos consumidores, o respeito a sua dignidade, saúde e segurança, a proteção de seus interesses econômicos, a melhoria da sua qualidade de vida, bem como a transparência e harmonia das relações de consumo, atendidos os seguintes princípios".

${ }^{1305}$ Aurisvaldo Melo Sampaio. As novas tecnologias..., cit., p. 140.
} 
voltados ao pós-consumo ${ }^{1306}$, assim como de mecanismos alternativos de solução de conflitos (CDC, art. 4, V), sempre por eles próprios custeados (supra, Cap. III, 3.1).

No entanto, como alerta Thierry Bourgoignie, a implantação de um sistema de fiscalização do mercado necessita identificar e promover as fontes de dados destinadas a detectarem os riscos relativos aos produtos oferecidos, isto porque, além da capacidade adquirida de agir em situação de urgência, essas informações permitem um melhor planejamento das atividades de monitoramento. ${ }^{1307}$

\subsection{Natureza jurídica}

Seria a precaução princípio ou standard de conduta?

A distinção tem relevância na medida em que o standard é mero fenômeno dos modelos gerais de comportamento (médio) social e ético juridicamente relevantes ${ }^{1308}$, surgindo como conteúdo latente e flexível da cláusula geral a encerrar

1306 Discorre Patrícia Faga Iglecias Lemos (Resíduos sólidos e responsabilidade civil pós-consumo. São Paulo: RT, 2011, p. 240/241), que “(...) compõem o foco central da responsabilidade pós-consumo os princípios do poluidor-pagador, da prevenção e da precaução. O poluidor-pagador reforça o papel preventivo ao determinar a eliminação das externalidades ambientais negativas do processo produtivo, sob pena de geração de ineficiências econômicas, falseando o equilíbrio entre a oferta e a demanda. Também impõe a criação de normas que gerem alteração na ordenação de valores decorrentes das regras de mercado, ou seja, os custos de prevenção dos efeitos adversos ao meio ambiente dever ser suportados pelo poluidor. $\mathrm{O}$ princípio da prevenção, por sua vez, permite evitar o dano, a partir da concepção e da otimização dos produtos, mediante melhores tecnologias para produtos e embalagens, que dilatem o tempo de utilização, por exemplo, bem como pela retificação de erros. Por outro lado, não se afasta a prevenção no final do ciclo, com reutilização, reciclagem e valorização energética, além de disposição final ambientalmente adequada. Embora a técnica comum seja o recurso ao princípio da precaução para a proteção de bens bióticos, entendemos que o princípio também se aplica na proteção dos abióticos, no caso, dos resíduos. Havendo incerteza científica, impõe-se a escolha da melhor opção em prol do meio ambiente, com adoção da técnica de inversão do ônus da prova. Sua aplicação tem como balizas os princípios da razoabilidade e da proporcionalidade". E prossegue a autora (p. 244): "por fim, defendemos uma interpretação ampliativa dos gestores de risco, vinculada tão somente à posse dos resíduos ou rejeitos. Quanto à responsabilidade compartilhada, uma exceção à regra da responsabilidade solidária se impõe a partir da PNRS, pois os papéis estão claros: fabricantes e importadores podem ser obrigados a cuidar da destinação ambientalmente adequada, enquanto distribuidores e comerciantes têm responsabilidade restrita à devolução do objeto ou resíduo. $\mathrm{O}$ consumidor, por sua vez, tem responsabilidade limitada à disposição adequada dos resíduos para coleta, ou, no caso da logística reversa, à devolução, conforme informação na cadeia produtiva".

1307 Sistemas de fiscalização do mercado e segurança dos produtos de consumo. Revista de Direito do Consumidor, São Paulo: RT, v. 76, out.-dez. 2010, p. 291. E prossegue referido autor (p. 292): “dentro do quadro das novas obrigações que se tira da lei de segurança geral dos produtos, os operadores econômicos devem informar às autoridades de fiscalização do mercado sobre os defeitos de não conformidade e os perigos de seus produtos que, uma vez postos em circulação no mercado, venham a apresentar (ver, em nível europeu, o art. 5.3 da Diretiva de 03.12.2001). Eles são igualmente obrigados a colaborar com suas autoridades, notadamente as comunicando de toda documentação ou informação pertinente (ver, a nível europeu, o art. 5.4 da mesma Diretiva)".

1308 Angelo Falzea. Ricerche di teoria generali Del diritto e di dogmatica giuridica. Milano: Giuffrè, 1999, p. $369 / 371$. 
hipótese de norma em branco ou de direito judicial; enquanto os princípios transformam o ordenamento em sistema, fixando diretrizes básicas e valores que o sustentem, autênticas metas a serem alcançadas.

Além disso, o processo interpretativo - ciência que é - não pode se ater somente às regras positivas (normatividade); ao revés, pois os princípios ${ }^{1309}$, em sua essência, é que funcionam como bases medulares do direito ${ }^{1310}$ e, por isso, reclamam acurado estudo e preocupação (principiologia).

\section{Esclarece, com precisão, Teresa Ancona Lopez:}

“(...) o 'princípio da precaução’ tem a característica de 'princípio jurídico' que tenta realizar os valores do naeminem laedere, da prudência e da segurança (outro princípio) e estabelece diretrizes normativas no sentido de evitar os danos, apreciando os riscos possíveis para que o pior não aconteça individual e socialmente. Dentro desse princípio, temos a idéia de precaução e aí temos que reenviar o standard, ou seja, diante do quadro que se apresenta, é necessário apreciar os possíveis danos, examinar as fontes científicas, políticas, econômicas, sociológicas, éticas, estatísticas, sempre usando antes princípios/standards, ou seja, a razoabilidade e a proporcionalidade ${ }^{1311}$, e ver se a

${ }^{1309}$ Segundo Carlos Maximiliano (Hermenêutica e Aplicação do Direito. $5^{\mathrm{a}}$ ed. São Paulo: Livraria Freitas Bastos, 1951, p. 356, exe. $n^{\circ} 1752$ ): "todo conjunto harmônico de regras positivas é apenas o resumo, a síntese, o substractum de um complexo de altos ditames, o índice materializado de um sistema orgânico, a concretização de uma doutrina, série de postulados que enfeixam princípios superiores. Constituem estes as diretivas ideais do hermeneuta, os pressupostos científicos da ordem jurídica. Se é deficiente o repositório de normas, se não oferece, explícita ou implicitamente, e nem sequer por analogia, o meio de regular ou resolver um caso concreto, o estudioso, o magistrado ou funcionário administrativo como que renova, em sentido inverso, o trabalho do legislador: este procede de cima para baixo, do geral ao particular; sobe aquele gradativamente, por indução, da idéia de foco para outra mais elevada, prossegue em generalizações sucessivas, e cada vez mais amplas, até encontrar a solução colimada (...)”.

${ }^{1310}$ Afirma Celso Antônio Bandeira de Mello (Curso de direito administrativo. $4^{\mathrm{a}}$ ed. São Paulo: Malheiros, 1993, p. 408/409) que princípio: “(...) é por definição, mandamento nuclear de um sistema, verdadeiro alicerce dele, disposição fundamental que se irradia sobre diferentes normas compondo-lhes o espírito e servindo de critério para sua exata compreensão e inteligência, exatamente por definir a lógica e a racionalidade do sistema normativo, no que lhe confere a tônica e lhe dá sentido harmônico. É o conhecimento dos princípios que preside à intelecção das diferentes partes componentes do todo unitário que há por nome sistema jurídico positivo. 4. Violar um princípio é muito mais grave que transgredir uma norma qualquer. A desatenção ao princípio implica ofensa não apenas a um específico mandamento obrigatório mas a todo o sistema de comandos. É a mais grave forma de ilegalidade ou inconstitucionalidade, conforme o escalão do princípio atingido, porque representa insurgência contra todo o sistema, subversão de seus valores fundamentais, contumélia irremissível a seu arcabouço lógico e corrosão de sua estrutura mestra. Isto porque, com ofendê-lo, abatem-se as vigas que o sustêm e alui-se toda a estrutura nelas esforçada".

${ }^{1311} \mathrm{Na}$ Comunicação da Comissão das Comunidades Européias relativa ao princípio da precaução, é sugerido que, sempre que seja necessário aplicar esse princípio, as medidas devem ser proporcionais ao nível de proteção escolhido e que "proporcionalidade significa adaptar as medidas ao nível de proteção escolhido. Raramente se pode reduzir o risco a zero, mas uma análise de riscos incompleta pode reduzir consideravelmente a gama de opções disponíveis aos gestores de risco. Uma proibição total nem sempre 
situação no tempo e no espaço em que se apresenta exige que se tomem medidas de precaução ou não. Como princípio, deve se harmonizar com outros princípios que, por acaso, estejam em colisão com a precaução, como o da livre iniciativa ou da paz social, pois atitudes de precaução não necessárias podem causar pânico social ou bloquear inovações.

Em resumo, como norma jurídica, o 'princípio da precaução', se não aplicado quando necessário, faz atuar a força coercitiva do Direito sancionando com reparações ou outras medidas aqueles que faltaram em prevenir ou evitar o dano. O mesmo se diga do uso errado desse princípio, que também enseja condenação e reparação."1312

A doutrina, de certa forma, acaba tratando o princípio da precaução também como princípio da prudência ou cautela ${ }^{1313}$ ou princípio da prevenção ${ }^{1314}$, mas agora tem prevalecido a primeira designação. ${ }^{1315}$

constitui uma resposta proporcional a um risco potencial. Contudo, em determinados casos, é a única resposta possível a um dado risco" (Bruxelas, 02.02.2000).

${ }_{1312}$ Princípio da precaução..., cit., p. 83/84. A propósito, alerta Paulo de Bessa Antunes (Direito ambiental. $11^{\mathrm{a}}$ ed. Rio de Janeiro: Lumen Juris, p. 37/38): "a única aplicação juridicamente legítima que se pode fazer do princípio da precaução é aquela que leve em consideração as leis existentes no País e que determine a avaliação dos impactos ambientais de uma certa atividade, conforme a legalidade infraconstitucional existente. Infelizmente, tem havido uma forte tendência a se considerar que o princípio da precaução é um superprincípio que se sobrepõe aos princípios fundamentais da República, tal como estabelecidos pela própria $\mathrm{CF}$, o que, evidentemente, é uma grave ruptura da legalidade constitucional e prova de precário conhecimento jurídico. Ante a possível existência de conflito entre uma norma legal expressa e um princípio setorial, há de prevalecer a norma positivada, salvo se ela se apresentar maculada pela inconstitucionalidade. Observe-se que, no caso, não se trata propriamente da prevalência de um princípio setorial, mas de uma afronta à Constituição, o que é uma preliminar inafastável. O princípio da precaução tem sido prestigiado pelo legislador brasileiro que, em muitas normas positivadas, determina uma série de medidas com vistas à avaliação dos impactos ambientais reais e potenciais gerados pelos diferentes empreendimentos. Ainda que extremamente relevante - o que é reconhecido por toda doutrina brasileira e pelo ordenamento jurídico -, o princípio da precaução não é dotado de normatividade capaz de fazer com que ele se sobreponha aos princípios da legalidade (um dos princípios setoriais reitores da administração pública) e, especialmente, aos princípios fundamentais da República, repita-se. A aplicação do princípio da precaução somente se justifica constitucionalmente quando observados os princípios fundamentais da República e ante a inexistência de norma capaz de determinar a adequada avaliação dos impactos ambientais. Fora de tais limites, a aplicação do princípio da precaução se degenera em simples arbítrio".

${ }^{1313}$ Paulo de Bessa Antunes, que em edição anterior da sua obra (1999, p. 28/29) afirma: "o princípio da prudência ou da cautela é aquele que determina que não se produzam intervenções no meio ambiente antes de ter a certeza de que estas não serão adversas para o meio ambiente".

${ }^{1314}$ Celso Antonio Pacheco Fiorillo e Marcelo Abelha Rodrigues. Manual de direito ambiental e legislação aplicável. $2^{\mathrm{a}}$ ed. São Paulo: Max Limonad, 1999, p. 140; Toshio Mukai. Direito ambiental sistematizado. $3^{\mathrm{a}}$ ed. Rio de Janeiro: Forense Universitária, 1998, p. 35, e Álvaro Luiz Valery Mirra. Princípios fundamentais do direito ambiental. Revista de Direito Ambiental, São Paulo: RT, Ano 1, n. 2, abr.-jun. 1996, p. 36.

${ }^{1315}$ Paulo Affonso Leme Machado. Direito ambiental brasileiro. $16^{\mathrm{a}}$ ed. São Paulo: Malheiros, 2008, p. 65 e ss., e Ramon Martín Mateo. Manual de derecho ambiental. Madrid: Trivium, 1988, p. 55, entre vários outros já citados neste trabalho. 


\subsection{Noção e extensão}

A precaução como disciplina do risco é algo recente, comum à sociedade contemporânea, onde o avanço tecnológico - gerado a partir da segunda etapa da revolução industrial - criou problemas novos, potencializando o risco de convivência (v.g., internet, atividade bancária, biotecnologia, meio ambiente, etc.); no entanto, atualmente é uma referência indispensável em todas as abordagens relativas aos riscos. ${ }^{1316}$

Nascida no direito ambiental, a precaução encontra - de forma sistematizada - sua chancela maior no princípio 15 da Declaração do Rio de Janeiro (ECO-92) 1317: “de modo a proteger o meio ambiente, o princípio da precaução deve amplamente observado pelos Estados, de acordo com suas capacidades. Quando houver ameaça de danos sérios e irreversíveis, a ausência de absoluta certeza científica não deve ser utilizada como razão para postergar medidas eficazes e economicamente viáveis para prevenir a degradação ambiental". ${ }^{1318}$

${ }^{1316}$ Michel Prieur. Droit de l'Environnement. 4 a ed. Paris: Dalloz, 2001, p. 145.
${ }^{1317}$ A ECO-92, Rio-92, Cúpula ou Cimeira da Terra são nomes pelos quais é das Nações Unidas para o Meio Ambiente e o Desenvolvimento (CNUMAD), realizada entre 3 e 14 de junho de 1992 no Rio de Janeiro. O seu objetivo principal era buscar meios de conciliar o desenvolvimento sócioeconômico com a conservação e proteção dos ecossistemas da Terra. A Conferência do Rio consagrou o conceito de desenvolvimento sustentável e contribuiu para a mais ampla conscientização de que os danos ao meio ambiente eram majoritariamente de responsabilidade dos países desenvolvidos. Reconheceu-se, ao mesmo tempo, a necessidade de os países em desenvolvimento receberem apoio financeiro e tecnológico para avançarem na direção do desenvolvimento sustentável. Naquele momento, a posição dos países em desenvolvimento tornou-se mais bem estruturada e o ambiente político internacional favoreceu a aceitação pelos países desenvolvidos de princípios como o das responsabilidades comuns, mas diferenciadas. A mudança de percepção com relação à complexidade do tema deu-se de forma muito clara nas negociações diplomáticas, apesar de seu impacto ter sido menor do ponto de vista da opinião pública. Disponível em http://pt.wikipedia.org/wiki/ECO-92.

${ }^{1318}$ Revela Teresa Ancona Lopez (Princípio da precaução..., cit., p. 85/86) que o princípio da precaução "surge no direito alemão na década de $70 \mathrm{com}$ vistas à proteção ambiental - é o Vorsorgeprinzip. Porém, também já havia aparecido em debates internacionais sobre a proteção ao meio ambiente, debates esses patrocinados pela 'Conferência das Nações Unidas sobre o Meio Ambiente Humano', em Estocolmo, no ano de 1972. Durante a década de 80, essa idéia ganha força, tendo siso afirmado expressamente pela primeira vez em 1987, na Conferência sobre o Mar do Norte, depois incorporado em diversos tratados e declarações internacionais sobre questões ambientais, como o controle de poluição. Porém, sua consagração como princípio somente acontece em 1992, na 'Declaração do Rio de Janeiro - Eco-92'. Assim, foi a partir daí que o princípio da precaução tomou força não só no direito ambiental, mas também começou a ser aplicado no direito sanitário (sangue contaminado), direito (alimentar) ('vaca louca') e foi aceito nos ramos do direito que têm como finalidade proteger a incolumidade física e a saúde dos indivíduos". Salienta, ainda, Patrícia Faga Iglecias Lemos (Direito ambiental. Responsabilidade Civil e proteção ao meio ambiente. $2^{\mathrm{a}}$ ed. São Paulo: RT, 2008, p. 159): "historicamente, enquanto o princípio da prevenção pode ser encontrado em tratados internacionais ambientais e outros atos internacionais, pelo menos desde 1930, o princípio da precaução começou a constar nos instrumentos legais internacionais somente em meados dos anos 80 . Seu objetivo está em orientar o desenvolvimento e a aplicação do direito ambiental nos casos de incerteza científica. (...) Tal princípio tem sido adotado em muitos tratados internacionais ambientais desde 1989. Embora sua formulação varie em cada instrumento, a linguagem do Princípio 15 recebe amplo suporte. Sua origem está nos acordos 
Tem-se, com isso, o inevitável reflexo da precaução - e também da prevenção - sobre o sistema de responsabilidade civil, ainda que de forma subliminar $^{1319}$, não só na esfera ambiental, mas dirigida especificamente para o futuro no intuito de evitar ou de diminuir o dano ${ }^{1320}$, exercendo função preventiva e/ou de gerenciamento de riscos em todas as questões atreladas à segurança ${ }^{1321}$ social e à do indivíduo ${ }^{1322}$, caracterizando-se pela ação antecipada diante do risco ou do perigo. ${ }^{1323}$ É postura de antecipação ${ }^{1324}$, de oposição ${ }^{1325}$, gerada pela possibilidade de dano grave, de difícil reparação ou até mesmo irreparável ${ }^{1326}$. O princípio

ambientais mais tradicionais que solicitam a ação baseada em pesquisas científicas ou métodos e conhecimentos disponíveis no momento. Para tais modelos, a ação só deve ser tomada quando existirem evidências científicas da ocorrência de danos ambientais significativos, o que implica dizer que, na sua ausência, nenhuma ação será necessária". Não se deve esquecer que a Convenção sobre a Mudança do Clima também assentou, no seu art. $3^{\circ}, 3$, que "as partes devem adotar medidas de precaução para prever, evitar ou minimizar as causas da mudança do clima e mitigar seus efeitos negativos. Quando surgirem ameaças de danos sérios ou irreversíveis, a falta de plena certeza científica não deve ser usada como razão para postergar essas medidas, levando em conta que as políticas e medidas adotadas para enfrentar a mudança do clima dever ser eficazes em função dos custos, de modo a assegurar benefícios mundiais ao menor custo possível". Essas duas Convenções, internalizadas no mesmo dia (03.02.1994), embora por Decretos Legislativos distintos ( $\mathrm{n}^{\circ} 2$ para a primeira e $\mathrm{n}^{\circ} 1$ para a segunda), como salienta Édis Milaré (Direito do ambiente. A gestão ambiental em foco. Doutrina. Jurisprudência. Glossário. 5a ed. São Paulo: RT, 2007, p. 769) incorporaram, "às expressas, o princípio da precaução na legislação pátria. Aliás, pode-se também dizer que o princípio já havia sido implicitamente adotado pela Constituição Federal de 1988, na preocupação do legislador em 'controlar a produção, a comercialização e o emprego de técnicas, métodos e substâncias que comportem risco para a vida, a qualidade de vida e o meio ambiente', manifestada no seu art. 225, V. Anotese, por fim, que a omissão na adoção de medidas de precaução, em caso de risco de dano ambiental grave ou irreversível, foi considerada pela Lei 9.605/1998 (Lei dos Crimes ambientais) como circunstância capaz de sujeitar o infrator a reprimenda mais severa, idêntica à do crime de poluição qualificado pelo resultado (art. $54, \S 3^{\circ}$ ). Por igual, a Lei 11.105/2005 (Lei da Biossegurança) também fez menção expressa ao princípio em suas exposições preliminares e gerais, ao mencionar como diretrizes 'o estímulo ao avanço científico na área de biossegurança e biotecnologia, a proteção à vida e à saúde humana, animal e vegetal, e a observância do princípio da precaução para a proteção do meio ambiente' (art. $1^{\circ}$, caput)".

1319 Teresa Ancona Lopez. Princípio da precaução..., cit., p. 108.

${ }^{1320}$ Mathilde Boutonnet (Le principe de précaution en droit de la responsabilité civile. Paris: LGDJ, 2005, $\mathrm{p}$. 294) fala em um novo fundamento a enriquecer o direito pensado e a "oferecer uma nova orientação preventiva ao direito positivo da responsabilidade civil". Para Ulrich Beck (La societé du risque - Sur la voie d'une autre modernité. Trad. do alemão. Paris: Alto-Aubier, 2001, p. 61): “(...) a verdadeira força social do argumento do risco reside justamente nos perigos que se projetam para o futuro. Na sociedade do risco, o passado perde sua função determinante para o presente. É o futuro que vem substituí-lo e é, então, alguma coisa de inexistente, de construído, que se torna a 'causa' da experiência e da ação no presente".

${ }^{1321}$ Para Teresa Ancona Lopez (Princípio da precaução..., cit., p. 101): “(...) é o paradigma da segurança que transforma os princípios da responsabilidade e da solidariedade em princípio da precaução".

${ }^{1322}$ Sustenta Aurisvaldo Melo Sampaio (As novas tecnologias..., cit., p. 131) que "a despersonalização da humanidade, identificada de outra forma na ficção, aqui, na vida real, assume este aspecto: os indivíduos não são sujeitos do desenvolvimento tecnológico. São objetos dele. A evolução tecnológica tornou-se um fim em si mesma. É absoluta. As pessoas são meras peças numa enorme engrenagem que não pode parar. Se necessário, alguns podem ser sacrificados, porque a marcha do desenvolvimento científico (rectius, econômico) não pode ser detida. Somos relativos".

${ }^{1323}$ Paulo Affonso Leme Machado. Direito ambiental..., cit., p. 67.

1324 Teresa Ancona Lopez. Princípio da precaução..., cit., p. 86.

${ }^{1325}$ Umberto Izzo. La precauzione nella responsabilità civile. Padova: CEDAM, 2004, p. 1. 
da precaução deve ser aplicado em situações de dúvida, de incerteza, num grau maior que o risco possível, como no phantom-risk dos anglo-saxões; incide, pois, a partir de uma moldura indeterminada, quando o conhecimento científico não consegue dar um parecer definitivo de sobre a existência ou a inexistência de perigo. ${ }^{1327}$

Nas palavras de José Cretella Neto, “(...) o princípio da precaução (precautionary principle) baseia-se na idéia de que qualquer incerteza deve ser interpretada com vistas à adoção de determinada medida de salvaguarda. Segundo esse princípio, a mera cogitação da existência de algum risco potencial à saúde ou ao meio ambiente, ainda que não suficientemente confirmado de forma científica, justifica a adoção de medidas que evitem o dano temido". ${ }^{1328}$

Adota-se, como referencial didático, em razão da sua completude, o conceito de precaução sugerido pela professora Teresa Ancona Lopez:

"Princípio da precaução é aquele que trata das diretrizes e valores do sistema de prevenção de riscos hipotéticos, coletivos ou individuais, que estão a ameaçar a sociedade ou seus membros com danos graves e irreversíveis e sobre os quais não há certeza científica; esse princípio exige a tomada de medidas drásticas e eficazes com o fito de prevenir o risco suposto e possível, mesmo diante da incerteza."

\subsection{Precaução x prevenção}

Conquanto encerrem conteúdos similares, voltados à busca da segurança exigida pela justiça social e ao controle dos riscos, sempre superiores à

\footnotetext{
${ }^{1326}$ François Ewald, Christian Gollier e Nicolas de Sadeleer (Le retour du malin génie - Esquisse d'une philosofhie de la précaution. In: Godard, Olivier (coord.). Le principe de précaution. Paris: Editions de la maison des sciences de l'homme, 1997, p. 124) advertem que "a única atitude racional é evitar a realização de uma ameaça de consequências irreversíveis. A precaução é uma atitude de proteção maior do que a indenização".

${ }_{1327}^{132}$ Teresa Ancona Lopez. Principio da precaução..., cit., p. 90 e 110.

${ }^{1328}$ Direito processual na Organização Mundial do Comércio - OMC. Rio de Janeiro: Forense, 2003, p. 224. Segundo Paulo de Bessa Antunes (Direito ambiental..., cit., p. 31), "um aspecto do Princípio da Precaução que tem sido muito pouco ressaltado é que prevenir riscos ou danos implica escolher quais os riscos ou danos pretendemos prevenir e quais aceitamos correr. Se feita racionalmente a escolha, escolheremos o risco menor em preferência ao maior. Contudo, nem sempre as escolhas são feitas racionalmente, pois a percepção do risco nem sempre guarda alguma relação com o risco real e, muitas vezes a escolha e feita com base na percepção e não no risco real”.

${ }^{1329}$ Principio da precaução..., cit., p. 90.
} 
zero $^{1330}$, não se confundem a precaução e a prevenção. Distinguem-se pelo estágio da incerteza e pela potencialidade do dano dela decorrente.

É dizer: se real o perigo, já constatado de modo científico ${ }^{1331}$, o tema é de prevenção; enquanto a precaução se ocupa do risco abstrato, incerto, duvidoso e hipotético. O juízo de probabilidade entre elas é, portanto, ontologicamente distinto ${ }^{1332}$ : a prevenção se ocupa da probabilidade do dano e a precaução da probabilidade do risco, o risco do risco; logo, é possível afirmar que medidas de precaução, uma vez definida a concretude do perigo, evoluem a posturas de prevenção.

“O incerto não é algo necessariamente inexistente. Ele pode não estar bem definido. Ou não ter suas dimensões ou seu peso ainda claramente apontados. $\mathrm{O}$ incerto pode ser uma hipótese, algo que não foi ainda verificado ou não foi constatado. Nem por isso, o incerto deve ser descartado, de imediato. $\mathrm{O}$ fato de o incerto não ser conhecido ou de não ser entendido aconselha que ele seja avaliado ou pesquisado.

A certeza equivale à ausência de dúvida e de imprecisão. $\mathrm{O}$ estado de certeza tem por objetivo nos dar segurança, sendo que a incerteza gera a insegurança. A informação incerta é um dos motivos de apelar-se para a aplicação do princípio da precaução."1333

No CDC tanto a prevenção quanto a precaução são aplicadas nas entrelinhas, informando todo o sistema de contenção de riscos estruturado a partir da garantia geral de segurança imposta (art. $4^{\mathrm{o}}$, caput $)^{1334}$, fonte primária dos outros dispositivos que tratam da matéria ${ }^{1335}$, seja na sua parte geral (arts. $4^{\circ}, \mathrm{V}, 6^{\circ}$, I, III, VI e

${ }^{1330}$ Gerd Winter. European..., cit., idem.

${ }^{1331}$ Paulo de Bessa Antunes (Direito ambiental..., cit., p. 42) assevera que, "o Princípio da Precaução e todas as discussões que têm ocorrido sobre o seu conteúdo estão claramente vinculados à incerteza científica quando à adoção ou não de determinada conduta ou procedimento, não registrando a doutrina a aplicação do princípio em casos de dúvidas quando à legalidade da atividade. Como regra, as atividades que têm dado ensejo à aplicação do princípio são atividades lícitas. Até porque as ilícitas são simplesmente proibidas. As paralisações que podem ser provocadas pela aplicação do PP são paralisações de atividades lícitas".

${ }_{1332}$ Philippe Kourilsky e Genevière Viney. Le principe de précaution. Paris: Odile Jacob, 2000, p. 18.

${ }^{1333}$ Paulo Affonso Leme Machado. Direito ambiental..., cit., p. 78.

${ }^{1334}$ A garantia geral de segurança, em verdade, tem foro constitucional (arts. $5^{\circ}$, caput, c.c. $6^{\circ}$, caput, c.c. $\left.225, \S 1^{\mathrm{o}}, \mathrm{V}\right)$.

${ }^{1335}$ Enfatiza, nesse sentido, o professor e Min. do STF Eros Roberto Grau (Interpretando..., cit., p. 188/189: “(...) o art. $4^{\circ}$ do Código do Consumidor é uma norma-objetivo, porque define os fins da política nacional das relações de consumo, quer dizer, ela define resultados a serem alcançados. Todas as normas de conduta e todas as normas de organização, que são as demais normas que compõem o Código do Consumidor, instrumentam a realização desses objetivos, com base nos princípios enunciados no próprio art. $4^{\circ}$. (...) Assim, todas as normas de organização e conduta, contidas no Código do Consumidor, devem ser interpretadas teleologicamente, finalisticamente, não por opção do intérprete, mas porque essa é uma 
VII, $8^{\circ}, 9^{\circ}$ e 10 ), seja na especial (arts. $12, \S 1^{\circ}, 14, \S 1^{\circ}, 31,37, \S 2^{\circ}, 39$, VIII, 51, I e III). ${ }^{1336}$

Todavia, é o art. $10^{1337}$ que alumia a adoção dessas balizas de prudência. Sua cabeça, expressamente, proíbe o fornecedor - contra quem milita a incerteza científica ${ }^{1338}$ - de colocar no mercado produto ou serviço ${ }^{1339}$ que deveria saber apresentar alto grau de nocividade ou periculosidade à saúde ou à segurança do consumidor. $^{1340}$

imposição do próprio Código. (...) A circunstância de existirem normas-objetivo que determinem a interpretação de normas de organização e conduta estreita terrivelmente a possibilidade dessa opção, porque a única interpretação correta é aquela que seja adequada à instrumentação da realização dos fins, no caso, os fins estipulados no art. $4^{\circ}$ do Código do Consumidor. (...) O intérprete deve repudiar qualquer solução interpretativa que não seja adequada à realização daqueles fins inscritos na norma-objetivo do art. $4^{\circ}$ ".

${ }^{1336}$ Entendem Agostinho Oli Koppe Pereira, Henrique Mioranza Koppe Pereira e Cleide Calgaro (A prevenção como elemento de proteção ao consumidor: a saúde e segurança do consumidor no Código de Proteção e Defesa do Consumidor brasileiro. Revista de Direito do Consumidor, São Paulo: RT, v. 63, out.dez. 2007, p. 12) que: “(...) o conceito de segurança (...) não pode ser um conceito restrito à ordem físicocorporal do indivíduo consumidor. Embora unidas numa só seção - saúde e segurança - não são elas a mesma coisa. A segurança é conceito mais amplo que a saúde, pois, além de abarcar os problemas com a vida, saúde e integridade física, também engloba os possíveis danos de ordem material ou econômica, que possam ocorrer ao patrimônio do consumidor".

${ }^{1337} \mathrm{CDC}$, art. 10: "o fornecedor não poderá colocar no mercado de consumo produto ou serviço que sabe ou deveria saber apresentar alto grau de nocividade ou periculosidade à saúde ou segurança. $\S 1^{\circ} \mathrm{O}$ fornecedor de produtos e serviços que, posteriormente à sua introdução no mercado de consumo, tiver conhecimento da periculosidade que apresentem, deverá comunicar o fato imediatamente às autoridades competentes e aos consumidores, mediante anúncios publicitários. $\S 2^{\circ}$ Os anúncios publicitários a que se refere o parágrafo anterior serão veiculados na imprensa, rádio e televisão, às expensas do fornecedor do produto ou serviço. § $3^{\circ}$ Sempre que tiverem conhecimento de periculosidade de produtos ou serviços à saúde ou segurança dos consumidores, a União, os Estados, o Distrito Federal e os Municípios deverão informá-los a respeito".

1338 “(...) controvérsia científica quanto à segurança do produto ou serviço, vale dizer, discute-se nos meios científicos acerca da sua segurança, de tal modo que não é possível afirmar-se, nesse momento, qual o grau de riscos que apresenta para os consumidores. Necessário salientar que não fazemos alusão a boatos vagos ou rumores difusos, que sempre correm - e cada vez com maior frequência e velocidade - nos dias atuais. Aludimos à controvérsia científica, como as que ocorrem nas hipóteses daquelas tecnologias aventadas apenas a título exemplificativo e para ilustrar a praticidade da discussão - no início deste trabalho (alimentos geneticamente modificados e radiação eletromagnética não-ionizante dos telefones celulares)" (Aurisvaldo Melo Sampaio. As novas tecnologias..., cit., p. 132 e 156).

1339 "A transfusão de sangue não pode representar para o receptor, segundo a lei e as normas administrativas, e também o senso comum, outro risco senão aquele inerente à própria terapêutica, não sendo aceitável que o receptor seja contaminado por uma doença que se conhecia, sabidamente transmissível pelo sangue, e cuja tecnologia para detectá-la encontrava-se disponível e acessível. A constatação de que o doador do sangue transfundido apresentava anticorpos do vírus da hepatite ' $\mathrm{C}$ ' explica o desenvolvimento dessa doença na receptora. Os danos materiais para curar, e os danos morais advindos do sofrimento provocado pela doença, decorrem do defeito do serviço, impondo sejam ressarcidos, tratando-se de responsabilidade objetiva pelo fato do serviço, na forma prevista no art. 14, do Código de Proteção ao Consumidor, aprovado pela lei $\mathrm{n}^{\circ}$ 8.078, de 11 de setembro de 1990" (TJSP, AC 10.608.4/8, rel. Ruiter Oliva, j. 17.02.1998).

1340 “(...) o alto grau de nocividade ou periculosidade, previsto no art. 10, há de ser entendido em consonância com o art. $8^{\circ}$, que admite a colocação no mercado de produtos cuja periculosidade seja considerada normal, porque compatível com a sua natureza de fruição. Daí a arguta observação da doutrina de que os riscos somente serão tidos como 'normais' ou de 'alto grau' em cotejo com os seus benefícios, pois há produtos portadores de intensa periculosidade ou até mesmo nocividade que são comercializados sem qualquer censura, dados os benefícios que proporcionam a sua utilização, a exemplo dos quimioterápicos utilizados no combate ao câncer" (Aurisvaldo Melo Sampaio. As novas tecnologias..., cit., p. 153). “(...) o critério para se 
Lídimo pilar do dever lateral de cuidado ${ }^{1341}$, vetor do mínimo ético exigível pela boa-fé objetiva, aqui, avultam elementos típicos de precaução; ao passo que a prevenção surge a partir do conhecimento posterior dessa periculosidade, autêntico encargo pós-contratual de vigilância ${ }^{1342}$, impondo imediata reação ao fornecedor $\left(\S 1^{\circ}\right)$, inclusive com o manejo do recall, e ao Estado $\left(\S 3^{\circ}\right) .{ }^{1343}$

definir o elevado grau de perigo é a adequabilidade das informações prestadas pelo empresário. Explico-me: se o produto ou serviço exigem para o seu seguro consumo uma tal ordem de cautelas e conhecimentos que não se conseguiriam transmitir com facilidade ao consumidor, em razão de sua alta complexidade, então o fornecimento está vedado" (Fábio Ulhoa Coelho. $O$ empresário..., cit., p. 74). "O fabricante responde pelo risco do desenvolvimento do produto e não pelo uso diário e contínuo que dele faz o operário que trabalha sem vigilância patronal. Os riscos normais e previsíveis, mencionados no art. $8^{\circ}$ da Lei 8.078/90, não são da responsabilidade do fabricante. De acordo com os dados constantes dos autos, a apelada, embora explorando o ramo de fabricação de equipamentos pesados há décadas, nunca sofreu uma reclamação por defeito de produto ou vício de informação e não consta que a prensa ofereça, fora da previsibilidade natural, risco extraordinário para a incolumidade física de seus usuários. Mantendo-se distância regulamentar, com equipamento bem controlado e testado, o acionamento dos pedais jamais provoca o impacto da guilhotina com perigo para as mãos do operador, salvo se este, por inadvertência ou para facilidade de atuação, movimente, com as mãos, o material a ser prensado" (TJSP, AC 121.643-4/1, rel. Ênio Santarelli Zuliani, j. 14.05.2002).

${ }^{1341}$ Aqui a preocupação se esparze sobre a integridade pessoal (moral ou física) e patrimonial dos contratantes, reciprocamente considerados. É uma obrigação de segurança da mesma forma dirigida a realizar o objetivo do contrato, o que se evidencia ainda mais se de consumo a relação jurídica. Discorrendo sobre a matéria no âmbito da Lei 8.078/90, assim se pronuncia Bruno Miragem (Direito..., cit., p. 73): "no que se refere aos deveres de proteção e cuidado com relação à pessoa e ao patrimônio da outra parte, o CDC igualmente prevê este efeito decorrente do princípio da boa-fé ao consagrar os direitos do consumidor à saúde e segurança, e ao estabelecer, em conseqüência, o dever do fornecedor de respeitá-los (artigos $8^{\circ}$ a 10 do $C D C$ ). A própria estrutura da relação de responsabilidade civil no CDC reflete esta idéia, ao distinguir entre a responsabilidade pelo fato do produto ou do serviço, e a responsabilidade pelo vício do produto ou do serviço, em razão do interesse tutelado do consumidor. No primeiro caso, protegendo-se a segurança do consumidor (artigos 12 a 14), e no segundo a finalidade pretendida por ele na realização do contrato de consumo (artigos 18 a 20)".

${ }_{1342}^{134}$ Claudia Lima Marques et alii. Comentários..., cit., p. 215.

1343 “- É dever do fornecedor a ampla publicidade ao mercado de consumo a respeito dos riscos inerentes a seus produtos e serviços. - A comercialização livre do medicamento SURVECTOR, com indicação na bula de mero ativador de memória, sem efeitos colaterais, por ocasião de sua disponibilização ao mercado, gerou o risco de dependência para usuários. - A posterior alteração da bula do medicamento, que passou a ser indicado para o tratamento de transtornos depressivos, com alto risco de dependência, não é suficiente para retirar do fornecedor a responsabilidade pelos danos causados aos consumidores. - $\mathrm{O}$ aumento da periculosidade do medicamento deveria ser amplamente divulgado nos meios de comunicação. A mera alteração da bula e do controle de receitas na sua comercialização, não são suficientes para prestar a adequada informação ao consumidor. - A circunstância de o paciente ter consumido o produto sem prescrição médica não retira do fornecedor a obrigação de indenizar. Pelo sistema do $\mathrm{CDC}$, o fornecedor somente se desobriga nas hipóteses de culpa exclusiva do consumidor (art. $12, \S 3^{\circ}$, do CDC), o que não ocorre na hipótese, já que a própria bula do medicamento não indicava os riscos associados à sua administração, caracterizando culpa concorrente do laboratório. - A caracterização da negligência do fornecedor em colocar o medicamento no mercado de consumo ganha relevo à medida que, conforme se nota pela manifestação de diversas autoridades de saúde, inclusive a OMC, o cloridrato de amineptina, princípio ativo do SURVECTOR, foi considerado um produto com alto potencial de dependência e baixa eficácia terapêutica em diversas partes do mundo, circunstâncias que inclusive levaram a seu banimento em muitos países. - Deve ser mantida a indenização fixada, a título de dano moral, para o paciente que adquiriu 


\subsection{Precaução x responsabilidade civil}

Ao menos no que concerne à Lei $8.078 / 90$, se bem aplicada $^{1344}$, a precaução esvazia a controvérsia sobre a efetiva existência de risco concreto na introdução no mercado de certo produto ou serviço, porquanto a dúvida sobre o risco (o dever saber) implicaria sustar o processo econômico até fosse ela convertida em certeza de segurança (o saber).

“(...) $\mathrm{O}$ fato é que, diante da incerteza científica quanto à periculosidade de um produto, e é isto o que aqui discutimos, não é dado ao fornecedor negligenciar essa incerteza e colocar o produto no mercado. Neste caso, ele 'deveria saber'. Ou seja, deve assegurar-se do potencial de riscos apresentados pelo produto antes de introduzi-lo no mercado. Ora, avilta os mais elementares princípios éticos - para não invocar a própria dignidade da pessoa humana, que no princípio da efetiva prevenção de danos ao consumidor busca realizar -, o fato de ser toda coletividade exposta a produtos ou serviços sobre cuja segurança pairam dúvidas.

Assim, havendo incerteza científica, ao fornecedor incumbe fazer prova cabal, absoluta, da inofensividade do produto."1345

O dano, com visibilidade antecipada, não se projeta, circunstância que - ao prevenir o prejuízo - elide o fator estruturante da responsabilidade. A prevenção, afora as hipóteses de damnum in re ipsa, em que o risco constatado prima facie alça status de dano (v.g., nucleares), teria semelhante efeito.

Sendo o fornecedor o titular originário, quase absoluto, das técnicas do encadeamento produtivo, independentemente da estimativa frustrada de lucro, é ele que primeiro deve ponderar a precaução, não se omitindo diante do quadro de

dependência da droga. Recurso Especial conhecido e provido” (STJ, REsp. 971.845/DF, rel. p/Ac. Min. Nancy Andrighi, j. 21.08.2008).

${ }^{1344} \mathrm{O}$ seu manejo incorreto, todavia, em razão do constante medo dos resultados, tal qual um freio do crescimento, paralisaria as inovações e as descobertas, indissociáveis dos perigos e dos riscos inerentes à evolução tecnológica. Daí o aviso de Teresa Ancona Lopez (Princípio da precaução..., cit., p. 92 e 97): “(...) deve haver precaução na aplicação da precaução. Essa aparente tautologia vem traduzir que a prevenção e a precaução são filhas da prudência que obriga os atores públicos e privados por seus atos (...) O perigo está no radicalismo em sua adoção que só conduzirá à estagnação do processo científico e tecnológico". É inegável, ainda, forte nos interesses econômicos que permeia, que a precaução pode ser erigida em camuflagem para o protecionismo comercial.

${ }^{1345}$ Aurisvaldo Melo Sampaio. As novas tecnologias..., cit., p. 157. 
incerteza $^{1346}$; no entanto, ainda nesse lapso que antecede a decisão de inovar o mercado, sempre mediante uma escolha política ${ }^{1347}$, proporcional ao nível de proteção procurado $^{1348}$, os outros atores envolvidos na cadeia de gerenciamento dos riscos também podem interferir.

Não deve se furtar o Estado, assim, e por todos os seus braços $^{1349}$, judiciário inclusive, a exercer seu papel de destaque nessa marcha da precaução $^{1350}$, até mesmo em sede de demandas - individuais ou coletivas - tendentes a impedir seja introduzido no mercado produto ou serviço que possa colocar em risco a segurança do consumidor, resolvendo-se eventuais dúvidas pela atitude mais segura.

Medular é o escopo de não permitir o dano, numa vertente preventiva da responsabilidade civil (a priori) ${ }^{1351}$, sempre assegurada a ampla informação

${ }^{1346}$ Alerta a professora Teresa Ancona Lopez (Princípio da precaução..., cit., p. 112/113 e 116/117) que “(...) é preciso ter em consideração a relação riscos/custos sociais e riscos/benefícios. Às vezes, é melhor ter o risco do que cortar benefícios melhores e maiores. (...) deve haver prudência na aplicação do princípio da precaução, ou seja, 'precaução na precaução' e, para isso, o uso dos princípios da razoabilidade e da proporcionalidade é indispensável. (...) Tratando-se de riscos que contêm a incerteza de danos e perigos graves e irreversíveis, não deverá a empresa colocar ou continuar mantendo no mercado esses produtos ou serviços; na dúvida, deverá sempre optar por não lançá-los".

${ }^{1347}$ François Ewald. Philosofhie politique du principe de précaution. In: Le principe de précaution. Paris: PUF, 2001, p. 46.

${ }^{1348}$ Adverte Aurisvaldo Melo Sampaio (As novas tecnologias..., cit., p. 150) que: “(...) os riscos que assolam a nossa sociedade - de consumo - são absolutamente distintos daqueles que a humanidade conheceu outrora, não apenas em face das suas peculiaridades intrínsecas, mas, sobretudo, em virtude da escala - por vezes planetária - que podem alcançar"; ou como sugere Fabiana Maria Martins Gomes de Castro (Sociedade de risco e o futuro do consumidor. Revista de Direito do Consumidor, São Paulo: RT, v. 44, out.-dez. 2002, p. 127) o fenômeno da globalização induziu ficassem os riscos democratizados em escala global.

${ }^{1349}$ Ressalta François Ewald (La précaution, une responsabilité de l'État. Le Monde - édition électronique, 10.03.2000, apud, Paulo Affonso Leme Machado. Direito ambiental..., cit., p. 82/83) que, "o princípio da precaução entra no domínio do direito público que se chama 'poder de polícia' da administração. O Estado, que, tradicionalmente, se encarrega da salubridade, da tranquilidade, da segurança, pode e deve para este fim tomar medidas que contradigam, reduzam, limitem, suspendam algumas das grandes liberdades do homem cidadão: expressão, manifestação, comércio, empresas. O princípio da precaução estende este poder de polícia. Em nome desse princípio, o Estado pode suspender uma grande liberdade, ainda mesmo que ele não possa apoiar sua decisão em uma certeza científica"

${ }^{1350}$ Anota a professora Teresa Ancona Lopez (Princípio da precaução..., cit., p. 114/115) que segundo a Comunicação da Comissão das Comunidades Européias (Bruxelas, 02.02.2000), três princípios específicos devem guiar o recurso ao princípio da precaução: 1) a aplicação do princípio deverá basear-se numa avaliação científica tão completa quanto possível. Essa avaliação deverá, na medida do possível, determinar em cada fase o grau de incerteza científica; 2) qualquer decisão de agir ou de não agir por força do princípio da precaução deverá ser precedida de uma avaliação do risco e das potenciais consequências da não ação (em especial as econômicas); 3) logo que os resultados da avaliação científica e/ou da avaliação do risco estiverem disponíveis, todas as partes interessadas deverão ter a possibilidade de participar do estudo das várias ações possíveis, com a maior transparência possível.

1351 “(...) não vemos inconveniente em ampliar ou estender a noção de responsabilidade para a prevenção ou precaução dos danos possíveis, graves e irreversíveis, pois a idéia fundamentadora de todo o sistema de responsabilidade civil é a da proibição de causar dano a outrem (alterum non laedere). Ora, uma função da responsabilidade civil que impeça a realização de danos estará garantindo a integridade física, moral e econômica dos cidadãos individualmente e da sociedade inteira. (...) Portanto, a responsabilidade civil não 
$\left(\mathrm{CDC} \text {, art. } 6^{\circ}, \mathrm{III}\right)^{1352}$, corolário da necessária transparência $\left(\mathrm{CDC} \text {, art. } 4^{\mathrm{o}}\right)^{1353}$; entretanto, mesmo com ele a análise das antecedentes medidas de precaução e de prevenção ainda mantém importância de destaque, sobretudo no que concerne ao rigor do procedimento adotado.

Preciso, mais uma vez, o magistério da professora titular do Largo São Francisco, Teresa Ancona Lopez, para quem “(...) a avaliação desses prejuízos $a$ posteriori levará em conta o gerenciamento dos riscos e o uso dos instrumentos antecipatórios dos perigos. A precaução e a prevenção devidas e não realizadas serão postas na balança das indenizações juntamente com todas as outras circunstâncias para chegar-se ao quantum debeatur". ${ }^{1354}$

\subsection{Risco residual x movimento pendular}

Admitida a idéia de ser o risco zero uma ilusão, autêntica utopia impossível de ser alcançada, mesmo com o exercício oportuno das práticas de

ser resume ao ressarcimento de danos (apesar de ainda ser sua principal função); é também prevenção e precaução de eventos danosos" (Teresa Ancona Lopez. Princípio da precaução..., cit., p. 124/126).

${ }^{1352}$ Nada obstante, em algumas circunstâncias (art. $8^{\circ}$ ), tenha o CDC admitido a teoria do risco permitido, também conhecida como periculosidade inerente, ressaltam Agostinho Oli Koppe Pereira, Henrique Mioranza Koppe Pereira e Cleide Calgaro (A prevenção..., cit., p. 14/15): “(...) o legislador do CDC adotou a teoria do risco permitido e assumido, na qual a sociedade aceita certos riscos em nome do desenvolvimento, não só tecnológico, como também interpessoal. (...) É de se deixar claro, no entanto, que a adoção da teoria do risco permitido e assumido não dispensa os fornecedores do dever de informar os consumidores sobre os riscos à sua saúde ou à sua segurança advindos da própria natureza ou fruição dos produtos e serviços. (...) $\mathrm{O}$ CDC é explícito, obrigando o fornecedor a dar informações necessárias e adequadas a respeito do produto ou serviço que possui riscos, mesmo os entendidos como normais e previsíveis". "DEFESA DO CONSUMIDOR - vício de segurança do produto - indenização por ato ilícito - patologia adquirida pela autora-apelante por suposta ingestão de contraceptivo oral de fabricação do laboratório-apelado - alegação de falha na informação - sobre a nocividade do produto - inocorrência - bula do medicamento que continha advertências sobre a ingestão - autora-apelante que não faz parte do grupo de risco - possível predisposição heredo-constitucional da autora, vale dizer, constituição predisposta a desenvolver o transtorno, que não pode imputar à ré o dever de indenizar, mesmo porque a bula do medicamento adverte ao profissional que o prescreve, para a realização de histórico e exames antes da prescrição - aprimoramento posterior das informações lançadas na bula e na caixa do medicamento que não pode ser considerado como assunção de culpa, mas, sim, risco do desenvolvimento - recurso não provido" (TJSP, AC 488.700-4/0-00, rel. Ruy Camilo, j. 23.10.2007).

1353 Os mesmos autores esclarecem que (A prevenção..., cit., p. 19): “(...) muitos acidentes não são provocados por defeitos intrínsecos ao produto ou serviço, mas por defeitos extrínsecos, ou seja, devido à falta ou má informação, o que leva ao uso incorreto ou inadequado deles, ou até mesmo ao uso pelo consumidor que não deve utilizá-lo, devido a um componente do produto ao qual é alérgico. Nesse sentido de prevenção, o legislador dispôs, nos arts. $8^{\circ}$ e $9^{\circ}$ do CDC sobe a obrigatoriedade de o fornecedor de informar aos consumidores sobre os riscos à saúde e à segurança que possam advir do produto ou serviço por ele fornecido".

${ }^{1354}$ Princípio da precaução..., cit., p. 109. 
prudência, não há como dissociar certo fator de risco das vigas naturais do desenvolvimento: o progresso e a pesquisa.

Ou, em outras palavras, conquanto aplicadas no grau máximo permitido ao fornecedor dentro do atual state of the art da ciência, a prevenção e a precaução permanecem incapazes de frear todos os perigos inerentes, em tese, a certos produtos e serviços ${ }^{1355}$; daí o que se entende por risco residual, que - apesar de manter a essência de risco - tem probabilidade mínima de ocorrência. ${ }^{1356}$

Mas isso representa um movimento pendular de resgate da importância da culpa na teoria da responsabilidade civil? A transferência dessa espécie residual de risco passa a ser admitida pelo sistema jurídico?

Não se trata de considerar culpado aquele que não tomou as medidas de prevenção de risco conhecido e previsível, nem aquele que, na dúvida, não adotou conduta de precaução; interessa, ao revés, que a responsabilidade do fornecedor independe da existência de culpa, apenas a ele interessando o quadro de incerteza (residual ou não) gerado pela sua atividade econômica.

Discorda-se, com todo respeito, da idéia da culpa como um mecanismo de prevenção do dano ${ }^{1357}$. A professora Teresa Ancona Lopez, contudo, admite

${ }^{1355}$ São conhecidas três modalidades de periculosidade (Aurisvaldo Melo Sampaio. As novas tecnologias..., cit., p. 152/154): a) a inerente; b) a adquirida e c) a exagerada. É impossível retirar a periculosidade inerente do produto ou do serviço sem comprometer sua utilidade, bastando o risco (e não o dano) para sua configuração. São necessários dois requisitos para a sua configuração: 1) normalidade (a periculosidade deve ser compatível com a natureza do produto e o seu modo normal de fruição) e 2) previsibilidade razoável, assim consideradas as expectativas legítimas do consumidor. A informação é fundamental. A periculosidade adquirida se atrela ao defeito, atraindo as consequências da responsabilidade civil; ela é induzida por um elemento agregado, que não integra a essência do produto e do serviço. A periculosidade exagerada revela uma enorme desproporção entre aquilo que seria aceitável (inerente) e os custos e benefícios sociais que apresenta. $\mathrm{O}$ fornecedor suporta uma obrigação negativa, de não colocar no mercado ou, se já tiver inovado, tão-logo tenha conhecimento do problema, deve divulgar amplamente a situação e, sendo necessário ante o grau de periculosidade verificado, retirar o produto de circulação.

${ }^{1356}$ Esclarece Teresa Ancona Lopez (Princípio da precaução..., cit., p. 90) que, “(...) alguns autores, partindo do fato de que não há risco zero, propõem que o risco residual seja suportado pela sociedade, principalmente depois de tomadas todas as medidas de segurança tentando reduzir ao mínimo o fator de risco. Outros acham que o 'risco residual' não pode ser colocado nos ombros da população, pois também é risco; esses que assim pensam são mais radicais e que têm formação sociológica".

${ }^{1357}$ No entender de Guido Alpa e Mario Bessone (La responsabilitá del produttore. $4^{\mathrm{a}}$ ed. Milão: Giuffrè, 1999, p. 108) “(...) tem-se afirmado que - ao lado do problema da distribuição racional de riscos e custos deve ser considerado o problema da prevenção dos danos na circulação de produtos defeituosos. Empregando-se o critério da culpa, que sanciona o fabricante que negligentemente construiu o produto, se induz o fabricante a preparar um produto melhor, a incrementar os controles, a aperfeiçoar os projetos de produção. Nessa perspectiva, porém, o critério da culpa não deveria considerar-se exclusivo, mas, ao contrário, integrativo do critério do risco da empresa: o primeiro se aplicaria para o risco evitável, o segundo para o risco inevitável". Já Nadège Voidey (Le risque en Droite Civil. Presses Universitaires d'Aix Marseille, 2005, p. 303), como indica Teresa Ancona Lopez (Princípio da precaução..., cit., p. 133), propõe que esse não-respeito ao princípio da precaução seja considerado um "defeito de precaução", fundamentado na culpa 
esse raciocínio, embora proponha seja o tema tratado em sede de culpa presumida, culpa essa abstrata e objetiva, permeada pela ação hipotética do gestor diligente e não pelas intenções determinantes dos comportamentos faltosos:

"Sem exageros, a responsabilidade preventiva, sendo fundada na culpa, tende a melhorar a conduta de seus atores, porquanto se agirem com toda precaução não poderão ser responsabilizados (o que seria injusto). Isso os leva a tomar atitudes que evitem o dano grave e quem sairá ganhando será a sociedade. Agindo de acordo com o sistema precaucional, estarão agindo conforme os moldes queridos e pensados pelo Direito.

\section{(...)}

Propomos para essa responsabilidade preventiva que o fundamento de responsabilidade no 'defeito de precaução' seja a presunção de culpa daquele que não respeitou o princípio da precaução diante de riscos hipotéticos ou conhecidos de danos irreversíveis."1358

A lógica do pensamento guarda ressonância no conteúdo material do princípio da isonomia, qual seja, na impossibilidade de se tratar igualmente (sem divisão de riscos) os desiguais (fornecedores relapsos de um lado e cumpridores das medidas de prudência de outro). O receio, louvável advirta-se, é que os integrantes da cadeia produtiva, com isso, temendo uma condenação certa diante da inatingível meta do risco zero, relaxem no exercício da precaução e da prevenção.

Porém, indaga-se: é disponível a busca do exercício adequado dos princípios da precaução e da prevenção? O sistema protetivo instituído pela Lei 8.078/90 admite essa opção do fornecedor?

Ora, como acima exposto, se ao fornecedor é - a um só tempo - proibido colocar no mercado produto que deveria saber apresentar alto grau de nocividade ou periculosidade à saúde ou à segurança do consumidor e imposto o dever de comunicar o fato imediatamente às autoridades e aos consumidores, se disso tomar conhecimento posterior $\left(\mathrm{CDC}\right.$, art. 10 e seu $\S 1^{\circ}$ ), não se mostra razoável admitir possa ele optar pelo não manejo eficaz da precaução e da prevenção.

do responsável pela gestão do risco. Essa culpa deverá ser provada pelas vítimas. E a culpa na precaução terá influência em julgamento no caso de o dano ter ocorrido.

${ }^{1358}$ Princípio da precaução..., cit., p. 132/134. 
Não tem o fornecedor esse livre trânsito sobre a tutela dos interesses do consumidor, graduados pela obrigação geral de segurança, pena de se consagrar - mutatis mutandis - inaceitável venire contra factum proprium (supra, Cap. IV, 6.2.1).

Legítima é a expectativa do consumidor no sentido de que os produtos e os serviços disponibilizados no mercado passaram por rígido e sério processo de precaução e, se o caso, após anterior risco hipotético se converter em perigo concreto, tenha ele na prevenção o exercício da transparência e da eticidade legalmente impostas.

Força é concluir, nesse passo, até porque não deixa de ser risco, que o risco residual também só ao fornecedor interessa, lídima res inter alios frente ao consumidor inocente, cuja atuação no processo produtivo se restringe a mero agente receptor que, materialmente vulnerável (CDC, art. $\left.4^{\circ}, \mathrm{I}\right)$, age amparado na confiança do proceder reto do seu parceiro contratual, por isso a ele é intransferível.

E mais. O completo ressarcimento do dano material causado ao consumidor é intangível (CDC, art. $\left.6^{\circ}, \mathrm{VI}\right)$, pouco importando se foram bem ou mal empregadas a precaução e a prevenção. Alguma flexibilidade, no entanto, por ser da essência do instituto a valoração subjetiva, é factível no âmbito da reparação extrapatrimonial, sendo permitido ponderar o comportamento diligente do fornecedor atento às medidas de prudência como parcela de destaque na estimativa prudencial $(\mathrm{CC}$, art. 944 , par. ún. ${ }^{1359}$, c.c. CDC, art. $7^{\circ}$, caput).

A própria professora Teresa Ancona Lopez acaba admitindo que, “(...) mesmo em se tratando de responsabilidade preventiva, a partir do evento dano o criador e gestor de riscos, que pode ser um empreendedor privado ou público, responderá segundo a teoria do risco". 1360

Não se deve colocar no oblívio que a Política Nacional de Relações de Consumo também se modula pela busca da harmonização dos interesses dos participantes das relações de consumo, compatibilizando a proteção do sujeito fraco com a necessidade de desenvolvimento econômico e tecnológico, de modo a viabilizar o equilíbrio nessa estrutura obrigacional $\left(\mathrm{CDC}\right.$, art. $\left.4^{\mathrm{o}}, \mathrm{III}\right) .^{1361}$

\footnotetext{
${ }^{1359}$ CC, art. 944, par. ún.: "se houver excessiva desproporção entre a gravidade da culpa e o dano, poderá o juiz reduzir, equitativamente, a indenização".

${ }_{1360}$ Princípio da precaução..., cit., p. 145.

1361 "Não se trata da precaução que tudo impede ou que tudo vê catástrofes ou males" (Paulo Affonso Leme Machado. Direito ambiental..., cit., p. 66).
} 
Se assim é, à míngua de base em direito positivo que a elas dê relevo ${ }^{1362}$, como uma possível alteração do art. 927, par. ún., do Código Civil, adequando-o aos modelos paradigmáticos italiano (art. 2.050 ${ }^{1363}$ ) e português (art. 493, $2^{1364}$ ), no mínimo, as medidas de precaução e de prevenção corretamente adotadas, que se revelaram incapazes de impedir o dano, permanecem com reduzida importância na análise da equação dos danos indenizáveis ao consumidor.

\subsection{Risco de desenvolvimento}

Considerando que o fornecedor não pode colocar no mercado produto ou serviço que sabe ou deveria saber apresentar alto grau de nocividade ou de perigo à saúde ou à segurança do consumidor (CDC, art. 10), será ele responsável se não tinha condições de saber do problema?

A matéria sub examine se afina às causas excludentes de responsabilidade e ao fornecedor que segue todas as regras (v.g., precaução) antes de explorar produto ou serviço novo, ignorando o comprometimento da sua essência.

$\mathrm{Na}$ sociedade de consumo massificado e de risco, constantemente submetida a avanços tecnológicos, é possível que após certo tempo de uso se descubra ser nocivo determinado produto ou serviço. A matriz de segurança esperada se abala, não pela negligência ou por eventual conduta dolosa do sujeito empreendedor, mas

1362 Anota Carlos Roberto Gonçalves (Responsabilidade subjetiva, responsabilidade objetiva, responsabilidade por fato de outrem, responsabilidade profissional etc.; preferências e privilégios creditórios (Artigos 927 a 965). In: Azevedo, Antonio Junqueira de (coord.). Comentários ao Código Civil. Parte especial do direito das obrigações. São Paulo: Saraiva, 2003, v. 11, p. 315-316) que, “o Código Civil brasileiro adotou solução mais avançada e mais rigorosa que a do direito italiano, também acolhendo a teoria do exercício da atividade perigosa e o princípio da responsabilidade independentemente de culpa nos casos especificados em lei, a par da responsabilidade subjetiva como regra geral, não prevendo, porém, a possibilidade de o agente, mediante inversão do ônus da prova, exonerar-se da responsabilidade se provar que adotou todas as medidas aptas a evitar o dano (art. 927 e parágrafo único). É fora de dúvida, no entanto, que a culpa exclusiva da vítima ou de terceiro e a força maior, por romperem o nexo causal, afastam a responsabilidade do agente".

${ }^{1363}$ Art. 2.050: "chiunque cagiona danno ad altri nello svolgimento di un'attività pericolosa, per sua natura $\mathrm{o}$ per la natura dei mezzi adoperati, e tenuto al risarcimento, se non prova di avere adottato tutte le misure idonee a evitare il danno". Ou em vernáculo (tradução livre): "qualquer um que causa dano a outrem no desenvolvimento de uma atividade perigosa, por sua natureza ou pela natureza dos meios utilizados, é obrigado ao ressarcimento, se não prova ter adotado todas as medidas idôneas para evitá-lo."

1364 Art. 493, 2: "quem causar danos a outrem no exercício de uma actividade, perigosa por sua própria natureza ou pela natureza dos meios utilizados, é obrigado a repará-los excepto se mostrar que empregou todas as providências exigidas pelas circunstâncias com o fim de os prevenir." 
pela sua insuperável e severa ignorância de acordo com o mais avançado state of the art, sempre numa concepção objetiva do fornecedor ideal. ${ }^{1365}$

Para James Marins, "o risco de desenvolvimento consiste na possibilidade de que um determinado produto venha a ser introduzido no mercado sem que possua defeito cognoscível, ainda que exaustivamente testado, ante o grau de conhecimento científico disponível à época de sua introdução, ocorrendo todavia, que, posteriormente, decorrido determinado período do início de sua circulação no mercado de consumo, venha a se detectar defeito, somente identificável ante a evolução dos meios técnicos e científicos, capaz de gerar danos aos consumidores". 1366

Como atribuir responsabilidade por algo que não se conhece? É lícito atribuir esse ônus ao fornecedor se para a responsabilidade objetiva é imprescindível que o risco seja calculado ${ }^{1367}$, o que inocorre no desconhecido?

Apesar do status alcançado no direito estrangeiro ${ }^{1368}$, no Brasil o risco de desenvolvimento ${ }^{1369}$ - mesmo com alguma dissidência na doutrina ${ }^{1370}$

1365 “(...) na lição de João Calvão da Silva (Responsabilidade civil do produtor. Coimbra: Almedina, 1990, p. 11 e ss), a exoneração da responsabilidade pelo risco do desenvolvimento requer a impossibilidade absoluta e objetiva de o fornecedor descobrir a existência do defeito, por falta ou insuficiência de meios técnicos e científicos idôneos e não a impossibilidade subjetiva do fornecedor em questão. $O$ critério determinante deve ser o mais avançado estado da ciência e técnica mundiais, entendido como essência do conhecimento" (TJRS, AC 70000228684, rel. Rejane Maria Dias de Castro Bins, j. 01.12.1999). E complementa o Min. Benjamin (et alii. Manual..., cit., p. 130): "a análise do grau de conhecimento científico não é feita tomando por base um fornecedor em particular. Importam, ao revés, as informações científicas disponíveis no mercado. Ou seja: pouco interessa o que um determinado fornecedor sabe, mas sim o que sabe a comunidade científica".

${ }^{1366}$ Responsabilidade da empresa..., cit., p. 128.

${ }^{1367}$ Destaca Bruno Miragen (Direito..., cit., p. 290): “(...) com relação aos ricos do desenvolvimento, do que se reclama é sobre a relativa imprevisibilidade destes riscos. Trata-se de danos imponderáveis quanto à sua ocorrência e extensão, razão pela qual a simples imputação de responsabilidade ao fornecedor romperia com a lógica do sistema de admissão de risco, em face da possibilidade de sua previsão e internalização como custo da atividade negocial, repassada ao mercado por intermédio da fixação dos preços".

${ }^{1368} \mathrm{O}$ art. $7^{\circ}$, "e", da Diretiva 374/85 considera o risco do desenvolvimento excludente de responsabilidade: "The producer shall not be liable as a result of this Directive if he proves: (...) e) that the state of scientific and technical knowledge at the time when he put the product into circulation was not such as to enable the existence of the defect to be discovered". Ou em vernáculo (tradução livre): "O produtor não deverá ser responsabilizado pelas consequências desta Diretiva se provar: (...) e) que o estado do conhecimento técnico e científico ao tempo em que o produto foi colocado em circulação era incapaz de detectar a existência do defeito". Acontece que o seu art. 15 apenas faculta aos Estados-Membros a adoção na forma proposta; daí porque existem variantes na amplitude das regras internas: a) Portugal (Lei 131/01, art. $5^{\circ}$ ) e Itália - rischi di sviluppo (Codice del Consumo/05, art. 118) o admitem de modo amplo; b) Alemanha - entwicklungsrisiken, Espanha - riesgos de desarrollo (Lei 22/94, art. 61) e França - risques de développement (Código Civil, art. 1.386-11 - alterado pela Lei 389/98) aceitam, com restrições, o efeito liberatório. Excluem-se do risco do desenvolvimento, respectivamente em cada um desses países: remédios, alimentos e remédios e elementos do corpo humano ou produtos que dele saíram (v.g., sangue, esperma, etc.). Lembra Bruno Miragem (Direito..., cit., p. 290) que, "no direito norte-americano, de sua vez, sobretudo por pressões dos fornecedores, em especial das seguradoras que vinham suportando o pagamento de altos valores de indenização, a tendência jurisprudencial de reconhecimento da responsabilidade do fornecedor, mesmo pelos riscos do 
não foi erigido em excludente de responsabilidade ${ }^{1371}$, ressaltada a natureza taxativa dos róis previstos pela Lei $8.078 / 90$ (arts. $12, \S 3^{\circ}$, e $14, \S 3^{\circ}$ ). ${ }^{1372}$

Observe-se, por oportuna, a intervenção de Bruno Miragem: “(...) a previsão normativa do artigo $12, \S 1^{\circ}$, III, que estabelece dentre as circunstâncias relevantes a serem consideradas para a determinação de um produto como defeituoso ou não, 'a época em que foi colocado em circulação' constitui critério de valoração para identificação e definição do defeito. Não pode ser confundida, deste modo, com hipótese de exclusão de responsabilidade, sob pena de subverter a sistemática do CDC. Assim também, o artigo 12, $\S 2^{\circ}$, ao estabelecer que 'o produto não é considerado defeituoso pelo fato de outro de melhor qualidade ter sido colocado no mercado'. Neste caso, não se trata,

desenvolvimento - com fundamento na strict liability - inverteu-se a questão, passando os Tribunais a reconhecê-la como causa de exclusão".

${ }_{1369}$ A expressão completa é: "riscos que o desenvolvimento técnico e científico não permitiu descobrir".

${ }^{1370}$ Sustenta James Marins (Responsabilidade da empresa..., cit., p. 134/136): "examinando-se, para tanto, a extensão do elemento valorativo 'época em que o produto foi colocado em circulação', em face do sistema do Código, para efeitos da responsabilidade civil do fornecedor pelo fato do produto. Com esse objetivo, há que se analisar sistematicamente o conjunto de dispositivos diretamente relacionados à segurança dos produtos e à responsabilização do fornecedor. É direito básico do consumidor 'a proteção da vida, saúde e segurança contra os riscos provocados por práticas no fornecimento de produtos e serviços considerados perigosos ou nocivos'. Já o art. 10 determina que 'o fornecedor não poderá colocar no mercado de consumo produto ou serviço que sabe ou deveria saber apresentar alto grau de nocividade ou periculosidade à saúde ou segurança'. Por fim,, o art. $12 \mathrm{em}$ seu $\S 1^{\circ}$, traça as lindes nas quais um produto pode ser considerado inseguro, estabelecendo que 'o produto é defeituoso quando não oferece a segurança que dele legitimamente se espera, levando em consideração as circunstâncias relevantes, entre as quais: (...) II - o uso e os riscos que razoavelmente dele se esperam; III - a época em que foi colocado em circulação'. Destra forma, exsurge do cotejo dos dispositivos legais acima transcritos o seguinte conteúdo global: o consumidor tem direito à proteção contra os riscos provocados por produtos considerados perigosos, não podendo, então, o fornecedor, inserir no mercado de consumo produtos que saiba ou deva saber serem nocivos, sendo considerados defeituosos os produtos que não atendam à segurança legitimamente esperada, tendo em vista a época em que foram colocados em circulação. Com base nesses pressupostos - predominantemente legais - pode-se afirmar que é lícito ao fornecedor inserir no mercado de consumo produtos que não sabia nem devia saber resultarem perigosos porque o grau de conhecimento científico à época da introdução do produto no mercado de consumo não permitia tal conhecimento. Diante disso não se pode dizer ser o risco de desenvolvimento defeito de criação, produção ou informação, enquadramento este que é indispensável para que se possa falar em responsabilidade do fornecedor. (...) não pode haver legítima expectativa de segurança que vá além da ciência existente. Isto é, qualquer expectativa de segurança somente é legítima se não pretender que o produto possa superar o próprio grau de conhecimento científico existente quando de sua introdução no mercado". Para Francisco Cavalcanti (Comentários..., cit., p. 45): "na verdade, o que veda a norma é a colocação de produtos nocivos e perigosos no mercado, sem o respeito às normas de segurança e salubridade recomendáveis pelos conhecimentos científicos existentes à época de sua produção". E arremata Gustavo Tepedino (Responsabilidade médica na experiência brasileira contemporânea. Revista Trimestral de Direito Civil, Rio de Janeiro: PADMA, 2000, ano I, v. 2, p. 65/66) no mesmo sentido, com apoio numa interpretação a contratio sensu dos arts. $6^{\circ}$, I, 10 e $12, \S 1^{\circ}$, do CDC.

${ }^{1371}$ Veja-se, a propósito, o enunciado 43, aprovado na I Jornada de Direito Civil promovida, com o apoio do Excelso Superior Tribunal de Justiça, pelo Conselho da Justiça Federal: "a responsabilidade civil pelo fato do produto, prevista no art. 931 do novo Código Civil, também inclui os riscos do desenvolvimento".

${ }^{1372}$ Também é essa a conclusão de Silmara Juny de Abreu Chinellato e de Antonio Carlos Morato (Responsabilidade civil e o risco do desenvolvimento nas relações de consumo. In: Nery, Rosa Maria de Andrade e Donnini, Rogério. Responsabilidade civil..., cit., p. 58/59). 
mais uma vez, de uma excludente de responsabilidade, mas de uma excludente de um critério de definição do conceito de defeito e de produto defeituoso, a exemplo do que ocorre com o artigo $14, \S 2^{\circ}$, quando estabelece que 'o serviço não é considerado defeituoso pela adoção de novas técnicas"." ${ }^{1373}$

Entretanto, tal qual alerta Adalberto Pasqualotto, com base na irrecusável compatibilização da defesa do consumidor com a necessidade de desenvolvimento econômico e tecnológico (CDC, art. $4^{\circ}$, III), há alternativas contemporizadoras, como “(...) a estipulação de prazo limitado de responsabilidade integral (10 anos, por hipótese, podendo variar conforme o produto), após o qual o fornecedor deixaria de responder pelos danos incertos e não imputáveis a defeitos de produção ou informação (toma-se como premissa que o chamado risco do desenvolvimento era um defeito imperceptível à época da concepção do produto); e, ainda, a limitação da indenização ao grau de suportabilidade econômica da empresa, procurando preservar a sua continuidade, em vista da sua função social. Nesse caso, a indenização aos consumidores poderia não ser integral". 1374

Deve ficar claro que não é a evolução científica que cria o problema de essência, ele já existia ${ }^{1375}$. Estava lá, só era à época imperceptível; logo, se de produção, concepção ou execução não importa, integra ele o risco da atividade e subordina o fornecedor à obrigação de indenizar, admitindo-se - também aqui - uma análise da conduta efetivamente adotada quando da introdução do produto e/ou serviço no mercado e da postura de transparência assumida após a descoberta do problema como componentes a serem considerados na estimativa do prejuízo extrapatrimonial.

O risco de desenvolvimento só se ajusta a um risco impensado. Se qualquer dúvida científica, por mínima que seja ${ }^{1376}$, permear a análise do fornecedor ideal, a matéria se desloca para um juízo de precaução, com todas as

\footnotetext{
${ }^{1373}$ Direito..., cit., p. 291/292.

${ }^{1374}$ Dará a reforma..., cit., p. 17/18.

1375 Destaca Teresa Ancona Lopez (Princípio da precaução..., cit., p. 177): “(...) não adianta afirmar que não há defeito. Há porque apareceu. Na verdade, no risco de desenvolvimento, o defeito sempre existiu, desde sua concepção, só que não era conhecido. Portanto, o fornecedor tem que admitir o defeito e tentar provar, por meio de prova dificílima, que agiu dentro do 'state of the art', no momento em que o produto foi lançado. Como vimos, a aferição desse conhecimento ou não, das técnicas e da ciência avançada, é de avaliação objetiva; os argumentos pessoais ou subjetivos, como falta de verba, por exemplo, estão descartados. O 'standard' que vai apoiar a interpretação de sua responsabilidade vai ser o do 'produtor bastante cuidadoso' ou 'produtor ideal', e nunca o do 'bom pai de família'”.

1376 Destaca Mathilde Boutonnet (Le principe de précaution..., cit., p. 485) que o risco de desenvolvimento leva o produtor a redobrar a prudência e a levar em conta todas as opiniões científicas, mesmo as dissidentes.
} 
consequências antes examinadas, em especial a opção livre de manter ou de sustar a disponibilização do produto e/ou do serviço. Exemplo hodierno dessa realidade diz respeito aos telefones celulares e às suas antenas de transmissão, visto que já existem estudos apontando o risco de câncer advindo do seu uso. ${ }^{1377}$

Problema sério ocorrerá quando o conhecimento do risco ou do próprio dano se projetar para todos de forma inegável. É que nunca se terá absoluta certeza de que a ignorância não era privilégio só do consumidor, que não tem acesso ao ciclo produtivo a ponto de constatar se - de fato $-\mathrm{o}$ fornecedor foi surpreendido com a descoberta ou se, tal qual se verificou no passado com as empresas fabricantes de cigarro, mascarou a verdade o quanto pôde até que o tempo o desnudou.

Não se vê problema algum, a partir da concepção autônoma de liberdade para cada um dos sujeitos da relação de consumo, que o fornecedor arque com a responsabilidade social pelo manejo do instrumento de captação do seu lucro (produtos e/ou serviços), ainda que atue como uma espécie de segurador virtual. ${ }^{1378}$

1377 Teresa Ancona Lopez. Princípio da precaução..., cit., p. 188, e Aurisvaldo Melo Sampaio. As novas tecnologias..., cit., p. 134/135.

${ }^{1378}$ Marcelo Junqueira Calixto. A responsabilidade civil dos fornecedores pelos riscos de desenvolvimento. Rio de Janeiro: Renovar, 2004, p. 192. 


\section{A RESPONSABILIDADE DAS EMPRESAS FABRICANTES DE CIGARROS}

Sem dúvida, a partir desses postulados, notadamente o diálogo entre o CDC e o art. 931 do CC (supra, 2.2.1), e de outros ${ }^{1379}$, mister se faz revisitar a responsabilidade civil das empresas fabricantes de cigarros ${ }^{1380}$, conquanto não se desconheça a postura assumida pela $4^{\mathrm{a}} \mathrm{T}$. do $\mathrm{STJ}{ }^{1381}$ sobre o tema, diametralmente oposta à diretriz que, tímida, de certo modo, vinha ganhando corpo nas Cortes Estaduais. ${ }^{1382}$

${ }^{1379}$ O Estado de São Paulo editou, em 07 de maio de 2009, a Lei 13.541, que proíbe o consumo de cigarros, cigarrilhas, charutos, cachimbos ou qualquer outro produto fumígeno, derivado ou não do tabaco, em ambientes coletivos, públicos ou privados.

${ }^{1380}$ Guilherme Ferreira da Cruz. A responsabilidade civil das empresas fabricantes de cigarros. Revista de Direito do Consumidor, São Paulo: RT, v. 47, abr.-jun. 2003, p. 67/117.

1381 "RESPONSABILIDADE CIVIL. TABAGISMO. AÇÃO REPARATÓRIA AJUIZADA POR FAMILIARES DE FUMANTE FALECIDO. PRESCRIÇÃO INOCORRENTE. PRODUTO DE PERICULOSIDADE INERENTE. INEXISTÊNCIA DE VIOLAÇÃO A DEVER JURÍDICO RELATIVO À INFORMAÇÃO. NEXO CAUSAL INDEMONSTRADO. TEORIA DO DANO DIREITO E IMEDIATO (INTERRUPÇÃO DO NEXO CAUSAL). IMPROCEDÊNCIA DO PEDIDO INICIAL. 1. Não há ofensa ao art. 535 do CPC quando o acórdão, de forma explícita, rechaça todas as teses do recorrente, apenas chegando a conclusão desfavorável a este. Também inexiste negativa de prestação jurisdicional quando o Tribunal de origem aprecia a questão de forma fundamentada, enfrentando todas as questões fáticas e jurídicas que lhe foram submetidas. 2. A pretensão de ressarcimento do próprio fumante (cuja prescrição é quinquenal, REsp. 489.895/SP), que desenvolvera moléstias imputadas ao fumo, manifesta-se em momento diverso da pretensão dos herdeiros, em razão dos alegados danos morais experimentados com a morte do fumante. Só a partir do óbito nasce para estes ação exercitável (actio nata), com o escopo de compensar o pretenso dano próprio. Preliminar de prescrição rejeitada. 3. O cigarro é um produto de periculosidade inerente e não um produto defeituoso, nos termos do que preceitua o Código de Defesa do Consumidor, pois o defeito a que alude o Diploma consubstancia-se em falha que se desvia da normalidade, capaz de gerar uma frustração no consumidor ao não experimentar a segurança que ordinariamente se espera do produto ou serviço. 4. Não é possível simplesmente aplicar princípios e valores hoje consagrados pelo ordenamento jurídico a fatos supostamente ilícitos imputados à indústria tabagista, ocorridos em décadas pretéritas - a partir da década de cinquenta -, alcançando notadamente períodos anteriores ao Código de Defesa do Consumidor e a legislações restritivas do tabagismo. 5. Antes da Constituição Federal de 1988 - raiz normativa das limitações impostas às propagandas do tabaco -, sobretudo antes da vasta legislação restritiva do consumo e publicidade de cigarros, aí incluindo-se notadamente o Código de Defesa do Consumidor e a Lei 9.294/96, não havia dever jurídico de informação que impusesse às indústrias do fumo uma conduta diversa daquela por elas praticada em décadas passadas. 6. Em realidade, afirmar que o homem não age segundo o seu livrearbítrio em razão de suposta 'contaminação propagandista' arquitetada pelas indústrias do fumo, é afirmar que nenhuma opção feita pelo homem é genuinamente livre, porquanto toda escolha da pessoa, desde a compra de um veículo a um eletrodoméstico, sofre os influxos do meio social e do marketing. É desarrazoado afirmar-se que nessas hipóteses a vontade não é livre. 7. A boa-fé não possui um conteúdo per se, a ela inerente, mas contextual, com significativa carga histórico-social. Com efeito, em mira os fatores legais, históricos e culturais vigentes nas décadas de cinquenta a oitenta, não há como se agitar o princípio da boa-fé de maneira fluida, sem conteúdo substancial e de forma contrária aos usos e aos costumes, os quais preexistiam de séculos, para se chegar à conclusão de que era exigível das indústrias do fumo um dever jurídico de informação aos fumantes. Não havia, de fato, nenhuma norma, quer advinda de lei, quer dos princípios gerais de direito, quer dos costumes, que lhes impusesse tal comportamento. 8. Além do mais, somente rende ensejo à responsabilidade civil o nexo causal demonstrado segundo os parâmetros jurídicos adotados pelo ordenamento. Nesse passo, vigora do direito civil brasileiro (art. 403 do CC/02 e art. 1.060 do $\mathrm{CC} / 16$ ), sob a vertente da necessariedade, a 'teoria do dano direto e imediato', também conhecida como 'teoria do nexo causal direto e imediato' ou 'teoria da interrupção do nexo causal'. 9. Reconhecendo-se a possibilidade de vários fatores contribuírem para o resultado, elege-se apenas aquele que se filia ao dano mediante uma relação de necessariedade, vale dizer, dentre os vários antecedentes causais, apenas aquele 
Essa controvérsia - ao contrário do que possa parecer - ainda não está definida, porquanto inexiste unanimidade entre os Ministros que integram a mais alta Corte infraconstitucional do País em relação a vários aspectos medulares que informam essa especial e massificada relação jurídica.

Tome-se o exemplo do prazo prescricional ${ }^{1383}$, em que qualquer mudança de composição pode alterar significamente o resultado hoje majoritário.

elevado à categoria de causa necessária do dano dará ensejo ao dever de indenizar. 10. A arte médica está limitada a afirmar a existência de fator de risco entre o fumo e o câncer, tal como outros fatores, como a alimentação, álcool, carga genética e o modo de vida. Assim, somente se fosse possível, no caso concreto, determinar quão relevante foi o cigarro para o infortúnio (morte), ou seja, qual a proporção causal existente entre o tabagismo e o falecimento, poder-se-ia cogitar de se estabelecer um nexo causal juridicamente satisfatório. 11. As estatísticas - muito embora de reconhecida robustez - não podem dar lastro à responsabilidade civil em casos concretos de mortes associadas ao tabagismo, sem que se investigue, episodicamente, o preenchimento dos requisitos legais. 12. Recurso especial conhecido em parte e, na extensão, provido" (STJ, REsp. 1.113.804/RS, rel. Min. Luis Felipe Salomão, j. 27.04.2010). "RECURSO ESPECIAL. RESPONSABILIDADE CIVIL. DANOS MORAIS. FUMANTE. EXERCÍCIO DO LIVREARBÍTRIO. RUPTURA DO NEXO DE CAUSALIDADE. VIOLAÇÃO AO ART. 535 NÃO CONFIGURADA. 1. Tendo o Tribunal a quo apreciado, com a devida clareza, toda a matéria relevante para a apreciação e julgamento do recurso, não há falar em violação ao art. 535 I e II do Código de Processo Civil. 2. É incontroverso nos autos que o Autor começou a fumar nos idos de 1988, mesmo ano em que as advertências contra os malefícios provocados pelo fumo passaram a ser veiculadas nos maços de cigarro. 3 . Tal fato, por si só, afasta as alegações do Recorrido acerca do desconhecimento dos malefícios causados pelo hábito de fumar, pois, mesmo assim, com as advertências, explicitamente estampadas nos maços, Miguel Eduardo optou por adquirir, espontaneamente, o hábito de fumar, valendo-se de seu livre-arbítrio. 4. Por outro lado, o laudo pericial é explícito ao afirmar que não pode comprovar a relação entre o tabagismo do Autor e o surgimento da Tromboangeíte Obliterante. 5. Assim sendo, rompido o nexo de causalidade da obrigação de indenizar, não há falar-se em direito à percepção de indenização por danos morais. 6. Recurso Especial parcialmente conhecido e, nessa extensão, provido" (STJ, REsp. 886.347/RS, rel. Min. Honildo Amaral de Mello Castro, j. 25.05.2010).

1382 "Responsabilidade civil - Indenização por danos morais e materiais - Tabagismo - Amputação dos membros inferiores - Vítima acometida de tromboangeíte aguda obliterante - Nexo causal configurado Incidência do Código de Defesa do Consumidor - Responsabilidade objetiva decorrente da teoria do risco assumido com a fabricação e comercialização do produto - Omissão dos resultados das pesquisas sobre o efeito viciante da nicotina - Dever de indenizar - Recurso improvido" (TJSP, AC 379.261.4/5-00, rel. Joaquim Garcia, j. 08.10.2008). "DANO MORAL. CIGARROS. Causas mortais que podem originar: 'enfisema pulmonar', 'arritmia cardíaca' e 'câncer pulmonar', entre outras. Nexo causal comprovado, face ao consumo do cigarro e o evento morte. Princípio da boa-fé objetiva que se aplica ao $\mathrm{CCV} / 16$, incidência do Código de Defesa do Consumidor (arts. $6^{\circ}$, incisos I, III, IV, VI e VIII, e 12, par. $1^{\text {o }}$ ) e art. 159 do CCv/16, na modalidade omissão na ação. Aplicação do art. 335 do CPC: 'regras de experiência comum'. Indenização devida (precedente: AC 70000144626, Redator para o acórdão Des. Adão Sérgio do Nascimento Cassiano, j. em 29.10.03, 9a Câmara Cível). Apelo parcialmente provido. Unânime” (TJRS, AC 70007090798, rel. Luis Augusto Coelho Braga, j. 19.11.2003).

${ }^{1383}$ CONSUMIDOR E CIVIL. ART. $7^{\circ}$ DO CDC. APLICAÇÃO DA LEI MAIS FAVORÁVEL. DIÁLOGO DE FONTES. RELATIVIZAÇÃO DO PRINCÍPIO DA ESPECIALIDADE. RESPONSABILIDADE CIVIL. TABAGISMO. RELAÇÃO DE CONSUMO. AÇÃO INDENIZATÓRIA. PRESCRIÇÃO. PRAZO. - O mandamento constitucional de proteção do consumidor deve ser cumprido por todo o sistema jurídico, em diálogo de fontes, e não somente por intermédio do CDC. - Assim, e nos termos do art. $7^{\circ}$ do $\mathrm{CDC}$, sempre que uma lei garantir algum direito para o consumidor, ela poderá se somar ao microssistema do CDC, incorporando-se na tutela especial e tendo a mesma preferência no trato da relação de consumo. - Diante disso, conclui-se pela inaplicabilidade do prazo prescricional do art. 27 do CDC à hipótese dos autos, devendo incidir a prescrição vintenária do art. 177 do $\mathrm{CC} / 16$, por ser mais favorável ao consumidor. Recente decisão da $2^{\mathrm{a}}$ Seção, porém, pacificou o entendimento quanto à incidência na espécie do prazo 
4.1 Abuso do poder econômico x autonomia da vontade

Observe-se, desde já, que as relações jurídicas estabelecidas no mundo contemporâneo são basicamente de consumo e, por isso, nelas incide o microssistema protetivo instituído pela Lei 8.078/90, sobretudo no que tange à vulnerabilidade material e à hipossuficiência processual do consumidor $\left(\mathrm{CDC}\right.$, arts. $4^{\mathrm{o}}, \mathrm{I}$, c.c. $\left.6^{\mathrm{o}}, \mathrm{VIII}\right)$.

Nenhuma dúvida remanesce neste ponto.

E o CDC, como exposto (supra, Cap. II, 1), há de ser entendido como uma lei principiológica que promove um corte horizontal no sistema jurídico pátrio, atribuindo, com isso, eficácia material às regras constitucionais no desiderato de realizar a dignidade da pessoa humana, a liberdade, a justiça, a solidariedade e a prevalência dos valores sociais $\left(\mathrm{CF}\right.$, arts. $1^{\circ}$, III e IV, c.c. $\left.3^{\circ}, \mathrm{I}\right)$.

Com efeito, a economia de massa que atualmente rege o mercado eliminou a concepção tradicional (falsa, aliás) da autonomia irrestrita da vontade. Esse declínio do voluntarismo coincide com a crise do paradigma do direito privado moldado pelo Estado liberal.

Diante de tal abuso do poder econômico, supostamente fundado numa ampla liberdade de contratar, percebeu-se que entre o forte e o fraco é a liberdade que escraviza e a lei que liberta ${ }^{1384}$. Isso obrigou o Estado a agir no sentido de assegurar o equilíbrio nessas relações (dirigismo contratual).

Com argúcia, indaga Luiz Amaral, “que liberdade há para quem desconhece as regras básicas do mercado, os produtos e seus similares, os preços e seus componentes? Que liberdade há para quem está sob pressões diversas (publicidade subliminar, rótulos e embalagens enganosas, monopólios, insuficiência salarial etc. e etc.? Que liberdade há para quem ignora o sentido e alcance das consequências jurídicas de

prescricional de 05 anos previsto no art. 27 do CDC, que deve prevalecer, com a ressalva do entendimento pessoal da Relatora. Recursos especiais providos (STJ, REsp. 1.009.591/RS, rel. Min. Nancy Andrighi, j. 13.04.2010).

${ }^{1384} \mathrm{O}$ resultado negativo do exercício da liberdade contratual foi condensado magnificamente nessa frase de Lacordaire, Jean-Baptiste-Henri Dominique (religioso dominicano, nascido a 2 de maio 1802 em Recey-surOurce [Côte-d'Or, Borgonha], e falecido a 21 de novembro 1861 em Sorèze [Tarn]. Foi padre, jornalista, educador, deputado e acadêmico, sendo considerado como um precursor do catolicismo moderno e restaurador em França da Ordem dos Pregadores), apud, Orlando Gomes. Contratos. 15 a ed. atual. e notas de Humberto Theodoro Júnior. Rio de Janeiro: Forense, 1995, p. 26. 
cláusulas contratuais exclusivamente arquitetadas pelo economicamente mais forte? Como se pode ver a famosíssima e secular liberdade contratual ou autonomia da vontade amiúde não passa de máscara para a vontade unilateral, e por isso mesmo e enquanto princípio absoluto, acha-se a caminho do museu de belas utopias jurídicas". ${ }^{1385}$

Indiscutivelmente, o consumidor foi um dos mais prejudicados nesse processo, tanto assim que, após o reconhecimento da ineficácia do modelo jurídico anterior, outorgaram-se-lhe direitos específicos e fundamentais. Dessa linha de pensamento surge o consumerismo.

Imbuído de valores já assimilados na comunidade internacional, o Brasil adota uma nítida postura intervencionista com a promulgação da Constituição Federal de 1988, propondo-se a tutelar situações de desigualdade e de desequilíbrio social.

Nessa quadra, a defesa do consumidor é erigida em princípio constitucional impositivo, exercendo dupla função: de meio para realização de existência digna e de diretriz (norma-objetivo).

Posterga-se, neste passo, o fetichismo da lei (v.g., Código Civil) para as relações de direito privado, que tem seu centro de gravidade deslocado para estatutos autônomos com vinculação direta (base de sustentação) em princípios e em regras constitucionais.

Observa-se a ineficácia do modelo jurídico anterior para enfrentar o desequilíbrio e os riscos inerentes às relações de consumo (insegurança), situação que exigiu uma postura intervencionista do Estado, agora dirigido à realização do social e à concretização das liberdades públicas.

A noção de liberdade do consumidor cede à sua necessidade.

4.2 Elementos inerentes à economia de massa

Tem-se o cuidado, agora, de não se vincular esses elementos apenas às típicas relações de consumo, assim definidas na Lei 8.078/90, pois o CDC nada mais fez do que positivar situações e realidades há muito identificadas na sociedade moderna - dirigidas à economia de massa, à globalização e ao mercado irracional - com

${ }^{1385}$ O Código..., cit., p. 71. 
destaque para o flagrante desequilíbrio entre os sujeitos envolvidos: o fornecedor e o consumidor.

É claro que essa preocupação não ficou restrita às particularidades do Brasil, pois a globalização gera a necessidade de fortalecimento da atuação estatal na proteção da sociedade e do indivíduo, principalmente no que se refere às relações consumeristas e à própria regulação do mercado, sempre com vistas a garantir a dignidade como núcleo mínimo intangível. ${ }^{1386}$

João Batista de Almeida esclarece que, "a proteção jurídica do consumidor não é tema que diga respeito a um único país; ao contrário, é tema supranacional, pois abrange todos os países, desenvolvidos ou em vias de desenvolvimento. A relevância do tema, as repercussões sentidas nos seguimentos sociais dos vários países, a sensibilidade para os problemas sociais e os direitos humanos, em suma, toda essa modificação nas relações de consumo, acabaram levando a ONU a se preocupar com a defesa do consumidor, aliás atitude esperada do organismo internacional, caixa de ressonância dos grandes temas que envolvem a melhoria da qualidade de vida dos povos". ${ }^{1387}$

Nessa trilha de preocupações é que se encontra a Res. 39/248 da Organização das Nações Unidas, aprovada em sessão plenária de 09.04.1985, inspirada na famosa declaração dos direitos do consumidor, proferida pelo Presidente John Kennedy, em 15.03.1962, data em que se comemora o dia internacional do consumidor.

A Res. 39/248, em última análise, traçou uma política geral de proteção ao consumidor destinada aos Estados filiados, tendo em conta seus interesses e necessidades em todos os países e, particularmente, nos em desenvolvimento, reconhecendo que o consumidor enfrenta, amiúde, desequilíbrio em face da capacidade econômica, nível de educação e poder de negociação. Reconhece, ainda, que todos os consumidores devem ter o direito de acesso a produtos que não sejam perigosos, assim como o de promover um desenvolvimento econômico e social justo, eqüitativo e seguro. $^{1388}$

Assinala James J. Marins de Souza que o $n^{\circ} 3$ dessas diretrizes indica os seguintes direitos básicos do consumidor:

\footnotetext{
${ }^{1386}$ Cristiano Chaves de Farias. A proteção do consumidor na era da globalização. Revista de Direito do Consumidor, São Paulo: RT, v. 41, jan.-mar. 2002, p. 90/91.

${ }^{1387}$ A proteção jurídica..., cit., p. 04.
} 
“a) a proteção dos consumidores frente aos riscos à sua saúde e à sua segurança;

b) a promoção e proteção dos interesses econômicos dos consumidores;

c) o acesso dos consumidores a uma informação adequada que os permita fazer eleições bem fundadas conforme os desejos e necessidades de cada qual;

d) a educação do consumidor;

e) a possibilidade de compensação efetiva ao consumidor;

f) a liberdade de constituir grupos ou outras organizações afins de consumidores e oportunidade para estas organizações de fazer ouvir suas opiniões nos processos de adoção de decisões que as afetem."1389

Parece fundamental assinalar, ainda, o relevante papel desempenhado pela CEE, ao constituir-se em fonte de direito. São editadas Resoluções, Diretivas, Proposições, Recomendações, etc. que interferem no direito interno de cada um dos integrantes da Comunidade. ${ }^{1390}$

Ressalte-se, neste particular, que o Conselho das Comunidades Européias aprovou ${ }^{1391}$ o "Programa Preliminar da Comunidade Econômica Européia para uma política de proteção e de informação dos consumidores”, estabelecendo em seu $n^{\circ} 3$ : os interesses dos consumidores podem ser agrupados em cinco categorias de direitos fundamentais: a) direito à proteção da saúde e da segurança; b) direito à proteção dos interesses econômicos; c) direito à reparação dos prejuízos; d) direito à informação e à educação; e) direito à representação (direito de ser ouvido). ${ }^{1392}$

Resta solarmente claro que, embora na essência desequilibrada essa relação, dois direitos básicos sempre foram reconhecidos e assegurados ao consumidor: à proteção da sua saúde e à correta e à precisa informação; logo, não se pode admitir nem amparar uma atividade econômica que ponha em risco qualquer um desses valores.

\footnotetext{
${ }^{1388}$ José Geraldo Brito Filomeno. Manual..., cit., p. 25.

1389 A Responsabilidade Civil do Fornecedor pelo Fato do Produto e do Serviço. Jurisprudência Brasileira (JB), Curitiba: Juruá, v. 166, abr.-mai. 1992, p.55.

${ }^{1390}$ Newton de Lucca. Direito do Consumidor. Aspectos práticos..., cit., p. 22.

${ }^{1391}$ Res. do Conselho de 14 de abril de 1975. Esse elenco de direitos é confirmado no Segundo Programa da Comunidade Econômica Européia, conforme a Res. do Conselho de 19 de maio de 1981.

${ }^{1392}$ Marins de Souza. A Responsabilidade Civil..., cit., p.55.
} 
Eis o mínimo esperado.

Trata-se da conjugação de seis elementos: 1) vulnerabilidade do consumidor; 2) inviabilidade de abuso no mercado; 3) harmonia e equilíbrio; 4) transparência; 5) confiança; e 6) boa-fé (objetiva).

E para se balizar os fundamentos da responsabilidade das empresas fabricantes de cigarros, desde já, é de se ressaltar que a exploração comercial do tabaco e da nicotina representa um negócio extremamente lucrativo, mas tolerado pelo Poder Público que, com isso, previne a clandestinidade que uma súbita proibição poderia causar - tal qual o fenômeno verificado durante a Lei Seca nos Estados Unidos ${ }^{1393}$ fomentadora de sensível evasão (sonegação) fiscal, sem prejuízo da ruptura do controle exercido sobre a qualidade e os componentes disponibilizados ao consumidor.

Infere-se da experiência comum neste plano que as companhias de tabaco, quando judicialmente acionadas, articulam suas defesas em três capítulos principais, onde sustentam basicamente a inexistência de: a) ato ilícito; b) nexo causal; e c) responsabilidade à luz do CDC; logo, todas essas teses e seus desdobramentos reclamam acurada análise dentro do contexto jurídico até aqui formado.

\subsection{Atividade lícita}

Em nada altera o deslinde da quaestio a licitude da atividade.

A prevalecer tal raciocínio simplista, todas as consequências ilícitas de atos, a priori, lícitos estariam imunes às regras da responsabilidade civil, o que é técnica e juridicamente inaceitável.

Tome-se o exemplo do cidadão intoxicado após comer um salgadinho (coxinha) adquirido numa cantina de determinada rodoviária. Vender salgadinhos também é atividade lícita, mas certamente ninguém sustentaria na espécie a ausência do dever de indenizar.

E a indústria farmacêutica? Será possível acreditar e defender a irresponsabilidade pelos danos causados por um remédio à população? Ora, não é simples como querem as companhias de tabaco? Vender remédios também é lícito. Por que com o cigarro é diferente?

${ }^{1393}$ Lei que vigorou nos Estados Unidos e proibia a venda de bebidas alcoólicas. 


\section{Ilusório o argumento.}

Se o exercício da sua atividade lícita compromete algum direito da população, isto somente interessa às companhias de tabaco diante da teoria do risco proveito, sobretudo se violados um dos pilares mestres da dignidade da pessoa humana $\left(\mathrm{CF}\right.$, arts. $1^{\mathrm{o}}$, III, c.c. $6^{\circ}$, caput): a saúde.

De fato, mesmo antes de se avaliar a presença - ou não - de defeito, é inegável que a responsabilidade em razão do risco está definitivamente consagrada e incorporada no Direito Brasileiro, in casu, com especial destaque para o art.12, e seus $\S \S$, do CDC. ${ }^{1394}$

Mas se alguma dúvida ainda remanescer, basta se voltem os olhos para o CC, diploma legislativo antenado com a evolução do direito e que, por certo, também rege a atividade de exploração do tabaco, mormente porque a Lei 8.078/90 não exclui a incidência da legislação interna ordinária $\left(\mathrm{CDC}\right.$, art. $\left.7^{\circ}, c a p u t\right)$ visando à melhor defesa do consumidor.

À guisa de exemplo, uma vez que já estudado o art. 927, par. ún. (supra, 2), retome-se a análise do art. 931 (supra, 2.2.1), que para Nelson Nery Junior e Rosa Maria de Andrade Nery encerra o chamado risco da atividade, pois "a norma determina que seja objetiva a responsabilidade quando a atividade do causador do dano, por sua natureza implicar risco para o direito de outrem. É a responsabilidade pelo risco da atividade. V. CDC $6^{\circ}$ VI, 12 e 18"1395. Ou como quer Maria Helena Diniz, "a obrigação de indenizar é, portanto, imposta por lei a certas pessoas independentemente da prática de qualquer ato ilícito, considerando-se que: a) determinadas atividades humanas criam um risco especial para outrem. (...) e b) o exercício de certos direitos deve implicar o dever de reparar o prejuízo que origina (CC, arts. $1.289,1.293$ e 1.251)". ${ }^{396}$

\footnotetext{
${ }^{1394} \mathrm{CDC}$, art. 12, caput: "o fabricante, o produtor, o construtor, nacional ou estrangeiro, e o importador respondem, independentemente da existência de culpa, pela reparação dos danos causados aos consumidores por defeitos decorrentes de projeto, fabricação, construção, montagem, fórmulas, manipulação, apresentação ou acondicionamento de seus produtos, bem como por informações insuficientes ou inadequadas sobre sua utilização e riscos".

${ }^{1395}$ Novo Código Civil e legislação extravagante anotados. São Paulo: RT, 2002, p. 323.

${ }^{1396}$ Curso de direito civil brasileiro. $16^{\mathrm{a}}$ ed. São Paulo: Saraiva, 2002, $7^{\circ}$ v., p. 49.
} 
A propósito, não se ponha no oblívio que a responsabilidade civil pelo fato do produto prevista nesse art. 931 do CC também inclui os riscos do desenvolvimento (supra, 3.7). ${ }^{1397}$

Possível dizer-se, nesta quadra, que a escolha de desenvolver uma atividade e/ou um produto aptos a gerar lucros estratosféricos, a despeito dos riscos a eles inerentes, certamente atrela o empreendedor aos ônus resultantes do exercício dessa livre opção. Isso apenas reflete uma diferente percepção dos riscos e, possivelmente, de valores diversos.

Longe de configurar a inócua excludente do exercício regular de direito, a atividade e/ou o produto de risco explorados pelas companhias de tabaco em muito se aproximam do abuso de direito.

\subsection{Conhecimento público dos riscos}

Abuso de direito, sim, pois mesmo há muito sabedoras dos males gerados pela ingestão do tabaco e dos efeitos viciantes da nicotina, passivamente relegaram seus consumidores à própria sorte, ora com o silêncio, ora com a negativa expressa da realidade.

Lembra Marcello D. Stalteri que há trezentos anos, de fato, o tabaco era acusado no velho continente como produto danoso à saúde, e a partir dos anos vinte, em função de experiências realizadas em seus próprios laboratórios, tinham conhecimento as empresas fabricantes de cigarros das características cancerígenas do produto, preferindo à divulgação de tais informações a sua ocultação. ${ }^{1398}$

Que adiantam, então, informações esparsas veiculadas por terceiros, como os consumidores, ignorantes acerca da efetiva potencialidade lesiva do cigarro, simplesmente porque não participavam - e não participam até hoje do processo de produção. $^{1399}$

${ }^{1397}$ Enunciado 43 aprovado na Jornada de Direito Civil, promovida pelo Centro de Estudos Judiciários do Conselho da Justiça Federal, no período de 11 a 13 de setembro de 2002, sob a coordenação científica do Min. Ruy Rosado de Aguiar Júnior, do Colendo Superior Tribunal de Justiça.

${ }^{1398}$ IL PROBLEMA DELLA RESPONSABILITÁ DEL PRODUTTORE DI SIGARETTE E IL CASO CIPOLLONE: L'ASSALTO ALLA CITTADELLA Ė REALMENTE COMINCIATO? Rivista di Diritto Civile. Italia: Padova, Casa Editrice Dott. Antonio Milani - CEDAM, nº 1, Gennaio-Febbraio, Anno XL, 1994, p. 189 e 217. Tradução livre.

${ }^{1399}$ Tal como nos Estados Unidos, litigantes europeus têm sido encorajados pela prova de que os fabricantes de cigarros sabem há muito tempo dos danos que seu produto causa. "À medida que os europeus forem 
Sem nenhum relevo para o deslinde da controvérsia assertivas como: a) é de amplo conhecimento público que o consumo do tabaco é um fator de risco para o surgimento de algumas doenças; b) a mídia no Brasil há décadas veicula informações sobre o tema nos diversos meios de comunicação; c) nenhum consumidor, por mais rudimentar a sua formação, deixou de saber dos riscos associados ao cigarro; d) ninguém jamais levou um cigarro à boca sem estar informado e advertido de que isso poderia causar males à saúde; e) o fato de um indivíduo decidir ignorar ou não acreditar em advertências e informações públicas acerca destes riscos é uma questão de livre arbítrio que não pode ser imputada às fornecedoras.

Adotando essa linha defensiva, parece claro que o fabricante de cigarro, (...) sempre negou publicamente a mortal periculosidade do fumo, exaltando até as propriedades inócuas dos cigarros, pretendendo ao mesmo tempo invocar o suposto conhecimento ab immemorabilia daquele grave perigo para os consumidores". ${ }^{1400}$

A propósito, em 14 de abril de 1994 os diretores-presidentes das sete maiores companhias de cigarro dos Estados Unidos ${ }^{1401}$ compareceram, como testemunhas, a uma audiência designada pelo Subcomitê de Saúde e Meio Ambiente, do Comitê de Energia e Comércio da Câmara dos Deputados Norte-Americana.

O presidente dos trabalhos, Representante Henry Waxman (D-CA), quando de sua abertura fez questão de consignar:

“A reunião do subcomitê está para começar. Eu pediria aos nossos convidados por favor tomem seus assentos. Esta é uma audiência histórica. Pela primeira vez, os diretores chefes de operações das companhias de cigarros do nosso país estão testemunhando juntos perante o Congresso dos Estados Unidos. Eles estão aqui porque este subcomitê tem jurisdição legislativa sobre essas

percebendo que a indústria visava a eles, mas mentia quanto aos perigos dos seus produtos, você verá um número ainda maior de processos sendo iniciados e vencidos", diz Richard Dynard, professor de direito e presidente do Tobacco Products Liability Project em Boston, Massachusetts (Aisha Labi. Tobacco on Trial: THE SMOKING GUN. TIME Magazine. USA, January, 2003, p. 23. Tradução livre).

${ }^{1400}$ Marcello D. Stalteri. Il problema..., cit., p. 220.

${ }^{1401}$ William Campbell, Presidente e Diretor Chefe de Operações da Philip Morris, Estados Unidos; James W. Johnston, Presidente das Organizações e Diretor Chefe de Operações da RJR Tobacco Company; Joseph Taddeo, Presidente da U.S. Tobacco Company; Andrew H. Tisch, Presidente das Organizações e Diretor Chefe de Operações da Lorillard Tobacco Company; Edward A. Horrigan, Presidente das Organizações e Diretor Chefe de Operações da Liggett Group Inc.; Thomas E. Sandefur, Presidente das Organizações e Diretor Chefe de Operações da Brown and Williamson Tobacco Corp.; e Donald S. Johnston, Presidente das Organizações e Diretor Chefe de Operações da American Tobacco Company. 
questões que afetam a nossa saúde. E não há questão de saúde tão importante quanto fumar.

Às vezes é mais fácil criar uma ficção do que enfrentar a verdade. A verdade é que os cigarros são simplesmente o produto de consumo mais perigoso jamais vendido. Quase meio milhão de americanos morrem anualmente por causa dos cigarros. Esta é uma estatística quase incompreensível que nos deixa perplexos. Imaginem a revolta da nossa nação se dois aviões jumbos lotados de passageiros caíssem todo dia, matando todos a bordo. Ainda assim, este é o mesmo número de americanos que os cigarros matam a cada 24 horas. Tristemente, este vício mortal começa com as nossas crianças. A cada dia 3.000 crianças começam a fumar. Em muitos casos, elas se tornam viciadas rapidamente e desenvolvem uma dependência que dura toda vida e é quase impossível rompê-la. Nos últimos 30 anos, vários ministros da saúde têm publicado uma série de relatórios esclarecedores detalhando os perigos que essas crianças eventualmente enfrentarão. Câncer de pulmão, doenças do coração, enfisema, câncer de bexiga e derrame, apenas algumas das doenças que o cigarro causa.

E agora nós sabemos que as crianças enfrentarão uma séria ameaça à saúde mesmo que não fumem. A fumaça ambiental do cigarro é um cancerígeno classe A e causa doenças em mais de um milhão de crianças todo ano. De fato, cinco ex-ministros da saúde dos Estados Unidos disseram este ano perante este subcomitê que a mais importante legislação sobre prevenção de doenças que nós poderíamos editar seria sobre restrições de fumar em lugares públicos. Este subcomitê logo agirá sobre essa legislação e considerará outras medidas também. Esta audiência ajudará nossos esforços ao nos mostrar uma perspectiva importante. Mas esses testemunhos são outrossim relevantes por outra razão. Por décadas, as companhias de cigarros têm-se eximido dos padrões de responsabilidade e sujeição que se aplicam a todas as outras corporações americanas. Companhias que vendem aspirina, carros e refrigerantes estão presas a rígidos padrões quando causam dano. Não permitimos que essas companhias vendam produtos que deliberadamente ameaçam os consumidores. Não permitimos que elas suprimam as provas dos perigos quando os danos ocorrem. Não permitimos que elas ignorem a ciência e o bom senso. E exigimos - quando 
esses problemas acontecem - que as corporações e os seus diretores sejam responsabilizados perante o Congresso e o povo.

Esta audiência marca o início de uma nova relação entre o Congresso e as companhias de cigarros. As velhas regras não valem mais. Os padrões que se aplicam a qualquer outra companhia agora estão valendo. Estamos ansiosos para ouvir o testemunho esta manhã e para trabalhar com essas companhias para começar a reduzir a extraordinária ameaça de saúde pública que o produto delas apresenta. Um antigo ditado popular diz que uma jornada de milhares de milhas deve começar com um simples passo. Hoje estamos dando o nosso primeiro passo. E muitos outros virão enquanto estivermos lidando com o mais grave problema de saúde enfrentado pela nossa nação."1402

Tomados os compromissos (juramentos) de dizer a verdade, toda a verdade, nada além da verdade, seguiu-se a inquirição. O momento crucial surge da pergunta formulada pelo Representante Ron Wyden (D-OR), sobretudo em razão das respostas dadas pelas testemunhas. Veja-se:

"Representante Ron Wyden (D-OR): (...) eu gostaria de começar as minhas indagações pela questão de se a nicotina causa dependência ou não. Deixe-me perguntar primeiro a você, e então eu gostaria que os outros em sequência também respondessem, se cada um de vocês acredita que a nicotina não causa dependência. Eu já ouvi todos vocês abordarem este tema. Apenas sim ou não. Vocês acreditam que a nicotina não causa dependência?

Sr. Campbell: (?) Eu acredito que a nicotina não causa dependência, sim.

Representante Wyden: Sr. Johnston?

Sr. Johnston: Congressista, os cigarros e a nicotina claramente não se enquadram nas clássicas definições de dependência. Não há intoxicação.

Representante Wyden: Nós consideraremos isto como um não, e novamente, o tempo é curto. Se vocês puderem apenas - eu acho que cada um de vocês acredita que a nicotina não causa dependência. Tão-só gostaríamos que isso ficasse registrado. 
Sr. Taddeo: (?) Eu não acredito que a nicotina ou nossos produtos causem dependência.

Sr. Horrigan: (?) Eu acredito que a nicotina não causa dependência.

Sr. Tisch: (?) Eu acredito que a nicotina não causa dependência.

Sr. Sandefur: (?) Eu acredito que a nicotina não causa dependência.

Sr. Donald Johnston: (?) E eu, também, acredito que a nicotina não causa dependência. ${ }^{1403}$

Sedutor, aos ouvidos predispostos, o jogo de palavras das companhias de tabaco, mas a quem elas pretendem convencer que só em 1999, após a edição da MP 2.039 e da Port. 695, tomaram conhecimento de que a nicotina é droga e causa dependência, nada obstante a acurada percepção para aquilo que chamam, sem nenhuma timidez, de fator de risco, além da notória tecnologia de ponta dos seus laboratórios, ao menos se espera que assim seja.

Afinal, desde 1988, graças à Port. 490, editada pela União Federal (!), já sabiam as companhias de tabaco que fumar é prejudicial à saúde; porém, mesmo assim e mais uma vez, coube ao Estado (Ministério da Saúde) impor uma informação mais clara e honesta, princípio básico e elementar da atividade econômica.

Por que as fornecedoras, em nome próprio, reconhecendo os efeitos nocivos do produto, não fizeram registrar na publicidade e nos maços dos seus cigarros: “a companhia tal adverte: fumar é prejudicial à saúde”?

Jamais!

Por que nenhuma das grandes companhias de tabaco norteamericana assumiu, em 1994 (cinco anos antes da esclarecedora e reveladora Medida Provisória brasileira), que a nicotina é droga e causa dependência?

Por que se limitam a sustentar uma larga difusão dos riscos para a saúde associados ao cigarro (v.g., governos, entidades e profissionais da área

1402 Disponível em www.pbs.org/wgbh/pages/frontline/shows/settlement/timelines/april94.html. Tradução livre. ${ }^{1403}$ Idem. 
médica, escolas, autoridades escolares, mídia, jornais e revistas populares), mas em nenhum momento justificam as companhias de tabaco o silêncio por tantos anos?

A resposta é uma só: falta de transparência e de lealdade para com o consumidor, descaradamente enganado por décadas, quiçá séculos, vilipendiado na sua confiança. ${ }^{1404}$

Mascarar essa verdade é o mesmo que esconder os raios solares do meio-dia com uma peneira por onde passa um foguete.

Referindo-se à recente adequação dos ditames traçados pela Comunidade Européia, discorre Marcello D. Stalteri:

“(...) não se pode certamente apagar com uma passada de esponja os culpáveis e talvez cúmplices atrasos do passado. Aqui a escolha do silêncio, em matéria de advertências, deixando os consumidores - inclusive os mais atentos e conscientes - com alguma dúvida sobre a real gravidade dos riscos assumidos, pelo menos em relação ao tipo e à quantidade de produto consumido, encontra imediata resposta em termos de maior volume de vendas, consequentemente mais benefícios econômicos para o fabricante. Tal procedimento, culposo ou doloso, pouco importa, não poderia eximir o fabricante de responsabilidade (...).

\section{$(\ldots)$}

Cumpre efetivamente admitir que há, entre os fabricantes de cigarro, o clássico prisoner's dilemma: nenhum deles daria o primeiro passo na busca de uma maior transparência sobre os riscos do uso do produto, se não tivesse certeza de ser logo imitado pelos próprios concorrentes."1405

Claro como o sol que reluz o abuso de direito.

Mister se faz, neste passo, trazer à colação o magistério de Silvio Rodrigues no que tange à hipótese sub examine, para que, “(...) a teoria atingiu seu pleno desenvolvimento com a concepção de Josserand, segundo a qual há abuso de direito quando ele não é exercido de acordo com a finalidade social para a qual foi conferido, pois, como diz este jurista, os direitos são conferidos ao homem para serem usados de uma

\footnotetext{
1404 Segundo Marcello D. Stalteri, essa violação atinge a mais comezinha das obrigações de qualquer fabricante: não enganar o consumidor (duty not to deceive). (...) a atitude nada transparente e correta dos fabricantes de cigarros a respeito da efetiva publicidade dos reais riscos enfrentados pelos fumantes (Il problema..., cit., p. 218 e 224$)$.

${ }^{1405}$ Il problema..., cit., p. 187 e 224.
} 
forma que se acomode ao interesse coletivo, obedecendo à sua finalidade, segundo o espírito da instituição". ${ }^{1406}$

Posto que remonte ao direito romano as primeiras divagações sobre o tema ${ }^{1407}$, o abuso de direito ganha status legislativo no Código Civil, ex vi de seu art. $187 .{ }^{1408}$

Força é concluir que um dos maiores abusos possível de ser praticado pelas fabricantes de cigarro (ávidas na busca de lucros) é a omissão deliberada dos fatores prejudiciais à saúde dos seus consumidores, inexoravelmente vinculados ao consumo do tabaco e da nicotina. Note-se que o dever de bem informar, antes de jurídico, é moral e sua não observância tisna, sem sombra de dúvida, o maior fim social que o exercício de um direito pode almejar: o respeito à dignidade da pessoa humana.

O procedimento se afasta, pois, da boa-fé objetiva e, só por isso, já se equipara a ato ilícito e gera o dever de indenizar, independentemente da existência de dano concreto.

É dizer: a mera violação de um direito subjetivo tutelado pela lei (v.g., adequada e correta informação) - mormente se instituído visando à preservação de atributo da personalidade ou da dignidade da pessoa humana (v.g., saúde) - é passível de reparação compulsória.

Ressalta Luiz Antonio Rizzatto Nunes que, "outro aspecto de relevo a ser destacado é o relativo à informação. Já o dissemos, informação é elemento inerente ao produto (e ao serviço). Dessa maneira, o consumidor pode sofrer dano por defeito não necessariamente do produto, mas da informação inadequada ou insuficiente que o acompanhe ou, ainda, pela falta de informação. A lei não menciona esta última

\footnotetext{
${ }^{1406}$ Direito civil, parte geral. $32^{\mathrm{a}}$ ed. São Paulo: Saraiva, 2002, v. 1, p. 321.

${ }^{1407}$ Lembra Silvio Rodrigues, idem, p. 319: “embora em sua forma atual seja recente a concepção de abuso de direito, o espírito, que inspira a teoria, já se encontrava na velha Roma. No estudo de seu histórico, feito no $2^{\circ}$ Capítulo de seu excelente livro sobre a matéria (Do abuso do direito no exercício da demanda, São Paulo, 1932), Jorge Americano mostra que a primeira impressão que se tem ao examinar textos antigos - de que os romanos desconheciam a idéia de abuso de direito, pois nullus videtur dolo facere qui suo jure utituré destruída por uma observação mais atenta. De fato, só a noção de abuso de direito pode conduzir à condenação de seu absolutismo, o que se encontra na palavra de Cícero (De Officis, 1,10), summum jus, summa injuria, ou na fórmula malitiis non est indulgendum, a qual condena não só os atos praticados à margem do direito, como também aqueles praticados abusivamente".

${ }^{1408}$ CC, art. 187: "também comete ato ilícito o titular de um direito que, ao exercê-lo, excede manifestamente os limites impostos pelo seu fim econômico ou social, pela boa-fé ou pelos bons costumes".
} 
hipótese, mas ela é decorrente das outras duas. Se a informação insuficiente pode gerar dano, sua ausência total, por mais força de razão, também". ${ }^{1409}$

Como uma luva, mais uma vez, cabe a intervenção de Nelson Nery Júnior e de Rosa Maria de Andrade Nery no sentido de que, "é categoria autônoma, de concepção objetiva e finalística, e não apenas dentro do âmbito estreito do ato emulativo (ato ilícito). Diferentemente do ato ilícito, que exige a prova do dano para ser caracterizado, o abuso de direito é aferível objetivamente e pode não existir dano e existir ato abusivo (Guilherme Fernandes Neto, O abuso de direito no Código de Defesa do Consumidor, 1999, p. 200). O abuso de direito é aferível de modo objetivo, prescindindo do dolo ou culpa e também do dano para caracterizar-se". 1410

\subsection{A questão da publicidade e das advertências}

Avulta da realidade instalada, rogando-se os elementos até aqui colhidos, que não é possível sustentar-se: a) uma inexigibilidade ou uma impossibilidade legal de prover informações e advertências distintas das que são impostas pela lei e pelos atos normativos federais; b) a inexistência do dever jurídico de informar ou de advertir com cláusulas diversas das que eram ditadas pela legislação; c) a legitimidade da publicidade das companhias de tabaco.

Ao invés de cumprirem sua obrigação primária: bem informar e, assim, não enganarem o consumidor - o que certamente nada tem a ver com a legislação e os critérios de cada época, muito menos com uma suposta aplicação retroativa da lei - as companhias de tabaco exploram a ignorância e a boa-fé dos consumidores.

(...) A pressão exercida pelos grandes produtores foi uníssona em tal sentido: a partir dos anos 40 e 50, procuram atribuir aos cigarros algo de fascínio e de graça pessoal e coletiva, utilizando com astúcia as mais agressivas técnicas publicitárias, afinadas com a literatura cinematográfica americana daquelas décadas, que pintava o produto como companheiro inseparável de vida dos protagonistas da grande tela.

Os cigarros eram considerados nessa época verdadeiro bem de consumo inócuo, tanto nos Estados Unidos como em outros lugares: na Itália a

${ }^{1409}$ Luiz Antonio Rizzatto Nunes. Comentários..., cit., p. 187. 
sua inclusão na 'cesta básica' de despesa de uma família normal, visava a apurar o índice de inflação. Não devemos esquecer, além do mais, que, para os soldados, têm os cigarros sido há muito reputados parte indispensável da ração diária, juntamente com bolachas e lataria diversa."1411

Registre-se, neste particular, que o jornal Folha de São Paulo, na sua edição de 03.12.2002, noticiou que, “a União Européia aprovou ontem, em Bruxelas (Bélgica), a proibição da propaganda de produtos derivados de tabaco em jornais, em revistas e na internet a partir de 2005 e em eventos esportivos internacionais a partir 2006. A proibição vale para todos os países-membros do bloco".

\subsection{Um histórico de respeito à lei}

Tal realidade poderia ser classificada como um exemplo típico de inexigibilidade de conduta diversa. Ou, em outras palavras, se não dá mais para enganar ou para mascarar o todo, como sempre foi feito, contenta-se com a fração não disciplinada pela lei (lato sensu); aliás, infinitamente maior, até porque, de modo proporcional e por incrível que pareça, diminui-se a tutela do consumidor.

Quanto maior o número de regulamentos normativos menor será a proteção, pois as companhias de tabaco certamente se limitarão ao cumprimento exato e mínimo das regras impostas (cf., a desproporcionalidade entre a duração das advertências e a da própria mensagem publicitária que se fazia veicular), ao mesmo tempo que os consumidores - agora com legitimidade - carregam sozinhos o fardo da sua natural ignorância, da falta de transparência e da deliberada violação da boa-fé objetiva.

Esse resultado foi apreendido pela arguta pena de Marcello D. Stalteri, da Universidade de Firenze, para quem, "os efeitos de tais intervenções do legislador foram paradoxalmente contraproducentes para os consumidores em matéria de tobacco litigation: salvo as dúvidas suscitadas acerca da mesma admissibilidade dos recursos contra o fabricante de cigarros (preemption), hoje resolvidas graças ao caso Cipollone, o aparecimento de tais advertências acabava por influenciar negativamente a possibilidade de invocar a ignorância do consumidor médio sobre os riscos do fumo. Surgido para tutelar o sujeito mais fraco, ditas providências voltaram-se contra estes,

${ }^{1410}$ Novo código civil..., cit., p. 110. 
restringindo as margens de um recurso vitorioso na medida inversamente proporcional seja à clareza, seja à incisividade das advertências feitas nos maços de cigarros". ${ }^{1412}$

Ora, se o art. 220, $\S 4^{\circ}$, da Constituição Federal estabelece que a propaganda comercial do tabaco conterá, sempre que necessário, advertência sobre os malefícios decorrentes do seu uso ${ }^{1413}$, indaga-se:

Quando é necessário respeitar a dignidade da pessoa humana, sua saúde inclusive?

Quando é necessário respeitar os valores sociais da livre iniciativa?

Quando é necessário respeitar a solidariedade?

Quando é necessário respeitar e defender o consumidor?

Apenas o sempre responde a essas indagações.

À evidência, não se exige lei para tal compreensão.

Muito pelo contrário, pois a boa-fé objetiva que orienta (hoje e sempre) as relações de consumo, derivada do respeito inexorável ao binômio transparência/confiança, ainda que sem imposição normativa, recomendava a adoção de uma postura tal qual a insculpida pelo legislador de 1990 no art. 10 , caput, c.c. seu $\S 1^{\text {o }}$, do CDC.

Como se admitir, então, um argumento no sentido de que as companhias de tabaco sempre seguiram rigorosamente as determinações normativas, tanto as veiculadas em portarias como as que se materializaram na lei vigente, incluindo todas as cláusulas de advertência por elas exigidas ao longo do tempo.

Somente cumpriram, no mínimo exigido, a obrigação legal (ou regulamentar), mas daí a inferir uma total isenção quanto aos desdobramentos nocivos causados pela sua atividade de risco, contrariamente ao que entendem as companhias de tabaco, vai muito longe.

Será (?) que foi o texto dos reveladores e esclarecedores atos normativos já mencionados (MP 2.039, reeditada inúmeras vezes, e a Port. 695, de $1^{\text {o }}$ de junho de 1999), a fonte da necessidade de se avisar que: "fumar causa câncer de pulmão";

\footnotetext{
${ }^{1411}$ Marcello D. Stalteri. Il problema..., cit., p. 189/190.

1412 Il problema..., cit., p. 203.

${ }^{1413} \mathrm{CF}$, art. $220, \S 4^{\circ}$ : "a propaganda comercial de tabaco, bebidas alcoólicas, agrotóxicas, medicamentos e terapias estará sujeita a restrições legais, nos termos do inciso II do parágrafo anterior, e conterá, sempre que necessário, advertência sobre os malefícios decorrentes do seu uso".
} 
"fumar provoca infarto do coração"; "a nicotina é droga e causa dependência"; "fumar causa impotência sexual; "crianças começam a fumar ao verem os adultos fumando".

Bem que as companhias de tabaco tentam direcionar essa conclusão; mas, sem nenhum sucesso, como discorre Stalteri, pois "os fabricantes, na realidade, melhor do que qualquer outro poderiam concorrer com as autoridades sanitárias em conseguir alcançar os indispensáveis objetivos de prevenção na matéria. Limitando-se à aposição de advertências previstas pela lei, estes continuaram a achar pouco conveniente propagar os efeitos danosos do produto, e muito menos investir seja na pesquisa relativa a modelos de patologias ligadas ao fumo, seja na introdução de eventuais intervenções dirigidas à interrupção daquele modelo acentuado de consumo, que aumenta em maneira geométrica os riscos de danos". 1414

Isto porque, “ (...) em Países como os Estados Unidos - onde a publicidade do produto ainda é admitida - as tobacco companies recorreram a técnicas de convencimento ainda mais subliminares e sofisticadas, tendentes a associar o produto a imagens de saúde e de juventude, afastando ao mesmo tempo do consumidor o impacto das advertências sobre a periculosidade do fumo". ${ }^{1415}$

Saliente-se, em arremate deste tópico, que a falta de publicidade nos países do antigo bloco comunista também não interfere na problemática, pois, no concernente aos esclarecimentos sobre males do fumo, estavam eles em pé de igualdade com as demais nações, nivelados pela omissão e pela falta de transparência dolosas.

\subsection{A questão do livre arbítrio}

Fala-se muito em livre-arbítrio, mas, sinceramente, o usuário de uma droga (nicotina) que causa dependência exerce liberdade ou sucumbe à sua necessidade?

Embora se possa até admitir - ignorando-se as décadas de maciça publicidade glamourosa, cuja influência negativa jamais poderá ser negada em sã consciência - que a decisão de fumar é fruto de uma liberdade pessoal, quem, fora as companhias de tabaco poderiam sustentar o insustentável: “exercida por um público

${ }^{1414}$ Il problema..., cit., p. 228. 
esclarecido"; "uma escolha voluntária e consciente"; "tal decisão é tão individual quanto a de deixar de fumar"; "não existe coisa alguma no cigarro (inclusive a nicotina) que obrigue alguém a optar por uma ou outra conduta"; "os fumantes não se tornam intoxicados nem fisicamente dependentes"; "tudo não passa de uma questão de motivação pessoal. Nada mais é preciso. Só força de vontade".

Esclarecido de que? Consciente de que? Alguém realmente acredita que se para de fumar do dia para noite, tal qual se acende um cigarro atrás do outro? E a nicotina, droga que gera dependência? E os prazerosos efeitos sensoriais que as pessoas comprovadamente experimentam ao fumar? E a manipulação da nicotina para aumentar, artificialmente, sua absorção pelo organismo (pulmões, cérebro e sistema nervoso central); efeito decorrente da utilização de amônia num processo conhecido como reforço de impacto? Em que galáxia o fumo não causa intoxicação?

Motivação pessoal e força de vontade contra dependência química, que paridade de armas!

Depois que o estrago está feito, pouco há se fazer!

Mas a precisa intervenção de Marcello D. Stalteri põe às claras a situação:

“(...) no caso dos cigarros existe plena imunidade da qual gozam até hoje os fabricantes, mesmo se há decênios circulem dados sobre a gravidade dos males à saúde dos fumantes. Seria simplismo, entretanto, tentar explicar tal imunidade com o clássico argumento da ausência de um dano contra ius a alguém que, perfeitamente ciente dos perigos a que se sujeita, consumindo o produto de maneira prolongada, decida livremente enfrentar o risco.

\section{(...)}

Os efeitos da dependência causados pela nicotina, por outro lado, facilitam o jogo dos fabricantes de cigarros, tornando os consumidores menos atentos e sensíveis aos avisos da ciência médica."1416

Se a nicotina não pode ser apontada como o motivo primário pelo qual as pessoas fumam, por certo, ao causar dependência química, representa o maior obstáculo para a interrupção do vício.

${ }^{1415}$ Il problema..., cit., p. 188. 
4.8 Inimputabilidade de danos $\mathrm{x}$ assunção de risco

Vencidas as teses do exercício de uma liberdade e da ampla e adequada informação sobre os malefícios do fumo, resta às fabricantes de cigarro o argumento fundado numa fictícia assunção de risco.

Como se falar em assunção se o risco não é - tal qual deveria ser - conhecido em sua plenitude (transparência e adequada informação)? Como se falar em assunção se o risco é exclusivo do fornecedor e não pode ser transferido a ninguém?

"Desde essa primeira fase da história da tobacco products liability notamos outrossim a presença de ulterior elemento, fundamental para o futuro curso da matéria: as cortes se mostraram reticentes em condenar o fabricante, reportando-se ao argumento da assunção do risco pelo consumidor. $\mathrm{O}$ fumante vinha sendo considerado, na realidade, muito perspicaz para poder compreender que ditas mensagens promocionais eram artificiosas, senão falsas: não se importando com os efeitos de dependência da nicotina, o fumante poderia livremente ter deixado de fumar, assumindo para si em caso contrário toda a responsabilidade sobre os futuros reveses que se manifestaram em seu prejuízo (...).

Enfim, com demasiada frequência pesam sobre as opções do consumidor as características aditivas do produto, a influência dos modelos de comportamento social difíceis de superar, graças também às técnicas de persuasão publicitária, ainda hoje exercidas com sucesso pelas tobacco companies.

Se tais circunstâncias fossem avaliadas de maneira preponderante em relação ao tradicional e simplista argumento da assunção do risco, seria mais fácil admitir uma compensation às vítimas do fumo."1417

O desconhecido e exclusivo risco é mesmo só das fornecedoras.

4.9 Nexo causal como requisito da obrigação de indenizar

${ }^{1416}$ Il problema..., cit., p. 07 e 11.

${ }^{1417}$ Il problema..., cit., p. 199 e 236/237. 
O grande sustentáculo das companhias de tabaco neste pormenor é a tentativa de estabelecer uma diferença entre fator de risco e causa, como se isso tivesse o efeito liberatório pretendido; porém, olvidam que para sua responsabilização civil basta o risco, aliás, inerente à sua atividade econômica, até porque, "os cigarros, na realidade, pertencem a uma categoria totalmente particular, isto é, a dos produtos ditos unavoidably unsafe per se, para os quais foi impossível evitar de maneira absoluta o risco dos danos, embora sejam estes usados com todas as precauções possíveis"1418, circunstância que os diferencia do álcool por exemplo.

No que tange aos problemas de saúde, os consumidores basicamente afirmam que eles foram adquiridos e agravados pelo uso do cigarro. Trata-se de duas articulações fáticas distintas que não se confundem. São, pois, autônomas e independentes.

Ora, conquanto se admita a tese de ser o fumo apenas um inocente fator de risco para a aquisição de inúmeras patologias, é certo que compromete a saúde do fumante, e tal vínculo - ainda que genérico - é suficiente para condicionar seu efeito prejudicial.

Pode até não ter sido mesmo a causa originária da doença ${ }^{1419}$; mas isso não importa, visto que funcionou como causa do agravamento do estado clínico do consumidor doente, circunstância aferível diante das particularidades do caso concreto.

Aí está outro alicerce do dever de indenizar. O agravamento do estado de saúde é per se um dano. Irrelevante é, assim, discutir-se a origem da doença.

Claro como o sol que reluz o nexo causal. ${ }^{1420}$

O dano é um só: comprometido estado de saúde do consumidor no seu atual estágio; assim, a hipótese, quando muito, seria de concausa simultânea e não concausa sucessiva. ${ }^{1421}$

\footnotetext{
${ }^{1418}$ Marcello D. Stalteri. Il problema..., cit., p. 209.

1419 Il problema..., cit., p. 184: "não devem ser desprezadas, todavia, as graves conseqüências vasocirculatórias, nem os danos sofridos pelo feto humano, no caso particular em que as fumantes sejam mulheres gestantes. Não é difícil imputar propriamente ao fumo patologias assim graves: além da nicotina e do alcatrão em relevante quantidade, os cigarros contêm mais de duas substâncias de natureza cancerígena, entre as quais os pesticidas usados no cultivo do tabaco".

${ }^{1420}$ Discorda a professora Teresa Ancona Lopez (Nexo causal e produtos potencialmente nocivos: a experiência brasileira do tabaco. São Paulo: Quartier Latin, 2008, p. 109/110), para quem "não há formação de nexo causal entre os danos possíveis do cigarro e a falta de conhecimento do fumante sobre o vício e os males do fumo, porque não há defeito de informação. Está perfeitamente claro para toda a sociedade que o cigarro é tóxico e nocivo à saúde. É fato óbvio e notório. Além disso, pelos dados da experiência sempre se
} 
Infere-se, portanto, que o atual estágio de comprometimento da saúde do consumidor - prejudicada pelo fumo - decorre direta e imediatamente do consumo de cigarros.

Sendo no mínimo fator de risco (como querem as companhias de tabaco), o consumo de cigarros não implica ruptura do liame de desdobramento natural da relação de causa e efeito, ao revés, atua como eficaz agente acelerador à medida que debilita a saúde do fumante. E isso é irrefutável.

Quanto à teoria da interrupção do nexo causal, de medular importância não se perder de vista a precisa advertência de Carlos Roberto Gonçalves, lembrando Agostinho Alvim, que “(...) a teoria da necessariedade da causa não tem o condão de resolver todas as dificuldades práticas que surgem, embora seja a que de modo mais perfeito e mais simples cristalize a doutrina do dano direto e imediato, adotada pelo nosso Código. Enneccerus, por sua vez, pondera: 'a difícil questão de saber até onde vai o nexo causal não se pode resolver nunca, de uma maneira plenamente satisfatória, mediante regras abstratas, mas em casos de dúvida o juiz há de resolver segundo sua livre convicção, ponderando todas as circunstâncias, segundo lhe faculta o $§ 287$ do LPC' (lei processual alemã)". ${ }^{1422}$

E alerta Marcello D. Stalteri que, “(...) em face dos casos de exposição múltipla das vítimas a substâncias tóxicas, nenhuma das quais passível de ser considerada causa exclusiva do dano, mesmo em virtude dos inevitáveis fatores naturais que concorrem para o resultado patológico, a escolha tem-se revelado sempre mais no sentido da procura de um conceito de causalidade sobre a base provável e estatística: a substantial connection entre agente tóxico e dano poderá ser demonstrada à vista dos elementos probatórios, que possam induzir o júri a considerar que a existência do fato contestado é mais provável do que sua inexistência". ${ }^{1423}$

Pode até ser que não exista nenhuma doença que ocorra apenas em fumantes e não ocorra em não fumantes, mas pelo menos, graças aos

soube que aspirar qualquer fumaça é muito ruim para a saúde, mais ainda uma fumaça venenosa, como a dos produtos do tabaco".

${ }^{1421}$ Segundo Carlos Roberto Gonçalves (Responsabilidade civil. 5a ed. São Paulo: Saraiva, 1994, p. 371), “a teoria do nexo causal encerra dificuldades porque, em razão do aparecimento de concausas, a pesquisa da verdadeira causa do dano nem sempre é fácil. Essas concausas podem ser sucessivas e simultâneas. Nas últimas, há um só dano, ocasionado por mais de uma causa. É a hipótese de um dano que pode ser atribuído a várias pessoas".

${ }^{1422}$ Responsabilidade civil..., cit., p. 374.

${ }^{1423}$ Il problema ..., cit., p. 222/223. 
reveladores e esclarecedores atos normativos mencionados (MP 2.039, reeditada inúmeras vezes, e a Port. 695, de $1^{\text {o }}$ de junho de 1999), hoje se tem a certeza (!) que fumar causa câncer de pulmão, impotência sexual e provoca infarto do coração.

$\mathrm{Na}$ tentativa de desviar o foco central da discussão, as grandes companhias de tabaco procuram outorgar uma inexistente relevância ao histórico pessoal, médico e familiar do consumidor, tal qual fazem pelo mundo afora.

"O Tobacco Institute tem tido um papel importante também em sede processual, no que diz respeito aos comportamentos uniformes a serem adotados contra aqueles que porventura tenham ousado pleitear ressarcimento. Com tal escopo, sem se importar com despesas, foi criado um network permanente entre estudos legais e um grupo de consultores técnicos, utilizados sabiamente em sede processual para contradizer, contra toda evidência científica, o nexo etiológico entre o fumo e o dano à saúde.

Os fabricantes tem sobretudo procurado desfrutar ao máximo as vantagens relativas à notável disparidade de meios econômicos em relação aos consumidores. Em particular, uma constante técnica dilatória na fundamental fase pré-debate (pretrial), utilizada para percorrer minuciosamente a vida passada da vítima dos danos com o escopo de encontrar um nexo etiológico diverso do fumo, servindo para alongar os tempos processuais e a enxugar portanto os certamente mais limitados recursos dos consumidores."

4.10 Possibilidade de consumo de diferentes marcas

A premissa maior, aqui, avulta da condição de fumante ostentada pelo consumidor; logo, sobre isso nada pode ser ventilado ou aceito pena de nítida incompatibilidade argumentativa.

Considerando que o cigarro é um produto de consumo bem popular, é praticamente impossível que um fumante jamais se tenha valido de uma das marcas disponibilizadas pela companhia de tabaco eleita para o polo passivo da ação reparatória.

${ }^{1424}$ Marcello D. Stalteri. Il problema..., cit., p. 193. 
Ainda que o consumidor também tenha fumado cigarros não produzidos por essa determinada empresa, nenhuma relevância concreta há na fixação do dever de indenizar, pois isto encerra típica responsabilidade solidária $\left(\mathrm{CDC}\right.$, arts. $7^{\circ}$, par. ún., c.c. $25, \S 1^{\text {o }}$, c.c. $\mathrm{CC} / 2002$, art. 942 , par. ún.).

Até na hipótese de consumo ao mesmo tempo de diversas marcas de cigarros seria possível considerar solidariamente responsáveis todos os fabricantes que venderam o produto para determinado sujeito, se bem que em medida proporcional à quantidade ou à duração do consumo. ${ }^{1425}$

Nessa linha de pensamento por igual se orienta Roberto Senise Lisboa:

"Se mais de um fornecedor tiver concorrido para a causação do dano, a responsabilidade civil pelo prejuízo moral puro ou cumulado com o dano patrimonial recairá sobre todos eles, segundo a sua participação no evento.

A responsabilidade perante o consumidor é, neste caso, solidária, por expressa disposição legal (art. $7^{\circ}$, par. ún., da Lei 8.078/90), viabilizando-se em prol do fornecedor que proceder ao pagamento da indenização o direito de regresso em face dos demais fornecedores que participaram para o fato."1426

Impende frisar, no entanto, que tal acertamento (CDC, art. 13, par. ún. ${ }^{1427}$ ) constitui res inter alios e, por isso, não pode prejudicar o consumidorvítima. As companhias de tabaco, havendo interesse, hão de resolver suas pendências financeiras em sede própria, até porque "em se tratando de ofensa ou violação ao direito de outrem, desnecessária a detalhada apuração da parcela de responsabilidade de cada um dos demandados. Em ação regressiva entre os responsáveis, o grau de responsabilidade de cada um poderá ser apurado". ${ }^{1428}$

\subsection{Risco do produto segundo o CDC}

\footnotetext{
${ }^{1425}$ Il problema..., cit., p. 223.

${ }^{1426}$ Responsabilidade civil..., cit., p. 240.

${ }^{1427}$ CDC, art. 13, par. ún.: "aquele que efetivar o pagamento ao prejudicado poderá exercer o direito de regresso contra os demais responsáveis, segundo sua participação na causação do evento danoso". ${ }^{1428} R T 784 / 292$.
} 
Em que pesem aos respeitáveis entendimentos em sentido contrário, o rol estatuído no art. 12, caput, da Lei 8.078/90 é numerus apertus; e não poderia ser de outra forma sob pena de se comprometer a ampla e a irrestrita proteção do consumidor ordenada pelo sistema constitucional vigente.

Implacável é Luiz Antonio Rizzatto Nunes sobre a questão, visto que, "como norma protetora do consumidor deve-se entender que o elenco das hipóteses aventadas é meramente exemplificativo. Qualquer outra possibilidade ligada ao produto, quer antes, durante ou após o processo de fabricação, pode implicar a qualificação do defeito - que sempre gera dano. Assim, por exemplo, pode-se falar no transporte do produto, na sua guarda, na confecção, enfim, não há alternativa capaz de excluir o produto da incidência legal. Nesse sentido entram no rol, também, a oferta e a publicidade relativa ao produto e que possam causar dano (cf. arts. 30, 31, 36 e 37)". ${ }^{1429}$

Afora isso, ressai à evidência, que as informações insuficientes ou inadequadas sobre sua utilização e riscos integram a concepção legal de defeito do produto firmada na Lei 8.078/90 (art. 12, caput, in fine), e aqui a matéria já foi examinada à exaustão. ${ }^{1430}$

Desprovidas de suporte fático-jurídico, nesta quadra, vagas e superficiais assertivas como: a) inexiste defeito de informação relativamente ao produto comercializado (cigarro); b) os riscos associados ao seu consumo são de amplo conhecimento público, mesmo antes da existência das cláusulas de advertência, e por isso situam-se dentro da expectativa legítima ou razoável do consumidor; e c) ninguém jamais precisaria ser advertido dos riscos (públicos e notórios).

Ao rigor desse raciocínio, neste contexto de ignorante escuridão ou de claridade manipulada, pergunta-se: é possível falar-se em risco razoavelmente esperado? É possível falar-se em expectativa legítima do consumidor? É possível falar-se em patamar da normalidade e da previsibilidade do risco?

Certo que somente um não rotundo responde a essas indagações, até porque as empresas de tabaco, mesmo quando indagadas pelo Congresso Norte-Americano (veja-se a dimensão da audácia!), nunca assumiram ou ratificaram com a

\footnotetext{
${ }^{1429}$ Comentários..., cit., p. 186.

${ }^{1430}$ C.f., o que foi dito nos tópicos: elementos inerentes à economia de massa (item 8.2), conhecimento público dos riscos (item 8.4), a questão da publicidade e das advertências (item 8.5), um histórico de respeito à lei (item 8.6) e a questão do livre arbítrio (item 8.7).
} 
necessária riqueza de detalhes e transparência, sponte propria, aquilo que sustentam ser periculosidade inerente do produto e/ou risco socialmente conhecido e disseminado.

Tão-só a irrestrita, a correta, a ampla, a adequada e a ostensiva informação (CDC, arts. $8^{\circ}$ c.c. $9^{\circ}$ ), concedida num regime de plena transparência e de respeito à confiança depositada, é que admite a noção de riscos razoavelmente esperados pelos consumidores. Ou, na assertiva de Arruda Alvin, “(...) o uso que deverá ser o considerado correto para o produto, para os efeitos da valoração da sua segurança, é exatamente aquele que se dessume de toda a informação que o cerca, especialmente a publicitária, destinada a influenciar o convencimento do consumidor (ver comentários ao artigo $8^{\circ}$ ). O risco razoável irá depender também das informações preventivas que devem, necessariamente, acompanhar o produto 'normalmente perigoso' (ver artigo $9^{\circ}$ ), ou seja, aquele que por sua própria natureza ou fruição apresenta algum grau de periculosidade ou nocividade". ${ }^{1431}$

Em outra obra James J. Marins de Souza desenvolve a idéia, afirmando que, “(...) há inegável proporção direta entre o grau de informação franqueado ao consumidor acerca de sua correta fruição, ou, nos termos do art. $8^{\circ}$ normal fruição e a segurança que o produto ou serviço apresenta, ou seja, quanto mais eficientemente o fornecedor propicia as indispensáveis informações sobre as características do produto ou serviço que possam de alguma forma preveni-lo ou orientar o utente sobre a melhor forma de usufruir o bem objeto da relação de consumo evitando eventuais perigos, mais seguro será considerado o produto ou serviço, para os efeitos legais, em benefício da segurança do consumidor. Ao contrário, se o fornecedor omite, intencionalmente ou não, características essenciais ao produto, especialmente aquelas que possam relacionar-se com riscos afetos à segurança e saúde dos consumidores, estará violando o sistema protetivo do Código". ${ }^{1432}$

E essa transparência, como se percebe a alho desarmado, não é, nem nunca foi, a tônica do procedimento adotado pelas companhias de tabaco.

Força é concluir, analisado-se as propriedades e os efeitos nocivos do fumo, que a mera ruptura das expectativas legítimas do consumidor, fundadas na sua inerente confiança e tuteladas por normas específicas, basta para materializar o que a Lei 8.078/90 chama de fato do produto (ou apenas defeito) e, consequentemente, impor uma reparação que na indenização se efetiva, porquanto, “(...) o produto pode ser

${ }^{1431}$ Código do Consumidor comentado..., cit., p. 108. 
defeituoso apesar de oferecer toda a segurança que legitimamente dele se espere. Aliás, esse é o elemento-chave e mais forte do defeito: a surpresa. O produto parece seguro, mas causa dano. Esse é que é o problema". ${ }^{1433}$

${ }^{1432}$ Responsabilidade da empresa..., cit., p. 126/127.

${ }^{1433}$ Luiz Antonio Rizzatto Nunes. Curso..., p. 266. 


\section{CAPÍTULO VII \\ RESUMO ANALÍTICO DA PROPOSTA}

\section{PROPOSIÇÕES ANALÍTICAS}

1.1 A tentatica de se construir uma teoria geral de proteção ao consumidor parte de três pilares: as Disposições Gerais da Lei 8.078/90, a Política Nacional das relações de consumo e os Direitos Básicos do consumidor.

$1.2 \mathrm{O}$ qualificativo da ordem pública não permite que as partes optem, mediante simples convenção, por afastar o microssistema protetivo instituído pelo CDC, salvo quando houver - nele próprio e para tanto - autorização expressa, como nas hipóteses de convenção coletiva (art. 107).

1.3 É esse o caráter inderrogável do Código, dirigido a proporcionar um equilíbrio entre consumidor e fornecedor, inviabilizando a obtenção de indevidas vantagens contratuais. A autonomia privada, assim, cede ao interesse social; no entanto, sempre no intuito de melhor proteger o sujeito mais fraco da relação.

1.4 A atribuição do caráter de ordem pública ao CDC provoca o ingresso do intérprete nas trilhas sinuosas do conflito de leis no tempo, em que ganham destaque as teorias de Roubier e de Matos Peixoto, principalmente quanto aos graus de retroatividade e a similitude entre os conceitos de incidência imediata e de retroatividade mínima.

1.5 A despeito do leading case do STF (ADI 493-0), não se pode perder de vista que também a defesa do consumidor alçou status de garantia fundamental, o que torna impossível cogitar-se de direito adquirido ao abuso e/ou da legitimidadede ato jurídico formalmente perfeito, porém ilícito ou inválido; daí porque, de modo excepcional, a retroatividade mínima deve ser admitida pelo sistema.

1.6 A defesa do consumidor como dever do Estado (valor social), a abranger de todos os poderes constituídos (Executivo, Legislativo e Judiciário), não se restringe pelo dogma da preservação do ato jurídico supostamente perfeito (valor individual).

1.7 Isto significa que o CDC disciplina os efeitos de negócios jurídicos que lhe são anteriores, dês que produzidos após a sua vigência. Raciocínio que também se projeta sobre as alterações legislativas supervenientes, a exemplo da que reduziu a multa moratória 
máxima de $10 \%$ para $2 \%$, a se concretizar mediante alteração ou simples adequação contratual.

$1.8 \mathrm{O}$ diálogo das fontes surge como importante mecanismo para a solução desses conflitos temporais, coordenando e harmonizando as diversas fontes legislativas plúrimas de um único ordenamento sistêmico, cada vez mais fluído e complexo, sem prévia exclusão de qualquer delas, num processo de coerência derivada.

1.9 O CDC expressamente admite esse diálogo (art. $7^{\circ}$, caput); contudo, com regência autônoma e primazia hierárquica, restringe a aplicação conjunta e útil das normas esparsas no sistema sempre em prol do consumidor.

1.10 Independentemente da repercussão social e da indisponibilidade do objeto, o caráter de interesse social outorgado às normas de consumo legitima o Ministério Público a defender, mediante Ações Coletivas, os interesses e os direitos individuais homogêneos dos consumidores.

1.11 Os elementos formadores da relação de consumo são o consumidor e o fornecedor (subjetivo), que fazem movimentar no mercado o núcleo determinante da circulação de riqueza: produtos e serviços (objetivo).

1.12 É irrelevante a relação de direito material primária que envolva as partes. Se evidenciados os pressupostos subjetivo e objetivo ela também será de consumo e, assim, preferencialmente regida pela Lei 8.078/90, à exceção daquelas de caráter trabalhista.

$1.13 \mathrm{O}$ CDC é uma lei principiológica que promove um corte horizontal no ordenamento jurídico, a atingir toda e qualquer relação inserida no seu âmbito, o que relega as outras leis, ainda válidas, a uma aplicação tão-só subsidiária.

1.14 São duas as categorias de consumidor: o próprio e o equiparado, que abrange a coletividade de pessoas, as vítimas do evento e todas as pessoas expostas às práticas comerciais e à proteção contratual.

$1.15 \mathrm{O}$ conceito de consumidor próprio veicula: dois critérios identificadores (pessoa física ou jurídica), dois núcleos de conduta (adquire ou utiliza) e um elemento finalista (destinatário final). A capacidade civil não foi erigida em sua elementar, pois numa economia de massa, formatada por ajustes impessoais, o ordenamento jurídico valora condutas que independem da vontade negociar das partes.

1.16 Trata-se do reconhecimento social de que simples ações humanas, com ou sem capacidade, bastam a estabelecer vínculos obrigacionais; daí a moldura da contratação de fato e do comportamento concludente. 
1.17 A norma não faz distinção: toda e qualquer pessoa jurídica (microempresa, multinacional, associação, fundação, etc.) pode ser consumidora. Essa foi a opção do legislador brasileiro, mas a proteção legal dependerá da análise concreta, caso a caso, da presença, ou não, do elemento teleológico.

$1.18 \mathrm{O}$ verbo adquirir vincula diretamente o consumidor e o fornecedor, enquanto o núcleo de conduta utilizar ampara aqueles que, mesmo sem adquirir, manejam ou consomem produtos e serviços no mercado.

1.19 As teorias finalista e maximalista não bastam para explicar o elemento teleológico do conceito de consumidor. A primeira, restritiva, por não admitir a utilização do bem ou do serviço para produção, ainda que indiretamente, chega a ser contra legem ao excluir a pessoa jurídica da proteção do Código. A segunda, ampliativa, contenta-se com a atuação do sujeito como destinatário fático do produto ou do serviço, o que confere um perfil por demais elástico não desejado pelo legislador.

1.20 Há de se compreender que o CDC regula a oferta de produtos e de serviços no mercado, independentemente do destino que lhes possa ser dado. Se os bens de consumo são acessíveis a qualquer pessoa, como opção do próprio risco assumido pelo fornecedor no exercício da atividade economicamente lucrativa explorada, a relação será de consumo.

1.21 A ideia de um consumidor equiparado parte da observação de que muitas pessoas, mesmo não sendo consumidoras stricto sensu, podem ser atingidas ou prejudicadas pelas atividades dos fornecedores no mercado.

1.22 Não há mais apenas a tutela individual do adquirente direto ou do usuário final. Defende-se os interesses sociais da massa de consumidores que intervém nas relações de consumo. A terminologia "equiparado" não implica nenhuma distinção de ordem prática ou jurídica entre os consumidores.

1.23 A equiparação de todas as vítimas do evento aos consumidores (art. 17) se justifica ante a potencial gravidade que pode resultar do fato do produto ou do serviço. Isto não alcança, entretanto, os efeitos do vício do produto ou do serviço (arts. 18 e ss), pois aí disciplina o Código lesões de menor gravidade ao consumidor.

$1.24 \mathrm{O}$ defeito, na sua essência, representa um plus em relação ao vício. É o vício qualificado pela ocorrência de dano, material ou moral, que extravasa o próprio produto ou serviço, alcançando tanto o consumidor próprio quanto eventuais terceiros estranhos à relação consumerista primária. 
1.25 Todavia, essa projeção externa lesiva não desqualifica a inicial moldura de vício; logo, mesmo no caso defeito, as possibilidades asseguradas nos arts. $18, \S 1^{\circ}$, 19 e 20 da Lei 8.078/90 permanecem à disposição do consumidor, pena de se mitigar o direito básico à ampla reparação do prejuízo.

$1.26 \mathrm{O}$ consumidor equiparado pela mera exposição (art. 29) encerra uma espécie de conceito difuso, porquanto reconhece que desde sempre todas as pessoas são consumidoras por estarem potencialmente expostas a toda e qualquer prática comercial. É a mais importante, ampla e abrangente norma extensiva prevista no CDC.

1.27 Fornecedor é todo aquele que provisiona o mercado, disponibilizando produtos e serviços ao consumidor. É gênero do qual o fabricante, o produtor, o construtor, o importador e o comerciante são espécies.

1.28 Nenhuma pessoa jurídica está, em princípio, excluída da abrangência legal. Pouco importa a forma da sua constituição, se sociedades civis (cooperativas inclusive) ou se comerciais e empresariais. Sua sujeição ao conceito de fornecedor dependerá, no caso concreto, da análise do modo como atua no mercado de consumo.

1.29 As instituições financeiras são fornecedoras. A matéria foi pacificada com o julgamento de improcedência, pelo STF, da ADI 2591, até porque é o sistema financeiro nacional que deve respeito à defesa do consumidor, um dos princípios gerais da ordem econômica (CF, art. 170, V).

1.30 Produto é qualquer bem, móvel ou imóvel, material ou imaterial, cuja representação primeira é o crédito.

1.31 Durável é o produto em que o consumo não importa sua imediata destruição física, ainda que não tenha sido pensado para vários usos (v.g., descartável); enquanto o não durável têm sua essência comprometida pela utilização ordinária.

$1.32 \mathrm{O}$ produto enviado sem prévia solicitação do consumidor a tipifica prática abusiva e se equipara à amostra grátis e libera o consumidor do pagamento. Mesmo gratuito, o produto permanece acobertado pelas garantias do CDC.

$1.33 \mathrm{O}$ conceito de serviço abrange qualquer atividade fornecida no mercado de consumo, pública ou privada, mediante remuneração (direta ou indireta). A única exceção material se atrela às relações de caráter trabalhista.

1.34 Embora quase sempre não duráveis, a se esgotarem com a prática da atividade humana dirigida, os serviços podem ser duráveis se houver estipulação contratual nesse sentido (força vinculante da oferta) ou se deixarem como resultado um produto. 
1.35 A política nacional das relações de consumo, que não se esgota em mera política de consumo, tende a privilegiar as necessidades da demanda e não as conveniências da oferta. Há de se indagar o que o mercado precisa e não o que o mercado aceita.

$1.36 \mathrm{O}$ art. $4^{\circ}$ do CDC estabelece parâmetros que devem nortear todo e qualquer ato de governo (Executivo, Legislativo e Judiciário), compatibilizando e harmonizando os interesses envolvidos. Funciona como norma-objetivo, devendo o intérprete repudiar qualquer solução hermenêutica que não se adéqüe aos princípios e aos fins nele previstos.

1.37 A vulnerabilidade, espinha dorsal da proteção ao consumidor, mas não uma elementar do seu conceito jurídico, é direito material outorgado a todos que a lei considera consumidores, pessoa jurídica inclusive.

1.38 Não é o vulnerável que será, per se, consumidor, mas todo o consumidor é materialmente vulnerável, sendo ele pessoa física ou jurídica, profissional ou não. Evidenciado o elemento teleológico (destinatário final), ressai ex vi legis a vulnerabilidade, que não se confunde com a hipossuficiência.

1.39 A hipossuficiência é um plus em relação à vulnerabilidade, que é aferida mediante um critério subjetivo, consumidor a consumidor. É característica restrita àqueles que, além de vulneráveis, vêem-se agravados nessa situação por sua individual condição de carência cultural, material ou de ambas.

1.40 A hipossuficiência ganha especial relevo como um dos requisitos para a inversão do ônus da prova, sua finalidade única. É instituto ontologicamente processual e tem como espécies a técnica, a jurídica e a fática (sócio-econômica e/ou informacional).

1.41 A ação governamental pretendida pelo legislador impõe ao Estado a necessidade de estar sempre apto ao utilizar os instrumentos legais no intuito de estimular a criação, a manutenção e a ampliação de mercados, além de incentivar os fornecedores a criarem, às suas expensas, tanto meios eficientes de controle de qualidade e segurança quanto mecanismos alternativos de solução de conflitos de consumo.

1.42 Dois exemplos bem sucedidos de autocontrole são a autorregulamentação da publicidade pelos próprios agentes do mercado (CONAR e CBARP) e o recall, este a funcionar como agente minimizador de danos dotado de essência preventiva.

1.43 Corolário da transparência o recall funciona como inteligente e eficaz instrumento de comunicação positiva entre fornecedor e consumidor, em especial quanto ao conhecimento de periculosidade ínsita posterior à introdução do produto ou do serviço 
no mercado; entretanto, sem nenhuma interferência na disciplina estruturante da responsabilidade civil.

1.44 O CDC consagra a inviabilidade de abuso no mercado. E esse abuso, na maior das vezes, se revela em práticas do comércio, em cláusulas contratuais e na cobrança de dívidas.

1.45 As práticas abusivas, comuns como a oferta e a publicidade, correspondem a comportamentos, contratuais ou não, que abusam da boa-fé e/ou da situação de inferioridade econômica ou técnica do consumidor. Sua origem está no abuso do poder econômico (sentido vertical), verdadeiras condições irregulares de negociação, que se concretizam pela mera potencialidade de dano. É conceito fluído e flexível, daí o caráter meramente exemplificativo das hipóteses previstas no art. 39 do Código.

1.46 As cláusulas abusivas, também previstas em rol exemplificativo, relativizam a autonomia da vontade, a impedir a inserção no contrato de dispositivos que reflitam a prepotência do sujeito economicamente mais forte. Elas se conectam ao paradigma da boafé objetiva, a desprezar a verificação do elemento subjetivo do fornecedor. O que interessa é o resultado, o desequilíbrio objetivo da avença, pouco importando que essa cláusula, nula de pleno direito, tenha sido aceita pelo consumidor.

1.47 A repetição dobrada do indébito, na forma do art. 42, par. ún., do CDC exige a conjugação de três pressupostos: a) a cobrança de dívida de consumo; b) o seu efetivo pagamento pelo consumidor e c) o engano injustificável do fornecedor.

1.48 Ao contrário do Código Civil, restrito às cobranças judiciais (as conhecidas demandas), o CDC deixa claro que o consumidor tem hipotético direito de repetição dobrada se, de qualquer maneira, for cobrado de modo indevido, pois o núcleo do tipo é cobrar, que é gênero de conduta.

1.49 A expressão dobro significa que o fornecedor deve restituir ao consumidor aquilo que foi pago mais o equivalente. A soma desses dois valores representa duas vezes o indevidamente exigido. Além disso, o diálogo das fontes permite que o consumidor, mesmo sem nada a pagar, mas injustamente cobrado, à semelhança do art. 940 do CC, possa receber aquilo que dele se exigiu.

1.50 Como exceção ao viés objetivo do Código, forte no necessário equilíbrio que deve reger essa especial relação jurídica, o engano justificável libera da sanção do dobro o fornecedor (a parcela paga sem causa será sempre repetível), a quem cabe demonstrar que 
não agiu com dolo ou culpa, o que retoma a clássica moldura da responsabilidade aquiliana.

1.51 A jurisprudência tem se orientado no sentido de que a robusta controvérsia judicial que permeia o tema da cobrança de juros e de encargos pelas instituições financeiras arreda os pressupostos autorizantes da devolução em dobro.

1.52 Teoricamente é possível distinguir os cadastros dos bancos de dados. Nos primeiros, as informações partem do consumidor e se dirigem à fornecedor certo e determinado; enquanto nos segundos, no seu próprio interesse, a informação é obtida pelos fornecedores no intuito de alimentar o mercado. Ambos têm natureza pública e estão submetidos às normas do CDC.

1.53 As inexatidões devem ser corrigidas de imediato, prazo razoável mínimo a ser aferido caso a caso, e comunicadas aos potenciais destinatários da informação dentro de cinco dias úteis. Por isso, é que a lei impôs ao arquivista, não ao credor, o dever de comunicar o consumidor, por escrito e previamente, sobre a abertura do registro. A norma é cogente e se refere a qualquer novo registro. Pouco importando de onde tenham vindo as informações registráveis (v.g., cartório de protesto).

1.54 A inadequação, formal ou material, da restritiva gera danos extrapatrimoniais. E a responsabilidade do credor é solidária, caso tenha fornecido as informações ao arquivista, seu parceiro negocial, autêntico preposto cobrador.

1.55 A manutenção indevida de registro depreciativo, originalmente legítimo, é tão grave quanto a inscrição sem causa. A mesma diligência adotada para a negativação deve permear a conduta dos credores e dos arquivistas no sentido inverso, cancelando a restritiva quando a sua causa geradora não mais exista no mundo jurídico, até porque essa informação há de ser corrigida de imediato.

$1.56 \mathrm{O}$ prazo máximo de manutenção das restritivas de crédito é de 5 anos contados do dia em que o registro se tornou possível: o vencimento da obrigação, pena de se permitirem anotações perpétuas, p. ex., se as informações passassem de um arquivista para outro no último dia do prazo da sua vida útil e assim por diante; no entanto, se prescrita a pretensão de crédito, não a meramente executiva, não mais podem ser disponibilizados esses dados.

$1.57 \mathrm{O}$ equilíbrio é a pedra angular da relação de consumo, a harmonizar os interesses envolvidos no intuito de impedir o confronto ou o acirramento de ânimos. Esse 
princípio, na busca do direito justo, limita os da obrigatoriedade e da autonomia da vontade.

1.58 Transparência é clareza qualitativa e quantitativa da informação. Objetivo implícito em quase todos os dispositivos do CDC e supõe a boa-fé e a reta intenção dos fornecedores. Traduz-se na oportunidade que deve ser dada ao consumidor tanto de conhecer os produtos e serviços que lhe são oferecidos quanto de lhe propiciar o prévio conhecimento do conteúdo do contrato.

$1.59 \mathrm{O}$ ideal de transparência, nos seus três graus (esclarecer, aconselhar e advertir) inverteu os tradicionais papéis dos sujeitos no mercado. Aquele que necessitava atuar, informar-se, perguntar, conseguir conhecimentos técnicos ou informações suficientes para realizar um bom negócio (caveat emptor), o consumidor, passou à confortável posição de titular de um direito subjetivo à informação; enquanto aquele que se encontrava na segura posição passiva, o fornecedor, passou a ser sujeito de um novo dever de informação (caveat vendictor), lídima conduta ativa de informar.

1.60 A manifestação de vontade do consumidor é dada almejando alcançar determinados interesses legítimos. No sistema do CDC leis imperativas irão proteger a confiança que o consumidor depositou na prestação contratual e na sua adequação ao fim razoavelmente esperado, o que também inclui a segurança do produto ou do serviço fornecido.

1.61 Dessa confiança decorrem três deveres anexos fundamentais: o de informar, o de cooperar e o de cuidado (segurança). Apesar de laterais ou secundários, enquanto contratuais, esses deveres representam verdadeiras obrigações acessórias a indicar que a relação contratual obriga não somente ao cumprimento da obrigação principal.

$1.62 \mathrm{O}$ cheque pós-datado, que é instituto jurídico e não apenas instrumento da praxe do mercado, tem natureza contratual e, por isso, o fornecedor que o aceita assume uma obrigação de não fazer, consistente em abster-se de apresentar o título ao sacado antes da data definida com o consumidor; logo, se quebrar a legítima confiança que lhe foi depositada (autêntica ruptura do contrato), responderá objetivamente pela violação.

1.63 A troca imotivada de mercadorias, dentro de uma panorama de boa-fé objetiva do consumidor, é prática que o fornecedor não pode recusar. É mais um risco inerente à liberdade de empreender e de explorar o mercado. Nos Estados Unidos da América, berço do capitalismo, a política de respeito à confiança depositada pelo consumidor é tão intensa 
que chega a prestigiar não só a troca de mercadorias, mas também a própria devolução total ou parcial - do dinheiro.

1.64 A garantia legal de adequação do produto ou do serviço - a qualidade para o atingimento do fim a que se destinam, com base em parâmetros de segurança, de durabilidade e de desempenho - independe de termo expresso, vedada a exoneração contratual do fornecedor, bem como a estipulação de cláusula que impossibilite, exonere ou atenue a obrigação de reparar em decorrência dos defeitos e/ou dos vícios encontrados.

1.65 Essa garantia de adequação é implícita ao objeto do contrato, irrestrita e incondicional, assegurando sua funcionabilidade ao alcançar tanto o fornecedor direto quanto outros fornecedores da cadeia de produção durante a vida útil do bem de consumo, mesmo se transmitido a sucessivos consumidores (produtos usados).

1.66 Os prazos de reclamação são os mesmos para os vícios de fácil constatação (aparente) ou os ocultos, fixando o legislador a diferença pela durabilidade, ou não, do produto ou do serviço. O termo inicial da contagem também é distinto (entrega efetiva do produto ou execução do serviço para um e quando ficar evidenciado o problema para o outro), mas prevalece a intenção de que consumidor tenha um contato real com o produto ou com o serviço para que a adequabilidade possa ser concretamente aferida.

1.67 A garantia contratual, que funciona tal qual um seguro deriva da vontade do fornecedor direto ou indireto, conquanto facultativa, é complementar à legal; daí porque o prazo para reclamar legalmente previsto continua o mesmo, mas o seu dies a quo é postergado para o final desse acréscimo de tempo. É dizer: com o término da garantia contratual têm início os prazos legais para o consumidor apresentar sua reclamação.

1.68 Não se vislumbra, per se, abusividade na conduta do fornecedor que oferece a garantia estendida, sobretudo porque o consumidor - se a adquirir - ficará livre, durante o prazo da avença, de discussões sobre a origem temporal do vício oculto, se antes ou se depois da vida útil do bem da vida adquirido ou utilizado.

1.69 Quanto ao sentido de obstar, não se pode perder de vista que a decadência tem um prazo a cumprir, ou seja, uma vez superada a causa obstativa ele vai, sem alterar sua natureza (e isso é importante), fluir novamente, o que põe de lado a ideia de mero limite de tempo para o exercício de direito subjetivo potestativo e impede possa alçar a inicial decadência contornos de prescrição, muito menos permitir que assuma tônus de uma ou de outra a depender da pretensão subsequente deduzida pelo consumidor. 
1.70 Tendo em vista que os prazos decadenciais do CDC são bastante exíguos, considerando a finalidade de proteção ao consumidor imposta pela eficácia condicionante dos princípios protetivos da Parte Geral, o melhor é conferir ao verbo obstar o sentido de invalidar o prazo já transcorrido, o que se assemelha ou se aproxima das hipóteses de interrupção.

$1.71 \mathrm{O}$ prazo de prescrição, que disciplina a reparação dos danos causados por defeito, é de cinco anos. Seu termo inicial depende do conhecimento do dano e da identificação do nexo de causalidade com o produto ou o serviço defeituoso.

1.72 No âmbito das demandas coletivas, a prescrição deveria guardar ressonância com a espécie de direito metaindividual por elas tutelado; daí porque a pretensão ligada aos individuais homogêneos se sujeitaria às mesmas regras da tutela individual de direitos disponíveis. O STJ, no entanto, tem se inclinado a reconhecer um lapso extintivo autônomo para as demandas não individuais, aplicando a elas analogicamente o prazo prescricional de cinco anos da ação popular, independentemente da natureza dos direitos nelas debatidos.

$1.73 \mathrm{O}$ diálogo das fontes impõe sejam considerados os prazos de decadência e de prescrição mais elásticos previstos no sistema, sem prejuízo das demais garantias asseguradas pelo CDC, materiais e processuais.

$1.74 \mathrm{O}$ curso do prazo prescricional é modulado pelas normas gerais constantes no Código Civil, tanto para a suspensão quanto para a interrupção. Impossível é a analogia com dispositivo vetado ou com hipótese ontologicamente distinta (decadência).

1.75 Se qualquer pessoa jurídica pode ser considerada fornecedora, a pública inclusive, o serviço público também está inserido no objeto das relações de consumo, mas sempre vinculado às suas características fundamentais: a adequação e a eficiência, além da continuidade para aqueles tidos como essenciais.

1.76 Não são o preço e o seu pagamento que determinam a prestação do serviço público, mas a lei. Ou seja, com ou sem pagamento do preço (tarifa), o Estado não pode eximir-se de prestar o serviço público, como determina a lei, seu único móvel.

$1.77 \mathrm{O}$ interesse da coletividade que permite a interrupção do fornecimento do serviço público essencial só pode ser a fraude praticada pelo usuário, único compatível com a dignidade da pessoa humana, com a justiça, com a solidariedade e com a defesa do consumidor. O importante, neste tema, é esclarecer a confusão entre o direito de crédito que tem o fornecedor (vinculado ao risco da sua atividade) e o direito que ele não tem de, 
sponte propria, cessar a prestação do serviço, notadamente se a hipótese versar sobre dívida pretérita, apenas diferenças de consumo.

1.78 A jurisprudência do STJ e do STF, ao distinguirem as figuras do consumidor e do contribuinte, se inclinam em relegar a disciplina do CDC apenas aos serviços públicos uti singuli, com remuneração específica por taxas ou tarifas. Aqueles outros, prestados uti universi diretamente pelo Estado, mantidos pelos tributos gerais, estariam fora do seu âmbito de cobertura.

1.79 A responsabilidade do agente prestador de serviço público, sem embargo do comando específico insculpido no art. $37, \S 6^{\circ}$, da $\mathrm{CF}$, quanto aos vícios e aos defeitos, fica restrita ao cumprimento (total ou parcial) da obrigação inadimplida e/ou à reparação dos danos causados, haja vista não existir espaço para restituição ou abatimento.

1.80 Conquanto esteja pacificado na jurisprudência infraconstitucional que é legítima a cobrança da tarifa básica de assinatura pelo uso dos serviços de telefonia fixa, ainda se acredita que esse encargo não é taxa nem tarifa, por isso que a operadora não pode fazer, em seu único e exclusivo benefício, uma espécie de mix, ou seja, obter - a um só tempo - o pagamento compulsório pela mera disponibilidade da taxa e o flexível regime contratual da tarifa.

1.81 As relações humanas devem se pautar por um padrão ético de confiança e lealdade, indispensável ao próprio desenvolvimento da convivência social. A expectativa de um comportamento adequado por parte do outro é uma postura indissociável da vida de relação, pressuposto da sua viabilidade. Os direitos devem ser exercitados de boa-fé; as obrigações têm de ser cumpridas de boa-fé; daí porque foi crescendo uma noção de boa-fé como uma regra de conduta, ética da confiança que dará o critério para a valoração judicial do comportamento.

1.82 Foi o Código Civil alemão $(B G B)$, fundamentado no seu tríplice alicerce (o direito romano, a ética cristã e o direito germânico), que reavivou a concepção romana de boa-fé, agora endereçada ao juiz, que terá no seu processo intelectual interpretativo de criação um valor autônomo não relacionado com a vontade dos sujeitos envolvidos.

1.83 A boa-fé apresenta dois sentidos diferentes: de estado psicológico do agente (subjetiva) e de regra de conduta (objetiva), este sim encerra conteúdo de princípio. A boa-fé subjetiva, assim, corresponde ao estado psicológico da pessoa, à sua intenção, ao seu convencimento - individual e equivocado - de estar agindo de forma a não prejudicar outrem na relação jurídica. Já a boa-fé objetiva significa uma regra de conduta de acordo 
com os ideais de honestidade e lealdade, isto é, as partes contratuais devem agir conforme um modelo de conduta social (com honestidade, retidão, lealdade e probidade), sempre respeitando a confiança e os interesses do outro.

1.84 A cláusula geral da boa-fé objetiva contém implícita uma regra de direito judicial, dirigida à atuação do juiz, que lhe impõe, por delegação, ao examinar o caso concreto, primeiramente fixar a norma de dever de acordo com a realidade do fato e o princípio a que a cláusula geral adere, para somente num segundo momento confrontar a conduta efetivamente realizada com aquela que as circunstâncias recomendavam, independentemente da verificação de má-fé subjetiva dos contratantes, a retomar a moldura da objetividade do injusto.

1.85 São três as principais funções da boa-fé objetiva: a) fonte autônoma de deveres especiais de conduta (supplendi ou ativa); b) limite ao exercício de direitos subjetivos (corrigendi gratia ou reativa) e c) critério de interpretação e concreção dos negócios jurídicos (adjuvandi ou interpretativa).

1.86 Como fonte autônoma de deveres especiais de conduta, percebe-se que o ajuste obriga não somente ao cumprimento do seu componente principal (a prestação), mas também das várias obrigações acessórias ou dos deveres a ele anexos, revertendo a inobservância de qualquer deles em quebra positiva do contrato, passível de reparação específica independentemente de culpa.

1.87 Integram esse grupo de deveres anexos os: de informar (esclarecimento, aconselhamento e consentimento informado), de colaborar (lealdade ou cooperação), de cuidado e de sigilo.

1.88 A atuar como limite ao exercício de direitos subjetivos, relega-se à boa-fé objetiva a função de obstar comportamentos que contrariem os pressupostos da lealdade e da probidade, ou seja, o exercício inadmissível de posições jurídicas (abuso de direito). Isto abrange dois grupos de casos: a) quando por meio do exercício do direito não são realizados os interesses protegidos pelo contrato ou pela lei e b) quando o titular do direito, ao exercê-lo, em qualquer fase contratual, se põe em contradição com seu comportamento anterior (venire contra factum proprium).

1.89 São quatro os pressupostos do venire: a) um comportamento; b) a geração de uma expectativa; c) o investimento nesse estado anímico causado, não necessariamente econômico e d) a conduta contraditória à inicial, referência da confiança depositada. 
1.90 No direito à saúde o venire contra factum proprium se atrela à investigação do consentimento informado, que tem - de fato - duas representações, pois da mesma forma se irradia sobre a pessoa do paciente, a quem cabe prestar todas as informações ao profissional da saúde, permitindo possa ele - a um só tempo - formular corretamente as hipóteses diagnósticas e sugerir o procedimento adequado.

1.91 A boa-fé objetiva, por via da suppressio, impede o exercício de um direito subjetivo não exercido em certas circunstâncias e durante um determinado lapso de tempo (conduta negativa em regra). É o abandono de uma posição jurídica que impossibilita ainda que momentaneamente - a realização de um direito, agora desprovido de eficácia por violar uma situação de justificada confiança de que ele nunca seria exercido. Dessa inação surge a surrectio, uma nova posição.

1.92 Caso o adimplemento, mesmo incompleto, se aproxime do resultado final pretendido quando do ajuste, sob o crivo das legítimas expectativas criadas e da reciprocidade das prestações assumidas, possível não mais será a resolução do vínculo. É o que se entende por adimplemento substancial, que pode qualitativo e/ou quantitativo de acordo com a importância - em todos os seus contornos - que tiverem as prestações dentro do espectro unitário do negócio, reservando-se ao credor apenas a busca de perdas e danos.

1.93 Também atua a boa-fé objetiva como critério de interpretação e concreção dos negócios jurídicos, que é dirigida à vontade contratual, não àquela que cada um dos sujeitos aderentes pura e simplesmente declararam; importante é o consenso a partir da intenção comum que se revelou de modo objetivo no ajuste, afastando-se a força vinculante das palavras que constaram do instrumento, agora relativizadas.

1.94 A boa-fé objetiva representa um limite à liberdade de contratar, haja vista suas exigências éticas submeterem e restringirem a autonomia da vontade, permitindo a construção de um sistema aberto, que evolui e se perfaz dia a dia pela incorporação dos variados casos apresentados pela prática social. É, neste passo, um importante referencial na conciliação de interesses conflitantes.

1.95 No CDC o princípio da boa-fé objetiva foi tratado nos arts. $4^{\circ}$, III, e 51 , IV, ambos a manter ou restabelecer o equilíbrio das posições contratuais, não apenas o econômico, uma vez que, em sede de relação de consumo, a regra é o desequilíbrio de forças, dependendo a composição real da análise de todo o ajuste.

1.96 A incidência desse princípio é ampla e irrestrita em todas as fases do ajuste, vistos que os contratantes são obrigados a guardar, assim nas negociações preliminares e 
conclusão do contrato, como em sua execução e fase pós-contratual, os princípios da probidade e da boa-fé.

1.97 Embora a República Federativa do Brasil tenha adotado, ao menos no plano formal, modelo aparentemente centralizador ao estabelecer que a saúde é direito de todos e dever do Estado, o fato é que a prévia ciência da impossibilidade de a estrutura assim se manter, no âmbito material, fez com que a Constituição de 1988 permitisse, conquanto sob a regulamentação, a fiscalização e o controle governamental, a execução dos serviços de saúde por terceiros.

1.98 Como atividade econômica, ainda que complementar ao sistema único, a assistência à saúde é livre à iniciativa privada, dês que se observem três regras mínimas: a) as entidades filantrópicas e sem fins lucrativos preferem às demais; b) é defeso destinar recursos públicos para auxílios ou subvenções a essas instituições, se empresariais e c) salvo previsão legal, direta ou indiretamente, empresas ou capitais estrangeiros não podem disso participar.

1.99 A atuação privada, nesse atuação, basicamente, está dividida em duas modalidades organizacionais de empresas: as de plano de saúde e as seguradoras, tratadas indistintamente pelo gênero operadoras. Distinguem-se em dois aspectos fundamentais: a) o modo como os serviços de saúde são prestados e b) a forma de remuneração. Enquanto nos planos, via de regra, o atendimento médico é feito por profissionais próprios ou credenciados, mediante custo pago diretamente pela empresa; as seguradoras agem por terceiros, reembolsando as despesas geradas. O mecanismo, contudo, não desconhece o possível trânsito nessa atuação.

1.100 A quase comutatividade desse contrato aleatório, representativo de uma lídima garantia, mais acentuada no seguro-saúde, cujo conteúdo não trata de questões verdadeiramente imprevisíveis (doença), só pode ser alcançada se a conduta das partes for dirigida pela boa-fé, tanto a subjetiva quanto a objetiva, no curso de toda a relação jurídica obrigacional. As falsas declarações, a partir de tais premissas, ganham especial relevo, sobretudo no que concerne às chamadas doenças preexistentes.

1.101 Preexistentes são as doenças e as lesões que o consumidor, ou seu responsável, saiba ser portador ou sofredor à época da contratação de planos ou de seguros privados de assistência à saúde. Necessários, assim, dois requisitos cumulativos: um objetivo, de existência da moléstia ou da lesão no momento da formação do contrato; outro subjetivo, do seu conhecimento por parte do consumidor ou do responsável. 
1.102 De qualquer forma, a existência de doença não impede a pessoa de contratar um plano de saúde, sendo inviável a recusa da operadora com base nesse motivo. Ela deve oferecer ao aderente duas alternativas: ou o aceita no plano com uma restrição temporária de cobertura, que não pode ultrapassar vinte e quatro meses, ou o aceita no palno sem qualquer restrição, mas, em contrapartida, lhe impõe um encargo financeiro extraordinário decorrente da preexistência e que também não pode ultrapassar esse mesmo prazo.

1.103 Esses dois únicos efeitos (cobertura parcial ou agravo do contrato) apenas são oponíveis ao consumidor, à sua escolha, durante os primeiros vinte e quatro meses do ajuste, prazo este de natureza decadencial, que uma vez escoados impossibilita qualquer restrição fundada em doença preexistente, volvendo as partes ao sinalagma obrigacional primitivo, ainda que o aderente tenha agido de má-fé.

1.104 As operadoras têm nesses vinte e quatro meses, presumida a boa-fé, o ônus de provar os quatro elementos fundamentais ao reflexo liberatório pretendido: a) existência da moléstia ou da lesão quando da contratação (objetivo); b) o seu conhecimento por parte do consumidor ou do responsável (subjetivo); c) o nexo etiológico entre o problema passado conhecido e a atual necessidade do aderente (causal); d) a relevância da omissão, o que se descaracteriza caso a doença não se manifeste por longo período de adimplemento do contrato.

1.105 A configuração e o exercício do direito de arependimento dependem da presença simultânea de quatro elementos: a) relação de consumo (sujeitos e objeto); b) aperfeiçoada fora do estabelecimento comercial do fornecedor; c) especialmente por telefone ou a domicílio (rol exemplificativo); e d) dentro de no minimo sete dias. Trata-se de um prazo legal de reflexão, um certo período de decantação em que o consentimento do consumidor se exercita em câmera lenta.

1.106 A medida se justifica em virtude da circunstância de que, fora do estabelecimento comercial, sem dúvida, o consumidor tem menos condições de avaliar o objeto adquirido (produto ou serviço), pois esse tipo de negócio é nitidamente mais agressivo, imprimindo à relação de consumo um desequilíbrio acentuado, o que o desobriga de anunciar as razões determinantes do seu arrependimento.

1.107 Seu caráter é de arbítrio absoluto (prerrogativa do consumidor), não se podendo, sob pretexto algum, limitar o exercício de tal direito, potestativo e não receptício, que vale pela só exteriorização da vontade de se arrepender, ou seja, independe de 
justificativa de ordem subjetiva. Representa autêntica denúncia vazia do contrato de consumo.

1.108 Caso o fornecimento de produtos ou a prestação de serviços tragam inerente também a assinatura de contrato (ainda que em momentos distintos), prevalece a contagem do prazo mais benéfica para o consumidor, haja vista sua acentuada vulnerabilidade pela submissão às técnicas agressivas de venda fora do estabelecimento comercial e a impossibilidade de ter tido acesso físico ao produto.

1.109 A intenção do CDC é evitar as vendas emocionais e proteger a vontade racional do consumidor, por isso que a disciplina do arrependimento há de aparzir sua incidência também sobre aquelas hipóteses em que o consumidor é atraído para dentro do estabelecimento comercial do fornecedor, a convite seu, e, em razão da estratégia adotada, é submetido à forte pressão psicológica que o impede de refletir e de manifestar livremente seu desejo.

1.110 À semelhança de precedentes internacionais, o legislador de 1990 preocupouse em fixar uma série de direitos básicos do consumidor. Em certa medida, o elenco de princípios do artigo $4^{\circ}$ da Lei 8.078/90 transporta-se aos direitos básicos dos consumidores num processo lógico de explicitação. A base, entretanto, continua a mesma: a) a vulnerabilidade; b) o dever governamental; c) a adequação; d) a boa-fé objetiva; e) a informação; e f) o acesso à justiça.

$1.111 \mathrm{O}$ direito à ampla informação, inexoravelmente derivado do princípio da transparência, se projeta em várias oportunidades na Lei 8.078/90, mas uma das suas principais vertentes, sem dúvida, por força das consequências que encerra, está na nova concepção de oferta (publicidade).

1.112 Se na concepção tradicional a oferta já era criadora de vínculos, na do CDC este poder de vinculação - declaração negocial voltada ao consumo - é ampliado, até porque toda informação, mesmo em forma de publicidade, suficientemente precisa constitui uma oferta (uma proposta contratual), vinculando o fornecedor. Formam quase uma unidade semântica, atuando a publicidade como meio de comunicação e de divulgação da oferta.

1.113 A atividade de comunicar-se por publicidade é uma opção do fornecedor (livre determinação), que, por suas características de atividade profissional (risco próprio) e por seus importantes e irreversíveis efeitos na sociedade, faz nascer vínculos obrigacionais. 
1.114 Oferecida a mensagem, por qualquer meio, ainda antes da formação do ajuste, sem necessidade de expressa aceitação, fica o fornecedor a ela vinculado, podendo o consumidor exigir seu cumprimento em congruência com a oferta que se fez anunciar, pois o caráter objetivo da oferta impede, via de regra, a retratação. É uma subordinação irresistível (verdadeiro estado de sujeição) que consiste na necessidade de suportar as consequências jurídicas da atuação do outro (consumidor).

1.115 Há, contudo, hipóteses de exclusão ou limitação da obrigatoriedade: a) as reservas; b) o termo; c) o caso fortuito e a força maior externos; d) a diversidade entre o anunciante e o fornecedor; e) o erro objetivo.

1.116 Distinguem-se a oferta ao público (negócio bilateral receptício) e a promessa ao público (negócio unilateral) porque nesta, embora a declaração seja feita a todos (indeterminação inicial), ela se concretizará em alguém em particular: a indeterminação é provisória. Na oferta ao público a indeterminação é definitiva, porque não visa a distinguir um entre o público, mas muitos e quantos se apresentarem como aceitantes, identificados ou interminados na massa.

1.117 Os princípios da transparência e da boa-fé exigem da oferta ao público a expressa menção da quantidade dos bens em estoque, a afastar a reserva tácita. $\mathrm{O}$ número de bens em estoque, indicados na oferta, além disso, deve ser compatível com o meio escolhido para a divulgação da proposta.

1.118 A oferta será obrigatória para o fornecedor durante o tempo nela fixado. Todavia, o silêncio do anúncio não implica a vinculação perpétua do fornecedor ao seu cumprimento, visto que a força obrigatória da oferta estará subordinada a um prazo razoável, assim entendido de acordo com as particularidades do caso concreto e do produto ou do serviço proposto.

1.119 Em regra, porque não participou da elaboração ou da veiculação do anúncio, o terceiro não pode ser obrigado a cumprir a oferta. Entretanto, persiste a vinculação se o terceiro mantém com o anunciante vínculo jurídico obrigando esse cumprimento (v.g., contrato de franquia ou de distribuição exclusiva) ou se de alguma maneira (v.g., captação de clientela, venda de outros produtos ou serviços, etc.) obtiver proveito da atividade promocional anunciada.

1.120 Havendo divergência entre a vontade interna e a vontade declarada, prevalece em princípio a vontade declarada, se e na medida em que despertou confiança e expectativas legítimas; contudo, forte no necessário equilíbrio entre os valores envolvidos, 
se o outro contratante sabia ou podia saber, razoável e objetivamente, que a vontade declarada não correspondia à vontade interna do seu parceiro, mitiga-se a vinculação.

1.121 Trata-se da teoria da confiança, fundada na aparência de seriedade da oferta (erro despercebido), onde será observada a boa-fé objetiva do consumidor aceitante, sem comprometer a análise de seu elemento subjetivo (má-fé) no caso concreto. De qualquer forma, a escusa fundada no erro é excepcional e sempre objetiva para o fornecedor, que deve conhecer o que oferece ao público, direta ou indiretamente.

1.122 No caso de recusa do cumprimento da oferta, da apresentação ou da publicidade, à livre e exclusiva escolha do consumidor, há três opções: a) exigir o cumprimento forçado da obrigação; b) aceitar outro produto ou prestação de serviço equivalente e c) rescindir o contrato, com direito à restituição de quantia eventualmente antecipada, monetariamente atualizada, e perdas e danos.

$1.123 \mathrm{O}$ poderio econômico - no processo de dominação do mercado, a impor a ideia de consumismo - orientou-se por instrumentos que visavam a dificultar, cada vez mais, a identificação clara da verdade na mensagem publicitária, símbolo próprio e verdadeiro da sociedade moderna, a arte de criar necessidades amparada no seu caráter persuasivo.

1.124 Nada obstante a clássica distinção entre publicidade e propaganda, a primeira com objetivo comercial/econômico e a segunda reservada à propagação de ideias, na linguagem comum as expressões são utilizadas indiferentemente, como sinônimas.

1.125 No confronto entre publicidade e verdade, admite-se algum exagero publicitário, facilmente perceptível, visando a captar a atenção do consumidor, dês que circunstancial às propriedades efetivas do produto ou do serviço anunciado; porém, inaceitável se revela o exagero dirigido às próprias características que se pretende vender, pena de a falta da verdade arranhar a ética constitucionalmente protegida, e com ela a dignidade humana, a justiça, a solidariedade e a boa-fé objetiva.

1.126 Identificam-se três possíveis vícios da publicidade: a) a enganosidade (objetiva); b) a abusividade (subjetiva) e c) a clandestinidade.

1.127 O CDC acolheu o princípio da identificação da mensagem publicitária, variante da transparência e da boa-fé objetiva, por isso que ela só é lícita quando o consumidor puder, fácil e imediatamente, identificá-la como tal. A publicidade que não quer assumir a sua essência, de uma forma ou de outra, dolosa ou inocentemente, objetiva enganar o consumidor. 
1.128 A conhecida técnica do merchandising afronta, de modo direto, a vedação legal; contudo, se perceptível a sua prática não haverá clandestinidade e ilicitude, pois a lei admite o assédio honesto e declarado ao consumidor, rechaçando a clandestinidade. A doutrina aponta o sistema de créditos - antes e depois - do programa onde se explorou a publicidade disfarçada, alertando o consumidor para o seu status de alvo de determinados anúncios, como suficiente para elidir a clandestinidade, o que parece razoável.

1.129 A publicidade enganosa pretende, por meio de ações ou omissões, induzir o consumidor a acreditar em alguma coisa que não corresponda à realidade do produto ou serviço em si. É o erro induzido do consumidor, que não se esgota na parte principal da mensagem. $\mathrm{O}$ anúncio é enganoso antes mesmo de atingir qualquer consumidor em concreto, por issso que não se exige prova de enganosidade real, bastando a mera enganosidade potencial.

1.130 A publicidade abusiva tem um contorno próprio, residual, distinto da enganosidade, o que permite possam os dois vícios conviver simultaneamente na mesma mensagem. É a publicidade antiética, que fere tanto a vulnerabilidade do consumidor quanto valores sociais básicos, não de um consumidor específico, lídimo exercício excessivo do instituto. Considerações individuais não podem ser a pedra de toque para a tutela da coletividade.

1.130 A publicidade comparativa pode ser aceita, dês que seu conteúdo seja objetivo. A comparação e o confronto de dados e características devem ser feitos entre elementos essenciais e verificáveis, não podendo caracterizar concorrência desleal nem denegrir a imagem do produto, serviço ou marca concorrente.

1.131 A contrapropaganda, que tem como objetivo lavar a informação inadequada da percepção do consumidor, restaurando a realidade dos fatos, a despeito do veto presidencial, não está restrita ao âmbito administrativo. O Poder Judiciário, na busca da efetividade da tutela protetiva do Código, pode impor a contrapropaganda.

1.132 A publicidade ilícita enseja o dever de reparação dos eventuais danos causados, ainda que potenciais e/ou difusos. É dizer: a simples divulgação de uma mensagem ilícita (clandestina, enganosa ou abusiva) causa, de forma geral e abstrata, dano extrapatrimonial a todos aqueles que a ela foram expostos, fato lesivo autorizante de reparação pecuniária e/ou de publicidade corretora (contrapropaganda).

1.133 Afora a indiscutível responsabilidade objetiva do fornecedor-anunciante, exclusiva quanto ao cumprimento compulsório da oferta, decorrência do princípio da 
vinculação, exsitem outros três sujeitos envolvidos no processo de gênese da publicidade ilícita: a agência, o veículo de comunicação e as celebridades que a apresentam.

1.134 A agencia ou o publicitário estão subordinados aos preceitos éticos do CBARP; daí porque sua atuação no mercado atrai o dever (jurídico e moral) de ser o primeiro juiz da licitude da mensagem, a qual deu vida e forma, visto que certamente tem, ou no mínimo deveria ter, instrumentos que isso lhe permitissem, inclusive se negando a trabalhar caso fosse exigida a confecção de mensagem clandestina, enganosa ou abusiva. Se assim não age, seja por dolo, seja por culpa caracterizado estará o ato próprio autorizante da sua responsabilidade objetiva e solidária com o seu parceiro de negócio, o fornecedor-anunciante.

$1.135 \mathrm{O}$ veículo de comunicação, por sua vez, não pode só retirar os bônus da mensagem publicitária, que dele depende na origem, como se pudesse ignorar certos valores morais mínimos e fazer circular qualquer tipo de publicidade. Tais empresas, da mesma forma que as agências, tem o dever jurídico e moral de não disseminarem à massa dos seus consumidores a ilicitude da campanha, o que atrai a sua responsabilização objetiva.

1.136 Se o custo da publicidade difundida integra sua receita, o veículo de comunicação passa a ser fornecedor ante o destinatário da mensagem, não para cumprimento compulsório da oferta, mas no que tange à garantia de licitude do que encampa com a sua estrutura de penetração social, instrumento de contato com o público, circunstância atrativa da obrigação de verificar, tecnicamente, o conteúdo do anúncio, medida protetiva que não se equipara à censura prévia.

1.137 Quanto às personalidades, não é possível admitir-se plena isenção daquele que empresta a sua imagem - geralmente conhecida e capaz de gerar confiança no espírito do consumidor - a uma publicidade que sabia ou deveria saber enganosa e/ou abusiva; contudo, a pedra de toque está no modo da sua atuação no anúncio. Se garantir certo resultado ou assegurar a existência de determinada propriedade do produto ou do serviço, como se testemunha de eficácia fosse, sem dúvida e sponte propria estará o garoto propaganda se erigindo à condição de fornecedor, restrito - é verdade - à ilicitude da mensagem que patrocina.

1.138 Mas a responsabilidade não pode ser objetivamente solidária. Isto porque essas pessoas, quase sempre artistas ou atletas, ao contrário das agências e dos veículos de informação, não têm na publicidade seu meio de vida, são anunciantes eventuais, não 
habituais; assim, deles não pode ser exigido um preparo técnico apto a permitir uma minuciosa investigação acerca da ilicitude da mensagem, quadro a ser analisado em cada caso concreto a partir do critério do consumidor razoavelmente atento e advertido, a atrair uma verificação do elemento subjetivo.

1.139 As provedoras de conteúdo não interferem na conexão do usuário à Internet, primeira etapa de deslocamento virtual, visto que, só com o speedy, em razão da tecnologia de banda larga (ADSL), o consumidor já consegue se lançar nos domínios da rede mundial de computadores.

1.140 Há que se distinguir o provedor de acesso (PSCI) do provedor de conteúdo e informação (PSI). O primeiro disponibiliza o aparato técnico para tornar possível o acesso do usuário ao ambiente virtual da conexão, o que integra o típico serviço de telecomunicações; enquanto ao segundo se reserva - no exercício de típico serviço de valor adicionado - a intermediação do trânsito pela rede, aproveitando a estrutura material da empresa de telefonia.

$1.141 \mathrm{O}$ que a LGT veda é que as empresas concessionárias do serviço exclusivo de telecomunicações prestem - ainda - serviço de provedor de conteúdo ou informação. $\mathrm{O}$ serviço de banda larga oferecido como apto a estabelecer uma conexão em alta velocidade e instantânea com a Internet está inserido no modelo típico dos serviços de telecomunicações.

1.142 A identificar um direito subjetivo do consumidor ao equilíbrio contratual, é que um dos direitos básicos do consumidor permite a modificação das cláusulas que estabeleçam prestações desproporcionais ou sua revisão em razão de fatos supervenientes que as tornem excessivamente onerosas. Nada obstante a nulidade de pleno direito que contamina as cláusulas abusivas o sistema jurídico autoriza o consumidor, no seu exclusivo interesse, forte no princípio da conservação dos negócios jurídicos, ao invés de desconstituí-lo total ou parcialmente, a adequar o vínculo obrigacional a parâmetros equilibrados e justos.

1.143 Ao modificar o ajuste o magistrado deve fazer a integração das demais cláusulas e do sentido estabelecido no contrato, mesmo alterando a sua economia primária, no esforço de mantê-lo em vigor. Importante é que nessa espécie de lesão consumerista a modificação das cláusulas depende exclusivamente da desproporcionalidade das prestações estabelecidas, fator permeado de tônus objetivo. 
1.144 A revisão é pura e unilateral em benefício do consumidor, pois não se tolera a divisão de riscos. Ela se contenta com o exame objetivo dos fatos supervenientes à contratação que tornem excessivamente onerosas as prestações, a tornar desnecessário perquirir sobre previsibilidade. Exige-se apenas a quebra da base objetiva do negócio.

1.145 A base objetiva se liga ao desaparecimento do fim essencial do contrato ou à destruição da relação de equivalência, elementos graduados pela boa-fé objetiva, em especial quando da concreta avaliação do nível de desequilíbrio gerado pelo fato superveniente sobre as prestações e da suportabilidade desse dano pelas partes.

1.146 Dentro da perspectiva da indeclinável facilitação da defesa dos direitos do consumidor é que devem ser analisados quatro institutos fundamentais à consecução dos objetivos protetivos traçados pelo sistema: a) o foro de eleição; b) a inversão do ônus da prova; c) a desconsideração da personalidade jurídica e d) a solidariedade ampla.

1.147 Quanto ao foro de eleição, a despeito das regras gerais de competência dispostas no Código de Processo Civil, visando a evitar a indesejada preponderância de um contratante sobre o outro, impõe-se a análise do abuso em cada caso concreto; no entanto, em sede da relação de consumo primária não há espaço para essa variante, pois a eficácia protetiva tanto constitucional quanto do CDC acabaram por criar uma espécie de competência territorial absoluta, a sempre facilitar a atuação processual do consumidor, na exata medida do seu interesse.

1.148 A competência do juízo em que reside o consumidor - próprio ou equiparado - é absoluta, devendo ser declarada de ofício. Ressalte-se que essa orientação está consagrada perante o STJ há mais de treze anos, inclusive com expresso afastamento do seu enunciado 33 no âmbito consumerista.

1.149 Em prestígio ao necessário equilibro que deve ser - a todo tempo concretizado pelo intérprete, essa prerrogativa do consumidor nasce circunscrita a certas bases lógicas inquebrantáveis. Exige-se o nexo etiológico entre o foro pretendido e a amplitude da sua defesa, o que arreda a escolha aleatória em detrimento do fornecedor. É que a ninguém, consumidor inclusive, é dado escolher o juízo onde pretende demandar.

1.150 Se a regra geral considera o domicílio do devedor como o lugar do pagamento (quérable), conversão da dívida em portable implica ato de renúncia, a exigir pleno exercício de vontade livre, o que não ocorre na relação de consumo. Por isso, diferença alguma há na manifestação de vontade aderente à eleição de foro contratual ou ao lugar do pagamento em título de crédito, pois ambos lhe foram impostos. 
1.151 A inversão do ônus da prova, fenômeno de direito material enquanto não concretizada, só ganha relevo a critério do juiz, segundo as regras ordinárias de experiência, dês que presentes um dos seus requisitos (não cumulativos): a verossimilhança da alegação ou a hipossuficiência do consumidor, por isso é ope iudicis. Seu espectro de incidência é geral, alcançando todas as situações em que, pela disciplina comum, a prova do fato caberia ao consumidor.

1.152 Entende-se a verossimilhança, no seu efeito prático, como a grande possibilidade - próxima de um juízo objetivo de certeza no caso concreto - de terem os fatos se desdobrado do modo descrito pelo consumidor. É uma valoração de quase mérito, a permitir que o juiz - seja no saneador, seja na sentença - avalie os pontos controvertidos da lide com base naquilo que ordinariamente acontece.

1.153 A hipossuficiência, que não se confunde com a vulnerabilidade, é instituto ontologicamente processual e, por isso, sua presença deve ser verificada caso a caso com o escopo de viabilizar seu único efeito: a inversão do ônus da prova. Ela comumente se projeta no mundo de três formas: a técnica, a jurídica e a fática (sócio-econômica ou informacional).

1.154 A despeito das duas clássicas correntes sobre o momento da inversão (entre o pedido inicial e o saneador ou quando do julgamento final), as quais não se excluem, o importante é visualizar que não existe um tempo certo ou errado para o juiz inverter o ônus da prova, seja porque o Código assim não definiu, seja porque cada parte deve tratar a marcha processual cuidando do exercício frutuoso da sua atividade probatória.

1.155 Como premissa, em litígio de consumo, o juiz pode distribuir o ônus da produção de determinada prova a qualquer tempo, desde a decisão liminar positiva que admite a demanda até na própria sentença, quando avalia os fatos provados e os não provados, afinal a possibilidade de inversão está prevista na lei, que a ninguém é dado desconhecer (LICC, art. $3^{\circ}$ ), o que afasta o perigo de surpresa e não implica prejulgamento, haja vista ser impossível antever o resultado da prova que teve invertido o ônus da sua produção.

$1.156 \mathrm{O}$ próprio sentido da inversão está em relegar a prova à parte que tenha melhores condições - principalmente técnicas, mas também econômicas - de produzi-la; aliás, são esses os contornos da teoria da carga dinâmica. Diante disso, a negativa de incluir o ônus econômico da prova no âmbito da inversão acaba por desconsiderar o caráter prevalecente da Lei 8.078/90. 
1.157 A inversão econômica não impõe que o fornecedor produza essa ou aquela prova. A essência de ônus permanece intacta; no entanto, tal qual orienta o STJ, embora ele não fique obrigado a antecipar os encargos a ela necessários, se não o fizer, presumir-se-ão verdadeiros os fatos contra ele afirmados. Possível, então, mas sempre em benefício do consumidor, separar essas duas inversões de ônus: o da prova e o do seu encargo econômico.

1.158 A desconsideração da personalidade jurídica tem seu fundamento nos princípios gerais de proibição do abuso de direito e permite ao Judiciário, excepcionalmente e no caso concreto, ignorar a personificação societária, como se a pessoa jurídica não existisse, atribuindo condutas e responsabilidades diretamente aos sócios e não à pessoa jurídica. $\mathrm{O}$ direito privado comum autoriza essa medida de exceção quando caracterizados o desvio de finalidade ou a confusão patrimonial.

1.159 A preocupação com a necessidade de se reparar, de modo efetido, todos os direitos lesados dos consumidores fez com que o CDC alargasse o espectro desse instrumento para também permitir seja desconsiderada a pessoa jurídica sempre que sua personalidade for, de alguma forma, ainda que meramente objetivo, obstáculo ao ressarcimento de prejuízos a eles impostos.

1.160 A teoria menor da desconsideração, acolhida pelo CDC, incide com a mera insolvência da pessoa jurídica, independentemente da existência de desvio de finalidade ou de confusão patrimonial. Para ela, o risco empresarial inerente às atividades econômicas não pode ser suportado pelo terceiro que contratou com a pessoa jurídica, mas pelos seus sócios e/ou administradores, ainda que demonstrem conduta administrativa proba e não exista prova de proceder culposo ou doloso.

$1.161 \mathrm{O}$ instante adequado para a parte cogitar da desconsideração da personalidade jurídica, via de regra, é o da concreta insuficiência do patrimônio societário frente aos seus débitos, matéria a ser enfrentada na fase de cumprimento de sentença; contudo, no âmbito das relações de consumo, embaraço algum há na prévia identificação de ser a medida necessária desde a inicial, sendo legítimo, prima facie, trazer ao polo passivo da demanda os sócios da empresa fornecedora.

1.162 No âmbito dos vícios, problemas ontologicamente menos graves, não há dificuldade em se perceber que o Código coloca todos os partícipes do ciclo de produção como responsáveis diretos, de forma que o consumidor poderá escolher e acionar diretamente qualquer dos envolvidos. 
1.163 Quanto ao fato do produto, nada obstante a disciplina do art. 13 do CDC, que fixa uma espécie de responsabilidade subsidiária, o ponto de partida deve ser a percepção de que o fabricante, o produtor, o construtor e o importador atuam em parceria com os comerciantes, seus lídimos distribuidores, quase sempre numa espécie de rede contratual conexa ou coligada, nesse processo de captação de clientela; é dizer, um fornecedor a se valer da reputação comercial do outro.

1.164 Aquele que se aproveita do nome, do conceito e da respeitabilidade dos fabricantes para atrair clientes no mercado de consumo, à evidência, contribui, ainda que tenuamente, para a causação do dano; daí porque na responsabilidade do fornecedor imediato a solidariedade também permanece intacta.

1.165 Isso não esvazia o espaço de incidência do art. 13 do CDC, que fica reservado à posterior equação dos interesses econômicos dos sujeitos envolvidos da cadeia de fornecimento. A rápida e eficaz tutela dos direitos do consumidor não se harmoniza com essas discussões sobre amplitude de responsabilidades, as quais melhor se afinam à esfera regressiva.

1.166 Acrescente-se a nova disciplina do defeito prevista no art. 931 do $\mathrm{CC}$, aplicável às relações de consumo, que não estabelece diferença entre os vários agentes da cadeia de fornecimento. Imputa-se responsabilidade objetiva e solidária a quem tenha colocado o produto no mercado, o que inclui o comerciante.

1.167 A expressão livre encontra base constitucional em três momentos distintos: a) como fundamento da República; b) como seu objetivo; e c) como princípio geral da ordem econômica, enquanto o sistema brasileiro admite apenas a livre iniciativa fundada em valores sociais; logo, percebe-se que a iniciativa não é tão livre assim.

$1.168 \mathrm{O}$ Estado deve garantir a livre iniciativa e a livre concorrência em benefício do consumidor, sob pena de se admitir uma exploração irracional e, até certo ponto, autofágica do mercado, que não pertence exclusivamente aos fornecedores.

$1.169 \mathrm{O}$ fornecedor, quando opta pela livre iniciativa, pelo livre exercício de qualquer atividade econômica, escolhe correr o risco do empreendimento. $\mathrm{O}$ consumidor, ao contrário, nem sempre é livre para autar no mercado, onde age na maior das vezes por necessidade. A liberdade é o oposto de necessidade, por isso nesta hipótese o Estado pode e deve intervir para garantir a dignidade humana.

1.170 A mesma liberdade que assegura ao agente empreendedor a iniciativa de explorar o mercado o vincula, de maneira exclusiva, aos riscos e aos percalços desse 
querer. Ou seja, o exercício dessa prerrogativa relega ao fornecedor todos os riscos da sua atividade econômica, inviabilizando qualquer tentativa de transferência desse ônus, mediante cláusula contratual expressa inclusive.

1.171 Trata-se da teoria do risco do negócio ou do risco da atividade, que deixa solarmente clara a distinção entre a liberdade do fornecedor e a necessidade do consumidor, condutas de mercado que não se confundem. Básico o fundamento: sem repartição adequada dos lucros, não é possível divisão dos riscos.

1.172 É essa a viga mestra da responsabilidade independente de culpa do CDC, mas a análise do elemento subjetivo não é de todo irrelevante, pois a culpa exclusiva do consumidor ou de terceiro rompe o nexo causal. Se concorrente, apenas a recomposição dos danos sofrerá, de modo proporcional, seus efeitos.

$1.173 \mathrm{O}$ estudo dos riscos que permeiam a relação de consumo, a partir do diálogo das fontes, não pode se apartar da disciplina simétrica do art. 927, par. ún, Código Civil. Essa cláusula geral, standard de conduta, fluído e flexível, aparece no sistema modulada por três elementares: atividade, normalmente desenvolvida e risco.

1.174 A atividade não se confunde com ato. Uma atividade é sempre caracterizada por uma série de atos, uma sequência coordenada e organizada, dirigidos à realização de determinado objetivo, um mesmo escopo. Isso firma o caráter do agir normalmente a ponto de excluir do espectro de incidência da norma o ato anormal, dissociado de contexto.

1.175 Não basta a mera repetição de atos, o exercício de uma atividade pressupõe uma sucessão contínua e repetida de atos que se desencadeiam no tempo e implicam mínimo de continuidade e predisposição dos meios empregados em seu desempenho.

1.176 Importante é o risco como atributo dessa atividade, o que distingue atividade de risco e risco da atividade. O fator de imputação da norma é a atividade de risco e não o risco da atividade. $\mathrm{O}$ risco deve ser necessário e não eventualmente presente, o que atrai a importância dos critérios estatísticos nessa definição; daí porque não se pode afirmar que atividades próprias do lazer, como a mera condução de veículo automotor (geradora de certo risco inerente), implicariam responsabilidade objetiva.

1.177 Aquele que exerce normalmente uma atividade perigosa deve ter um cuidado especial para impedir a ocorrência do dano. Se este acontece, presume-se que os cuidados não foram adequados. O perigo deve ser excepcional, porquanto de um modo geral toda a atividade enseja algum tipo de risco; a culpa somente pode ser desconsiderada como 
elemento da responsabilização quando as circunstâncias evidenciarem que a conduta adotada era inadequada ao risco oferecido pela atividade.

1.178 É a produção o fator de risco e não o produto dela resultante. Essa regra de responsabilidade objetiva, restritiva, só terá aplicação se a atividade do agente causador do dano for normalmente arriscada. Se o elemento de risco ou de perigo estiver na própria essência do produto e não no processo de produção, a reparação do dano, também independentemente de culpa, encontrará regência no art. 931 Código Civil.

$1.179 \mathrm{O}$ art. 931 do Código Civil, à semelhança do art. 12 da Lei 8.078/90, tipifica o chamado fato do produto, mas sem o elemento extra do defeito. A consequência, imposta pelo diálogo das fontes, na busca do melhor amparo do consumidor, é ampliar a noção do fato do produto previsto no $\mathrm{CDC}$, tanto para dispensar a ideia do necessário problema agregado como pressuposto da responsabilidade sem culpa quanto para não distinguir, $\mathrm{p}$. ex., a responsabilidade do comerciante.

1.180 No risco integral se diz que a causalidade é pura, independe de qualquer elemento valorativo externo, como na responsabilidade do Estado por danos ambientais e nucleares, bens essencialmente coletivos; daí a socialização dos riscos que a todos interessa e a necessidade até de reparação do dano involuntário. Basta apenas que a conduta humana seja a causa material da eclosão do evento lesivo.

$1.181 \mathrm{O}$ risco mitigado não se contenta com uma causalidade bastante em si mesma, ao contrário, exige um elemento qualificativo externo, que modula o fato danoso. É o caso da responsabilidade sem culpa do CDC que, ao definir a inexistência do defeito como excludente, acabou erigindo esse problema agregado em fator autorizante da obrigação de indenizar.

$1.182 \mathrm{O}$ risco criado vincula à reparação independente de culpa aquele que cria ou expõe outrem a risco, posto que lícita a atividade desenvolvida; no entanto, deve existir um interesse nesse desempenho, mesmo que não seja econômico. Agora, se a atividade for dirigida ao lucro tem-se o risco proveito, representado pela parêmia segundo a qual cabem os ônus àquele que percebe os bônus (ubi commodum, ibi incommodum ou ubi emolumentum, ibi onus).

1.183 É possível identificar-se um desdobramento no risco proveito em face do sujeito passivo do dano: a) o risco de empresa, atrela o empreendedor a qualquer evento danoso inerente ao processo produtivo ou distributivo e b) o risco profissional, se a vítima for empregado ou preposto do titular da atividade econômica. 
1.184 Há, também, o risco defeito e o risco perigo. O risco defeito é o possível comprometimento do objeto da circulação de riqueza (vício ou defeito), enquanto o risco perigo se vincula à exploração de atividade de risco intrinsecamente perigosa; ou seja, que gera perigo mediante desempenho ordinário e não extraordinário, tolerada apenas por ser socialmente útil.

1.185 Pode-se afirmar, nesta quadra, a partir das classificações propostas, que o microssistema da Lei 8.078/90 apresenta, para a responsabilidade civil, o risco proveito (empresa), defeito ou perigo, com causalidade mitigada.

1.186 Se a Política Nacional de Relações de Consumo impõe uma ação governamental voltada a garantir no mercado produtos e serviços com padrões adequados de qualidade e segurança, lídimo programa de intervenção permanente, a prevenção e a precaução, tal qual nos problemas difusos, devem conduzir a direção correta do agir individual.

1.187 A precaução é um princípio que estabelece diretrizes normativas no sentido de evitar o dano individual e/ou coletivo dentro de um contexto de incerteza científica. Isso implica, sempre com base na razoabilidade e na proporcionalidade, a definição de um standard de conduta voltado a realizar os valores da prudência e da segurança. É uma referência indispensável em todas as abordagens relativas aos riscos.

1.188 A precaução se projeta sobre o sistema de responsabilidade civil especificamente no intuito de evitar ou de diminuir o dano, exercendo função preventiva e/ou de gerenciamento de riscos em todas as questões atreladas à segurança social e à do indivíduo, caracterizando-se pela ação antecipada diante do risco ou do perigo.

1.189 É postura de antecipação gerada pela possibilidade de dano grave, de difícil reparação ou até mesmo irreparável. O princípio da precaução deve ser aplicado em situações de dúvida, de incerteza, sempre a atrair uma medida de salvaguarda. Incide a partir de uma moldura indeterminada, quando o conhecimento científico não consegue dar um parecer definitivo de sobre a existência ou a inexistência de perigo.

1.190 Conquanto encerrem conteúdos similares, voltados à busca da segurança exigida pela justiça social e ao controle dos riscos, sempre superiores à zero, não se confundem a precaução e a prevenção. Distinguem-se pelo estágio da incerteza e pela potencialidade do dano dela decorrente.

1.191 Se real o perigo, já constatado de modo científico, o tema é de prevenção; enquanto a precaução se ocupa do risco abstrato, incerto, duvidoso e hipotético. O juízo de 
probabilidade entre elas é distinto: a prevenção se ocupa da probabilidade do dano e a precaução da probabilidade do risco, o risco do risco; logo, é possível afirmar que medidas de precaução, uma vez definida a concretude do perigo, evoluem a posturas de prevenção.

1.192 No CDC tanto a prevenção quanto a precaução são aplicadas nas entrelinhas, informando todo o sistema de contenção de riscos estruturado a partir da garantia geral de segurança imposta, fonte primária dos outros dispositivos que tratam da matéria, seja na sua parte geral (arts. $4^{\circ}, \mathrm{V}, 6^{\circ}$, I, III, VI e VII, $8^{\circ}, 9^{\circ}$ e 10 ), seja na especial (arts. $12, \S 1^{\circ}$, $14, \S 1^{\circ}, 31,37, \S 2^{\circ}, 39$, VIII, 51, I e III).

1.193 Ganha destaque o art. 10 do CDC, que alumia a adoção dessas balizas de prudência. Sua cabeça, expressamente, proíbe o fornecedor - contra quem milita a incerteza científica - de colocar no mercado produto ou serviço que deveria saber apresentar alto grau de nocividade ou periculosidade à saúde ou à segurança do consumidor.

1.194 Lídimo pilar do dever lateral de cuidado, vetor do mínimo ético exigível pela boa-fé objetiva, nesse dispositivo, avultam elementos típicos de precaução; ao passo que a prevenção surge a partir do conhecimento posterior dessa periculosidade, autêntico encargo pós-contratual de vigilância, impondo imediata reação ao Estado $\left(\S 3^{\circ}\right)$ e ao fornecedor $\left(\S 1^{\circ}\right)$, inclusive com o manejo do recall.

1.195 No âmbito do CDC, se bem aplicada, a precaução esvazia a controvérsia sobre a efetiva existência de risco concreto na introdução no mercado de certo produto ou serviço, porquanto a dúvida sobre o risco (o dever saber) implicaria sustar o processo econômico até fosse ela convertida em certeza de segurança (o saber). Ou seja, o fornecedor deve se assegurar dos potenciais riscos apresentados pelo produto antes de introduzi-lo no mercado.

1.196 Seu objetivo é não permitir o dano, numa vertente preventiva da responsabilidade civil; entretanto, mesmo com ele a análise das antecedentes medidas de precaução e de prevenção ainda mantém importância de destaque, sobretudo quanto ao rigor do procedimento adotado como um dos fatores da balança das indenizações.

1.197 Admitida a idéia de ser o risco zero uma ilusão, autêntica utopia impossível de ser alcançada, mesmo com o exercício oportuno das práticas de prudência, não há como dissociar certo fator de risco das vigas naturais do desenvolvimento: o progresso e a pesquisa. 
1.198 Conquanto aplicadas no grau máximo permitido ao fornecedor dentro do atual state of the art da ciência, a prevenção e a precaução permanecem incapazes de frear todos os perigos inerentes, em tese, a certos produtos e serviços; daí o que se entende por risco residual, que - apesar de manter a essência de risco - tem probabilidade mínima de ocorrência.

1.199 Não se trata de considerar culpado aquele que não tomou as medidas de prevenção de risco conhecido e previsível, nem aquele que, na dúvida, não adotou conduta de precaução; interessa, ao revés, que a responsabilidade do fornecedor independe da existência de culpa, apenas a ele interessando o quadro de incerteza (residual ou não) gerado pela sua atividade econômica.

$1.200 \mathrm{O}$ fornecedor não pode optar pelo não manejo eficaz da precaução e da prevenção. Os interesses do consumidor são graduados pela obrigação geral de segurança, por isso sua a legítima expectativa de que os produtos e os serviços disponibilizados no mercado passaram por rígido e sério processo de precaução e, se o caso, após anterior risco hipotético se converter em perigo concreto, tenha ele na prevenção o exercício da transparência e da eticidade legalmente impostas.

1.201 O risco residual, que não deixa de ser risco, também só ao fornecedor interessa, lídima res inter alios frente ao consumidor inocente, cuja atuação no processo produtivo se restringe a mero agente receptor que, materialmente vulnerável, age amparado na confiança do proceder reto do seu parceiro contratual, por isso a ele é intransferível.

$1.202 \mathrm{O}$ completo ressarcimento do dano material causado ao consumidor é intangível, pouco importando se foram bem ou mal empregadas a precaução e a prevenção. Alguma flexibilidade, no entanto, por ser da essência do instituto a valoração subjetiva, é factível no âmbito da reparação extrapatrimonial, sendo permitido ponderar o comportamento diligente do fornecedor atento às medidas de prudência como parcela de destaque na estimativa prudencial.

1.203 Na sociedade de consumo massificado e de risco, constantemente submetida a avanços tecnológicos, é possível que após certo tempo de uso se descubra ser nocivo determinado produto ou serviço. A matriz de segurança esperada se abala, não pela negligência ou por eventual conduta dolosa do sujeito empreendedor, mas pela sua insuperável e severa ignorância de acordo com o mais avançado state of the art, sempre numa concepção objetiva do fornecedor ideal. 
1.204 Apesar do status alcançado no direito estrangeiro, no Brasil o risco do desenvolvimento não foi erigido em excludente de responsabilidade, ressaltada a natureza taxativa dos róis previstos no CDC.

1.205 Não é a evolução científica que cria o problema de essência, ele já existia. Estava lá, só era à época imperceptível; logo, integra ele o risco da atividade e subordina o fornecedor à obrigação de indenizar, admitindo-se - também aqui - uma análise da conduta efetivamente adotada quando da introdução do produto e/ou serviço no mercado e da postura de transparência assumida após a descoberta do problema como componentes a serem considerados na estimativa do prejuízo extrapatrimonial.

$1.206 \mathrm{O}$ risco de desenvolvimento só se ajusta a um risco impensado. Se qualquer dúvida científica, por mínima que seja, permear a análise do fornecedor ideal, a matéria se desloca para um juízo de precaução, com todas consequências da opção livre de manter ou de sustar a disponibilização do produto e/ou do serviço.

1.207 Problema sério ocorrerá quando o conhecimento do risco ou do próprio dano se projetar para todos de forma inegável. É que nunca se terá absoluta certeza de que a ignorância não era privilégio só do consumidor, que não tem acesso ao ciclo produtivo a ponto de constatar se - de fato - o fornecedor foi surpreendido com a descoberta ou se, tal qual se verificou no passado com as empresas fabricantes de cigarro, mascarou a verdade o quanto pôde até que o tempo o desnudou.

1.208 Sem dúvida, a partir do diálogo entre o CDC e o art. 931 do CC, mister se faz revisitar a responsabilidade civil das empresas fabricantes de cigarros, conquanto não se desconheça a postura assumida pela $4^{\mathrm{a}} \mathrm{T}$. do STJ sobre o tema, diametralmente oposta à diretriz que, tímida, de certo modo, vinha ganhando corpo nas Cortes Estaduais.

1.209 Para se balizar os fundamentos da responsabilidade das empresas fabricantes de cigarros, não se pode perder de vista que a exploração comercial do tabaco e da nicotina representa um negócio extremamente lucrativo, mas tolerado pelo Poder Público que, com isso, previne a clandestinidade que uma súbita proibição poderia causar.

$1.210 \mathrm{O}$ fornecedor tem a responsabilidade social de recompor os reflexos ilícitos (danos) gerados pelo exercício da sua atividade lícita. Longe de configurar a inócua excludente do exercício regular de direito, a atividade e/ou o produto de risco explorados pelas companhias de tabaco em muito se aproximam do abuso de direito.

1.211 Um dos maiores abusos possível de ser praticado pelas fabricantes de cigarro é a omissão deliberada dos fatores prejudiciais à saúde dos seus consumidores, 
inexoravelmente vinculados ao consumo do tabaco e da nicotina. Note-se que o dever de bem informar, antes de jurídico, é moral e sua não observância tisna, sem sombra de dúvida, o maior fim social que o exercício de um direito pode almejar: o respeito à dignidade da pessoa humana.

1.212 Ao invés de cumprirem sua obrigação primária de bem informar, o que certamente nada tem a ver com a legislação e os critérios de cada época, muito menos com uma suposta aplicação retroativa da lei, as companhias de tabaco exploram a ignorância e a boa-fé dos consumidores.

1.213 Em países como os Estados Unidos - onde a publicidade do produto ainda é admitida - as companias de tabaco recorrem a técnicas de convencimento ainda mais subliminares e sofisticadas, tendentes a associar o produto a imagens de saúde e de juventude, afastando ao mesmo tempo do consumidor o impacto das advertências sobre a periculosidade do fumo.

$1.214 \mathrm{O}$ usuário de uma droga (nicotina) age por necessidade, não com liberdade, o que afasta o seu livre-arbítrio. Inexiste motivação pessoal e força de vontade contra dependência química. Se a nicotina não pode ser apontada como o motivo primário pelo qual as pessoas fumam, por certo, representa o maior obstáculo para a interrupção do vício.

1.215 Conquanto se admita possa ser o fumo apenas um fator de risco para a aquisição de inúmeras patologias, é certo que compromete e debilita a saúde do fumante, e tal vínculo - ainda que genérico - é suficiente para condicionar seu efeito prejudicial. Ou seja, pode até não ter sido mesmo a causa originária da doença; mas isso não importa, visto que funcionou como causa do agravamento do estado clínico do consumidor doente.

1.216 E o agravamento do estado de saúde é per se um dano, alicerce da obrigação de indeniar. Irrelevante é, assim, presente esse nexo causal, discutir-se a origem da doença, até porque o dano é um só: comprometido estado de saúde do consumidor no seu atual estágio. 


\section{CONCLUSÃO}

Partindo-se da constitucionalização do princípio impositivo da proteção ao consumidor, que deixou patente o propósito intervencionista do Estado em situações de desigualdade e de desequilíbrio obrigacional, chega-se à concretude desse desiderato com a promulgação, em 11 de setembro de 1990, da Lei 8.078.

De importância medular em vários aspectos, cumpre destacar que o Código de Proteção e Defesa do Consumidor representou um deslocamento do centro de gravidade do direito privado e, neste campo, promoveu uma real mitigação do fetichismo do Código Civil como fonte legislativa única para a solução de conflitos.

Em razão do seu caráter principiológico, a Lei 8.078/90 promove um corte horizontal no sistema, atingindo toda e qualquer relação jurídica inserida no seu âmbito; daí a importância de bem compreender a amplitude e a profundidade das suas regras materiais positivas, sobretudo por ser o CDC um microssistema, especial e aberto, diretamente submetido aos parâmetros normativos da Carta Magna.

Há tempos, já nos idos de 1992, com a autoridade de cooautor do anteprojeto do CDC, Nelson Nery Júnior destacava que "os princípios gerais das relações de consumo estão enumerados nos arts. $1^{\circ}$ ao $7^{\circ}$ do Código. Tudo o mais que consta da lei é, por assim dizer, uma projeção desses princípios gerais, isto é, uma espécie de pormenorização daqueles princípios de modo a fazê-los efetivos e operacionalizá-los. Estas normas não são, de regra, programáticas, desprovidas de eficácia, mas concretas cuja eficácia vem descrita em todo o corpo do Código". ${ }^{1434}$

Ao rigor desse raciocínio, o presente trabalho teve o desafio de alumiar esse necessário vínculo entre as partes geral e especial da Lei 8.078/90 e, com isso, efetiva e concretamente identificar os reflexos condicionantes dos seus princípios sobre o direito material positivo das relações de consumo.

$\mathrm{Ou}$, em outras palavras, o direito material de proteção e defesa do consumidor foi investigado e estudado a partir das regras inscritas na Parte Geral do seu Código, lídimo vetor interpretativo nuclear para a correta cognição e aplicação do microssistema instituído pela Lei 8.078/90. 
Com efeito, essa filosofia permeou todo o trabalho exegético desenvolvido, na difícil tarefa de harmonizar os interesses, tensos e em constante ebulição, dos consumidores e dos fornecedores, sujeitos que atuam como indispensáveis fatores vivos de circulação de riqueza no mercado.

Foi o que se percebeu quando do enfrentamento de complexas questões de direito material, v.g., as relativas aos conflitos de direito intertemporal, à adequada inteligência do elemento finalista do conceito de consumidor, ao direito de o sujeito vulnerável receber - mesmo sem pagamento algum - o que dele se cobrou indevidamente, à responsabilidade solidária entre o credor e o arquivista de dados e entre o fornecedor indireto e o comerciante também pelo fato do produto, à correta intelecção do sentido de obstar a decadência, ao termo inicial do praxo de reflexão, à possibilidade de imposição judicial da contrapropaganda, à responsabilidade civil de todos os envolvidos na cadeia da publicidade ilícita, à eventual divergência entre a oferta e o contrato, à inversão do ônus da prova a qualquer momento no processo, inclusive quanto ao seu encargo econômico, ao uso dos prazos extintivos mais elásticos previstos no sistema, e tantas outras.

Eis a original contribuição da tese que ora se propõe à ciência jurídica brasileira: um inovador viés da força normativa autônoma da Parte Geral do CDC que, em última análise, funciona como norma-objetivo tendente a realizar os padrões teleológicos nela definidos e, assim, por carregarem tônus prevalecente explicativo do que já se contém, as regras de organização e de conduta previstas na Parte Especial sofrem seus reflexos condicionantes.

${ }^{1434}$ Os princípios gerais do Código Brasileiro de Defesa do Consumidor. Revista de Direito do Consumidor, São Paulo: RT, v. 3, set.-dez. 1992, p. 51. 


\section{BIBLIOGRAFIA}

AGUIAR JÚNIOR, Ruy Rosado de. Aspectos do Código de Defesa do Consumidor. Revista Ajuris, Porto Alegre: Ajuris, v. 52, p. 167/187, 1991.

. A boa-fé na relação de consumo. Revista de Direito do Consumidor, São Paulo: RT, v. 14, abr.-jun. 1995.

. Extinção dos contratos por incumprimento do devedor. Rio de Janeiro: Aide, 1991.

. Responsabilidade civil no novo Código Civil. Revista do Tribunal de Contas do Estado do Rio Grande do Sul, Porto Alegre, v. 36, mai. 2004, p. 86/90, Edição especial.

ALMEIDA, Carlos Ferreira. Os direitos dos consumidores. Coimbra: Almedina, 1982.

. Direito do consumo. Coimbra: Almedina, 2005.

ALMEIDA, João Batista de. A proteção jurídica do consumidor. $2^{\text {a }}$ ed. São Paulo: Saraiva, 2000.

. Manual de direito do consumidor. $4^{\mathrm{a}}$ ed. São Paulo: Saraiva, 2010.

. A revisão dos contratos no Código do Consumidor. In: MARQUES, Cláudia Lima

e MIRAGEM, Bruno (org.). Doutrinas essenciais. Direito do consumidor. Contratos de consumo. São Paulo: RT, 2011, v. IV.

ALMEIDA, Renato Franco de e COELHO, Aline Bayeri. Assinatura nos serviços de telefonia: $\quad$ ilegalidade. Disponível em http://www1.jus.com.br/doutrina/texto.asp?id=5700.

ALMEIDA COSTA, Mário Júlio de. Direito das obrigações. 9ª ed. Coimbra: Almedina, 2004.

. Direito das obrigações. Coimbra: Almedina, 1979.

ALPA, Guido. Esercizio del diritto e abuso del diritto. In: ALPA, Guido; RUFFOLO, U.; ZENCOVICH, V. Zeno (coord.). Casi e questioni di diritto privato. v. 9 - Atto illecito e responsabilità civile. $8^{\mathrm{a}}$ ed. Milão: Giuffrè, 2000.

e BESSONE, Mario. La responsabilitá del produttore. $4^{\mathrm{a}}$ ed. Milão: Giuffrè, 1999. . Diritto privato dei consumi. Bologna: Il Mulino, 1986.

AMARAL, Francisco. Direito civil, introdução. $3^{\mathrm{a}}$ ed. Rio de Janeiro: Renovar, 2000. 
AMARAL JÚNIOR, Alberto do. A boa-fé e do controle das cláusulas contratuais abusivas nas relações de consumo. Revista de Direito do Consumidor, São Paulo: RT, v. 6, abr.-jun. 1993.

AMARAL, Luiz. O código, a política e o Sistema Nacional de Defesa do Consumidor. Revista de Direito do Consumidor, São Paulo: RT, v. 6, abr.-jun. 1993.

AMORIM FILHO, Agnelo. Critério científico para distinguir a prescrição da decadência e para identificar as ações imprescritíveis. RT, São Paulo: RT, v. 300, p. 7/37.

ANDRADE, Fábio Siebeneichler. Considerações sobre o regime da prescrição no Código Civil de 2002 e seus efeitos quanto à lei de defesa do consumidor. In: PASQUALOTTO, Adalberto e PFEIFFER, Roberto Augusto Castellanos (coord). Código de Defesa do Consumidor e o Código Civil de 2002. Convergências e assimetrias. RT: São Paulo, 2005.

ANGEIROS, Luciana. Internet - O Direito na era virtual. In: SCHOUERI, Luís Eduardo (org.). $2^{\mathrm{a}}$ ed. Rio de Janeiro: Forense, 2001.

ANTUNES, Paulo de Bessa. Direito ambiental. $11^{\mathrm{a}}$ ed. Rio de Janeiro: Lumen Juris.

ARAUJO, Luiz Alberto David e NUNES JÚNIOR, Vidal Serrano. Curso de direito constitucional. $4^{\mathrm{a}}$ ed. São Paulo: Saraiva, 2001.

ARRUDA ALVIM NETO, José Manoel. Tratado de direito processual civil. São Paulo: RT, 1990, v. 1.

; et alii. Código do Consumidor comentado. $2^{\mathrm{a}}$ ed. São Paulo: RT, 1995.

ATALIBA, Geraldo. Hipótese de incidência tributária. $2^{\mathrm{a}}$ ed. São Paulo: RT, 1975.

AZEVEDO, Álvaro Villaça. Teoria geral dos contratos típicos e atípicos. São Paulo: Atlas, 2002.

- Teoria geral das obrigações e responsabilidade civil. 11ª ed. São Paulo: Atlas, 2008.

AZEVEDO, Antonio Junqueira de. A boa fé na formação dos contratos. Revista de Direito do Consumidor, São Paulo: RT, v. 3, set.-dez. 1992.

. Responsabilidade pré-contratual no Código de Defesa do Consumidor: estudo comparativo com a responsabilidade pré-contratual no direito comum. Revista de Direito do Consumidor, São Paulo: RT, v. 18, abr.-jun. 1996.

. O direito pós-moderno e a codificação. Revista de Direito do Consumidor, São Paulo: RT, v. 33, jan.-mar. 2000.

. Estudos e pareceres de direito privado. São Paulo: Saraiva, 2004. 
BACCARO, Renato F. Da Desnecessidade de contratar o segundo provedor de acesso à Internet e as liminares favoráveis ao consumidor. Revista de Direito do Consumidor, São Paulo: RT, v. 48, out.-dez. 2003.

BANDEIRA DE MELLO, Celso Antônio. Curso de direito administrativo. $4^{\mathrm{a}}$ ed. São Paulo: Malheiros, 1993. . Prestação de serviços públicos e administração indireta. $2^{\mathrm{a}}$ ed. São Paulo: RT, 1983.

BARRETO, Wanderlei de Paula. O princípio da boa-fé na experiência alemã. Revista autônoma de direito privado, Curitiba: Juruá, v. 2, jan.-mar. 2007. . O princípio da boa-fé na experiência alemã. Palestra proferida no II Congresso Nacional de Direito Civil. Desafios e perspectivas da nova codificação: contratos, responsabilidade civil e relações de consumo. Em homenagem ao Ministro Sálvio de Figueiredo Teixeira. CIETP: Curitiba, Paraná, setembro/2004.

BASTOS, Celso Ribeiro. Curso de direito constitucional. $13^{\mathrm{a}}$ ed. São Paulo: Saraiva, 1990.

BAUDRILLARD, Jean. A sociedade de consumo. Trad. de Artur Mourão. Lisboa: Edições $70,1981$.

BECK, Ulrich. La societé du risque - Sur la voie d'une autre modernité. Trad. do alemão. Paris: Alto-Aubier, 2001.

BECKER, Anelise. A doutrina do adimplemento substancial no direito brasileiro e em perspectiva comparativista. Revista da Faculdade de Direito da Universidade Federal do Rio Grande do Sul. Porto Alegre: Livraria dos Advogados, n. 1, v. 9, nov. 1993.

BENETI, Sidnei Agostinho e BENETI FILHO, Sidnei Agostinho. In: TEIXEIRA, Sálvio de Figueiredo (coord.). Direito \& Medicina. Aspectos jurídicos da medicina. Belo Horizonte: Del Rey, 2000.

BENJAMIN, Antônio Herman de Vasconcellos e. O direito do consumidor. RT, São Paulo: RT, v. 670, p. 49.

; et alii. Código Brasileiro de Defesa do Consumidor, comentado pelos autores do anteprojeto. $4^{\mathrm{a}}$ ed. São Paulo: Forense Universitária, 1996.

; et alii. Comentários ao Código de Defesa do Consumidor. $2^{\mathrm{a}}$ ed. São Paulo: RT, 2006.

; et alii. Manual de direito do consumidor. São Paulo: RT, 2008. 
; et alii. Código Brasileiro de Defesa do Consumidor, comentado pelos autores do anteprojeto. Direito Material. 10 a ed. Rio de Janeiro: Forense, 2011.

BERNAL, José Manuel M. El abuso del derecho. Madrid: Montecorvo, 1982.

BESSA. Leonardo Roscoe. O consumidor e os limites dos bancos de dados de proteção do crédito. São Paulo: RT, 2003.

- Vícios dos produtos: paralelo entre o CDC e o Código Civil. In: PASQUALOTTO, Adalberto e PFEIFFER, Roberto Augusto Castellanos (coord). Código de Defesa do Consumidor e o Código Civil de 2002. Convergências e assimetrias. RT: São Paulo, 2005.

; et alii. Manual de direito do consumidor. São Paulo: RT, 2008.

BEVILÁQUA, Clóvis. Theoria geral do direito civil. $6^{\text {a }}$ ed. São Paulo: Editora Paulo de Azevedo, 1953.

BITTAR, Carlos Alberto. Responsabilidade civil nas atividades perigosas. Responsabilidade civil - doutrina e jurisprudência. São Paulo: Saraiva, 1984.

. Responsabilidade civil nas atividades nucleares. São Paulo: RT, 1985. . Reparação civil por danos morais. $2^{\mathrm{a}}$ ed. São Paulo: RT, 1994.

. Teoria e prática da concorrência desleal. São Paulo: Forense Universitária, 2005.

BOBBIO, Norberto. Teoria do ordenamento jurídico. São Paulo/Brasília: Pollis/Universidade de Brasília, 1990, p. 92. . Teoria generale del diritto. Torino: Giappichelli, 1993.

BONFIN, Paulo Andreatto. Considerações sobre a ilegalidade da tarifa de assinatura mensal de telefone fixo. $\quad$ Disponível em http://www1.jus.com.br/doutrina/texto.asp?id=5701.

BOURGOIGNIE, Thierry. O conceito jurídico de consumidor. Revista de Direito do Consumidor, São Paulo: RT, v. 2, 1992.

. O conceito de abusividade em relação aos consumidores e a necessidade de seu controle através de uma cláusula geral. Revista de Direito do Consumidor, São Paulo: RT, v. 6, abr.-jun. 1993.

. Sistemas de fiscalização do mercado e segurança dos produtos de consumo. Revista de Direito do Consumidor, São Paulo: RT, v. 76, out.-dez. 2010.

BOUTONNET, Mathilde. Le principe de précaution en droit de la responsabilité civile. Paris: LGDJ, 2005.

BRECCIA, Umberto. Le Obrigazioni (Trattato do direito privado). Milano: Giuffré, 1991. 
CÁCERES, Eliana. Os direitos básicos do consumidor - uma contribuição. Revista de Direito do Consumidor, São Paulo: RT, v. 10, abr.-jun. abr1994.

CAENAGEM, R. C. Van. Uma introdução histórica ao direito privado. Trad. Carlos Eduardo Machado. São Paulo: Martins Fontes, 1995.

CALDEIRA, Mirella D'Angelo. O conceito de consumidor no parágrafo único do art. $2^{\circ}$ do Código de Defesa do Consumidor. Artigos de doutrina: Saraiva, disponível em www.saraivajur.com.br.

. e CALDEIRA, Patrícia. O conceito de profissionais liberais: uma nova proposta. Revista dignidade. Programa de Pós-graduação em direito da Universidade Metropolitana de Santos (Unimes). Ano 1, nº 1, 2002.

CALIXTO, Marcelo Junqueira. A responsabilidade civil dos fornecedores pelos riscos de desenvolvimento. Rio de Janeiro: Renovar, 2004.

CAMPOS, Maria Luiza de Sabóia. Publicidade: responsabilidade civil perante o consumidor. São Paulo: Cultural Paulista, 1996.

CANOTILHO, J. J. Gomes. Direito constitucional e teoria da constituição. $4^{\mathrm{a}}$ ed. Coimbra: Almedina.

CARVALHO SOBRINHO, Linneu Rodrigues de. Seguros e planos de saúde. São Paulo: Juarez de Oliveira, 2001.

CARVALHO, Nelly. Publicidade: a linguagem da sedução. $3^{\mathrm{a}}$ ed. São Paulo: Ática, 2004.

CASADO, Márcio Mello. Proteção do consumidor de crédito bancário e financeiro. $2^{\mathrm{a}}$ ed. São Paulo: RT, 2006.

CASO, Rúben Héctor Compagnucci de. La doctrina de los próprios actos y la declaración tácita de la voluntad. In: La Ley, t. 1985-A, Buenos Aires, 1985.

CASTRO. Fabiana Maria Martins Gomes de. Sociedade de risco e o futuro do consumidor. Revista de Direito do Consumidor, São Paulo: RT, v. 44, out.-dez. 2002.

CAVALCANTI, Francisco de Queiroz Bezerra. Comentários ao Código de Proteção e Defesa do Consumidor. Belo Horizonte: Livraria Del Rey, 1991.

CAVALIERI FILHO, Sérgio. Programa de responsabilidade civil. $5^{\mathrm{a}}$ ed. Rio de Janeiro: Malheiros, 2003.

. Programa de direito do consumidor. São Paulo: Atlas, 2008.

CENEVIVA, Walter. Publicidade e direito do consumidor. São Paulo: RT, 1991.

CERVEIRA FILHO, Mário Mercadorias: trocá-las ou não? Artigos de doutrina: Saraiva, disponível no site www.saraivajur.com.br. 
CHAVES, Antônio. Responsabilidade pré-contratual. Rio de Janeiro: Forense, 1959.

CHAVES, Rui Moreira. Código da publicidade anotado. $2^{\mathrm{a}}$ ed. Coimbra: Almedina, 2005.

CHINELlATO, Silmara Juny de Abreu e MORATO, Antonio Carlos. In: NERY, Rosa Maria de Andrade e DONNINI, Rogério (coord). Responsabilidade civil. Estudos em homenagem ao professor Rui Geraldo Camargo Viana. São Paulo: RT, 2009.

COELHO, Fábio Ulhoa. Desconsideração da personalidade jurídica. São Paulo: RT, 1989.

. O empresário e os direitos do consumidor. São Paulo: Saraiva, 1994.

- Código Comercial e legislação complementar anotados. $3^{\text {a }}$ ed. São Paulo: Saraiva, 1997.

. Manual de Direito Comercial. 14ª ed. São Paulo: Saraiva, 2003.

COÊLHO, Sacha Calmon N. Curso de direito tributário brasileiro. Rio de Janeiro: Forense, 1999.

COLAÇO, Magalhães. Concessões de serviços públicos. Lisboa, 1928.

COMPARATO, Fábio Konder. A proteção do consumidor: importante capítulo do direito econômico. Defesa do Consumidor - Textos Básicos, Brasília: MJ/CNDC, 1987.

. A proteção do consumidor na Constituição brasileira de 1988. Revista de Direito Mercantil, São Paulo: RT, v. 80, out.-dez. 1990.

. e SALOMÃO FILHO, Calixto. O poder de controle na sociedade anônima. $4^{\mathrm{a}}$ ed. Rio de Janeiro: Forense, 2005.

COSTA, Geraldo de Faria Martins da. O direito do consumidor endividado e a técnica do prazo de reflexão. Revista de Direito do Consumidor, São Paulo: RT, v. 43, jul.-set. 2002, p. 266.

COUILBAUlT, François; ELIASHBERG, Constant; LATRASSE. Michel. Les grands principes de l'assurance. $5^{\mathrm{a}}$ ed. Paris: Dalloz, 2002.

COUTO E SILVA, Clóvis V. do. A obrigação como processo. São Paulo: Bushatsky, 1976.

CRETElla JÚNIOR, José et alii. Comentários ao Código do Consumidor. Rio de Janeiro: Forense, 1992.

CRETELLA NETO, José. Direito processual na Organização Mundial do Comércio OMC. Rio de Janeiro: Forense, 2003.

CRUZ, Diniz Ferreira da. Lei complementar em matéria tributária. São Paulo: José Bushatsky, 1978. 
. Do imposto sobre vendas e consignações. São Paulo: José Bushatsky, 1963.

CRUZ, Gilberto Ferreira da. O direito e o processo administrativo disciplinar no Estado Democrático de Direito brasileiro. Dissertação de mestrado apresentada à Faculdade de Direito da Universidade Metropolitana de Santos (Unimes), 2001.

CRUZ, Guilherme Ferreira da. Princípios constitucionais das relações de consumo e dano moral: outra concepção. São Paulo: RT, 2008.

. A responsabilidade civil das empresas fabricantes de cigarros. Revista de Direito do Consumidor, São Paulo: RT, v. 47, abr.-jun. 2003, 67/117.

. A internet banda larga e seus provedores: imposição legal ou abusiva venda casada? RT, São Paulo: RT, v. 851, p. 44/62.

. A ilegalidade da abusiva tarifa de assinatura mensal do serviço de telefonia fixa e o consequente direito à repetição do indébito. Revista de Direito do Consumidor, São Paulo: RT, v. 55, jul.-set. 2005, p. 371/384.

. Cadernos Jurídicos. Escola Paulista da Magistratura. São Paulo: Imprensa Oficial do Estado de São Paulo, no 23, ano 5, set.-out. 2004.

DELGADO, José Augusto. A ética e a boa-fé no novo Código Civil. Questões controvertidas do novo Código Civil. São Paulo: Método, 2003.

DENARI, Zelmo et alii. Código Brasileiro de Defesa do Consumidor - Comentado pelos autores do anteprojeto. $4^{\mathrm{a}}$ ed. São Paulo: Forense Universitária, 1996.

DI PIETRO, Maria Sylvia Zanella. Direito administrativo. 12 ${ }^{\mathrm{a}}$ ed. São Paulo: Atlas, 2000.

DIAS, João Álvaro. Procriação assistida e responsabilidade médica. Coimbra: Ed. Coimbra, 1996.

DIAS, Lucia Ancona Lopez de Magalhães. Onerosidade excessiva e revisão contratual no direito privado brasileiro. In: FERNANDES, Wanderlei (coord.). Fundamentos $e$ princípios dos contratos empresariais. Série GVlaw. São Paulo: Saraiva, 2009. . Publicidade e direito. São Paulo: RT, 2010.

DINIZ, Maria Helena. Curso de direito civil brasileiro. Responsabilidade civil. $16^{\mathrm{a}}$ ed. São Paulo: Saraiva, $2002,7^{\circ} \mathrm{v}$.

- Curso de direito civil brasileiro. Teoria das obrigações contratuais e extracontratuais. $17^{\mathrm{a}}$ ed. São Paulo: Saraiva, $2002,3^{\mathrm{o}} \mathrm{v}$.

DIREITO, Carlos Alberto Menezes; CAVALIERI FILHO, Sérgio. In: TEIXEIRA, Sálvio de Figueiredo (coord.). Comentários ao novo Código Civil. Rio de Janeiro: Forense, 2004, v 13. 
DISTASO, Nicola. I contratti in generale. Torino: Unione tipográfico, 1980, v. I.

EBERLIN, Fernando Büscher Von Teschenhausen. Contratação refletida na sociedade de consumo: o direito de arrependimento como proteção do consentimento do consumidor. Revista de Direito do Consumidor, São Paulo: RT, v. 76, out.-dez. 2010.

EFING, Antônio Carlos. Contratos e procedimentos bancários à luz do Código de Defesa do Consumidor. $1^{\text {a }}$ ed. São Paulo: RT, 2000.

. Bancos de dados e cadastro de consumidores. São Paulo: RT, 2002.

EKMEKDJIAN, Miguel Ángel. Tratado de derecho constitucional. Buenos Aires: Depalma, 1993.

EWALD, François; GOLLIER, Christian; SADELEER, Nicolas de. Le retour du malin génie - Esquisse d'une philosofhie de la précaution. In: GODARD, Olivier (coord.). Le principe de précaution. Paris: Editions de la maison des sciences de l'homme, 1997.

. Philosofhie politique du principe de précaution. In: Le principe de précaution. Paris: PUF, 2001.

FALZEA, Angelo. Ricerche di teoria generali Del diritto e di dogmatica giuridica. Milano: Giuffrè, 1999.

FARIAS, Cristiano Chaves de. A proteção do consumidor na era da globalização. Revista de Direito do Consumidor, São Paulo: RT, v. 41, jan.-mar. 2002.

FERNANDES NETO, Antonio Joaquim. Plano de saúde e direito do consumidor. Belo Horizonte: Del Rey, 2002.

FERRARRA, Rosario. Contributo allo studio della tutella del consumatore. Milano: Giuffrè, 1983.

FILOMENO, José Geraldo Brito et alii. Código Brasileiro de Defesa do Consumidor, comentado pelos autores do anteprojeto. $4^{\mathrm{a}}$ ed. São Paulo: Forense Universitária, 1996.

; Manual de direitos do consumidor. $5^{\mathrm{a}}$ ed. São Paulo: Atlas, 2001.

FIORILLO, Celso Antonio Pacheco. Os sindicatos e a defesa dos interesses difusos no direito processual civil brasileiro. São Paulo: RT, 1995.

- e RODRIGUES, Marcelo Abelha. Manual de direito ambiental e legislação aplicável. $2^{\mathrm{a}}$ ed. São Paulo: Max Limonad, 1999. 
. O direito de antena em face do direito ambiental no Brasil. São Paulo: Saraiva, 2000.

FONSECA, João Bosco Leopoldino da. Cláusulas abusivas nos contratos. Rio de Janeiro: Forense, 1993.

FRANÇA, R. Limongi. A irretroatividade das leis e o direito adquirido. $4^{\mathrm{a}}$ ed. São Paulo: RT, 1994.

FRANZONI, Massimo. La responsabilità oggettiva: il danno da cose, da esercizio di attività periculose, da circolazione di veicoli. Padova: CEDAM, 1995, v. 2.

FROTA, Mário. Política de Consumidores na União Européia. $O$ acervo do direito europeu de consumo. Coimbra: Almedina, 2003.

FUSI, Maurizio; TESTA Paulina e COTTAFAVI Pierluigi. La publicità ingannevole. Milano: Giuffrè, 1993.

GALDINO, Valéria Silva. Cláusulas abusivas. São Paulo: Saraiva, 2001.

GIDI, Antonio. Legitimidade para agir em ações coletivas. Revista de Direito do Consumidor, São Paulo: RT, v. 14, abr.-jun. 1995.

GODOY, Cláudio Luiz Bueno de. Função social do contrato. $3^{\text {a }}$ ed. São Paulo: Saraiva, 2009.

. Responsabilidade civil pelo risco da atividade. São Paulo: Saraiva, 2009.

- Código Civil comentado. Doutrina e jurisprudência. In: Min. Cezar Peluso (coord.). $3^{\text {a }}$ ed. Barueri: Manole, 2009.

GOMES, Orlando. Direito econômico. São Paulo: Saraiva, 1977.

. O princípio da boa-fé no Código Civil Português. Revista Jurídica, Rio de Janeiro, 1980.

. Seguro saúde - Regime jurídico. Seguro de reembolso de despesas de assistência médico-hospitalar - Contrato semi-público. Revista de Direito Público, São Paulo: RT, no 76, ano XVIII, out.-dez. 1985.

. Contratos. $15^{\mathrm{a}}$ ed. Atual. e notas de Humberto Theodoro Júnior. Rio de Janeiro: Forense, 1995.

GONÇALVES, Carlos Roberto. Responsabilidade civil. $8^{\text {a }}$ ed. São Paulo: Saraiva, 2003. Responsabilidade subjetiva, responsabilidade objetiva, responsabilidade por fato de outrem, responsabilidade profissional etc.; preferências e privilégios creditórios (Artigos 927 a 965). In: AZEVEDO, Antonio Junqueira de (coord.). Comentários ao 
Código Civil. Parte especial do direito das obrigações. São Paulo: Saraiva, 2003, v. 11.

. Direito civil brasileiro. v. 2. Teoria Geral das Obrigações. $8^{a}$ ed. São Paulo: Saraiva, 2011, p. 281.

GONÇALVES, Luiz da Cunha. Tratado de direito civil. São Paulo: Max Limonad, 1957, v. 12 , t. 2.

GRAU, Eros Roberto. A ordem econômica na Constituição de 1988 (interpretação e crítica). São Paulo: RT, 1991.

. Interpretando o Código de Defesa do Consumidor; algumas notas. Revista de Direito do Consumidor, São Paulo: RT, v. 5, jan.-mar. 1993.

GREGORI, Maria Stella. Planos de saúde. A ótica da proteção do consumidor. São Paulo: RT, 2007.

GRINOVER, Ada Pellegrini. A ação civil pública e a defesa de interesses individuais homogêneos. Revista de Direito do Consumidor, São Paulo: RT, v. 5, jan.-mar. 1993. . et alii. Código Brasileiro de Defesa do Consumidor, comentado pelos autores do anteprojeto. $4^{\mathrm{a}}$ ed. São Paulo: Forense Universitária, 1996.

. Contratos de consumo e ônus da prova. In: LOPEZ, Teresa Ancona e AGUIAR JÚNIOR, Ruy Rosado de (coord.). Contratos de consumo e atividade econômica. Série GVlaw. São Paulo: Saraiva, 2009.

GUIMARÃES, Otávio Moreira. A boa-fé no direito civil brasileiro. São Paulo: RT, 1938.

GUIMARÃES, Paulo Jorge Scartezzini. A publicidade ilícita e a responsabilidade civil das celebridades que dela participam. $2^{\mathrm{a}}$ ed. São Paulo: RT, 2007.

- Vícios do produto e do serviço por qualidade, quantidade e insegurança.

Cumprimento imperfeito do contrato. $2^{\mathrm{a}}$ ed. São Paulo: RT, 2007.

HIRONAKA, Giselda Maria Fernandes Novaes. Responsabilidade pressuposta. Belo Horizonte: Del Rey, 2005.

IZZO, Umberto. La precauzione nella responsabilità civile. Padova: CEDAM, 2004.

JACOBINA, Paulo Vasconcelos. A publicidade no direito do consumidor. Rio de Janeiro: Forense, 1996.

JAYME, Erik. Identité culturelle et intégration: Le droit internationale privé postmoderne. In: Recueil des Cours de l'Académie de Droit International de la Haye. 1995, II. . Visões para uma teoria pós-moderna do direito comparado. RT, São Paulo: RT, v. 759, jan. 1999, p. 24. 
KÖNDGEN, Johannes. Selbstbindung ohne Vertrag: zur Haftung aus geschätsbezogenem Handeln. Tübingen: Mohr, 1981.

KOURILSKY, Philippe e VINEY, Genevière. Le principe de précaution. Paris: Odile Jacob, 2000.

KRAUT, Alfredo Jorge. Los derechos de los pacientes. Buenos Aires: Abeledo-Perrot, 1997.

LABI, Aisha. Tobacco on Trial: THE SMOKING GUN. TIME Magazine. USA, January, 2003.

LAMBERT-FAIVRE, Yvonne. Droit des assurances. 11ª ed. Paris: Dalloz, 2001.

LARENZ, Karl. Base del negocio jurídico y cumplimiento de los contratos. Trad. Carlos Fernández Rodríguez. Madrid: Revista de Derecho Privado, 1956.

. Derecho de obligaciones, t. I. Trad. Jaime Santos Brinz. Madrid: Editorial Revista de Derecho Privado, 1958.

LEIRIA, Cláudio da Silva. Transfusões de sangue contra a vontade de paciente da religião Testemunhas de Jeová: uma gravíssima violação dos direitos humanos. Disponível em http://jusvi.com/artigos/39291.

LEMOS, Patrícia Faga Iglesias. Direito ambiental: responsabilidade civil e proteção ao meio ambiente. $2^{\mathrm{a}}$ ed. São Paulo: RT, 2008. Resíduos sólidos e responsabilidade civil pós-consumo. São Paulo: RT, 2011.

LEWICKI, Bruno. Panorama da boa-fé objetiva. In: TEPEDINO, Gustavo (coord.). Problemas de direito civil - constitucional. Rio de Janeiro: Renovar, 2000.

LIMA, Alvino. Culpa e risco. $2^{\mathrm{a}}$ ed. Rev. e Atual. por Ovídio Rocha Barros Sandoval. São Paulo: RT, 1998.

LISBOA, Roberto Senise. Responsabilidade civil nas relações de consumo. São Paulo: RT, 2001.

LÔBO, Paulo Luiz Neto. Condições gerais dos contratos e cláusulas abusivas. São Paulo: Saraiva, 1991.

LOPES, José Reinaldo de Lima. Consumidores de seguros e planos de saúde. Saúde e responsabilidade: seguros e planos de assistência privada à saúde. São Paulo: RT, 1999.

LOPES, Maria Elizabete Vilaça. O consumidor e a publicidade. Revista de Direito do Consumidor, São Paulo: RT, v. 1, 1992. 
LOPEZ, Teresa Ancona. Princípio da precaução e evolução da responsabilidade civil. Tese para concurso de Professor Titular apresentada ao Departamento de Direito Civil da Faculdade de Direito da Universidade de São Paulo (USP), 2008. - Nexo causal e produtos potencialmente nocivos: a experiência brasileira do tabaco. São Paulo: Quartier Latin, 2008.

. Princípios contratuais. In: FERNANDES, Wanderley (coord.). Fundamentos e princípios dos contratos empresariais. Série GV/law. São Paulo: Saraiva, 2009.

. Exercício do direito e suas limitações: abuso do direito. In: NERY, Rosa Maria de Andrade e DONNINI, Rogério (coord). Responsabilidade civil. Estudos em homenagem ao professor Rui Geraldo Camargo Viana. São Paulo: RT, 2009.

. Princípio da precaução e evolução da responsabilidade civil. São Paulo: Quartier Latin, 2010.

LORENZETTI, Ricardo Luís. Responsabilidad civil de los médicos. Buenos Aires: Rubinzal-Culzoni, 1997, t. I e II.

. Consumidores. Santa Fé: Rubinzal-Culzoni, 2003, p. 204.

LOTUFO, Renan. Comentários ao novo Código Civil. São Paulo: Saraiva, 2003, v. I.

LOUREIRO, Francisco Eduardo. Planos e seguros de saúde. In: TAVARES DA SILVA, Regina Beatriz (coord.). Responsabilidade Civil. Responsabilidade civil na área da saúde. São Paulo: Saraiva, 2007.

LUCCA, Newton de. A proteção contratual no Código de Defesa do Consumidor. Revista de Direito do Consumidor, São Paulo: RT, v. 5, jan.-fev. 1993.

. O Código de Defesa do Consumidor: discussões sobre o seu âmbito de aplicação. Revista de Direito do Consumidor, São Paulo: RT, v. 6, abr.-jun. 1993.

. Direito do consumidor. Aspectos práticos - perguntas e respostas. São Paulo: RT, 1995.

. Direito do consumidor. 2a ed. São Paulo: Quartier Latin, 2008.

MACHADO, Paulo Affonso Leme. Direito ambiental brasileiro. $16^{\text {a }}$ ed. São Paulo: Malheiros, 2008.

MACHADO, Pedro Antonio de Oliveira. INTERNET. Acesso via banda larga. Provedores de serviço de acesso. Revista de Direito do Consumidor, São Paulo: RT, v. 47, jul.set. 2003.

MALUF, Carlos Alberto Dabus. A transação no direito civil e no processo civil. 2. ed. São Paulo: Saraiva, 1999. 
MARINS DE SOUZA, James J. A responsabilidade civil do fornecedor pelo fato do produto e do serviço. Jurisprudência Brasileira (JB), Curitiba: Juruá, v. 166, abr.jun. 1992.

- Responsabilidade da empresa pelo fato do produto (os acidentes de consumo no Código de Proteção e Defesa do Consumidor). São Paulo: RT, 1993.

MARQUES, Claudia Lima et alii. Estudos sobre a proteção do consumidor no Brasil e no Mercosul. 1. ed. Porto Alegre: Editora Livraria dos Advogados Porto Alegre, 1994. v. 1.

. Expectativas legítimas dos consumidores nos planos e seguros privados de saúde e os atuais projetos de lei. Revista de Direito do Consumidor, São Paulo: RT, v. 20, out.-dez. 1996.

. Planos privados de assistência à saúde. Desnecessidade de opção do consumidor pelo novo sistema. Opção a depender da conveniência do consumidor. Abusividade de cláusula contratual que permite a resolução do contrato coletivo por escolha do fornecedor. Revista de Direito do Consumidor, São Paulo: RT, v. 31, jul.-set. 1999.

; Contratos no Código de Defesa do Consumidor. O novo regime das relações contratuais. $4^{\text {a }}$ ed. São Paulo: RT, 2002.

. O diálogo entre o Código de Defesa do Consumidor e o Novo Código Civil: do "diálogo das fontes" no combate às cláusulas abusivas. Revista de Direito do Consumidor, São Paulo: RT, v. 45, jan.-mar. 2003.

- Superação das antinomias pelo diálogo das fontes: o modelo brasileiro de coexistência entre o Código de Defesa do Consumidor e o Código Civil de 2002. Revista de Direito do Consumidor, São Paulo: RT, v. 51, jul.-set. 2004, p. 34/67.

. Violação do dever de boa-fé de informar corretamente, atos negociais omissivos afetando o direito/liberdade de escolha. Nexo causal entre a falha/defeito de informação e defeito de qualidade dos produtos de tabaco e o dano final morte. Responsabilidade do fabricante do produto, direito a ressarcimento dos danos materiais e morais, sejam preventivos, reparatórios ou satisfatórios. Revista dos Tribunais, São Paulo: RT, v. 835, p. 75/133, 2005.

. Três tipos de diálogos entre o Código de Defesa do Consumidor e o Código Civil de 2002: superação das antinomias pelo “diálogo das fontes”. In: PASQUALOTTO, Adalberto e PFEIFFER, Roberto Augusto Castellanos (coord). Código de Defesa do 
Consumidor e o Código Civil de 2002. Convergências e assimetrias. RT: São Paulo, 2005.

- Proteção do Consumidor no comércio eletrônico e a chamada nova crise do contrato: por um direito do consumidor aprofundado. Revista de Direito do Consumidor, São Paulo: RT, v. 57, jan.-mar. 2006, p. 09/59.

A chamada nova crise do contrato e o modelo de direito privado brasileiro: crise de confiança ou de crescimento do contrato? In: MARQUES, Cláudia Lima (coord.). A nova crise do contrato. Estudos sobre a nova teoria contratual. São Paulo: RT, 2007.

. O novo direito privado brasileiro após a decisão da ADIN dos Bancos (ADI 2591). Revista de Direito do Consumidor, São Paulo: RT, v. 61, p. 40-75, 2007.

; et alii. Manual de direito do consumidor. São Paulo: RT, 2008.

; et alii. Comentários ao Código de Defesa do Consumidor. $3^{\mathrm{a}}$ ed. São Paulo: RT, 2010.

MARTINS, Flávio Alves. A boa-fé objetiva e sua formalização no direito das obrigações brasileiro. Rio de Janeiro: Lúmen Juris, 2000.

MARTINS, João Marcos Brito. Direito de seguro. Rio de Janeiro: Forense Universitária, 2002.

MARTINS-COSTA, Judith. Sistema e cláusula geral: a boa-fé objetiva no processo obrigacional. Tese (Doutorado) - Faculdade de Direito. São Paulo: USP, 1996. . A boa-fé no direito privado. $2^{\mathrm{a}}$ tir. São Paulo: RT, 2000.

. Os campos normativos da boa-fé objetiva: as três perspectivas do direito privado brasileiro. Revista Forense, Rio de Janeiro: Forense, v. 382, nov.-dez., 2005.

- Princípio da confiança legítima e princípio da boa-fé objetiva. Termo de compromisso de cessação (TCC) ajustado com o CADE. Critérios da interpretação contratual: os "sistemas de referência extracontratuais" ("circunstâncias do caso") e sua função no quadro semântico da conduta devida. Princípio da unidade ou coerência hermenêutica e "usos do tráfego". Adimplemento contratual. RT. São Paulo: RT, v. 852, out.-2006.

MATEO, Ramon Martín. Manual de derecho ambiental. Madrid: Trivium, 1988.

MAXIMILIANO, Carlos. Hermenêutica e aplicação do direito. $5^{\text {a }}$ ed. São Paulo: Livraria Freitas Bastos, 1951, ex. n. 1752. 
MAZEAUD, Denis. Loyauté, solidarité, fraternité: la nouvelle devise contractuelle? In L'avenir du droit: mélanges em hommage à François Terré, Paris: PUF, 1999.

MAZON, Marília. O controle e a prevenção do dano ao consumidor perante a publicidade abusiva. Revista de Direito do Consumidor, São Paulo: RT, v. 78, abr.-jun. 2011.

MEDAUAR, Odete. Direito administrativo moderno. $3^{\text {a }}$ ed. São Paulo: RT, 1999.

MEIRELLES, Hely Lopes. Direito Administrativo Brasileiro. $20^{\mathrm{a}}$ ed. Atual. por Eurico de Andrade Azevedo, Délcio Balestero Aleixo e José Emanuel Burle Filho. São Paulo: Malheiros, 1995.

. Direito administrativo brasileiro. 16 ${ }^{\mathrm{a}}$ ed. São Paulo: RT, 1991.

MELLO FILHO, José Celso de. Constituição Federal anotada. $2^{\mathrm{a}}$ ed. São Paulo: Saraiva, 1986.

MELlO, Heloísa Carpena Vieira de. A boa-fé como parâmetro da abusividade no direito contratual. In: TEPEDINO, Gustavo (coord.). Problemas de direito civil constitucional. Rio de Janeiro: Renovar, 2000.

MELO, Nehemias Domingos de. Texto sobre a legalidade da assinatura mensal de telefonia fixa. Disponível em http://www1.jus.com.br/doutrina/texto.asp?id=5699.

MENEZES CORDEIRO, Antônio Manuel da Rocha e. Da boa-fé no direito civil. Coimbra: Almedina, 1984, v. 1 e 2.

MILARÉ, Edis. Direito do ambiente. A gestão ambiental em foco. Doutrina. Jurisprudência. Glossário. 5a ed. São Paulo: RT, 2007.

MIRAGEM, Bruno. Direito do consumidor. São Paulo: RT, 2008.

MIRRA, Álvaro Luiz Valery. Princípios fundamentais do direito ambiental. Revista de Direito Ambiental, São Paulo: RT, Ano 1, n. 2, abr.-jun. 1996.

MONATERI, Píer Giuseppe. La responsabilità civile per lo svolgimento di attività pericolose. Disponível em http://www.notiziariogiuridico.it/attpericolose.html.

MONTEIRO, Washington de Barros. Curso de direito civil. Direito das obrigações $-2^{\mathrm{a}}$ parte. $23^{\mathrm{a}}$ ed. São Paulo: Saraiva, $1989,5^{\circ}$ v.

MORAES, Alexandre de. Direitos humanos fundamentais. $3^{\mathrm{a}}$ ed. São Paulo: Atlas, 2000.

MORAES, Irany Novah. Erro médico e a lei. $4^{\mathrm{a}}$ ed. São Paulo: Lejus, 1998.

MORAIS, Fernando de Gravato. Contratos de crédito ao consumo. Coimbra: Almedina, 2007.

MORATO, Antonio Carlos. Pessoa jurídica consumidora. São Paulo: RT, 2009. 
MOTA PINTO, Carlos Alberto da. Teoria geral do direito civil. $3^{\mathrm{a}}$ ed. Coimbra: Ed. Coimbra, 1999.

MOTA PINTO, Paulo da. Declaração tácita e comportamento concludente no negócio jurídico. Coimbra: Almedina, 1995.

MUKAI, Toshio. Direito ambiental sistematizado. $3^{\mathrm{a}}$ ed. Rio de Janeiro: Forense Universitária, 1998.

NEGREIROS, Teresa. Teoria do contrato. Novo paradigma. Rio de Janeiro: Renovar, 2003.

NERY JÚNIOR, Nelson. Os princípios gerais do Código brasileiro de Defesa do Consumidor. Revista de Direito do Consumidor, São Paulo: RT, v. 3, set.-dez. 1992. ; et alii. Código Brasileiro de Defesa do Consumidor, comentado pelos autores do anteprojeto. $4^{\mathrm{a}}$ ed. São Paulo: Forense Universitária, 1996. . Princípios do processo Civil na Constituição Federal. 10a ed. São Paulo: RT, 2010 .

. e NERY, Rosa Maria Andrade. Novo Código Civil e legislação extravagante anotados. São Paulo: RT, 2002.

. e NERY, Rosa Maria de Andrade. Leis civis comentadas. São Paulo: RT, 2006.

. e NERY, Rosa Maria de Andrade. Código Civil comentado. $6^{\mathrm{a}}$ ed. São Paulo: RT, 2008.

NORONHA, Fernando. O direito dos contratos e seus princípios fundamentais (autonomia privada, boa-fé, justiça contratual). São Paulo: Saraiva, 1994.

. Direito das obrigações. São Paulo: Saraiva, 2003, v. 1.

NOVAIS, Alinne Arquette Leite. Os novos paradigmas da teoria contratual: O princípio da boa-fé objetiva e o princípio da tutela do hipossuficiente. In: TEPEDINO, Gustavo (coord.). Problemas de direito civil - constitucional. Rio de Janeiro: Renovar, 2000.

NUSDEO, Fabio; et alii. Comentários ao Código do Consumidor. Rio de Janeiro: Forense, 1992.

NUNES JÚNIOR, Vidal Serrano. Publicidade comercial: proteção e limites na Constituição de 1988. São Paulo: Juarez de Oliveira, 2001.

. A publicidade comercial dirigida ao público infantil. Constituição Federal. Avanços, contribuições e modificações no processo democrático brasileiro. In: MARTINS, Ives Gandra e REZEK, Francisco (coord.). São Paulo: coedição Centro de Extensão Universitária e RT, 2008. 
OLIVEIRA, Celso Marcelo de. Contrato de seguro. Campinas: LZN, 2002.

OLIVEIRA, Guilherme de. Temas de direito da medicina. Coimbra: Ed. Coimbra, 1999.

PASQUALOTTO, Adalberto. Os serviços públicos no Código de Defesa do Consumidor. Revista de Direito do Consumidor, São Paulo: RT, v. 1, 1992.

. Conceitos fundamentais do Código de Defesa do Consumidor. RT, São Paulo: RT, v. 666, p. 48.

. Os efeitos obrigacionais da publicidade no Código de Defesa do Consumidor. São Paulo: RT, 1997.

- A regulamentação dos planos e seguros de assistência à saúde - Uma interpretação construtiva. São Paulo: RT, 1999.

- e PFEIFFER, Roberto Augusto Castellanos (coord.). Código de Defesa do Consumidor e o Código Civil de 2002. Convergências e assimetrias. RT: São Paulo, 2005.

. Oferta e publicidade no Código de Defesa do Consumidor. In: LOPEZ, Teresa Ancona e AGUIAR JÚNIOR, Ruy Rosado de (coord.). Contratos de consumo e atividade econômica. Série GVlaw. São Paulo: Saraiva, 2009.

. Dará a reforma ao Código de Defesa do Consumidor um sopro de vida? Revista de Direito do Consumidor, São Paulo: RT, v. 78, abr.-jun. 2011.

PEIXOTO, Matos. Limite temporal da lei. RT, São Paulo: RT, ano 37, jun. 1948, v. 173.

PENTEADO, Luciano de Camargo. Figuras parcelares da boa-fé objetiva e venire contra factum proprium. Disponível em http://www.flaviotartuce.adv.br/secoes/artigosc.asp.

PEREIRA, Agostinho Oli Koppe; PEREIRA, Henrique Mioranza Koppe; CALGARO, Cleide. A prevenção como elemento de proteção ao consumidor: a saúde e segurança do consumidor no Código de Proteção e Defesa do Consumidor brasileiro. Revista de Direito do Consumidor, São Paulo: RT, v. 63, out.-dez. 2007.

PEREIRA, Caio Mário da Silva. Instituições de direito civil. Contratos. Rio de Janeiro: Forense, 1993, v. III.

. Responsabilidade civil. $9^{\text {a }}$ ed. Rio de Janeiro: Forense, 1999.

PEREIRA, Marco Antonio Marcondes. Concorrência desleal por meio da publicidade.

São Paulo: Juarez de Oliveira, 2001.

PEREIRA, Regis Fichtner. A responsabilidade pré-contratual: teoria geral e responsabilidade pela ruptura das negociações contratuais. Rio de Janeiro: Renovar, 2001. 
PEZZELLA, Maria Cristina Cereser. O princípio da boa-fé objetiva no direito privado alemão e brasileiro. Revista de Direito do Consumidor, São Paulo: RT, v. 23-24, jul.dez. 1997.

PFEIFFER, Roberto Augusto Castellanos. Práticas abusivas, cobranças de dívidas e cadastros de consumo. In: LOPEZ, Teresa Ancona e AGUIAR JÚNIOR, Ruy Rosado de (coord.). Contratos de consumo e atividade econômica. Série GVlaw. São Paulo: Saraiva, 2009.

. Proteção do consumidor e defesa da concorrência: paralelo entre práticas abusivas e infrações contra a ordem econômica. Revista de Direito do Consumidor, São Paulo: RT, v. 76, out.-dez. 2010.

PLANIOL, Marcel. Traité élémentaire de droit civil. $4^{\mathrm{a}}$ ed. Paris: Libraire Générale de Droit et de Jurisprudence, 1906, v. I.

PONTES DE MIRANDA, Francisco Cavalcanti. Comentários à Constituição de 1967 com a emenda no 1 de 1969. $2^{\mathrm{a}}$ ed. São Paulo: RT, 1971, t. V.

- Comentários ao Código de Processo Civil. Atual. Legislativa de Sergio Bermudes. 5. ed. Rio de Janeiro: Forense, 1997, t. I.

PRIEUR, Michel. Droit de l'Environnement. $4^{\text {a }}$ ed. Paris: Dalloz, 2001.

PRODETTI, Carla e PRODETTI, Ettore. Medici e biologici nella giurisprudenza. Milão: Giuffrè, 1998.

RÁO, Vicente. O direito e a vida dos direitos. Quinto Milheiro - reedição. São Paulo: Max Limonad, 1960, v. I - t. II.

REALE, Miguel. O projeto do Código Civil. São Paulo: Saraiva, 1986.

RIPERT, Georges. O regimen democrático e o direito civil moderno. Trad. J. Cortezão. São Paulo: Saraiva, 1937.

RIZZARDO, Arnaldo. Planos de assistência e seguros de saúde. Porto Alegre: Livraria do Advogado, 1999.

RIZZATTO NUNES, Luiz Antonio. O cheque pré-datado e o direito do consumidor. Lex Jurisprudência dos Tribunais de Alçada Civil de São Paulo. São Paulo: Lex, 1999, ano 33, v. 176, p. 9-12.

. Comentários ao Código de Defesa do Consumidor. Direito Material (arts. $1^{o}$ a 54). São Paulo: Saraiva, 2000.

. Comentários à lei de plano privado de assistência à saúde. $2^{\mathrm{a}}$ ed. São Paulo: Saraiva, 2000. 
. Curso de direito do consumidor. $2^{\mathrm{a}}$ ed. São Paulo: Saraiva, 2005.

. Comentários ao Código de Defesa do Consumidor. 4ª ed. São Paulo: Saraiva, 2009.

. É inconstitucional qualquer Medida Provisória que pretenda afastar o Código de

Defesa do Consumidor. Artigos de doutrina: Saraiva. Disponível em Www.saraivajur.com.br.

. As ações coletivas e a defesa do consumidor, da ordem econômica e da economia popular. Artigos de doutrina: Saraiva. Disponível em www.saraivajur.com.br.

. O Código de Defesa do Consumidor e o artigo 192 da Constituição Federal:

conflito entre lei ordinária e lei complementar? Artigos de doutrina: Saraiva. Disponível em www.saraivajur.com.br.

ROCHA, Silvio Luís Ferreira da. A oferta no Código de Defesa do Consumidor. São Paulo: Lemos Editorial, 1997.

. Responsabilidade civil do fornecedor pelo fato do produto no direito brasileiro. 2. ed. São Paulo: RT, 2000.

. Contratos de assistência médica pré-pagos e disciplina prevista na Lei 9.656, de 3 de junho de 1998. In: MARQUES, Cláudia Lima; SCHMITT, Cristiano Heineck; LOPES, José Reinaldo de Lima; PFEIFFER, Roberto Augusto Castellanos (coord.). Saúde e responsabilidade 2. A nova assistência privada à saúde. São Paulo: RT, 2008.

RODRIGUES, Álvaro da Cunha Gomes. Consentimento informado e intervenção médica. Direito da medicina I. Coimbra: Ed. Coimbra, 2002.

RODRIGUES, Bruno Lemos. Aspectos legais dos contratos de seguro-saúde. São Paulo: Thomson IOB, 2006.

RODRIGUES, João Vaz. O consentimento informado para o ato médico no ordenamento jurídico português. Coimbra: Ed. Coimbra, 2001.

RODRIGUES, Silvio. Direito civil. Parte geral. 32ª ed. São Paulo: Saraiva, 2002, v. 1.

. Direito civil. Parte geral das obrigações. $30^{\text {a }}$ ed. São Paulo: Saraiva, 2002, v. 2.

ROPPO, Enzo. Enzo Roppo. O contrato. Coimbra: Almedina, 1988.

ROUBIER, Paul. Le droit transitoire - Conflits des lois dans le temps. $2^{\mathrm{a}}$ ed. Paris: Éditions Dalloz et Sirey, 1960.

RUBIO, Maria Paz Garcia. La responsabilidade precontratual en el derecho español. Madrid: Tecnos, 1991. 
SAMPAIO, Aurisvaldo Melo. As novas tecnologias e o princípio da efetiva prevenção de danos ao consumidor. Revista de Direito do Consumidor, São Paulo: RT, v. 49, jan.mar. 2004.

SANTANA, Héctor Valverde. Prescrição e decadência nas relações de consumo. São Paulo: RT. 2003.

SANTOS, Fernando Gherardini. Direito e marketing. São Paulo: RT, 2000.

SANTOS, Ricardo Bechara. Direito de seguro no cotidiano. Rio de Janeiro: Forense, 1999.

SAUPHANOR, Nathalie. L'Influence du Droit de la Consommation sur le système juridique. Paris: LGDJ, 2000.

SCAFF, Fernando Campos. As novas figuras contratuais e a autonomia da vontade. Revista da Faculdade de Direito, São Paulo: USP, v. 91, 1996, p. 141-159.

. A responsabilidade do empresário pelo fato do produto e do serviço, do Código Civil ao Código de Proteção e Defesa do Consumidor. RT, São Paulo: RT, v. 737, p. 23-33.

- As relações jurídicas privadas no direito à saúde. Tese de Livre Docência apresentada ao Departamento de Direito Civil da Faculdade de Direito da Universidade de São Paulo (USP), 2006.

. Direito à saúde no âmbito privado. Contratos de adesão, planos de saúde e seguro-saúde. São Paulo: Saraiva, 2010.

SCHMITT, Cristiano Heineck. Cláusulas abusivas na relação de consumo. $2^{\mathrm{a}}$ ed. São Paulo: 2008.

. e PERES, Fabiana Pietros, Contrato de time-sharing: nuances acerca da proteção do consumidor no direito comunitário e no direito brasileiro. Revista de Direito do Consumidor, São Paulo: RT, v. 76, out.-dez. 2010.

SCHREIBER, Anderson. A proibição do comportamento contraditório. Tutela da confiança e venire contra factum proprium. Rio de Janeiro: Renovar, 2005.

SERPA LOPES, Miguel Maria de. O silêncio como manifestação de vontade. $3^{\mathrm{a}}$ ed. Rio de Janeiro: Livraria Freitas Bastos, 1961.

SILVA, Agathe E. Schmidt da. Cláusula geral de boa-fé nos contratos de consumo. Revista de Direito do Consumidor, São Paulo: RT, v. 17, jan.-mar. 1996.

SILVA, Eva Sônia Moreira da. Da responsabilidade pré-contratual por violação dos deveres de informação. Coimbra: Almedina, 2003. 
SILVA, João Calvão da. Responsabilidade civil do produtor. Coimbra: Almedina, 1999.

SILVA, Jorge Alberto Quadros de Carvalho. Código de Defesa do Consumidor anotado. São Paulo: Saraiva, 2001.

SILVA, Luís Renato Ferreira da. Revisão dos contratos: do Código Civil ao Código do Consumidor. Rio de Janeiro: Forense, 1998.

SILVA FILHO, Artur Marques. Código do Consumidor, responsabilidade civil pelo fato de produto e do serviço. $R T$, São Paulo: RT, v. 666, p. 35-47.

SILVEIRA, Alípio. A boa-fé no Código Civil. $3^{\mathrm{a}}$ ed. São Paulo: Editora Universitária de Direito, $1972,1^{\circ} \mathrm{v}$.

SILVEIRA, Karyna Rocha Mendes da. Doença preexistente nos planos de saúde. São Paulo: Saraiva, 2009.

SILVEIRA, Reynaldo Andrade da. Práticas mercantis no direito do consumidor. Curitiba: Juruá, 2000.

SIMÃO, José Fernando. Vícios do produto no novo Código Civil e no Código do Consumidor: responsabilidade civil. São Paulo: Atlas, 2003.

. A boa-fé objetiva: nova disciplina de um velho instituto. Revista da Faculdade de Direito, Fundação Armando Álvares Penteado, v. 3, p. 162-178, 2005.

. O prazo para reclamação por vícios ocultos nas relações civis e de consumo: críticas aos artigos 455 do Código Civil e 26 de Código de Defesa do Consumidor. In: BARROSO, Lucas Abreu (org.). Introdução crítica ao Código Civil. Rio de Janeiro: Forense, 2006, v. 1 , p. 181/206.

A teoria do risco no novo Código Civil. Disponível em http://www.professorsimao.com.br/artigos_simao_a_teoria_do_risco.htm.

- A boa-fé e o novo Código Civil - Parte III. Disponível em http://www.professorsimao.com.br/artigos_simao_a_boa_fe_03.htm.

SODRÉ, Marcelo Gomes. Formação do sistema nacional de defesa do consumidor. São Paulo: RT, 2007.

SOMMA, Alessandro. Autonomia privata e struttura del consenso contrattuale. Milão: Giuffrè, 2000.

STALTERI, Marcello D. Il problema della responsabilità del produttore di sigarette e il caso cipollone: l'assalto alla cittadella è realmente cominciato? Rivista di Diritto Civile, Italia: Padova, Casa Editrice Dott. Antonio Milani-CEDAM, nº 1, GennaioFebbraio, Anno XL, 1994. 
STIGLITZ, Gabriel A. Protección jurídica del consumidor. $2^{\mathrm{a}}$ ed. Buenos Aires: Depalma, 1990.

. Gabriel e Rubén. Derechos y defensa de los consumidores. Buenos Aires: La Rocca, 1994.

. Las acciones colectivas em proteccion del consumidor. Revista de Direito do Consumidor, São Paulo: RT, v. 15, jul.-out. 1995.

STOLFI, Giuseppe. Il principio di buona fede. Rivista del diritto commercialle. Milano, 1964, v. LXII.

STÜRMER, Bertram Antônio. Banco de dados e habeas data no código do consumidor. Revista de Direito do Consumidor, São Paulo: RT, v. 1, mar. 1992.

TARTUCE, Flávio. O princípio da boa-fé objetiva em matéria contratual. Apontamentos em relação do novo Código Civil e visão do Projeto 6.902/02. Disponível em http://www.flaviotartuce.adv.br/secoes/artigos.asp.

TEPEDINO, Gustavo. O Código Civil, os chamados microssistemas e a Constituição: premissas para uma reforma legislativa. In: TEPEDINO, Gustavo (coord.). Problemas de direito civil - constitucional. Rio de Janeiro: Renovar, 2000.

- Responsabilidade médica na experiência brasileira contemporânea. Revista Trimestral de Direito Civil, Rio de Janeiro: PADMA, 2000, ano I, v. 2.

. As relações de consumo e a nova teoria contratual. Temas de direito civil. $2^{\mathrm{a}}$ ed. Rio de Janeiro: Renovar, 2001.

et alii. Código Civil interpretado conforme a Constituição da República. Rio de Janeiro: Renovar, 2006, v. II.

TIMM, Luciano Benetti. Os grandes modelos de responsabilidade civil no direito privado: da culpa ao risco. Revista de Direito do Consumidor, São Paulo: RT, v. 55, jul.-set. 2005.

TRIMARCHI, Pietro. Rischio e responsabilità oggettiva. Milano: Giuffrè, 1961.

TOURINHO, Daniela de Oliveira. Provimento de acesso de alta velocidade na Internet. Revista do Advogado, São Paulo: AASP, nº 69, maio de 2003.

VALE, Maria do Carmo e OLIVEIRA, Guilherme de. Consentimento informado em menores.

Disponível

em http://www.ceic.pt/portal/page/portal/CEIC/Documentos/DOCUMENTOS_REFLEX $\mathrm{AO} /$ Consent\%20Inf\%20Menores.pdf. 
VARELA, João de Matos Antunes. Das obrigações em geral. 10a ed. Coimbra: Almedina, 2000, v. 1 .

VENOSA, Sílvio de Salvo. Direito civil. Teoria geral das obrigações e teoria geral dos contratos. $3^{\text {a }}$ ed. São Paulo: Atlas, 2003, v. II.

VIANA, Rui Geraldo Camargo. Temas atuais de direito civil na Constituição Federal. São Paulo: RT, 2000, v. 1.

. Rotulagem dos alimentos geneticamente modificados. Matéria federal. In: MARQUES, Cláudia Lima e MIRAGEM, Bruno (org.). Doutrinas essenciais. Direito do consumidor. Teoria de qualidade e danos. São Paulo: RT, 2011, v. V.

VOIDEY, Nadège. Le risque en Droite Civil. Presses Universitaires d'Aix Marseille, 2005.

WALD, Arnoldo. O direito do consumidor e suas repercussões em relação às instituições financeiras. RT, São Paulo: RT, v. 666, p. 7.

WALDMAN, Ricardo Libel. Teoria do risco e filosofia do direito: uma análise jusfilosófica do parágrafo único do art. 927 do novo Código Civil. Revista de Direito do Consumidor, São Paulo: RT, v. 56, out.-dez 2005.

WATANABE, Kazuo; et alii. Código Brasileiro de Defesa do Consumidor, comentado pelos autores do anteprojeto. $4^{\mathrm{a}}$ ed. São Paulo: Forense Universitária, 1996. ; et alii. Código Brasileiro de Defesa do Consumidor, comentado pelos autores do anteprojeto. Processo Coletivo. 10 a ed. Rio de Janeiro: Forense, 2011.

. Breve reflexão sobre a natureza jurídica da sentença de nulidade de casamento. $R T$, São Paulo: RT, v. 542, p. 25/28.

WIEACKER, Franz. El princípio general de la buena fé. Madri: Civitas, 1977.

WINTER, Gerd. European Environmental Law - A Corporative Perspective. Aldershot: Dartmouth Publishing Co., 1996.

ZENUN, Augusto. Comentários ao Código do Consumidor. $2^{\mathrm{a}}$ ed. Rio de Janeiro: Forense, 1998. 
ANEXOS

1. LEI 8.078/90 (texto compilado até 26.07.2011)

\section{LEI No 8.078, DE 11 DE SETEMBRO DE 1990.}

Dispõe sobre a proteção do consumidor e dá outras providências.

O PRESIDENTE DA REPÚBLICA, faço saber que o Congresso Nacional decreta e eu sanciono a seguinte lei:

TÍTULO I

Dos Direitos do Consumidor

CAPÍTULO I

Disposições Gerais

Art. $1^{\circ} \mathrm{O}$ presente código estabelece normas de proteção e defesa do consumidor, de ordem pública e interesse social, nos termos dos arts. $5^{\circ}$, inciso XXXII, 170, inciso V, da Constituição Federal e art. 48 de suas Disposições Transitórias.

Art. $2^{\circ}$ Consumidor é toda pessoa física ou jurídica que adquire ou utiliza produto ou serviço como destinatário final.

Parágrafo único. Equipara-se a consumidor a coletividade de pessoas, ainda que indetermináveis, que haja intervindo nas relações de consumo.

Art. $3^{\circ}$ Fornecedor é toda pessoa física ou jurídica, pública ou privada, nacional ou estrangeira, bem como os entes despersonalizados, que desenvolvem atividade de produção, montagem, criação, construção, transformação, importação, exportação, distribuição ou comercialização de produtos ou prestação de serviços.

$\S 1^{\circ}$ Produto é qualquer bem, móvel ou imóvel, material ou imaterial.

$\S 2^{\circ}$ Serviço é qualquer atividade fornecida no mercado de consumo, mediante remuneração, inclusive as de natureza bancária, financeira, de crédito e securitária, salvo as decorrentes das relações de caráter trabalhista.

\section{CAPÍTULO II \\ Da Política Nacional de Relações de Consumo}

Art. $4^{\circ}$ A Política Nacional das Relações de Consumo tem por objetivo o atendimento das necessidades dos consumidores, o respeito à sua dignidade, saúde e segurança, a proteção de seus interesses econômicos, a melhoria da sua qualidade de vida, bem como a transparência e harmonia das relações de consumo, atendidos os seguintes princípios: (Redação dada pela Lei n ${ }^{\circ} 9.008$, de 21.3.1995)

I - reconhecimento da vulnerabilidade do consumidor no mercado de consumo;

II - ação governamental no sentido de proteger efetivamente o consumidor: 
a) por iniciativa direta;

b) por incentivos à criação e desenvolvimento de associações representativas;

c) pela presença do Estado no mercado de consumo;

d) pela garantia dos produtos e serviços com padrões adequados de qualidade, segurança, durabilidade e desempenho.

III - harmonização dos interesses dos participantes das relações de consumo e compatibilização da proteção do consumidor com a necessidade de desenvolvimento econômico e tecnológico, de modo a viabilizar os princípios nos quais se funda a ordem econômica (art. 170, da Constituição Federal), sempre com base na boa-fé e equilíbrio nas relações entre consumidores e fornecedores;

IV - educação e informação de fornecedores e consumidores, quanto aos seus direitos e deveres, com vistas à melhoria do mercado de consumo;

V - incentivo à criação pelos fornecedores de meios eficientes de controle de qualidade e segurança de produtos e serviços, assim como de mecanismos alternativos de solução de conflitos de consumo;

VI - coibição e repressão eficientes de todos os abusos praticados no mercado de consumo, inclusive a concorrência desleal e utilização indevida de inventos e criações industriais das marcas e nomes comerciais e signos distintivos, que possam causar prejuízos aos consumidores;

VII - racionalização e melhoria dos serviços públicos;

VIII - estudo constante das modificações do mercado de consumo.

Art. $5^{\circ}$ Para a execução da Política Nacional das Relações de Consumo, contará o poder público com os seguintes instrumentos, entre outros:

I - manutenção de assistência jurídica, integral e gratuita para o consumidor carente;

II - instituição de Promotorias de Justiça de Defesa do Consumidor, no âmbito do Ministério Público;

III - criação de delegacias de polícia especializadas no atendimento de consumidores vítimas de infrações penais de consumo;

IV - criação de Juizados Especiais de Pequenas Causas e Varas Especializadas para a solução de litígios de consumo;

V - concessão de estímulos à criação e desenvolvimento das Associações de Defesa do Consumidor.

$\S 1^{\circ}$ (Vetado).

$\S 2^{\circ}$ (Vetado).

\section{CAPÍTULO III}

Dos Direitos Básicos do Consumidor 
Art. $6^{\circ}$ São direitos básicos do consumidor:

I - a proteção da vida, saúde e segurança contra os riscos provocados por práticas no fornecimento de produtos e serviços considerados perigosos ou nocivos;

II - a educação e divulgação sobre o consumo adequado dos produtos e serviços, asseguradas a liberdade de escolha e a igualdade nas contratações;

III - a informação adequada e clara sobre os diferentes produtos e serviços, com especificação correta de quantidade, características, composição, qualidade e preço, bem como sobre os riscos que apresentem;

IV - a proteção contra a publicidade enganosa e abusiva, métodos comerciais coercitivos ou desleais, bem como contra práticas e cláusulas abusivas ou impostas no fornecimento de produtos e serviços;

V - a modificação das cláusulas contratuais que estabeleçam prestações desproporcionais ou sua revisão em razão de fatos supervenientes que as tornem excessivamente onerosas;

VI - a efetiva prevenção e reparação de danos patrimoniais e morais, individuais, coletivos e difusos;

VII - o acesso aos órgãos judiciários e administrativos com vistas à prevenção ou reparação de danos patrimoniais e morais, individuais, coletivos ou difusos, assegurada a proteção Jurídica, administrativa e técnica aos necessitados;

VIII - a facilitação da defesa de seus direitos, inclusive com a inversão do ônus da prova, a seu favor, no processo civil, quando, a critério do juiz, for verossímil a alegação ou quando for ele hipossuficiente, segundo as regras ordinárias de experiências;

IX - (Vetado);

$\mathrm{X}$ - a adequada e eficaz prestação dos serviços públicos em geral.

Art. $7^{\circ}$ Os direitos previstos neste código não excluem outros decorrentes de tratados ou convenções internacionais de que o Brasil seja signatário, da legislação interna ordinária, de regulamentos expedidos pelas autoridades administrativas competentes, bem como dos que derivem dos princípios gerais do direito, analogia, costumes e eqüidade.

Parágrafo único. Tendo mais de um autor a ofensa, todos responderão solidariamente pela reparação dos danos previstos nas normas de consumo.

\section{CAPÍTULO IV}

Da Qualidade de Produtos e Serviços, da Prevenção e da Reparação dos Danos

\section{SEÇÃO I}

Da Proteção à Saúde e Segurança

Art. $8^{\circ}$ Os produtos e serviços colocados no mercado de consumo não acarretarão riscos à saúde ou segurança dos consumidores, exceto os considerados normais e previsíveis em decorrência de sua natureza e fruição, obrigando-se os fornecedores, em qualquer hipótese, a dar as informações necessárias e adequadas a seu respeito. 
Parágrafo único. Em se tratando de produto industrial, ao fabricante cabe prestar as informações a que se refere este artigo, através de impressos apropriados que devam acompanhar o produto.

Art. $9^{\circ} \mathrm{O}$ fornecedor de produtos e serviços potencialmente nocivos ou perigosos à saúde ou segurança deverá informar, de maneira ostensiva e adequada, a respeito da sua nocividade ou periculosidade, sem prejuízo da adoção de outras medidas cabíveis em cada caso concreto.

Art. 10. O fornecedor não poderá colocar no mercado de consumo produto ou serviço que sabe ou deveria saber apresentar alto grau de nocividade ou periculosidade à saúde ou segurança.

$\S 1^{\circ} \mathrm{O}$ fornecedor de produtos e serviços que, posteriormente à sua introdução no mercado de consumo, tiver conhecimento da periculosidade que apresentem, deverá comunicar o fato imediatamente às autoridades competentes e aos consumidores, mediante anúncios publicitários.

$\S 2^{\circ}$ Os anúncios publicitários a que se refere o parágrafo anterior serão veiculados na imprensa, rádio e televisão, às expensas do fornecedor do produto ou serviço.

$\S 3^{\circ}$ Sempre que tiverem conhecimento de periculosidade de produtos ou serviços à saúde ou segurança dos consumidores, a União, os Estados, o Distrito Federal e os Municípios deverão informá-los a respeito.

Art. 11. (Vetado).

\section{SEÇÃO II}

Da Responsabilidade pelo Fato do Produto e do Serviço

Art. 12. O fabricante, o produtor, o construtor, nacional ou estrangeiro, e o importador respondem, independentemente da existência de culpa, pela reparação dos danos causados aos consumidores por defeitos decorrentes de projeto, fabricação, construção, montagem, fórmulas, manipulação, apresentação ou acondicionamento de seus produtos, bem como por informações insuficientes ou inadequadas sobre sua utilização e riscos.

$\S 1^{\circ} \mathrm{O}$ produto é defeituoso quando não oferece a segurança que dele legitimamente se espera, levando-se em consideração as circunstâncias relevantes, entre as quais:

I - sua apresentação;

II - o uso e os riscos que razoavelmente dele se esperam;

III - a época em que foi colocado em circulação.

$\S 2^{\circ} \mathrm{O}$ produto não é considerado defeituoso pelo fato de outro de melhor qualidade ter sido colocado no mercado.

$\S 3^{\circ} \mathrm{O}$ fabricante, o construtor, o produtor ou importador só não será responsabilizado quando provar:

I - que não colocou o produto no mercado; 
II - que, embora haja colocado o produto no mercado, o defeito inexiste;

III - a culpa exclusiva do consumidor ou de terceiro.

Art. 13. O comerciante é igualmente responsável, nos termos do artigo anterior, quando:

I - o fabricante, o construtor, o produtor ou o importador não puderem ser identificados;

II - o produto for fornecido sem identificação clara do seu fabricante, produtor, construtor ou importador;

III - não conservar adequadamente os produtos perecíveis.

Parágrafo único. Aquele que efetivar o pagamento ao prejudicado poderá exercer o direito de regresso contra os demais responsáveis, segundo sua participação na causação do evento danoso.

Art. 14. O fornecedor de serviços responde, independentemente da existência de culpa, pela reparação dos danos causados aos consumidores por defeitos relativos à prestação dos serviços, bem como por informações insuficientes ou inadequadas sobre sua fruição e riscos.

$\S 1^{\circ} \mathrm{O}$ serviço é defeituoso quando não fornece a segurança que o consumidor dele pode esperar, levando-se em consideração as circunstâncias relevantes, entre as quais:

I - o modo de seu fornecimento;

II - o resultado e os riscos que razoavelmente dele se esperam;

III - a época em que foi fornecido.

$\S 2^{\circ} \mathrm{O}$ serviço não é considerado defeituoso pela adoção de novas técnicas.

$\S 3^{\circ} \mathrm{O}$ fornecedor de serviços só não será responsabilizado quando provar:

I - que, tendo prestado o serviço, o defeito inexiste;

II - a culpa exclusiva do consumidor ou de terceiro.

$\S 4^{\circ}$ A responsabilidade pessoal dos profissionais liberais será apurada mediante a verificação de culpa.

Art. 15. (Vetado).

Art. 16. (Vetado).

Art. 17. Para os efeitos desta Seção, equiparam-se aos consumidores todas as vítimas do evento.

Da Responsabilidade por Vício do Produto e do Serviço 
Art. 18. Os fornecedores de produtos de consumo duráveis ou não duráveis respondem solidariamente pelos vícios de qualidade ou quantidade que os tornem impróprios ou inadequados ao consumo a que se destinam ou lhes diminuam o valor, assim como por aqueles decorrentes da disparidade, com a indicações constantes do recipiente, da embalagem, rotulagem ou mensagem publicitária, respeitadas as variações decorrentes de sua natureza, podendo o consumidor exigir a substituição das partes viciadas.

$\S 1^{\circ}$ Não sendo o vício sanado no prazo máximo de trinta dias, pode o consumidor exigir, alternativamente e à sua escolha:

I - a substituição do produto por outro da mesma espécie, em perfeitas condições de uso;

II - a restituição imediata da quantia paga, monetariamente atualizada, sem prejuízo de eventuais perdas e danos;

III - o abatimento proporcional do preço.

$\S 2^{\circ}$ Poderão as partes convencionar a redução ou ampliação do prazo previsto no parágrafo anterior, não podendo ser inferior a sete nem superior a cento e oitenta dias. Nos contratos de adesão, a cláusula de prazo deverá ser convencionada em separado, por meio de manifestação expressa do consumidor.

$\S 3^{\circ} \mathrm{O}$ consumidor poderá fazer uso imediato das alternativas do $\S 1^{\circ}$ deste artigo sempre que, em razão da extensão do vício, a substituição das partes viciadas puder comprometer a qualidade ou características do produto, diminuir-lhe o valor ou se tratar de produto essencial.

$\S 4^{\circ}$ Tendo o consumidor optado pela alternativa do inciso I do $\S 1^{\circ}$ deste artigo, e não sendo possível a substituição do bem, poderá haver substituição por outro de espécie, marca ou modelo diversos, mediante complementação ou restituição de eventual diferença de preço, sem prejuízo do disposto nos incisos II e III do $\S 1^{\circ}$ deste artigo.

$\S 5^{\circ}$ No caso de fornecimento de produtos in natura, será responsável perante o consumidor o fornecedor imediato, exceto quando identificado claramente seu produtor.

$\S 6^{\circ}$ São impróprios ao uso e consumo:

I - os produtos cujos prazos de validade estejam vencidos;

II - os produtos deteriorados, alterados, adulterados, avariados, falsificados, corrompidos, fraudados, nocivos à vida ou à saúde, perigosos ou, ainda, aqueles em desacordo com as normas regulamentares de fabricação, distribuição ou apresentação; destinam.

III - os produtos que, por qualquer motivo, se revelem inadequados ao fim a que se

Art. 19. Os fornecedores respondem solidariamente pelos vícios de quantidade do produto sempre que, respeitadas as variações decorrentes de sua natureza, seu conteúdo líquido for inferior às indicações constantes do recipiente, da embalagem, rotulagem ou de mensagem publicitária, podendo o consumidor exigir, alternativamente e à sua escolha:

I - o abatimento proporcional do preço; 
II - complementação do peso ou medida;

III - a substituição do produto por outro da mesma espécie, marca ou modelo, sem os aludidos vícios;

IV - a restituição imediata da quantia paga, monetariamente atualizada, sem prejuízo de eventuais perdas e danos.

$\S 1^{\circ}$ Aplica-se a este artigo o disposto no $\S 4^{\circ}$ do artigo anterior.

$\S 2^{\circ} \mathrm{O}$ fornecedor imediato será responsável quando fizer a pesagem ou a medição e o instrumento utilizado não estiver aferido segundo os padrões oficiais.

Art. 20. O fornecedor de serviços responde pelos vícios de qualidade que os tornem impróprios ao consumo ou lhes diminuam o valor, assim como por aqueles decorrentes da disparidade com as indicações constantes da oferta ou mensagem publicitária, podendo o consumidor exigir, alternativamente e à sua escolha:

I - a reexecução dos serviços, sem custo adicional e quando cabível;

II - a restituição imediata da quantia paga, monetariamente atualizada, sem prejuízo de eventuais perdas e danos;

III - o abatimento proporcional do preço.

$\S 1^{\circ}$ A reexecução dos serviços poderá ser confiada a terceiros devidamente capacitados, por conta e risco do fornecedor.

$\S 2^{\circ}$ São impróprios os serviços que se mostrem inadequados para os fins que razoavelmente deles se esperam, bem como aqueles que não atendam as normas regulamentares de prestabilidade.

Art. 21. No fornecimento de serviços que tenham por objetivo a reparação de qualquer produto considerar-se-á implícita a obrigação do fornecedor de empregar componentes de reposição originais adequados e novos, ou que mantenham as especificações técnicas do fabricante, salvo, quanto a estes últimos, autorização em contrário do consumidor.

Art. 22. Os órgãos públicos, por si ou suas empresas, concessionárias, permissionárias ou sob qualquer outra forma de empreendimento, são obrigados a fornecer serviços adequados, eficientes, seguros e, quanto aos essenciais, contínuos.

Parágrafo único. Nos casos de descumprimento, total ou parcial, das obrigações referidas neste artigo, serão as pessoas jurídicas compelidas a cumpri-las e a reparar os danos causados, na forma prevista neste código.

Art. 23. A ignorância do fornecedor sobre os vícios de qualidade por inadequação dos produtos e serviços não o exime de responsabilidade.

Art. 24. A garantia legal de adequação do produto ou serviço independe de termo expresso, vedada a exoneração contratual do fornecedor. 
Art. 25. É vedada a estipulação contratual de cláusula que impossibilite, exonere ou atenue a obrigação de indenizar prevista nesta e nas seções anteriores.

$\S 1^{\circ}$ Havendo mais de um responsável pela causação do dano, todos responderão solidariamente pela reparação prevista nesta e nas seções anteriores.

$\S 2^{\circ}$ Sendo o dano causado por componente ou peça incorporada ao produto ou serviço, são responsáveis solidários seu fabricante, construtor ou importador e o que realizou a incorporação.

\section{SEÇÃO IV \\ Da Decadência e da Prescrição}

Art. 26. O direito de reclamar pelos vícios aparentes ou de fácil constatação caduca em:

I - trinta dias, tratando-se de fornecimento de serviço e de produtos não duráveis;

II - noventa dias, tratando-se de fornecimento de serviço e de produtos duráveis.

$\S 1^{\circ}$ Inicia-se a contagem do prazo decadencial a partir da entrega efetiva do produto ou do término da execução dos serviços.

$\S 2^{\circ}$ Obstam a decadência:

I - a reclamação comprovadamente formulada pelo consumidor perante o fornecedor de produtos e serviços até a resposta negativa correspondente, que deve ser transmitida de forma inequívoca;

II - (Vetado).

III - a instauração de inquérito civil, até seu encerramento.

$\S 3^{\circ}$ Tratando-se de vício oculto, o prazo decadencial inicia-se no momento em que ficar evidenciado o defeito.

Art. 27. Prescreve em cinco anos a pretensão à reparação pelos danos causados por fato do produto ou do serviço prevista na Seção II deste Capítulo, iniciando-se a contagem do prazo a partir do conhecimento do dano e de sua autoria.

Parágrafo único. (Vetado).

\section{SEÇÃO V}

Da Desconsideração da Personalidade Jurídica

Art. 28. O juiz poderá desconsiderar a personalidade jurídica da sociedade quando, em detrimento do consumidor, houver abuso de direito, excesso de poder, infração da lei, fato ou ato ilícito ou violação dos estatutos ou contrato social. A desconsideração também será efetivada quando houver falência, estado de insolvência, encerramento ou inatividade da pessoa jurídica provocados por má administração.

$\S 1^{\circ}$ (Vetado). 
$\S 2^{\circ}$ As sociedades integrantes dos grupos societários e as sociedades controladas, são subsidiariamente responsáveis pelas obrigações decorrentes deste código.

$\S 3^{\circ}$ As sociedades consorciadas são solidariamente responsáveis pelas obrigações decorrentes deste código.

$\S 4^{\circ}$ As sociedades coligadas só responderão por culpa.

$\S 5^{\circ}$ Também poderá ser desconsiderada a pessoa jurídica sempre que sua personalidade for, de alguma forma, obstáculo ao ressarcimento de prejuízos causados aos consumidores.

\section{CAPÍTULO V \\ Das Práticas Comerciais \\ SEÇÃO I \\ Das Disposições Gerais}

Art. 29. Para os fins deste Capítulo e do seguinte, equiparam-se aos consumidores todas as pessoas determináveis ou não, expostas às práticas nele previstas.

\section{SEÇÃO II \\ Da Oferta}

Art. 30. Toda informação ou publicidade, suficientemente precisa, veiculada por qualquer forma ou meio de comunicação com relação a produtos e serviços oferecidos ou apresentados, obriga o fornecedor que a fizer veicular ou dela se utilizar e integra o contrato que vier a ser celebrado.

Art. 31. A oferta e apresentação de produtos ou serviços devem assegurar informações corretas, claras, precisas, ostensivas e em língua portuguesa sobre suas características, qualidades, quantidade, composição, preço, garantia, prazos de validade e origem, entre outros dados, bem como sobre os riscos que apresentam à saúde e segurança dos consumidores.

Parágrafo único. As informações de que trata este artigo, nos produtos refrigerados oferecidos ao consumidor, serão gravadas de forma indelével. (Incluído pela Lei $\mathrm{n}^{\circ} 11.989$, de 2009)

Art. 32. Os fabricantes e importadores deverão assegurar a oferta de componentes e peças de reposição enquanto não cessar a fabricação ou importação do produto.

Parágrafo único. Cessadas a produção ou importação, a oferta deverá ser mantida por período razoável de tempo, na forma da lei.

Art. 33. Em caso de oferta ou venda por telefone ou reembolso postal, deve constar o nome do fabricante e endereço na embalagem, publicidade e em todos os impressos utilizados na transação comercial.

Parágrafo único. É proibida a publicidade de bens e serviços por telefone, quando a chamada for onerosa ao consumidor que a origina. (Incluído pela Lei $\mathrm{n}^{\mathrm{o}} 11.800$, de 2008). 
Art. 34. O fornecedor do produto ou serviço é solidariamente responsável pelos atos de seus prepostos ou representantes autônomos.

Art. 35. Se o fornecedor de produtos ou serviços recusar cumprimento à oferta, apresentação ou publicidade, o consumidor poderá, alternativamente e à sua livre escolha:

I - exigir o cumprimento forçado da obrigação, nos termos da oferta, apresentação ou publicidade;

II - aceitar outro produto ou prestação de serviço equivalente;

III - rescindir o contrato, com direito à restituição de quantia eventualmente antecipada, monetariamente atualizada, e a perdas e danos.

\section{SEÇÃO III}

Da Publicidade

Art. 36. A publicidade deve ser veiculada de tal forma que o consumidor, fácil e imediatamente, a identifique como tal.

Parágrafo único. O fornecedor, na publicidade de seus produtos ou serviços, manterá, em seu poder, para informação dos legítimos interessados, os dados fáticos, técnicos e científicos que dão sustentação à mensagem.

Art. 37. É proibida toda publicidade enganosa ou abusiva.

$\S 1^{\circ}$ É enganosa qualquer modalidade de informação ou comunicação de caráter publicitário, inteira ou parcialmente falsa, ou, por qualquer outro modo, mesmo por omissão, capaz de induzir em erro o consumidor a respeito da natureza, características, qualidade, quantidade, propriedades, origem, preço e quaisquer outros dados sobre produtos e serviços.

$\S 2^{\circ}$ É abusiva, dentre outras a publicidade discriminatória de qualquer natureza, a que incite à violência, explore o medo ou a superstição, se aproveite da deficiência de julgamento e experiência da criança, desrespeita valores ambientais, ou que seja capaz de induzir o consumidor a se comportar de forma prejudicial ou perigosa à sua saúde ou segurança.

$\S 3^{\circ}$ Para os efeitos deste código, a publicidade é enganosa por omissão quando deixar de informar sobre dado essencial do produto ou serviço.

$\S 4^{\circ}$ (Vetado).

Art. 38. O ônus da prova da veracidade e correção da informação ou comunicação publicitária cabe a quem as patrocina.

SEÇÃO IV

Das Práticas Abusivas

Art. 39. É vedado ao fornecedor de produtos ou serviços, dentre outras práticas abusivas: (Redação dada pela Lei $n^{\circ} 8.884$, de 11.6.1994) 
I - condicionar o fornecimento de produto ou de serviço ao fornecimento de outro produto ou serviço, bem como, sem justa causa, a limites quantitativos;

II - recusar atendimento às demandas dos consumidores, na exata medida de suas disponibilidades de estoque, e, ainda, de conformidade com os usos e costumes;

III - enviar ou entregar ao consumidor, sem solicitação prévia, qualquer produto, ou fornecer qualquer serviço;

IV - prevalecer-se da fraqueza ou ignorância do consumidor, tendo em vista sua idade, saúde, conhecimento ou condição social, para impingir-lhe seus produtos ou serviços;

$\mathrm{V}$ - exigir do consumidor vantagem manifestamente excessiva;

VI - executar serviços sem a prévia elaboração de orçamento e autorização expressa do consumidor, ressalvadas as decorrentes de práticas anteriores entre as partes;

VII - repassar informação depreciativa, referente a ato praticado pelo consumidor no exercício de seus direitos;

VIII - colocar, no mercado de consumo, qualquer produto ou serviço em desacordo com as normas expedidas pelos órgãos oficiais competentes ou, se normas específicas não existirem, pela Associação Brasileira de Normas Técnicas ou outra entidade credenciada pelo Conselho Nacional de Metrologia, Normalização e Qualidade Industrial (Conmetro);

IX - recusar a venda de bens ou a prestação de serviços, diretamente a quem se disponha a adquiri-los mediante pronto pagamento, ressalvados os casos de intermediação regulados em leis especiais; (Redação dada pela Lei $n^{\circ}$ 8.884, de 11.6.1994)

$\mathrm{X}$ - elevar sem justa causa o preço de produtos ou serviços. (Incluído pela Lei $\mathrm{n}^{\mathrm{o}}$ $\underline{8.884, \text { de 11.6.1994) }}$

XI - Dispositivo incluído pela MPV $\mathrm{n}^{\circ} 1.890-67$, de 22.10.1999, transformado em inciso XIII, quando da conversão na Lei $\mathrm{n}^{\circ}$ 9.870, de 23.11.1999

XII - deixar de estipular prazo para o cumprimento de sua obrigação ou deixar a fixação de seu termo inicial a seu exclusivo critério.(Incluído pela Lei $\mathrm{n}^{\circ}$ 9.008, de $\underline{21.3 .1995)}$

XIII - aplicar fórmula ou índice de reajuste diverso do legal ou contratualmente estabelecido. (Incluído pela Lei n ${ }^{\circ} 9.870$, de 23.11.1999)

Parágrafo único. Os serviços prestados e os produtos remetidos ou entregues ao consumidor, na hipótese prevista no inciso III, equiparam-se às amostras grátis, inexistindo obrigação de pagamento.

Art. 40. O fornecedor de serviço será obrigado a entregar ao consumidor orçamento prévio discriminando o valor da mão-de-obra, dos materiais e equipamentos a serem empregados, as condições de pagamento, bem como as datas de início e término dos serviços. 
$\S 1^{\circ}$ Salvo estipulação em contrário, o valor orçado terá validade pelo prazo de dez dias, contado de seu recebimento pelo consumidor.

$\S 2^{\circ}$ Uma vez aprovado pelo consumidor, o orçamento obriga os contraentes e somente pode ser alterado mediante livre negociação das partes.

$\S 3^{\circ} \mathrm{O}$ consumidor não responde por quaisquer ônus ou acréscimos decorrentes da contratação de serviços de terceiros não previstos no orçamento prévio.

Art. 41. No caso de fornecimento de produtos ou de serviços sujeitos ao regime de controle ou de tabelamento de preços, os fornecedores deverão respeitar os limites oficiais sob pena de não o fazendo, responderem pela restituição da quantia recebida em excesso, monetariamente atualizada, podendo o consumidor exigir à sua escolha, o desfazimento do negócio, sem prejuízo de outras sanções cabíveis.

\section{SEÇÃO V \\ Da Cobrança de Dívidas}

Art. 42. Na cobrança de débitos, o consumidor inadimplente não será exposto a ridículo, nem será submetido a qualquer tipo de constrangimento ou ameaça.

Parágrafo único. O consumidor cobrado em quantia indevida tem direito à repetição do indébito, por valor igual ao dobro do que pagou em excesso, acrescido de correção monetária e juros legais, salvo hipótese de engano justificável.

Art. 42-A. Em todos os documentos de cobrança de débitos apresentados ao consumidor, deverão constar o nome, o endereço e o número de inscrição no Cadastro de Pessoas Físicas - CPF ou no Cadastro Nacional de Pessoa Jurídica - CNPJ do fornecedor do produto ou serviço correspondente. (Incluído pela Lei $\mathrm{n}^{\mathrm{o}} 12.039$, de 2009)

\section{SEÇÃO VI}

Dos Bancos de Dados e Cadastros de Consumidores

Art. 43. O consumidor, sem prejuízo do disposto no art. 86, terá acesso às informações existentes em cadastros, fichas, registros e dados pessoais e de consumo arquivados sobre ele, bem como sobre as suas respectivas fontes.

$\S 1^{\circ}$ Os cadastros e dados de consumidores devem ser objetivos, claros, verdadeiros e em linguagem de fácil compreensão, não podendo conter informações negativas referentes a período superior a cinco anos.

$\S 2^{\circ} \mathrm{A}$ abertura de cadastro, ficha, registro e dados pessoais e de consumo deverá ser comunicada por escrito ao consumidor, quando não solicitada por ele.

$\S 3^{\circ} \mathrm{O}$ consumidor, sempre que encontrar inexatidão nos seus dados e cadastros, poderá exigir sua imediata correção, devendo o arquivista, no prazo de cinco dias úteis, comunicar a alteração aos eventuais destinatários das informações incorretas.

$\S 4^{\circ}$ Os bancos de dados e cadastros relativos a consumidores, os serviços de proteção ao crédito e congêneres são considerados entidades de caráter público. 
$\S 5^{\circ}$ Consumada a prescrição relativa à cobrança de débitos do consumidor, não serão fornecidas, pelos respectivos Sistemas de Proteção ao Crédito, quaisquer informações que possam impedir ou dificultar novo acesso ao crédito junto aos fornecedores.

Art. 44. Os órgãos públicos de defesa do consumidor manterão cadastros atualizados de reclamações fundamentadas contra fornecedores de produtos e serviços, devendo divulgá-lo pública e anualmente. A divulgação indicará se a reclamação foi atendida ou não pelo fornecedor.

$\S 1^{\circ}$ É facultado o acesso às informações lá constantes para orientação e consulta por qualquer interessado.

$\S 2^{\circ}$ Aplicam-se a este artigo, no que couber, as mesmas regras enunciadas no artigo anterior e as do parágrafo único do art. 22 deste código.

Art. 45. (Vetado).

\author{
CAPÍTULO VI \\ Da Proteção Contratual \\ SEÇÃO I \\ Disposições Gerais
}

Art. 46. Os contratos que regulam as relações de consumo não obrigarão os consumidores, se não lhes for dada a oportunidade de tomar conhecimento prévio de seu conteúdo, ou se os respectivos instrumentos forem redigidos de modo a dificultar a compreensão de seu sentido e alcance.

Art. 47. As cláusulas contratuais serão interpretadas de maneira mais favorável ao consumidor.

Art. 48. As declarações de vontade constantes de escritos particulares, recibos e précontratos relativos às relações de consumo vinculam o fornecedor, ensejando inclusive execução específica, nos termos do art. 84 e parágrafos.

Art. 49. O consumidor pode desistir do contrato, no prazo de 7 dias a contar de sua assinatura ou do ato de recebimento do produto ou serviço, sempre que a contratação de fornecimento de produtos e serviços ocorrer fora do estabelecimento comercial, especialmente por telefone ou a domicílio.

Parágrafo único. Se o consumidor exercitar o direito de arrependimento previsto neste artigo, os valores eventualmente pagos, a qualquer título, durante o prazo de reflexão, serão devolvidos, de imediato, monetariamente atualizados.

Art. 50. A garantia contratual é complementar à legal e será conferida mediante termo escrito.

Parágrafo único. O termo de garantia ou equivalente deve ser padronizado e esclarecer, de maneira adequada em que consiste a mesma garantia, bem como a forma, $\mathrm{o}$ prazo e o lugar em que pode ser exercitada e os ônus a cargo do consumidor, devendo serlhe entregue, devidamente preenchido pelo fornecedor, no ato do fornecimento, 
acompanhado de manual de instrução, de instalação e uso do produto em linguagem didática, com ilustrações.

\section{SEÇÃO II \\ Das Cláusulas Abusivas}

Art. 51. São nulas de pleno direito, entre outras, as cláusulas contratuais relativas ao fornecimento de produtos e serviços que:

I - impossibilitem, exonerem ou atenuem a responsabilidade do fornecedor por vícios de qualquer natureza dos produtos e serviços ou impliquem renúncia ou disposição de direitos. Nas relações de consumo entre o fornecedor e o consumidor pessoa jurídica, a indenização poderá ser limitada, em situações justificáveis;

II - subtraiam ao consumidor a opção de reembolso da quantia já paga, nos casos previstos neste código;

III - transfiram responsabilidades a terceiros;

IV - estabeleçam obrigações consideradas iníquas, abusivas, que coloquem o consumidor em desvantagem exagerada, ou sejam incompatíveis com a boa-fé ou a eqüidade;

\section{V - (Vetado);}

VI - estabeleçam inversão do ônus da prova em prejuízo do consumidor;

VII - determinem a utilização compulsória de arbitragem;

VIII - imponham representante para concluir ou realizar outro negócio jurídico pelo consumidor;

IX - deixem ao fornecedor a opção de concluir ou não o contrato, embora obrigando o consumidor;

$\mathrm{X}$ - permitam ao fornecedor, direta ou indiretamente, variação do preço de maneira unilateral;

XI - autorizem o fornecedor a cancelar o contrato unilateralmente, sem que igual direito seja conferido ao consumidor;

XII - obriguem o consumidor a ressarcir os custos de cobrança de sua obrigação, sem que igual direito the seja conferido contra o fornecedor;

XIII - autorizem o fornecedor a modificar unilateralmente o conteúdo ou a qualidade do contrato, após sua celebração;

XIV - infrinjam ou possibilitem a violação de normas ambientais;

$\mathrm{XV}$ - estejam em desacordo com o sistema de proteção ao consumidor;

XVI - possibilitem a renúncia do direito de indenização por benfeitorias necessárias.

$\S 1^{\circ}$ Presume-se exagerada, entre outros casos, a vontade que: 
I - ofende os princípios fundamentais do sistema jurídico a que pertence;

II - restringe direitos ou obrigações fundamentais inerentes à natureza do contrato, de tal modo a ameaçar seu objeto ou equilíbrio contratual;

III - se mostra excessivamente onerosa para o consumidor, considerando-se a natureza e conteúdo do contrato, o interesse das partes e outras circunstâncias peculiares ao caso.

$\S 2^{\circ}$ A nulidade de uma cláusula contratual abusiva não invalida o contrato, exceto quando de sua ausência, apesar dos esforços de integração, decorrer ônus excessivo a qualquer das partes.

\section{$\S 3^{\circ}$ (Vetado).}

$\S 4^{\circ}$ É facultado a qualquer consumidor ou entidade que o represente requerer ao Ministério Público que ajuíze a competente ação para ser declarada a nulidade de cláusula contratual que contrarie o disposto neste código ou de qualquer forma não assegure o justo equilíbrio entre direitos e obrigações das partes.

Art. 52. No fornecimento de produtos ou serviços que envolva outorga de crédito ou concessão de financiamento ao consumidor, o fornecedor deverá, entre outros requisitos, informá-lo prévia e adequadamente sobre:

I - preço do produto ou serviço em moeda corrente nacional;

II - montante dos juros de mora e da taxa efetiva anual de juros;

III - acréscimos legalmente previstos;

IV - número e periodicidade das prestações;

$\mathrm{V}$ - soma total a pagar, com e sem financiamento.

$\S 1^{\circ}$ As multas de mora decorrentes do inadimplemento de obrigações no seu termo não poderão ser superiores a dois por cento do valor da prestação.(Redação dada pela Lei $\underline{\left.\mathrm{n}^{\circ} 9.298, \text { de } 1^{\circ} .8 .1996\right)}$

$\S 2^{\circ}$ É assegurado ao consumidor a liquidação antecipada do débito, total ou parcialmente, mediante redução proporcional dos juros e demais acréscimos.

\section{$\S 3^{\circ}$ (Vetado).}

Art. 53. Nos contratos de compra e venda de móveis ou imóveis mediante pagamento em prestações, bem como nas alienações fiduciárias em garantia, consideram-se nulas de pleno direito as cláusulas que estabeleçam a perda total das prestações pagas em benefício do credor que, em razão do inadimplemento, pleitear a resolução do contrato e a retomada do produto alienado.

\section{$\S 1^{\circ}$ (Vetado).}

$\S 2^{\circ}$ Nos contratos do sistema de consórcio de produtos duráveis, a compensação ou a restituição das parcelas quitadas, na forma deste artigo, terá descontada, além da vantagem 
econômica auferida com a fruição, os prejuízos que o desistente ou inadimplente causar ao grupo.

$\S 3^{\circ}$ Os contratos de que trata o caput deste artigo serão expressos em moeda corrente nacional.

\section{SEÇÃO III}

\section{Dos Contratos de Adesão}

Art. 54. Contrato de adesão é aquele cujas cláusulas tenham sido aprovadas pela autoridade competente ou estabelecidas unilateralmente pelo fornecedor de produtos ou serviços, sem que o consumidor possa discutir ou modificar substancialmente seu conteúdo.

$\S 1^{\circ} \mathrm{A}$ inserção de cláusula no formulário não desfigura a natureza de adesão do contrato.

$\S 2^{\circ}$ Nos contratos de adesão admite-se cláusula resolutória, desde que a alternativa, cabendo a escolha ao consumidor, ressalvando-se o disposto no $\S 2^{\circ}$ do artigo anterior.

$\S 3^{\mathrm{o}}$ Os contratos de adesão escritos serão redigidos em termos claros e com caracteres ostensivos e legíveis, cujo tamanho da fonte não será inferior ao corpo doze, de modo a facilitar sua compreensão pelo consumidor. (Redação dada pela $\mathrm{n}^{0} 11.785$, de $\underline{2008)}$

$\S 4^{\circ}$ As cláusulas que implicarem limitação de direito do consumidor deverão ser redigidas com destaque, permitindo sua imediata e fácil compreensão.

\section{$\S 5^{\circ}$ (Vetado)}

\section{CAPÍTULO VII}

Das Sanções Administrativas

(Vide Lei $\mathrm{n}^{\circ} 8.656$, de 1993)

Art. 55. A União, os Estados e o Distrito Federal, em caráter concorrente e nas suas respectivas áreas de atuação administrativa, baixarão normas relativas à produção, industrialização, distribuição e consumo de produtos e serviços.

$\S 1^{\circ}$ A União, os Estados, o Distrito Federal e os Municípios fiscalizarão e controlarão a produção, industrialização, distribuição, a publicidade de produtos e serviços e o mercado de consumo, no interesse da preservação da vida, da saúde, da segurança, da informação e do bem-estar do consumidor, baixando as normas que se fizerem necessárias.

\section{$\S 2^{\circ}$ (Vetado).}

$\S 3^{\circ}$ Os órgãos federais, estaduais, do Distrito Federal e municipais com atribuições para fiscalizar e controlar o mercado de consumo manterão comissões permanentes para elaboração, revisão e atualização das normas referidas no $\S 1^{\circ}$, sendo obrigatória a participação dos consumidores e fornecedores.

$\S 4^{\circ}$ Os órgãos oficiais poderão expedir notificações aos fornecedores para que, sob pena de desobediência, prestem informações sobre questões de interesse do consumidor, resguardado o segredo industrial. 
Art. 56. As infrações das normas de defesa do consumidor ficam sujeitas, conforme o caso, às seguintes sanções administrativas, sem prejuízo das de natureza civil, penal e das definidas em normas específicas:

I - multa;

II - apreensão do produto;

III - inutilização do produto;

IV - cassação do registro do produto junto ao órgão competente;

V - proibição de fabricação do produto;

VI - suspensão de fornecimento de produtos ou serviço;

VII - suspensão temporária de atividade;

VIII - revogação de concessão ou permissão de uso;

IX - cassação de licença do estabelecimento ou de atividade;

X - interdição, total ou parcial, de estabelecimento, de obra ou de atividade;

XI - intervenção administrativa;

XII - imposição de contrapropaganda.

Parágrafo único. As sanções previstas neste artigo serão aplicadas pela autoridade administrativa, no âmbito de sua atribuição, podendo ser aplicadas cumulativamente, inclusive por medida cautelar, antecedente ou incidente de procedimento administrativo.

Art. 57. A pena de multa, graduada de acordo com a gravidade da infração, a vantagem auferida e a condição econômica do fornecedor, será aplicada mediante procedimento administrativo, revertendo para o Fundo de que trata a Lei $\mathrm{n}^{\circ} 7.347$, de 24 de julho de 1985, os valores cabíveis à União, ou para os Fundos estaduais ou municipais de proteção ao consumidor nos demais casos. (Redação dada pela Lei $\mathrm{n}^{\circ} 8.656$, de 21.5.1993)

Parágrafo único. A multa será em montante não inferior a duzentas e não superior a três milhões de vezes o valor da Unidade Fiscal de Referência (Ufir), ou índice equivalente que venha a substituí-lo. (Parágrafo acrescentado pela Lei $n^{\circ} 8.703$, de 6.9.1993)

Art. 58. As penas de apreensão, de inutilização de produtos, de proibição de fabricação de produtos, de suspensão do fornecimento de produto ou serviço, de cassação do registro do produto e revogação da concessão ou permissão de uso serão aplicadas pela administração, mediante procedimento administrativo, assegurada ampla defesa, quando forem constatados vícios de quantidade ou de qualidade por inadequação ou insegurança do produto ou serviço.

Art. 59. As penas de cassação de alvará de licença, de interdição e de suspensão temporária da atividade, bem como a de intervenção administrativa, serão aplicadas mediante procedimento administrativo, assegurada ampla defesa, quando o fornecedor 
reincidir na prática das infrações de maior gravidade previstas neste código e na legislação de consumo.

$\S 1^{\circ}$ A pena de cassação da concessão será aplicada à concessionária de serviço público, quando violar obrigação legal ou contratual.

$\S 2^{\circ}$ A pena de intervenção administrativa será aplicada sempre que as circunstâncias de fato desaconselharem a cassação de licença, a interdição ou suspensão da atividade.

$\S 3^{\circ}$ Pendendo ação judicial na qual se discuta a imposição de penalidade administrativa, não haverá reincidência até o trânsito em julgado da sentença.

Art. 60. A imposição de contrapropaganda será cominada quando o fornecedor incorrer na prática de publicidade enganosa ou abusiva, nos termos do art. 36 e seus parágrafos, sempre às expensas do infrator.

$\S 1^{\circ}$ A contrapropaganda será divulgada pelo responsável da mesma forma, freqüência e dimensão e, preferencialmente no mesmo veículo, local, espaço e horário, de forma capaz de desfazer o malefício da publicidade enganosa ou abusiva.

\section{$\S 2^{\circ}$ (Vetado)}

\section{$\S 3^{\circ}$ (Vetado).}

\section{TÍTULO II}

Das Infrações Penais

Art. 61. Constituem crimes contra as relações de consumo previstas neste código, sem prejuízo do disposto no Código Penal e leis especiais, as condutas tipificadas nos artigos seguintes.

Art. 62. (Vetado).

Art. 63. Omitir dizeres ou sinais ostensivos sobre a nocividade ou periculosidade de produtos, nas embalagens, nos invólucros, recipientes ou publicidade:

Pena - Detenção de seis meses a dois anos e multa.

$\S 1^{\circ}$ Incorrerá nas mesmas penas quem deixar de alertar, mediante recomendações escritas ostensivas, sobre a periculosidade do serviço a ser prestado.

$\S 2^{\circ}$ Se o crime é culposo:

Pena Detenção de um a seis meses ou multa.

Art. 64. Deixar de comunicar à autoridade competente e aos consumidores a nocividade ou periculosidade de produtos cujo conhecimento seja posterior à sua colocação no mercado:

Pena - Detenção de seis meses a dois anos e multa.

Parágrafo único. Incorrerá nas mesmas penas quem deixar de retirar do mercado, imediatamente quando determinado pela autoridade competente, os produtos nocivos ou perigosos, na forma deste artigo. 
Art. 65. Executar serviço de alto grau de periculosidade, contrariando determinação de autoridade competente:

Pena Detenção de seis meses a dois anos e multa.

Parágrafo único. As penas deste artigo são aplicáveis sem prejuízo das correspondentes à lesão corporal e à morte.

Art. 66. Fazer afirmação falsa ou enganosa, ou omitir informação relevante sobre a natureza, característica, qualidade, quantidade, segurança, desempenho, durabilidade, preço ou garantia de produtos ou serviços:

Pena - Detenção de três meses a um ano e multa.

$\S 1^{\mathrm{o}}$ Incorrerá nas mesmas penas quem patrocinar a oferta.

$\S 2^{\circ}$ Se o crime é culposo;

Pena Detenção de um a seis meses ou multa.

Art. 67. Fazer ou promover publicidade que sabe ou deveria saber ser enganosa ou abusiva:

Pena Detenção de três meses a um ano e multa.

Parágrafo único. (Vetado).

Art. 68. Fazer ou promover publicidade que sabe ou deveria saber ser capaz de induzir o consumidor a se comportar de forma prejudicial ou perigosa a sua saúde ou segurança:

Pena - Detenção de seis meses a dois anos e multa:

Parágrafo único. (Vetado).

Art. 69. Deixar de organizar dados fáticos, técnicos e científicos que dão base à publicidade:

Pena Detenção de um a seis meses ou multa.

Art. 70. Empregar na reparação de produtos, peça ou componentes de reposição usados, sem autorização do consumidor:

Pena Detenção de três meses a um ano e multa.

Art. 71. Utilizar, na cobrança de dívidas, de ameaça, coação, constrangimento físico ou moral, afirmações falsas incorretas ou enganosas ou de qualquer outro procedimento que exponha o consumidor, injustificadamente, a ridículo ou interfira com seu trabalho, descanso ou lazer:

Pena Detenção de três meses a um ano e multa.

Art. 72. Impedir ou dificultar o acesso do consumidor às informações que sobre ele constem em cadastros, banco de dados, fichas e registros:

Pena Detenção de seis meses a um ano ou multa. 
Art. 73. Deixar de corrigir imediatamente informação sobre consumidor constante de cadastro, banco de dados, fichas ou registros que sabe ou deveria saber ser inexata:

Pena Detenção de um a seis meses ou multa.

Art. 74. Deixar de entregar ao consumidor o termo de garantia adequadamente preenchido e com especificação clara de seu conteúdo;

Pena Detenção de um a seis meses ou multa.

Art. 75. Quem, de qualquer forma, concorrer para os crimes referidos neste código, incide as penas a esses cominadas na medida de sua culpabilidade, bem como o diretor, administrador ou gerente da pessoa jurídica que promover, permitir ou por qualquer modo aprovar o fornecimento, oferta, exposição à venda ou manutenção em depósito de produtos ou a oferta e prestação de serviços nas condições por ele proibidas.

Art. 76. São circunstâncias agravantes dos crimes tipificados neste código:

I - serem cometidos em época de grave crise econômica ou por ocasião de calamidade;

II - ocasionarem grave dano individual ou coletivo;

III - dissimular-se a natureza ilícita do procedimento;

IV - quando cometidos:

a) por servidor público, ou por pessoa cuja condição econômico-social seja manifestamente superior à da vítima;

b) em detrimento de operário ou rurícola; de menor de dezoito ou maior de sessenta anos ou de pessoas portadoras de deficiência mental interditadas ou não;

V - serem praticados em operações que envolvam alimentos, medicamentos ou quaisquer outros produtos ou serviços essenciais .

Art. 77. A pena pecuniária prevista nesta Seção será fixada em dias-multa, correspondente ao mínimo e ao máximo de dias de duração da pena privativa da liberdade cominada ao crime. Na individualização desta multa, o juiz observará o disposto no art. 60 , $\S 1^{\circ}$ do Código Penal.

Art. 78. Além das penas privativas de liberdade e de multa, podem ser impostas, cumulativa ou alternadamente, observado o disposto nos arts. 44 a 47, do Código Penal:

I - a interdição temporária de direitos;

II - a publicação em órgãos de comunicação de grande circulação ou audiência, às expensas do condenado, de notícia sobre os fatos e a condenação;

III - a prestação de serviços à comunidade.

Art. 79. O valor da fiança, nas infrações de que trata este código, será fixado pelo juiz, ou pela autoridade que presidir o inquérito, entre cem e duzentas mil vezes o valor do Bônus do Tesouro Nacional (BTN), ou índice equivalente que venha a substituí-lo. 
Parágrafo único. Se assim recomendar a situação econômica do indiciado ou réu, a fiança poderá ser:

a) reduzida até a metade do seu valor mínimo;

b) aumentada pelo juiz até vinte vezes.

Art. 80. No processo penal atinente aos crimes previstos neste código, bem como a outros crimes e contravenções que envolvam relações de consumo, poderão intervir, como assistentes do Ministério Público, os legitimados indicados no art. 82, inciso III e IV, aos quais também é facultado propor ação penal subsidiária, se a denúncia não for oferecida no prazo legal.

\section{TÍTULO III \\ Da Defesa do Consumidor em Juízo \\ CAPÍTULO I \\ Disposições Gerais}

Art. 81. A defesa dos interesses e direitos dos consumidores e das vítimas poderá ser exercida em juízo individualmente, ou a título coletivo.

Parágrafo único. A defesa coletiva será exercida quando se tratar de:

I - interesses ou direitos difusos, assim entendidos, para efeitos deste código, os transindividuais, de natureza indivisível, de que sejam titulares pessoas indeterminadas e ligadas por circunstâncias de fato;

II - interesses ou direitos coletivos, assim entendidos, para efeitos deste código, os transindividuais, de natureza indivisível de que seja titular grupo, categoria ou classe de pessoas ligadas entre si ou com a parte contrária por uma relação jurídica base;

III - interesses ou direitos individuais homogêneos, assim entendidos os decorrentes de origem comum.

Art. 82. Para os fins do art. 81, parágrafo único, são legitimados concorrentemente: (Redação dada pela Lei n ${ }^{\circ} 9.008$, de 21.3.1995)

I - o Ministério Público,

II - a União, os Estados, os Municípios e o Distrito Federal;

III - as entidades e órgãos da Administração Pública, direta ou indireta, ainda que sem personalidade jurídica, especificamente destinados à defesa dos interesses e direitos protegidos por este código;

IV - as associações legalmente constituídas há pelo menos um ano e que incluam entre seus fins institucionais a defesa dos interesses e direitos protegidos por este código, dispensada a autorização assemblear.

$\S 1^{\circ} \mathrm{O}$ requisito da pré-constituição pode ser dispensado pelo juiz, nas ações previstas nos arts. 91 e seguintes, quando haja manifesto interesse social evidenciado pela dimensão ou característica do dano, ou pela relevância do bem jurídico a ser protegido. 


\section{$\S 2^{\circ}$ (Vetado).}

\section{$\S 3^{\circ}$ (Vetado).}

Art. 83. Para a defesa dos direitos e interesses protegidos por este código são admissíveis todas as espécies de ações capazes de propiciar sua adequada e efetiva tutela.

Parágrafo único. (Vetado).

Art. 84. Na ação que tenha por objeto o cumprimento da obrigação de fazer ou não fazer, o juiz concederá a tutela específica da obrigação ou determinará providências que assegurem o resultado prático equivalente ao do adimplemento.

$\S 1^{\circ}$ A conversão da obrigação em perdas e danos somente será admissível se por elas optar o autor ou se impossível a tutela específica ou a obtenção do resultado prático correspondente.

$\S 2^{\circ} \mathrm{A}$ indenização por perdas e danos se fará sem prejuízo da multa (art. 287 , do Código de Processo Civil).

$\S 3^{\circ}$ Sendo relevante o fundamento da demanda e havendo justificado receio de ineficácia do provimento final, é lícito ao juiz conceder a tutela liminarmente ou após justificação prévia, citado o réu.

$\S 4^{\circ} \mathrm{O}$ juiz poderá, na hipótese do $\S 3^{\circ}$ ou na sentença, impor multa diária ao réu, independentemente de pedido do autor, se for suficiente ou compatível com a obrigação, fixando prazo razoável para o cumprimento do preceito.

$\S 5^{\circ}$ Para a tutela específica ou para a obtenção do resultado prático equivalente, poderá o juiz determinar as medidas necessárias, tais como busca e apreensão, remoção de coisas e pessoas, desfazimento de obra, impedimento de atividade nociva, além de requisição de força policial.

Art. 85. (Vetado).

\section{Art. 86. (Vetado).}

Art. 87. Nas ações coletivas de que trata este código não haverá adiantamento de custas, emolumentos, honorários periciais e quaisquer outras despesas, nem condenação da associação autora, salvo comprovada má-fé, em honorários de advogados, custas e despesas processuais.

Parágrafo único. Em caso de litigância de má-fé, a associação autora e os diretores responsáveis pela propositura da ação serão solidariamente condenados em honorários advocatícios e ao décuplo das custas, sem prejuízo da responsabilidade por perdas e danos.

Art. 88. Na hipótese do art. 13, parágrafo único deste código, a ação de regresso poderá ser ajuizada em processo autônomo, facultada a possibilidade de prosseguir-se nos mesmos autos, vedada a denunciação da lide.

Art. 89. (Vetado) 
Art. 90. Aplicam-se às ações previstas neste título as normas do Código de Processo Civil e da Lei $\mathrm{n}^{\circ} 7.347$, de 24 de julho de 1985, inclusive no que respeita ao inquérito civil, naquilo que não contrariar suas disposições.

\section{CAPÍTULO II}

Das Ações Coletivas Para a Defesa de Interesses Individuais Homogêneos

Art. 91. Os legitimados de que trata o art. 82 poderão propor, em nome próprio e no interesse das vítimas ou seus sucessores, ação civil coletiva de responsabilidade pelos danos individualmente sofridos, de acordo com o disposto nos artigos seguintes. (Redação dada pela Lei ${ }^{\circ} 9.008$, de 21.3.1995)

Art. 92. O Ministério Público, se não ajuizar a ação, atuará sempre como fiscal da lei.

Parágrafo único. (Vetado).

Art. 93. Ressalvada a competência da Justiça Federal, é competente para a causa a justiça local:

I - no foro do lugar onde ocorreu ou deva ocorrer o dano, quando de âmbito local;

II - no foro da Capital do Estado ou no do Distrito Federal, para os danos de âmbito nacional ou regional, aplicando-se as regras do Código de Processo Civil aos casos de competência concorrente.

Art. 94. Proposta a ação, será publicado edital no órgão oficial, a fim de que os interessados possam intervir no processo como litisconsortes, sem prejuízo de ampla divulgação pelos meios de comunicação social por parte dos órgãos de defesa do consumidor.

Art. 95. Em caso de procedência do pedido, a condenação será genérica, fixando a responsabilidade do réu pelos danos causados.

Art. 96. (Vetado).

Art. 97. A liquidação e a execução de sentença poderão ser promovidas pela vítima e seus sucessores, assim como pelos legitimados de que trata o art. 82 .

Parágrafo único. (Vetado).

Art. 98. A execução poderá ser coletiva, sendo promovida pelos legitimados de que trata o art. 82, abrangendo as vítimas cujas indenizações já tiveram sido fixadas em sentença de liquidação, sem prejuízo do ajuizamento de outras execuções. (Redação dada pela Lei $\mathrm{n}^{\circ}$ 9.008, de 21.3.1995)

$\S 1^{\circ}$ A execução coletiva far-se-á com base em certidão das sentenças de liquidação, da qual deverá constar a ocorrência ou não do trânsito em julgado.

$\S 2^{\circ}$ É competente para a execução o juízo:

I - da liquidação da sentença ou da ação condenatória, no caso de execução individual; 
II - da ação condenatória, quando coletiva a execução.

Art. 99. Em caso de concurso de créditos decorrentes de condenação prevista na Lei n. ${ }^{\circ} 7.347$, de 24 de julho de 1985 e de indenizações pelos prejuízos individuais resultantes do mesmo evento danoso, estas terão preferência no pagamento.

Parágrafo único. Para efeito do disposto neste artigo, a destinação da importância recolhida ao fundo criado pela Lei $\mathrm{n}^{\circ} 7.347$ de 24 de julho de 1985, ficará sustada enquanto pendentes de decisão de segundo grau as ações de indenização pelos danos individuais, salvo na hipótese de o patrimônio do devedor ser manifestamente suficiente para responder pela integralidade das dívidas.

Art. 100. Decorrido o prazo de um ano sem habilitação de interessados em número compatível com a gravidade do dano, poderão os legitimados do art. 82 promover a liquidação e execução da indenização devida.

Parágrafo único. O produto da indenização devida reverterá para o fundo criado pela Lei n. ${ }^{\circ} 7.347$, de 24 de julho de 1985 .

\section{CAPÍTULO III}

\section{Das Ações de Responsabilidade do Fornecedor de Produtos e Serviços}

Art. 101. Na ação de responsabilidade civil do fornecedor de produtos e serviços, sem prejuízo do disposto nos Capítulos I e II deste título, serão observadas as seguintes normas:

I - a ação pode ser proposta no domicílio do autor;

II - o réu que houver contratado seguro de responsabilidade poderá chamar ao processo o segurador, vedada a integração do contraditório pelo Instituto de Resseguros do Brasil. Nesta hipótese, a sentença que julgar procedente o pedido condenará o réu nos termos do art. 80 do Código de Processo Civil. Se o réu houver sido declarado falido, o síndico será intimado a informar a existência de seguro de responsabilidade, facultando-se, em caso afirmativo, o ajuizamento de ação de indenização diretamente contra o segurador, vedada a denunciação da lide ao Instituto de Resseguros do Brasil e dispensado o litisconsórcio obrigatório com este.

Art. 102. Os legitimados a agir na forma deste código poderão propor ação visando compelir o Poder Público competente a proibir, em todo o território nacional, a produção, divulgação distribuição ou venda, ou a determinar a alteração na composição, estrutura, fórmula ou acondicionamento de produto, cujo uso ou consumo regular se revele nocivo ou perigoso à saúde pública e à incolumidade pessoal.

$\S 1^{\circ}$ (Vetado).

\section{$\S 2^{\circ}$ (Vetado)}

\section{CAPÍTULO IV \\ Da Coisa Julgada}

Art. 103. Nas ações coletivas de que trata este código, a sentença fará coisa julgada:

I - erga omnes, exceto se o pedido for julgado improcedente por insuficiência de provas, hipótese em que qualquer legitimado poderá intentar outra ação, com idêntico 
fundamento valendo-se de nova prova, na hipótese do inciso I do parágrafo único do art. 81 ;

II - ultra partes, mas limitadamente ao grupo, categoria ou classe, salvo improcedência por insuficiência de provas, nos termos do inciso anterior, quando se tratar da hipótese prevista no inciso II do parágrafo único do art. 81;

III - erga omnes, apenas no caso de procedência do pedido, para beneficiar todas as vítimas e seus sucessores, na hipótese do inciso III do parágrafo único do art. 81 .

$\S 1^{\circ}$ Os efeitos da coisa julgada previstos nos incisos I e II não prejudicarão interesses e direitos individuais dos integrantes da coletividade, do grupo, categoria ou classe.

$\S 2^{\circ} \mathrm{Na}$ hipótese prevista no inciso III, em caso de improcedência do pedido, os interessados que não tiverem intervindo no processo como litisconsortes poderão propor ação de indenização a título individual.

$\S 3^{\circ}$ Os efeitos da coisa julgada de que cuida o art. 16, combinado com o art. 13 da Lei $n^{\circ} 7.347$, de 24 de julho de 1985, não prejudicarão as ações de indenização por danos pessoalmente sofridos, propostas individualmente ou na forma prevista neste código, mas, se procedente o pedido, beneficiarão as vítimas e seus sucessores, que poderão proceder à liquidação e à execução, nos termos dos arts. 96 a 99.

$\S 4^{\circ}$ Aplica-se o disposto no parágrafo anterior à sentença penal condenatória.

Art. 104. As ações coletivas, previstas nos incisos I e II e do parágrafo único do art. 81, não induzem litispendência para as ações individuais, mas os efeitos da coisa julgada erga omnes ou ultra partes a que aludem os incisos II e III do artigo anterior não beneficiarão os autores das ações individuais, se não for requerida sua suspensão no prazo de trinta dias, a contar da ciência nos autos do ajuizamento da ação coletiva.

\section{TÍTULO IV}

\section{Do Sistema Nacional de Defesa do Consumidor}

Art. 105. Integram o Sistema Nacional de Defesa do Consumidor (SNDC), os órgãos federais, estaduais, do Distrito Federal e municipais e as entidades privadas de defesa do consumidor.

Art. 106. O Departamento Nacional de Defesa do Consumidor, da Secretaria Nacional de Direito Econômico (MJ), ou órgão federal que venha substituí-lo, é organismo de coordenação da política do Sistema Nacional de Defesa do Consumidor, cabendo-lhe:

I - planejar, elaborar, propor, coordenar e executar a política nacional de proteção ao consumidor;

II - receber, analisar, avaliar e encaminhar consultas, denúncias ou sugestões apresentadas por entidades representativas ou pessoas jurídicas de direito público ou privado;

III - prestar aos consumidores orientação permanente sobre seus direitos e garantias;

IV - informar, conscientizar e motivar o consumidor através dos diferentes meios de comunicação; 
V - solicitar à polícia judiciária a instauração de inquérito policial para a apreciação de delito contra os consumidores, nos termos da legislação vigente;

VI - representar ao Ministério Público competente para fins de adoção de medidas processuais no âmbito de suas atribuições;

VII - levar ao conhecimento dos órgãos competentes as infrações de ordem administrativa que violarem os interesses difusos, coletivos, ou individuais dos consumidores;

VIII - solicitar o concurso de órgãos e entidades da União, Estados, do Distrito Federal e Municípios, bem como auxiliar a fiscalização de preços, abastecimento, quantidade e segurança de bens e serviços;

IX - incentivar, inclusive com recursos financeiros e outros programas especiais, a formação de entidades de defesa do consumidor pela população e pelos órgãos públicos estaduais e municipais;

$X-$ (Vetado).

XI - (Vetado).

XII - (Vetado)

XIII - desenvolver outras atividades compatíveis com suas finalidades.

Parágrafo único. Para a consecução de seus objetivos, o Departamento Nacional de Defesa do Consumidor poderá solicitar o concurso de órgãos e entidades de notória especialização técnico-científica.

\section{TÍTULO V}

Da Convenção Coletiva de Consumo

Art. 107. As entidades civis de consumidores e as associações de fornecedores ou sindicatos de categoria econômica podem regular, por convenção escrita, relações de consumo que tenham por objeto estabelecer condições relativas ao preço, à qualidade, à quantidade, à garantia e características de produtos e serviços, bem como à reclamação e composição do conflito de consumo.

$\S 1^{\circ}$ A convenção tornar-se-á obrigatória a partir do registro do instrumento no cartório de títulos e documentos.

$\S 2^{\circ}$ A convenção somente obrigará os filiados às entidades signatárias.

$\S 3^{\circ}$ Não se exime de cumprir a convenção o fornecedor que se desligar da entidade em data posterior ao registro do instrumento.

Art. 108. (Vetado).

\section{TÍTULO VI \\ Disposições Finais}

Art. 109. (Vetado). 
Art. 110. Acrescente-se o seguinte inciso IV ao art. $1^{\circ}$ da Lei ${ }^{\circ} 7.347$, de 24 de julho de 1985:

"IV - a qualquer outro interesse difuso ou coletivo".

Art. 111. O inciso II do art. $5^{\circ}$ da Lei $n^{\circ} 7.347$, de 24 de julho de 1985, passa a ter a seguinte redação:

"II - inclua, entre suas finalidades institucionais, a proteção ao meio ambiente, ao consumidor, ao patrimônio artístico, estético, histórico, turístico e paisagístico, ou a qualquer outro interesse difuso ou coletivo".

Art. $112 . \mathrm{O} \S 3^{\circ}$ do art. $5^{\circ}$ da Lei $\mathrm{n}^{\circ} 7.347$, de 24 de julho de 1985 , passa a ter a seguinte redação:

“§ $3^{\circ}$ Em caso de desistência infundada ou abandono da ação por associação legitimada, o Ministério Público ou outro legitimado assumirá a titularidade ativa”.

Art. 113. Acrescente-se os seguintes $\S \S 4^{\circ}, 5^{\circ}$ e $6^{\circ}$ ao art. $5^{\circ}$. da Lei n. ${ }^{\circ} 7.347$, de 24 de julho de 1985:

“§ 4..$^{\circ}$ O requisito da pré-constituição poderá ser dispensado pelo juiz, quando haja manifesto interesse social evidenciado pela dimensão ou característica do dano, ou pela relevância do bem jurídico a ser protegido.

§ 5. ${ }^{\circ}$ Admitir-se-á o litisconsórcio facultativo entre os Ministérios Públicos da União, do Distrito Federal e dos Estados na defesa dos interesses e direitos de que cuida esta lei. (Vide Mensagem de veto) (Vide REsp 222582 /MG - STJ)

$\S 6^{\circ}$ Os órgãos públicos legitimados poderão tomar dos interessados compromisso de ajustamento de sua conduta às exigências legais, mediante combinações, que terá eficácia de título executivo extrajudicial". (Vide Mensagem de veto) (Vide REsp 222582 /MG $\underline{\mathrm{STJ})}$

Art. 114. O art. 15 da Lei $\mathrm{n}^{\circ}$ 7.347, de 24 de julho de 1985, passa a ter a seguinte redação:

“Art. 15. Decorridos sessenta dias do trânsito em julgado da sentença condenatória, sem que a associação autora lhe promova a execução, deverá fazê-lo o Ministério Público, facultada igual iniciativa aos demais legitimados".

Art. 115. Suprima-se o caput do art. 17 da Lei $n^{\circ} 7.347$, de 24 de julho de 1985 , passando o parágrafo único a constituir o caput, com a seguinte redação:

“Art. 17. “Art. 17. Em caso de litigância de má-fé, a associação autora e os diretores responsáveis pela propositura da ação serão solidariamente condenados em honorários advocatícios e ao décuplo das custas, sem prejuízo da responsabilidade por perdas e danos".

Art. 116. Dê-se a seguinte redação ao art. 18 da Lei n 7.347 , de 24 de julho de 1985: 
“Art. 18. Nas ações de que trata esta lei, não haverá adiantamento de custas, emolumentos, honorários periciais e quaisquer outras despesas, nem condenação da associação autora, salvo comprovada má-fé, em honorários de advogado, custas e despesas processuais".

Art. 117. Acrescente-se à Lei n ${ }^{\circ}$ 7.347, de 24 de julho de 1985, o seguinte dispositivo, renumerando-se os seguintes:

"Art. 21. Aplicam-se à defesa dos direitos e interesses difusos, coletivos e individuais, no que for cabível, os dispositivos do Título III da lei que instituiu o Código de Defesa do Consumidor".

Art. 118. Este código entrará em vigor dentro de cento e oitenta dias a contar de sua publicação.

Art. 119. Revogam-se as disposições em contrário.

Brasília, 11 de setembro de 1990; $169^{\circ}$ da Independência e $102^{\circ}$ da República.

FERNANDO COLLOR

Bernardo Cabral

Zélia M. Cardoso de Mello

Ozires Silva 


\section{Presidência da República \\ Casa Civil \\ Subchefia para Assuntos Jurídicos}

MENSAGEM No 664, DE 11 DE SETEMBRO DE 1990.

\section{EXCELENTÍSSIMO SENHOR PRESIDENTE DO SENADO FEDERAL:}

Tenho a honra de comunicar a Vossa Excelência que, nos termos do parágrafo $1^{\circ}$ do artigo 66 da Constituição Federal, resolvi vetar parcialmente o Projeto de Lei $n^{\circ}$ 97/89 (n ${ }^{\circ}$ 3.683/89, na Câmara dos Deputados), que "dispõe sobre a proteção do consumidor e dá outras providências".

Os dispositivos ora vetados, que considero contrários ao interesse público ou inconstitucionais, são os seguintes:

\section{$\S 1^{\circ}$ do art. $5^{\circ}$}

“§ $1^{\circ}$ - Os Estados, Distrito Federal e Municípios manterão órgãos de atendimento gratuito para orientação dos consumidores".

Esta disposição contraria o princípio federativo, uma vez que impõe aos Estados, ao Distrito Federal e aos Municípios a obrigação de manter determinados serviços gratuitos.

\section{$\S 2^{\circ}$ do art. $5^{\circ}$}

"A União, os Estados, o Distrito Federal e os Municípios poderão fiscalizar preços e autuar os infratores, observado seu prévio tabelamento pela autoridade competente".

Cabe à lei que estabelecer o tabelamento, à vista de excepcional interesse público, indicar a autoridade competente para fiscalizá-lo. A cláusula prevista no $\S 2^{\circ}$ outorga atribuição genérica, incompatível com a segurança jurídica dos administrados, pois enseja a possibilidade de ser o mesmo fato objeto de fiscalizações simultâneas pelos diferentes órgãos.

\section{$\underline{\text { Inciso IX do art. } 6^{\circ}}$}

"IX - a participação e consulta na formulação das políticas que os afetam diretamente, e a representação de seus interesses por intermédio das entidades públicas ou privadas de defesa do consumidor".

O dispositivo contraria o princípio da democracia representativa ao assegurar, de forma ampla, o direito de participação na formulação das políticas que afetam diretamente o consumidor. O exercício do poder pelo povo faz-se por intermédio de representantes legitimamente eleitos, excetuadas as situações previstas expressamente na Constituição (C.F. arte 14, I). Acentue-se que o próprio exercício da iniciativa popular no processo legislativo está submetido a condições estritas (CF., arte $\left.61, \S 2^{\circ}\right)$.

\section{$\underline{\text { Art. } 11}$}


“Art. 11 - O produto ou serviço que, mesmo adequadamente utilizado ou fruído, apresenta alto grau de nocividade ou periculosidade será retirado imediatamente do mercado pelo fornecedor, sempre às suas expensas, sem prejuízo da responsabilidade pela reparação de eventuais danos."

O dispositivo é contrário ao interesse público, pois, ao determinar a retirada do mercado de produtos e serviços que apresentem "alto grau de nocividade ou periculosidade", mesmo quando "adequadamente utilizados", impossibilita a produção e o comércio de bens indispensáveis à vida moderna (e.g. materiais radioativos, produtos químicos e outros). Cabe, quanto a tais produtos e serviços, a adoção de cuidados especiais, a serem disciplinados em legislação específica.

\section{Art. 15}

“Art. 15 - Quando a utilização do produto ou a prestação do serviço causar dano irreparável ao consumidor, a indenização corresponderá ao valor integral dos bens danificados."

A redação equivocada do dispositivo redunda em reduzir a amplitude da eventual indenização devida ao consumidor, uma vez que a restringe ao valor dos bens danificados, desconsiderando os danos pessoais.

\section{$\underline{\text { Arts. } 16}, \underline{45}$ e $\$ 3^{\circ}$ do art. 52}

"Art. 16 - Se comprovada a alta periculosidade do produto ou do serviço que provocou o dano, ou grave imprudência, negligência ou imperícia do fornecedor, será devida multa civil de até um milhão de vezes o Bônus do Tesouro Nacional - BTN, ou índice equivalente que venha substituí-lo, na ação proposta por qualquer dos legitimados à defesa do consumidor em juízo, a critério do juiz, de acordo com a gravidade e proporção do dano, bem como a situação econômica do responsável."

“Art. 45 - As infrações ao disposto neste Capítulo, além de perdas e danos, indenização por danos morais, perda dos juros e outras sanções cabíveis, ficam sujeitas à multa de natureza civil, proporcional à gravidade da infração e à condição econômica do infrator, cominada pelo juiz na ação proposta por qualquer dos legitimados à defesa do consumidor em juízo."

Art. 52 -

“ $\S 3^{\circ}$ - O fornecedor ficará sujeito a multa civil e perda dos juros, além de outras sanções cabíveis, se descumprir o disposto neste artigo."

$\mathrm{O}$ art. 12 e outras normas já dispõem de modo cabal sobre a reparação do dano sofrido pelo consumidor. Os dispositivos ora vetados criam a figura da "multa civil", sempre de valor expressivo, sem que sejam definidas a sua destinação e finalidade.

\section{Art. 26. $\$ 2^{\circ}$ II}

"Art.26 -

$\S 2^{\circ}-$

II - a reclamação formalizada perante os órgãos ou entidades com atribuições de defesa do consumidor, pelo prazo de noventa dias." 
O dispositivo ameaça a estabilidade das relações jurídicas, pois atribui a entidade privada função reservada, por sua própria natureza, aos agentes públicos (e.g. Cod. Civil, art. 172 e Cod. Proc. Civil, art. 219, § $1^{\circ}$ )

\section{Parágrafo único do art. 27}

“Art. 27 -

Parágrafo único - Interrompe-se o prazo de prescrição do direito de indenização pelo fato do produto ou serviço nas hipóteses previstas no $\S 1^{\circ}$ do artigo anterior, sem prejuízo de outras disposições legais."

Essa disposição padece de grave defeito de formulação, que impossibilita o seu entendimento, uma vez que o $\S 1^{\circ}$ do art. 26 refere-se ao termo inicial dos prazos de decadência, nada dispondo sobre interrupção da prescrição.

\section{$\$ 1^{\circ}$ do art. 28}

"Art. 28 -

$\S 1^{\mathrm{o}}$ - A pedido da parte interessada, o juiz determinará que a efetivação da responsabilidade da pessoa jurídica recaia sobre o acionista controlador, o sócio majoritário, os sócios-gerentes, os administradores societários e, no caso de grupo societário, as sociedades que a integram."

O caput do art. 28 já contém todos os elementos necessários à aplicação da desconsideração da personalidade jurídica, que constitui, conforme doutrina amplamente dominante no direito pátrio e alienígena, técnica excepcional de repressão a práticas abusivas.

\section{$\S 4^{\circ}$ do art. 37, e $\$ \S 2^{\circ}$ e $\underline{3^{\circ} \text { do art. } 60 .}$}

“Art. 37 -

$\S 4^{\circ}$ - Quando o fornecedor de produtos ou serviços se utilizar de publicidade enganosa ou abusiva, o consumidor poderá pleitear indenização por danos sofridos, bem como a abstenção da prática do ato, sob pena de execução específica, para o caso de inadimplemento, sem prejuízo da sanção pecuniária cabível e de contra-propaganda, que pode ser imposta administrativa ou judicialmente.

Art. 60 -

$\S 2^{\circ}$ - A contra-propaganda será aplicada pelos órgãos públicos competentes da proteção ao consumidor, mediante procedimento administrativo, assegurada ampla defesa, cabendo recurso para o Ministro de Estado da respectiva área de atuação administrativa, quando a mensagem publicitária for de âmbito nacional.

$\S 3^{\circ}$ - Enquanto não promover a contra-propaganda, o fornecedor, além de multa diária e outras sanções, ficará impedido de efetuar, por qualquer meio, publicidade de seus produtos e serviços.”

A imposição de contra-propaganda, sem que se estabeleçam parâmetros legais precisos, pode dar ensejo a sérios abusos, que poderão redundar até mesmo na paralisação 
da atividade empresarial, como se vê, aliás, do disposto no $\S 3^{\circ}$ do art. 60. Por outro lado, é inadmissível, na ordem federativa, atribuir a Ministro de Estado competência para apreciar em grau de recurso a legitimidade de atos de autoridade estadual ou municipal, tal como previsto no $\S 2^{\circ}$ do art. 60 .

\section{$\underline{\text { Inciso } X \text { do art. } 39}$}

"Art. 39 -

Inciso X - praticar outras condutas abusivas."

O princípio do Estado de Direito (CF. art. $1^{\circ}$ ) exige que as normas legais sejam formuladas de forma clara e precisa, permitindo que os seus destinatários possam prever e avaliar as conseqüências jurídicas dos seus atos. É, portanto, inconstitucional a consagração de cláusulas imprecisas, sobretudo em dispositivo de natureza penal.

\section{$\underline{\text { Inciso V do art. } 51}$}

"Art. $51-$

V -Segundo as circunstâncias e, em particular, segundo a aparência global do contrato, venham, após sua conclusão, a surpreender o consumidor."

Reproduz, no essencial, o que já está explicitado no inciso IV. É, portanto, desnecessário.

\section{$\S 3^{\circ}$ do art. $51, \S 5^{\circ}$ do art. 54 e $§ 2^{\circ}$ do art. 82}

"Art. $51-$

$\S 3^{\circ}$ - O Ministério Público, mediante inquérito civil, pode efetuar o controle administrativo abstrato e preventivo das cláusulas contratuais gerais, cuja decisão terá caráter geral.

Art. 54 -

$\S 5^{\circ}$ - Cópia do formulário-padrão será remetida ao Ministério Público, que, mediante inquérito civil, poderá efetuar o controle preventivo das cláusulas gerais dos contratos de adesão.

Art. 82

$\S 2^{\circ}$ - Admitir-se-á o litisconsórcio facultativo entre os Ministérios Públicos da União, do Distrito Federal e dos Estados, na defesa dos interesses e direitos de que cuida este Código."

Tais dispositivos transgridem o art. $128, \S 5^{\circ}$, da Constituição Federal, que reserva à lei complementar a regulação inicial das atribuições e da organização do Ministério Público. O controle amplo e geral da legitimidade de atos jurídicos somente pode ser confiado ao Poder Judiciário (C.F, art. $5^{\circ}, \mathrm{XXXV)}$ ). Portanto, a outorga de competência ao Ministério Público para proceder ao controle abstrato de cláusulas contratuais desfigura o perfil que o Constituinte imprimiu a essa instituição (CF., arts 127 e 129). O controle 
abstrato de cláusulas contratuais está adequadamente disciplinado no art. $51, \S 4^{\mathrm{o}}$, do Projeto. Vetado o $\S 3^{\circ}$ do art. 51, impõe-se, também, vetar o $\S 5^{\circ}$ do art. 54.

Por outro lado, somente pode haver litisconsórcio $\left(\operatorname{art} .82, \S 2^{\circ}\right.$ ) se a todos e a cada um tocar qualidade que lhe autorize a condução autônoma do processo. O art. 128 da Constituição não admite o litisconsórcio constante do projeto.

\section{$\S 1^{\circ}$ do art. 53}

"Art. 53 -

$\S 1^{\circ}$ - Na hipótese prevista neste artigo, o devedor inadimplente terá direito a compensação ou à restituição das parcelas quitadas à data da resolução contratual, monetariamente atualizada, descontada a vantagem econômica auferida com a fruição."

Torna-se necessário dar disciplina mais adequada à resolução dos contratos de compra e venda, por inadimplência do comprador. A venda de bens mediante pagamento em prestações acarreta diversos custos para o vendedor, que não foram contemplados na formulação do dispositivo. A restituição das prestações, monetariamente corrigidas, sem levar em conta esses aspectos, implica tratamento iníquo, de conseqüências imprevisíveis e danosas para os diversos setores da economia.

\section{$\S 2^{\circ}$ do art. 55}

"Art. 55 -

$\S 2^{\circ}$ - As normas referidas no parágrafo anterior deverão ser uniformizadas, revistas e atualizadas, a cada dois anos."

A União não dispõe, na ordem federal, de competência para impor aos Estados e Municípios obrigação genérica de legislar (CF., arts. 18, 25 e 29).

\section{Art. 62}

"Art. 62 - Colocar no mercado, fornecer ou expor para fornecimento produtos ou serviços impróprios.

Pena - Detenção de seis meses a dois anos e multa.

$\S 1^{\mathrm{o}}$ - Se o crime é culposo:

Pena - Detenção de três meses a um ano ou multa.

$\S 2^{\circ}$ - As penas deste artigo são aplicáveis sem prejuízo das correspondentes à lesão corporal e à morte."

Em se tratando de norma penal, é necessário que a descrição da conduta vedada seja precisa e determinada. Assim, o dispositivo afronta a garantia estabelecida no art. $5^{\circ}$, XXXIX, da Constituição.

\section{Parágrafo Único do art. 67}

"Art. 67 - 
Parágrafo único - Incorrerá nas mesmas penas, quem fizer ou promover publicidade de modo que dificulte sua identificação imediata."

A norma em causa, enunciada como acréscimo a dispositivo que criminaliza a publicidade abusiva ou enganosa, não descreve, de forma clara e precisa, a conduta que pretende vedar. Assim, o dispositivo viola a garantia constitucional consagrada no inciso XXXIX do art. $5^{\circ}$ da Constituição.

\section{Parágrafo único do art. 68}

"Art. 68 -

Parágrafo único - Incorrerá nas mesmas penas quem fizer ou promover publicidade sabendo-se incapaz de atender à demanda."

A publicidade abusiva já está criminalizada no art. 67 do Projeto. Trata-se, portanto, de norma redundante.

\section{$\S 3^{\circ}$ do art. 82}

"Art. 82 -

$\S 3^{0}$ - Os órgãos públicos legitimados poderão tomar dos interessados compromisso de ajustamento de sua conduta às exigências legais, mediante cominações, que terá eficácia de título executivo extrajudicial."

É juridicamente imprópria a equiparação de compromisso administrativo a título executivo extrajudicial (C.P.C., art. 585, II). É que, no caso, o objetivo do compromisso é a cessação ou a prática de determinada conduta, e não a entrega de coisa certa ou pagamento de quantia fixada.

\section{Parágrafo único do art. 83}

"Art. 83 -

Parágrafo único - Poderá ser ajuizada, pelos legitimados no artigo anterior ou por qualquer outro interessado, ação visando o controle abstrato e preventivo das cláusulas contratuais gerais."

O controle abstrato de atos jurídicos constitui atividade excepcional do Judiciário (CF., art. 5, $\mathrm{XXXV)}$. A eficácia "erga omnes" de decisão proferida nessa modalidade de controle exige redobrada cautela na instituição de processos dessa índole. A pluralidade de entes legitimados a propor "ação visando ao controle abstrato e preventivo de cláusulas contratuais gerais", com a probabilidade da instauração de inúmeros processos de controle abstrato, constitui séria ameaça à segurança jurídica. Assim, é suficiente a disciplina que o $\S 4^{\circ}$ do art. 51 do projeto dá à matéria.

\section{$\underline{\text { Arts. } 85}$ e $\underline{86}$}

“Art. 85 - Contra atos ilegais ou abusivos de pessoas físicas ou jurídicas que lesem direito líquido e certo, individual, coletivo ou difuso, previsto neste Código, caberá ação mandamental, que se regerá pelas normas da lei do mandado de segurança. 
Art. 86 - Aplica-se o habeas data à tutela dos direitos e interesses dos consumidores.”

As ações de mandado de segurança e de habeas data destinam-se, por sua natureza, à defesa de direitos subjetivos públicos e têm, portanto, por objetivo precípuo os atos de agentes do Poder Público. Por isso, a sua extensão ou aplicação a outras situações ou relações jurídicas é incompatível com sua índole constitucional. Os artigos vetados, assim, contrariam as disposições dos incisos LXXI e LXXII do art. $5^{\circ}$ da Carta Magna.

\section{$\underline{\text { Art. } 89}$}

“Art. 89 - As normas deste Título aplicam-se, no que for cabível, a outros direitos ou interesses difusos, coletivos e individuais homogêneos, tratados coletivamente."

A extensão das normas específicas destinadas à proteção dos direitos do consumidor a outras situações excede dos objetivos propostos no código, alcançando outras relações jurídicas não identificadas precisamente e que reclamam regulação própria e adequada. Nos termos do art. 48 do Ato das Disposições Constitucionais Transitórias, deve o legislador limitar-se a elaborar Código de Defesa do Consumidor.

\section{Parágrafo único do art. 92}

“Art. 92 -

Parágrafo único - Aplica-se à ação prevista no artigo anterior o art. $5^{\circ}, \S \S 2^{\circ}$ a $6^{\circ}$, da Lei $n^{\circ}$ 7.347, de 24 de julho de 1985."

Esse dispositivo considera a nova redação que o art. 113 do projeto dá ao art. $5^{\circ}$ da Lei $\mathrm{n}^{\mathrm{o}} 7.347$, de 24 de julho de 1985 , acrescentando-lhe novos $\S \S 5^{\circ}$ e $6^{\circ}$, que seriam decorrência dos dispositivos constantes dos $\S \S 2^{\circ}$ e $3^{\circ}$ do art. 82. Esses dispositivos foram vetados, pelas razões expendidas. Assim também, vetam-se, no aludido art.113, as redações dos $\S \S 5^{\circ}$ e $6^{\circ}$.

\section{$\underline{\text { Art. } 96}$}

“Art. 96 - Transitada em julgado a sentença condenatória, será publicado edital, observado o disposto no art. 93."

O art. 93 não guarda pertinência com a matéria regulada nessa norma.

\section{Parágrafo único do art. 97}

“Art. 97 -

Parágrafo único - A liquidação de sentença, que será por artigos, poderá ser promovida no foro do domicílio do liquidante, cabendo-lhe provar, tão-só, o nexo de causalidade, o dano e seu montante."

Esse dispositivo dissocia, de forma arbitrária, o foro dos processos de conhecimento e de execução, rompendo o princípio da vinculação quanto à competência entre esses processos, adotado pelo Código de Processo Civil (Art. 575) e defendido pela melhor doutrina. Ao despojar uma das partes da certeza quanto ao foro de execução, tal preceito lesa o princípio de ampla defesa assegurado pela Constituição (Art. $5^{\circ}, \mathrm{LV}$ ). 


\section{$\S 1^{\circ}$ do art. 102}

“Art. $102-$

$\S 1^{\circ}$ - Os fornecedores poderão ingressar no feito como assistentes."

A redação do dispositivo parece equivocada. Os fornecedores, no caso de ação contra o Poder Público, para proibir a comercialização de produtos por eles fornecidos, são, na sistemática processual vigente, litisconsortes, e não meros assistentes (CPC, Arts. 46 e 47).

\section{$\S 2^{\circ}$ do art. 102}

"Art. 102 -

$\S 2^{\mathrm{o}}$ - O retardamento pela autoridade competente, por mais de sessenta dias, do cumprimento de decisão judicial em ação de que trata este artigo configura crime de responsabilidade, nos termos da Lei."

A norma somente seria admissível se o dispositivo se referisse ao cumprimento de decisão judicial final, transitada em julgado.

\section{$\underline{\text { Inciso X do art. } 106}$}

“Art. $106-$

$\mathrm{X}$ - requisitar bens em quantidade suficiente para fins de estudos e pesquisas, com posterior comprovação e divulgação de seus resultados;"

Esse preceito contraria o disposto nos incisos XXII e XXV do arte $5^{\circ}$ da Constituição.

\section{Inciso XI do art. 106}

“Art. $106-$

XI - encaminhar anteprojetos de lei, por intermédio do Ministério da Justiça, ao Congresso Nacional, bem como ser ouvido com relação a projetos de lei que versem sobre preços, qualidade, quantidade e segurança de bens e serviços;'

Trata-se de disposição que contraria o art. 61 da Constituição.

\section{Inciso XII do art. 106}

"Art. $106-$

XII - celebrar convênios com entidades nacionais e internacionais;”

A celebração de tratados, convenções e atos internacionais é de competência privativa do Presidente da República. (Constituição Federal, art. 84, VII).

\section{$\underline{\text { Art. } 108}$}

“Art. 108 - Podem as partes signatárias da convenção fixar sanções em caso de seu descumprimento, inclusive para fins de imposição de penalidade administrativa pela autoridade competente." 
A atividade administrativa deve estar subordinada estritamente à Lei (C.F. art. 37). A imposição de penalidade administrativa por descumprimento de convenções celebradas entre entidades privadas afronta o princípio da legalidade e o postulado da segurança jurídica, elementos essenciais ao Estado de Direito.

\section{Art. 109}

“Art. 109 - O preâmbulo da Lei n’. 7.347, de 24 de julho de 1985, passa a ter a seguinte redação:

"Disciplina a ação civil pública de responsabilidade por danos causados ao meio ambiente, ao consumidor, a bens e direitos de valor artístico, estético, histórico, turístico e paisagístico, assim como a qualquer outro interesse difuso ou coletivo, e dá outras providências".

Não cabe à lei alterar a ementa de outra lei, até porque as ementas não têm qualquer conteúdo normativo.

Estas as razões que me levaram a vetar parcialmente o projeto em causa, as quais ora submeto à elevada apreciação dos Senhores Membros do Congresso Nacional.

Brasília, em 11 de setembro de 1990. 